\title{
DEFORMAÇÕES DEPENDENTES DO TEMPO EM MUROS DE SOLO REFORÇADO COM GEOTÊXTEIS
}

Carina Maia Lins Costa

Tese apresentada à Escola de Engenharia de São Carlos, da Universidade de São Paulo, como parte dos requisitos para obtenção do título de Doutor em Geotecnia

ORIENTADOR: Prof. Dr. Benedito de Souza Bueno EESC, Universidade de São Paulo CO-ORIENTADOR: Prof. Dr. Jorge Zornberg Universidade do Texas em Austin, EUA

São Carlos

2004 
Ficha catalográfica preparada pela Seçăo de Tratamento da Informaçăo do Serviço de Biblioteca - EESCNSP

C837d

Costa, Carina Maia Lins

Deformaçōes dependentes do tempo em muros de solo reforçado com geotêxteis / Carina Maia Lins Costa. -- São Carlos, 2004.

Tese (Doutorado) -- Escola de Engenharia de São Carlos-Universidade de São Paulo, 2004.

Area: Geotecnia.

Orientador: Prof. Dr. Benedito de Souza Bueno.

Co-orientador : Prof. Dr. Jorge Zornberg.

1. Geotêxtil. 2. Fluência. 3. Relaxação. 4. Solo reforçado. 5. Geossintéticos. I. Título. 
FOLHA DE JULGAMENTO

Candidata: Engenheira CARINA MAIA LINS COSTA

Tese defendida e julgada em 17-12-2004 perante a Comissão Julgadora:

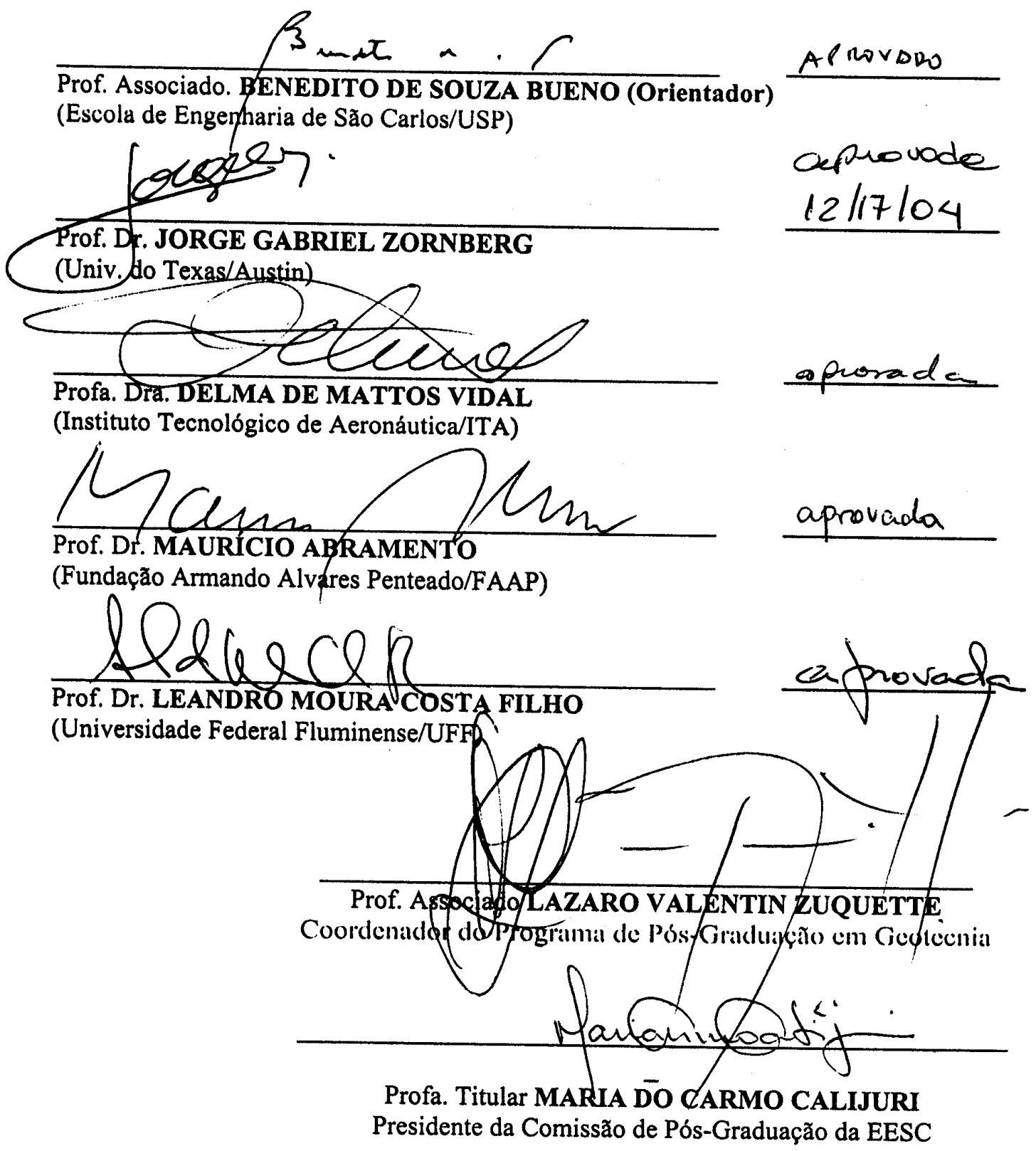


Ao meu esposo, companheiro em todos os momentos; aos meus pais, avós e minha irmã pelo apoio e incentivo. 


\section{Agradecimentos}

Ao Prof. Benedito Bueno pela orientação e amizade durante a elaboração deste trabalho.

A Yuri Costa pela inestimável e constante ajuda no decorrer de todo o trabalho.

À Coordenadoria de Aperfeiçoamento de Pessoal de Nível Superior, CAPES, pela concessão da bolsa de estudos.

Ao Prof. Jorge Zornberg pela co-orientação deste trabalho.

Aos amigos do grupo de Geossintéticos, Paulo Lodi, Paulo Márcio, Sidnei, Luiz Baras, Vinícius, Márcio e Érika, pelo apoio e amizade.

Aos técnicos do laboratório de Geossintéticos, Clever Valentin e Silvio Wick, pelo apoio constante nas atividades de laboratório.

Aos engenheiros Silvio Palma e Vitor /Ober S.A pela ajuda na seleção de geotêxteis para ensaio.

Aos engenheiros Flávio Montez/ Huesker Ltda. e Rogério Busch/ Propex do Brasil pelo apoio na seleção de materiais para ensaio.

Aos amigos Susan e Eduardo Dell'Avanzi pela inestimável ajuda na etapa do trabalho desenvolvida da Universidade do Colorado.

Aos amigos Fabiana Arriaga e Chunling Li pelo apoio nos ensaios em centrífuga.

Ao amigo Fernando Lavoi pela ajuda na execução de alguns ensaios.

Aos professores e amigos do Departamento de Geotecnia, especialmente aos professores Orêncio Vilar, Gene Stancati, Nélio Gaioto e Lázaro Zuquette.

Aos funcionários do Departamento de Geotecnia, especialmente a Maristela Batissaco, Álvaro, Herivelto, Neiva e aos técnicos José Luiz Guerra, Antônio Garcia, Oscar e Benedito pela ajuda durante todo o desenvolvimento deste trabalho.

À empresa Tortuga Ltda. pela confecção da manta de borracha utilizada no equipamento desenvolvido. 


\section{Sumário}

Lista de Figuras

Lista de Tabelas xiii

Lista de Abreviaturas, Siglas e Símbolos $\quad$ XV

Resumo xxi

Abstract xxii

$\begin{array}{ll}\text { Capítulo } 1 \text { Introdução } & 1\end{array}$

$\begin{array}{lc}\text { Capítulo } 2 \text { Revisão Bibliográfica } & 6\end{array}$

2.1 Fluência e relaxação de geotêxteis $\quad 6$

2.1.1 Conceitos básicos 6

2.1.1.1 Módulo de rigidez por fluência $\quad 7$

2.1.1.2 Módulo de rigidez por relaxação

2.1.1.3 Comparação entre os mecanismos de fluência e relaxação 8

2.1.2 Ensaios para avaliar as deformações ao longo do tempo 11

2.1.2.1 Métodos de ensaio 11

2.1.2.2 Equipamentos utilizados 15

2.1.2.2.1 Ensaios de fluência sem confinamento $\quad 15$

$\begin{array}{ll}\text { 2.1.2.2.2 Ensaios com confinamento } & 16\end{array}$

2.1.2.2.1 Equipamentos nos quais a carga é aplicada diretamente ao geotêxtil 16

2.1.2.2.2.2 Equipamentos nos quais o solo solicita o geotêxtil 20

2.1.3 Fatores que afetam as deformações dos geotêxteis ao longo do tempo 25

2.1.3.1 Tipo de polímero e tipo de geotêxtil 25

$\begin{array}{ll}\text { 2.1.3.2 Temperatura } & 27\end{array}$

$\begin{array}{ll}\text { 2.1.3.3 Tempo de carregamento } & 28\end{array}$ 
2.1.3.4.1 Sem considerar o comportamento tensão-deformação do solo 29

2.1.3.4.2 Considerando o comportamento tensão-deformação do solo 31

2.1.3.4.2.1 Ângulo de atrito do solo mobilizado após o carregamento (curto 32 prazo)

2.1.3.4.2.2 Características de fluência do solo confinante

2.2 Deformações em muros de solo reforçado com geossintéticos

2.2.1 Fatores que afetam as deformações 35

2.2.1.1 Comportamento mecânico do solo 35

2.2.1.2 Rigidez do reforço 36

2.2.1.3 Comprimento do reforço 36

$\begin{array}{ll}\text { 2.2.1.4 Arranjo das inclusões } & 37\end{array}$

2.2.1.5 Tipo de face $\quad 40$

2.2.1.6 Processo de compactação do solo 44

2.2.2 As deformações no dimensionamento de muros de solo reforçado 46

2.2.2.1 Estado limite último 46

2.2.2.2 Estado limite de utilização 51

2.2.2.2.1 Métodos de previsão de deslocamentos 52

2.2.2.2.1.1 Método de EHRL1CH (1995) 54

2.2.2.2.1.2 Método de SAWICKI (1999) 58

2.2.3 Deformações e deslocamentos observados em muros de solo reforçado 61 com geossintéticos

Capítulo 3 Investigação das deformações ao longo do tempo em $\quad 74$ elementos de solo reforçado com geotêxteis

$\begin{array}{ll}\text { 3.1 Desenvolvimento do equipamento } & 74\end{array}$

3.1.1 Configurações adotadas durante o desenvolvimento do equipamento 75

3.1.2 Mecanismo de funcionamento da configuração final do equipamento $\quad 84$

3.2 Descrição do equipamento $\quad 86$

3.2.1 Configuração dos ensaios com solo e reforço 86 
3.2.2 Configuração dos ensaios apenas com solo

3.2.3 Caixa de ensaios e sistema de garras $\quad 89$

3.2.4 Sistema para obtenção da deformação no geotêxtil 90

3.2.5 Obtenção da força atuante nas paredes $\quad 94$

3.2.6 Sistema para aplicação da tensão vertical 96

3.2.7 Acessórios desenvolvidos para a preparação do solo 98

$\begin{array}{ll}3.3 \text { Geotêxtil e solo utilizados } & 101\end{array}$

$\begin{array}{ll}\text { 3.3.1 Geotêxtil utilizado } & 101\end{array}$

$\begin{array}{ll}\text { 3.3.2 Solo utilizado } & 104\end{array}$

$\begin{array}{ll}3.4 \text { Descrição dos ensaios realizados } & 105\end{array}$

3.4.1 Ensaios para investigação do atrito nas faces do corpo-de-prova 105

$\begin{array}{ll}\text { 3.4.2 Ensaios com o equipamento desenvolvido } & 113\end{array}$

3.4.2.1 Procedimentos de ensaio 113

3.4.2.1.1 Ensaios com o elemento de solo reforçado 113

$\begin{array}{ll}\text { 3.4.2.1.2 Ensaios apenas com solo } & 114\end{array}$

$\begin{array}{ll}\text { 3.4.2.2 Ensaios realizados } & 114\end{array}$

$\begin{array}{ll}\text { 3.5 Apresentação e análise dos resultados } & 116\end{array}$

$\begin{array}{ll}\text { 3.5.1 Ensaios apenas com solo } & 116\end{array}$

$\begin{array}{ll}\text { 3.5.2 Análise das tensões medidas } & 125\end{array}$

3.5.3 Análise da força na lateral móvel $\quad 130$

$\begin{array}{ll}\text { 3.5.4 Ensaios com o elemento de solo reforçado } & 134\end{array}$

Capítulo 4 Investigação das deformações ao longo do tempo em 155 muros de solo reforçado através de ensaios em centrífuga

4.1 Princípios e limitações de modelos físicos em centrífuga 155

$\begin{array}{lr}\text { 4.1.1 Leis de escala } & 156\end{array}$

4.1.2 Limitações dos ensaios em centrifuga $\quad 159$

$\begin{array}{ll}\text { 4.1.3 Objetivos da modelagem em centrífuga } & 160\end{array}$

$\begin{array}{ll}\text { 4.2 Descrição geral dos modelos construídos } & 161\end{array}$ 
$\begin{array}{lc}\text { 4.3.1 Caixa utilizada } & 163\end{array}$

$\begin{array}{ll}\text { 4.3.2 Centrífuga utilizada } & 164\end{array}$

$\begin{array}{ll}\text { 4.3.3 Instrumentação dos ensaios } & 166\end{array}$

$\begin{array}{ll}\text { 4.3.3.1 LVDT's } & 166\end{array}$

$\begin{array}{ll}\text { 4.3.3.2 Sistema de aquisição de imagens } & 166\end{array}$

$\begin{array}{ll}\text { 4.3.3.3 Sistema para obtenção da temperatura } & 167\end{array}$

$\begin{array}{ll}\text { 4.3.4 Solo utilizado } & 169\end{array}$

$\begin{array}{ll}\text { 4.3.5 Materiais empregados como reforço } & 170\end{array}$

$\begin{array}{ll}\text { 4.3.5.1 Geotêxtil de poliéster } & 170\end{array}$

$\begin{array}{ll}\text { 4.3.5.2 Geotêxtil de polipropileno } & 174\end{array}$

$\begin{array}{ll}\text { 4.4 Procedimento de montagem dos modelos } & 175\end{array}$

$\begin{array}{ll}4.5 \text { Procedimento de execução dos ensaios } & 180\end{array}$

$\begin{array}{ll}\text { 4.5.1 Ensaios de ruptura } & 180\end{array}$

$\begin{array}{ll}\text { 4.5.2 Ensaios de fluência } & 180\end{array}$

$\begin{array}{ll}\text { 4.6 Ensaios realizados } & 181\end{array}$

$\begin{array}{ll}\text { 4.6.1 Programa de ensaios } & 181\end{array}$

$\begin{array}{ll}4.7 \text { Resultados obtidos } & 182\end{array}$

$\begin{array}{ll}\text { 4.7.1 Curvas aceleração x recalque } & 182\end{array}$

$\begin{array}{ll}\text { 4.7.2 Curvas tempo x recalque } & 187\end{array}$

4.7.3 Resultados obtidos através da aquisição de imagens - deslocamentos e $\quad 189$ deformações

$\begin{array}{ll}\text { 4.7.4 Temperatura } & 192\end{array}$

$\begin{array}{ll}\text { 4.8 Análise dos resultados } & 194\end{array}$

$\begin{array}{ll}\text { 4.8.1 Ensaios de ruptura } & 194\end{array}$

$\begin{array}{ll}\text { 4.8.1.1 Definição da aceleração na ruptura } & 194\end{array}$

$\begin{array}{ll}\text { 4.8.1.2 Localização da superfície de ruptura } & 197\end{array}$

$\begin{array}{ll}\text { 4.8.1.3 Efeito do confinamento } & 200\end{array}$ 
4.8.1.4 Distribuição da força máxima no reforço com a profundidade

4.8.1.5 Ângulo de atrito mobilizado

4.8.1.6 Comparação dos resultados obtidos com previsões teóricas

Capítulo 5 Discussão geral dos resultados e mecanismos de deformação em longo prazo em muros de solo reforçado

5.1 Avaliação dos resultados obtidos com relação a investigações anteriores reportadas na literatura

5.1.1 Considerações sobre o comportamento observado em obras 221 instrumentadas

5.1.2 Comparação com resultados obtidos em protótipos

5.1.3 Comparação com resultados obtidos através de outros modelos reduzidos

5.2 Discussão geral sobre mecanismos de interação ao longo do tempo 233

5.3 Considerações finais com relação à previsão de deformações ao 247 longo do tempo em muros de solo reforçado

Capítulo 6 Conclusões

Anexo A

Anexo B 


\section{Lista de Figuras}

FIGURA 2.1 - Ensaios de fluência (a) curvas deformação versus tempo $\quad 8$ (b) curvas isócronas.

FIGURA 2.2 - Ensaios de relaxação (a) curvas força versus tempo (b) 8 curvas isócronas.

FIGURA 2.3 - Rigidez por fluência inferior à rigidez por relaxação

FIGURA 2.4 - Rigidez por relaxação inferior à rigidez por fluência.

FIGURA 2.5 - Curvas Sherby-Dorn (McGOWN et al., 1986).

$\begin{array}{lllllll}\text { FIGURA 2.6 - Determinação da carga de ruptura por fluência } & 14\end{array}$ (ZAMMITT, 1998).

$\begin{array}{llllll}\text { FIGURA } 2.7 \text { - Tipos de ensaios para investigar as deformações } & 15\end{array}$ dependentes do tempo.

FIGURA 2.8 - Equipamento usado em ensaio de fluência não confinada 16 (ASTM, 1994).

FIGURA 2.9 - Esquema de um ensaio com confinamento

FIGURA 2.10 - Vista geral do equipamento para ensaio de fluência $\quad 18$ confinada (McGOWN et al., 1982)

FIGURA 2.11 - Sistema de confinamento (McGOWN et al., 1982).

FIGURA 2.12 - Sistema utilizado para obter as deformações do geotêxtil 20 (McGOWN et al., 1982).

FIGURA 2.13 - Esquema de um equipamento com confinamento no qual o solo solicita o geotêxtil

FIGURA 2.14 - Esquema do equipamento desenvolvido por WU \& HELWANY (1996)

FIGURA 2.15 - Equipamento desenvolvido por HELWANY \& SHIN (1998)

FIGURA 2.16 - Equipamento desenvolvido por BOYLE (1995) 
FIGURA 2.18 - Curvas de fluência para fibras de diferentes polímeros (a) $20 \%$ da resistência à tração (b) $60 \%$ da resistência à tração (DEN HOEDT, 1986).

FIGURA 2.19 - Fluência de um geotêxtil de PP a diferentes temperaturas e níveis de carregamento (MÜLLER-ROCHHOLZ \& KIRSCHNER, 1990).

FIGURA 2.20 - Efeito do tempo de carregamento no recalque após a carga ser mantida constante (GOTTARDI \& SIMONINI, 2000).

FIGURA 2.21 - Resultados de ensaios de fluência de geotêxteis (a) não tecido, termoligado, 33\% PEAD e 67\% PP (b) não tecido, $100 \%$ PET, agulhado (McGOWN et al., 1982).

FIGURA 2.22 - Curva de compatibilidade para determinação do equilíbrio em solos reforçados (a) ângulo de atrito mobilizado - deformação lateral (b) força - deformação no reforço (c) curva de compatibilidade de deformação (McGOWN et al, 1998).

FIGURA 2.23 - Efeito do tipo de solo e reforço com base na 36 compatibilidade de deformação

FIGURA 2.24 - Geometria dos modelos reduzidos estudados por PALMEIRA \& LANZ (1994)

FIGURA 2.25 - (a) Deslocamentos dos muros 1, 8 e 7 (b) deslocamentos dos muros 1,2,3 (PALMEIRA \& LANZ, 1994).

FIGURA 2.26 - Deslocamentos dos muros 1, 4, 5 e 6 (a) q=10,7 kPa (b) $\mathrm{q}=58,7 \mathrm{kPa}$ (PALMEIRA \& LANZ, 1994)

FIGURA 2.27 - Arranjos de muros considerados por ROWE \& HO

FIGURA 2.28 - Deslocamentos horizontais na face para os diferentes arranjos considerados por ROWE \& HO (1998).

FIGURA 2.29 - Mecanismo de ruptura progressiva provocado pela ruptura local, por compressão do solo, imediatamente atrás da face (TATSUOKA, 1992).

FIGURA 2.30 - Tipos de distribuição de força no reforço em estruturas de solo reforçado (TATSUOKA, 1992).

FIGURA 2.31 - Compatibilidade de deformação considerando as tensões induzidas por efeito da compactação (EHRLICH \& AZAMBUJA, 2003). 
FIGURA 2.32 - Distribuição da máxima tensão em cada camada de reforço com a profundidade por efeito da compactação (modificado de EHRLICH \& AZAMBUJA, 2003).

FIGURA 2.33 - Mecanismos envolvidos na estabilidade externa (a) tombamento, (b)deslizamento, (c) capacidade de carga da fundação (KOERNER, 1998)

FIGURA 2.34 - Mecanismo de ruptura geral

FIGURA 2.35 - Mecanismos de ruptura a serem considerados no dimensionamento de muros de solo reforçado (JEWELL, 1996).

FIGURA 2.36 - Zona ativa e resistente de um maciço reforçado

FIGURA 2.37 - Curva de referência ou ruptura por fluência (PALMEIRA, 1999)

FIGURA 2.38 - Resistência à tração a longo prazo (curva isócrona) 52 (PALMEIRA, 1999).

FIGURA 2.39 - Curva para estimativa do deslocamento lateral no final da construção (MITCHELL \& CHRISTOPHER, 1990 modificado para dimensões em metros).

FIGURA 2.40 - Distribuição de tensões ao longo do reforço (EHRLICH, 1995).

FIGURA 2.41 - Ábaco para a determinação das tensões máximas no reforço (EHRLICH e MITCHELL, 1994)

FIGURA 2.42 - Representação esquemática de um muro de solo reforçado (SAWICKI, 1999).

FIGURA 2.43 - Distribuição de tensão no reforço (SAWICKI, 1999).

FIGURA 2.44 - Modelo reológico adotado por SAWICKI (1999) (SAWICKI \& KAZIMIEROWICZ-FRANKOWSKA, 1998).

FIGURA 2.45 - Deslocamentos horizontais observados em faces de muros de solo reforçado

FIGURA 2.46 - Porcentagem da resistência à tração para uma deformação correspondente a $1 \%$ e $2 \%$.

FIGURA 3.1 - Configuração inicial do equipamento, sem escala, 76 dimensões em mm. 
FIGURA 3.2 - (a) Bolsa inflável inicialmente utilizada (b) processo de dobra da bolsa: 1)configuração inicial, 2) processo de dobra para reduzir espessura, 3) configuração após processo de dobra

FIGURA 3.3 - (a) Configuração desejada para a bolsa inferior (b) configuração resultante pela deformação da bolsa durante preparação do corpo-de-prova.

FIGURA 3.4 - Mecanismo de dissipação de carga no reforço antes de atingir a célula de carga

FIGURA 3.5 - (a) Esquema da garra 2 (b) haste e cabos utilizados na garra (c) peças para conexão dos cabos de aço à célula de carga.

FIGURA 3.6 - Sistema para aplicação da tensão confinante utilizado durante o desenvolvimento do equipamento.

FIGURA 3.7 - Terceira configuração testada para o equipamento, sem escala, dimensões em mm.

FIGURA 3.8 - Esquema do sistema para a aplicação de tensão vertical finalmente adotado.

FIGURA 3.9 - Configuração final do equipamento

FIGURA 3.10 - Detalhe do mecanismo de transmissão de carga

FIGURA 3.11 - Equipamento desenvolvido

FIGURA 3.12 - Esquema do equipamento desenvolvido

FIGURA 3.13 - Detalhe do motor e sistema de eixos

FIGURA 3.14 - Esquema do sistema para movimentação das paredes (vista superior)

FIGURA 3.15 - Esquema da caixa de ensaios (a) vista lateral (b) vista superior (sem escala, dimensões em $\mathrm{mm}$ )

FIGURA 3.16 - Sistema ótico para obtenção de deformações no geotêxtil (a) configuração inicial (b) movimentação da fibra após deformação do geotêxtil.

FIGURA 3.17 - Disposição das hastes na manta (sem escala) 
FIGURA 3.19 - (a) Sistema de movimentação relógio-haste (b) detalhe do parafuso com rosca de precisão

FIGURA 3.20 - Esquema do sistema de movimentação relógio-haste

FIGURA 3.21 - Curva de calibração da célula de carga

FIGURA 3.22 - Detalhe de fixação da célula para ensaios apenas com solo

FIGURA 3.23 - Câmara de ar projetada

FIGURA 3.24 - Esquema da câmara de ar desenvolvida (a) vista superior sem camada de borracha (b) corte AA'

FIGURA 3.25 - Pistão pneumático utilizado na câmara de ar.

FIGURA 3.26 - Vista geral do equipamento de chuva de areia

FIGURA 3.27 - Esquema do difusor (a) vista superior (b) corte AB (sem escala; dimensões em mm)

FIGURA 3.28 - Calibração da chuva de areia, curva $D_{\mathrm{r}}$ versus diâmetro do orifício.

FIGURA 3.29 - Resultados dos ensaios de tração.

FIGURA 3.30 - (a) Equipamento utilizado nos ensaios de fluência (b) detalhe das hastes utilizadas para obtenção das deformações.

FIGURA 3.31 - Resultados dos ensaios de fluência sem confinamento para $5 \%, 9,5 \%, 12 \%$ e $20 \%$ da resistência à tração.

FIGURA 3.32 - Curva granulométrica da areia utilizada

FIGURA 3.33 - Esquema dos ensaios de interface

FIGURA 3.34 - Ângulo de atrito para a graxa B após $\sigma_{\mathrm{n}}$ constante por um determinado tempo antes do ensaio.

FIGURA 3.35 - Esquema de disposição das células no ensaio S2T (a) 116 vista superior (b) vista lateral.

FIGURA 3.36 - Carga x deformação - ensaio S1 
FIGURA 3.37 - Tensão horizontal a x deformação - ensaio S1

FIGURA 3.38 - Carga x deformação - ensaio S3

FIGURA 3.39 - Tensão horizontal x deformação - ensaio S3

FIGURA 3.40 - Carga x deformação - ensaio S4

FIGURA 3.41 - Tensão horizontal x deformação - ensaio S4

FIGURA 3.42 - Carga x deformação - ensaio S5

FIGURA 3.43 - Tensão horizontal x deformação - ensaio S5

FIGURA 3.44 - Carga x deformação - ensaio SR6

FIGURA 3.45 - Tensão horizontal x deformação - ensaio SR6

FIGURA 3.46 - Carga x deformação - ensaio SR7

FIGURA 3.47 - Tensão horizontal x deformação - ensaio SR7

FIGURA 3.48 - Carga x deformação - ensaio S8

FIGURA 3.49 - Tensão horizontal x deformação - ensaio S8

FIGURA 3.50 - Carga x deformação - ensaio S9

FIGURA 3.51 - Tensão horizontal x deformação - ensaio S9

FIGURA 3.52 - Tensão horizontal prevista e obtida nos ensaios.

FIGURA 3.53 - Variação da tensão e da força em relação aos valores obtidos para $\varepsilon=0,3 \%$ (ensaio S3).

FIGURA 3.54 - Variação da tensão e da força em relação aos valores obtidos para $\varepsilon=0,3 \%$ (ensaio S5).

FIGURA 3.55 - Esquema de propagação da tensão vertical aplicada (sem escala, dimensões em mm). 
FIGURA 3.56 - Esquema de propagação da tensão vertical com a deformação do corpo-de-prova (sem escala, dimensões em $\mathrm{mm})$.

FIGURA 3.57 - Variação do ângulo de atrito mobilizado com a 134 deformação (ensaio S3).

FIGURA 3.58 - Carga $x$ tempo - ensaio SR1

FIGURA 3.59 - Deformação x tempo - ensaio SR1

FIGURA 3.60 - Carga $x$ tempo - ensaio SR2R

FIGURA 3.61 - Deformação x tempo - ensaio SR2R

FIGURA 3.62 - Carga $x$ tempo - ensaio SR3R

FIGURA 3.63 - Deformação x tempo - ensaio SR3R

FIGURA 3.64 - Carga x tempo - ensaio SR4

FIGURA 3.65 - Deformação x tempo - ensaio SR4

FIGURA 3.66 - Carga x tempo - ensaio SR5

FIGURA 3.67 - Deformação x tempo - ensaio SR5

FIGURA 3.68 - Carga $x$ tempo - ensaio SR6R

FIGURA 3.69 - Deformação x tempo - ensaio SR6R

FIGURA 3.70 - Resultados dos ensaios de relaxação

FIGURA 3.71 - Comparação entre as deformações ao longo do tempo obtidas em diferentes tipos de ensaio

FIGURA 3.72 - Comparação entre as deformações obtidas no ensaio SR6R e em ensaios de fluência.

FIGURA 3.73 - Comparação entre ensaio SR6R e ensaio com descarregamento. 
FIGURA 3.74 - Variação da carga no ensaio SR6R e no ensaio com 152 descarregamento.

FIGURA 3.75 - Resultado obtido em ensaio utilizando o equipamento 153 desenvolvido por BOYLE (1995).

FIGURA 4.1 - Tensões verticais (a) no protótipo (b) no modelo 156

FIGURA 4.2 - Configuração dos modelos, corte esquemático sem 162 escala.

FIGURA 4.3 - Caixa utilizada para a confecção dos modelos

$\begin{array}{lll}\text { FIGURA } 4.4 \text { - Centrífuga utilizada } & 165\end{array}$

FIGURA 4.5 - Esquema da centrífuga utilizada (KO, 1988). 165

FIGURA 4.6 - Modelo posicionado dentro da centrífuga pronto para 167 ensaio

FIGURA 4.7 - Distribuição dos termopares no modelo, sem escala dimensões em mm (a) corte esquemático (b) vista superior.

FIGURA 4.8 - Curva granulométrica da areia Monterey n. 30.

FIGURA 4.9 - Garras confeccionadas para os ensaios de tração

FIGURA 4.10 - Resultados dos ensaios de tração para o geotêxtil de PET.

FIGURA 4.11 - Curvas deformação x tempo obtidas para o material de PET para 25, 40 e $60 \%$ da resistência à tração

FIGURA 4.12 - Curvas deformação x tempo obtidas para o material de PET para $80 \%$ da resistência à tração

FIGURA 4.13 - Resultados dos ensaios de tração para o geotêxtil de PP.

FIGURA 4.14 - Curvas deformação x tempo obtidas para o material de PP para 40, 60 e $80 \%$ da resistência à tração

FIGURA 4.15 - Modelo com camada de fundação preparada e com suportes de apoio colocados

FIGURA 4.16 - Sucção do excesso de areia. 
FIGURA 4.17 - Trincheira preparada para envelopamento.

FIGURA 4.18 - Modelo sendo preparado (pluviação de areia)

FIGURA 4.19 - Modelo finalizado

FIGURA 4.20 - Comportamento aceleração x recalque (LVDT 1) obtido para os modelos da série 1 .

FIGURA 4.21 - Modelo R-PET-4 após ensaio

FIGURA 4.22 - Comportamento aceleração x recalque (LVDT 1) obtido para os modelos da série 2 .

FIGURA 4.23 - Curva Aceleração x recalque (ensaios R-PET-1P)

FIGURA 4.24 - Curva Aceleração x recalque (ensaios R-PET-1, 2, 3 e 4)

FIGURA 4.25 - Curva Aceleração x recalque (ensaio R-PP-1P)

FIGURA 4.26 - Curva Aceleração x recalque (ensaios R-PP-1 e 2)

FIGURA 4.27 - Curva Aceleração x recalque (ensaios F-PET-1, 2, 3 e 4)

FIGURA 4.28 - Curva Aceleração x recalque (ensaios F-PP-1, 2, 3 e 4)

FIGURA 4.29 - Recalque $\mathrm{x}$ tempo para os modelos da série 1

FIGURA 4.30 - Recalque $\mathrm{x}$ tempo para os modelos da série 2

FIGURA 4.31 - Comportamento da função sigmóide utilizada

FIGURA 4.32 - Distribuição de deformação resultante da função de deslocamento adotada.

FIGURA 4.33 - Deslocamentos dos marcos de areia obtidos para o ensaio R-PET-3, camada 10.

FIGURA 4.34 - Deformação no reforço para o ensaio R-PET-3, camada 10 .

FIGURA 4.35 - Temperatura medida no ensaio F-PP-3 através dos termopares T1, T2, T3 e T4. 
FIGURA 4.36 - Comportamento típico "aceleração x recalque" obtido para os modelos da série 1 .

FIGURA 4.37 - Resultado típico obtido no ensaio de tração para o PET.

FIGURA 4.38 - Rasgos nos geotêxteis (a) PET, ensaio R-PET-2, camada 6 (b) PP, ensaio R-PP-2, camada 9.

FIGURA 4.39 - Localização da superfície de ruptura para os modelos R-PET-2 e R-PET-3

FIGURA 4.40 - Localização da superfície para o modelo R-PP-2

FIGURA 4.41 - Variação da aceleração na ruptura com o número de camadas no modelo (ZORNBERG et al., 1998a)

FIGURA 4.42 - Mecanismo de estriccão (a) sem impregnação de partículas (b) com impregnação.

FIGURA 4.43 - (a) Impregnação de partículas em geotêxteis (b) Impregnação de partículas em geotêxteis com o aumento da tensão (c) Impregnação de partículas no material dos modelos (d) Impregnação de partículas no material dos modelos com o aumento de tensão.

FIGURA 4.44 - Distribuição da força máxima com a profundidade adotada em projetos

FIGURA 4.45 - Distribuição retangular da força no reforço

FIGURA 4.46 - Distribuição da deformação máxima em cada camada com a profundidade (z) observada no modelo R-PET-3

FIGURA 4.47 - Padrão de deformação observado nos modelos - ensaio R-PET-3

FIGURA 4.48 - Padrão de deformação observado em um muro de contenção convencional (modificado de TOYOSAWA et al. 2002).

FIGURA 4.49 - Comparação entre as deformações obtidas nos modelos $\left(40 \% a_{r}\right)$ e as obtidas nos ensaios de fluência não confinada $\left(40 \% \mathrm{~T}_{\text {ult }}\right)$, geotêxtil de PET.

FIGURA 4.50 - Comparação entre as deformações obtidas nos modelos $\left(60 \% a_{r}\right)$ e as obtidas nos ensaios de fluência não confinada $\left(60 \% \mathrm{~T}_{\text {ult }}\right)$, geotêxtil de PET. 
FIGURA 4.51 - Comparação entre as deformações obtidas nos modelos $\left(80 \% \mathrm{a}_{\mathrm{r}}\right)$ e as obtidas nos ensaios de fluência não confinada $\left(80 \% \mathrm{~T}_{\text {ult }}\right)$, geotêxtil de PET.

FIGURA 4.52 - Comparação entre as deformações obtidas nos modelos $\left(40 \% a_{r}\right)$ e as obtidas nos ensaios de fluência não confinada $\left(40 \% \mathrm{~T}_{\text {ult }}\right)$, geotêxtil de PP.

FIGURA 4.53 - Comparação entre as deformações obtidas nos modelos $\left(60 \% \mathrm{a}_{\mathrm{r}}\right)$ e as obtidas nos ensaios de fluência não confinada $\left(60 \% \mathrm{~T}_{\text {ult }}\right)$, geotêxtil de PP.

FIGURA 4.54 - Comparação entre as deformações obtidas nos modelos $\left(80 \% \mathrm{a}_{\mathrm{r}}\right)$ e as obtidas nos ensaios de fluência não confinada $\left(80 \% \mathrm{~T}_{\text {ult }}\right)$, geotêxtil de PP.

FIGURA 4.55 - Distribuição de deformação para faces flexíveis.

FIGURA 5.1 - (a) Estimativa da carga no reforço no muro com base em ensaios de tração (b) fluência em laboratório para a carga $\mathrm{T}_{\mathrm{a} 1}$ e deformações com o tempo no muro.

FIGURA 5.2 - Ensaios de tração realizados com diferentes taxas de deformação (BOYLE, 1996).

FIGURA 5.3 - Efeito da taxa de deformação na avaliação da carga no reforço com base na deformação verificada no muro.

Diferença entre ensaios de fluência com tempos de carregamento diferentes.

FIGURA 5.5 - Procedimento mais adequado para a comparação das deformações ao longo do tempo em muros com resultados de ensaios.

FIGURA 5.6 - Configuração dos protótipos (ALLEN \& BATHURST, 2002b)

FIGURA 5.7 - Curva tensão x deformação do solo com indicação da possibilidade de restrição da fluência do reforço pela presença do solo.

FIGURA 5.8 - Elemento de solo reforçado 
FIGURA 5.9 - Mecanismo quando o solo apresenta menor tendência à fluência $\left(\varepsilon_{0}<\varepsilon_{\mathrm{p}}\right)$ (a) Força requerida pelo solo e tensão no reforço imediatamente após a aplicação de $\sigma_{\mathrm{v}}$ (b) força requerida pelo solo ao longo do tempo (c) força no reforço ao longo do tempo (d) compatibilidade entre carga requerida e força no reforço ao longo do tempo.

FIGURA 5.10 - Mecanismo quando o solo apresenta menor tendência à fluência $\left(\varepsilon_{0}>\varepsilon_{\mathrm{p}}\right)$ (a) Força requerida pelo solo e tensão no reforço imediatamente após a aplicação de $\sigma_{\mathrm{v}}$ (b) força requerida pelo solo ao longo do tempo (c) força no reforço ao longo do tempo (d) compatibilidade entre carga requerida e força no reforço ao longo do tempo.

FIGURA 5.11 - Força $\mathrm{x}$ deformação no reforço para compatibilizar as necessidades entre solo e reforço quando $\varepsilon_{0}>\varepsilon_{\mathrm{p}}$

FIGURA 5.12 - Mecanismo quando o solo apresenta uma maior tendência à fluência em relação ao reforço (a) Força requerida pelo solo e tensão no reforço imediatamente após a aplicação de $\sigma_{\mathrm{v}}$ (b) força requerida pelo solo ao longo do tempo (c) força no reforço ao longo do tempo (d) compatibilidade entre carga requerida e força no reforço ao longo do tempo.

FIGURA 5.13 - Taxa de fluência tipicamente observada para areias (MURAYAMA et al., 1984).

FIGURA 5.14 - Taxa de fluência observada em geossintéticos (GT geotêxtil tecido, GG - geogrelha).

FIGURA 5.15 - Comparação entre tendência à fluência de areias e geossintéticos para um mesmo nível de carregamento.

FIGURA 5.16 - Comparação entre tendência à fluência de areias e geossintéticos para níveis de carregamento diversos. 


\section{Lista de Tabelas}

TABELA 2.1 - Fatores de redução considerando a fluência (KOERNER, 1998).

TABELA 2.2 - Fatores de redução para a resistência à tração 50 (KOERNER, 1998).

TABELA 2.3 - Deslocamentos e deformações observados em protótipos de muros de solo reforçado e em obras instrumentadas.

TABELA 2.4 - Localização da máxima deformação registrada 65 considerando todas as inclusões.

TABELA 3.1 - Resultados dos ensaios de gramatura e tração do 101 geotêxtil tecido

TABELA 3.2 - Ângulo de atrito de pico obtido nos ensaios triaxiais $\quad 105$

TABELA 3.3 - Ensaios realizados com graxa A.

TABELA 3.4 - Ensaios inicialmente realizados com a graxa B.

TABELA 3.5 - Ensaios realizados com a graxa B.

TABELA 3.6 - Ensaios de cisalhamento para seleção da proporção de pó de PTFE $\left(\sigma_{\mathrm{n}}=50 \mathrm{kPa}, \mathrm{v}=1 \mathrm{~mm} / \mathrm{min}\right)$.

TABELA 3.7 - Ensaios de cisalhamento com graxa B + 20\% de PTFE.

TABELA 3.8 - Ensaios e testes realizados com o equipamento desenvolvido.

TABELA 3.9 - Ensaios de relaxação

TABELA 3.10 - Resultado do ensaio S2T

TABELA 3.11 - Valores utilizados para estimativa do atrito lateral.

TABELA 3.12 - Valores registrados para a carga nos ensaios com reforço. 
TABELA 3.14 - Redução da carga após 10 h em relação ao valor inicial.

TABELA 3.15 - Redução da carga após 10 h em relação ao valor inicial 148 para ensaios SR5 e SR6R.

TABELA 3.16 - Valores adotados na estimativa de $\mathrm{P}_{\mathrm{r}}$ após $10 \mathrm{~h}$ de ensaio 148

TABELA 4.1 - Fatores de escala utilizados em modelagem em 158 centrífuga

TABELA 4.2 - Fatores de escala para estruturas de solo reforçado 159 (ZORNBERG et al., 1997)

TABELA 4.3 - Resistência à tração e deformação na ruptura para o geotêxtil de PET.

TABELA 4.4 - Resistência à tração e deformação na ruptura para o geotêxtil de PP.

TABELA 4.5 - Ensaios realizados

TABELA 4.6 - Temperaturas registradas nos ensaios

TABELA 4.7 - Valores de $\mathrm{a}_{\mathrm{r}}$ adotados em cada ensaio.

TABELA 4.8 - Aceleração prevista através da expressão 4.6 para os modelos.

TABELA 5.1 - Relação entre a taxa de fluência nos ensaios 230 convencionais e nos protótipos. 


\title{
Lista de siglas, abreviaturas e símbolos
}

\author{
ABNT - Associação Brasileira de Normas Técnicas \\ AC - Após construção \\ AS - Após sobrecarga \\ ASTM - American Society for Testing and Materials \\ GG - Geogrelha \\ GT - Geotêxtil \\ HDPE - Polietileno de alta densidade \\ ISO - International Organization for Standardization \\ LDPE - Polietileno de baixa densidade \\ NBR - Norma Brasileira Registrada \\ PA - Poliamida \\ PE - Polietileno \\ PET - Poliéster \\ PP - Polipropileno \\ PVC - Policloreto de Vinila \\ PTFE - Teflon \\ A ～- área \\ $\mathrm{A}_{\mathrm{b}} \quad$ - Área do corpo-de-prova em contato com a borracha
}



$\mathrm{A}_{\mathrm{v}} \quad$ - Área do corpo-de-prova em contato com o vidro
a - Comprimento do reforço na zona ativa, aceleração
$a_{\text {colapso }}$ - Aceleração para a qual se observa o desmoronamento do modelo
$a_{\mathrm{r}} \quad$ - Aceleração na ruptura
$\mathrm{C}_{\mathrm{u}}$ - Coeficiente de não uniformidade
c $\quad$ - Coesão
$\mathrm{D}_{\mathrm{r}} \quad$ - Densidade relativa
e $\quad$ - Espessura da manta

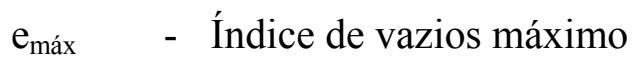
$\mathrm{e}_{\min } \quad$ - Índice de vazios mínimo
F $\quad-$ Força
$\mathrm{F}_{\mathrm{h} 0,3} \quad$ - Força horizontal para uma deformação igual a $0,3 \%$
$\mathrm{F}_{\mathrm{h} 1} \quad-$ Força horizontal na lateral 1 da caixa de ensaios
$\mathrm{F}_{\mathrm{h} 2} \quad-$ Força horizontal na lateral 2 da caixa de ensaios
$\mathrm{FR}_{\mathrm{amb}}$ - Fator de redução devido a danos ambientais
$\mathrm{FR}_{\mathrm{DB}}$ - Fator de redução para degradação biológica
$\mathrm{FR}_{\mathrm{DI}}$ - Fator de redução para danos de instalação
$\mathrm{FR}_{\mathrm{DQ}}$ - Fator de redução para degradação química
$\mathrm{FR}_{\mathrm{FL}} \quad$ - Fator de redução para fluência 
$\mathrm{f}_{\mathrm{m}} \quad$ - Fator de redução que leva em conta incertezas sobre o material do reforço

g - Aceleração da gravidade

J - Rigidez do reforço

$\mathrm{J}_{\text {fluência }} \quad$ - Rigidez do reforço por fluência

$\mathrm{J}_{\text {relaxação }}$ - Rigidez do eforço por relaxação

$\mathrm{H} \quad-$ Altura

K - Rigidez do elemento de mola

$\mathrm{k}_{\mathrm{a}} \quad$ - Coeficiente de empuxo ativo

$\mathrm{k}_{0} \quad-$ Coeficiente de empuxo em repouso

L $\quad$ - Comprimento

$\mathrm{N} \quad$ - Fator de escala para a aceleração no modelo

n $\quad$ - Número de reforços

$\mathrm{P}_{\mathrm{sa}} \quad$ - Carga sem atrito na caixa

$\mathrm{P}_{\mathrm{r}} \quad$ - Carga registrada pela célula de carga

q $\quad-$ Sobrecarga

$\mathrm{S}_{\mathrm{h}} \quad$ - Espaçamento horizontal

$\mathrm{S}_{\mathrm{v}} \quad$ - Espaçamento vertical

$\mathrm{T} \quad$ - Força de tração no reforço

$\mathrm{T}_{\mathrm{adm}} \quad-$ Resistência admissível 


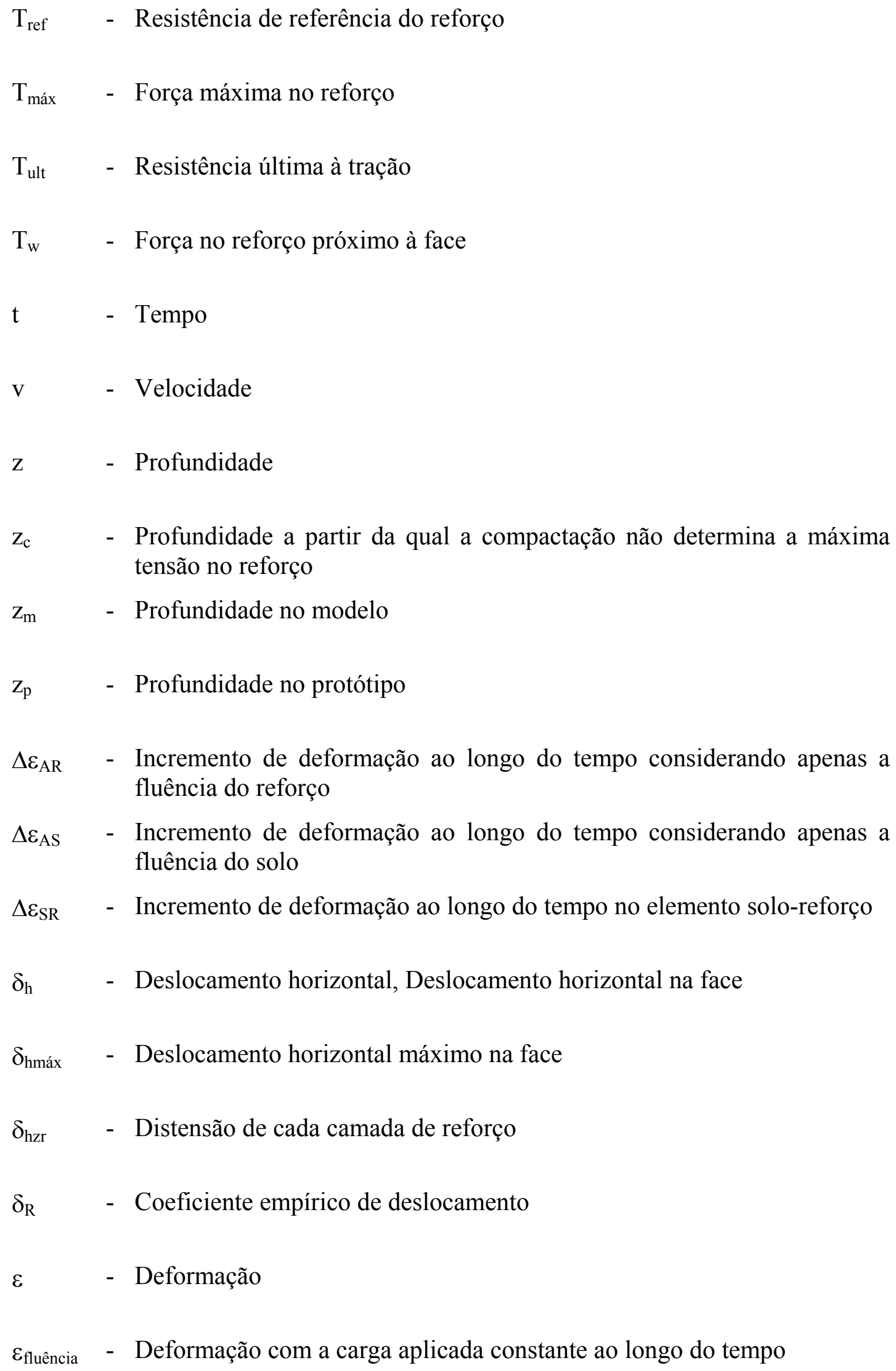
tensão no reforço

$\mathrm{Z}_{\mathrm{m}} \quad$ - Profundidade no modelo

$\mathrm{z}_{\mathrm{p}} \quad-\quad$ Profundidade no protótipo

$\Delta \varepsilon_{\mathrm{AR}}$ - Incremento de deformação ao longo do tempo considerando apenas a fluência do reforço

$\Delta \varepsilon_{\mathrm{AS}}$ - Incremento de deformação ao longo do tempo considerando apenas a fluência do solo

$\Delta \varepsilon_{\mathrm{SR}} \quad-$ Incremento de deformação ao longo do tempo no elemento solo-reforço

$\delta_{\mathrm{h}} \quad-$ Deslocamento horizontal, Deslocamento horizontal na face

$\delta_{\text {hmáx }} \quad$ - Deslocamento horizontal máximo na face

$\delta_{\text {hzr }} \quad$ - Distensão de cada camada de reforço

$\delta_{\mathrm{R}} \quad$ - Coeficiente empírico de deslocamento

$\varepsilon \quad$ - Deformação

$\varepsilon_{\text {fluência }} \quad$ - Deformação com a carga aplicada constante ao longo do tempo 


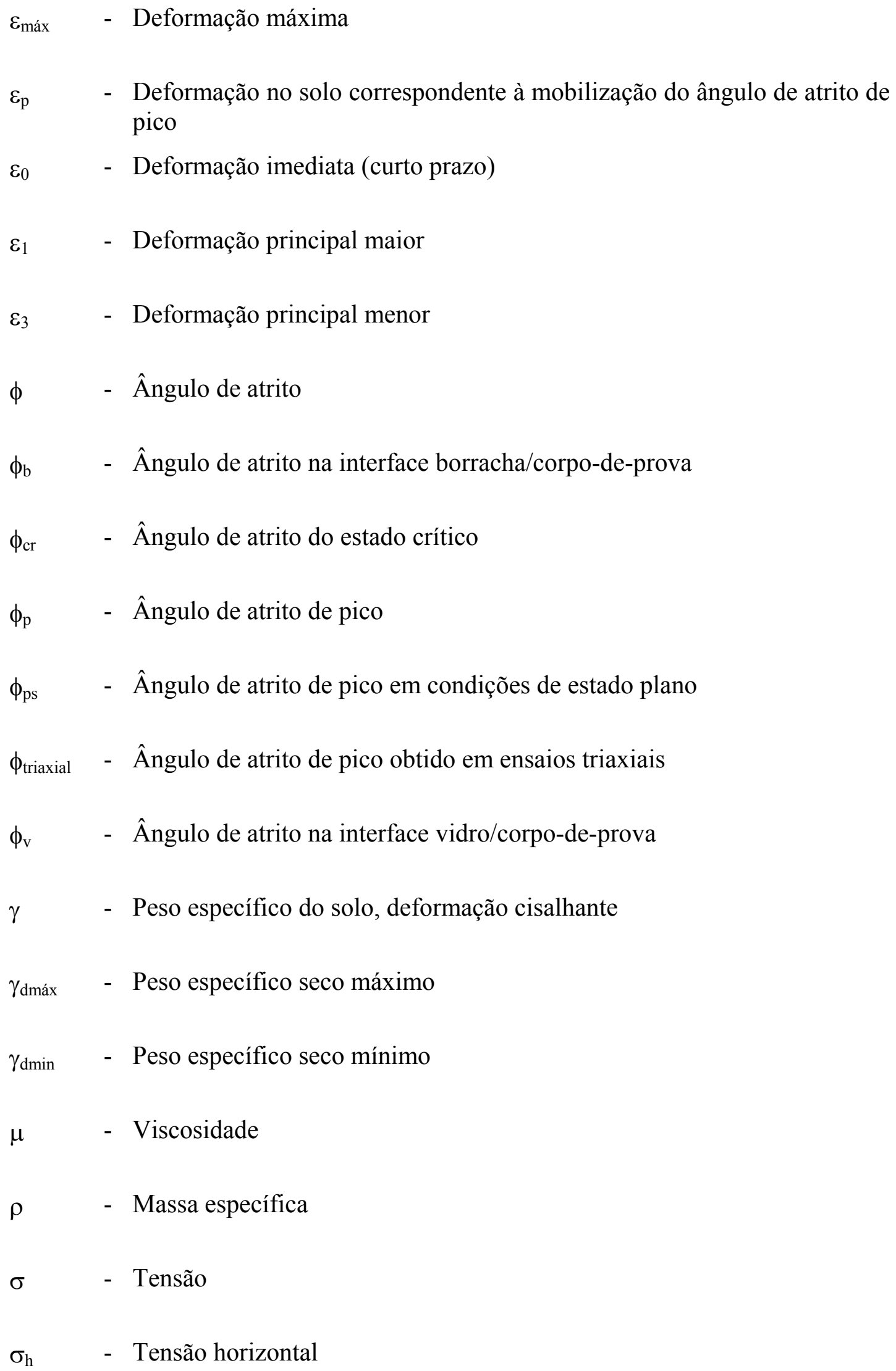




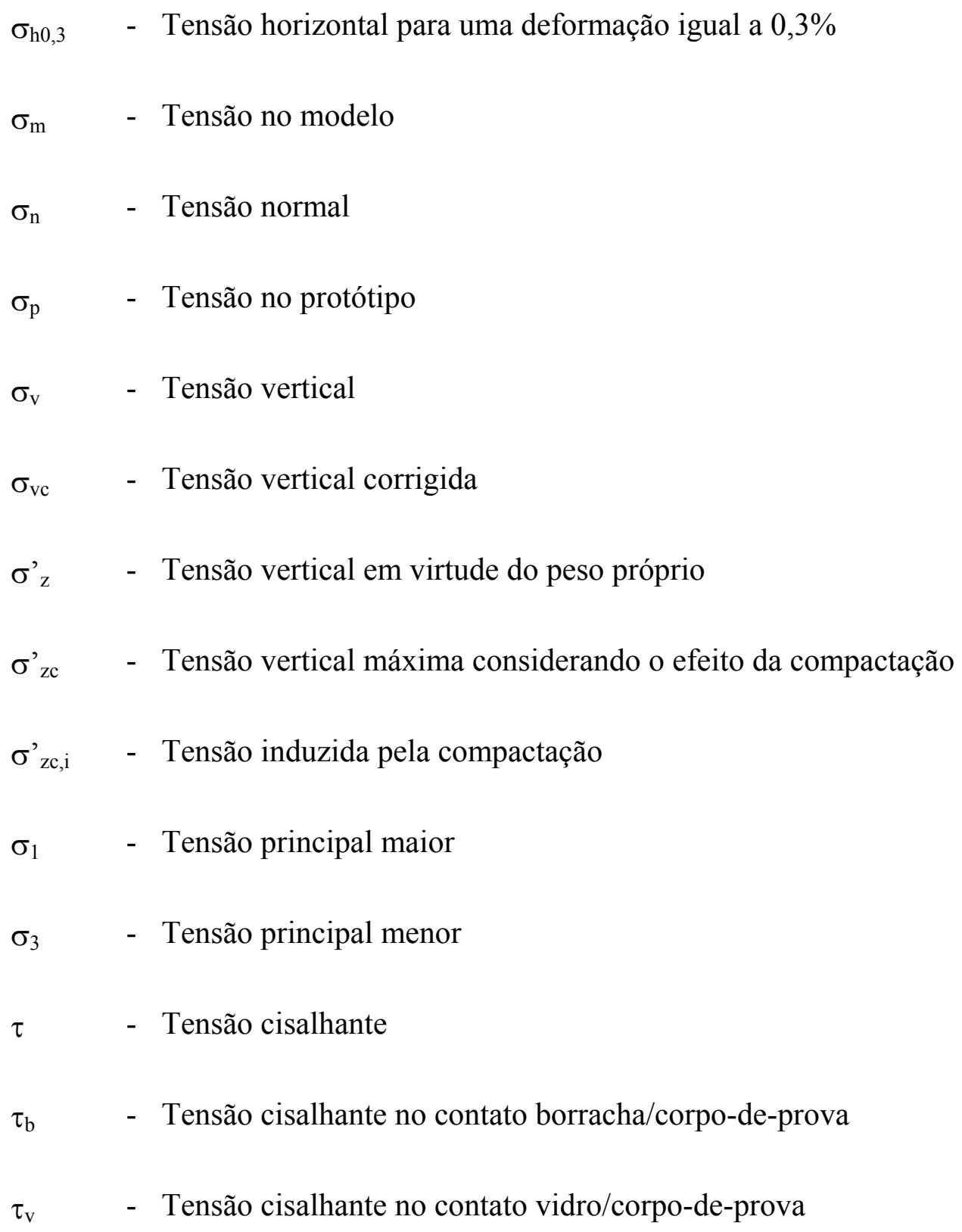




\section{Resumo}

COSTA, C. M. L. (2004). Deformações dependentes do tempo em muros de solo reforçado com geotêxteis. Tese - Escola de Engenharia de São Carlos, Universidade de São Paulo, São Carlos, 2004.

Este trabalho apresenta um estudo sobre deformações de geotêxteis ao longo do tempo, considerando interações entre reforço e solo confinante em muros de solo reforçado. O programa experimental desenvolvido para esse fim envolveu duas etapas básicas. Na primeira etapa, um novo equipamento foi desenvolvido na Escola de Engenharia de São Carlos/USP, para a realização de ensaios de fluência com um elemento de solo reforçado. O equipamento desenvolvido permite simular o mecanismo típico de transferência de carga em estruturas de solo reforçado, isto é, o solo solicita o geotêxtil. Esse equipamento também possibilita que solo e geotêxtil apresentem deformações ao longo do tempo de forma interativa. Nessa etapa, o programa de ensaios foi conduzido utilizando-se uma areia pura e um geotêxtil de polipropileno. Na segunda etapa deste trabalho, modelos de muros de solo reforçado foram ensaiados em centrífuga na Universidade do Colorado em Boulder, EUA. Os referidos modelos foram construídos utilizando-se uma areia e mantas de poliéster e de polipropileno. Alguns modelos foram carregados até a ruptura com acréscimo de aceleração, enquanto outros foram observados, no decorrer do tempo, sob aceleração constante. Nos ensaios para investigação de fluência, deformações significativas foram observadas, ocorrendo, inclusive, a manifestação de ruptura em determinados modelos, após algumas horas de ensaio. Os ensaios realizados nas duas etapas do trabalho revelaram aspectos importantes relativos à interação solo-reforço. Com base na interpretação dos resultados experimentais, apresenta-se uma discussão sobre mecanismos de deformação, em função do tempo, em muros de solo reforçado.

Palavras-chave: geotêxtil, fluência, relaxação, solo reforçado, geossintéticos. 


\section{Abstract}

COSTA, C. M. L. (2004). Time-dependent deformations in geotextile reinforced soil walls. Thesis - School of Engineering at Sao Carlos, University of Sao Paulo, Sao Carlos, 2004.

This thesis presents a study on the time-dependent deformations of geotextiles in reinforced soil walls considering the long-term interactive behavior between the reinforcement and the confining soil. The experimental program comprised two distinct phases. In the first phase, a new equipment was designed and constructed at the School of Engineering at Sao Carlos/USP, Brazil, in an attempt to perform creep tests with an element of reinforced soil. This equipment simulates the typical load transfer mechanism in reinforced soil structures, that is, the load is transferred from the soil to the reinforcement. This equipment also allows long-term interactive deformations between the soil and the geotextile. The testing program of this phase was conducted using a pure dry sand and a polypropylene geotextile. In the second phase of this research, models of reinforced soil walls were tested in a centrifuge facility at the University of Colorado at Boulder, USA. The models were built using a pure dry sand and a polyester or polypropylene geotextile. The models were either loaded until failure increasing the centrifugal acceleration or tested under constant acceleration. Considerable strains were observed in the creep tests, and some of the models failed after a few hours. The testing programs carried out in this study revealed important aspects of the soil-reinforcement interaction. Based on the analyses of the experimental results a broad discussion on long-term deformation mechanisms in reinforced soil walls is made herein.

Keywords: geotextile, creep, stress relaxation, reinforced soil, geosynthetics. 
Capítulo 1

\section{Introdução}

Os muros de solo reforçado com geossintéticos constituem uma solução de engenharia atraente do ponto de vista econômico e apresentam vantagens expressivas do ponto de vista técnico, motivo pelo qual representam uma alternativa em obras de contenção com tendência crescente de utilização. Todavia, a despeito das vantagens, os geossintéticos possuem um comportamento tensão-deformação dependente do tempo, revelado, por exemplo, mediante fluência, isto é, deformação ao longo do tempo sob carga constante.

O comportamento dependente do tempo de geotêxteis apresenta-se extremamente importante em muros de solo reforçado já que, em tais estruturas, o reforço é solicitado à tração durante toda a vida útil da obra. Nesses casos, a consideração da fluência é de fundamental importância em projetos, pois resulta em dois efeitos potencialmente nocivos ao desempenho da estrutura:

(i) pode provocar deformações excessivas e, portanto, inaceitáveis do ponto de vista de utilização da estrutura, principalmente, considerando-se o elevado tempo de vida útil de algumas obras;

(ii) pode provocar ruptura, o que implica, na maioria das vezes, conseqüências catastróficas.

Esse problema tem sido considerado em projetos de muros de solo reforçado, aplicando-se, geralmente, um fator de redução para a resistência à tração do reforço em virtude da possibilidade de fluência. Valores entre 2 e 5 são freqüentemente 
empregados, a depender do polímero e do tipo de estrutura considerada.

Os procedimentos de dimensionamento utilizados atualmente em muros de solo reforçado têm resultado em obras com excelente desempenho e que não apresentam deformações significativas em função do tempo. Em obras instrumentadas, tais deformações têm sido menores que os valores esperados, quando confrontadas com resultados de ensaios de fluência do reforço em laboratório. No entanto, esse comportamento ainda não foi devidamente esclarecido. Assim, embora os métodos para projeto resultem em estruturas que apresentam um adequado comportamento ao longo do tempo, o real mecanismo desenvolvido em longo prazo é ainda muito pouco compreendido.

Com relação ao conhecimento acumulado até o presente momento, destaca-se o fato de algumas pesquisas terem demonstrado que a presença de confinamento pode reduzir a fluência de geotêxteis não tecidos. Uma outra questão, no que diz respeito aos mecanismos de interação desenvolvidos ao longo do tempo, é a possibilidade da fluência do solo confinante interferir na fluência do reforço. WU \& HELWANY (1996) afirmam, por exemplo, que quando o solo apresenta menor susceptibilidade à fluência em relação ao reforço, a menor tendência à fluência do solo tende a restringir a fluência do reforço. No entanto, ao se avaliar as pesquisas presentes na literatura referentes ao assunto, fica evidente que esses mecanismos de interação solo-reforço, no decorrer do tempo, ainda não estão devidamente discutidos e comprovados.

Assim sendo, apesar da importância do tema e do interesse crescente da comunidade científica, nos últimos anos, acerca desses mecanismos, ainda se percebe uma acentuada ausência de informações com relação à deformação de geotêxteis em função do tempo na presença de solo. Nesse contexto, ALLEN \& BATHURST (2002) relatam que uma atenção considerável tem sido dispensada ao estudo do comportamento, em longo prazo, de muros de solo reforçado considerando, apenas, os geossintéticos, porém, um esforço bastante limitado tem sido dispensado no sentido de estabelecer o desempenho da estrutura como um todo. Com efeito, para um melhor entendimento do comportamento da estrutura, necessário se faz considerar o problema em função de todos os elementos componentes e não, unicamente, em função do reforço. 
Diante desse cenário, investigações sobre o comportamento dependente do tempo dos geossintéticos, considerando sua aplicação em muros de solo reforçado, são necessárias e altamente justificáveis, já que o maior fator de redução da resistência à tração do reforço empregado em projetos deve-se à possibilidade de fluência. A comprovação da menor fluência do reforço em virtude de restrições causadas pelo solo poderia, por exemplo, viabilizar a adoção de métodos de dimensionamento menos conservadores, reduzindo ainda mais os custos envolvidos nesse tipo de solução.

Tais aspectos ratificam a importância do tema e se apresentaram com motivação para o desenvolvimento deste trabalho cujo escopo consistiu em estudar as deformações dependentes do tempo de geotêxteis em muros de solo reforçado, considerando possíveis interações entre o geotêxtil e o solo confinante, e não apenas o comportamento isolado do material.

\subsection{Objetivos}

Como citado, embora o interesse pelos efeitos da fluência dos geossintéticos em obras geotécnicas venha crescendo a cada dia, muito ainda se faz necessário para uma compreensão mais adequada do problema. $\mathrm{Na}$ intenção de contribuir para um melhor entendimento dessa questão, o presente trabalho teve por objetivos específicos:

a) Projetar e desenvolver um novo equipamento que possibilite a realização de ensaios de fluência com um elemento composto por um geotêxtil confinado entre duas camadas de solo. Esse equipamento deve permitir que o solo solicite o geotêxtil e ambos possam deformar ao longo do tempo (na tentativa de se reproduzir, na medida do possível, as condições de solicitação em campo);

b) Realizar ensaios para testar o equipamento desenvolvido e investigar alguns aspectos referentes à interferência das características de fluência do solo confinante na fluência dos geotêxteis;

c) Estudar o mecanismo de fluência em muros de solo reforçado através de modelos reduzidos em centrífuga, investigando aspectos como ruptura por 
fluência e mecanismos de interação entre reforços. Adicionalmente, verificar se a magnitude das deformações da estrutura, no decorrer do tempo, está de acordo com o comportamento esperado para o geotêxtil, considerando os ensaios de fluência com o material isolado.

d) Tomando por base os resultados obtidos, proceder a uma discussão sobre possíveis mecanismos de deformação ao longo do tempo em muros de solo reforçado.

O programa experimental desenvolvido foi conduzido em duas instituições diferentes: a etapa relativa aos itens ' $a$ ' e 'b' foi realizada na Escola de Engenharia de São Carlos/USP, enquanto a etapa relativa aos modelos em centrífuga (item c) foi realizada na Universidade do Colorado em Boulder, EUA.

\subsection{Organização do texto}

A tese está dividida de acordo com a seqüência cronológica das etapas de pesquisa efetuadas, a fim de facilitar a compreensão do trabalho desenvolvido. Primeiramente, um novo equipamento foi desenvolvido para avaliar o comportamento, com o tempo, de um elemento composto por um geotêxtil confinado entre duas camadas de solo (etapa 1). Os resultados encontrados nessa etapa auxiliaram a interpretação dos resultados obtidos em condições mais complexas, isto é, modelos de muros de solo reforçado com geotêxteis (etapa 2). Por fim, os resultados obtidos em ambas as etapas foram avaliados a fim de fomentar uma reflexão sobre os mecanismos de interação solo-reforço ao longo do tempo em muros de solo reforçado, considerando situações mais abrangentes que as presentes na parte experimental.

Além deste capítulo, o trabalho encontra-se dividido em mais cinco capítulos. No capítulo 2, apresenta-se uma revisão bibliográfica referente ao tema de pesquisa, dividida, por sua vez, em duas partes principais: i) fluência e relaxação de geotêxteis e ii) deformações em muros de solo reforçado. Na parte relativa à fluência e relaxação de geotêxteis, significativa ênfase é dispensada a equipamentos e procedimentos de ensaio, em virtude do desenvolvimento do equipamento que 
constituiu parte do escopo da pesquisa. No capítulo 3, descreve-se toda a primeira etapa do trabalho, realizada no Laboratório de Geossintéticos da EESC/USP enquanto os ensaios em centrífuga, conduzidos na Universidade do Colorado, são apresentados e analisados no capítulo 4. Em seguida, no capítulo 5, algumas reflexões sobre o tema são efetuadas e, finalmente, no capítulo 6, são expostas as principais conclusões obtidas. 
Capítulo 2

\section{Revisão Bibliográfica}

\subsection{Fluência e relaxação de geotêxteis}

\subsubsection{Conceitos básicos}

Os materiais poliméricos apresentam um comportamento tensão $\mathrm{X}$ deformação dependente do tempo, e nesse sentido dois comportamentos distintos são tradicionalmente identificados: fluência e relaxação. A fluência representa a deformação que esses materiais apresentam ao longo do tempo, sob carregamento constante. A relaxação, por outro lado, corresponde a uma diminuição da carga, no decorrer do tempo, quando a deformação do material é impedida, e permanece constante com o passar do tempo.

Como citado, a fluência de geotêxteis constitui um aspecto importante a ser ponderado em projetos de muros de solo reforçado, pois pode provocar deformações excessivas e uma eventual ruptura. A caracterização da relaxação também pode ser relevante, por exemplo, caso a menor tendência à fluência do solo impeça, de fato, a deformação do geotêxtil ao longo do tempo em muros de solo reforçado.

Não obstante a possibilidade de relaxação de geotêxteis em muros de solo reforçado, a caracterização do comportamento dependente do tempo tem sido 
efetuada, tradicionalmente, através de ensaios de fluência. Tal preferência deve-se, segundo KALIAKIN et al. (2000), principalmente a dois fatores: primeiro, os procedimentos de dimensionamento de estruturas de solo reforçado com geossintéticos são baseados na interpretação de ensaios de fluência e segundo, os ensaios de fluência são mais simples de serem realizados.

De qualquer forma, alguns conceitos básicos relativos à fluência e relaxação de geotêxteis são discutidos a seguir.

\subsubsection{Módulo de rigidez por fluência}

A fluência de geossintéticos é caracterizada através de ensaios nos quais corpos de prova são submetidos a carregamentos constantes, correspondentes a uma parcela da resistência à tração. Conforme mostrado na Figura 2.1a, a observação das deformações, com o passar do tempo, para diferentes níveis de carga $\left(\mathrm{T}_{1}, \mathrm{~T}_{2}, \mathrm{~T}_{3}, \mathrm{~T}_{4}\right.$, $\mathrm{T}_{5}$ ), permite a obtenção de curvas denominadas isócronas (Figura 2.1b). Essas curvas representam a relação carga $\mathrm{x}$ deformação para um mesmo tempo após aplicação do carregamento. $\mathrm{O}$ procedimento de construção da curva isócrona correspondente a um tempo igual a $1 \mathrm{~h}$ encontra-se indicado na Figura 2.1.

A relação entre um determinado valor de carga $(\mathrm{T})$ e a correspondente deformação $(\varepsilon)$ obtida através das curvas isócronas representa a rigidez por fluência ( $\mathrm{J}_{\text {fluência }}$, como mostrado na Figura 2.1b.

\subsubsection{Módulo de rigidez por relaxação}

No que se refere à relaxação, a caracterização desse comportamento pode ser efetuada através de ensaios nos quais a deformação ao longo do tempo é impedida após a aplicação do carregamento inicial. De forma semelhante aos ensaios de fluência, podem-se obter curvas isócronas, como mostrado na Figura 2.2, e a relação entre a carga e a deformação obtida através dessas curvas corresponde à rigidez por relaxação $\left(\mathrm{J}_{\text {relaxação }}\right)$. 

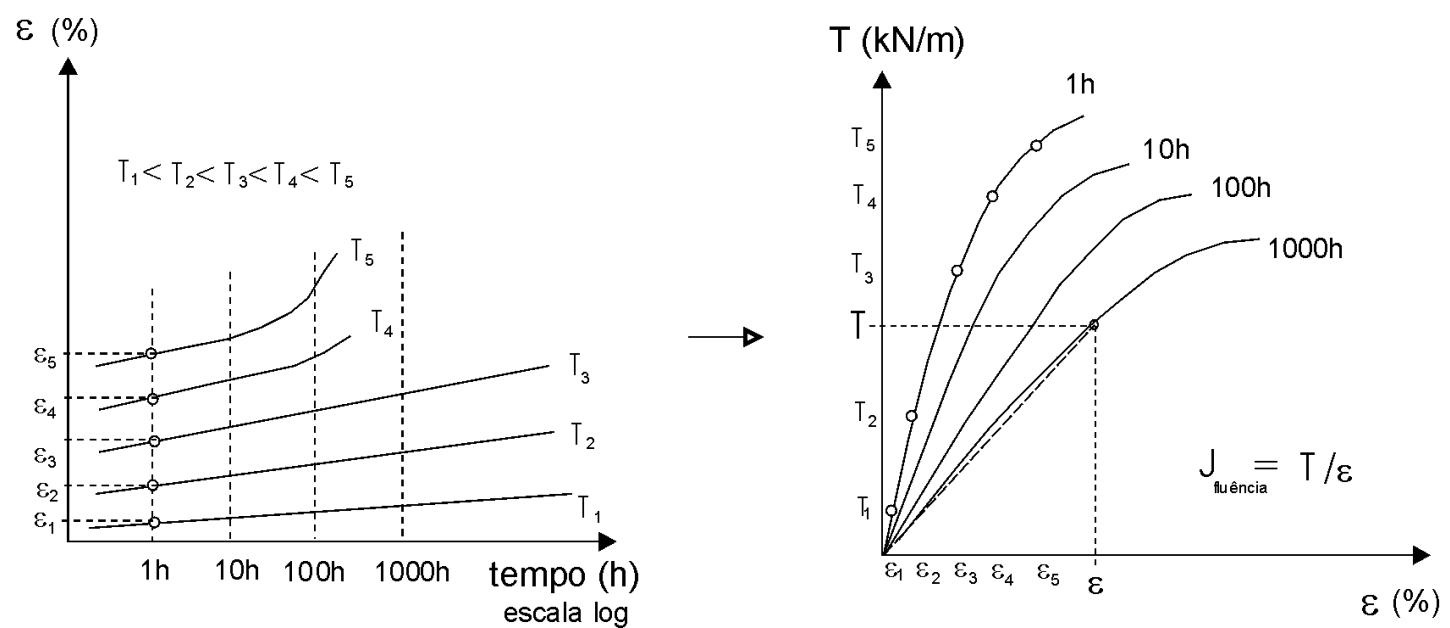

FIGURA 2.1 - Ensaios de fluência (a) curvas deformação versus tempo (b) curvas isócronas.
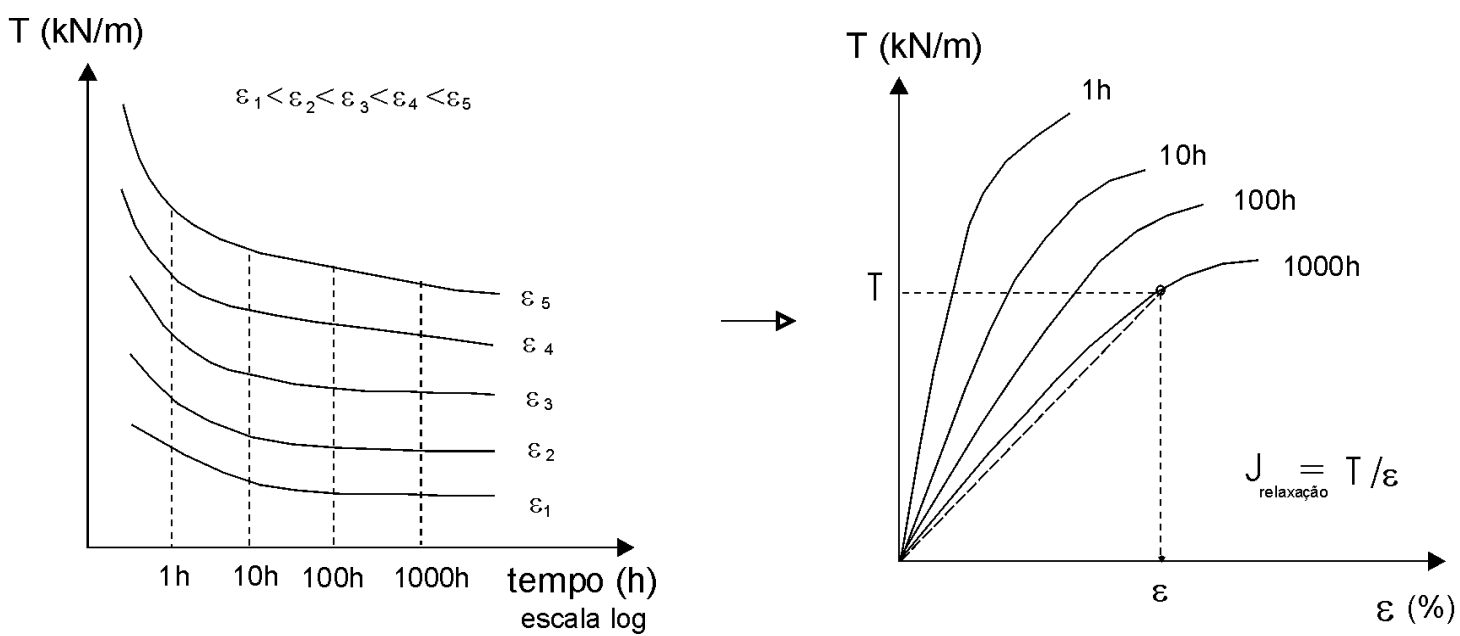

FIGURA 2.2 - Ensaios de relaxação (a) curvas força versus tempo (b) curvas isócronas.

\subsubsection{Comparação entre os mecanismos de fluência e relaxação}

A Figura 2.3 apresenta a trajetória carga - deformação em ensaios de fluência e relaxação para um mesmo intervalo de tempo. $\mathrm{O}$ trecho $\mathrm{OA}$ corresponde à fase de aplicação do carregamento, enquanto os trechos $\mathrm{AC}$ e $\mathrm{AB}$ correspondem às fases de fluência e relaxação, respectivamente. Como ilustrado na Figura, o comportamento dependente do tempo, tanto em termos de fluência quanto de relaxação, provoca uma diminuição da rigidez dos geossintéticos, ao longo do tempo, em relação à rigidez 
considerando apenas o comportamento em curto prazo caracterizado, por exemplo, através de ensaios de tração (i.e, $\mathrm{J}_{\text {fluência }}<\mathrm{J}_{\mathrm{OA}}$ e $\mathrm{J}_{\text {relaxação }}<\mathrm{J}_{\mathrm{OA}}$ ). A perda de rigidez devido à fluência deve-se ao acréscimo de deformação com o tempo, enquanto a redução da capacidade de carga do geossintético, quando a deformação é impedida, responde pela diminuição da rigidez em ensaios de relaxação.

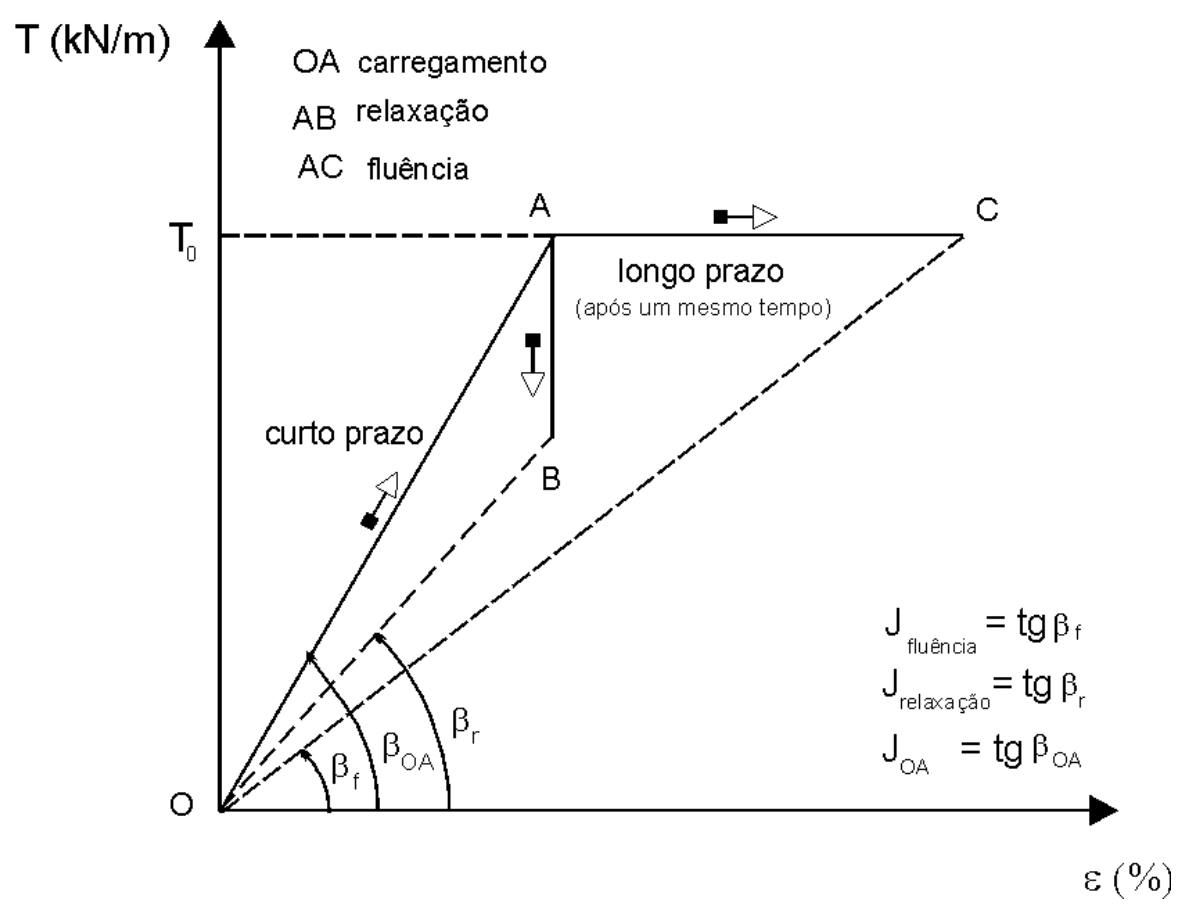

FIGURA 2.3 - Rigidez por fluência inferior à rigidez por relaxação.

Com relação a essa questão, a rigidez dos geossintéticos, obtida para um mesmo tempo após a aplicação da carga inicial $\mathrm{T}_{0}$ (ver Figura 2.3), mediante ensaios de fluência e através de ensaios de relaxação, não é necessariamente igual, como ilustrado na Figura 2.3. Se os módulos obtidos através dessas duas abordagens fossem iguais, as curvas isócronas obtidas nos ensaios por fluência poderiam ser utilizadas, por exemplo, para estimar a diminuição da carga no geossintético quando a deformação permanece constante, suprimindo a necessidade de realização de ensaios de relaxação. No entanto, o módulo obtido para um mesmo intervalo de tempo por meio de ensaios de fluência pode, ainda, ser menor ou maior que o valor obtido em ensaios de relaxação. A Figura 2.3 ilustra uma condição em que a rigidez 
por fluência é inferior à rigidez por relaxação, enquanto a Figura 2.4 ilustra o comportamento oposto, ou seja, rigidez por fluência maior do que por relaxação.

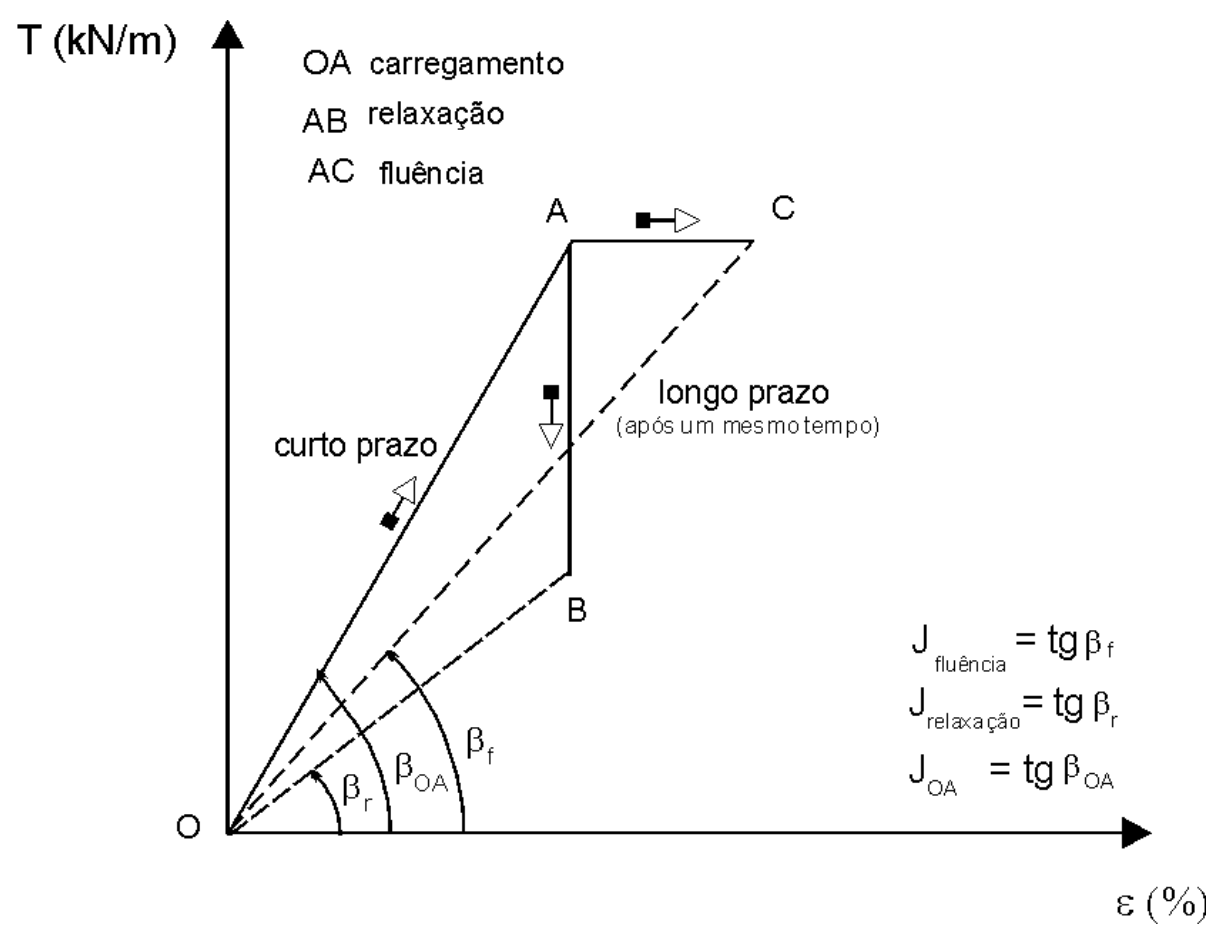

FIGURA 2.4 - Rigidez por relaxação inferior à rigidez por fluência.

A diferença entre o módulo de rigidez obtido em ensaios de fluência e em ensaios de relaxação depende do material e das condições consideradas. Os resultados obtidos por THORNTON (2001) para um geossintético de polipropileno mostram módulos de rigidez por fluência e por relaxação semelhantes para um tempo de observação reduzido (aproximadamente $20 \mathrm{~min}$ ), sendo o módulo de relaxação um pouco inferior ao valor obtido nos ensaios de fluência. Para um maior período de observação, no entanto, o módulo por fluência foi inferior ao módulo por relaxação. Para uma carga inicial em torno de $25 \%$ da resistência à tração, por exemplo, o módulo por fluência para um tempo igual a 3000h foi inferior à metade do módulo obtido por relaxação. Já os resultados mostrados por WALTERS et al. (2002), também considerando um material de polipropileno, indicam um comportamento oposto, ou seja, rigidez por relaxação inferior à rigidez por fluência. 
Apesar das diferenças entre o módulo de rigidez por fluência e por relaxação, isto é, o comportamento de relaxação do geossintético não pode ser adequadamente estimado através de ensaios de fluência, como já citado, o comportamento dependente do tempo tem sido tradicionalmente estudado unicamente através de ensaios de fluência. Apenas recentemente a relaxação de geossintéticos vem sendo considerada com mais destaque.

Ressalta-se que na revisão bibliográfica exposta a seguir o comportamento dependente do tempo de geotêxteis é discutido com ênfase em resultados obtidos através de ensaios de fluência, em virtude da relativa escassez de pesquisas sobre relaxação de geossintéticos.

\subsubsection{Ensaios para avaliar as deformações ao longo do tempo}

\subsubsection{Métodos de ensaio}

Os ensaios para avaliar as deformações dependentes do tempo podem ser divididos em ensaios nos quais o geotêxtil encontra-se confinado e ensaios nos quais o geotêxtil não se apresenta confinado. A divisão leva em conta o fato do corpo de prova estar ou não, submetido ao efeito de tensões confinantes durante a realização do ensaio, geralmente entre camadas de solo. Os ensaios com confinamento, obviamente, se aproximam mais da condição de solicitação dos geotêxteis em campo, contudo, esses ensaios provocam dificuldades adicionais com a relação à execução e interpretação dos resultados.

A norma brasileira referente ao assunto diz respeito à fluência sem confinamento, e como ainda se encontra em processo de discussão, alguns resultados disponíveis de fluência de geotêxteis nacionais têm por base normas internacionais (ex., ASTM D5262, 1994; ISO 13431, 1998). No caso de fluência com confinamento, nenhuma norma (em nível mundial) estabelece uma técnica para esses ensaios que, portanto, são baseados nas normas relativas à fluência sem confinamento.

Nos ensaios de fluência sem confinamento, corpos de prova, normalmente com 200 mm de largura (fluência de faixa larga), são submetidos a carregamentos constantes correspondentes a uma parcela da resistência à tração. Duas abordagens 
diferentes podem ser adotadas, dependendo do aspecto a ser investigado. Para caracterizar as deformações ao longo do tempo, cargas entre $10 \%$ e $40 \%$ da resistência à tração são geralmente aplicadas, procedendo-se ao registro das deformações em tempos pré-estabelecidos. Caso a ruptura por fluência seja o objeto de interesse, costumam-se aplicar cargas entre $60 \%$ e $90 \%$ da resistência à tração e o registro do tempo de ruptura corresponde à informação mais importante.

Os ensaios para os maiores níveis de carregamento, em geral, atingem 1000 horas, enquanto os efetuados com menores cargas podem atingir mais de 10.000 horas (MURRAY \& McGOWN, 1988). Assim, o tempo de ensaio naturalmente constitui um grande empecilho em estudos de fluência.

Uma alternativa usada para suplantar esse problema consiste na utilização da temperatura como aliada em ensaios de laboratório, já que a mesma acelera o processo de fluência, reduzindo o tempo de duração dos ensaios. Os ensaios realizados com utilização de temperaturas elevadas são denominados acelerados e os resultados obtidos nos ensaios, quando devidamente tratados, permitem obter curvas de fluência correspondentes a um período de tempo bem superior ao tempo de ensaio.

Os métodos de ensaios acelerados apresentam algumas variações e o tratamento dos dados pode ser efetuado, por exemplo, com auxílio da equação de Arrhenius, como descrito em maiores detalhes por KOERNER et al. (1992), FARRAG (1997) e THORNTON et al. (1997). Um método que vem obtendo destaque atualmente é o método proposto por THORNTON et al. (1998), denominado Stepped Isothermal Method (SIM). Esse método é discutido detalhadamente por BARAS (2001) que apresenta uma compilação de métodos de execução e tratamento de ensaios acelerados.

Os resultados obtidos em ensaios sem confinamento, acelerados ou não, podem ser apresentados de diversas formas, cada uma facilitando a análise dos resultados sob determinado ponto de vista. Além das curvas deformação x tempo e das curvas isócronas, mostradas anteriormente, é comum ainda a utilização de curvas denominadas Sherby-Dorn. Estas curvas apresentam o logaritmo da taxa de deformação x deformação, mostrando claramente quando o material se aproxima da ruptura, linha de instabilidade mostrada na Figura 2.5. 


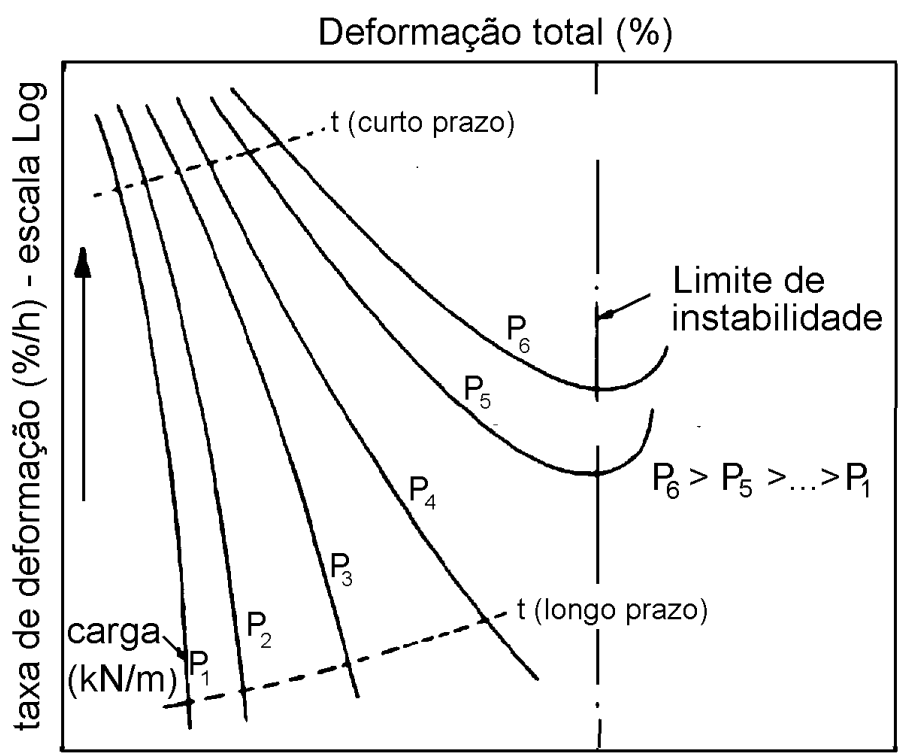

FIGURA 2.5 - Curvas Sherby-Dorn (McGOWN et al., 1986).

Os resultados dos ensaios para verificação de ruptura por fluência são geralmente apresentados como mostra a Figura 2.6, demonstrando, na maioria das vezes, um comportamento linear (MÜLLER-ROCHHOLZ, 1998). Com base nos resultados, é possível realizar um estudo estatístico e traçar uma curva correspondente a um limite inferior de confiança, considerando uma probabilidade de ocorrência igual a 95\% (GREENWOOD, 1998; ZAMMITT, 1998). Tais ensaios permitem a determinação da carga de ruptura por fluência, que pode ser obtida através da extrapolação da curva de limite inferior, tendo em vista o tempo de utilização da obra, no caso da Figura 2.6, 120 anos.

Com relação aos ensaios com confinamento, não existe consenso no que diz respeito aos procedimentos de ensaio e apresentação de resultados já que, como mencionado anteriormente, esse ensaio não se encontra normalizado. De uma forma geral e com base na revisão da literatura realizada, considera-se que se podem distinguir duas abordagens distintas em ensaios com confinamento: ensaios nos quais a carga é aplicada diretamente ao geotêxtil e ensaios nos quais o solo solicita o geotêxtil. 
No primeiro caso, pretende-se estudar o comportamento do reforço quando confinado no solo, considerando o efeito da tensão confinante, bem como uma eventual impregnação de partículas no geotêxtil. Nessa abordagem, a manta é confinada entre camadas de solo e uma força de tração é aplicada diretamente ao geotêxtil, por meio, por exemplo, de pesos mortos.

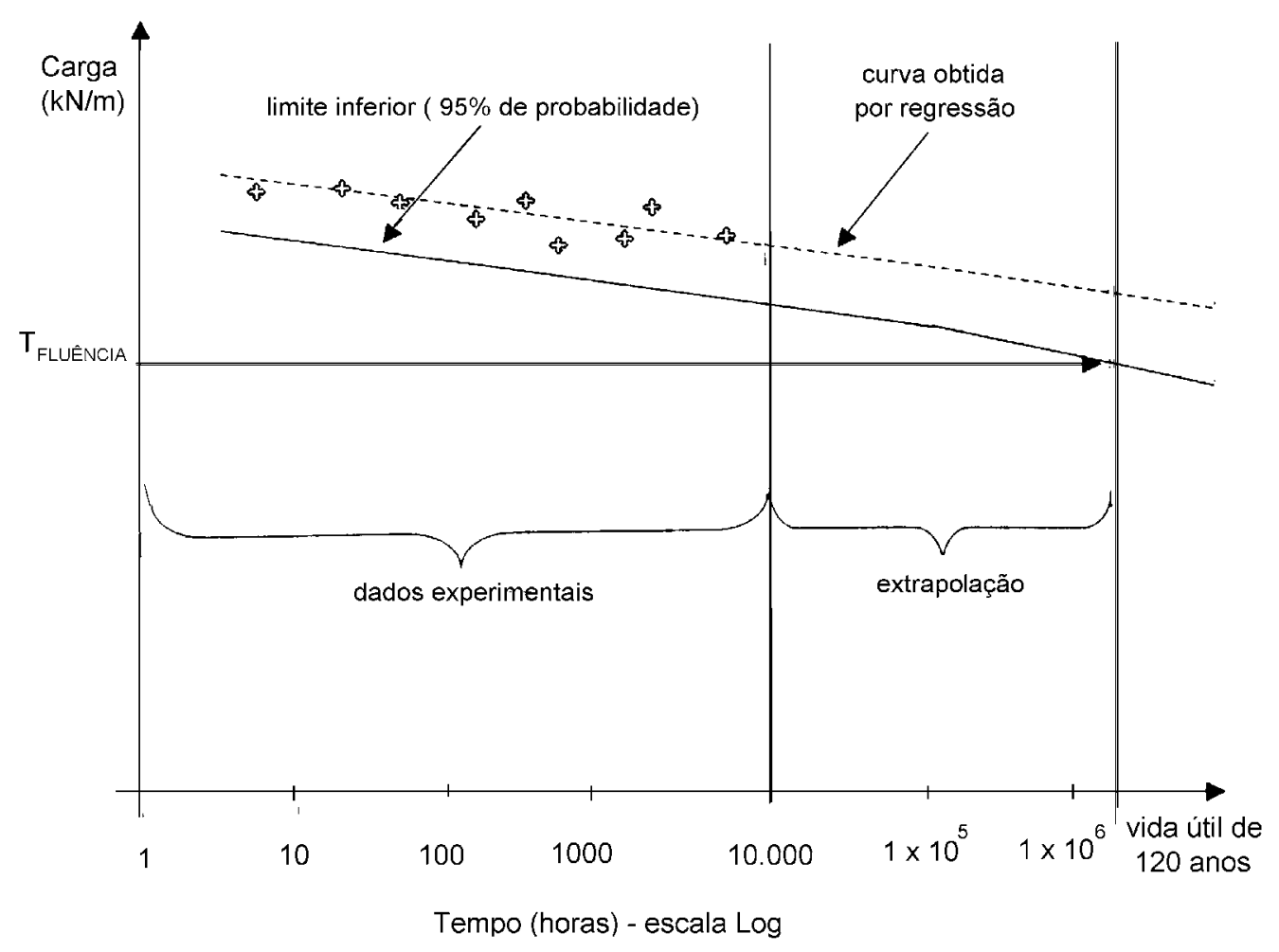

FIGURA 2.6 - Determinação da carga de ruptura por fluência (ZAMMITT, 1998).

Outro tipo de ensaio consiste em confinar o geotêxtil entre camadas de solo que podem deformar, permitindo a interferência do comportamento tensãodeformação do solo no processo. Nesse tipo de ensaio, aplica-se um carregamento ao solo e este, por sua vez, solicita o geotêxtil. Assim, pode-se avaliar, por exemplo, como a tendência fluência do solo interfere na fluência do reforço. Esses ensaios serão discutidos mais detalhadamente a seguir.

A Figura 2.7 resume os tipos de ensaios mencionados. A divisão mostrada na Figura 2.7 corresponde aos tipos de ensaios já realizados até o presente momento. A 
princípio é possível realizar um ensaio com confinamento acelerado, porém, não foram encontrados registros desse tipo de ensaio na literatura.

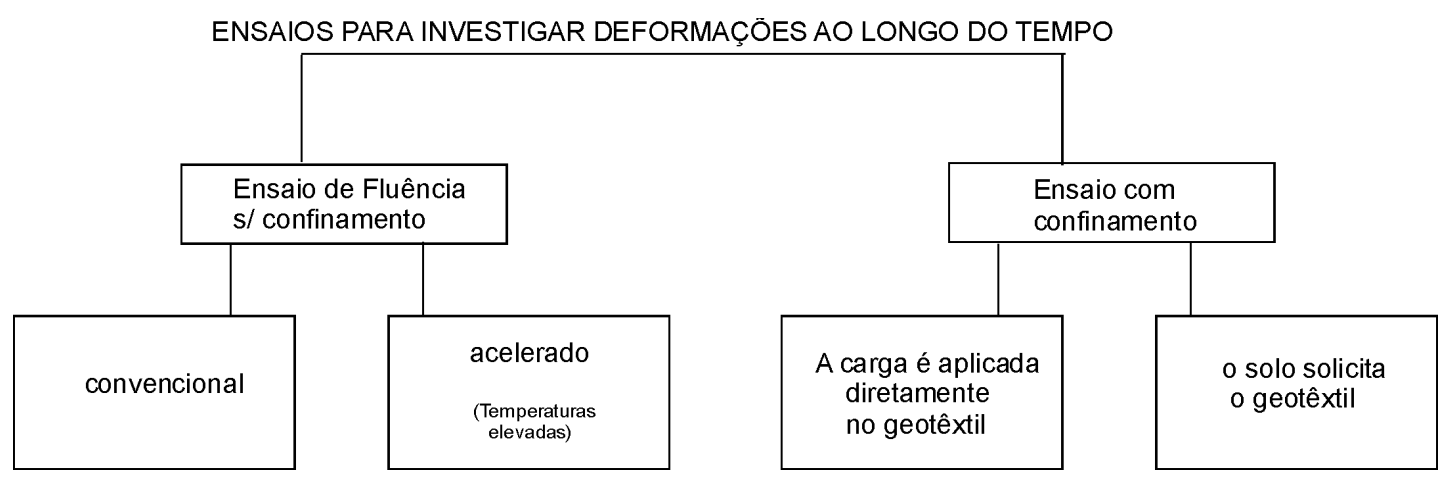

FIGURA 2.7 - Tipos de ensaios para investigar as deformações dependentes do tempo.

\subsubsection{2 - Equipamentos utilizados}

\subsection{Ensaios de fluência sem confinamento}

Os equipamentos utilizados para ensaios não confinados são relativamente simples e, apesar de algumas diferenças, envolvem três divisões básicas: sistema de ancoragem, sistema para acompanhamento das deformações e sistema de aplicação de carga, como pode ser observado na Figura 2.8. Nesse equipamento, a fixação do geotêxtil é realizada através de garras que devem possuir, no mínimo, mesma largura do corpo de prova e impedir qualquer espécie de deslizamento. Um conjunto de pesos submete a amostra a um esforço de tração constante, ao passo que as deformações são obtidas ao longo do tempo, através de extensômetros. O mesmo tipo de equipamento é utilizado em ensaios acelerados, acrescentando-se apenas uma câmara para controle de temperatura que possibilite a variação da temperatura, conforme o método utilizado. Alguns equipamentos para ensaios acelerados são mostrados em BARAS (2001). 


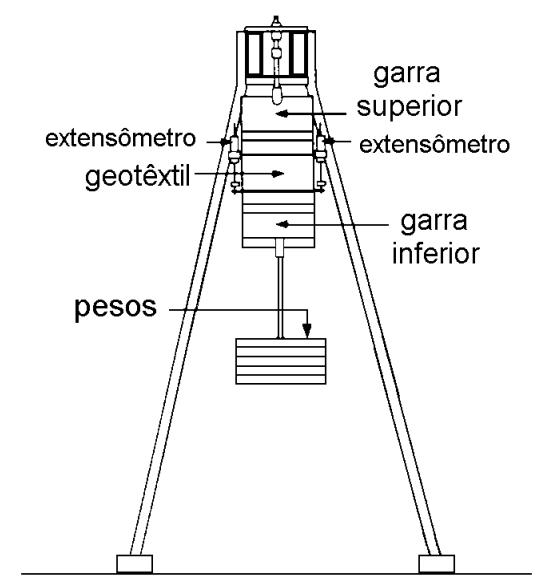

FIGURA 2.8 - Equipamento usado em ensaio de fluência não confinada (ASTM, 1994).

\subsection{Ensaios com confinamento}

\subsection{Equipamentos nos quais a carga é aplicada diretamente ao geotêxtil}

Para os ensaios com confinamento nos quais a carga é aplicada diretamente ao geotêxtil, os equipamentos utilizados são constituídos pelos mesmos componentes do equipamento apresentado na Figura 2.8, apenas com o acréscimo de um sistema para aplicação de confinamento. A Figura 2.9 mostra um esquema de um equipamento para ensaios com confinamento. Nesse tipo de equipamento, o geotêxtil é tracionado aplicando-se uma carga constante (T) diretamente ao corpo de prova, na maioria das vezes, através de pesos mortos. Além da força de tração, uma tensão confinante é aplicada ao corpo de prova que se encontra geralmente inserido entre duas camadas de solo impedidas de se deformar durante o ensaio.

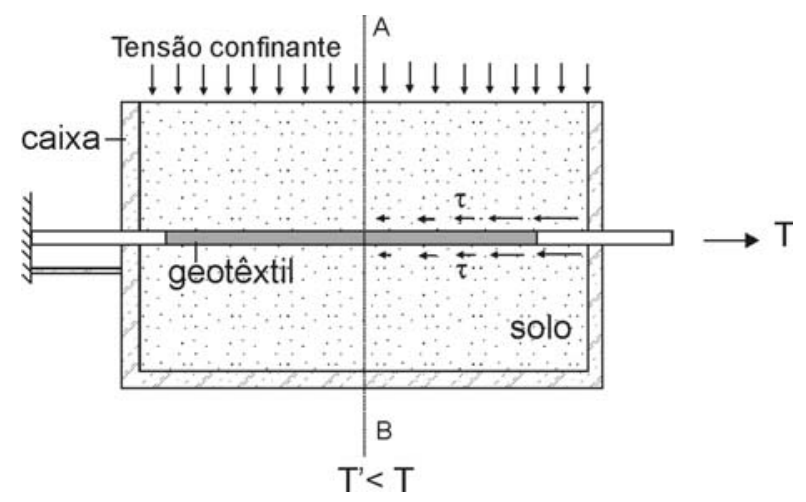

FIGURA 2.9 - Esquema de um ensaio com confinamento 
Os ensaios com confinamento são bem mais complexos que os sem confinamento, tanto com relação à montagem dos ensaios quanto à análise dos resultados. WU (1991) procede a uma ampla discussão de alguns problemas relacionados ao sistema utilizado para confinamento em equipamentos de tração confinada disponíveis até então. Esses problemas podem perfeitamente ser estendidos ao caso de ensaios de fluência com confinamento, em que a carga é transmitida diretamente ao geotêxtil. Para WU (1991), na maioria dos equipamentos existentes ocorre movimento relativo entre o solo confinante e o geotêxtil, provocando mobilizações de forças de atrito na interface. Esse processo resulta em um comportamento carga-alongamento que reflete dois mecanismos distintos: (i) ação do confinamento, (ii) ação de forças de atrito e/ou de adesão ao longo da interface.

A ação do confinamento abrange o efeito da tensão confinante na estrutura da manta e, eventualmente, a ação de partículas de solo impregnadas no geotêxtil. A Figura 2.9 ilustra um possível efeito das forças de atrito e adesão, mostrando um esquema de um ensaio com confinamento. Nesse caso, como o solo encontra-se contido pela caixa, caso seja aplicada uma força $(\mathrm{T})$ tracionando o geotêxtil, o movimento relativo solo-geotêxtil e solo-garra, ocasionado pela deformação do geotêxtil, provocará o aparecimento de tensões cisalhantes. Com o desenvolvimento dessas tensões, o corpo de prova fica submetido a cargas diferentes ao longo de seu comprimento que são inferiores àquela que foi aplicada. Essa questão é ilustrada na Figura 2.9, a carga $\left(\mathrm{T}^{\prime}\right)$ que atua na posição indicada pelo corte $\mathrm{AB}$ é inferior à carga (T) aplicada.

Esse fato dificulta imensamente a análise dos resultados, pois a fluência observada nesse equipamento já será menor que a observada em um ensaio sem confinamento, em que se aplique a mesma carga T. Isso ocorre porque no caso com confinamento, a carga efetiva ao longo do corpo de prova é menor que a carga $\mathrm{T}$ aplicada, e quanto menor a carga, menor a fluência. Ou seja, pode-se atribuir erroneamente ao confinamento, uma redução da fluência que, de fato, deve-se a uma redução de carga.

No entanto, mesmo ciente do problema, é difícil conceber um sistema de confinamento capaz de verificar unicamente o efeito da tensão na manta e da 
imbricação de partículas. Os sistemas de confinamento relatados na literatura (ex. EL-FERMAOUI \& NOWATZKI, 1982; LESHCHINSKY \& FIELD, 1987; SIEL et al.,1987; KOKKALIS \& PAPACHARISIS, 1989; WU \& ARABIAN, 1990; LING et al, 1992; WILSON-FAHMY et al., 1993; TUPA \& PALMEIRA, 1995) incorporam senão esse, outros tipos de problemas, como discutidos por COSTA (1999).

Os poucos resultados de ensaios de fluência com confinamento disponíveis na literatura foram obtidos, na sua maioria, utilizando-se o equipamento proposto por McGOWN et al. (1982) (Figura 2.10). No dispositivo desenvolvido por esses autores, o geotêxtil é confinado em contato com delgadas camadas de solo (10 ou 25 mm de espessura), em ambas as faces. A tensão confinante é aplicada através de bolsas pressurizadas por ar comprimido (Figura 2.11) e o sistema de aplicação de carga é composto por um conjunto de pesos.

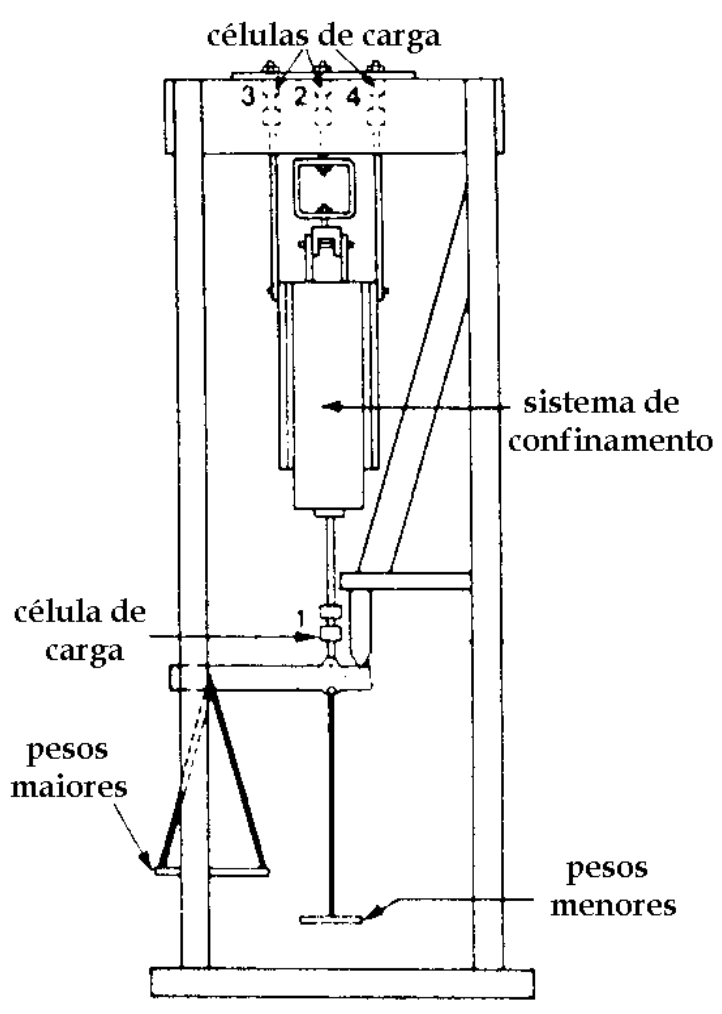

FIGURA 2.10 - Vista geral do equipamento para ensaio de fluência confinada (McGOWN et al., 1982) 
Cada bolsa é inserida em uma caixa metálica e, nas proximidades das garras, o geotêxtil é reforçado com a aplicação de uma resina. Algumas células de carga são estrategicamente posicionadas a fim de verificar processos de transferência da carga aplicada para partes do equipamento, em virtude de forças de atrito mobilizadas nas interfaces solo-geotêxtil e solo-zonas reforçadas.

A deformação do geotêxtil é obtida com base no deslocamento das extremidades do corpo de prova, como mostra o esquema da Figura 2.12. Para tanto, finas hastes de aço são presas nas extremidades das regiões reforçadas, perpendicularmente ao comprimento do corpo de prova (hastes transversais), as pontas dessas hastes se encaixam nas fendas de duas placas laterais. Hastes verticais colocadas nas fendas e conectadas às hastes transversais se estendem ao exterior da caixa, sendo ligadas a relógios comparadores.

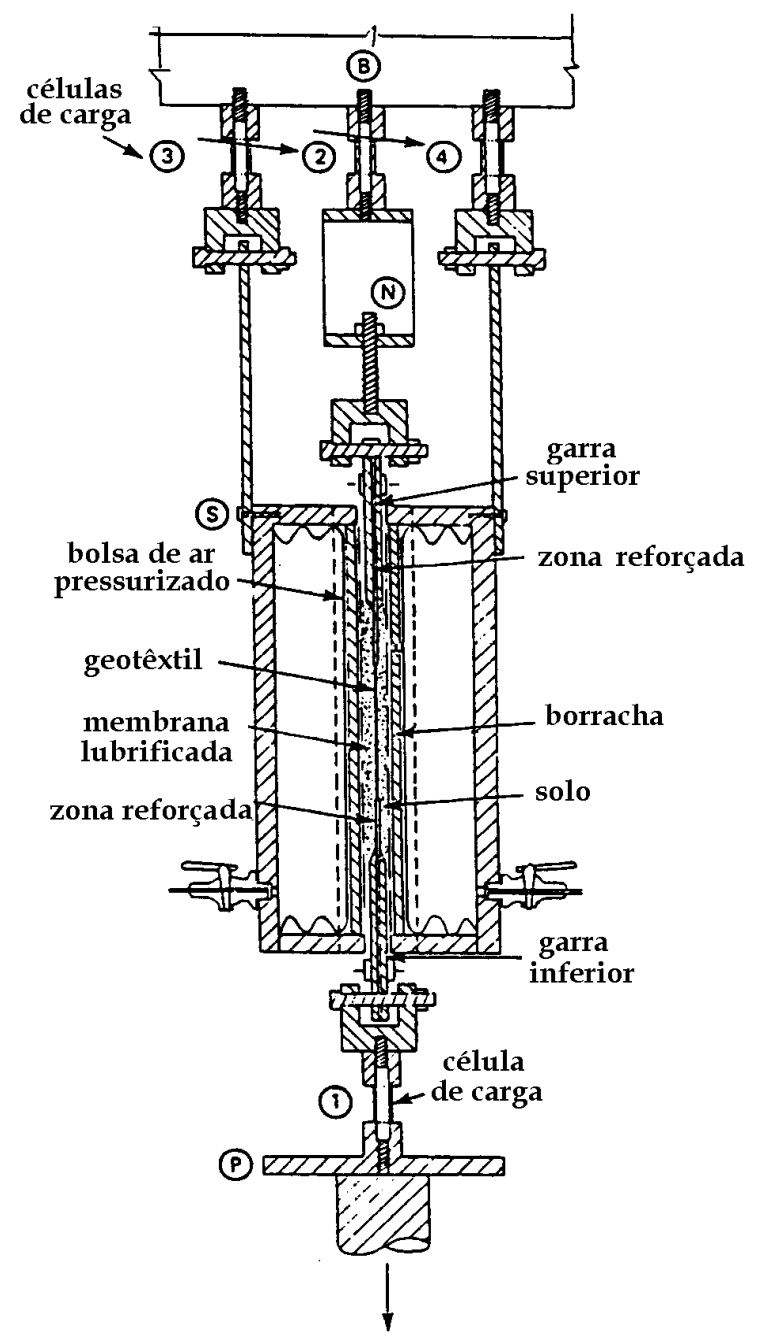

FIGURA 2.11 - Sistema de confinamento (McGOWN et al., 1982). 


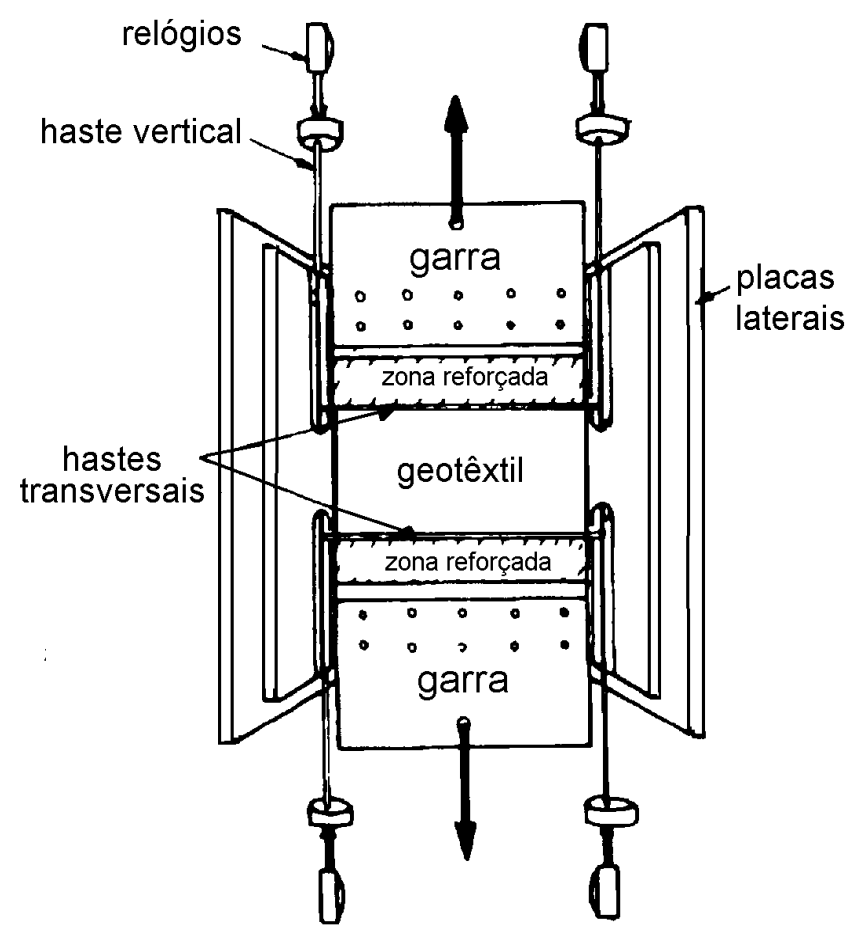

FIGURA 2.12 - Sistema utilizado para obter as deformações do geotêxtil (McGOWN et al., 1982).

Entre as dificuldades encontradas por ocasião do desenvolvimento desse equipamento, os autores apontam a manutenção do contato solo-geotêxtil durante o processo de deformação, perfuração da bolsa por partículas de solo e transferência da carga aplicada em virtude de forças de atrito. As principais críticas associadas a esse equipamento dizem respeito às dificuldades de montagem do ensaio, principalmente com relação à preparação do solo. Nos ensaios desenvolvidos pelos autores, foram utilizadas unicamente camadas de areia, no entanto, a necessidade de compactação, caso outros tipos de materiais sejam considerados, deve constituir um empecilho para uso desse aparelho, exigindo algum tipo de adaptação.

\subsection{Equipamentos nos quais o solo solicita o geotêxtil}

A Figura 2.13 apresenta um esquema de um equipamento com confinamento no qual o solo solicita o geotêxtil. O equipamento possui um outro princípio de funcionamento em relação ao mostrado na Figura 2.9, pois, ao contrário deste, a 
carga não é aplicada diretamente ao geotêxtil. Esse procedimento é substituído pela aplicação de um carregamento vertical constante no topo da camada de solo que, ao se deformar, traciona então o geotêxtil. Vale destacar que, nesse caso, o processo de solicitação do geotêxtil é bem mais condizente com as condições presentes nas estruturas de solo reforçado, já que o solo solicita o geotêxtil. Alguns equipamentos relatados na literatura, que apresentam essa concepção de funcionamento, são descritos em maiores detalhes a seguir.

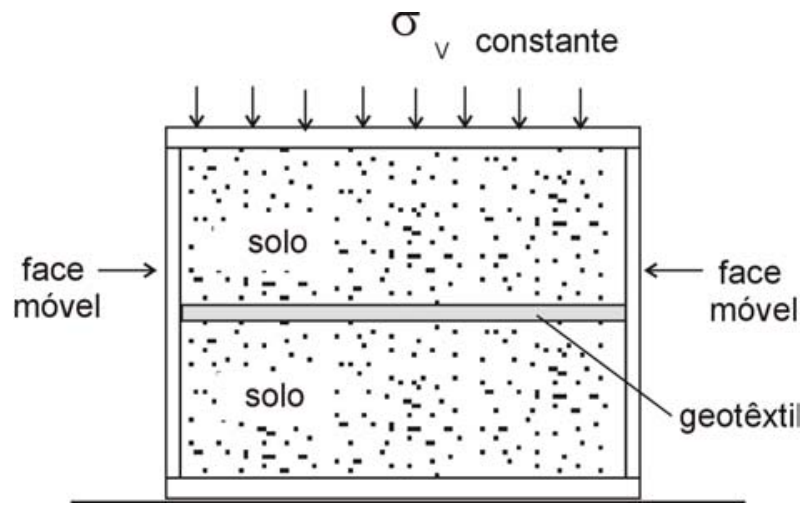

FIGURA 2.13 - Esquema de um equipamento com confinamento no qual o solo solicita o geotêxtil.

- Equipamento desenvolvido por WU \& HELWANY (1996)

O equipamento desenvolvido por WU \& HELWANY (1996) é constituído basicamente por um elemento de solo reforçado, depositado em uma caixa rígida (Figura 2.14). O elemento de solo reforçado é composto por duas camadas de solo, pelo reforço e por duas placas de aço flexíveis que permitem que solo e inclusão deformem ao longo do tempo, quando da aplicação de uma carga vertical constante na superfície da massa de solo reforçada.

As camadas de solo possuem uma altura $(\mathrm{H})$ igual a $300 \mathrm{~mm}$ e o reforço possui um comprimento (L) igual a $450 \mathrm{~mm}$. As deformações do geotêxtil, ao longo do tempo, são acompanhadas através de strain gages. 


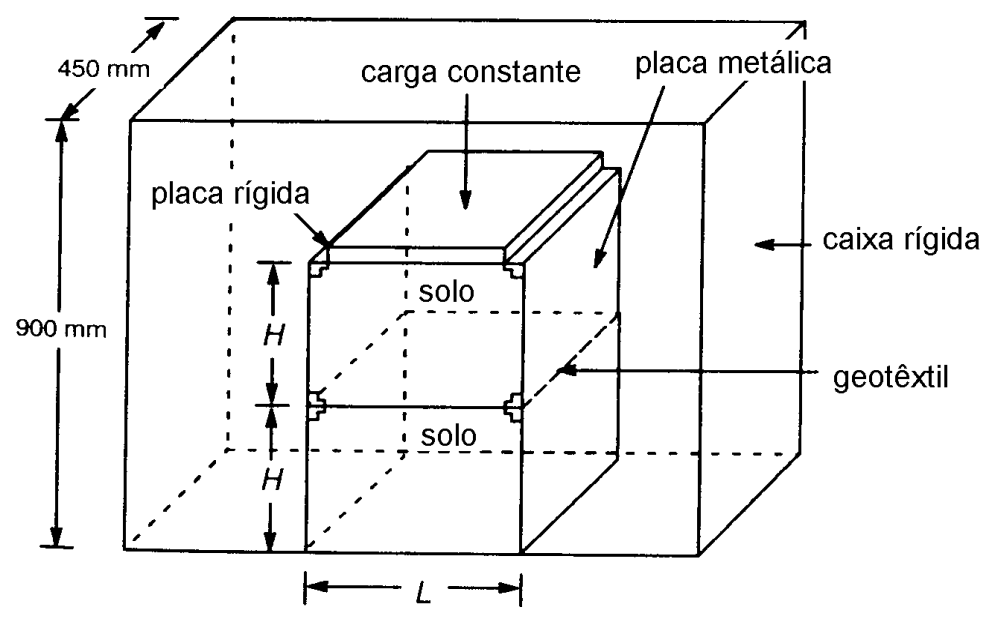

FIGURA 2.14 - Esquema do equipamento desenvolvido por WU \& HELWANY (1996)

- Equipamento desenvolvido por HELWANY \& SHIN (1998)

O equipamento desenvolvido por HELWANY \& SHIN (1998) é mostrado na Figura 2.15. O equipamento é constituído por uma caixa com capacidade para acomodar um corpo de prova com dimensões de 200 x 300 x $300 \mathrm{~mm}$. O elemento de solo reforçado é composto por um geotêxtil confinado entre duas camadas de solo, cada uma com $100 \mathrm{~mm}$ de espessura, e é solicitado através de duas bolsas de ar comprimido que aplicam uma tensão constante na base e no topo do corpo-de-prova. Uma bolsa de ar, posicionada na lateral 1 da caixa, possibilita ainda a aplicação de uma tensão confinante horizontal.

A lateral 1 mostrada na Figura 2.15 é composta por uma face flexível constituída por uma chapa de aço com $0,5 \mathrm{~mm}$ de espessura. Essa face é conectada ao reforço através de uma garra no ponto A, mostrado na Figura 2.15, e não está impedida de apresentar movimentação durante o ensaio, permitindo a deformação do corpo-de-prova. A lateral 2 da caixa de ensaios é fixa, não apresentando movimentação durante o ensaio. As demais laterais da caixa também são fixas, a fim de garantir a manutenção do estado plano de deformação.

Uma célula de carga posicionada próxima à lateral 2 permite registrar a carga no ponto B do reforço (ver Figura 2.15). O ensaio é realizado aplicando-se uma tensão vertical constante ao longo do tempo e permitindo que solo e reforço 
apresentem deformação de forma interativa. A carga no ponto B e o deslocamento da face no ponto A (obtido através de relógio comparador) são registrados durante o ensaio.

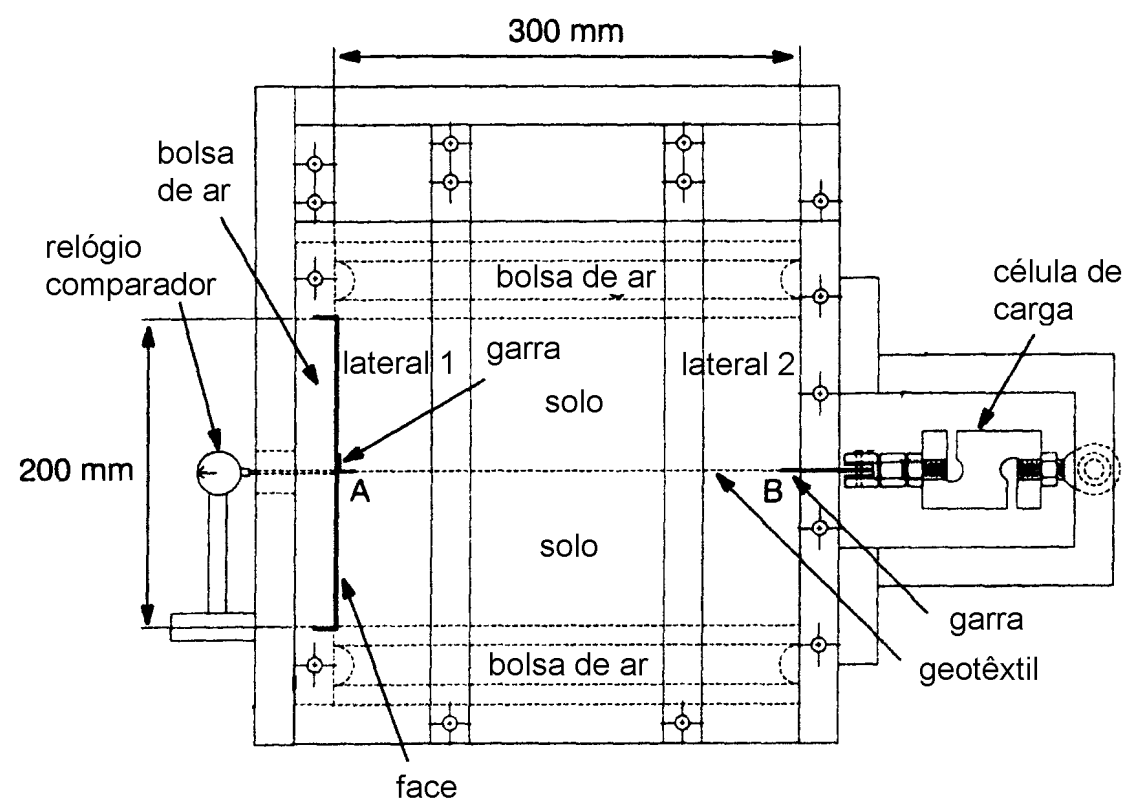

FIGURA 2.15 - Equipamento desenvolvido por HELWANY \& SHIN (1998)

- Equipamento desenvolvido por BOYLE (1995)

O equipamento desenvolvido por BOYLE (1995) é apresentado na Figura 2.16. Nesse equipamento, a tensão vertical é aplicada através de duas bolsas de ar (uma na base, outra no topo do corpo-de-prova). As laterais da caixa em contato com o corpo-de-prova são constituídas por chapas rígidas e a lateral 1 é livre para deslocar horizontalmente em virtude da aplicação da tensão vertical.

$\mathrm{O}$ equipamento garante a manutenção do estado de deformação plana e a deformação horizontal do solo, em virtude da movimentação da lateral 1, é limitada pela tensão confinante aplicada pela bolsa lateral e pela força de tração induzida no reforço. Este último possui dimensões correspondentes a $200 \mathrm{~mm}$ de largura e 100 $\mathrm{mm}$ de comprimento, sendo confinado entre duas camadas de solo com $100 \mathrm{~mm}$ de espessura. Uma célula de carga possibilita ainda o registro da carga no reforço nas proximidades da lateral 1 e LVDT's são utilizados para obtenção dos deslocamentos nas faces do corpo-de-prova. 


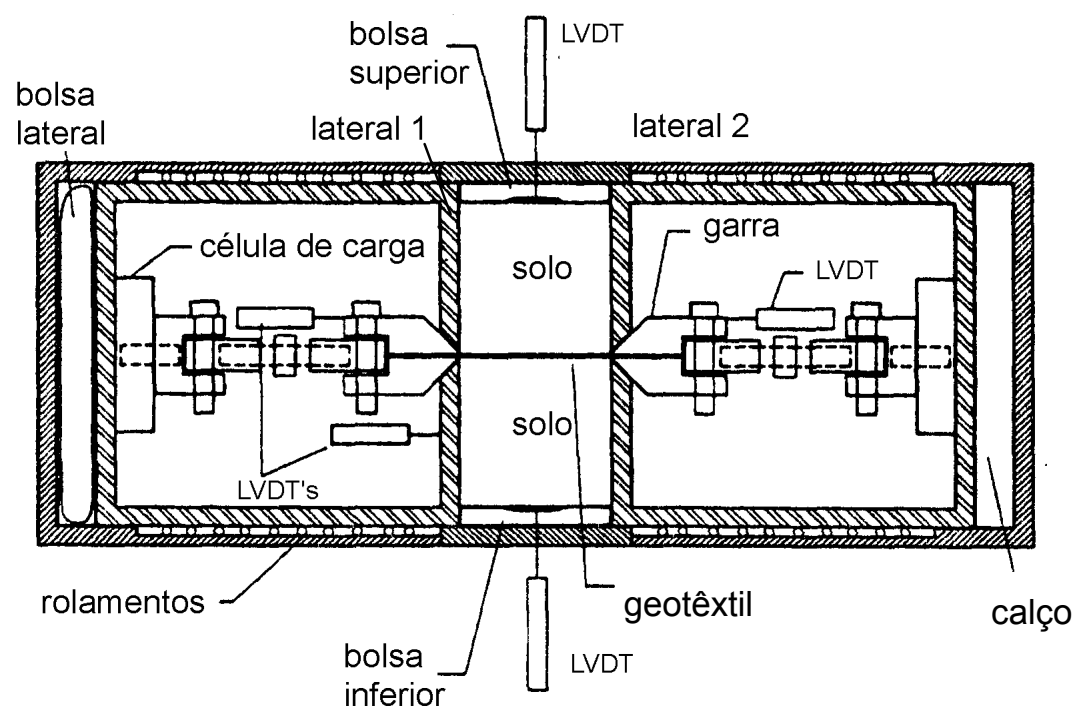

FIGURA 2.16 - Equipamento desenvolvido por BOYLE (1995).

Esse equipamento não foi desenvolvido com o objetivo de estudar o mecanismo de deformação com o tempo em elementos de solo reforçado. O aparelho foi construído para avaliar a deformação do elemento (curto prazo) com o aumento da tensão vertical aplicada, utilizando-se solos e geotêxteis diversos. No entanto, alguns ensaios foram realizados por BOYLE (1995) mantendo-se a tensão vertical constante por um determinado intervalo de tempo, observando-se então a carga e movimentação das laterais.

- Equipamento desenvolvido por LARSON (1992) apud ABRAMENTO (1993)

Um outro exemplo de equipamento em que a carga é transmitida ao reforço pelo solo é o dispositivo desenvolvido por LARSON (1992). Esse aparelho, designado como APSR cell (Automated Plane Strain Reinforcement), foi desenvolvido no departamento de engenharia do MIT (Massachusetts Institute of Technology), tendo sido utilizado em ensaios com uma areia e uma inclusão metálica. Embora não tenham sido empregados geossintéticos nos ensaios, o equipamento foi desenvolvido também visando a utilização desses materiais. Ressalta-se ainda que a realização de ensaios para avaliar a fluência do reforço não constituiu o objetivo principal do equipamento, porém seu princípio de funcionamento permitiria sua utilização com tal propósito. 
A Figura 2.17 apresenta um esquema do equipamento composto por um reforço intercalado por camadas de solo com $285 \mathrm{~mm}$ de altura, $450 \mathrm{~mm}$ de largura e $152 \mathrm{~mm}$ de espessura. A massa de solo é submetida a uma tensão horizontal confinante e à medida que a tensão vertical é aumentada, solicita o reforço. Bolsas de água permitem a aplicação da tensão vertical na massa de solo e deslocamentos e tensões no contorno da massa de solo podem ser acompanhados através de LVDT's e células de tensão, respectivamente. O reforço é fixo por um sistema de garras em uma de suas extremidade (ponto A) e uma célula de carga permite o registro na carga nessa posição. Deformações internas na massa de solo podem ser obtidas através de técnicas de raios-X.

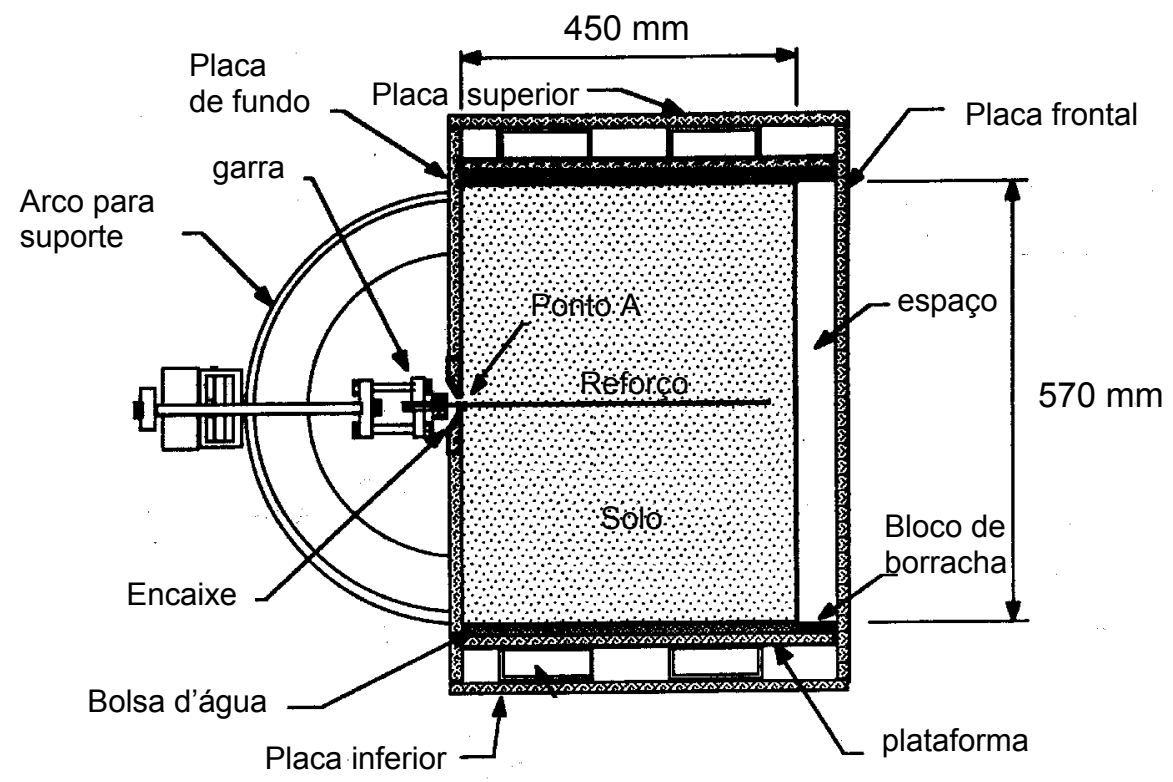

FIGURA 2.17 - Equipamento desenvolvido por LARSON (1992)

\subsubsection{Fatores que afetam as deformações dos geotêxteis ao longo do tempo}

\subsubsection{Tipo de polímero e tipo de geotêxtil}

As propriedades dos polímeros influenciam de forma marcante a fluência dos geotêxteis. Sobre essa questão, a susceptibilidade à fluência aumenta na seguinte seqüência: poliéster, poliamida, polipropileno e polietileno (DEN HOEDT, 1986; ABRAMENTO, 1995). 
A diferença na fluência, em virtude do tipo de polímero, pode ser evidenciada, em sua forma mais simples, através do comportamento das fibras que compõem os geotêxteis. A Figura 2.18 ilustra esse fato, apresentando uma comparação entre as deformações em função do tempo de fibras compostas por diferentes polímeros, para dois níveis de carregamento diferentes. Destaca-se que apesar de úteis no sentido de refletir unicamente a influência do polímero, os ensaios de fluência realizados com fibras podem não reproduzir o comportamento de geotêxteis confeccionados com as mesmas fibras como mostrado por GREENWOOD (1990).

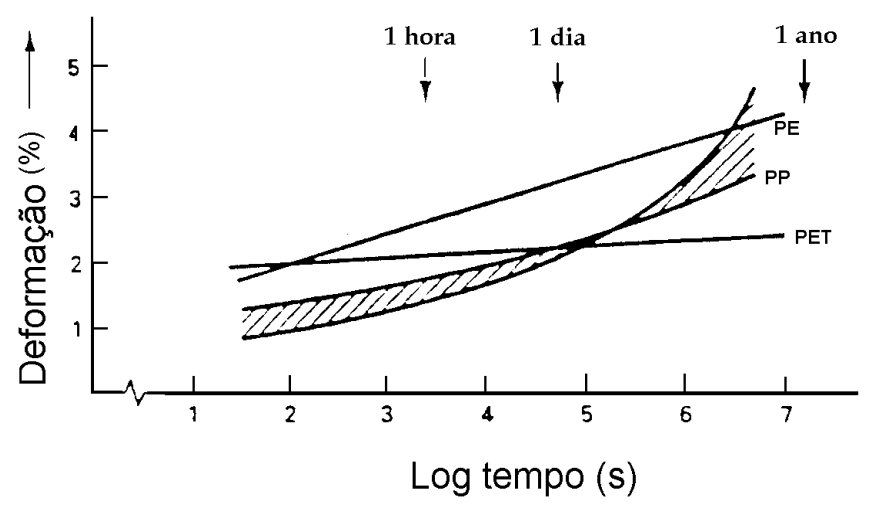

(a)

Área hachurada corresponde aos piores e melhores resultados obtidos papa o PP.

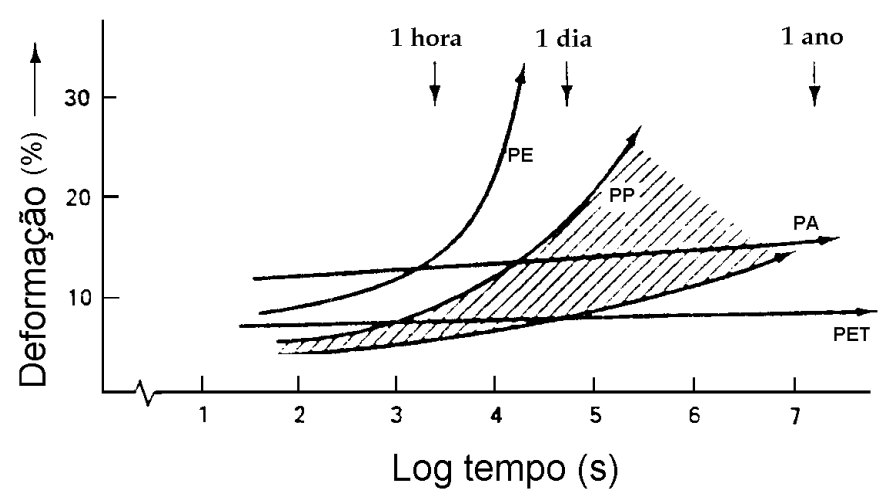

(b)

FIGURA 2.18 - Curvas de fluência para fibras de diferentes polímeros (a) 20\% da resistência à tração (b) 60\% da resistência à tração (DEN HOEDT, 1986).

O tipo de polímero também provoca comportamentos distintos no caso de ruptura. Para os geotêxteis de poliéster a deformação de ruptura em ensaios de fluência se aproxima daquela apresentada em ensaios de tração convencionais, já no 
caso de geotêxteis de polipropileno, as deformações de ruptura por fluência são superiores às obtidas em ensaios de tração (MSOUTI et al., 1997). Essa conduta diferenciada, segundo DEN HOEDT (1986), deve-se à existência de deslizamentos entre as cadeias poliméricas nas regiões cristalinas do polipropileno.

Com relação à estrutura das mantas, alguns autores consideram a existência de uma fluência estrutural relacionada à movimentação e realinhamento das fibras ao longo do tempo (RIMOLDI \& MONTANELLI, 1993). Nesse sentido, os resultados encontrados por SHRESTHA \& BELL (1982) demonstram uma maior tendência à fluência para geotêxteis não tecidos em comparação aos tecidos. No caso dos não tecidos, foi detectada uma fluência mais acentuada para geotêxteis com filamentos contínuos em oposição aos confeccionados com fibras cortadas. Alguns autores, como LEVACHER et al. (1994) e MSOUTI et al. (1997), no entanto, afirmam que os geotêxteis não tecidos apresentam maiores deformações totais medidas em ensaios de fluência sem confinamento, contudo, não há diferença significativa entre a fluência de geotêxteis tecidos e não tecidos.

\subsubsection{Temperatura}

A temperatura acelera a fluência dos geotêxteis, razão pela qual essa variável deve ser controlada nos ensaios. Os geotêxteis de polipropileno são mais sensíveis aos efeitos da temperatura que os de poliéster (MATICHARD et al., 1990; LEVACHER et al., 1994; CAZZUFFI et al., 1997) e, de acordo com ALLEN (1991), tal comportamento deve-se ao fato do polipropileno estar acima de sua temperatura de transição vítrea nas condições térmicas encontradas normalmente no solo, ao contrário do poliéster.

MÜLLER-ROCHHOLZ \& KIRSCHNER (1990) estudaram o efeito da temperatura, realizando ensaios de fluência em um geotêxtil tecido de PP a $10^{\circ} \mathrm{C}$ e $30^{0} \mathrm{C}$, adotando dois níveis de carregamento para cada temperatura. Os resultados encontrados por esses autores podem ser observados na Figura 2.19 e demonstram uma nítida influência da temperatura nas deformações apresentadas pelo geotêxtil. Para as condições adotadas nesses ensaios, o nível de carregamento teve uma maior influência do que a temperatura nas deformações registradas ao longo do tempo. 


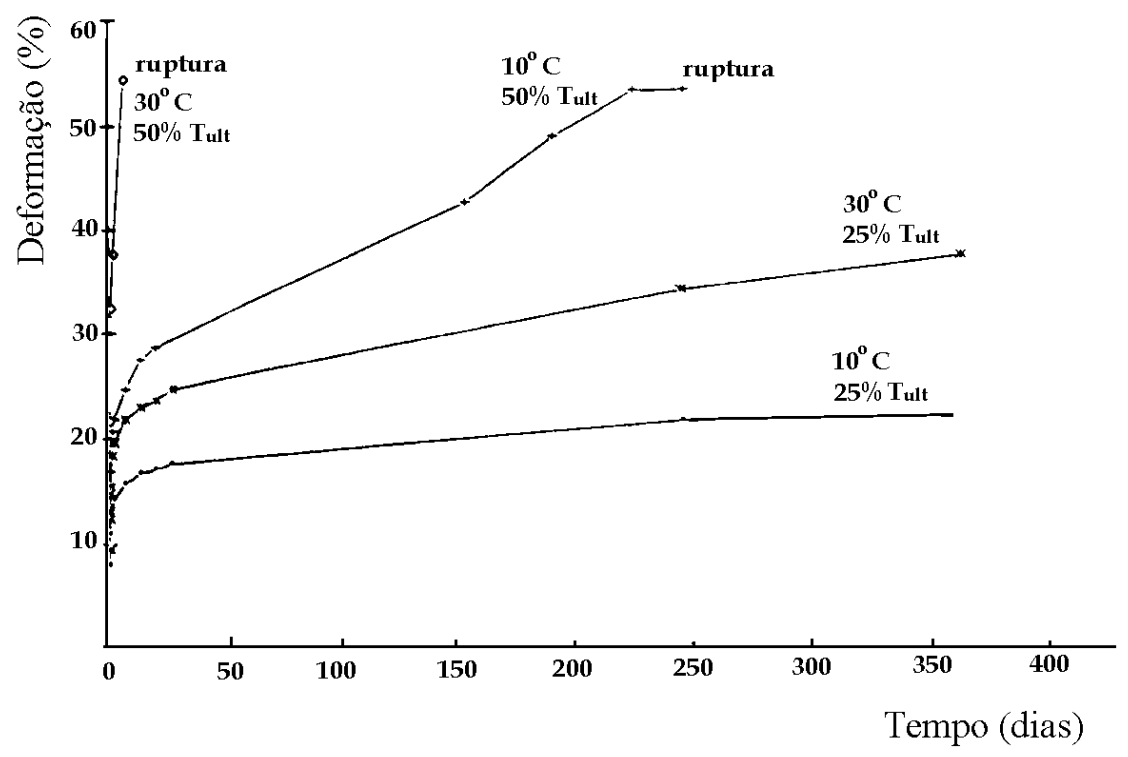

FIGURA 2.19 - Fluência de um geotêxtil de PP a diferentes temperaturas e níveis de carregamento (MÜLLER-ROCHHOLZ \& KIRSCHNER, 1990).

\subsubsection{Tempo de carregamento}

A velocidade de aplicação da carga em um ensaio de fluência interfere na taxa de deformação no decorrer do tempo. Quando a carga é aplicada lentamente as deformações dependentes do tempo já se manifestam durante o tempo de carregamento e a subseqüente deformação, quando a carga é mantida constante, é inicialmente reduzida.

RIMOLDI \& MONTANELLI (1993) realizaram ensaios de fluência com geossintéticos aplicando uma carga correspondente a $40 \%$ da resistência à tração, considerando diferentes velocidades de aplicação para essa mesma carga. Em um ensaio, a carga foi aplicada em poucos segundos e, em outros dois ensaios, a carga foi aplicada em um tempo igual a 3 min e 1 hora. A maior deformação inicial foi observada no ensaio com maior tempo de aplicação da carga. No entanto, a taxa de fluência observada no início desse ensaio foi inferior à taxa de deformação observada nos ensaios com um menor tempo de aplicação da carga. Apenas para um tempo superior a $1 \mathrm{~h}$ com a carga mantida constante, a taxa de fluência nos três ensaios tornou-se semelhante. 
GOTTARDI \& SIMONINI (2000) realizaram ensaios em modelos de muros de solo reforçado que também ilustram o efeito da velocidade de carregamento na fluência. Esses modelos foram construídos utilizando-se uma areia pura como aterro e um reforço de polipropileno. A Figura 2.20 expõe o recalque observado no topo de estruturas idênticas, para uma mesma sobrecarga, aplicada, porém, considerando diferentes tempos de carregamento. Os recalques ao longo do tempo, mostrados na Figura 2.20, correspondem aos valores após a sobrecarga ser mantida constante.

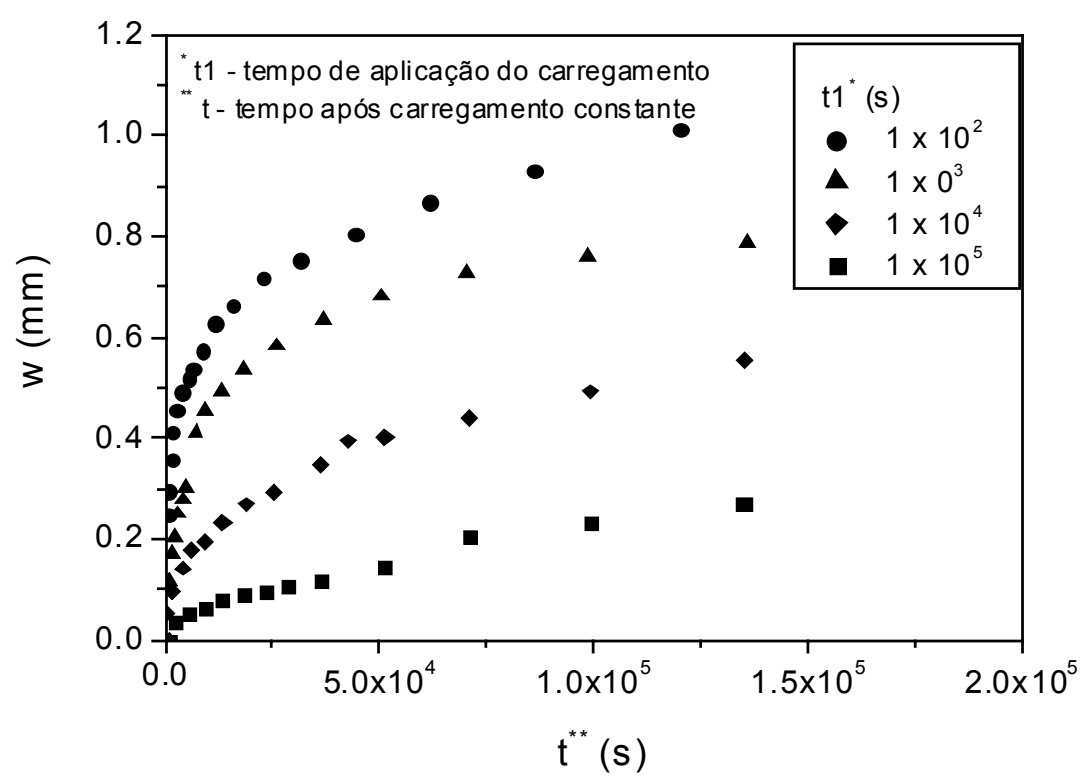

FIGURA 2.20 - Efeito do tempo de carregamento no recalque após a carga ser mantida constante (GOTTARDI \& SIMONINI, 2000).

Como é possível constatar na Figura 2.20, a taxa inicial de deslocamento com o tempo apresenta uma variação acentuada, dependendo da velocidade de carregamento. Quanto maior o tempo para a aplicação da carga, menor a taxa de recalque, inicialmente verificada nos ensaios.

\subsubsection{Presença de solo e tensão confinante}

\subsection{Sem considerar o comportamento tensão-deformação do solo}

O comportamento de alguns geotêxteis quando enterrados no solo, pode ser bem diferente daquele obtido em ensaios nos quais esses materiais encontravam-se 
em isolamento (BALLEGEER \& WU, 1993; TUPA \& PALMEIRA, 1995). Essa diferença se manifesta tanto em ensaios de tração como de fluência.

Nesse item descrevem-se os efeitos da presença do solo e da tensão confinante que podem ser observados em equipamentos nos quais a carga é aplicada diretamente ao geotêxtil (item 2.1.2.2.2.1). Ou seja, sem considerar o comportamento tensão-deformação do solo, já que este apenas confina o reforço, não apresentando deformações ao longo do tempo.

McGOWN et al. (1982) foram os primeiros pesquisadores a investigar o efeito do confinamento na fluência de geotêxteis. A Figura 2.21 demonstra os resultados encontrados por esses autores em ensaios com geotêxteis não tecidos, sem e com confinamento. No caso do geotêxtil composto por $67 \%$ de polipropileno e $33 \%$ de polietileno (Figura 2.21a), o confinamento suprimiu quase que totalmente a fluência que o mesmo havia apresentado em isolamento. A notável redução das deformações totais reflete tanto uma diminuição da deformação inicial quanto das deformações dependentes do tempo.

Esse efeito, em geotêxteis não tecidos, deve-se ao fato de que, com o confinamento, a estricção da amostra é reduzida, restringindo a movimentação das fibras e o alinhamento das mesmas na direção de aplicação da carga (MSOUTI et al., 1997). A estricção pode ser reduzida pelos seguintes mecanismos:

i) atrito solo-geotêxtil na direção perpendicular à solicitação;

ii) a tensão normal aplicada pode aumentar o atrito entre as fibras;

iii) uma possível impregnação de solo na manta diminui a possibilidade de deslizamento entre fibras.

Com relação ao efeito do confinamento em geotêxteis não tecidos, KOERNER (1998) destaca que o maior efeito ocasionado pelo confinamento está relacionado aos não tecidos agulhados, seguidos então, pelos demais tipos (termoligados e resinados).

WU \& HONG (1994) realizaram ensaios de fluência confinada para geotêxteis não tecidos, um termoligado, outro agulhado, compostos pela associação de PP-PE e PP-PET, respectivamente, considerando diferentes pressões de confinamento $(50,100$ e $200 \mathrm{kPa})$. Os resultados obtidos confirmaram a redução da 
fluência por ação do confinamento, para ambos geotêxteis, no entanto, esse efeito só se apresentou significativo para uma pressão confinante de $200 \mathrm{kPa}$.
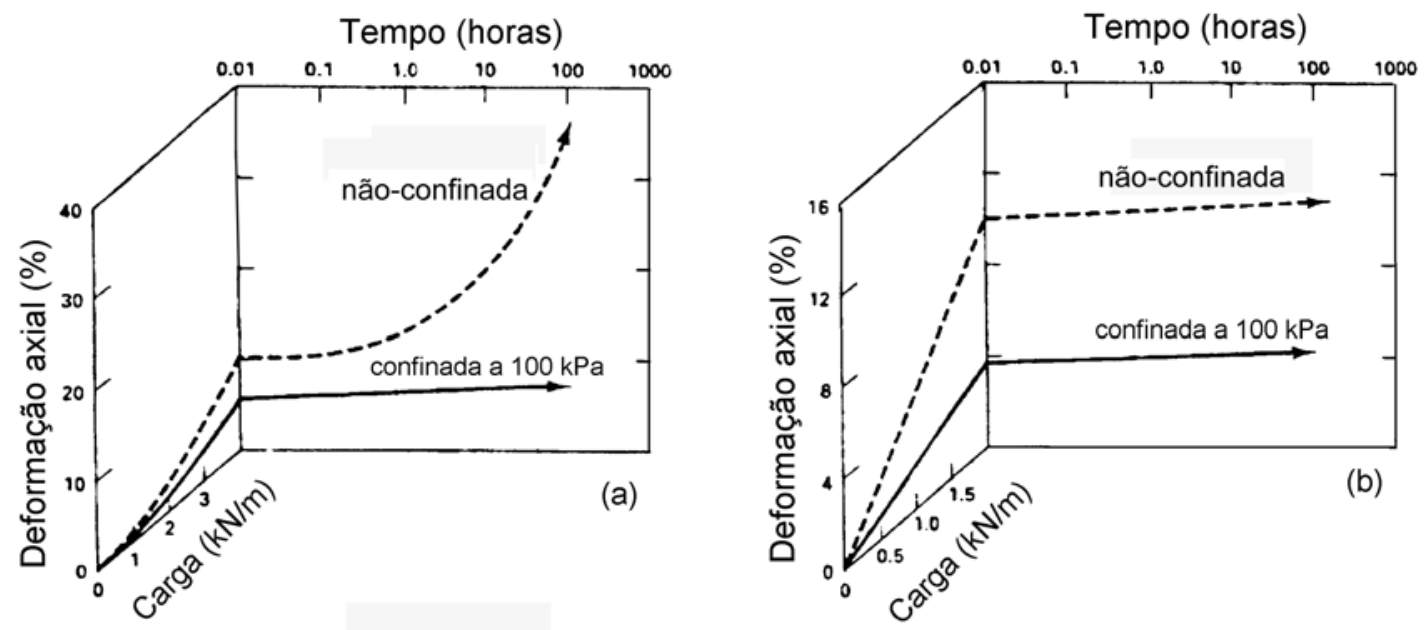

FIGURA 2.21 - Resultados de ensaios de fluência de geotêxteis (a) não tecido, termoligado, 33\% PEAD e 67\% PP (b) não tecido, 100\% PET, agulhado (McGOWN et al., 1982).

LEVACHER et al. (1994) também encontraram resultados menos satisfatórios que os apresentados por McGOWN et al. (1982), relatando a existência de apenas sensíveis diferenças entre o comportamento de fluência de geotêxteis não tecidos isolados e confinados com $100 \mathrm{kPa}$, em uma areia fina.

Os geotêxteis tecidos, ao contrário de alguns resultados de materiais não tecidos, têm demonstrado pouca ou nenhuma diferença em seu comportamento de fluência por efeito do confinamento (LEVACHER et al., 1994; KOERNER, 1998; MSOUTI et al., 1997).

\subsection{Considerando o comportamento tensão-deformação do solo}

Quando se considera o comportamento tensão-deformação do solo, como nos equipamentos nos quais o solo solicita o geotêxtil, alguns outros aspectos, além dos citados anteriormente, devem ser ponderados.

Estudos considerando o efeito do comportamento mecânico do solo na fluência dos geossintéticos são extremamente raros e esses efeitos são discutidos geralmente em caráter especulativo. Alguns autores (McGOWN et al., 1998, 
KOERNER, 1998) consideram que, em estruturas de solo reforçado, o ângulo de atrito do solo mobilizado em curto prazo afeta as deformações ao longo do tempo dos geossintéticos. Um outro aspecto, relacionado ao solo de aterro, que pode ser capaz de modificar as deformações do geossintético, diz respeito às características de fluência do solo (HELWANY, 1993). Esses aspectos serão discutidos a seguir.

\subsection{1 Ângulo de atrito do solo mobilizado após o carregamento (curto prazo)}

Com base na hipótese de compatibilidade de deformação solo-reforço, McGOWN et al. (1998) consideram que o ângulo de atrito do solo mobilizado em curto prazo interfere nas deformações dependentes do tempo do reforço. A hipótese de compatibilidade de deformação solo-reforço é freqüentemente assumida para análise de deformações em muros de solo reforçado em condições de trabalho e estabelece que a deformação do solo na direção do reforço é igual à deformação do reforço. Sendo assim, não ocorre deslizamento relativo na interface solo-reforço.

O conceito de compatibilidade de deformação possibilita compreender o estado de equilíbrio em um muro de solo reforçado. Esse equilíbrio será estabelecido com a igualdade das forças disponíveis no reforço em relação às forças requeridas no mesmo. A Figura 2.22 ilustra o conceito de compatibilidade de deformação no caso de um muro escorado durante a construção. Inicialmente, solo e reforço não apresentam deformação e a força requerida para o equilíbrio corresponde ao empuxo do solo na condição de repouso (ponto A na Figura 2.22c). Com a retirada do escoramento, passam a ocorrer deformações e a força requerida para o equilíbrio diminui progressivamente até um valor mínimo correspondente à mobilização do ângulo de atrito de pico do solo $\left(\phi_{\mathrm{p}}\right)$. A partir desse valor, a força requerida aumenta até a mobilização do ângulo de atrito do estado crítico ( $\left.\phi_{\text {cr }}\right)$. Já a força disponível no reforço aumenta continuamente com o desenvolvimento de deformações como mostrado na Figura 2.22b e o equilíbrio acontece com a interseção das duas curvas mostradas na Figura 2.22c (ponto B).

Considerando o conceito de compatibilidade de deformação, caso o equilíbrio em curto prazo entre a força requerida e a disponível no reforço seja estabelecido 
antes da mobilização do ângulo de atrito de pico do solo, quando o sistema começar a deformar pela tendência à fluência do reforço, o acréscimo de deformação permitirá a mobilização de um maior ângulo de atrito do solo até que o pico seja atingido. A maior mobilização de resistência do solo provocará uma redução da força requerida no reforço (McGOWN et al., 1998). Assim, essa redução irá resultar em menores deformações ao longo do tempo já que uma menor carga no reforço implica menor fluência.

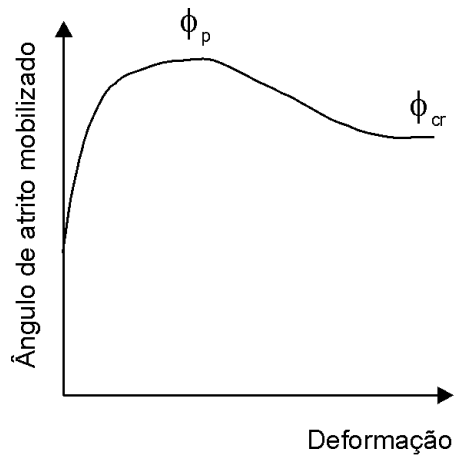

(a)

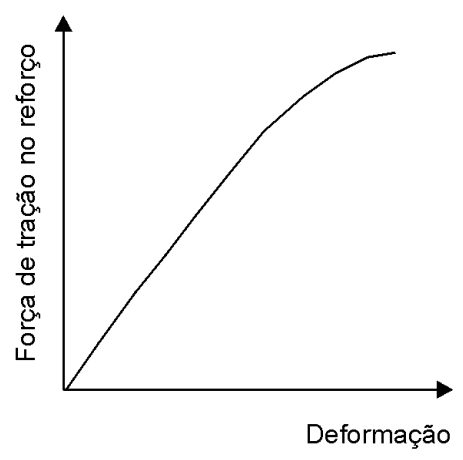

(b)

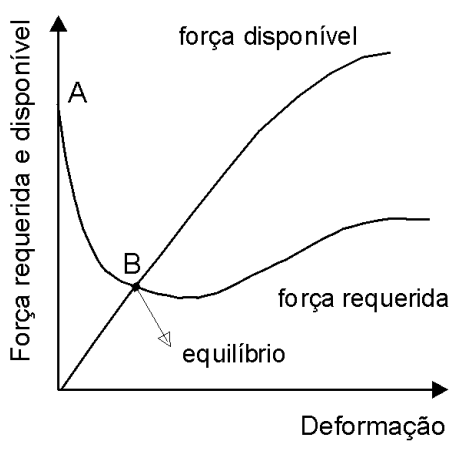

(c)

FIGURA 2.22 - Curva de compatibilidade para determinação do equilíbrio em solos reforçados (a) ângulo de atrito mobilizado - deformação lateral (b) força - deformação no reforço (c) curva de compatibilidade de deformação (McGOWN et al, 1998).

Uma outra situação possível corresponde ao estabelecimento do equilíbrio inicial com a mobilização de um ângulo de atrito entre o valor de pico e o correspondente ao estado crítico. Nesse caso, embora não citado por McGOWN et al. (1998), a carga no reforço aumentaria ao longo do tempo. Por último, considerando a situação hipotética correspondente à mobilização de um ângulo de atrito em curto prazo correspondente ao estado crítico poder-se-ia esperar deformações ao longo do tempo, de fato, sob carga constante.

\subsection{Características de fluência do solo confinante}

WU \& HELWANY (1996) investigaram a interferência da fluência do solo na fluência dos geotêxteis, utilizando o equipamento mostrado na Figura 2.14. Como mostrado anteriormente, o elemento de solo reforçado, composto por um reforço entre duas camadas de solo, era solicitado mediante a aplicação de uma carga vertical 
constante na superfície da massa de solo. As deformações do geotêxtil, ao longo do tempo, foram acompanhadas por meio de strain gages enquanto a força atuante no reforço após a aplicação da carga foi estimada através da deformação inicial dos strain gages.

Nesse estudo, dois ensaios foram conduzidos utilizando-se um geotêxtil de polipropileno não tecido termoligado cujo comportamento, segundo WU \& HELWANY (1996), não apresenta efeito de confinamento em virtude da tensão confinante e de uma possível imbricação de partículas na estrutura da manta. Primeiramente, utilizou-se uma areia, em seguida, uma argila (caolinita) com grande tendência a apresentar fluência.

Os resultados mostraram que as deformações iniciais do geotêxtil em ambos os casos foram semelhantes às obtidas em ensaios com o geotêxtil isolado. No entanto, as deformações ao longo do tempo foram bem diferentes das obtidas com o material isolado. Segundo os autores, no caso da areia confinando o geotêxtil, o solo tem a tendência de se deformar mais lentamente que o geotêxtil e a deformação para um tempo igual a 43200 min foi aproximadamente quatro vezes menor em relação ao ensaio com o geotêxtil isolado. Já para a argila, o solo tem a tendência de se deformar mais rapidamente que o geotêxtil. Considerando um tempo de 2700 min, a deformação obtida foi 2,5 vezes superior à obtida com o material em isolamento.

De acordo com os resultados, a deformação do geotêxtil com o tempo foi significativamente afetada pela presença do solo. Segundo WU \& HELWANY (1996), se o solo confinante tem a tendência de se deformar mais rapidamente que o reforço, o geossintético irá restringir a deformação do solo em virtude do atrito e adesão existente entre ambos. Situação inversa ocorre, caso o geossintético tenha a tendência de se deformar mais rapidamente que o solo.

\subsection{Deformações em muros de solo reforçado com geossintéticos}

A magnitude das deformações em muros de solo reforçado depende de fatores como: tipo de face, rigidez do reforço, características mecânicas do solo, arranjo e comprimento das inclusões, métodos construtivos, entre outros (ROWE \& HO, 1992). 
Até o presente, a grande maioria dos estudos que analisam fatores que afetam a movimentação de estruturas de solo reforçado tem abordado o problema sem considerar o comportamento em longo prazo. Assim, os resultados mostrados a seguir não consideram, na sua grande maioria, a fluência do reforço. No entanto, certamente os mesmos fatores que afetam o comportamento imediato também respondem por alterações no comportamento em longo prazo. Destaca-se que alguns fatores ligados à fluência do reforço e que afetam as deformações presentes na estrutura (ex. tipo de polímero, confinamento) já foram expostos anteriormente no item 2.1.3.

\subsubsection{Fatores que afetam as deformações}

\subsubsection{Comportamento mecânico do solo}

O comportamento tensão versus deformação do solo, obviamente, influencia as deformações presentes em um muro de solo reforçado. Essa influência pode ser facilmente compreendida considerando o conceito de compatibilidade de deformação. Considerando um mesmo reforço, estruturas compostas por solos com capacidade de mobilizar uma determinada resistência com uma pequena deformação apresentam menores deformações para atingir o equilíbrio do que estruturas compostas por solos que necessitam de maiores deformações para mobilizar a mesma resistência. Esse comportamento é ilustrado na Figura 2.23, e como se pode observar, com solos mais rígidos o equilíbrio ocorre para menores deformações do que para solos com menor rigidez (pontos 1 e 2 , respectivamente).

HELWANY et al. (1999) realizaram um extenso estudo sobre o efeito do tipo de solo utilizado no comportamento de muros mediante simulações numéricas. Os autores consideraram 16 solos diferentes, 3 valores de rigidez para o reforço e 3 alturas diferentes para a estrutura. $\mathrm{O}$ deslocamento máximo apresentado pela face foi, notoriamente, influenciado pelo tipo de solo. Solos rígidos resultaram em menores deslocamentos da estrutura e segundo os autores, esse parâmetro influenciou o comportamento da estrutura de forma mais marcante que a rigidez do reforço. Esse mesmo comportamento também foi obtido por PEDROSO (2000). 


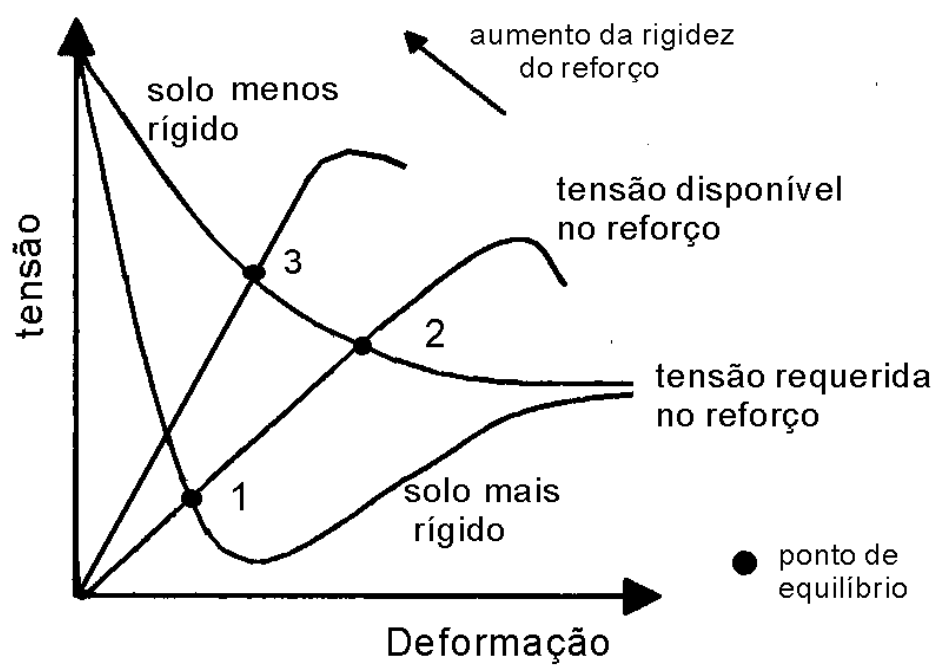

FIGURA 2.23 - Efeito do tipo de solo e reforço com base na compatibilidade de deformação

\subsubsection{Rigidez do reforço}

A influência do tipo de reforço nos deslocamentos pode ser entendida utilizando-se novamente o conceito de compatibilidade de deformação (Figura 2.23). Quando estruturas idênticas, porém com reforços com rigidez diferente são consideradas, o equilíbrio (pontos 3 e 2 mostrados na Figura 2.23) ocorre com menores movimentações na estrutura com reforços mais rígidos (PEDROSO, 2000; ROWE \& HO, 1998; LING et al., 1995).

No entanto, o efeito do tipo de reforço é menos marcante nos deslocamentos horizontais do que o tipo de solo. Segundo HELWANY et al. (1999), o efeito da rigidez do reforço é mais perceptível para solos com baixa resistência e rigidez.

\subsubsection{Comprimento do reforço}

O comprimento da inclusão, ou mais precisamente a relação entre o comprimento e a altura de estrutura $(\mathrm{L} / \mathrm{H})$, tem grande importância nos deslocamentos. A redução do valor de $\mathrm{L} / \mathrm{H}$ acarreta maiores deslocamentos na face.

O decréscimo do valor $\mathrm{L} / \mathrm{H}$ provoca uma redução da força estabilizante (devido ao peso da massa reforçada) que é necessária para garantir o equilíbrio da estrutura. 
Assim, quando o valor $\mathrm{L} / \mathrm{H}$ é reduzido, o empuxo da massa de solo não reforçado produz um momento que induz tensões verticais elevadas na base da estrutura, provocando maiores deslocamentos.

A relação L/H tem uma forte influência sobre os deslocamentos da face, principalmente, para L/H <0,7 (THAMM, 1990) e, segundo HO \& ROWE (1996), a adoção de $\mathrm{L}=0,7 \mathrm{H}$ constitui uma boa recomendação para projeto.

\subsubsection{Arranjo das inclusões}

A disposição das inclusões no maciço de solo, naturalmente, afeta a movimentação da estrutura. PALMEIRA \& LANZ (1994) investigaram essa questão através de modelos reduzidos de muros de solo reforçado. A Figura 2.24 apresenta a geometria dos muros estudados.

A Figura 2.25a ilustra a influência do comprimento do reforço, confirmando maiores deslocamentos para menores comprimentos. Observando-se a diferença entre os muros 2 e 1 (Figura 2.25b) e entre os muros 1 e 7 (Figura 2.25a) que tiveram espaçamento e comprimento reduzidos à metade respectivamente, percebe-se que a variação de comprimento influenciou os deslocamentos de forma muito mais intensa que a variação do espaçamento.

Comparando-se os resultados obtidos para os muros 1, 2 e 3 (Figura 2.25b) é possível verificar o efeito do espaçamento das inclusões nos deslocamentos horizontais dos modelos Percebe-se que o muro 1, com menor espaçamento, apresentou o melhor resultado. Comparando-se os arranjos 2 e 3 percebe-se que a intercalação de inclusões com comprimentos reduzidos (arranjo 3) não apresentou nenhum beneficio para o desempenho da estrutura. 
Geometria dos muros ensaiados ( $\mathrm{mm})$

\begin{tabular}{rccrcccc}
\hline muro & $H$ & $B$ & \multicolumn{1}{c}{$S$} & $a$ & $x$ & $y$ & $s$ \\
\hline 1 & 440 & 220 & 50 & - & - & - & - \\
2 & 440 & 220 & 100 & - & - & - & - \\
3 & 440 & 220 & 100 & 110 & - & - & - \\
4 & 440 & 220 & 50 & - & 110 & 200 & - \\
5 & 440 & 110 & 50 & - & 110 & 200 & - \\
6 & 440 & 220 & 100 & - & - & 200 & 50 \\
7 & 440 & 110 & 50 & - & - & - & - \\
8 & 440 & 160 & 50 & - & - & - & - \\
\hline
\end{tabular}

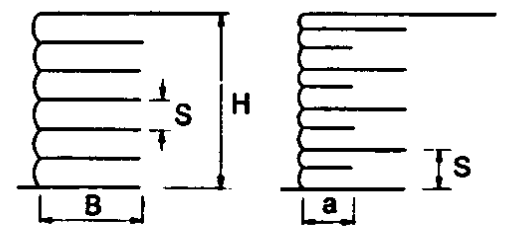

muro $1,2,7$ e 8

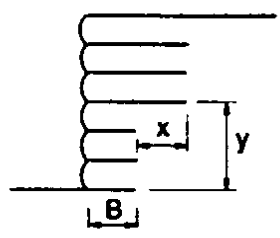

muro 5

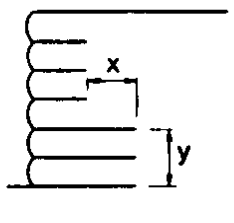

muro 4 muro 3

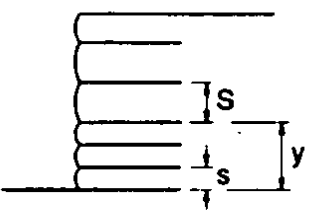

muro 6

FIGURA 2.24 - Geometria dos modelos reduzidos estudados por PALMEIRA \& LANZ (1994)

Com relação aos deslocamentos obtidos para os muros 1, 4, 5 e 6 (Figura 2.26), o muro 1 apresentou o menor deslocamento máximo da face. Os muros 4 e 5 apresentaram deslocamentos acentuados nas regiões em que o comprimento do reforço foi reduzido, principalmente o muro 4. Os deslocamentos do muro 6 não foram muito diferentes dos apresentados pelo muro 1, principalmente, para a menor sobrecarga.

ROWE \& HO (1998) analisaram diferentes arranjos para o reforço através de simulação numérica. A Figura 2.27 mostra as configurações consideradas, adotandose sempre o mesmo número de camadas e mantendo-se constante a soma dos comprimentos de cada reforço utilizado em uma determinada configuração. 

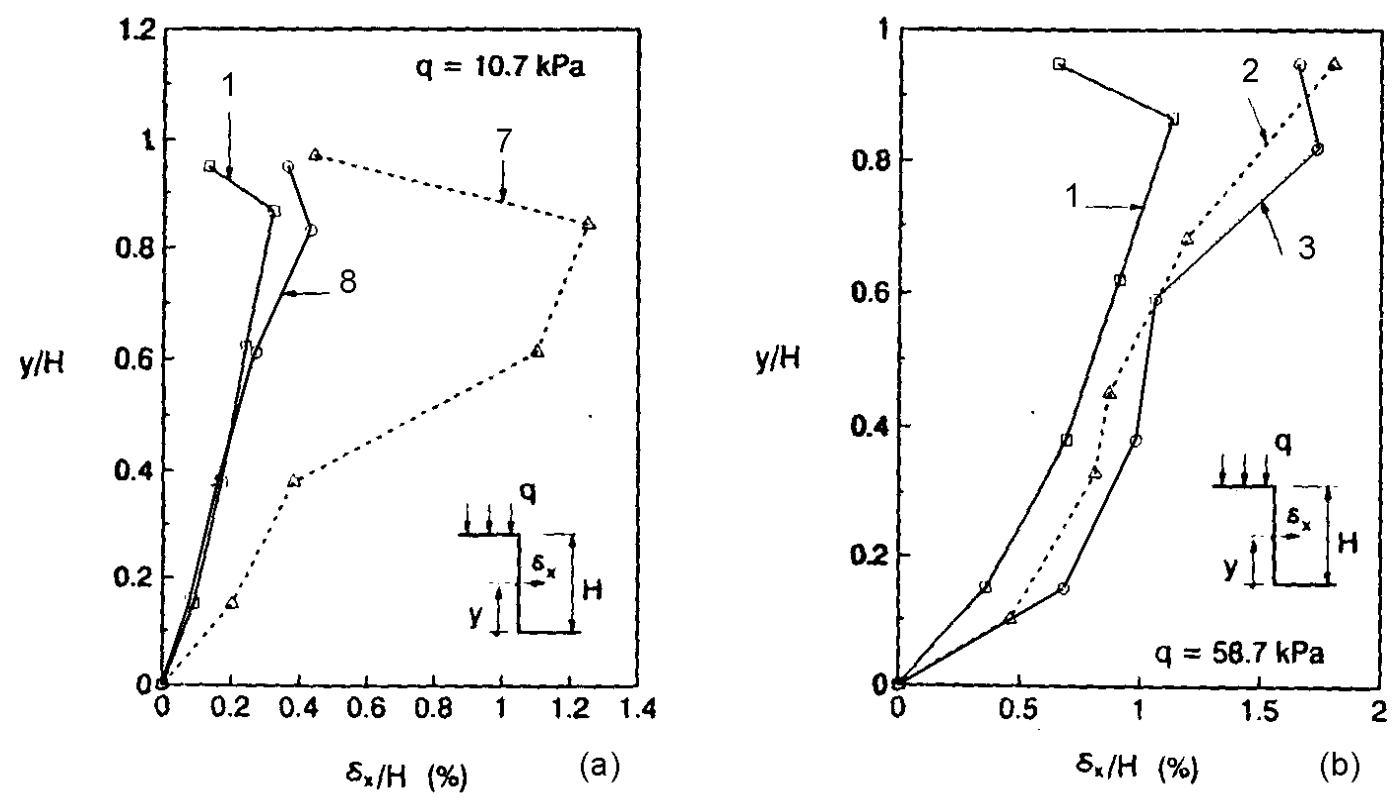

FIGURA 2.25 - (a) Deslocamentos dos muros 1, 8 e 7 (b) deslocamentos dos muros 1,2,3 (PALMEIRA \& LANZ, 1994).
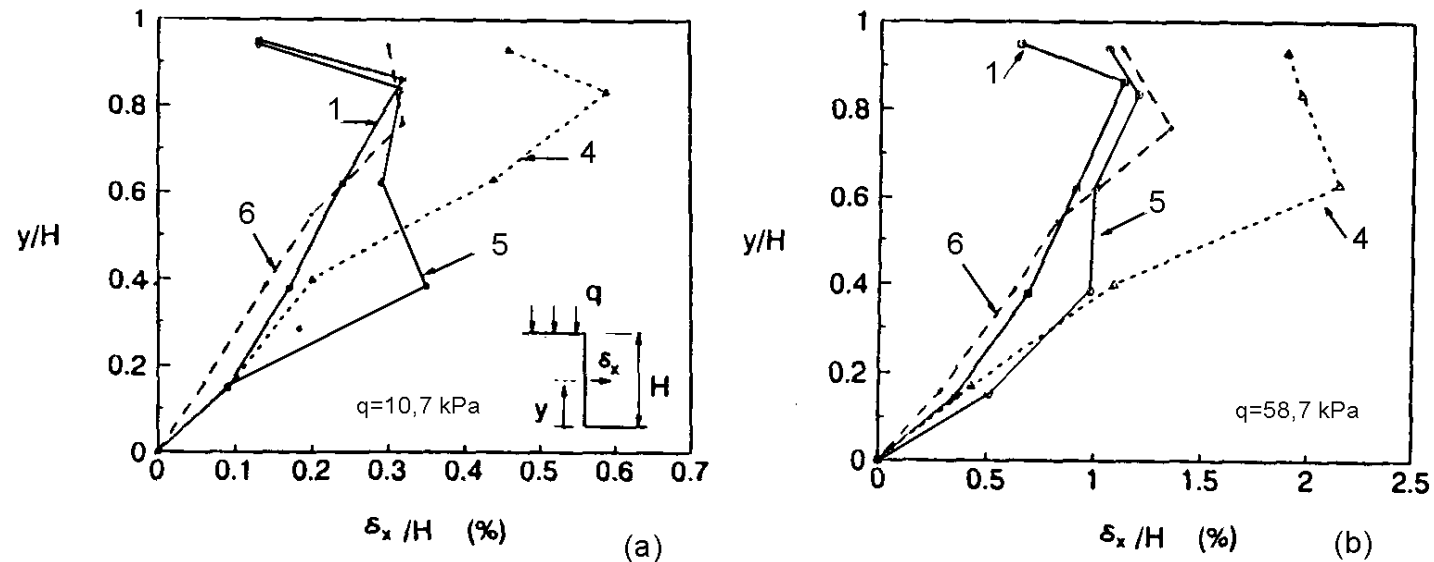

FIGURA 2.26 - Deslocamentos dos muros 1, 4, 5 e 6 (a) q=10,7 kPa

(b) $\mathrm{q}=58,7 \mathrm{kPa}$ (PALMEIRA \& LANZ, 1994)
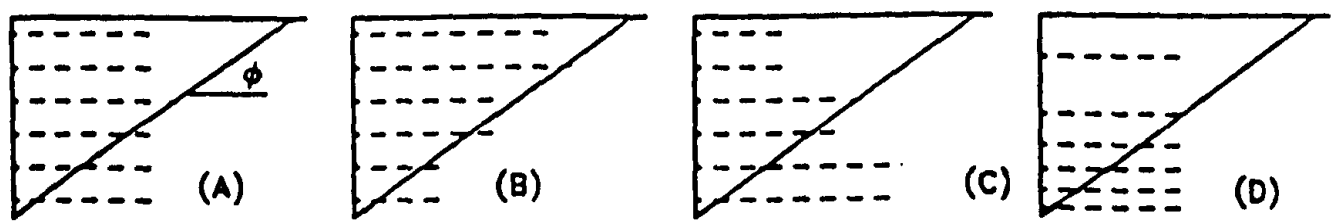

FIGURA 2.27 - Arranjos de muros considerados por ROWE \& HO (1998). 
O arranjo A corresponde a uma distribuição uniforme do reforço com mesmo comprimento e espaçamento. A relação $\mathrm{L} / \mathrm{H}$ utilizada no arranjo A não foi identificada, mas analisando-se uma outra publicação desses autores (HO \& ROWE, 1996) acredita-se que a relação adotada para esse arranjo foi $\mathrm{L} / \mathrm{H}=0,7$. O esquema $B$ apresenta o mesmo espaçamento, porém o comprimento do reforço é variável, o qual se estende até as proximidades de uma linha de inclinação igual ao ângulo de atrito do solo. $\mathrm{O}$ arranjo $\mathrm{C}$ é o contrário do $\mathrm{B}$ e a configuração $\mathrm{D}$ possui comprimento uniforme (igual ao adotado para o arranjo A) e espaçamento decrescente com a altura.

Observando-se a Figura 2.28, percebe-se que em termos de deslocamento horizontal na face, o esquema $\mathrm{B}$ foi o mais eficiente. $\mathrm{O}$ arranjo $\mathrm{A}$ embora menos eficiente se aproximou bastante do B, possivelmente, por apresentar uma relação $\mathrm{L} / \mathrm{H}$ $=0,7$ para a qual a movimentação da face já não é afetada significativamente pelo comprimento do reforço. Os esquemas $\mathrm{C}$ e $\mathrm{D}$ tiveram um desempenho semelhante e inferior aos demais.

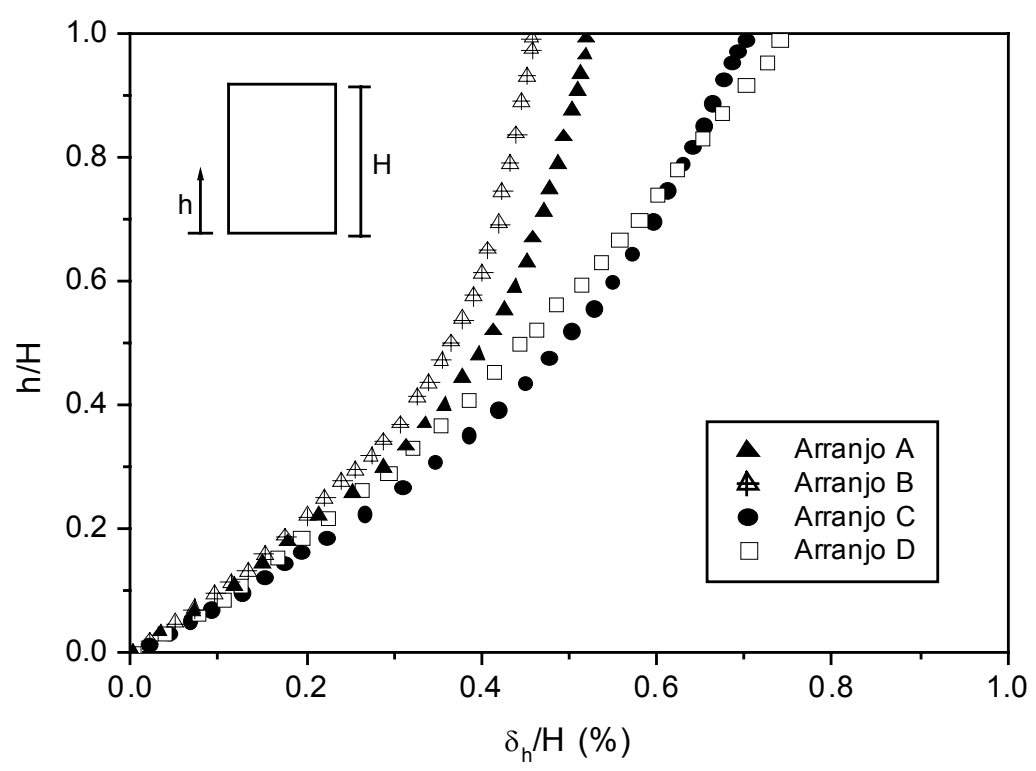

FIGURA 2.28 - Deslocamentos horizontais na face para os diferentes arranjos considerados por ROWE \& HO (1998).

\subsubsection{Tipo de face}

Inicialmente, a presença da face em uma estrutura de solo reforçado era 
justificada por motivos estéticos, facilidade construtiva e para uma maior durabilidade da obra, evitando vandalismo e degradação do reforço. Atualmente, entretanto, a influência da face na estabilidade da estrutura já se encontra amplamente reconhecida e muitos trabalhos evidenciam o papel do tipo de face no desempenho da estrutura (ex. NAKAMURA et al., 1988; TATSUOKA, 1989; MURATA et al., 1990; MURATA et al., 1992; TATSUOKA et al., 1992; TATSUOKA et al., 1997; TSUKADA et al., 1998).

Segundo TATSUOKA (1992), a ausência de uma face adequada pode resultar em uma ruptura local, imediatamente atrás da face (Figura 2.29). O mecanismo de ruptura local corresponde a uma espécie de "arrancamento do solo", o solo na região ativa é expulso do maciço enquanto o reforço permanece estacionário ancorado na zona passiva. Esse processo cuja maior probabilidade de ocorrência está nas camadas inferiores pode induzir uma ruptura progressiva em direção ao interior do maciço, resultando no colapso global da estrutura. A presença de uma face com rigidez apropriada provoca um confinamento do solo nas proximidades da face e evita a instauração do referido mecanismo.

(3) recalque

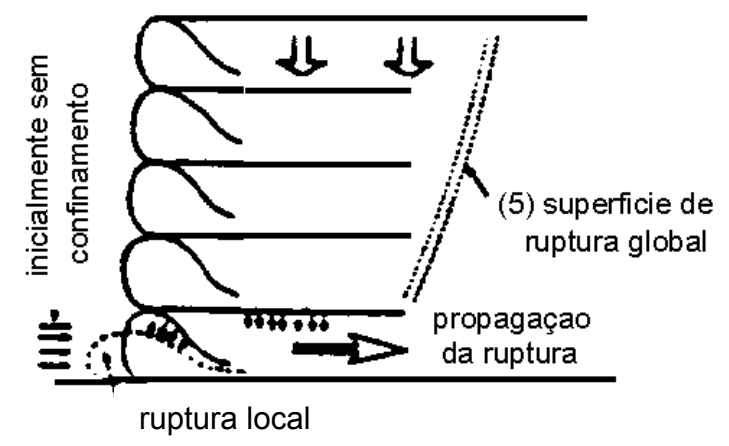

FIGURA 2.29 - Mecanismo de ruptura progressiva provocado pela ruptura local, por compressão do solo, imediatamente atrás da face (TATSUOKA, 1992).

$\mathrm{Na}$ verdade, a presença de uma face contribui para estabilidade de uma estrutura de solo reforçado de uma forma muito mais ampla e não apenas através da rigidez local. TATSUOKA (1992) define outros tipos de rigidez denominados rigidez global como: rigidez axial, ao cisalhamento e à flexão. Nesse caso, é possível a transmissão através da face de forças axiais, tensões cisalhantes (entre os elementos de compõem a face) e momentos fletores, respectivamente. Algumas faces podem ainda contribuir com a estabilidade da estrutura através de alguma resistência em 
virtude do peso próprio como em estruturas de contenção convencionais.

A rigidez da face também afeta a distribuição da força de tração $(\mathrm{T})$ no reforço. A Figura 2.30 ilustra as duas situações extremas dessa distribuição. $\mathrm{Na}$ distribuição $\mathrm{A}$, a força de tração ao longo do comprimento do reforço é constante entre a face e a superfície de ruptura e igual a um valor máximo $\left(\mathrm{T}_{\operatorname{máxA}}\right)$. Após a superfície de ruptura ocorre um decréscimo até a força se tornar nula. Na distribuição $\mathrm{B}$, a força máxima ocorre na superfície de ruptura, diminuindo até zero tanto em direção à face $\left(\mathrm{T}_{\mathrm{w}}=0\right)$ quanto em direção à região passiva. $\mathrm{Na}$ realidade, as distribuições observadas em estruturas de solo reforçado situam-se geralmente entre as duas situações mostradas na Figura 2.30 e se aproximam da distribuição A, à medida que a rigidez da face aumenta.

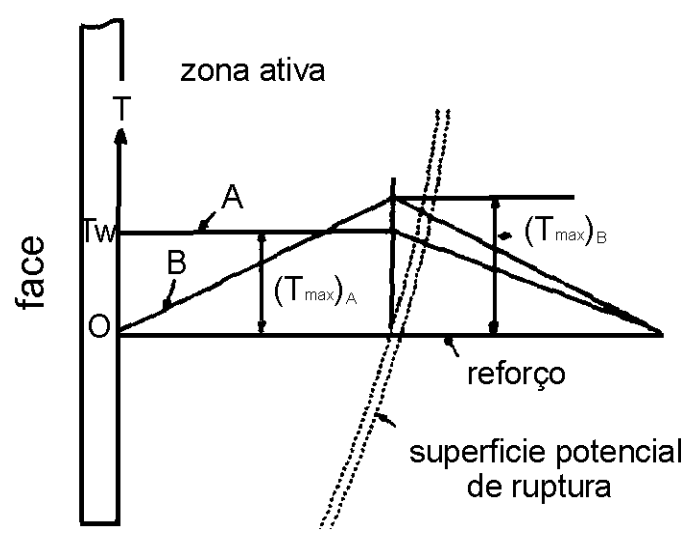

FIGURA 2.30 - Tipos de distribuição de força no reforço em estruturas de solo reforçado (TATSUOKA, 1992).

No que diz respeito à influência do tipo de face nos deslocamentos da estrutura, NAKANE et al. (1990) investigaram o comportamento de três muros de solo reforçado com geogrelha, tendo uma areia como material de aterro. Os muros possuíam 4,5 $\mathrm{m}$ de altura e diferentes tipos de face. Os resultados encontrados por esses autores mostraram que os deslocamentos registrados na face foram bem mais pronunciados para as faces com menor rigidez. NAEMURA et al. (1991) também observaram comportamentos distintos entre dois muros de solo reforçado com geogrelha, com $5 \mathrm{~m}$ de altura, e diferentes tipos de face. $\mathrm{O}$ solo de aterro era uma areia e, igualmente, menores deslocamentos foram observados para a estrutura com face em blocos de concreto, que apresentava a maior rigidez.

Como visto, com relação a deslocamentos em curto prazo, o aumento da 
rigidez da face reduz os deslocamentos após o término da construção e a magnitude dessa redução depende tanto da rigidez local quanto da rigidez global que a mesma apresenta. Faces dotadas de alta rigidez axial, por exemplo, apresentam menores recalques que o solo adjacente. Assim, o atrito mobilizado entre a face e o solo de aterro provoca uma redução das tensões verticais, e conseqüentemente, uma redução da força e das deformações nos reforços (ROWE \& HO, 1992).

Para movimentações em longo prazo, entretanto, não existe um comportamento definido no que diz respeito à rigidez da face. Os resultados obtidos por NAKANE et al. (1990) e NAEMURA et al. (1991), por exemplo, apresentam menores deslocamentos em curto prazo para estruturas com faces mais rígidas, mas com relação às movimentações ao longo do tempo os resultados são discrepantes. NAKANE et al. (1990) identificaram um melhor comportamento ao longo do tempo com o aumento da rigidez da face. NAEMURA et al. (1991), entretanto, mostra maiores deslocamentos ao longo do tempo para a estrutura com face mais rígida.

WAWRYCHUK apud ROWE \& HO (1992) também observaram comportamentos diferentes a curto e longo prazo comparando estruturas semelhantes, porém com faces distintas, uma, com face composta por painéis contínuos de madeira e outra, com face constituída por painéis segmentados de madeira. A estrutura com face mais rígida apresentou menores deslocamentos na face para cada sobrecarga aplicada (cerca de 2x menor), no entanto, manifestou maior fluência que a estrutura com face menos rígida.

Vale destacar que as implicações práticas do fato de uma estrutura com face mais rígida apresentar maior fluência depende da intensidade do processo e de sua vida útil. Possivelmente, os deslocamentos totais registrados em uma estrutura com face rígida que apresentou uma fluência mais acentuada ainda sejam menores que os deslocamentos totais de uma estrutura com face menos rígida que apresentou maiores deslocamentos iniciais e menor fluência.

Um aspecto importante com relação ao tipo de face diz respeito ao método construtivo. O desenvolvimento dos deslocamentos em estruturas com faces contínuas escoradas e com faces com construção incremental (ex. muros envelopados) ocorre de forma distinta. No primeiro caso, os deslocamentos manifestam-se após a construção com a retirada das escoras. No segundo caso, os 
deslocamentos acontecem durante o processo de construção e compactação do aterro, assim, uma determinada camada acumula a movimentação das camadas anteriores.

\subsubsection{Processo de compactação do solo}

A compactação influencia sobremaneira o comportamento de solos reforçados. As tensões horizontais induzidas durante a compactação podem invalidar as hipóteses assumidas durante o projeto, pois podem exceder o valor previsto devido ao peso próprio do aterro (JONES, 1990). Razão pela qual se deve considerar seu efeito em projetos.

Alguns métodos (ex. BROMS, 1971; INGOLD, 1979) permitem quantificar as tensões geradas durante a compactação em estrutura de contenção. Com relação a deslocamentos, o acréscimo no estado de tensão em função da compactação provoca, conseqüentemente, um aumento dos deslocamentos horizontais da face. A Figura 3.30 ilustra o efeito da compactação nas deformações observadas nas estruturas, com base no conceito de compatibilidade de deformação. Como mostrado na Figura 3.30, quando as tensões no solo induzidas pela compactação são maiores do que as tensões pelo peso próprio, o equilíbrio é estabelecido para um valor de deformação no reforço superior ao valor esperado sem considerar o processo de compactação.

Um artifício utilizado para reduzir os deslocamentos na face devido ao processo de compactação consiste na introdução de uma camada vertical compressível entre a face e o aterro. O emprego dessa camada permite reduzir o empuxo atuante na face, pois possibilita a movimentação do solo durante a construção, que ocorre, no entanto, sem a necessidade de movimentação da face (YEO et al., 1992). Assim, os deslocamentos são minimizados devido à redução do

empuxo atuante na face. É possível ainda obter o mesmo efeito do emprego de placas de material sintético, reduzindo o grau de compactação do aterro nas proximidades da face (MARQUES, 1994).

A compactação pode representar o principal fator de influência nas tensões desenvolvidas no reforço. Em outras palavras, a força e a deformação máxima em cada camada de reforço devem-se às tensões resultantes do processo de compactação. A compactação determina a máxima tensão no reforço para 
profundidades inferiores a $\mathrm{z}_{\mathrm{c}}$ (Figura 3.31), a partir da qual a tensão no solo devido ao peso próprio das camadas sobrejacentes excede a tensão induzida pela compactação. Como mostrado na Figura 3.31, devido ao efeito da compactação, a distribuição da máxima tensão em cada inclusão com a profundidade pode se apresentar diferente da distribuição esperada devido ao peso próprio da estrutura. Segundo EHRLICH \& MITCHELL (1994), as tensões em virtude do peso próprio em muros de solo reforçado são inferiores às tensões ocasionadas pela compactação, geralmente, até a estrutura atingir cerca de $6 \mathrm{~m}$ de altura, ou seja, $\mathrm{z}_{\mathrm{c}}=6,0 \mathrm{~m}$.

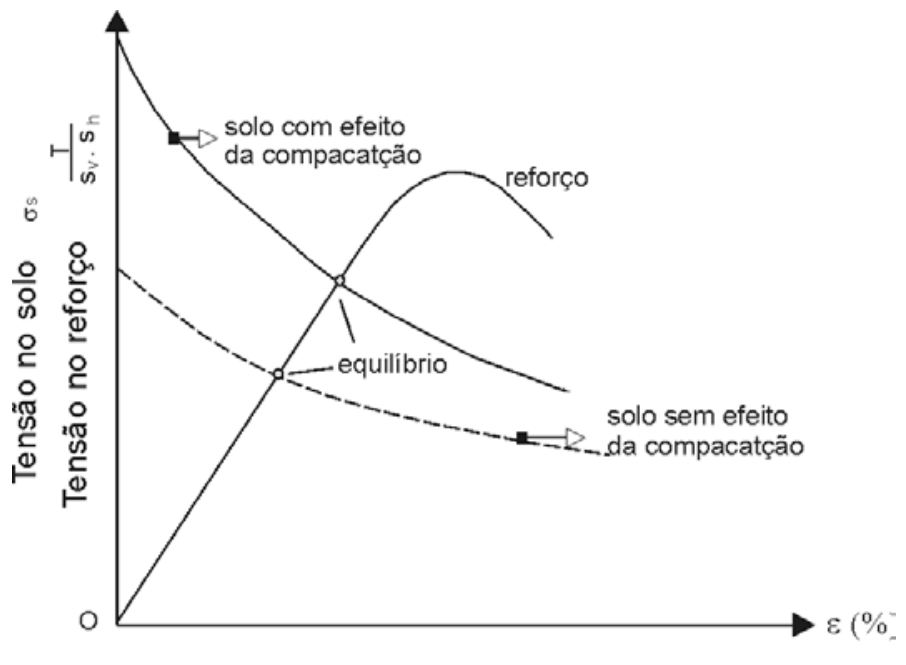

Obs. S, , Sh Espaçamento vertical e horizontal entre reforços

FIGURA 2.31 - Compatibilidade de deformação considerando as tensões induzidas por efeito da compactação (EHRLICH \& AZAMBUJA, 2003).
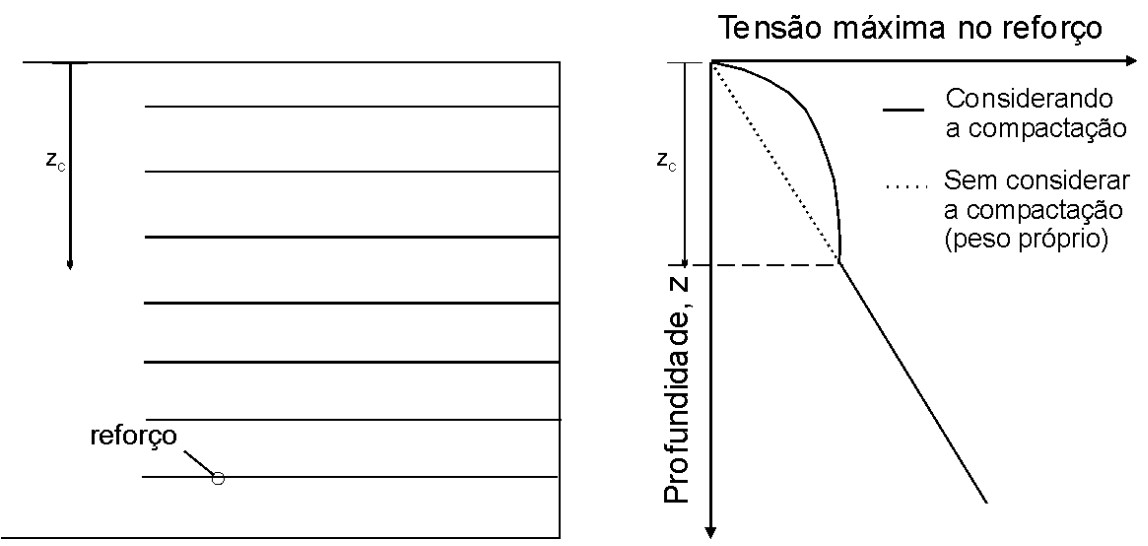

FIGURA 2.32 - Distribuição da máxima tensão em cada camada de reforço com a profundidade por efeito da compactação (modificado de EHRLICH \& AZAMBUJA, 2003). 


\subsubsection{As deformações no dimensionamento de muros de solo reforçado}

No que diz respeito ao dimensionamento de muros de solo reforçado, inicialmente, pouca ou quase nenhuma atenção era dispensada às deformações da estrutura (McGOWN et al., 1998). Atualmente, embora ainda não seja uma prática generalizada, o dimensionamento envolve a verificação da estrutura com relação à ruptura (estado limite último) e com relação a deformações excessivas (estado limite de utilização).

\subsubsection{Estado limite último}

Duas etapas básicas costumam ser consideradas no dimensionamento de muros de solo reforçado, com relação ao estado limite último: verificação da estabilidade externa e verificação da estabilidade interna.

$\mathrm{Na}$ análise da estabilidade externa, o muro é assumido como um corpo rígido e a segurança deve ser garantida considerando-se, geralmente, os seguintes mecanismos de ruptura: tombamento e deslizamento na base da estrutura, capacidade de carga do solo de fundação e ruptura geral por superfícies de deslizamento envolvendo o maciço reforçado (Figuras 2.35 e 2.36), semelhantemente ao dimensionamento de estruturas de contenção convencionais.

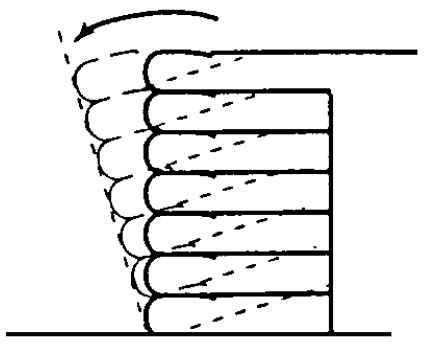

(a)

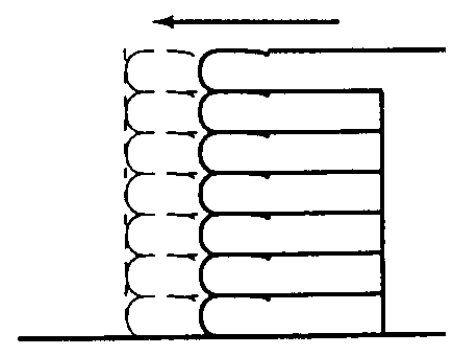

(b)

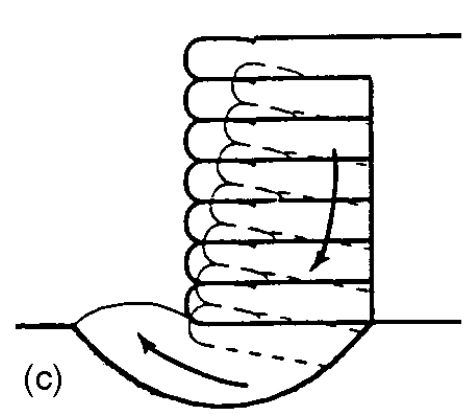

FIGURA 2.33 - Mecanismos envolvidos na estabilidade externa (a) tombamento, (b)deslizamento, (c) capacidade de carga da fundação (KOERNER, 1998) 


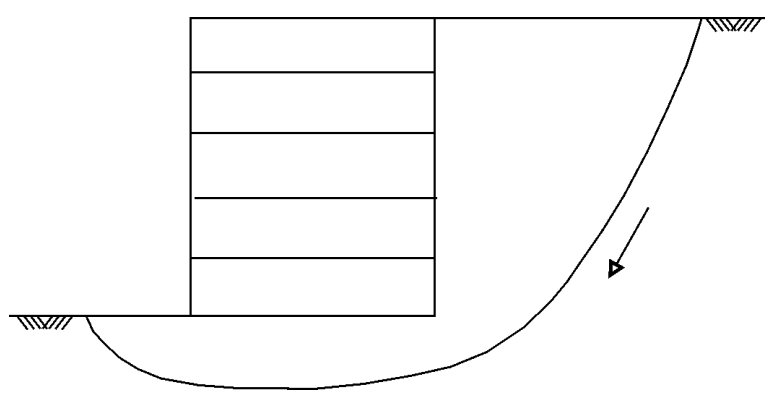

FIGURA 2.34 - Mecanismo de ruptura geral

$\mathrm{Na}$ estabilidade interna, superfícies de ruptura inteiramente contidas na zona reforçada são consideradas. Mecanismos de ruptura como os mostrados na Figura 2.35 necessitam ainda ser investigados e podem ser considerados com parte da verificação da estabilidade externa (mecanismo geral mostrado na Figura 2.34 com superfícies de ruptura interceptando alguma inclusão).

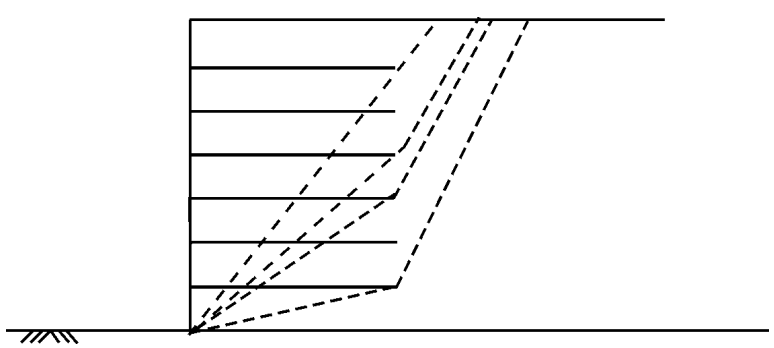

FIGURA 2.35 - Mecanismos de ruptura a serem considerados no dimensionamento de muros de solo reforçado (JEWELL, 1996).

A análise da estabilidade interna envolve pelo menos dois aspectos básicos: ruptura e arrancamento dos reforços. Nessa etapa, soluções baseadas em equilíbrio limite são empregadas, como por exemplo, o método adotado pelo U.S. Forest Service e os propostos por LESHCHINSKY \& PERRY (1989), LESHCHINSKY \& BOEDEKER (1989) e JEWELL (1991). Nesses métodos, o maciço reforçado é dividido em duas regiões: zona ativa e resistente (Figura 2.36), devendo as inclusões resistir aos esforços de tração sem que ocorra ruptura, bem como, possuir comprimento suficiente na zona resistente a fim de evitar o arrancamento. 


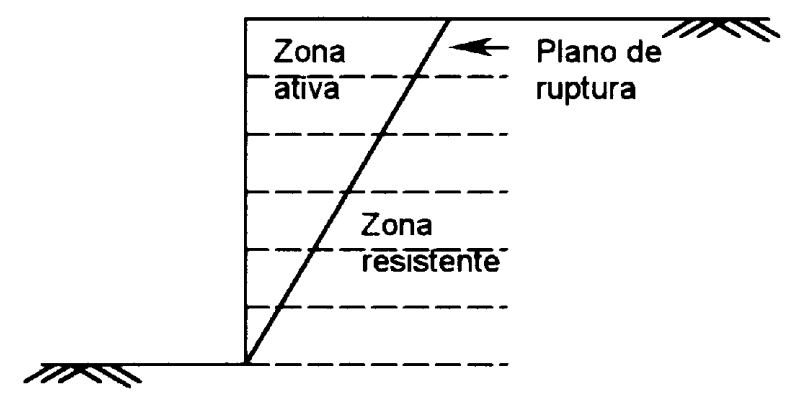

FIGURA 2.36 - Zona ativa e resistente de um maciço reforçado

Com relação à estabilidade interna, a possibilidade de ruptura é analisada comparando-se a força requerida em cada inclusão para manter o equilíbrio, com a força disponível em cada inclusão (resistência admissível do reforço). É nessa etapa do dimensionamento que surge uma importante interferência das deformações no projeto, ou mais especificamente da fluência do geossintético. Como esse processo provoca ruptura é preciso considerar as deformações ao longo do tempo já na análise de estado limite último, e não apenas no estado limite de deformação.

A resistência admissível do reforço pode ser obtida com base em ensaios de tração, aplicando-se fatores de redução à resistência à tração devido a diferentes mecanismos capazes de reduzir a resistência do geossintético, como mostrado em KOERNER (1998). Nesse caso, a resistência admissível $\left(\mathrm{T}_{\mathrm{adm}}\right)$ pode ser obtida de acordo com a expressão 2.1 .

$\mathrm{T}_{\mathrm{adm}}=\frac{\mathrm{T}_{\mathrm{ult}}}{\mathrm{FR}_{\mathrm{DI}} \cdot \mathrm{FR}_{\mathrm{FL}} \cdot \mathrm{FR}_{\mathrm{DQ}} \cdot \mathrm{FR}_{\mathrm{DB}}}$

Onde,

$\mathrm{T}_{\text {ult }}$ - Resistência última à tração;

$\mathrm{FR}_{\mathrm{DI}}$ - Fator de redução para danos de instalação;

$\mathrm{FR}_{\mathrm{FL}}$ - Fator de redução para fluência;

$\mathrm{FR}_{\mathrm{DQ}}$ - Fator de redução para degradação química;

$\mathrm{FR}_{\mathrm{DB}}$ - Fator de redução para degradação biológica. 
Alguns fatores de redução encontrados na literatura, para fluência de geotêxteis, considerando diferentes tipos de polímeros encontram-se na Tabela 2.1. Os valores mais baixos devem ser aplicados a obras com uma menor vida útil, enquanto os valores mais elevados se aplicam à situação inversa. Em geral, o fator de redução com relação à fluência corresponde à relação entre a carga de ruptura convencional e a que leva o geotêxtil à ruptura em virtude desse mecanismo (ABRAMENTO, 1995).

TABELA 2.1 - Fatores de redução considerando a fluência (KOERNER, 1998)

\begin{tabular}{l|c|c|c}
\hline Polímero & DEN HOEDT (1986) & LAWSON (1986) & KOERNER (1998) \\
\hline Polipropileno & 4,0 & $2,5-5,0$ & $3,0-4,0$ \\
Polietileno & 4,0 & $2,5-5,0$ & $3,0-4,0$ \\
Poliamida & 2,5 & $1,5-2,5$ & $2,0-2,5$ \\
Poliéster & 2,0 & $1,5-2,5$ & $2,0-2,5$ \\
\hline
\end{tabular}

Uma outra abordagem para a determinação da resistência admissível consiste em aplicar fatores de redução à carga que causa ruptura por fluência como descrito por PALMEIRA (1999). Nesse caso, a expressão 2.2 deve ser utilizada, sendo imprescindível que se disponha de ensaios de fluência do material.

$\mathrm{T}_{\mathrm{adm}}=\mathrm{T}_{\mathrm{ref}} / \mathrm{FR}_{\mathrm{DI}} \cdot \mathrm{FR}_{\mathrm{amb}} \cdot \mathrm{f}_{\mathrm{m}}$

Onde:

$\mathrm{T}_{\text {ref }}$ - resistência de referência do reforço;

$\mathrm{FR}_{\mathrm{DI}}$ - fator de redução devido a danos de instalação;

$\mathrm{FR}_{\mathrm{amb}}$ - fator de redução devido a danos ambientais;

$\mathrm{f}_{\mathrm{m}}$ - fator que leva em conta incertezas sobre o material do reforço.

A resistência de referência do reforço $\left(T_{\text {ref }}\right)$ deve contemplar o tempo de vida útil da obra, devendo ser obtida do gráfico de ruptura por fluência (Figura 2.37). Essa concepção de projeto representa um procedimento mais coerente que a anterior já que permite adotar um valor de resistência admissível realmente adequado ao tempo de utilização da estrutura. 
Em cada abordagem utilizada para a determinação da resistência admissível, algumas variações podem existir com relação aos mecanismos considerados, como o emprego de fatores de redução distintos para degradação por radiação ultravioleta e envelhecimento químico (ex. ALLEN, 1991), ou a utilização de um único coeficiente englobando degradação química e biológica, como proposto por JEWELL \& GREENWOOD (1988). McGOWN et al. (1998) identificam ainda um fator de redução do material para levar em conta as incertezas da extrapolação dos dados de ensaio e um fator de redução geral por possíveis discrepâncias das propriedades do material em relação às especificações do fabricante.

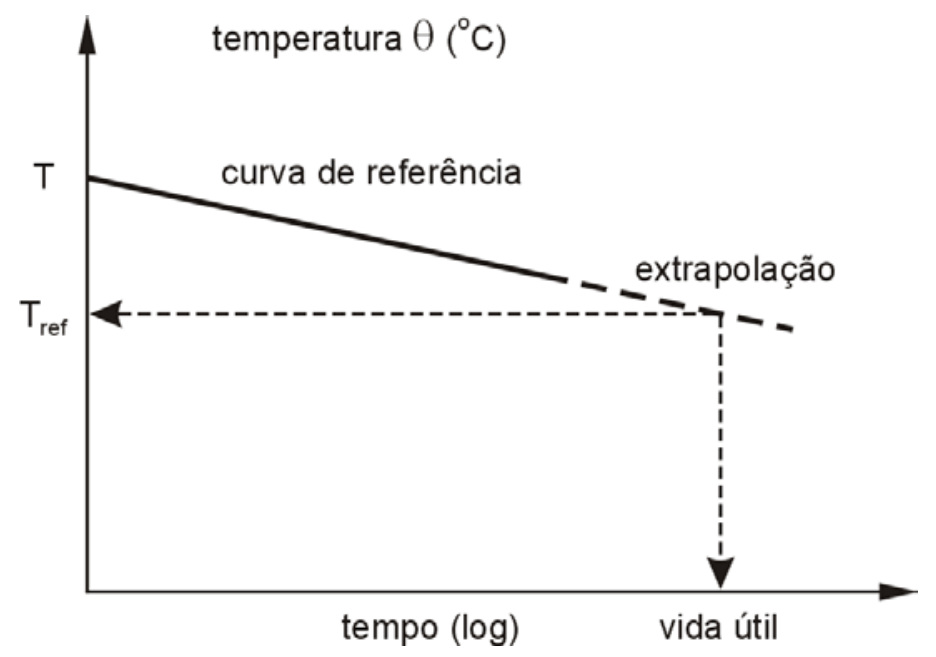

FIGURA 2.37 - Curva de referência ou ruptura por fluência (PALMEIRA, 1999)

Os fatores de redução empregados para o cálculo da resistência admissível possuem uma ampla faixa de variação a depender do tipo de obra e do tipo de polímero. A Tabela 2.2 serve de indicativo com relação a valores utilizados em muros de solo reforçado.

TABELA 2.2 - Fatores de redução para a resistência à tração (KOERNER, 1998)

\begin{tabular}{c|c|c|c}
\hline $\begin{array}{c}\text { Danos de } \\
\text { instalação }\end{array}$ & *Fluência & $\begin{array}{c}\text { Degradação } \\
\text { química }\end{array}$ & $\begin{array}{c}\text { Degradação } \\
\text { biológica }\end{array}$ \\
\hline 1,1 a 2,0 & 2,0 a 4,0 & 1,0 a 1,5 & 1,0 a 1,3 \\
\hline
\end{tabular}

* menor valor para aplicações com pequena vida útil e/ou obras onde as deformações por fluência não são importantes. 


\subsubsection{Estado limite de utilização}

A verificação do estado limite de utilização é geralmente efetuada adotandose uma deformação limite no reforço cujo valor depende do impacto visual causado pela deformação da face e de critérios de utilização de estruturas suportadas pelo muro. Uma deformação limite igual a 1\% é geralmente recomendada (JONES, 1990; BS 8006, 1995).

O equilíbrio interno deve ser novamente verificado a fim de averiguar sua manutenção considerando a carga no reforço correspondente ao valor limite de deformação adotado. Nessa verificação, valores mais realistas devem ser adotados para avaliar as cargas atuantes e as propriedades do solo e do reforço (JEWELL, 1996).

Segundo McGOWN et al. (1998), em condições de trabalho, o equilíbrio em muros de solo reforçado ocorre com a mobilização de um ângulo de atrito para o solo compreendido entre o valor de repouso e o valor de pico. Assim, não existe uma recomendação com relação à adoção de um único valor de ângulo de atrito e valores distintos devem ser adotados considerando o limite de deformação em questão.

O limite de deformação adotado deve contemplar o tempo de utilização da estrutura. Desse modo, a resistência admissível no reforço, considerando o estado limite de utilização é obtida com base em ensaios de fluência a partir de curvas isócronas.

Contudo, frequentemente, a verificação do estado limite de utilização não é viável quando geotêxteis não tecidos são empregados. Isso ocorre, pois, esses materiais apresentam deformações em isolamento bem superiores aos limites de deformação recomendados, mesmo para pequenos valores de carga, e, geralmente, não se encontram disponíveis dados de ensaios confinados. Assim, embora sejam esperadas deformações reduzidas em campo quando se utilizam geotêxteis não tecido por efeitos de confinamento, geralmente não é possível proceder a um dimensionamento adequado do estado limite de utilização.

A expressão (2.3) apresentada em PALMEIRA (1999) exemplifica a obtenção da resistência admissível em análises de deformação da estrutura. 
$\mathrm{T}_{\mathrm{adm}}=\mathrm{T}(\varepsilon, \mathrm{t}, \theta) / \mathrm{FR}_{\mathrm{DI}} \cdot \mathrm{FR}_{\mathrm{amb}} \cdot \mathrm{f}_{\mathrm{m}}$

Onde:

$\mathrm{FR}_{\mathrm{DI}}$ - fator de redução devido a danos de instalação;

$\mathrm{FR}_{\mathrm{amb}}$ - fator de redução devido a danos ambientais;

$\mathrm{f}_{\mathrm{m}}$ - fator que leva em conta incertezas sobre o material do reforço.

$\mathrm{T}(\varepsilon, \mathrm{t}, \theta)$ - resistência à tração correspondente a deformação $\varepsilon$ em um tempo de carregamento t, a uma temperatura $\theta$ (Figura 2.38). Esse valor corresponde à resistência à tração obtida a partir de curvas isócronas para situações específicas de deformação, tempo (vida útil) e temperatura operacional.

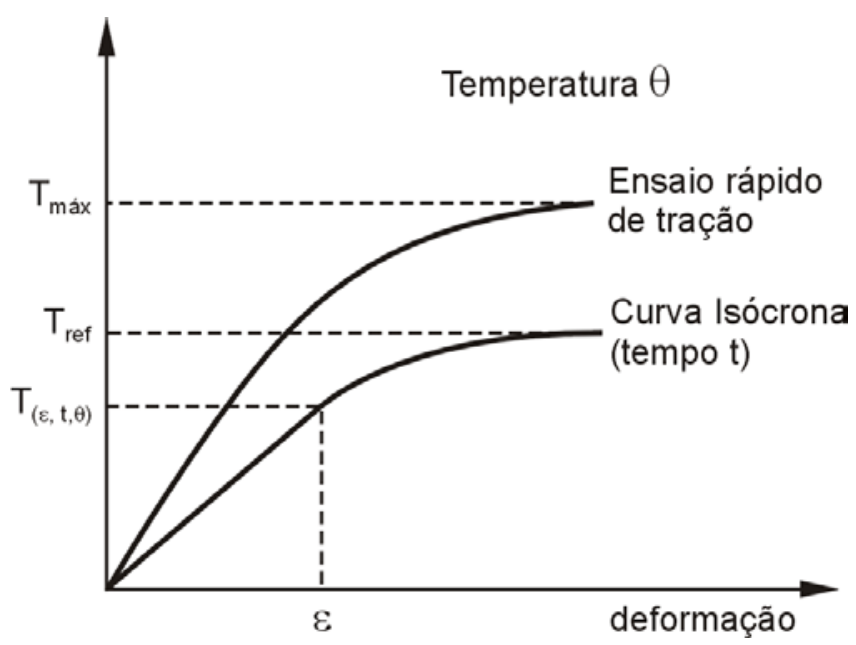

FIGURA 2.38 - Resistência à tração a longo prazo, curva isócrona (PALMEIRA, 1999).

\subsubsection{Métodos de Previsão de deslocamentos}

Uma outra abordagem para análises de deformação consiste na utilização de métodos específicos para previsão de deslocamentos na face. No que diz respeito a tais procedimentos, não é fácil englobar todos os aspectos intervenientes em um único método, já que muitos fatores podem influenciar os deslocamentos em muros 
de solo reforçado. Assim, os métodos disponíveis para a previsão de deslocamentos são poucos e, naturalmente, não consideram todos os fatores que interferem nos deslocamentos da face.

MITCHELL \& CHRISTOPHER (1990) propõem a utilização da curva empírica mostrada na Figura 2.39 para uma estimativa inicial do deslocamento máximo esperado na face em muros de solo reforçado. Esse gráfico pode ser utilizado para reforços inextensíveis e, também, considerando a utilização de geossintéticos (reforços extensíveis). As relações mostradas na Figura 2.39 foram estabelecidas com base na instrumentação de muros de $6,0 \mathrm{~m}$ de altura, com areia e pedregulho como material de aterro, e faces compostas, na sua maioria, por painéis segmentados.

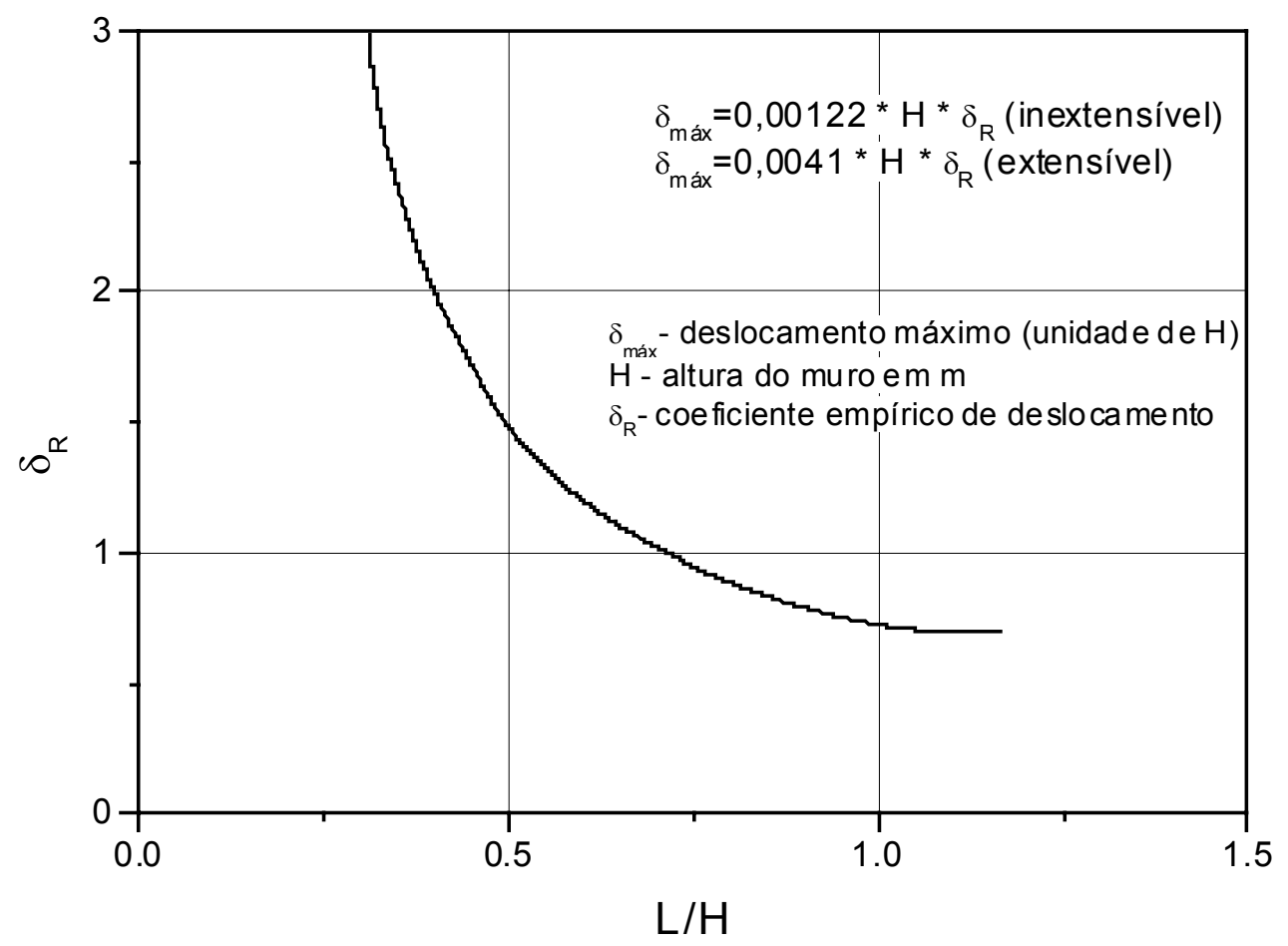

Nota: deve-se aumentar $\delta_{\mathrm{R}} 25 \%$ para ca da $19 \mathrm{kPa}$ de sobre carga

FIGURA 2.39 - Curva para estimativa do deslocamento lateral no final da construção (MITCHELL \& CHRISTOPHER, 1990 - modificado para dimensões em metros)

Outros dois métodos descritos na literatura para previsão de deslocamentos 
são descritos a seguir: o método de EHRLICH (1995) e o método proposto por SAWICKI (1999).

\subsection{Método de EHRLICH (1995)}

O método proposto por EHRLICH (1995) permite avaliar as movimentações de muros de solo reforçado sob condições de trabalho. Esse autor classifica os movimentos em massas de solo reforçado em dois grandes grupos, os que se originam de deformações externas e os que ocorrem devido a deformações internas à zona reforçada. As deformações externas correspondem à rotação devido à excentricidade de cargas e recalques da base do muro. A distensão dos reforços (sob a ação das tensões internas) somada à parcela devido à distorção e deflexão devido ao empuxo de terra da massa não reforçada são responsáveis pelas deformações internas. Ressalta-se que esse método permite considerar o efeito da compactação no valor das tensões internas.

O procedimento para cálculo da distensão dos reforços sob ação das tensões na massa de solo é descrito a seguir. Maiores detalhes sobre o método podem ser encontrados em EHRLICH (1995).

\section{- Distensão dos reforços}

Para obtenção das deformações provenientes da distensão dos reforços faz-se necessário primeiramente, conhecer as tensões atuantes nas inclusões. O método proposto por EHRLICH \& MITCHELL (1994), que considera o efeito da compactação nas tensões do maciço reforçado, foi adotado para obtenção da máxima tensão em cada camada de reforço.

O método de EHRLICH \& MITCHELL (1994) assume aderência perfeita na interface solo/reforço e distribuição de tensão nos reforços conforme a linha tracejada mostrada na Figura 2.40. A interação solo/reforço é modelada admitindose comportamento elástico não linear para o solo e linear para o reforço. 


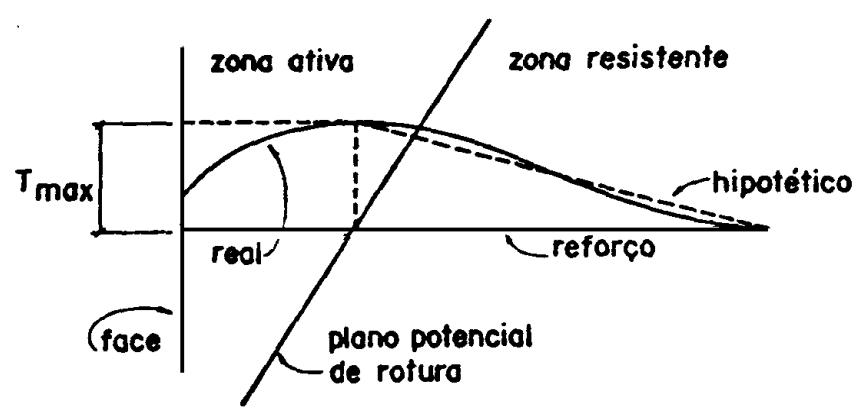

FIGURA 2.40 - Distribuição de tensões ao longo do reforço (EHRLICH, 1995).

A Figura 2.41 apresenta ábacos para determinação da máxima força de tração no reforço $\left(\mathrm{T}_{\text {máx }}\right)$ pelo método proposto por EHRLICH \& MITCHELL (1994), válidos para solos não coesivos. Esse parâmetro é calculado a partir do ângulo de atrito do solo $\left(\phi^{\prime}\right)$, do espaçamento vertical $\left(\mathrm{S}_{\mathrm{v}}\right)$ e horizontal dos reforços $\left(\mathrm{S}_{\mathrm{h}}\right)$, da tensão vertical em virtude do peso próprio $\left(\sigma^{\prime}{ }_{z}\right)$ e da tensão vertical máxima considerando o efeito da compactação $\left(\sigma_{\text {zc }}^{\prime}\right)$. O valor da tensão induzida pela compactação $\left(\sigma_{\text {zc,i }}^{\prime}\right)$ pode ser obtido através da expressão (2.4) para compactação efetuada por rolo compactador. $\mathrm{O}$ parâmetro $\beta$ mostrado na Figura 2.41 reflete a deformabilidade do reforço. No caso de geossintéticos, tipicamente, têm-se $8<\beta<300$ (EHRLICH \& AZAMBUJA, 2003). Ressalta-se que o método proposto por EHRLICH \& MITCHELL (1994) foi revisto posteriormente para levar em conta o efeito da coesão do solo. Ábacos para a determinação de $\mathrm{T}_{\text {máx, }}$ considerando a coesão do solo podem ser encontrados em DANTAS \& EHRLICH (1999).

$\sigma_{\mathrm{zc}, \mathrm{i}}^{\prime}=\frac{\left(1+\mathrm{K}_{\mathrm{a}}\right)}{\left(1+\mathrm{K}_{0}\right)}\left[\frac{\gamma^{\prime} \cdot \mathrm{Q} \cdot \mathrm{N}_{\gamma}}{2 \mathrm{~L}}\right]^{1 / 2}$

onde,

Q - força estática equivalente do rolo;

L - comprimento do rolo; 
$\mathrm{K}_{\mathrm{a}}$ - coeficiente de empuxo ativo $\left(\mathrm{K}_{\mathrm{a}}=\operatorname{tg}^{2}\left(45-\phi^{\prime} / 2\right)\right.$;

$\mathrm{K}_{0}$ - coeficiente de empuxo no repouso $\left(\mathrm{K}_{0}=1\right.$ - $\left.\operatorname{sen} \phi '\right)$;

$\mathrm{N}_{\gamma}$ - coeficiente de capacidade de carga e pode ser calculado por:

$\mathrm{N}_{\gamma}=\operatorname{tg}\left(45+\frac{\phi^{\prime}}{2}\right) \cdot\left[\operatorname{tg}^{4}\left(45+\frac{\phi^{\prime}}{2}\right)-1\right]$

Para compactadores que têm como base de aplicação do esforço de compactação, uma placa de área $\mathrm{A}$, o valor de $\sigma_{\text {zc,i }}$ deve ser obtido por:

$\sigma_{\mathrm{zc}, \mathrm{i}}^{\prime}=\mathrm{Q} / \mathrm{A}$

As tensões no maciço de solo provenientes do lançamento de novas camadas (peso próprio) podem progressivamente ultrapassar o valor das tensões induzidas pela compactação. Assim, para profundidades onde $\sigma_{z}^{\prime}$ ultrapassa $\sigma_{z c, i}$ o valor da tensão vertical máxima induzida pelo processo construtivo $\left(\sigma_{z c}^{\prime}\right)$ é igual a $\sigma_{z \text {. }}^{\prime}$ Caso contrário, deve-se adotar $\sigma_{\mathrm{zc}}^{\prime}=\sigma_{\mathrm{zc}, \mathrm{i}}^{\prime}$

Após o cálculo de $T_{\text {máx }}$ e considerando a distribuição de forças mostrada na Figura 2.41, pode-se finalmente obter o valor da distensão de cada camada de reforço $\left(\delta_{\mathrm{hzr}}\right)$, através da expressão $(2.7)$.

$\delta_{\text {hzr }}=\frac{1}{2} \cdot\left[\frac{\mathrm{T}_{\text {máx }} \cdot \mathrm{B}}{\mathrm{A}_{\mathrm{r}} \cdot \mathrm{E}_{\mathrm{r}}}\right] \cdot\left[1+\operatorname{tg}\left(45-\frac{\phi}{2}\right) \cdot \frac{\mathrm{z}}{\mathrm{B}}\right]$

onde,

$\mathrm{A}_{\mathrm{r}}$ - área do reforço; 
$\mathrm{E}_{\mathrm{r}}$ - módulo de deformação do reforço.

O deslocamento total no topo do muro deve englobar as movimentações das camadas inferiores no caso de processo construtivo incremental (ex. muro envelopado), ou seja, corresponde ao somatório da distensão do reforço em cada camada.

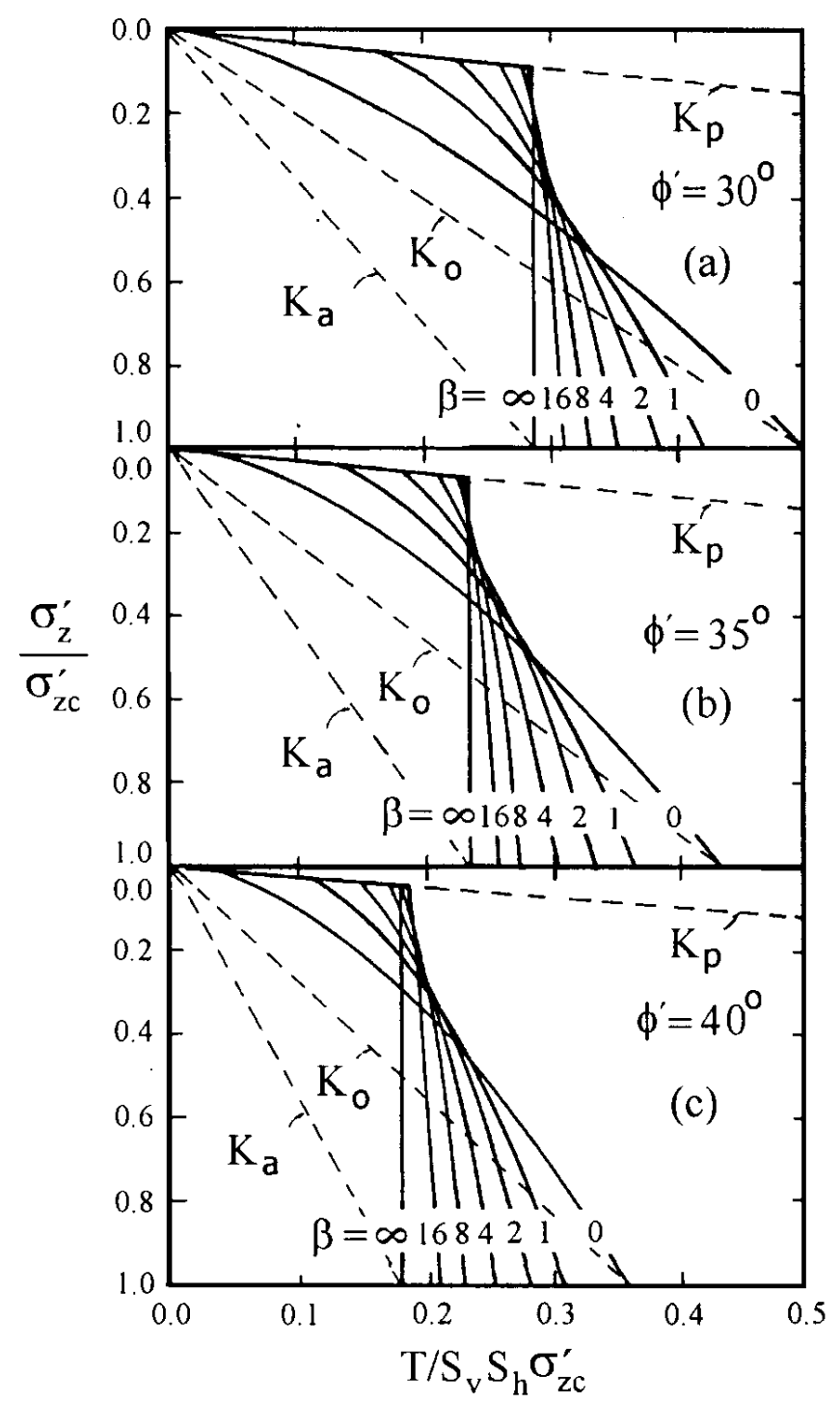

FIGURA 2.41 - Ábaco para a determinação das tensões máximas no reforço (EHRLICH e MITCHELL, 1994) 


\subsection{Método de SAWICKI (1999)}

O método proposto por SAWICKI (1999) permite prever os deslocamentos na face em muros de solo reforçado levando em conta a fluência do reforço. Esse método foi desenvolvido considerando a utilização de uma areia como solo de aterro e, de uma forma geral, não apresenta grandes inovações com relação a procedimentos e hipóteses de cálculo. A diferença básica consiste em assumir um modelo visco-elástico para o reforço e, em admitir que a fluência ocorre apenas na zona ativa enquanto na região de ancoragem (zona passiva) solo e reforço são considerados rígidos.

A Figura 2.42 mostra o esquema de um muro de solo reforçado considerado por SAWICKI (1999), onde $\phi$ corresponde ao ângulo de atrito do solo e $\mathrm{S}_{\mathrm{v}}$, ao espaçamento entre camadas. O primeiro passo para a utilização do método consiste em assumir uma distribuição para as forças de tração no reforço. A força $T$ no reforço deve ser estimada de acordo com a expressão (2.8), como comumente adotado em métodos de dimensionamento de muros de solo reforçado.

$\mathrm{T}=\sigma_{\mathrm{r}} \cdot \mathrm{S}_{\mathrm{y}}$

onde,

$\sigma_{\mathrm{r}}$ - tensão no reforço;

$\mathrm{S}_{\mathrm{v}}$ - espaçamento entre camadas de reforço.

zona ativa

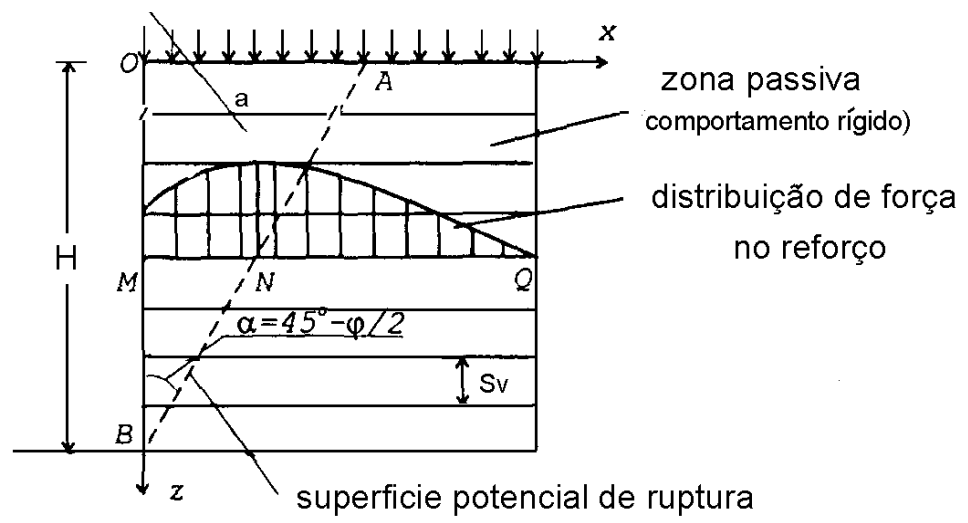

FIGURA 2.42 - Representação esquemática de um muro de solo reforçado (SAWICKI, 1999). 
A Figura 2.43 ilustra a obtenção da tensão em uma camada de reforço $\left(\sigma_{\mathrm{r}}\right)$. SAWICKI (1999) admite presença de face rígida, assim, a mesma tensão na face pode ser assumida na superfície de ruptura $\left(\sigma_{M}=\sigma_{N}\right.$, ver Figura 2.43). A distribuição admitida da tensão no reforço com a profundidade é mostrada na Figura 2.43. No caso de uma sobrecarga q aplicada, a distribuição de $\sigma_{\mathrm{r}}$ com a profundidade é trapezoidal e a expressão (2.9) deve ser utilizada.

$\sigma_{\mathrm{r}}=\sigma_{\mathrm{M}}=\sigma_{\mathrm{N}}=\gamma \cdot \mathrm{z} \cdot \operatorname{tg}^{2} \cdot \alpha+\mathrm{q} \cdot \operatorname{tg}^{2} \alpha$

onde,

$\gamma$ - peso específico do solo.

ao longo de $\mathrm{OB}$

ao longo de $A B$

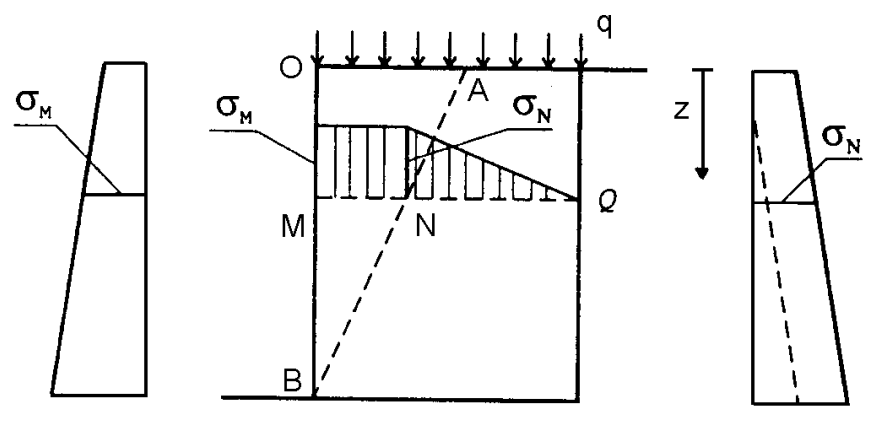

FIGURA 2.43 - Distribuição de tensão no reforço (SAWICKI, 1999).

Após a estimativa da distribuição de tensão no reforço, os deslocamentos na face podem ser calculados, assumindo-se compatibilidade de deformação entre solo e reforço. Para obter as deformações do reforço, SAWICKI (1999) adota o modelo visco-elástico com três parâmetros mostrado na Figura 2.44, destacando que outros modelos reológicos também podem ser adotados. 

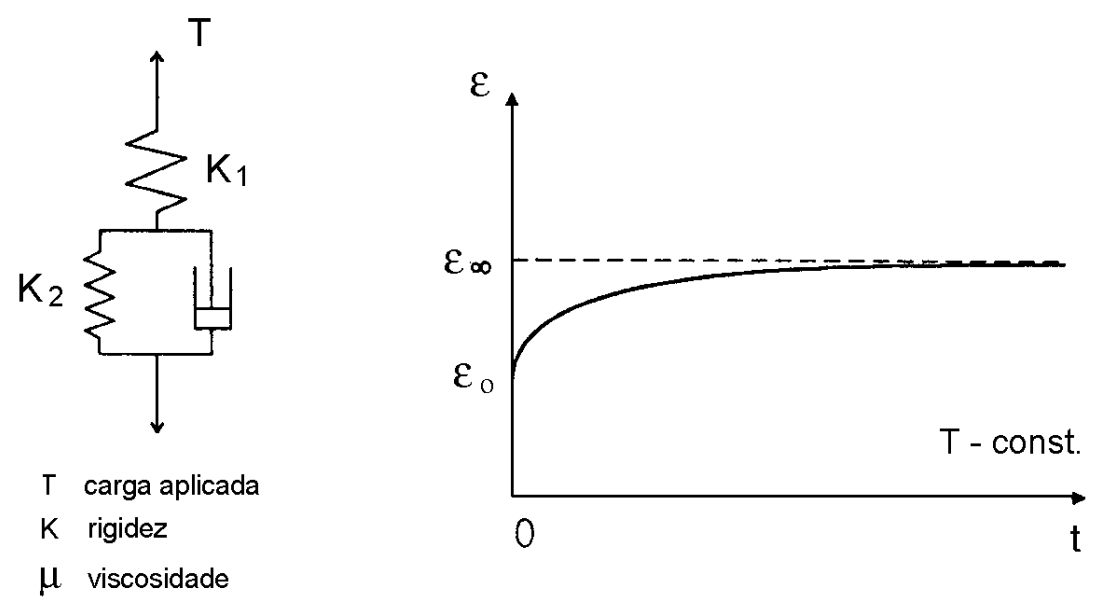

FIGURA 2.44 - Modelo reológico adotado por SAWICKI (1999)

(SAWICKI \& KAZIMIEROWICZ-FRANKOWSKA, 1998).

Para o modelo com três parâmetros mostrado na Figura 2.44, a deformação do reforço $(\varepsilon)$ deve ser obtida através da expressão 2.10 .

$\varepsilon=\mathrm{T} \varphi^{*}(\mathrm{t})$

onde,

$\varphi^{*}(\mathrm{t})=\frac{1}{\mathrm{~K}^{*}}-\frac{1}{\mathrm{~K}_{2}} \exp \left(-\frac{\mathrm{K}_{2}}{\eta} \mathrm{t}\right)$

$\mathrm{K}^{*}=\frac{\mathrm{K}_{1} \mathrm{~K}_{2}}{\mathrm{~K}_{1}+\mathrm{K}_{2}}$

Os parâmetros do material $K_{1}, K_{2}$ e $\eta$ devem ser determinados experimentalmente para o material em questão. Considerando o início do carregamento ( $\mathrm{t} \rightarrow 0$ ), determina-se $\mathrm{K}_{1}$ através da expressão (2.13) e, considerando-se $\mathrm{t} \rightarrow \infty, \mathrm{K}_{2}$ pode ser calculado através da expressão (2.14) (SAWICKI \& KAZIMIEROWICZ-FRANKOWSKA, 1998). 
$\mathrm{K}_{1}=\frac{\mathrm{T}}{\varepsilon_{0}}$

$\mathrm{K}_{2}=\frac{\mathrm{T}}{\varepsilon_{\infty}-\varepsilon_{0}}$

onde,

$\varepsilon_{0}$ - deformação imediata;

$\varepsilon_{\infty}$ - deformação limite mostrada na Figura 2.44.

O deslocamento horizontal da face $\delta_{\mathrm{h}}$, a uma profundidade $\mathrm{z}$, pode obtido através da eq. (2.16). Substituindo-se os valores de $a$ e $\varepsilon$ na eq. (2.15), e considerando a presença de sobrecarga, o valor de $\delta_{\mathrm{h}}$ é dado pela expressão (2.17). Nesse caso, a deformada da face assume forma parabólica.

$\delta_{\mathrm{h}}=\mathrm{a} \varepsilon$

$\delta_{\mathrm{h}}=\sigma_{\mathrm{r}} \cdot(\mathrm{H}-\mathrm{z}) \cdot \mathrm{S}_{\mathrm{V}} \cdot \varphi^{*}(\mathrm{t}) \cdot \operatorname{tg} \alpha$

$\delta_{\mathrm{h}}=(\gamma \cdot \mathrm{z}+\mathrm{q}) \cdot \operatorname{tg}^{2} \alpha \cdot(\mathrm{H}-\mathrm{z}) \cdot \mathrm{S}_{\mathrm{V}} \cdot \varphi^{*}(\mathrm{t}) \cdot \operatorname{tg} \alpha$

onde,

a - comprimento do reforço na zona ativa (ver Figura 2.42).

\subsubsection{Deformações e deslocamentos observados em muros de solo reforçado com geossintéticos}

A Tabela 2.3, apresentada no final do capítulo, expõe uma compilação de dados presentes na literatura com relação à magnitude de deformações e deslocamentos observados em obras instrumentadas e em protótipos de muros de solo reforçado com geossintéticos. Os deslocamentos mostrados foram observados na face da estrutura, com exceção dos muros relatados por EHRLICH et al. (1994) e 
PEDROSO (2000), para os quais os valores foram observados a 0,6 e a 1,5 m da face, respectivamente.

Considerando as diferentes características das estruturas mostradas na Tabela 2.3 (altura variando de 2,0 a 12,6 m, diferentes carregamentos e tipos de solo, face e reforço), o comportamento em curto prazo, naturalmente, apresentou uma significativa variação. De uma forma geral, os deslocamentos são pequenos e o máximo deslocamento apresentado na face após a construção encontra-se em torno de 0,5 a $1,0 \% \mathrm{H}$, enquanto a máxima deformação variou de 0,4 a 1,2\% para geogrelhas e de 0,7 a $3 \%$ para geotêxteis.

A Figura 2.45 apresenta o padrão de deslocamentos horizontais observados na face em estruturas descritas na Tabela 2.3. O padrão mostrado na Figura 2.45a foi observado em estruturas que tinham, em comum, faces escoradas durante a construção. A configuração mostrada na Figura 2.45b foi observada em protótipos com aplicação de sobrecarga através de bolsa de ar, assim é possível que o sistema de aplicação de sobrecarga tenha limitado a movimentação no topo da estrutura. $O$ fato de se aplicar uma sobrecarga através de barras de ferro foi utilizado por BENIGNI et al. (1996) para justificar a menor movimentação no topo da estrutura, após aplicação de sobrecarga (Figura 2.45c).

No entanto, identificar com clareza que fatores provocam determinado padrão de deslocamento na face não é fácil. Por exemplo, na estrutura descrita por MARQUES (1994), a sobrecarga também era aplicada através de bolsa de ar e, ainda assim, o padrão obtido foi o mostrado na Figura 2.45a. O padrão da Figura 2.45d foi observado antes e após da sobrecarga, o que exclui, pelo menos nesse caso, uma menor movimentação do topo em virtude da sobrecarga. A configuração mostrada na Figura $2.45 \mathrm{e}$ foi obtida para um muro com solo envelopado sem sobrecarga (PEDROSO, 2000) muito semelhante ao muro descrito por EHRLICH et al. (1994). No entanto, embora o padrão de movimentação não seja apresentado por EHRLICH et al. (1994), o máximo deslocamento ocorreu a $1 \mathrm{~m}$ de altura e não no topo da estrutura como em PEDROSO (2000). Na verdade, as diversas configurações certamente resultam da combinação dos vários aspectos intervenientes na movimentação da estrutura (tipo de solo, reforço, face, características construtivas, 
etc) sendo difícil prevê a configuração do perfil de deslocamentos horizontais na face.
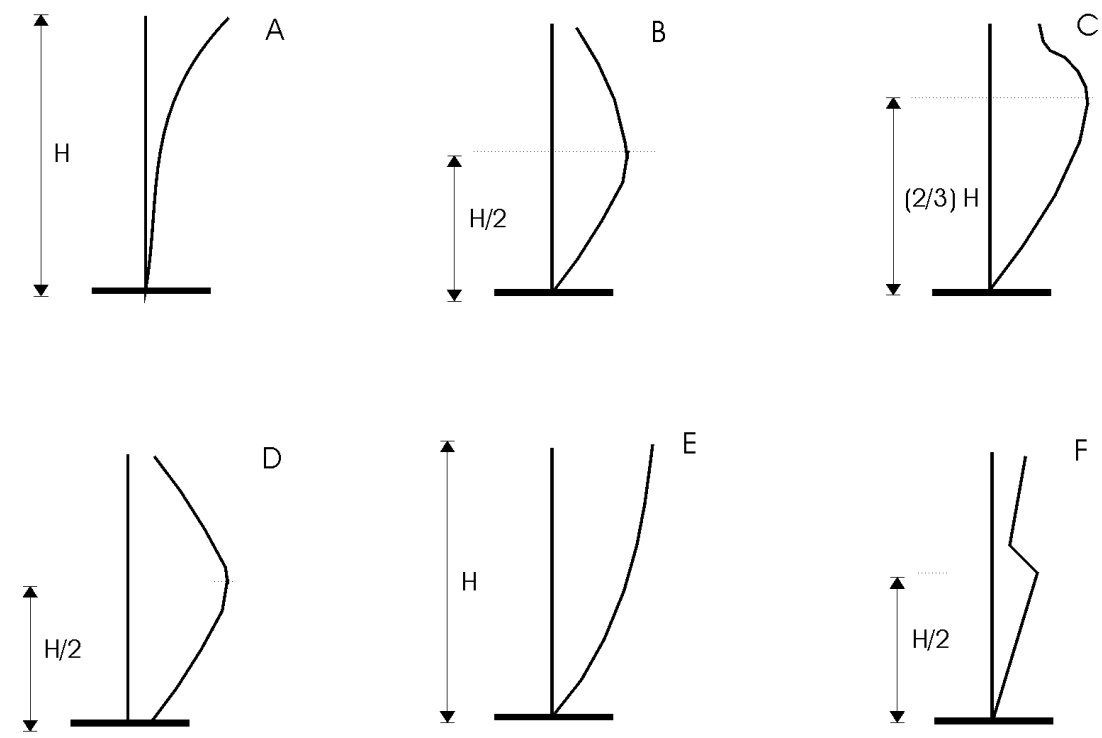

(A) - BATHURST (1992); MARQUES, 1994

(B) - WU (1992);

(C) - BENIGNI et al. (1996);

(D) - TSUKADA (1998);

(E) - PEDROSO (2000);

(F) ALLEN et al. (1992).

FIGURA 2.45 - Deslocamentos horizontais observados em faces de muros de solo reforçado.

O grande consenso com relação aos dados expostos na Tabela 2.3 parece ser o valor reduzido dos deslocamentos, o que, a princípio representa uma excelente constatação, pois denota o desempenho satisfatório desse tipo de estrutura. No entanto, freqüentemente os autores destacam que as deformações e os deslocamentos observados foram consideravelmente inferiores ao valor esperado, o que seria um indicativo que os métodos utilizados para projeto são conservadores (ex. ALLEN et al, 1992; TSUKADA, 1998). Na verdade, diversos autores, não só através da observação de deslocamentos em estruturas reais, têm afirmado que os métodos utilizados em projeto são conservadores (ex. RESL, 1990; THAMM, 1990; JABER \& MITCHELL, 1990; ROWE \& HO, 1992, BENJAMIM et al. 2003; BATHURST, 2004).

Segundo ROWE \& HO (1992) o conservadorismo presente nos projetos deve-se a três principais fatores: 
i) Devido a receios com relação a um adequado controle da construção, como por exemplo, grau de compactação de acordo com as especificações de projeto, os parâmetros de resistência do solo adotados em projetos são menores que os de fato verificados;

ii) Muitos fatores de redução com relação à resistência à tração do reforço são adotados em virtude de aspectos como fluência; danos de instalação, entre outros, fazendo com que a resistência admissível do reforço em projetos corresponda a uma parcela bastante reduzida da resistência à tração a curto prazo;

iii) Os muros são estruturas cujo comportamento depende de quatro elementos básicos: solo de aterro, reforço, face e fundação. Os métodos geralmente não consideram as interações possíveis entre esses elementos e conseqüentemente não são capazes de descrever adequadamente o comportamento real das estruturas.

Esse último aspecto destacado por ROWE \& HO (1992) é sem dúvida fundamental, pois decorridos cerca de trinta anos desde o advento dos muros de solo reforçados com geossintético, já não se tem dúvida sobre o desempenho satisfatório desse tipo de estrutura, a grande questão consiste em entender de fato $\mathbf{o}$ comportamento e as diversas interações envolvidas.

A construção de protótipos e a instrumentação de obras constituem ferramentas importantes nesse sentido, mas poucos são os casos relatados na literatura que realmente constituem exemplos de estruturas com uma instrumentação abrangente. Dos muros descritos na Tabela 5.1, por exemplo, apenas nas estruturas relatadas por SIMAC et al (1990), ALLEN et al (1992), WU (1992) e TSUKADA (1998), tensões na massa de solo e/ou na face foram monitoradas.

Um aspecto observado em obras instrumentadas e que ressalta a importância de se considerar a interação dos elementos que interferem na estrutura diz respeito à constatação que, freqüentemente, o último nível de reforço não é a inclusão sob maior solicitação na estrutura como se costuma assumir (BATHURST et at, 1989; JABER \& MITCHELL, 1990). A Tabela 2.4 mostra a localização da máxima deformação, considerando todas as camadas instrumentadas, em algumas estruturas 
descritas na Tabela 2.3. As deformações foram observadas após a construção do muro (antes da aplicação de sobrecarga, no caso de muros com aplicação de sobrecarga). Como se pode observar, a máxima deformação não ocorre na base do muro (isto é, $\mathrm{z} / \mathrm{H}=1$ ) como implícito na grande maioria dos métodos de dimensionamento. Tal comportamento pode ser provocado, entre outros fatores, pelo fato da fundação provocar uma significativa restrição à movimentação do aterro reforçado na interface aterro/fundação ou ainda pela redução da tensão vertical com a profundidade, e conseqüente diminuição da tensão horizontal, em virtude do atrito desenvolvido entre o solo e a face da estrutura.

TABELA 2.4 - Localização da máxima deformação registrada considerando todas as inclusões.

\begin{tabular}{llll|l}
\hline \multicolumn{1}{c}{ Referência } & $\mathrm{z} / \mathrm{H}$ & & & \\
\hline SIMAC et al. (1990) & 0,83 & & \\
ALLEN et al. (1992) & 0,42 & & \\
GOUC \& MATICHARD (1992) & 0,10 & \\
FISHMAN et al (1993) & 0,54 & \\
OCHIAI \& FUKUDA (1996) & & \\
\hline
\end{tabular}

Alguns aspectos citados por ROWE \& HO (1992) como responsáveis por reduzidos valores das tensões horizontais observados em obras instrumentadas podem ainda ser destacados como possíveis causas dos valores de deslocamentos e deformações observados em obras serem menores que os esperados:

i) o ângulo de atrito adotado para o aterro é geralmente baseado no ângulo de pico obtido através de ensaios de compressão triaxial. Porém, em muros de solo reforçado o estado de deformação plana prevalece e sabe-se que o ângulo de atrito no estado plano pode ser alguns graus maior que o determinado através de ensaios triaxiais;

ii) existência de uma coesão aparente devido à natureza não saturada do aterro.

A não consideração da coesão do solo de aterro, prática comum no dimensionamento de estruturas de solo reforçado (SILVA \& VIDAL, 1999), de fato, deve concorrer com o conservadorismo dos projetos. Esse aspecto é muito importante para análise de muros de solo reforçado no Brasil já que os solos 
brasileiros na maioria das vezes são bastante coesivos. A não consideração da coesão no dimensionamento do muro descrito por EHRLICH et al. (1994) (Tabela 2.3), por exemplo, deve ser um dos principais motivos dos reduzidos valores de deslocamentos observados, já que os autores destacam que a massa de solo argiloso poderia manter-se estável sem a presença dos reforços pela elevada coesão em virtude da condição não saturada do aterro.

Considerando então todos esses aspectos que concorrem para uma baixa solicitação do reforço em estruturas reais, não é de se esperar uma fluência acentuada do reforço. Com efeito, esse é o comportamento normalmente observado em obras instrumentadas, embora o número de obras observadas por um período de tempo superior a alguns dias seja bastante reduzido. $\mathrm{O}$ que pode ser observado facilmente na Tabela 2.3.

Nas estruturas dispostas na Tabela 2.3, é possível analisar a questão da fluência através das deformações no reforço apenas nas estruturas descritas por SIMAC et al. (1990), WU (1992), ALLEN et al. (1992) e CARRUBA et al. (2000). De qualquer forma, mesmo sem o acompanhamento ao longo do tempo, o nível de deformação dos geossintéticos registrado em curto prazo em obras instrumentadas já denota a baixa solicitação do reforço indicando que a fluência não deve ser significativa.

A Figura 2.46 ilustra a baixa solicitação do reforço em obras, apresentando uma compilação de dados realizada com base em trabalhos da literatura referentes a ensaios de tração com geossintéticos. Nessa Figura, apresenta-se o nível de carga (em relação à resistência obtida nos ensaios de tração) para um determinado valor de deformação no reforço, considerando vários tipos de geossintéticos. O nível de carga é apresentado para uma deformação igual a 1\% e $2 \%$ que correspondem aos valores de deformação máxima freqüentemente registrados em obras instrumentadas.

Observando-se a Figura 2.46, apesar dos diferentes tipos de reforços considerados (geogrelha de PE e PET e geotêxtil tecido de PP), pode-se considerar que para deformações iguais a $1 \%$ e $2 \%$, respectivamente, o nível de carga no reforço corresponde aproximadamente a apenas 10 e $20 \%$ da resistência à tração. Com esse nível de solicitação, a fluência do reforço em muros instrumentados não deve ser, de fato, significativa. 


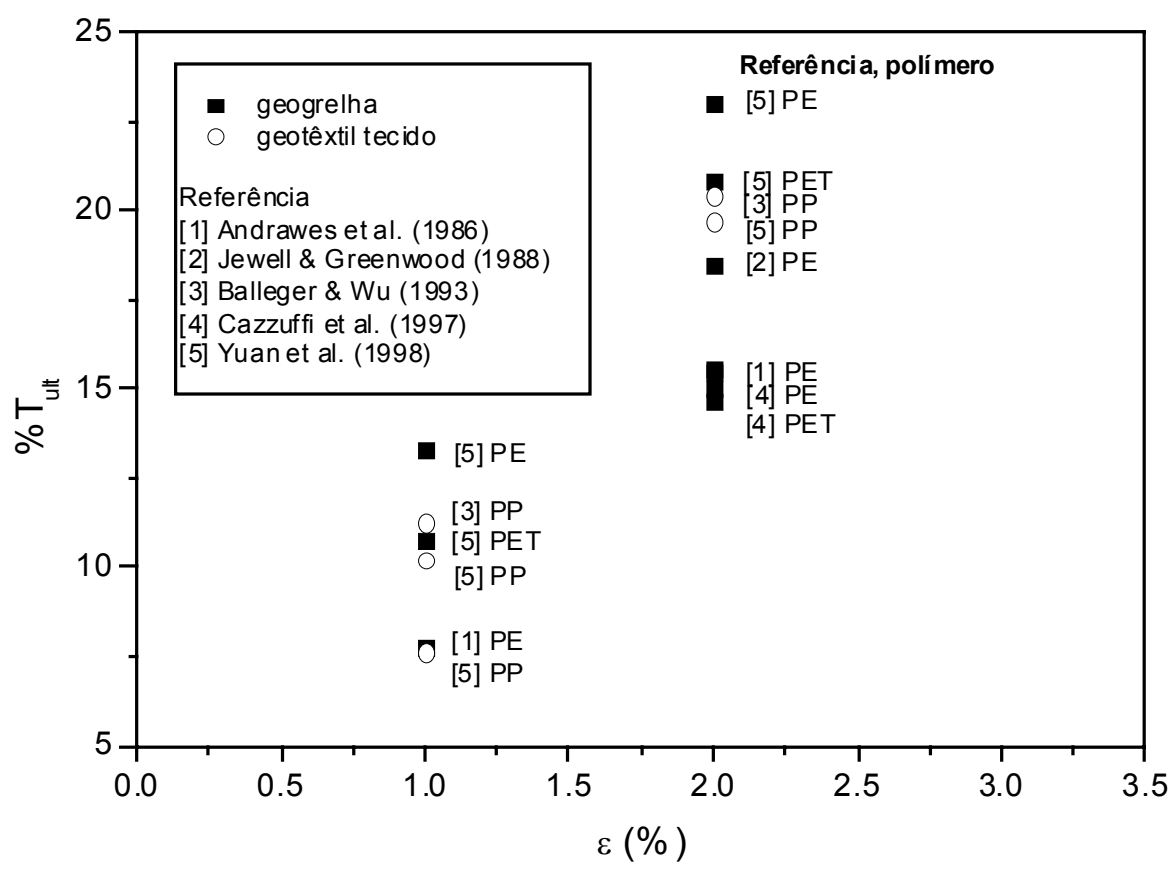

FIGURA 2.46 - Porcentagem da resistência à tração para uma deformação correspondente a 1 e $2 \%$.

Assim, apesar da fluência ter a possibilidade de provocar grandes problemas em muros de solo reforçado, freqüentemente tal comportamento não tem sido verificado na prática. Entre outros fatores, certamente a baixa solicitação do reforço na maioria das obras, resultado do conservadorismo dos métodos, contribui de forma decisiva para esse comportamento.

Com relação às estruturas dispostas na Tabela 2.3 que apresentam as deformações no reforço ao longo do tempo, nos muros descritos por SIMAC et al. (1990) e WU (1992), não houve movimentação com o tempo enquanto na descrita por ALLEN et al. (1992) e CARRUBA et al. (2000) ocorreu um discreto aumento da deformação do geossintético com o passar do tempo. No caso da estrutura descrita por ALLEN et al. (1992), constatou-se ainda uma tendência de estabilização das deformações em longo prazo.

Observando os deslocamentos na face ou em sua proximidade percebe-se ainda alguma movimentação ao longo do tempo nos muros relatados por EHRLICH el al. (1994), BENIGNI et al. (1996), TSUKADA et al. (1998) e PEDROSO (2000). Nesse último caso, o reforço utilizado foi um geotêxtil de PP com grande potencial 
de fluência e, mesmo se adotando um coeficiente de redução unitário para a fluência, a movimentação com o tempo, segundo o autor, não foi significativa, ocorrendo uma estabilização dos deslocamentos após 202 dias de observação.

Ressalta-se que essa questão de deformação em longo prazo em estruturas instrumentadas será revista e melhor discutida no capítulo 5, após a apresentação dos resultados encontradas na parte experimental desenvolvida na presente tese. 


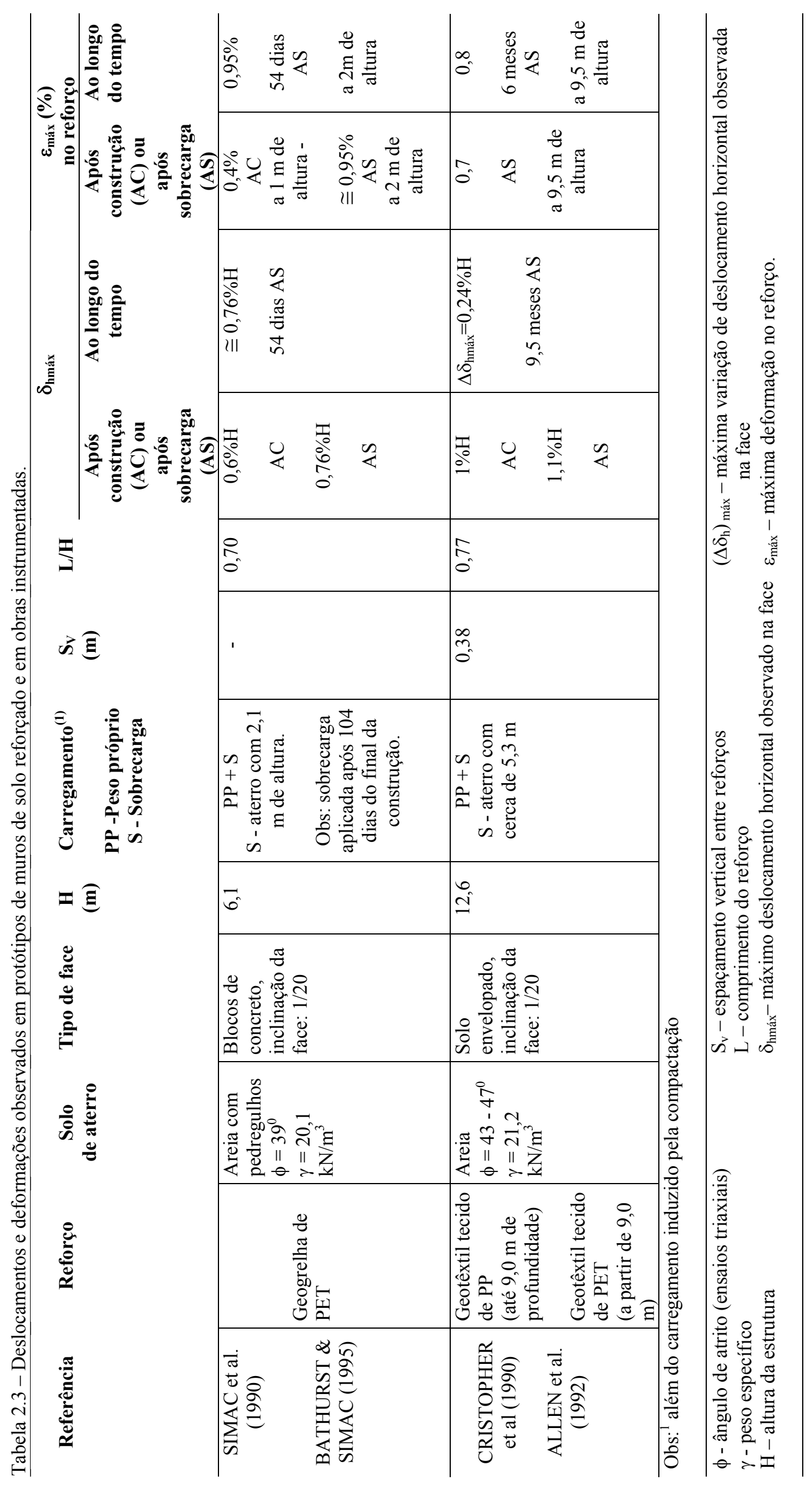

9 


\begin{tabular}{|c|c|c|c|c|c|}
\hline ब葛 & 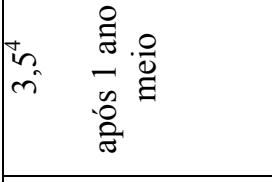 & ' & 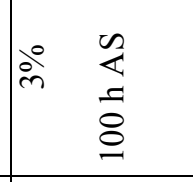 & 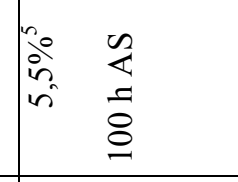 & $\begin{array}{l}\frac{1}{0} \\
0 \\
0 \\
0 \\
0 \\
0.0 \\
\frac{0}{2}\end{array}$ \\
\hline & 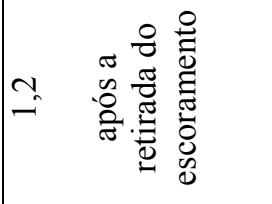 & 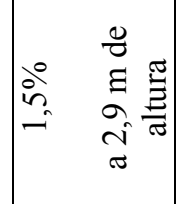 & 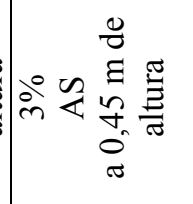 & 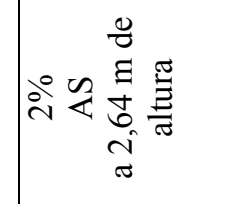 & 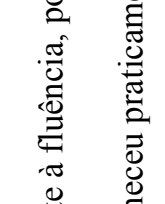 \\
\hline 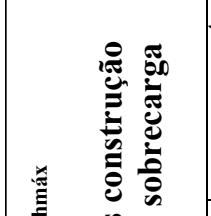 & 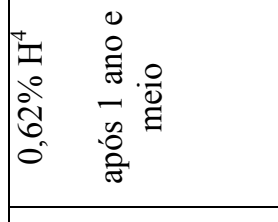 & ' & & ' & 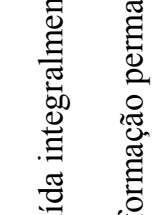 \\
\hline | & 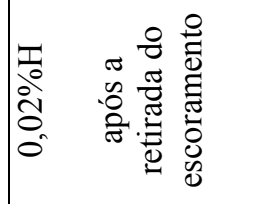 & ' & 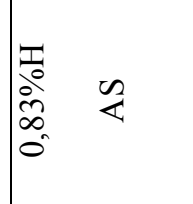 & 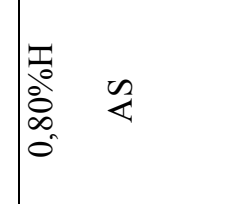 & 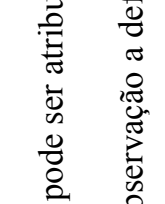 \\
\hline 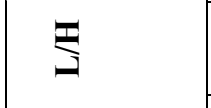 & $\stackrel{8}{R}$ & $\begin{array}{l}8 \\
8 \\
0 \\
0\end{array}$ & 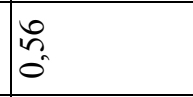 & $\begin{array}{l}0 \\
0 \\
0 \\
0\end{array}$ & \\
\hline 的量 & 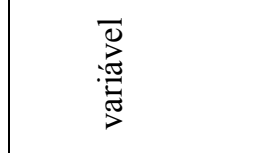 & $\overrightarrow{0}$ & 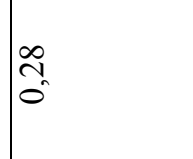 & \begin{tabular}{l}
$\infty$ \\
\hdashline \\
0 \\
0
\end{tabular} & \\
\hline 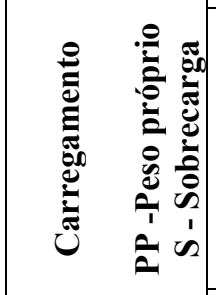 & 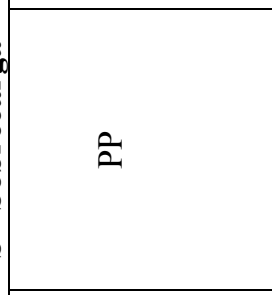 & $\tilde{\Xi}$ & 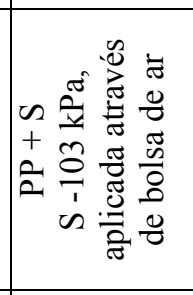 & 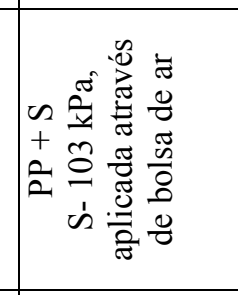 & 定 \\
\hline$\pm \widehat{\mathrm{E}}$ & $\vec{n}$ & in & in & iri & \\
\hline 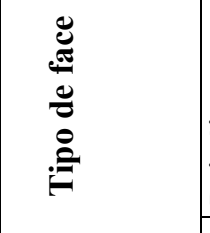 & 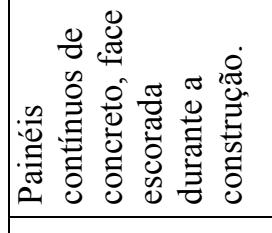 & 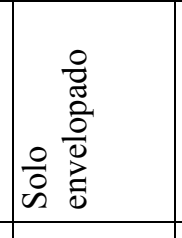 & 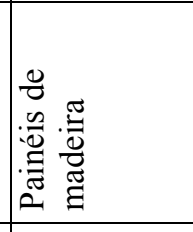 & 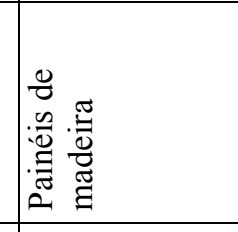 & \\
\hline 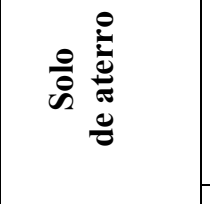 & 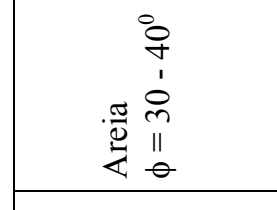 & 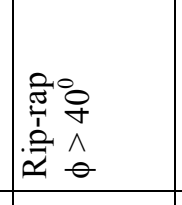 & 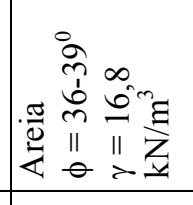 & 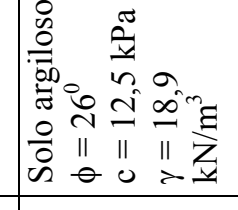 & \\
\hline 竎 & 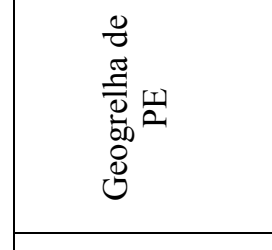 & 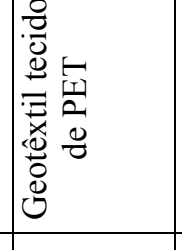 & 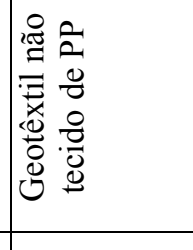 & 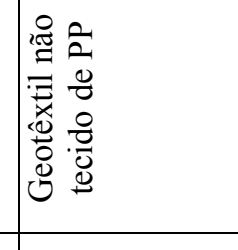 & 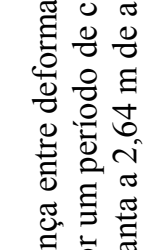 \\
\hline 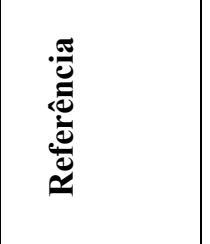 & 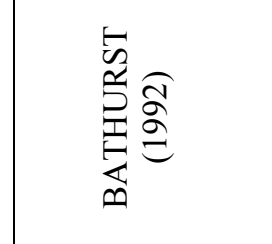 & 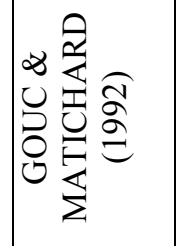 & 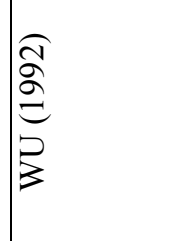 & $\begin{array}{l}\widehat{1} \\
\text { Dे } \\
0 \\
3 \\
3\end{array}$ & 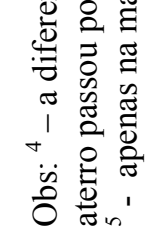 \\
\hline
\end{tabular}




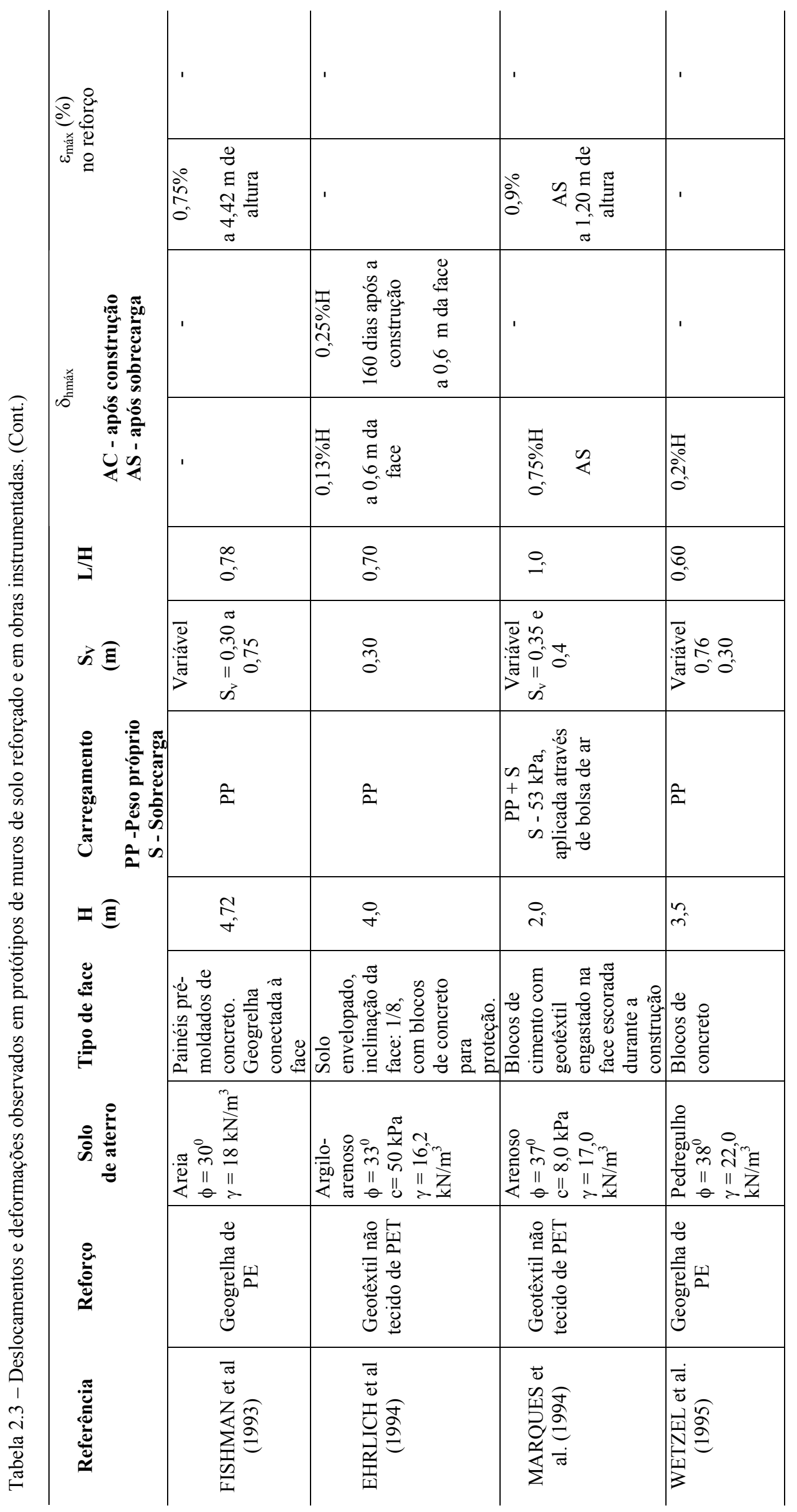




\begin{tabular}{|c|c|c|c|c|}
\hline ఠ̊ & ' & & 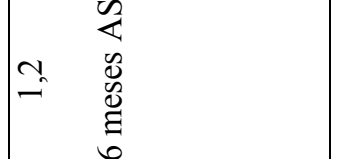 & ' \\
\hline 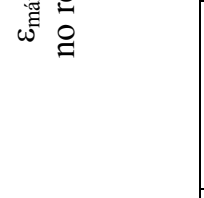 & ' & & 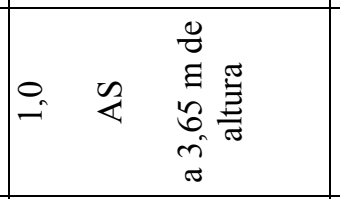 & . \\
\hline 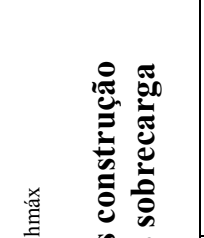 & 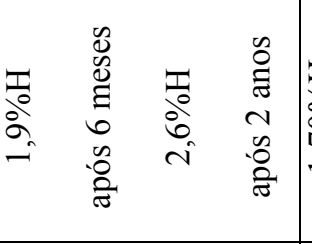 & 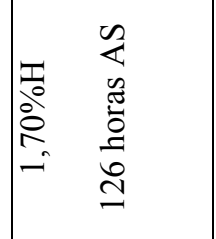 & 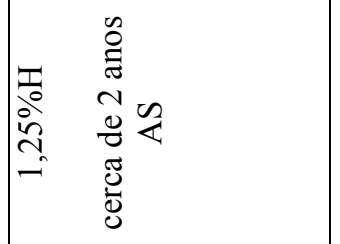 & . \\
\hline 年 & 装 & 雹 & 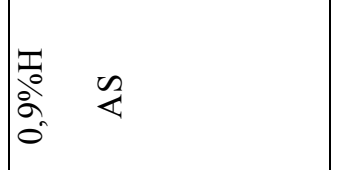 & $\begin{array}{l}\text { Tें } \\
\text { 今े } \\
\text { ò }\end{array}$ \\
\hline$\Xi$ & $\Xi$ & 早 & $\stackrel{n}{:}$ & : \\
\hline 尚金 & $\begin{array}{l}\text { ñ } \\
\text { an }\end{array}$ & : & 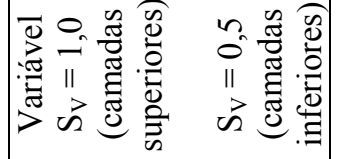 & $\stackrel{8}{\circ}$ \\
\hline 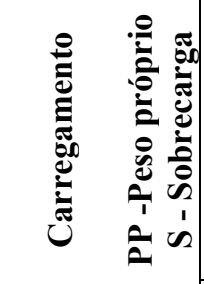 & $\tilde{\Xi}$ & 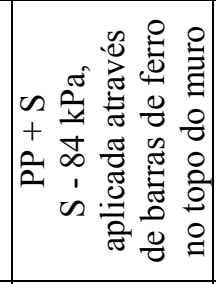 & $\begin{array}{l}\infty \\
+ \\
2 \\
2 \\
2\end{array}$ & $\tilde{\Xi}$ \\
\hline$\pm \widehat{\mathrm{E}}$ & $\stackrel{\infty}{\stackrel{\infty}{=}}$ & in & ${ }_{\infty}$ & $\vec{m}$ \\
\hline 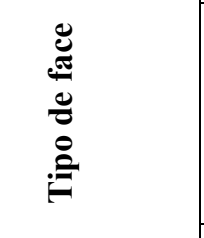 & 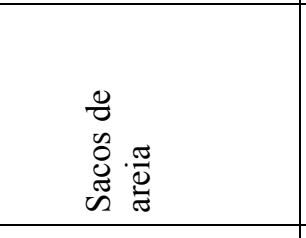 & 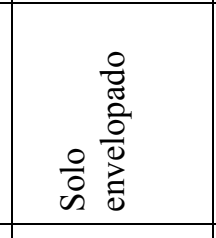 & 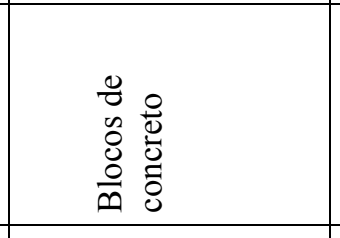 & 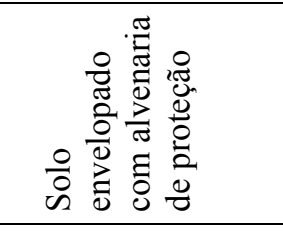 \\
\hline 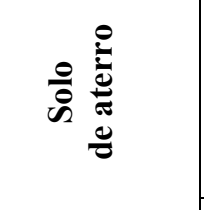 & 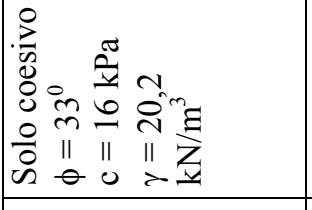 & 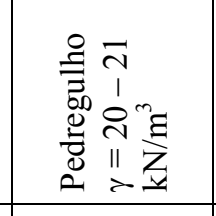 & 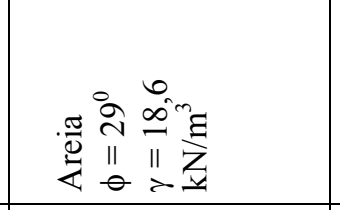 & 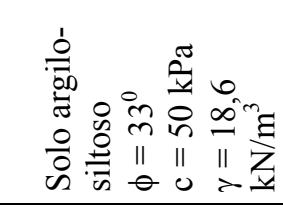 \\
\hline 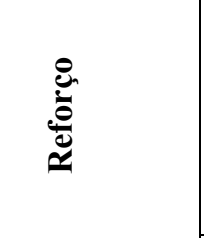 & 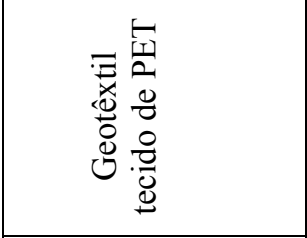 & 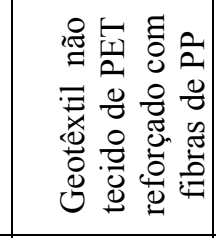 & 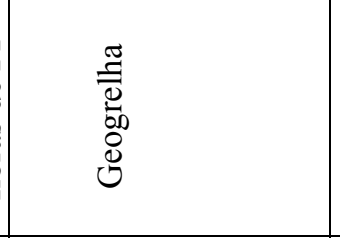 & 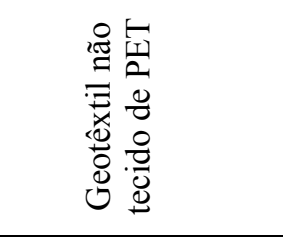 \\
\hline 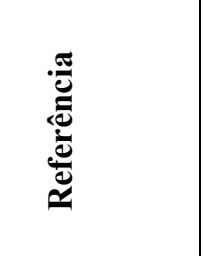 & 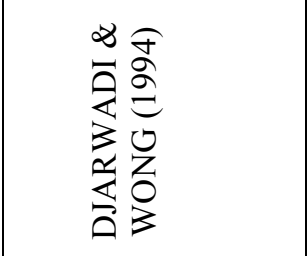 & 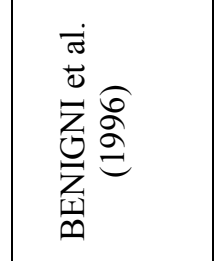 & 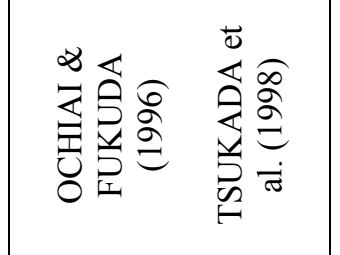 & 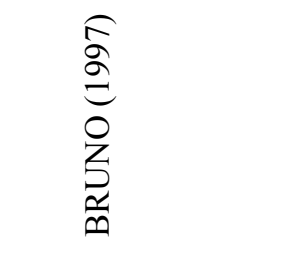 \\
\hline
\end{tabular}




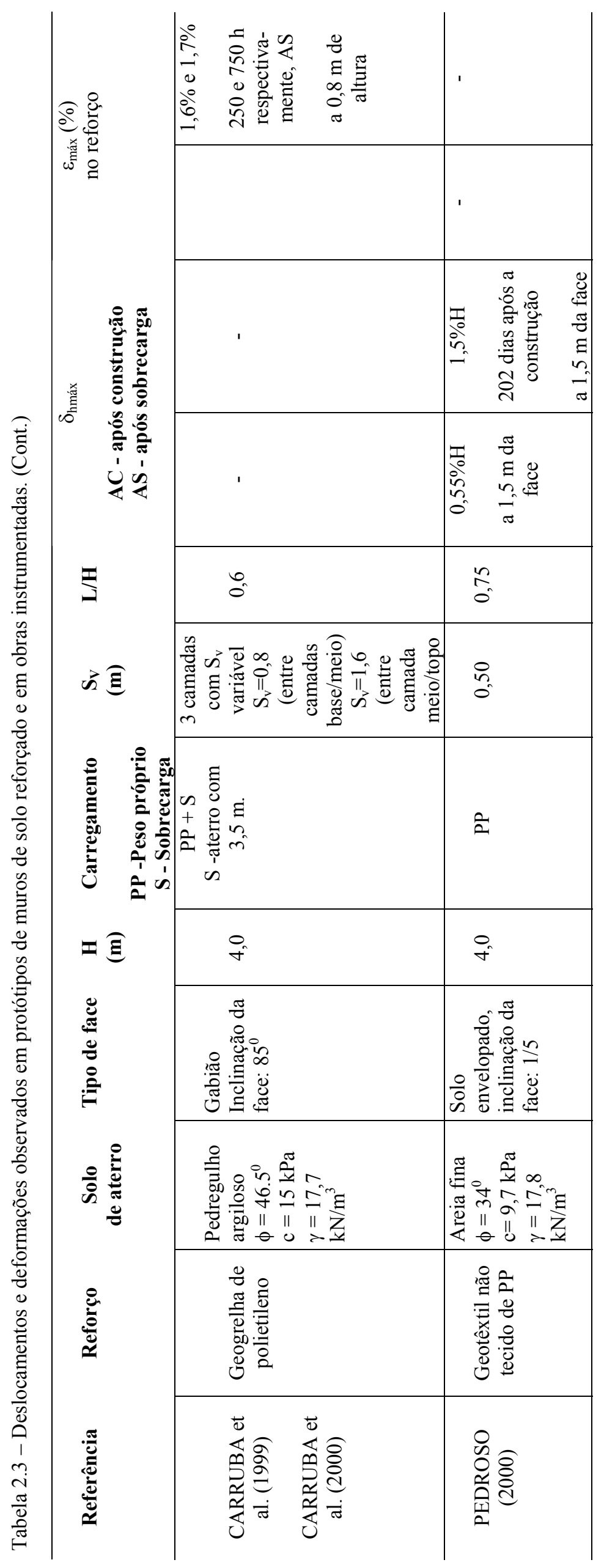




\section{Investigação das deformações ao longo do tempo em elementos de solo reforçado com geotêxteis}

Este capítulo apresenta a primeira etapa do presente trabalho, conduzida no laboratório de geossintéticos da EESC/USP. Nessa etapa, a confecção de um equipamento para observação das deformações de um elemento de solo reforçado, no decorrer do tempo, constituiu o escopo principal do trabalho. A seguir, as principais dificuldades encontradas durante a fase de desenvolvimento do aparelho são discutidas a fim de possibilitar uma melhor compreensão da configuração final adotada. Neste capítulo, apresenta-se uma descrição detalhada da versão final do equipamento e os ensaios realizados, principalmente, para testar o sistema desenvolvido são ainda mostrados e os resultados discutidos.

\section{1 - Desenvolvimento do equipamento}

Como discutido no capítulo 2, o princípio geral de funcionamento dos equipamentos nos quais o solo solicita o geotêxtil consiste em confinar o reforço entre camadas de solo, permitindo que ambos os materiais tenham liberdade para apresentar deformações ao longo do tempo. Nesses ensaios, uma tensão vertical é aplicada ao solo que, por sua vez, solicita o reforço. 
Com base nessa idéia geral, o equipamento foi desenvolvido e nesse sentido destaca-se que os termos "elemento solo-reforço" ou "elemento de solo reforçado" são utilizados nesta tese para designar um corpo-de-prova composto por um reforço intercalado entre duas camadas de solo.

A configuração inicial do equipamento foi concebida com base nos poucos aparelhos descritos na literatura para o mesmo fim, mas visando uma instrumentação mais abrangente do ensaio e uma análise mais ampla dos resultados. $\mathrm{O}$ equipamento proposto por WU \& HELWANY (1996), por exemplo, permite quantificar as deformações no reforço, mas não permite a observação da carga no geotêxtil ao longo do tempo. O equipamento desenvolvido por HELWANY \& SHIH (1998) possibilita o registro da carga, mas não permite a obtenção da deformação no reforço. No caso do presente trabalho, o aparelho foi desenvolvido visando a obtenção tanto da carga quanto da deformação no geotêxtil, já que a carga atuante no reforço é indispensável para realizar análises mais amplas sobre as deformações observadas em função do tempo.

\subsubsection{Etapas preliminares de desenvolvimento do equipamento}

A fase de desenvolvimento do equipamento foi iniciada com o projeto e a confecção de uma caixa com dimensões internas de 200 x 410 x $550 \mathrm{~mm}$ para conter o elemento de solo reforçado a ser ensaiado. A caixa foi construída com dimensões bem maiores que as previstas para o elemento solo-reforço a fim de permitir a variação das dimensões do corpo-de-prova, caso necessário.

Diferentes configurações para o equipamento foram testadas até a escolha final do esquema a ser adotado. As dimensões e as características detalhadas das peças que foram, de fato, utilizadas no esquema final do equipamento são mostradas no item 3.2. As características das peças que foram utilizadas apenas na fase de desenvolvimento e, posteriormente, descartadas são brevemente descritas neste item. Destaca-se mais uma vez que o equipamento foi desenvolvido com o objetivo de obter tanto a carga quanto a deformação no reforço. Assim, diversos testes foram realizados até que fosse possível registrar a carga e a conseqüente deformação ao longo tempo, pelo menos em algum trecho do reforço. 
Os testes efetuados durante o desenvolvimento e calibração do equipamento foram realizados utilizando-se um geotêxtil tecido. A escolha por um geotêxtil tecido teve por objetivo facilitar as análises, já que os geotêxteis tecidos praticamente não apresentam efeitos de confinamento no que diz respeito à redução de estricção (como no caso de geotêxteis não tecidos). A ausência dos referidos efeitos possibilita que as diferenças encontradas entre ensaios sem e com confinamento sejam associadas a possíveis interferências do comportamento mecânico do solo nas deformações do reforço e cuja investigação faz parte dos objetivos dessa etapa do trabalho.

Nos testes realizados na fase preliminar de desenvolvimento, utilizou-se uma areia preparada com uma densidade relativa igual a 75\% através de chuva de areia. Os detalhes referentes às características da areia e do geotêxtil utilizados nos ensaios com o elemento solo-reforço são descritos em detalhe no item 3.3.

A Figura 3.1 apresenta a primeira configuração testada para o equipamento. Uma camada de reforço com $300 \mathrm{~mm}$ de comprimento e $200 \mathrm{~mm}$ de largura foi confinada entre duas camadas de solo com $100 \mathrm{~mm}$ de comprimento. Uma bolsa de ar pressurizado foi colocada no topo do elemento de solo reforçado para a aplicação de uma tensão vertical às camadas de solo. Uma célula de carga a base de strain gages foi projetada e construída para acompanhar a solicitação no reforço no ponto A. Além disso, uma garra foi construída e posicionada no exterior da caixa para fixar o geotêxtil na posição mostrada na Figura 3.1.

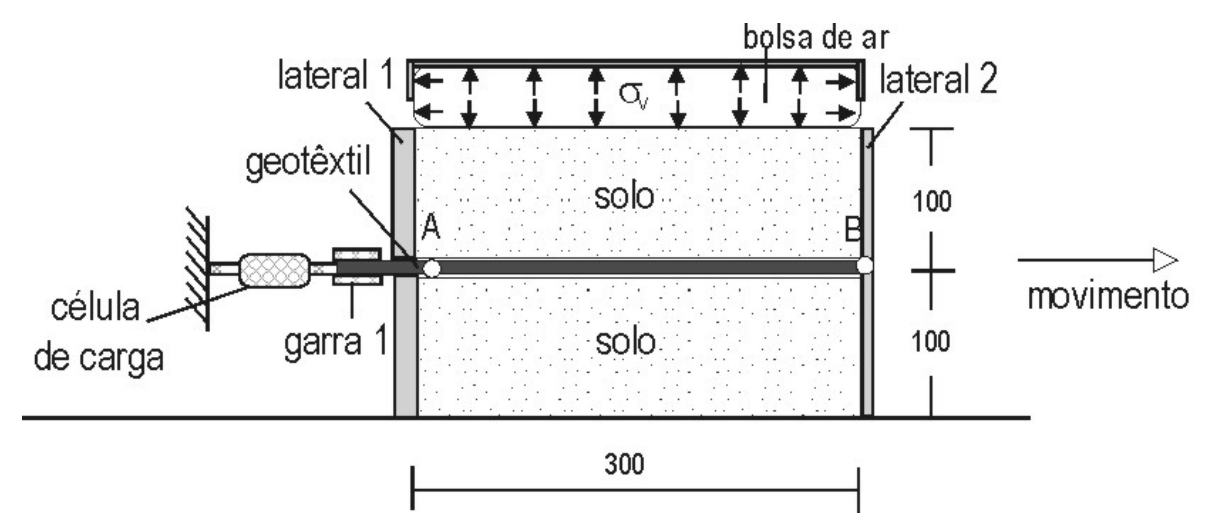

FIGURA 3.1 - Configuração inicial do equipamento (sem escala, dimensões em mm). 
A deformação do elemento de solo reforçado era possível através da movimentação da lateral 2 da caixa de ensaios, permanecendo a lateral 1 estática. A lateral 2, constituída por uma chapa de aço inox com $1 \mathrm{~mm}$ de espessura, era ligada ao reforço na posição indicada pelo ponto B na Figura 3.1. A conexão do geotêxtil à face no ponto $\mathrm{B}$ constituía a única restrição à movimentação da lateral 2. Assim, após aplicação da tensão vertical, solo e reforço podiam deformar de forma interativa.

Para redução do atrito lateral na caixa, as faces 1 e 2 foram lubrificadas com graxa de silicone e recobertas com filmes plásticos. Por serem de vidro, as faces 3 e 4 foram mantidas sem lubrificação, uma vez que o ângulo de atrito entre o vidro e a areia já é bastante reduzido, em comparação ao ângulo de atrito entre superfícies metálicas e areia (o ângulo de atrito vidro/areia apresenta um valor em torno de $6^{0}$, BUENO, 1987). Duas camadas de plástico lubrificadas com graxa de silicone foram ainda colocadas entre a bolsa e a camada superior de solo.

Pretendia-se obter a deformação no reforço posicionando-se strain gages em diferentes posições ao longo do seu comprimento, mas como os strain gages ainda não estavam disponíveis para serem usados, os testes foram iniciados apenas com medida de carga para verificar a viabilidade da configuração pretendida. $O$ valor da deformação nas proximidades do ponto A poderia ser relacionado à carga registrada pela célula de carga.

Com relação à aplicação da tensão vertical, a concepção de uma bolsa de ar adequada constituiu um problema a ser solucionado durante toda a etapa de desenvolvimento do equipamento, já que dois aspectos distintos precisavam ser atendidos:

i) $\mathrm{O}$ contato da bolsa com a lateral 2, que poderia ocorrer em virtude do recalque da camada de solo (ver Figura 3.1), deveria ser impedido. Esse contato não poderia ocorrer para evitar a aplicação de uma tensão horizontal na parede móvel por ação da bolsa, solicitando conseqüentemente o reforço. $\mathrm{O}$ carregamento na lateral 2 deveria ser aplicado exclusivamente pelo solo, a fim de garantir o princípio de funcionamento do equipamento, ou seja, a carga sendo transmitida ao reforço através do solo. 
ii) Para garantir a aplicação da tensão vertical, o contato entre o solo e a câmara de ar deveria ser mantido durante todo o ensaio, mesmo para grandes deformações.

Por serem, de certa forma, antagônicos, o atendimento simultâneo desses dois aspectos não é fácil. A primeira condição impede que as paredes das caixas possam ser usadas para confinar lateralmente bolsas de ar. Sem confinamento, a utilização de materiais extremamente flexíveis fica impossibilitada. Por outro lado, a segunda condição requer materiais flexíveis.

A Figura 3.2 mostra o primeiro modelo de bolsa utilizado. Essa bolsa foi confeccionada pela empresa SANSUY S.A, utilizando-se uma manta de PVC reforçada com fibras de PET. As condições 'i' e 'ii' acima citadas foram atendidas através de um processo de dobra manual, comprimindo a bolsa como mostrado na Figura 3.2(b) a fim de reduzir sua espessura inicial $(50 \mathrm{~mm})$. Com a configuração adquirida após o processo de dobra, a bolsa, que era confinada entre a camada de solo e a tampa da caixa de ensaios, podia acompanhar o recalque da camada de solo, mas era rígida o suficiente na lateral para não entrar em contado com a face móvel da caixa. Ressalta-se que as dimensões da primeira configuração de ensaio foram condicionadas, principalmente, por já existir uma bolsa de ar disponível no laboratório de geossintéticos com dimensões de 300 x $200 \mathrm{~mm}$.

O equipamento foi sendo desenvolvido procurando-se, sempre que possível, adotar a configuração de ensaio mais simples possível. Assim, em lugar de duas bolsas para a aplicação da tensão vertical no solo, como utilizado por HELWANY \& SHIH (1998), Figura 2.15, a possibilidade de utilização de apenas uma bolsa de ar, posicionada na parte superior do corpo-de-prova, foi inicialmente averiguada.

Adicionalmente, a confecção de uma bolsa de ar inferior para o equipamento é mais complicada. Isso se deve ao fato de que a câmara de ar inferior deve acompanhar as deformações do solo, precisando ser rígida e ter a face plana (pelo menos no momento de preparação das camadas de solo), pois funciona também como base da caixa de testes. A utilização de uma bolsa na base semelhante à mostrada na Figura 3.2 provocaria a movimentação da camada de solo durante a preparação, como ilustrado na Figura 3.3. 

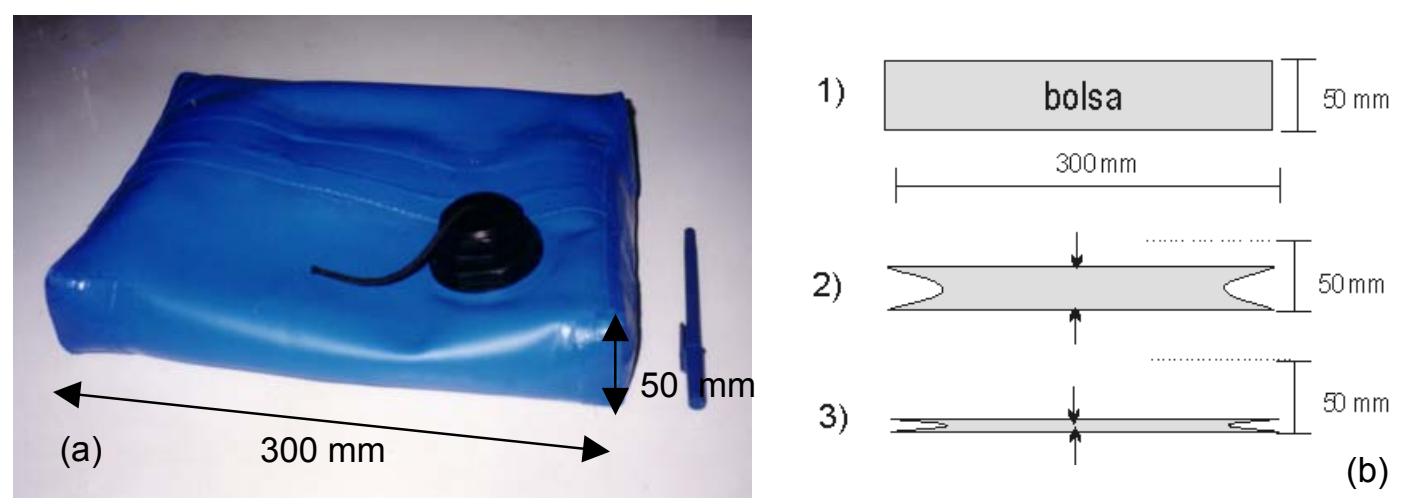

FIGURA 3.2 - (a) Bolsa inflável inicialmente utilizada (b) processo de dobra da bolsa: 1) configuração inicial, 2) processo de dobra para reduzir espessura 3) configuração após processo de dobra.

(a)

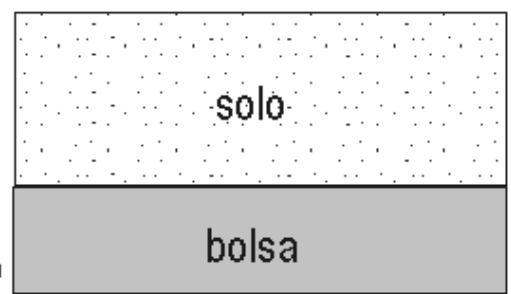

(b)

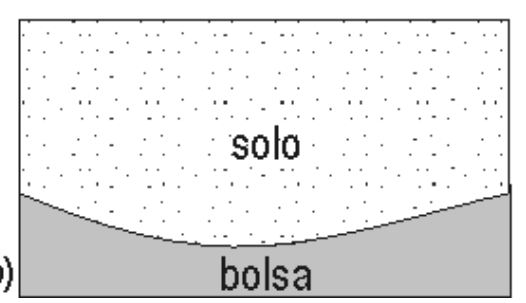

FIGURA 3.3 - (a) configuração desejada para a bolsa inferior (b) configuração resultante pela deformação da bolsa durante preparação do corpo-de-prova.

O primeiro teste do equipamento com a configuração mostrada na Figura 3.1, aplicando-se uma tensão vertical correspondente a 100 kPa, não revelou resultados satisfatórios. Nenhuma carga foi registrada pela célula de carga, fato de certa forma previsível devido ao comprimento do corpo-de-prova adotado em função da dimensão da bolsa $(\mathrm{L}=300 \mathrm{~mm})$. Como ilustrado na Figura 3.4, a carga atuante no reforço no ponto $\mathrm{D}$, em virtude da região instável hipotética ' $a b c$ ', estaria, provavelmente, sendo dissipada pelo atrito com o solo na região estável antes de atingir a célula de carga. 


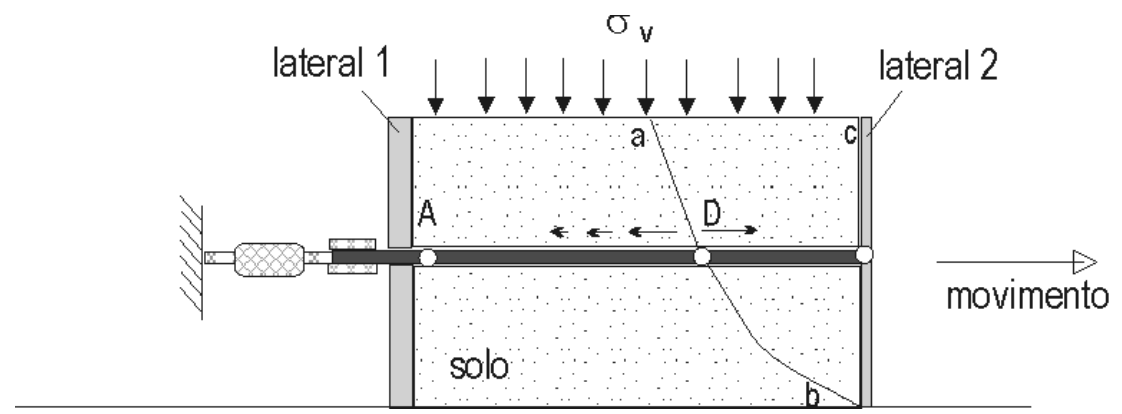

FIGURA 3.4 - Mecanismo de dissipação de carga no reforço antes de atingir a célula de carga

Diante desse resultado, uma segunda configuração foi adotada para o equipamento. O comprimento do corpo-de-prova foi reduzido para $200 \mathrm{~mm}$, sendo necessária a confecção de uma nova bolsa com 200 x 200 mm. As demais dimensões e procedimentos foram mantidos. Não obstante, a nova bolsa confeccionada apresentou-se muito rígida nos cantos o que dificultou a adoção do procedimento de dobra mostrado na Figura 3.2. Por essa razão, a bolsa perdeu a capacidade de se acomodar completamente aos recalques da camada de solo, principalmente, na região sob seus cantos.

De qualquer forma, o equipamento foi testado utilizando-se a bolsa de ar com 200 x $200 \mathrm{~mm}$. Novamente, nenhuma carga foi registrada pela célula de carga. Tal comportamento poderia ser devido ao problema de funcionamento da bolsa, descrito anteriormente, bem como devido ao mecanismo mostrado na Figura 3.4 (dissipação da carga por atrito).

Iniciou-se então o desenvolvimento de uma terceira configuração para o equipamento. Uma segunda garra (garra 2) foi confeccionada para auxiliar o desenvolvimento do equipamento e investigar o mecanismo de dissipação da carga no reforço. A garra 2 foi projetada com dimensões bastante reduzidas a fim de ser posicionada dentro da caixa de ensaio. O funcionamento dessa garra é ilustrado na Figura 3.5. O geotêxtil era enrolado em uma haste de aço com $4 \mathrm{~mm}$ de diâmetro e prensado através de chapas de aço inox com $1 \mathrm{~mm}$ de espessura, dotadas de parafusos (Figura 3.5a e b). A haste de aço era conectada à célula de carga, no exterior da caixa, através de quatro cabos de aço como mostrado na Figura 3.5c, permitindo que a carga atuante no geotêxtil na posição da garra fosse registrada pela célula. 


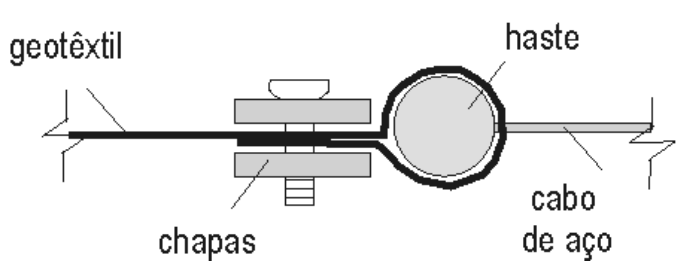

(a)

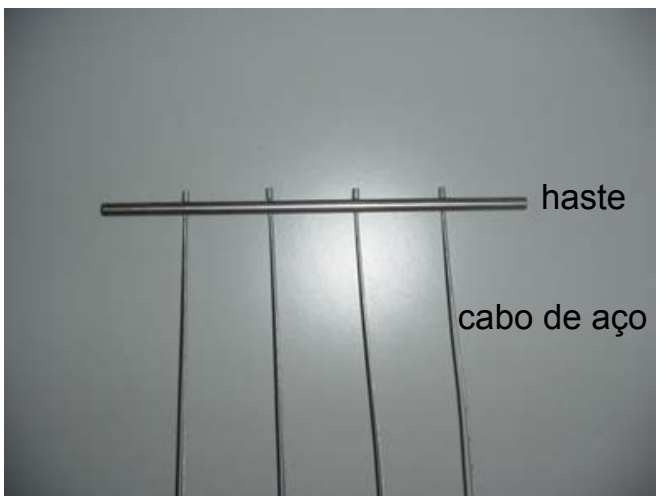

(b)

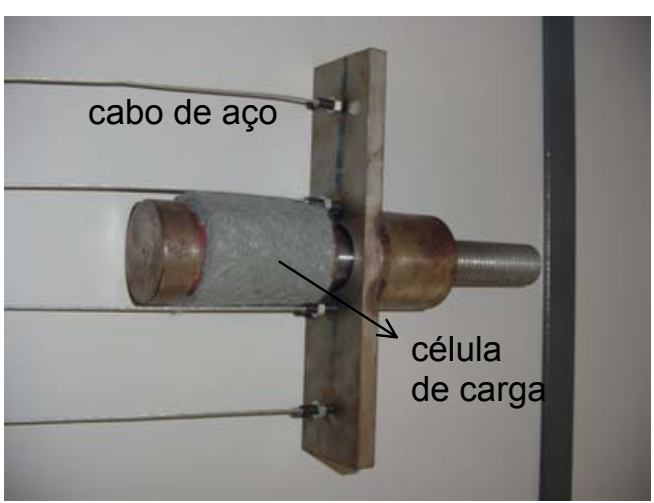

(c)

FIGURA 3.5 - (a) Esquema da garra 2 (b) haste e cabos utilizados na garra (c) peças para conexão dos cabos de aço à célula de carga.

A Figura 3.6 mostra o novo sistema desenvolvido para a aplicação da tensão vertical. Uma estrutura metálica em U transmite ao solo a pressão aplicada através de uma câmara de ar de motocicleta. A chapa mostrada na Figura 3.6a é impedida de se movimentar, enquanto a peça em U pode se movimentar acompanhando os recalques da camada de solo.

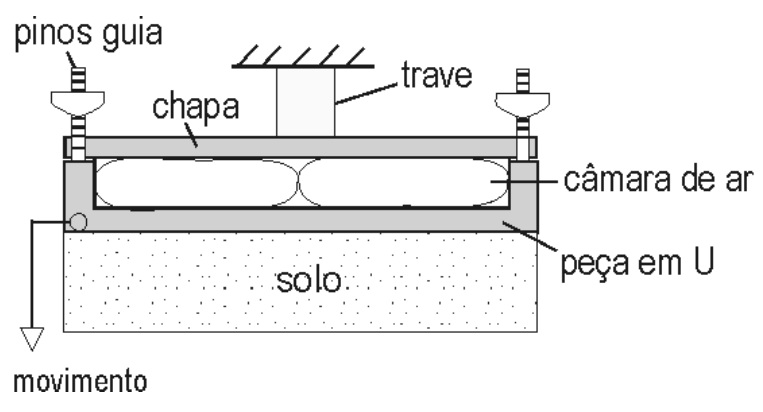

(a)

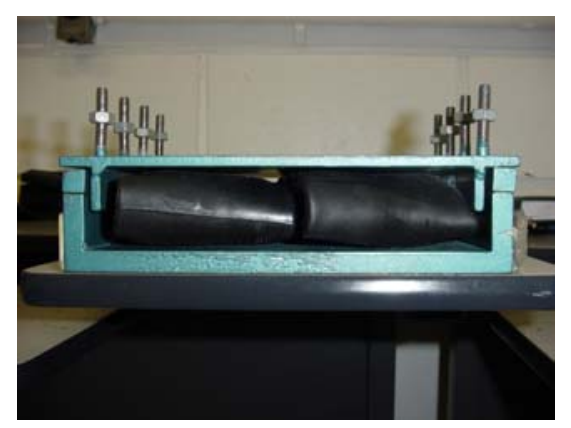

(b)

FIGURA 3.6 - Sistema para aplicação da tensão confinante utilizado durante o desenvolvimento do equipamento. 
A terceira configuração adotada para o equipamento é esquematizada na Figura 3.7. O novo sistema desenvolvido para aplicação do carregamento permitiu também a aplicação da tensão vertical na base da camada de solo inferior. Não obstante, assim como na configuração anterior, nenhuma carga foi registrada na célula de carga, após a aplicação de uma pressão igual a 100 kPa nas câmaras de ar.

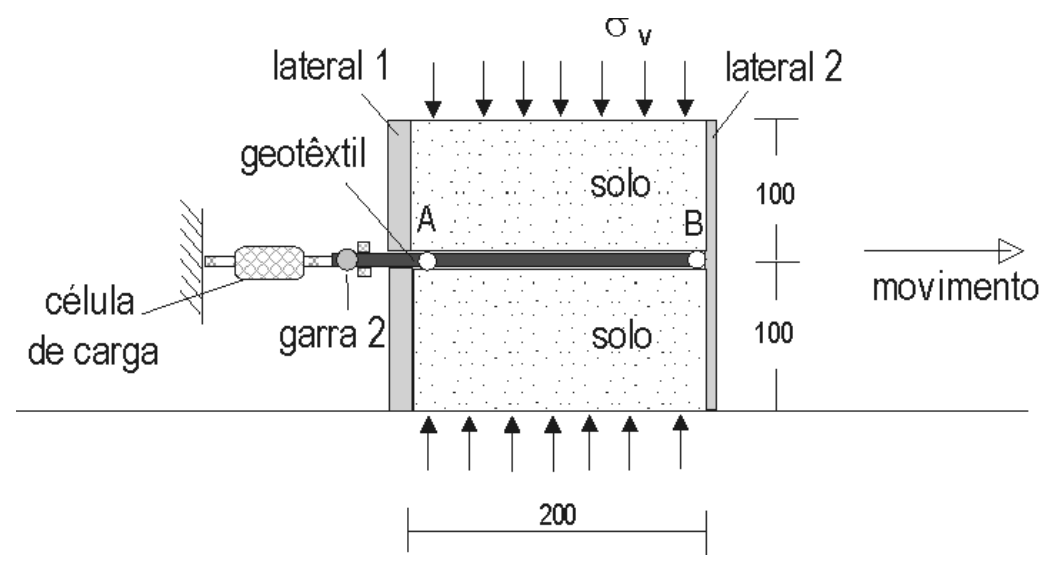

FIGURA 3.7 - Terceira configuração testada para o equipamento (sem escala, dimensões em mm).

Um teste foi então realizado sob as mesmas condições, posicionando-se a garra 2 no interior da caixa, a $50 \mathrm{~mm}$ do ponto A mostrado na Figura 3.7. Com essa configuração, uma carga correspondente a cerca de $0,05 \mathrm{kN}$ foi registrada pela célula. Em seguida, um novo teste foi efetuado com a garra a $100 \mathrm{~mm}$ do ponto A e a célula indicou uma carga de $0,2 \mathrm{kN}$. Com a garra a $150 \mathrm{~mm}$ do ponto $\mathrm{A}$, cerca de $0,14 \mathrm{kN}$ foi registrado pela célula.

Adotando-se um ângulo de atrito $(\phi)$ correspondente a $38^{0}$ para areia utilizada, e utilizando-se a expressão (3.1) tem-se, para $\sigma_{\mathrm{v}}=100 \mathrm{kPa}$, que a força resultante na lateral 2 corresponderia cerca de $0,95 \mathrm{kN}$ (desprezando perdas por atrito nas faces da caixa). Esse valor é maior que os valores apontados pela célula de carga, entretanto, os testes realizados com a garra 2 foram bem mais satisfatórios que os anteriores, visto que pelo menos alguma carga foi registrada.

$\mathrm{F}=\mathrm{K}_{\mathrm{a}} \sigma_{\mathrm{v}} \mathrm{A}$ 
Onde,

F - força na lateral 2;

$\mathrm{K}_{\mathrm{a}}$ - coeficiente de empuxo ativo, $\mathrm{K}_{\mathrm{a}}=\operatorname{tg}^{2}(45-\phi / 2)$;

$\sigma_{\mathrm{v}}-$ tensão vertical;

A - área da lateral 2.

Nesse estágio de desenvolvimento do equipamento, as seguintes hipóteses foram cogitadas para justificar o reduzido valor da carga registrada:

i) A tensão vertical aplicada e a conseqüente força no reforço estaria sendo dissipada pelo atrito nas laterais da caixa;

ii) A tensão vertical atuante seria menor que o valor pretendido. Pois, a câmara de ar mostrada na Figura 3.6 não apresentou a expansão desejada e nem toda a peça em $U$ ficou em contato com a câmara de ar.

Diante desse cenário, algumas medidas foram tomadas para evitar os problemas descritos nos itens 'i' e 'ii'. Primeiramente, resolveu-se adotar um processo de lubrificação com graxa freqüentemente descrito na literatura (ex. TATSUOKA et al, 1984; BOYLE, 1995; KETCHART \& WU, 2002). Assim, todas as faces da caixa foram lubrificadas com graxa de silicone com a posterior colocação de membranas de látex entre as faces e o corpo-de-prova. Um amplo programa de ensaios de cisalhamento direto de interface foi realizado a fim de selecionar a graxa a ser utilizada e auxiliar a investigação do atrito desenvolvido na caixa de testes. $O$ programa de ensaios é descrito no item 3.4.1.

Com relação ao aspecto discutido no item 'ii', um novo sistema para a aplicação da tensão vertical foi projetado e confeccionado (Figura 3.8). Uma manta de borracha é presa na peça 1, que se encontra livre para se movimentar quando da aplicação da pressão. O movimento da peça 1 possibilita o contato da borracha com o solo durante o ensaio. Esse mecanismo de aplicação de tensão corresponde ao sistema finalmente adotado para o equipamento e será descrito em maiores detalhes no item 3.2.6. 

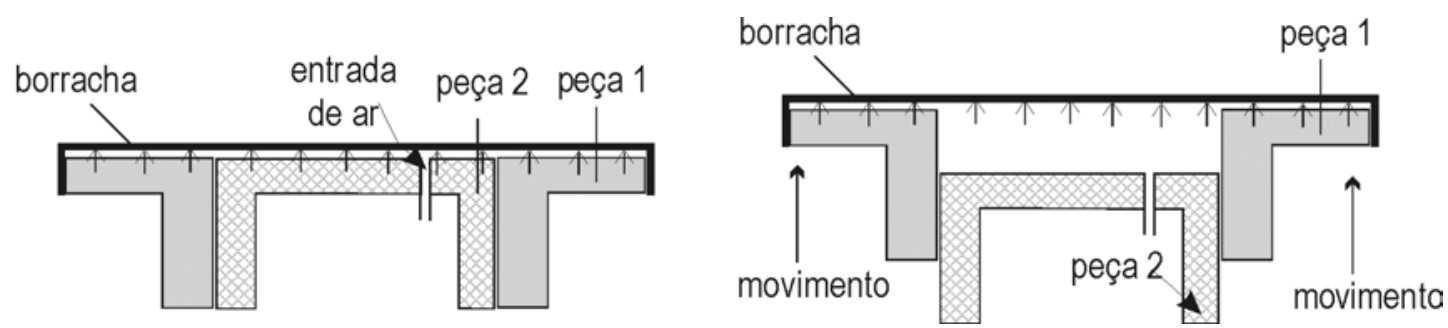

FIGURA 3.8 - Esquema do sistema para a aplicação de tensão vertical finalmente adotado.

\subsubsection{Mecanismo de funcionamento da configuração final do equipamento}

Paralelamente ao desenvolvimento do sistema utilizado para aplicar a tensão vertical mostrado na Figura 3.8, algumas modificações foram introduzidas no equipamento visando melhorar seu desempenho. A Figura 3.9 mostra o esquema final adotado. Novas laterais 1 e 2, com rigidez superior às antigas laterais, foram projetadas e confeccionadas para a caixa. Essas laterais encontram-se ligadas a pórticos rígidos, como mostrado na Figura 3.9, permitindo que ambas as faces 1 e 2 possam se movimentar, a depender da interação entre o solo e o reforço. Garras novas foram confeccionadas e posicionadas conforme mostrado na Figura 3.9, permitindo a ancoragem do reforço em suas duas extremidades.

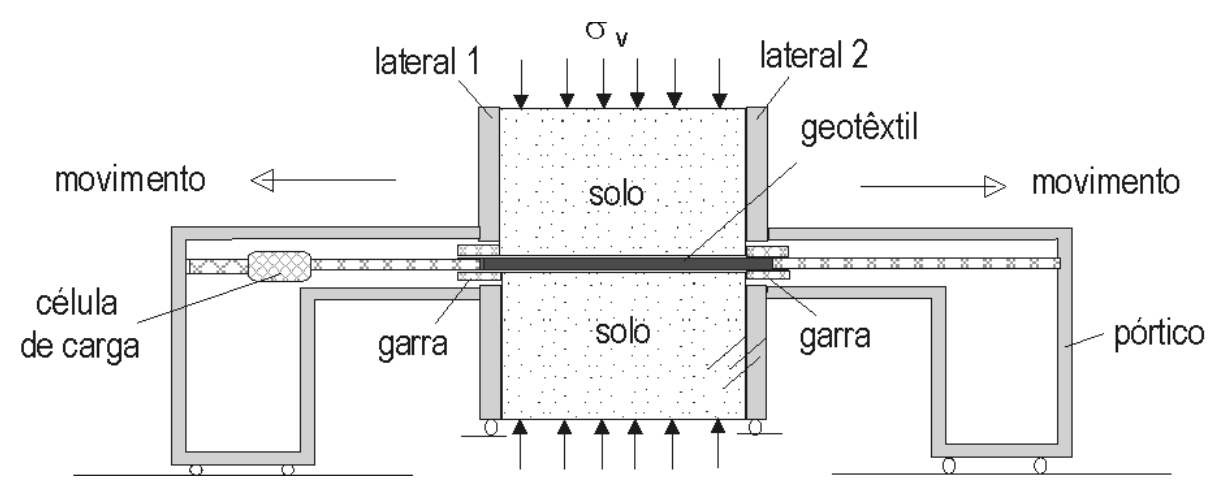

FIGURA 3.9 - Configuração final do equipamento

O funcionamento do equipamento pode ser compreendido observando-se o detalhe mostrado na Figura 3.10 o qual ilustra o mecanismo para obtenção da carga no reforço no ponto A. O princípio de funcionamento pode ser descrito da seguinte forma: 
i) Primeiramente, a tensão vertical é aplicada às camadas de solo através das câmaras de ar pressurizado, resultando no desenvolvimento de tensões horizontais (as forças $F_{h 1} \quad F_{h 2}$ são resultantes da tensão horizontal atuante na parte superior e inferior da lateral da caixa, respectivamente).

ii) A movimentação da parede causada pela ação de $F_{h 1}$ e $F_{h 2}$ é limitada pela presença do reforço, ligado à parede através da conexão "garrapórtico" mostrada na Figura 3.10. Nesse mecanismo de interação, o geotêxtil apresenta deformação e permite o deslocamento da lateral móvel até a força no reforço atingir um valor igual a $F_{h 1}+F_{h 2}$.

iii) Como a única ligação existente entre a parede da caixa e o reforço ocorre através da conexão "garra-pórtico", a presença da célula de carga, posicionada entre essa conexão e a garra, permite o registro da forca resultante $\left(\mathrm{F}_{\mathrm{h} 1}+\mathrm{F}_{\mathrm{h} 2}\right)$. A força resultante, proveniente da solicitação do solo na parede móvel, corresponde à força atuante no reforço no ponto A.

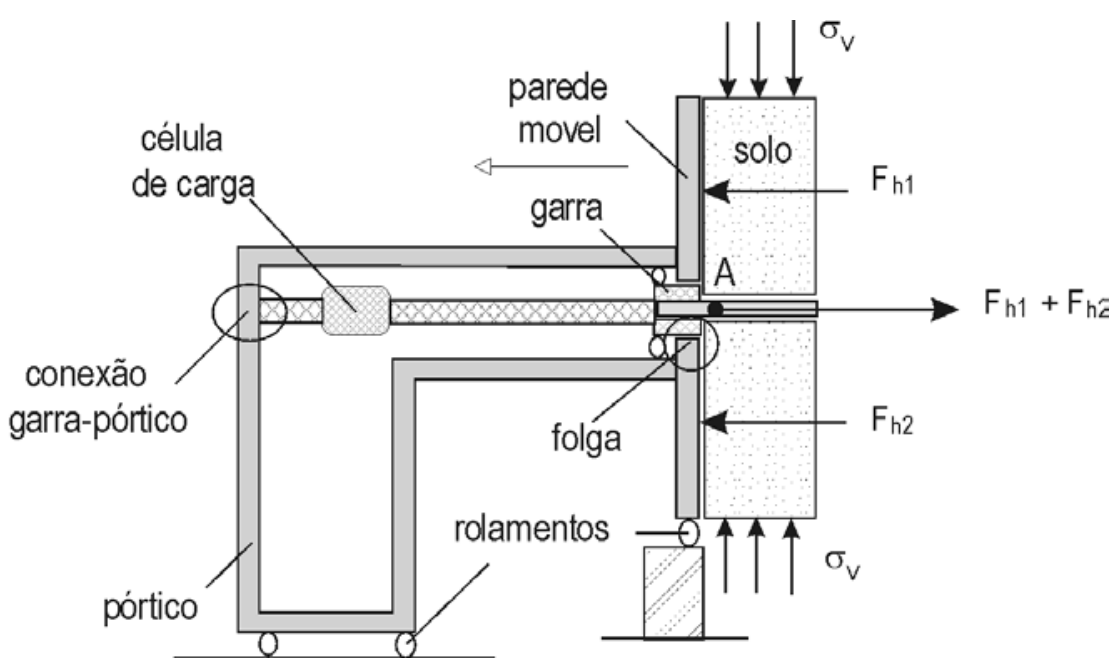

FIGURA 3.10 - Detalhe do mecanismo de transmissão de carga

Essa configuração para o equipamento permitiu que o solo e o reforço apresentassem deformações ao longo do tempo de maneira interativa, e a carga registrada atingiu níveis satisfatórios. Em complementação, tal configuração 
possibilitou ainda a execução de outros tipos de ensaios, além daqueles com elementos de solo reforçado, como será mostrado em seguida.

\section{2 - Descrição do equipamento}

\subsubsection{Configuração dos ensaios com solo e reforço}

A configuração final do equipamento desenvolvido é mostrada na Figura 3.11 enquanto um esquema do mesmo é apresentado na Figura 3.12. O equipamento é composto basicamente por: uma caixa fixa a uma mesa de apoio, um conjunto de garras para a fixação do geotêxtil, um sistema para aplicação de tensões verticais à massa de solo e um sistema para a obtenção de deformações no geotêxtil.

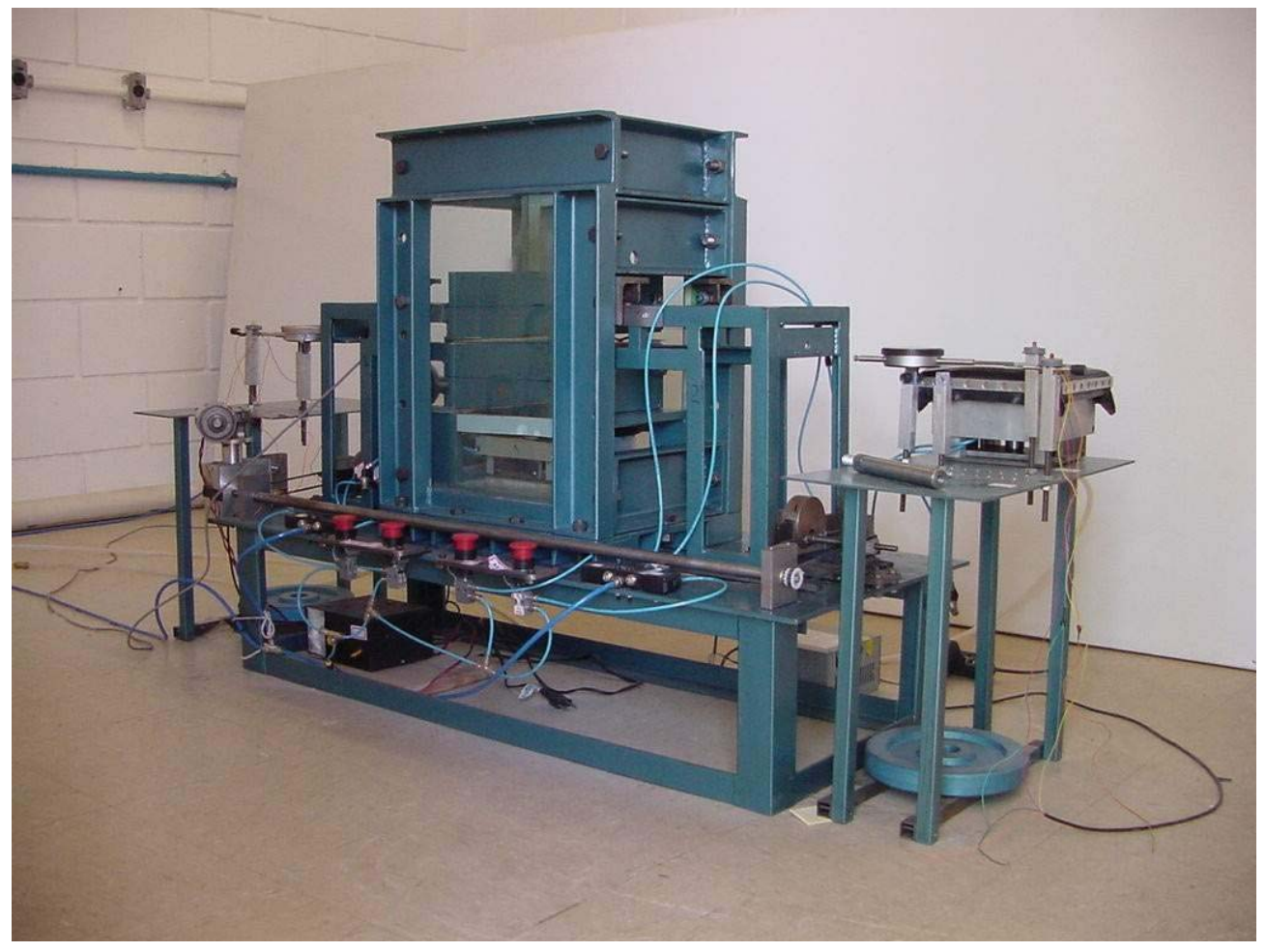

FIGURA 3.11 - Equipamento desenvolvido 


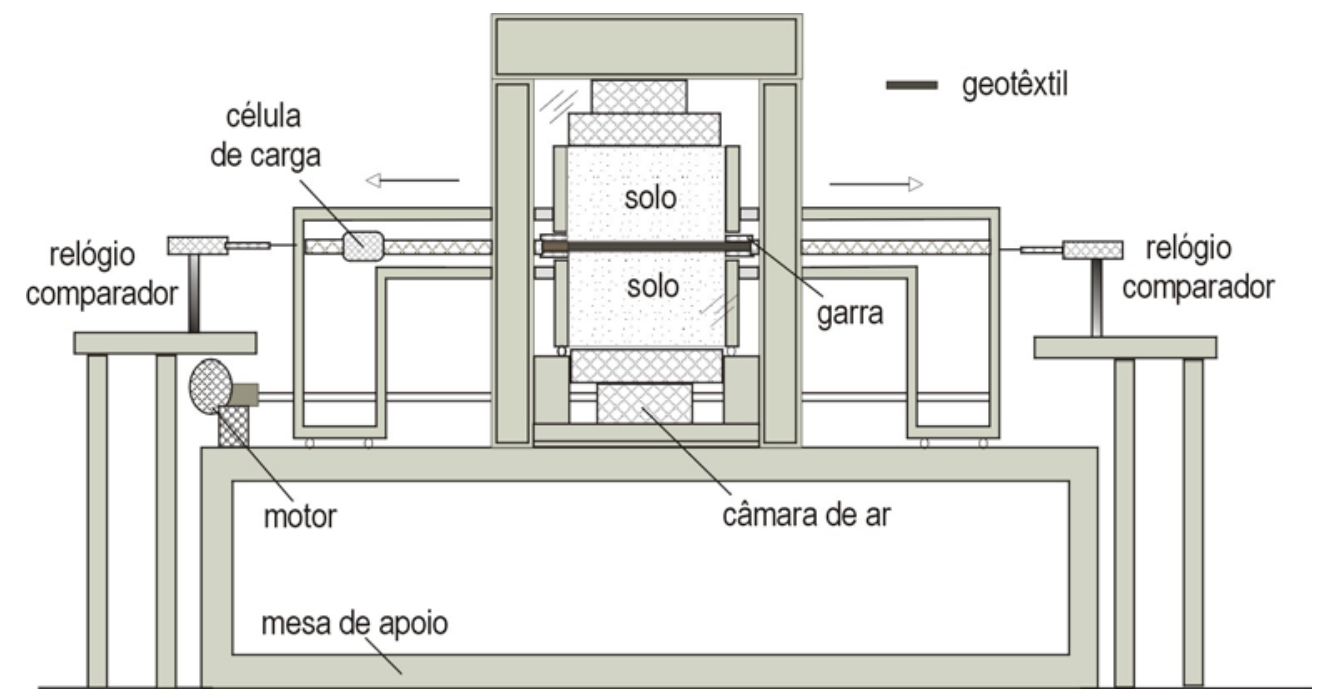

FIGURA 3.12 - Esquema do equipamento desenvolvido

No equipamento desenvolvido, um geotêxtil com dimensões de 200 x 200 mm é confinado entre camadas de solo de $100 \mathrm{~mm}$ de espessura. As deformações no reforço podem ser obtidas considerando o comprimento total do corpo-de-prova (200 $\mathrm{mm}$ ) ou em diferentes trechos do mesmo, como será descrito em detalhes no item 3.2 .4 .

\subsubsection{Configuração do ensaio apenas com solo}

O equipamento desenvolvido ainda permite a realização de ensaios utilizando apenas o solo (sem a utilização do reforço). Essa modalidade de teste possibilita acompanhar a força na parede móvel da caixa, causada por um carregamento vertical aplicado à massa de solo, à medida que as paredes se deslocam a uma velocidade constante. Um corpo-de-prova com 200 x 200 x 200 mm é utilizado no ensaio.

Para permitir a movimentação das laterais 1 e 2 da caixa a uma velocidade constante, um sistema motorizado foi desenvolvido. Cada parede móvel, antes suportada pelo reforço, é acoplada a um eixo individual preso a um mancal, como mostrado nas Figuras 3.13 e 3.14. Os eixos individuais são ligados a um eixo maior através de correias. Um motor de baixa rotação (100 r.pm), associado a um conjunto de engrenagens, aciona o movimento do eixo maior e torna possível a movimentação 
simultânea das paredes a uma velocidade constante. As engrenagens permitem a translação das paredes com velocidades iguais a 0,$1 ; 0,7 ; 1$ e $4 \mathrm{~mm} / \mathrm{min}$. Os deslocamentos da parede são obtidos através de um relógio comparador, com curso de $50 \mathrm{~mm}$ e resolução de $0,01 \mathrm{~mm}$, posicionado próximo ao centro da mesma.

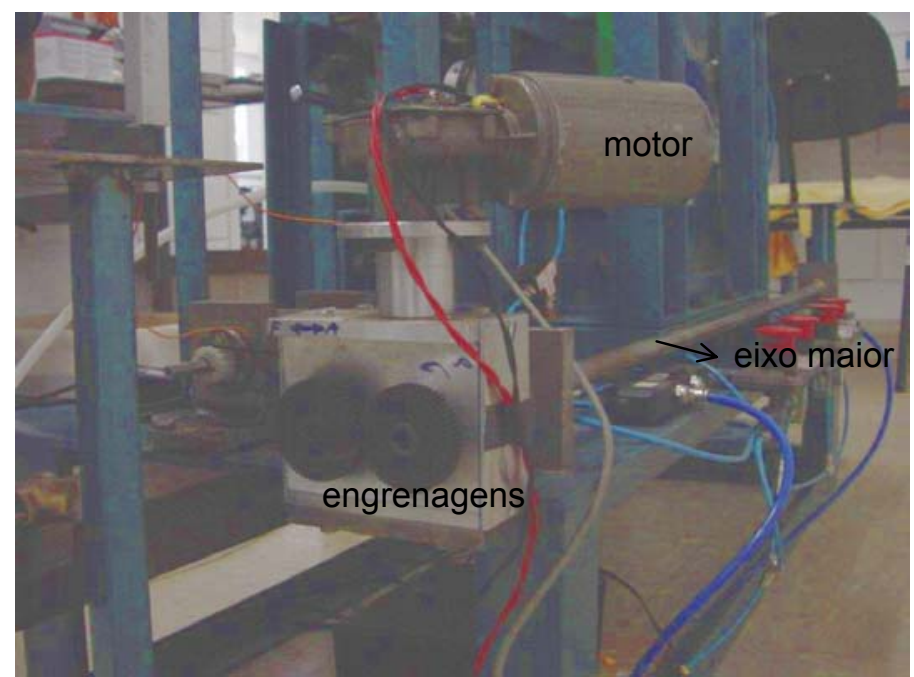

FIGURA 3.13 - Detalhe do motor e sistema de eixos

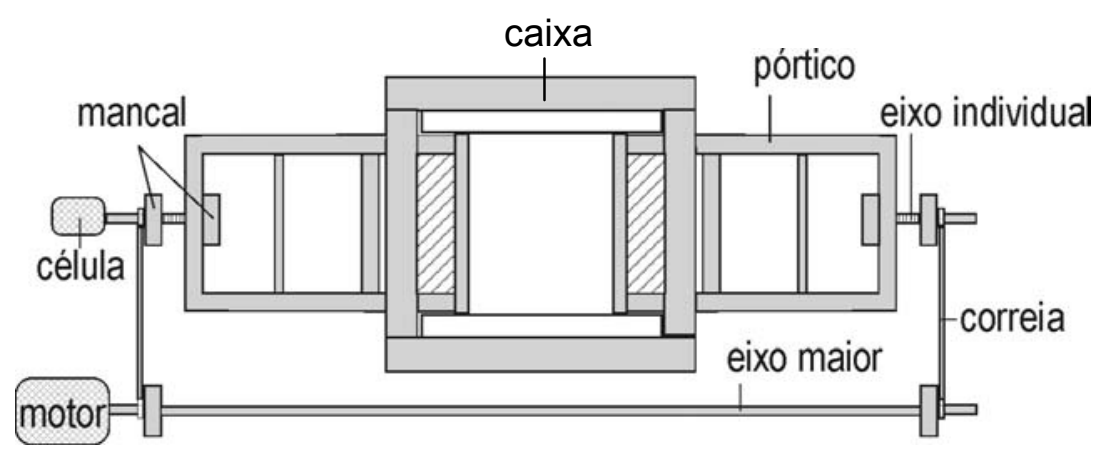

FIGURA 3.14 - Esquema do sistema para movimentação das paredes (vista superior)

A realização de ensaios apenas com solo constitui uma inovação com relação aos equipamentos descritos na literatura para averiguar o comportamento de 
elementos de solo reforçado. Esse tipo de ensaio revelou-se de grande de importância para o programa experimental conduzido nesta pesquisa, pois permitiu avaliar o comportamento do solo no mesmo equipamento utilizado nos ensaios com o elemento solo-reforço.

\subsubsection{Caixa de ensaios e sistema de garras}

A estrutura móvel da caixa de ensaios abrange as paredes que compõem os lados 1 e 2 mostrados na Figura 3.15, bem como o respectivo pórtico. Cada parede é composta por duas chapas (inferior e superior) com $13 \mathrm{~mm}$ de espessura, 200mm de largura e $95 \mathrm{~mm}$ de altura. Os pórticos foram confeccionados a partir de cantoneiras de aço e possuem rolamentos que deslizam sobre a mesa de apoio, permitindo a movimentação das laterais 1 e 2 . As paredes 1 e 2 não são ligadas aos lados 3 e 4 e estão apoiadas sobre blocos de aço a fim de permitir o encaixe da câmara de ar inferior.

As laterais 3 e 4 são constituídos por perfis de aço tipo $U$ com diferentes dimensões (perfil U1 - 76,2 x 38,1 x 6,55 mm, perfil U2 - 101,6 x 41,28 x 6,27 mm) e por uma cantoneira de 19,05 x 19,05 x 4,76 mm que servem de apoio para uma placa de vidro com $30 \mathrm{~mm}$ de espessura. A utilização de vidro possibilitava a visualização do corpo-de-prova e das câmaras de ar, facilitando a identificação de eventuais problemas durante a fase de desenvolvimento do equipamento. Alguns perfis metálicos (tipo U1) são empregados para permitir a ligação e o travamento dos lados 3 e 4.

No que diz respeito ao sistema de fixação do geotêxtil, cada garra é constituída por duas chapas de aço com 200 x 40 x 5 mm (largura, comprimento e espessura, respectivamente), conectadas através de parafusos com $3 \mathrm{~mm}$ de diâmetro. Como os geotêxteis utilizados são tecidos, era possível passar os parafusos entre as fibras da manta, durante o processo de fixação do geotêxtil à garra, sem a necessidade de perfuração do reforço. 


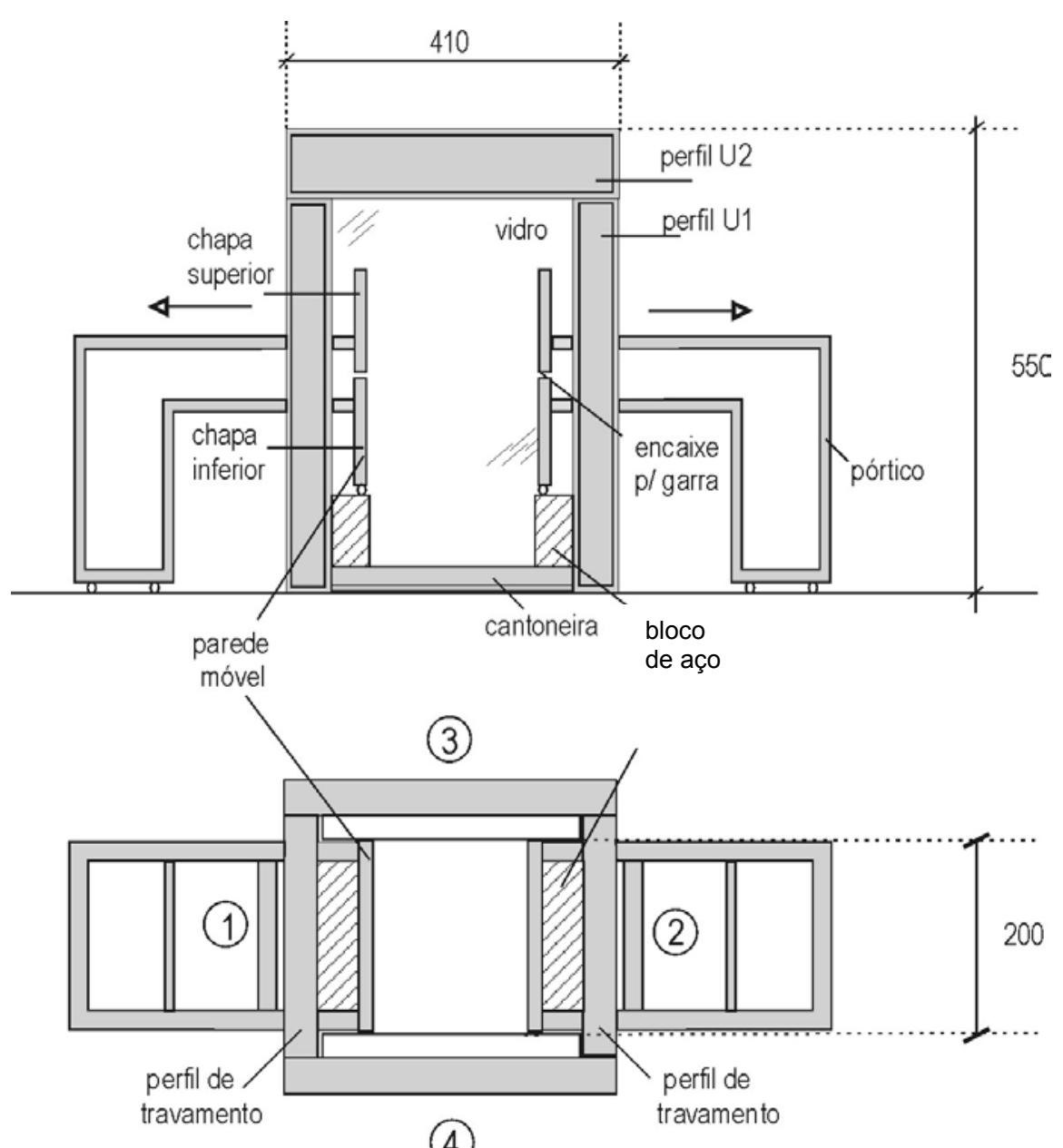

(4)

FIGURA 3.15 - Esquema da caixa de ensaios (a) vista lateral (b) vista superior (sem escala, dimensões em mm)

\subsubsection{Sistema para obtenção da deformação no geotêxtil}

O sistema para obter as deformações no reforço passou por algumas modificações desde a configuração inicial até a versão final do equipamento. Inicialmente, pretendia-se obter as deformações com strain gages. No entanto, a possibilidade de desenvolvimento de um outro sistema, a base de fibra ótica, substituiu essa opção.

O esquema do dispositivo com fibra ótica é mostrado na Figura 3.16. Um tubo flexível (com uma microlente de safira em uma extremidade) deveria ser fixado ao ponto cujo deslocamento se pretendia obter. Uma extremidade da fibra seria inserida no tubo (inicialmente em contato com a microlente) e poderia se 
movimentar livremente, enquanto a outra extremidade da fibra permaneceria fixa. ̀̀ medida que o geotêxtil apresentasse deformação, a extremidade da fibra se afastaria da microlente. O registro do tempo necessário para um pulso de luz gerado por um laser percorrer o caminho de ida e volta, da ponta fixa da fibra até a microlente, permitiria obter o deslocamento (x) do ponto desejado (Figura 3.16b).
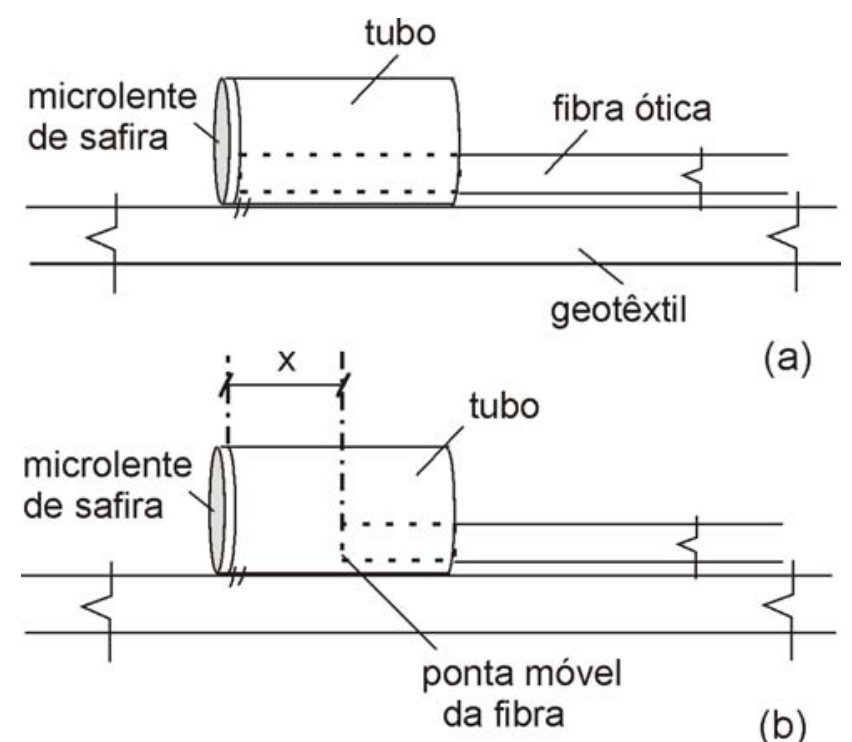

FIGURA 3.16 - Sistema ótico para obtenção de deformações no geotêxtil (a) configuração inicial (b) movimentação da fibra após deformação do geotêxtil.

O sistema idealizado com fibra ótica possuía como vantagens o fato de apresentar uma potencial resolução de cerca de $0,0001 \mathrm{~mm}$ e possibilitar a instrumentação de diversos trechos do reforço, introduzindo uma perturbação mínima ao ensaio (bem inferior a outros tipos de instrumentação presentes na literatura). Para se ter uma noção das dimensões envolvidas, a microlente de safira possuía diâmetro de $0,05 \mathrm{~mm}$ e existiam fibras disponíveis no mercado com diâmetro inferior a $1 \mathrm{~mm}$.

Não obstante, por uma série de fatores, entre os quais dificuldades na obtenção de componentes importados para a montagem da mesa ótica, o tempo de desenvolvimento do sistema tornou-se bastante elevado. Assim, para não comprometer o cronograma do presente trabalho, após cerca de 1 ano de 
desenvolvimento, esse sistema foi suprimido dos objetivos desta tese e transferido para um outro trabalho em parceria com o Instituto de Física da USP/São Carlos.

Diante de tal situação, um novo dispositivo para medir as deformações no reforço foi idealizado, de modo a atender as necessidades no menor tempo possível. As deformações foram então obtidas através da medida dos deslocamentos de hastes fixas à manta. Quatro hastes diferentes foram usadas para acompanhar os deslocamentos de quatro pontos no reforço, permitindo a obtenção da deformação da manta em trechos distintos. Os deslocamentos das hastes foram registrados mediante a utilização de relógios comparadores A Figura 3.17 mostra as posições de fixação das hastes na manta.

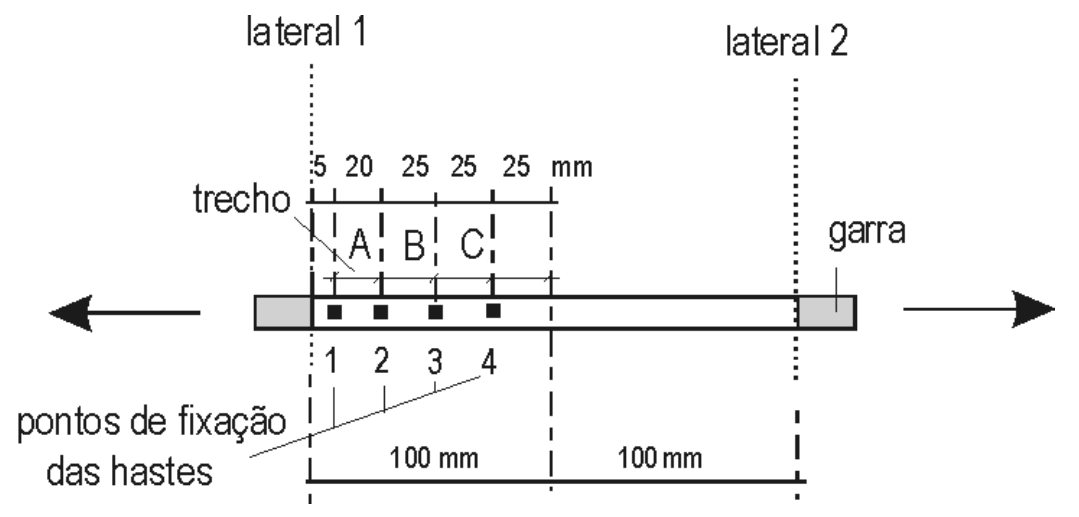

FIGURA 3.17 - Disposição das hastes na manta (sem escala)

As hastes utilizadas eram de aço inox e seus diâmetros foram selecionados a fim de reduzir perturbações no solo. Hastes utilizadas em tratamentos odontológicos com diâmetro correspondente a $0,6 \mathrm{~mm}$ foram consideradas adequadas para $\mathrm{o}$ propósito em questão. Para possibilitar uma movimentação adequada dentro da caixa, as hastes eram lubrificadas com graxa de silicone e deslizavam dentro de um tubo de proteção de aço inox, com diâmetro externo igual a $0,8 \mathrm{~mm}$.

A fixação das hastes na manta era feita prendendo-se sua extremidade no ponto de medição no geotêxtil, utilizando-se uma amarração com fio de cobre. A presença de um sulco na extremidade da haste (Figura 3.18) permitia a acomodação 
do fio de cobre, evitando deslizamentos. Após esse procedimento, a região do enlace era recoberta por uma camada de resina epóxi (araldite).

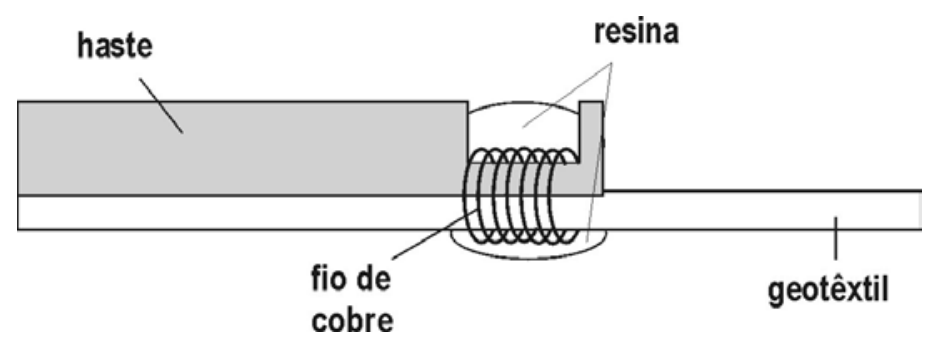

FIGURA 3.18 - Detalhe de fixação da haste

Os relógios comparadores utilizados para obter os deslocamentos das hastes possuíam curso de $50 \mathrm{~mm}$ e resolução de $0,01 \mathrm{~mm}$. Os relógios não eram apoiados diretamente nas hastes, visto que a força de reação do relógio provocaria a flexão das mesmas. Assim, alguns acessórios foram desenvolvidos a fim de viabilizar o contato entre o relógio e a haste, como pode ser observado na Figura 3.19. Os relógios foram invertidos, de modo que o contato com a haste era feito utilizando-se a extremidade 1 do relógio (ver Figura 3.20), movendo-se o parafuso apoiado na extremidade 2. O parafuso foi confeccionado sob encomenda para essa finalidade e possui rosca especial, com capacidade de movimentar peças com resolução de centésimo de milímetro.

Para evitar que o parafuso fosse girado em excesso, o que provocaria flexão da haste e, portanto, erros na leitura, montou-se um circuito elétrico que acendia um led quando do contato relógio-haste. $\mathrm{O}$ esquema do circuito é mostrado na Figura 3.20. Como se pode observar, o contato relógio-haste fecha o circuito e acende o led, evitando que se continue a girar o parafuso e garantindo a acurácia e a repetibilidade da medida. 

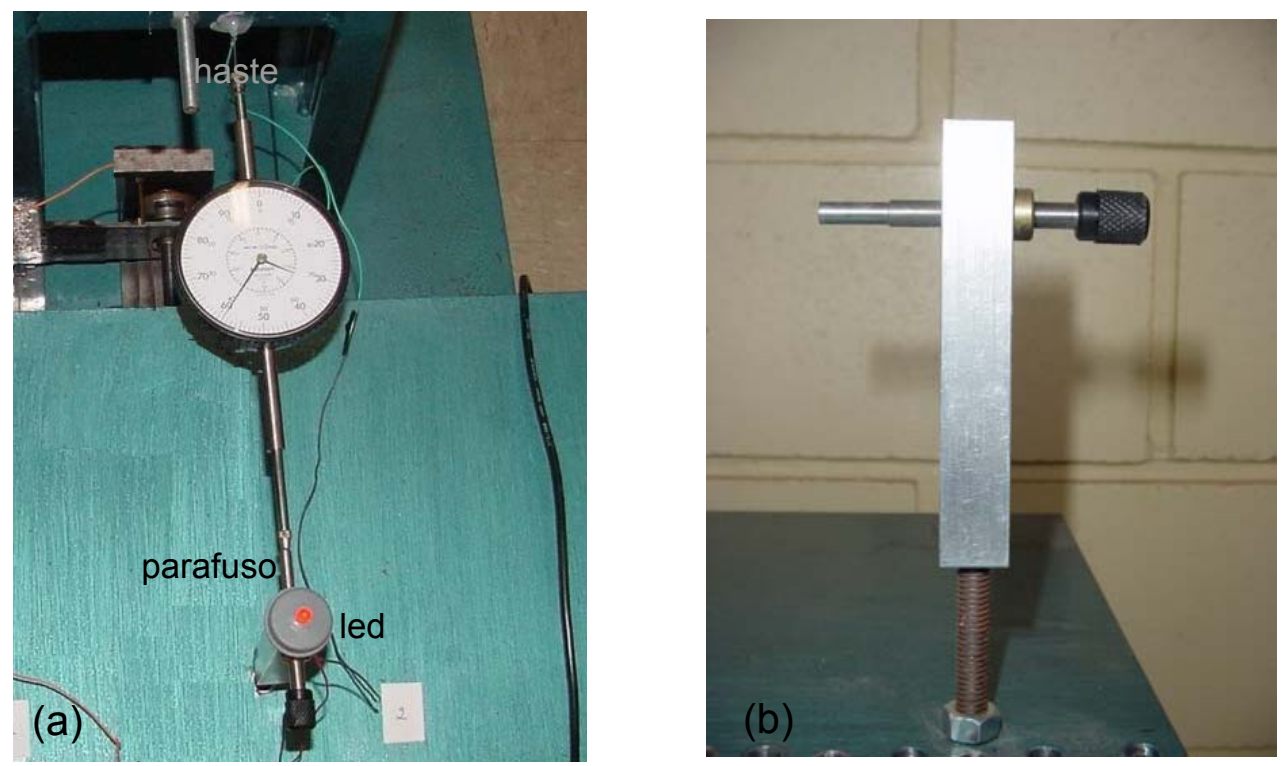

FIGURA 3.19 - (a) sistema de movimentação relógio-haste (b) detalhe do parafuso com rosca de precisão

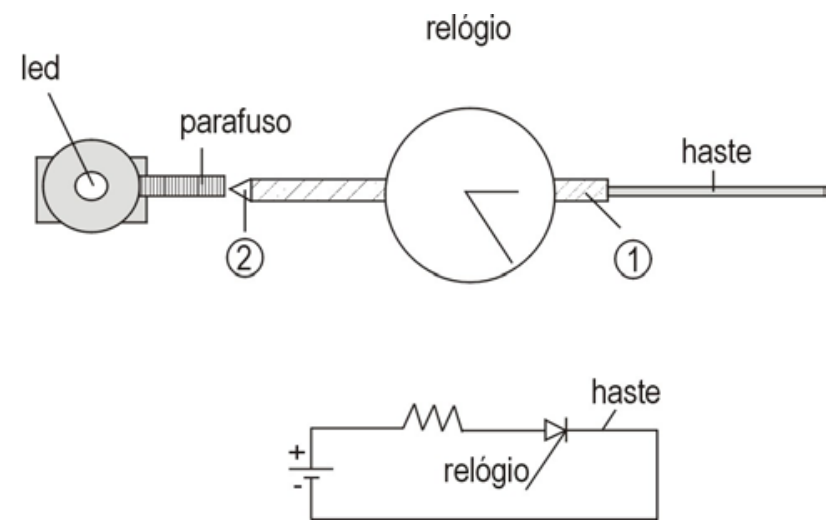

FIGURA 3.20 - Esquema do sistema de movimentação relógio-haste

\subsubsection{Obtenção da força atuante nas paredes}

Nos ensaios com geotêxtil, a força atuante na lateral móvel 1 era obtida através de uma célula de carga posicionada entre a garra e o pórtico como mostrado na Figura 3.9. Em lugar da célula projetada e confeccionada inicialmente, que apresentou problemas de estabilidade ao longo do tempo, uma célula de carga comercialmente disponível foi utilizada nos ensaios e testes realizados com o 
equipamento definitivo. A célula utilizada é de fabricação da Precision Transducers Ltda (modelo ST250) com capacidade de 2,5 kN. Uma fonte e um multímetro digital de fabricação da Minipa, modelos MPS 30060 e MDM-8155, eram responsáveis pela excitação e pela leitura de saída da célula, respectivamente. Sob tais condições, a célula apresentou uma resolução de 0,25 N.

A Figura 3.21 exibe a curva de calibração da célula de carga para diferentes ciclos de carregamento e descarregamento, mostrando excelente repetibilidade e ausência de histerese. Testes realizados mantendo-se a carga constante durante um certo intervalo de tempo revelaram que o sistema possui alta estabilidade. Por exemplo, uma carga de $1,0 \mathrm{kN}$ mantida por $48 \mathrm{~h}$ resultou em uma oscilação de apenas $2,5 \mathrm{~N}$.

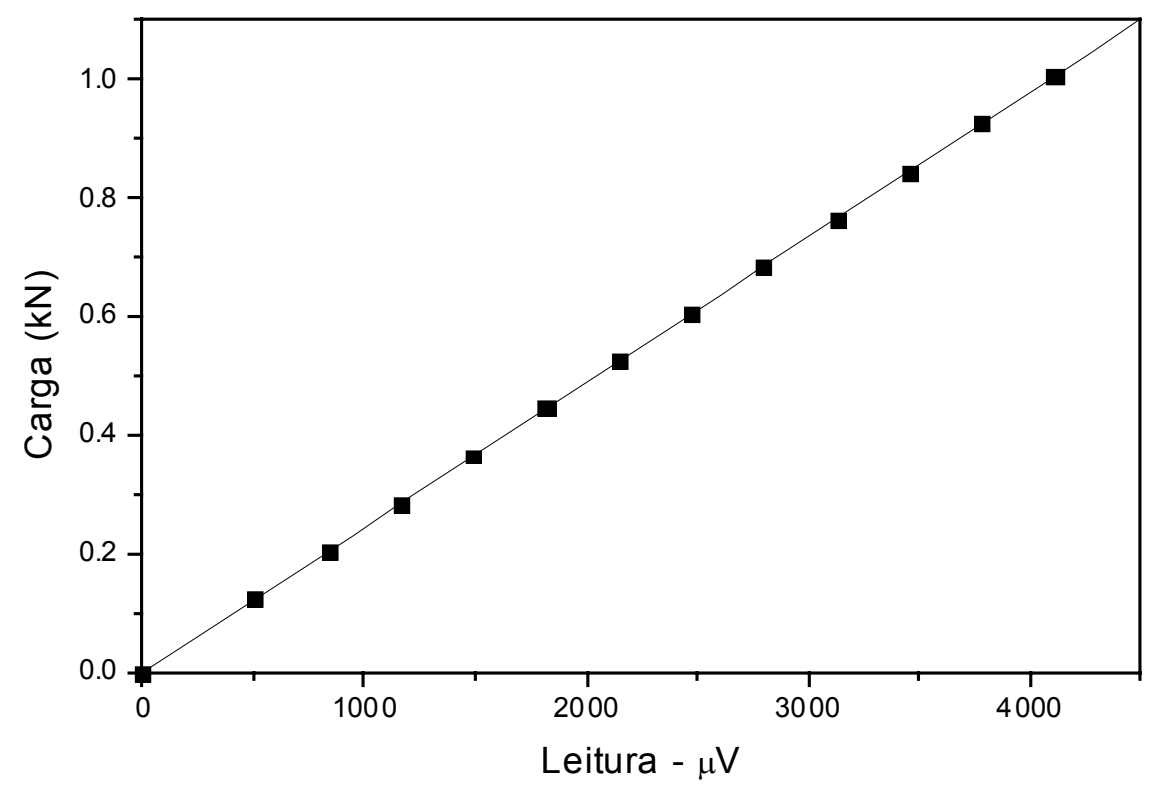

Figura 3.21 - Curva de calibração da célula de carga

Nos ensaios apenas com solo, a célula era posicionada conforme o esquema de montagem ilustrado na Figura 3.22. Esses ensaios contaram ainda com células de tensão inseridas nas camadas de solo (células de inclusão) e embutidas na lateral 1 (células de interface) para medir a tensão vertical e horizontal, respectivamente. As células de inclusão e interface possuíam diâmetro igual a $30 \mathrm{~mm}$, capacidade de 200 $\mathrm{kPa}$ e foram fabricadas pela Kyowa Eletronic Instruments Co., Ltd. (modelos BE$2 \mathrm{KC}$ e BE-2KD, respectivamente). 


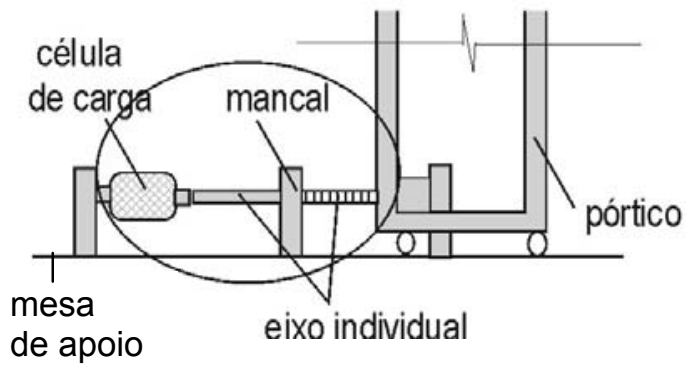

FIGURA 3.22 - Detalhe de fixação da célula para ensaios apenas com solo

\subsubsection{Sistema para aplicação da tensão vertical}

A tensão vertical era aplicada à massa de solo através de duas câmaras pressurizadas com ar comprimido, posicionadas na base e no topo do corpo-deprova. O dispositivo consistia de uma armação de alumínio à qual era fixada uma manta de borracha produzida sob encomenda pela empresa Tortuga Ltda, fornecedora de câmaras de ar utilizadas pela fabricante de pneus Goodyear. A Figura 3.23 mostra a câmara de ar confeccionada.

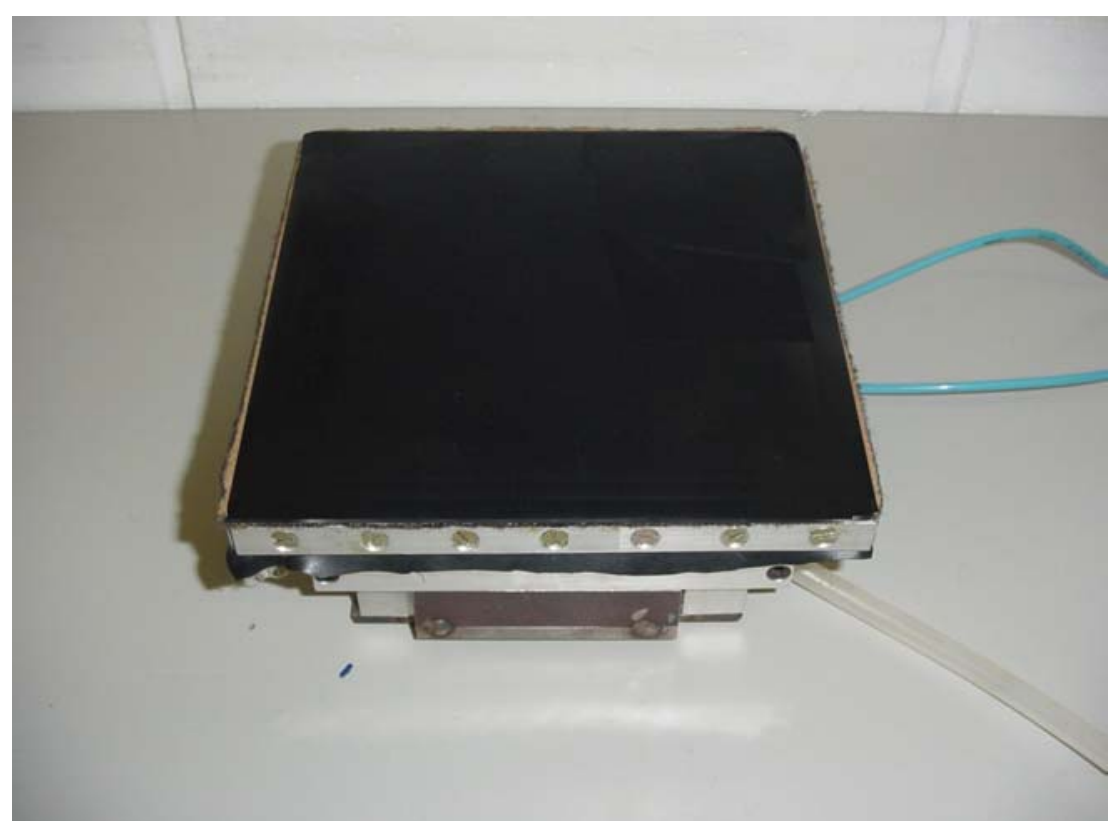

FIGURA 3.23 - Câmara de ar projetada 
A Figura 3.24 apresenta um esquema com as dimensões da câmara de ar desenvolvida. Como descrito anteriormente, o princípio de funcionamento consiste na movimentação da peça 1 (na qual a manta de borracha é presa) pela aplicação de ar pressurizado entre a borracha e as peças 1 e 2 mostradas na Figura 3.24 (o contato entre as peças 1 e 2 é vedado à passagem de ar). Um pistão pneumático auxilia o movimento ascendente da plataforma que por sua vez desloca a peça 1. A Figura 3.25 exibe o pistão utilizado.

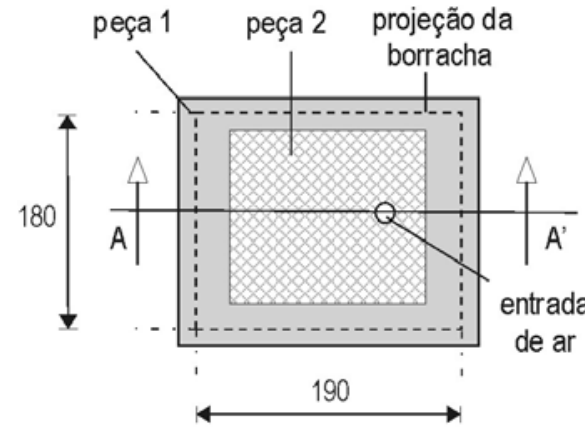

parede(1)

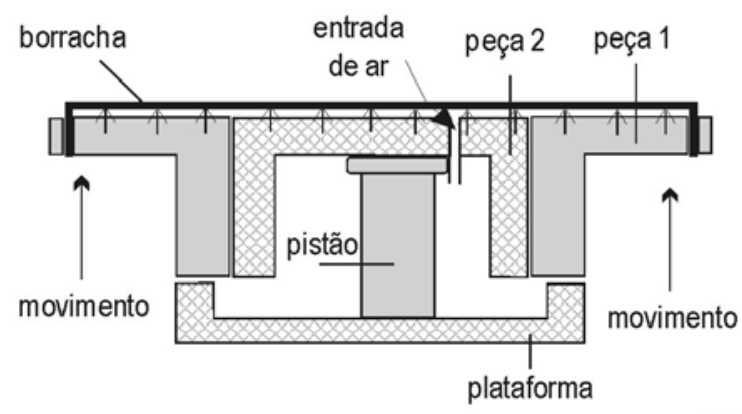

(b)

FIGURA 3.24 - Esquema da câmara de ar desenvolvida

(a) vista superior sem a camada de borracha (b) corte AA'

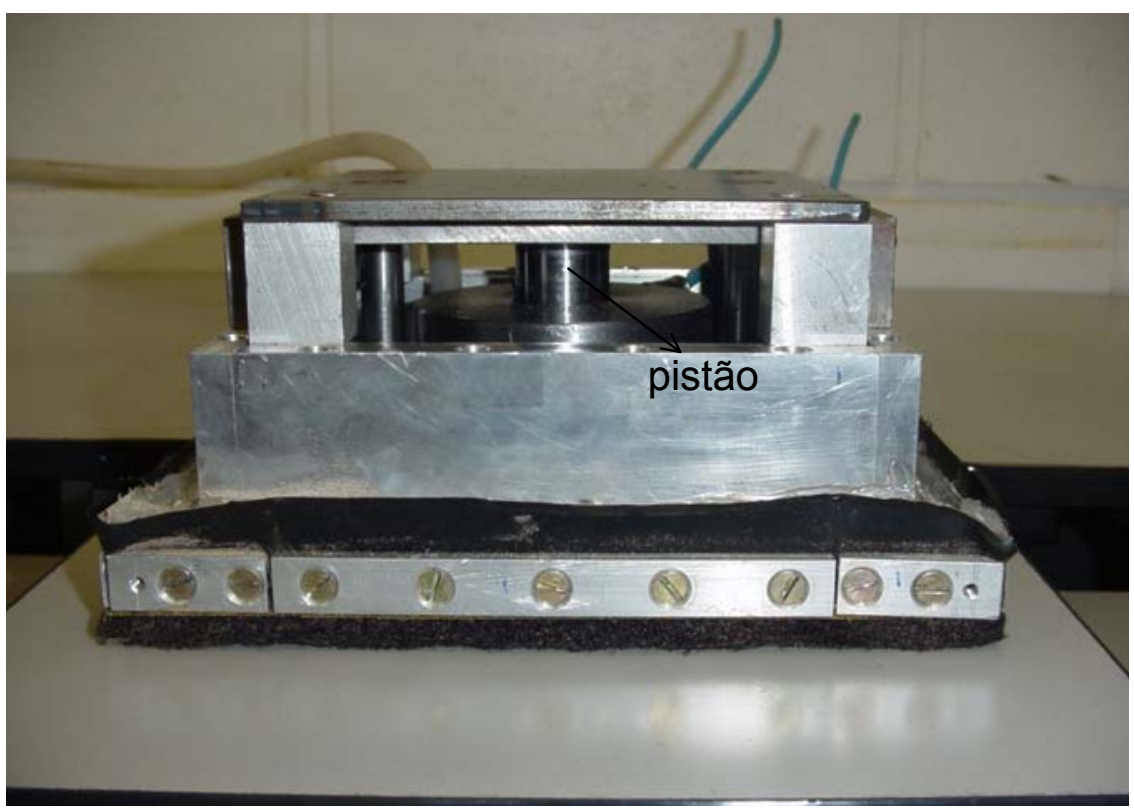

FIGURA 3.25 - Pistão pneumático utilizado na câmara de ar. 
A pressão nas câmaras era controlada através de manômetros com capacidade de $400 \mathrm{kPa}$ e resolução de $2 \mathrm{kPa}$. A tensão aplicada pelo sistema desenvolvido foi aferida através de células de tensão (células de inclusão do mesmo modelo citado no item 3.2.5) posicionadas em contato com a câmara. O mesmo valor registrado pelo manômetro foi indicado pela célula.

\subsubsection{Acessórios desenvolvidos para a preparação do solo}

A técnica de chuva de areia foi adotada para a preparação do solo nos ensaios. O equipamento desenvolvido para esse fim teve por base o trabalho de RAD \& TUMAY (1987), que realizam um extenso estudo sobre os fatores que afetam a densidade de amostras obtidas através do referido método.

A Figura 3.26 mostra o equipamento desenvolvido, composto por um pórtico de aço, um reservatório no topo e um conjunto de peneiras localizadas sob este último, denominado difusor. O procedimento da chuva consiste em liberar a areia armazenada no reservatório que atinge a caixa de ensaios após passar pelo difusor, o qual permite a obtenção de amostras mais homogêneas.

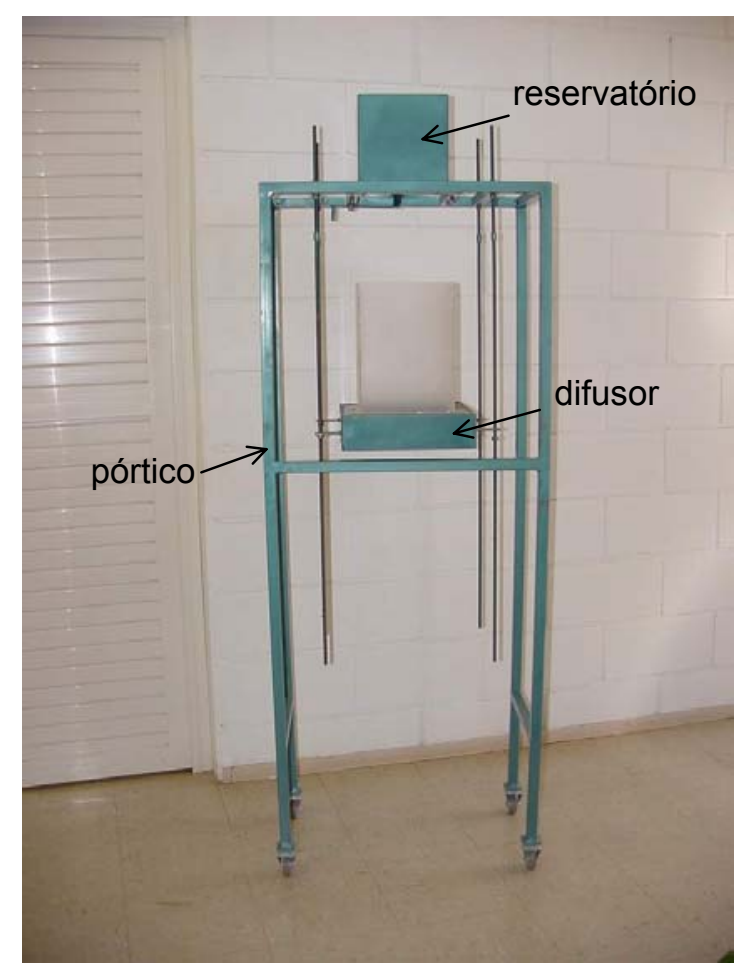

FIGURA 3.26 - Vista geral do equipamento de chuva de areia 
O pórtico é composto por perfis de seção transversal de $25 \times 25 \mathrm{~mm}$, possuindo as seguintes dimensões: 0,65 $\mathrm{m}$ de comprimento, 0,35 $\mathrm{m}$ de largura e 1,60 $\mathrm{m}$ de altura, determinadas de acordo com as dimensões da caixa de teste. A presença de rolamentos na base do pórtico permite a fácil movimentação do equipamento sobre a caixa. O reservatório possui dimensões de 200 × 200 x $200 \mathrm{~mm}$, sendo dotado de um fundo composto por uma chapa perfurada que permite a liberação da areia através da abertura de uma escotilha. A Figura 3.27 mostra um esquema do difusor que é composto por duas peneiras de 200 x $200 \mathrm{~mm}$, com abertura de $6 \mathrm{~mm}$, defasadas $45^{\circ}$ e distantes $450 \mathrm{~mm}$ entre si. O difusor é acoplado ao reservatório através de quatro barras rosqueadas.
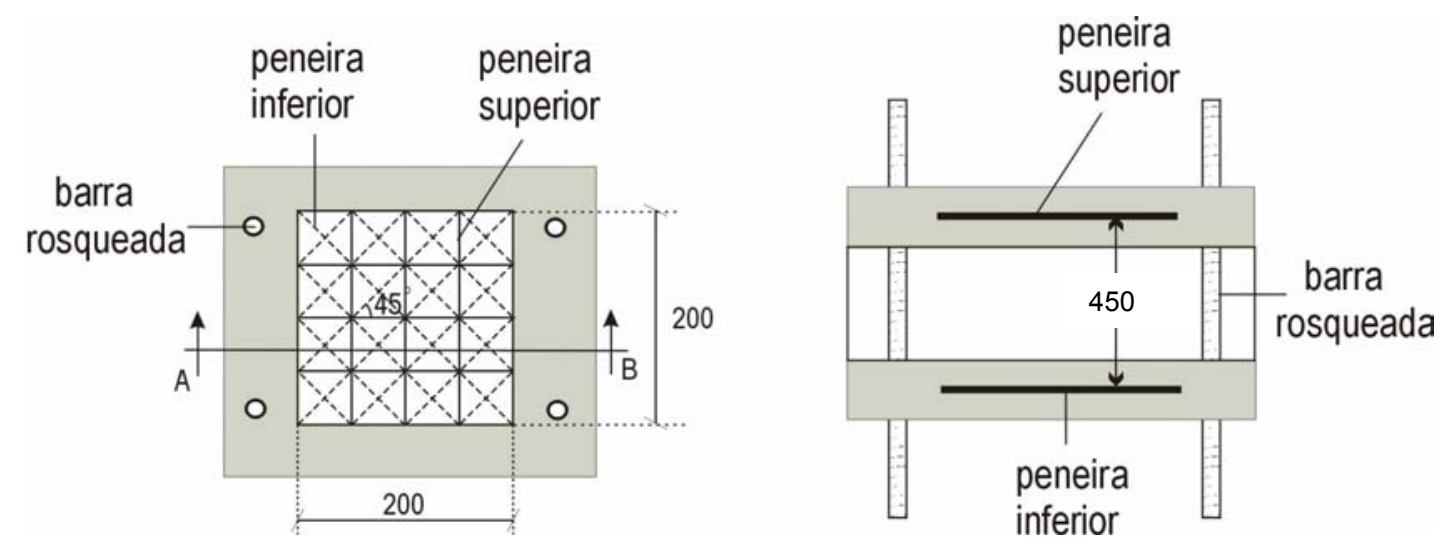

FIGURA 3.27 - Esquema do difusor (a) vista superior (b) corte AB (sem escala; dimensões em mm)

As amostras de solo com diferentes densidades foram obtidas, mantendo-se constante a distância entre o difusor e o topo da caixa de testes e alterando-se a descarga do material. A densidade da areia é determinada, principalmente, pela vazão do material e pela altura de queda. Aspectos como: distância do reservatório ao difusor, quantidade de peneiras, distância entre peneiras, entre outros, exercem um efeito secundário (RAD \& TUMAY, 1987). A descarga da areia foi variada através do diâmetro dos orifícios da chapa do fundo do reservatório.

A seleção dos diâmetros dos orifícios e da altura de queda foi efetuada através de um processo de calibração. Primeiramente, com a vazão mantida constante, 
amostras de solo foram preparadas em um recipiente de volume conhecido (200 $\mathrm{x}$ $200 \times 100 \mathrm{~mm}$ ), variando-se a altura de queda da areia. Através da determinação do peso da amostra, foi possível avaliar a densidade obtida para cada altura estabelecida. Observou-se que a densidade da areia permanece constante para alturas superiores a $200 \mathrm{~mm}$.

A segunda parte da calibração foi realizada a fim de estabelecer a relação entre o diâmetro dos orifícios da chapa e a densidade resultante. A calibração foi efetuada de acordo com o mesmo procedimento descrito anteriormente, exceto pelo fato de que, nesse caso, a distância entre o difusor e o topo do recipiente permanecia constante, enquanto a vazão da areia (diâmetro dos furos) era variada. A Figura 3.28 mostra a relação obtida entre a densidade relativa $\left(\mathrm{D}_{\mathrm{r}}\right)$ e o diâmetro do orifício.

Nos ensaios realizados neste trabalho, as amostras de solo foram preparadas com densidades relativas iguais a 50 e 100\%. Para tanto, foram utilizadas chapas com orifícios de 13 e $4 \mathrm{~mm}$ de diâmetro, respectivamente, mantendo-se a distância do difusor ao topo da caixa igual a $650 \mathrm{~mm}$.

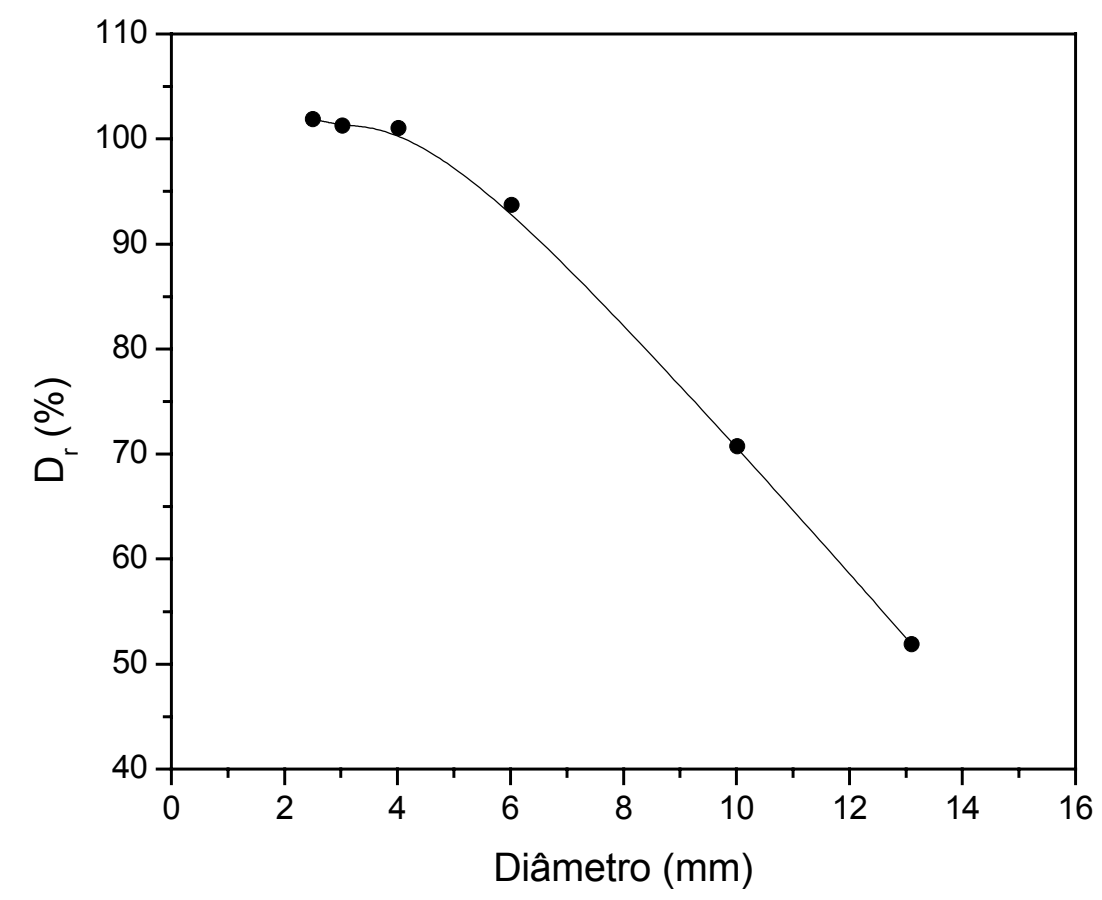

FIGURA 3.28 - Calibração da chuva de areia, curva $\mathrm{D}_{\mathrm{r}}(\%)$ versus diâmetro do orifício (mm). 


\subsection{Geotêxtil e solo utilizados}

\subsection{1 - Geotêxtil utilizado}

Todos os ensaios foram realizados utilizando-se um geotêxtil tecido de polipropileno. Como citado, a escolha por um geotêxtil tecido teve por objetivo facilitar as análises, já que os geotêxteis não tecidos apresentam efeitos de confinamento no que diz respeito à redução de estricção causada por pressão na manta e imbricação de partículas.

Dentre os poucos geotêxteis disponíveis comercialmente com resistência adequada para os ensaios, o geotêxtil tecido utilizado foi selecionado por ser o produto com menor coeficiente de variação de resistência nos ensaios de tração. Assim, a variabilidade do material foi reduzida ao máximo, facilitando a análise dos resultados dos ensaios com o elemento de solo reforçado. Ressalta-se que o emprego de materiais alternativos para simular um geotêxtil tecido também foi averiguado. Mantas poliméricas tecidas (PP) utilizadas para a confecção de sacos com finalidades diversas e mantas plásticas (PE) foram consideradas. Entretanto, os materiais apresentaram alta variabilidade.

A Tabela 3.1 apresenta a gramatura, a resistência à tração e a deformação na ruptura do geotêxtil, determinadas segundo a ABNT (NBR 12568 e NBR 12824). As curvas obtidas nos ensaios de tração são mostradas na Figura 3.29. Os resultados correspondem à direção longitudinal do material, direção que foi utilizada nos ensaios com o elemento de solo reforçado. A resistência na direção transversal é aproximadamente $7 \%$ maior que o valor na direção longitudinal.

TABELA 3.1 - Resultados dos ensaios de gramatura e tração do geotêxtil tecido

\begin{tabular}{ccc}
\hline Característica & Valor médio & $\begin{array}{c}\text { Coeficiente de } \\
\text { variação (\%) }\end{array}$ \\
\hline Gramatura & $126 \mathrm{~g} / \mathrm{m}^{2}$ & 1 \\
Resistência & $21 \mathrm{kN} / \mathrm{m}$ & 1,8 \\
Deformação na ruptura & $33(\%)$ & 3 \\
\hline
\end{tabular}




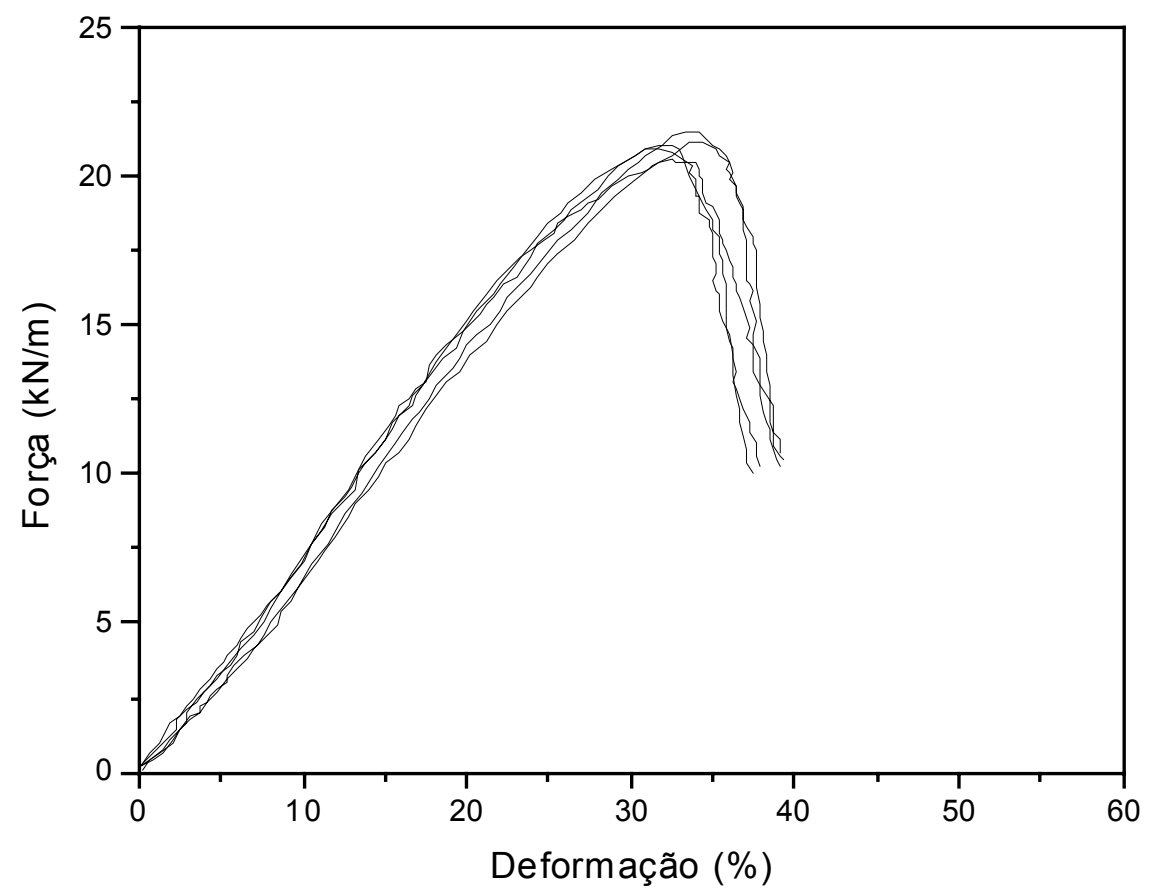

FIGURA 3.29 - Resultados dos ensaios de tração.

Alguns ensaios de fluência sem confinamento foram realizados para caracterizar o geotêxtil e permitir a análise dos ensaios com o elemento de solo reforçado. A Figura 3.30 mostra o equipamento utilizado nos ensaios, composto basicamente por um cavalete, garras e um conjunto de pesos. As deformações foram obtidas medido-se a distância entre duas hastes, posicionadas na região central do corpo-de-prova (ver Figura 3.30b), com um paquímetro com resolução de 0,02 mm. As hastes possuíam sulcos nas duas extremidades e eram fixadas ao geotêxtil através do mesmo procedimento mostrado na Figura 3.18.

A Figura 3.31 mostra os resultados dos ensaios de fluência sem confinamento, realizados com base na norma ISO 13431. Os níveis de carregamento aplicados foram selecionados de acordo com o nível de carga no reforço registrado nos ensaios com o elemento de solo reforçado. 

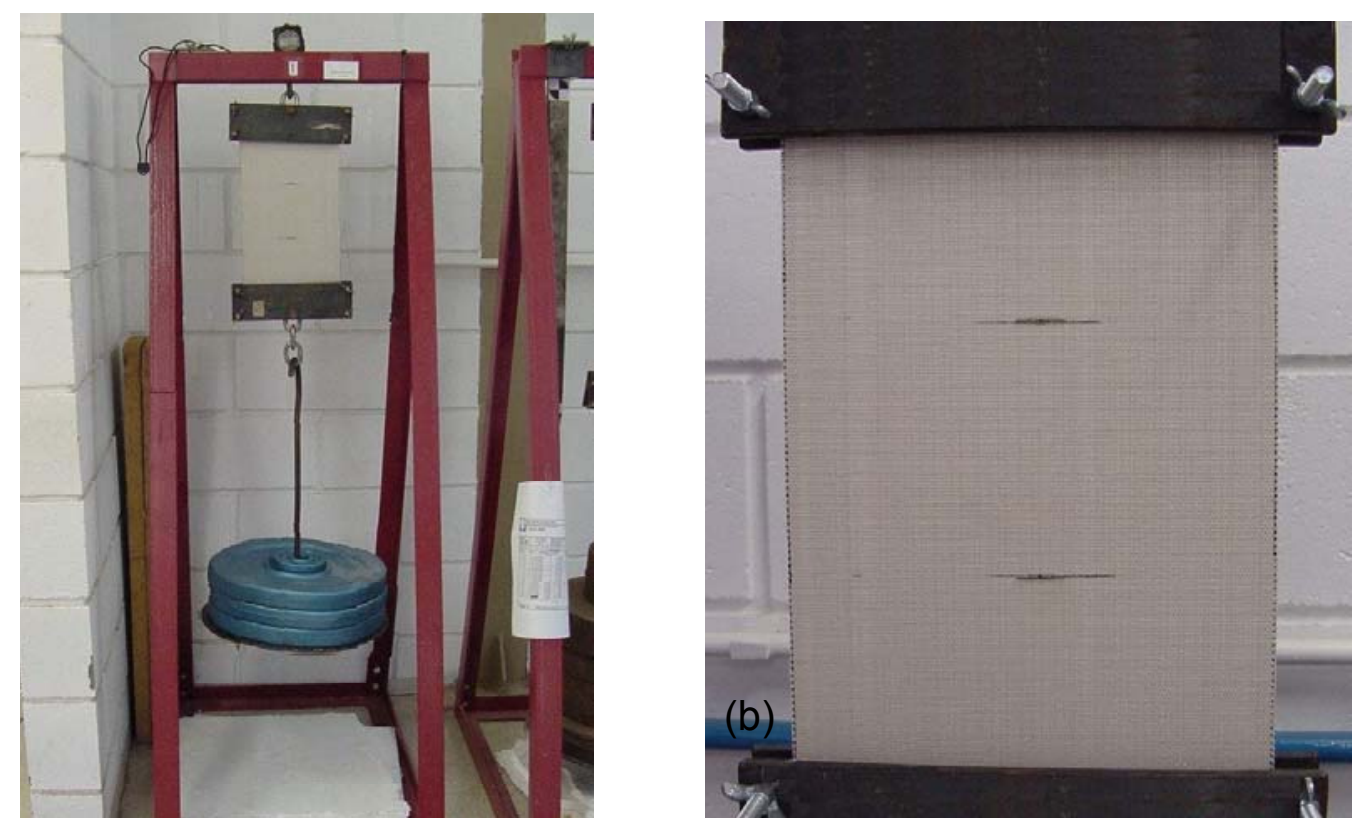

FIGURA 3.30 - (a) Equipamento utilizado nos ensaios de fluência (b) detalhe das hastes utilizadas para obtenção das deformações.

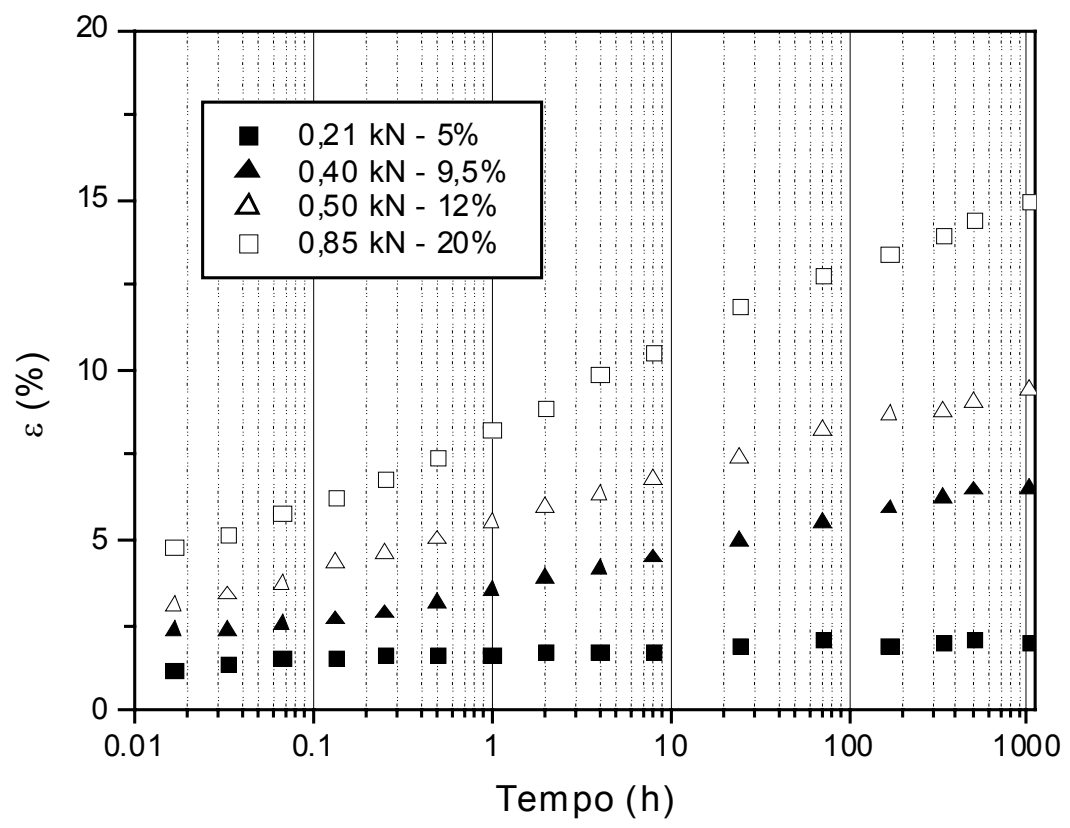

FIGURA 3.31 - Resultados dos ensaios de fluência sem confinamento para $5 \%, 9,5 \%, 12 \%$ e $20 \%$ da resistência à tração. 


\subsubsection{Solo utilizado}

Uma areia pura, proveniente de uma jazida localizada à Rodovia SP-215 e comercialmente denominada "areia Itaporã", foi utilizada durante a fase de desenvolvimento do equipamento e nos ensaios posteriormente realizados. Trata-se de uma areia média a fina, mal-graduada e classificada como SP de acordo com o Sistema Unificado de Classificação de Solos. O resultado da análise granulométrica, realizada de acordo com a ABNT (NBR-7181/84), é exibido na Figura 3.32. O coeficiente de não uniformidade da referida areia é igual a 2,7.

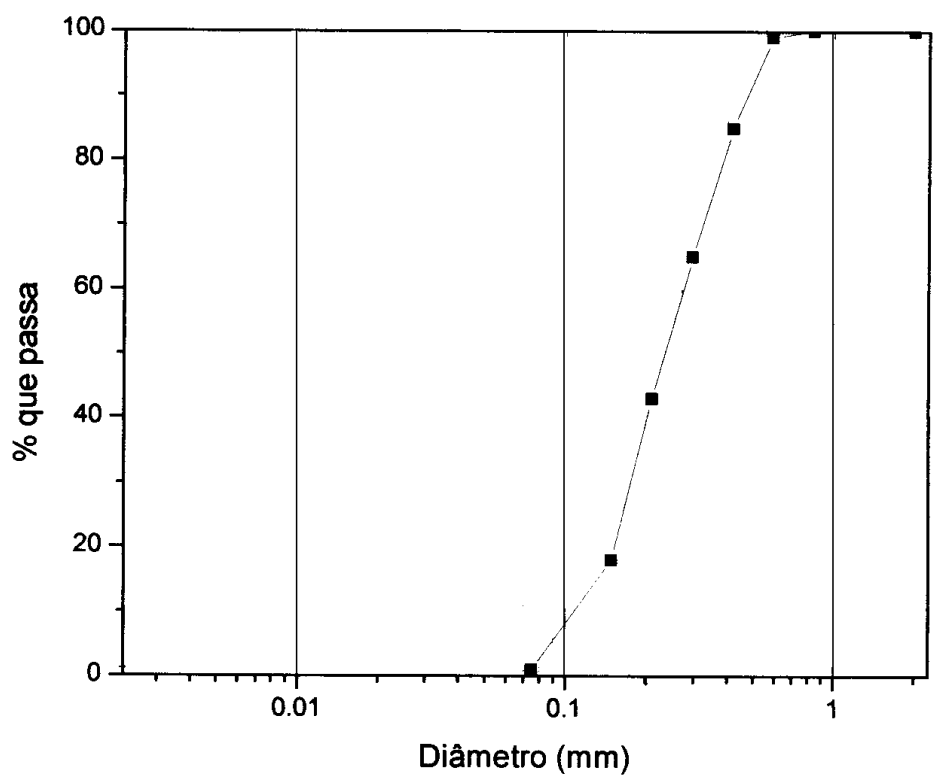

Figura 3.32 - Curva granulométrica da areia utilizada

$\mathrm{O}$ índice de vazios máximo $\left(\mathrm{e}_{\max }\right)$ para a areia, obtido segundo a ABNT (NBR12004/90), é igual a 0,87, correspondendo a um peso específico seco mínimo $\left(\gamma_{\mathrm{d}, \min }\right)$ igual a $14,2 \mathrm{kN} / \mathrm{m}^{3}$. O índice de vazios mínimo $\left(\mathrm{e}_{\min }\right)$, determinado de acordo com a NBR12051/91, é igual a 0,50, equivalendo a um peso específico seco máximo $\left(\gamma_{\mathrm{d}, \max }\right)$ igual a $17,7 \mathrm{kN} / \mathrm{m}^{3}$. O peso específico dos sólidos é igual a $26,5 \mathrm{kN} / \mathrm{m}^{3}$.

Ensaios de compressão triaxial, com $\mathrm{D}_{\mathrm{r}}=50 \%$ e $100 \%$, revelaram os valores de ângulo de atrito de pico mostrados na Tabela 3.2. O valor do ângulo de atrito estimado no estado crítico corresponde a $\phi_{\mathrm{cr}}=33^{0}$. 
TABELA 3.2 - Ângulo de atrito de pico obtido nos ensaios triaxiais.

\begin{tabular}{cccc}
\hline Série & $\mathrm{D}_{\mathrm{r}}(\%)$ & $\sigma_{3}(\mathrm{kPa})$ & $\left.\phi_{\mathrm{p}}{ }^{0}{ }^{0}\right)$ \\
\hline \multirow{2}{*}{1} & 50 & 50 & 38 \\
& & 100 & 37 \\
& & 200 & 34 \\
\hline \multirow{2}{*}{2} & \multirow{2}{*}{100} & 50 & 40 \\
& & 100 & 39 \\
& & 200 & 38 \\
\hline
\end{tabular}

A utilização de solos coesivos não foi considerada na parte experimental desenvolvida nesta pesquisa por causa do cronograma do trabalho e para simplificar as interpretações dos resultados, possibilitando assim um melhor entendimento dos mecanismos desenvolvidos. Após uma compreensão mais adequada do comportamento com solos não coesivos, a utilização de materiais coesivos deve-se seguir, naturalmente, em trabalhos futuros, a fim de permitir o avanço do conhecimento sobre o tema.

\subsection{Descrição dos ensaios realizados}

\subsubsection{Ensaios para investigação do atrito nas faces do corpo-de-prova}

A investigação do atrito nas paredes da caixa foi realizada através de ensaios de cisalhamento de interface, utilizando-se uma prensa empregada para cisalhamento direto de solos, com pequenas adaptações. A Figura 3.33 mostra o esquema adotado. Primeiramente, a membrana de látex era colada a um bloco de alumínio com faces polidas, com dimensões de 100 x $100 \mathrm{~mm}$. Em seguida, o bloco era inserido na parte superior da caixa da prensa de cisalhamento, sobre um bloco de madeira revestido com vidro, metal ou borracha. Esses materiais foram empregados para representar as faces em contato com o corpo-de-prova nos ensaios com o elemento de solo reforçado (vidro e metal nas laterais da caixa e borracha no contato entre o corpo-deprova e a câmara de ar). A borracha e o metal utilizados foram os mesmos 
empregados na confecção da câmara de ar e da caixa, respectivamente. O contato entre a membrana e material ensaiado (vidro, metal ou borracha) era lubrificado com graxa de silicone.

A Tabela 3.3 apresenta os ensaios inicialmente realizados, adotando-se uma velocidade de $1 \mathrm{~mm} / \mathrm{min}$ e empregando-se uma graxa de silicone produzida pela empresa Implastec Ltda, denominada no presente trabalho como graxa A. O ângulo de atrito encontrado em cada ensaio, calculado de acordo com a expressão 3.2, é também mostrado na Tabela 3.3.

$\phi=\operatorname{arctg}\left(\tau / \sigma_{\mathrm{n}}\right)$

onde:

$\tau$ - tensão cisalhante;

$\sigma_{\mathrm{n}}-$ tensão normal;

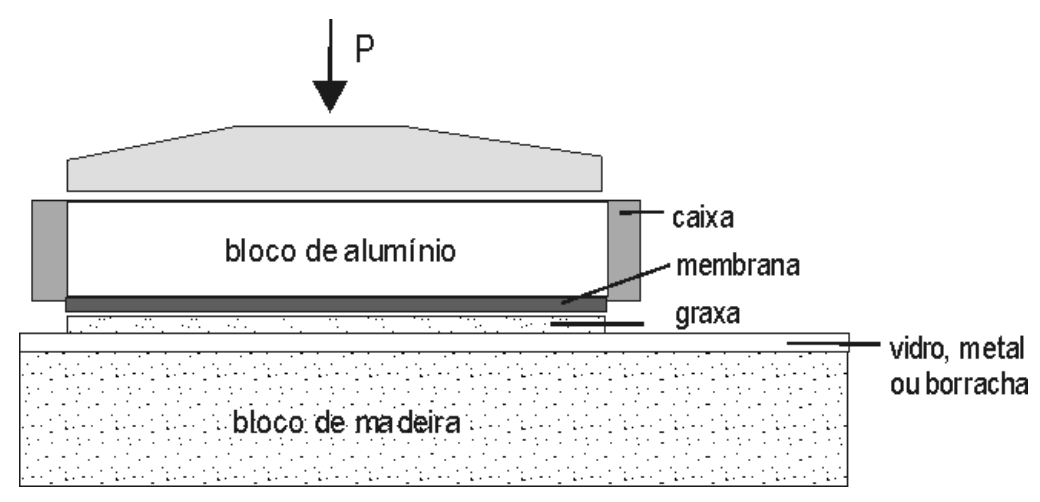

Figura 3.33 - Esquema dos ensaios de interface

Os valores obtidos para o ângulo de atrito com a graxa $\mathrm{A}$ foram maiores que os reportados na literatura para graxas de silicone. Com a finalidade de reduzir ao máximo o atrito nas interfaces, essa graxa foi então substituída pela mesma graxa de silicone utilizada em diversos trabalhos, como TATSUOKA et al (1984) e GOTO et al. (1993). Trata-se de uma graxa produzida pela empresa Dow Corning ("highvacuum silicone grease") que será doravante designada como graxa B. A Tabela 3.4 
mostra os ensaios efetuados com a graxa B, seguindo os mesmos procedimentos adotados nos ensaios com a graxa A.

TABELA 3.3 - Ensaios realizados com graxa A.

\begin{tabular}{ccccc}
\hline & Configuração & & $\begin{array}{c}\sigma_{\mathrm{n}} \\
(\mathrm{kPa})\end{array}$ & $\begin{array}{c}\phi_{\mathrm{p}} \\
\left({ }^{0}\right)\end{array}$ \\
\hline Membrana & graxa A & Metal & 10 & 8,0 \\
\hline Membrana & graxa A & Metal & 25 & 4,0 \\
\hline Membrana & graxa A & Metal & 50 & 3,1 \\
\hline Membrana & graxa A & Metal & 100 & 2,2 \\
\hline Membrana & graxa A & Metal & 200 & 2,0 \\
\hline
\end{tabular}

$\sigma_{\mathrm{n}}-$ tensão normal, $\phi_{\mathrm{p}}-$ ângulo de atrito de pico

TABELA 3.4 - Ensaios inicialmente realizados com a graxa B.

\begin{tabular}{ccccc}
\hline & Configuração & & $\begin{array}{c}\sigma_{\mathrm{n}} \\
(\mathrm{kPa})\end{array}$ & $\begin{array}{c}\phi_{\mathrm{p}} \\
\left({ }^{0}\right)\end{array}$ \\
\hline Membrana & graxa B & Vidro & 10 & 2 \\
\hline Membrana & graxa B & Vidro & 25 & 1,5 \\
\hline Membrana & graxa B & Vidro & 50 & 0,4 \\
\hline Membrana & graxa B & Metal & 50 & 0,4 \\
\hline Membrana & graxa B & Borracha & 50 & 0,5 \\
\hline Membrana & graxa B & Borracha & 100 & 0,3 \\
\hline
\end{tabular}

$\sigma_{\mathrm{n}}-$ tensão normal, $\phi_{\mathrm{p}}-$ ângulo de atrito de pico

Os resultados na Tabela 3.4 estão de acordo com os valores de ângulo de atrito reportados na literatura para a graxa B e demonstram o excelente resultado na redução de atrito que se pode obter através do procedimento de lubrificação com a graxa adequada. 
No entanto, como destacado por KUHN (1998), as graxas são fluidos de comportamento reológico complexo, sendo preciso investigar as mudanças de suas propriedades com o tempo. Nesse sentido, alguns pesquisadores têm alertado sobre alterações que ocorrem com o tempo no ângulo de atrito em interfaces lubrificadas com graxa (ex. ARTHUR \& DALILI, 1979; TATSUOKA et al, 1984). A Tabela 3.5 mostra alguns ensaios de cisalhamento com a graxa B, após a tensão normal ser mantida constante por um determinado intervalo (tempo de espera, $t_{e}$ ) antes da etapa de cisalhamento. Os valores anteriormente exibidos na Tabela 3.4 foram obtidos para $\mathrm{t}_{\mathrm{e}}=0,167 \mathrm{~h}(10 \mathrm{~min})$. A Figura 3.34 mostra a variação do ângulo de atrito de interface com o tempo para $\sigma_{\mathrm{n}}=50 \mathrm{kPa}$.

TABELA 3.5 - Ensaios realizados com a graxa B (velocidade de cisalhamento igual a $1 \mathrm{~mm} / \mathrm{min}$ ).

\begin{tabular}{cccccc}
\hline & Configuração & & $\begin{array}{c}\sigma_{\mathrm{n}} \\
(\mathrm{kPa})\end{array}$ & $\begin{array}{c}\mathrm{t}_{\mathrm{e}} \\
(\mathrm{h})\end{array}$ & $\begin{array}{c}\phi_{\mathrm{p}} \\
\left({ }^{0}\right)\end{array}$ \\
\hline Membrana & graxa B & Vidro & 50 & 0,167 & 0,4 \\
\hline Membrana & graxa B & Vidro & 50 & 4 & 1,6 \\
\hline Membrana & graxa B & Vidro & 50 & 10 & 3,0 \\
\hline Membrana & graxa B & Vidro & 50 & 16 & 4,0 \\
\hline Membrana & graxa B & Vidro & 50 & 24 & 6,4 \\
\hline Membrana & graxa B & Borracha & 100 & 0,167 & 0,3 \\
\hline Membrana & graxa B & Borracha & 100 & 10 & 6,1 \\
\hline
\end{tabular}

$\sigma_{\mathrm{n}}-$ tensão normal, $\mathrm{t}_{\mathrm{e}}-$ tempo de espera, $\phi_{\mathrm{p}}-$ ângulo de atrito de pico

Como se pode observar na Figura 3.34, apesar do pequeno valor quando o ensaio é imediatamente iniciado, o ângulo de atrito apresenta um substancial acréscimo à medida que o tempo de espera é aumentado. Tal comportamento já foi evidenciado anteriormente por outros autores como por TATSUOKA et al (1984). Segundo o autor, esse fato ocorre devido ao escoamento da graxa sob a aplicação da tensão normal, o que provoca a deterioração da lubrificação. 


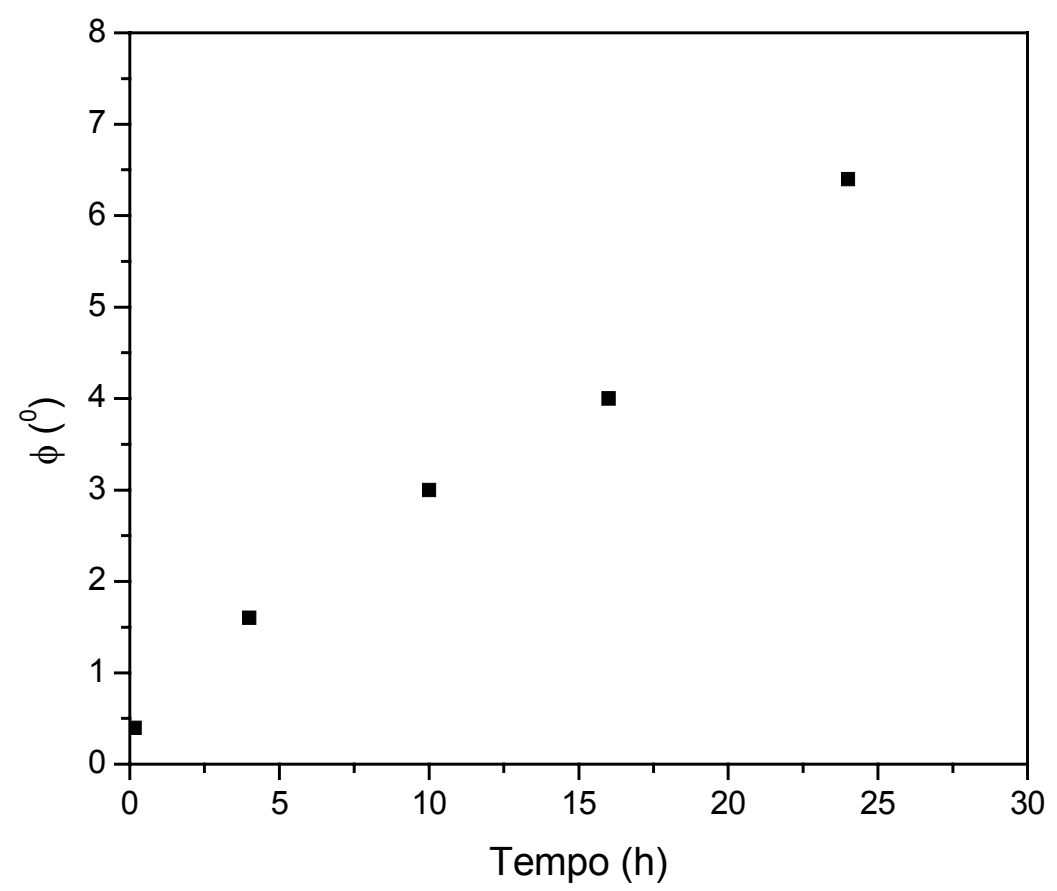

FIGURA 3.34 - Ângulo de atrito para a graxa B após $\sigma_{\mathrm{n}}$ constante por um determinado tempo antes do ensaio.

Para melhorar o desempenho de graxas ao longo do tempo, ARTHUR \& DALILI (1979) e TATSUOKA et al. (1984) sugerem a adição de pó de PTFE (Poly Tetra Fluoro Ethylene) ou pó de Teflon, como comercialmente conhecido. O pó de Teflon reduz o escoamento da graxa e a conseqüente variação de $\phi$, mas, por outro lado, aumenta o ângulo de atrito. Assim, deve-se investigar a quantidade ideal de PTFE a ser adicionada à graxa.

De modo a elucidar essa questão, uma série de ensaios de cisalhamento foi executada, adicionando-se pó de PTFE à graxa B. Produzido pela empresa Dupont, o pó de Teflon utilizado era composto por microesferas com diâmetro de $20 \mu \mathrm{m}$. O composto era preparado misturando-se o pó à graxa com o auxílio de uma espátula. A Tabela 3.6 apresenta os resultados obtidos. A percentagem indicada corresponde ao peso do pó em relação ao peso total do composto (graxa+PTFE). O ângulo de atrito para a mistura com 50\% de PTFE foi o que apresentou o menor acréscimo para $\mathrm{t}_{\mathrm{e}}=10 \mathrm{~h}$ (aumento em $\phi_{\mathrm{p}}$ igual a $45 \%$ ). Entretanto, quanto maior o percentual de PTFE, maior o valor do ângulo de atrito. Dessa forma, a mistura correspondente a $20 \%$ foi selecionada para ser utilizada nos ensaios por já apresentar uma variação ao 
longo do tempo bem menor do que com a graxa pura e possuir o menor $\phi_{\mathrm{p}}$ entre as proporções testadas.

TABELA 3.6 - Ensaios para seleção da proporção de pó de PTFE ( $\left.\sigma_{\mathrm{n}}=50 \mathrm{kPa}, \mathrm{v}=1 \mathrm{~mm} / \mathrm{min}\right)$.

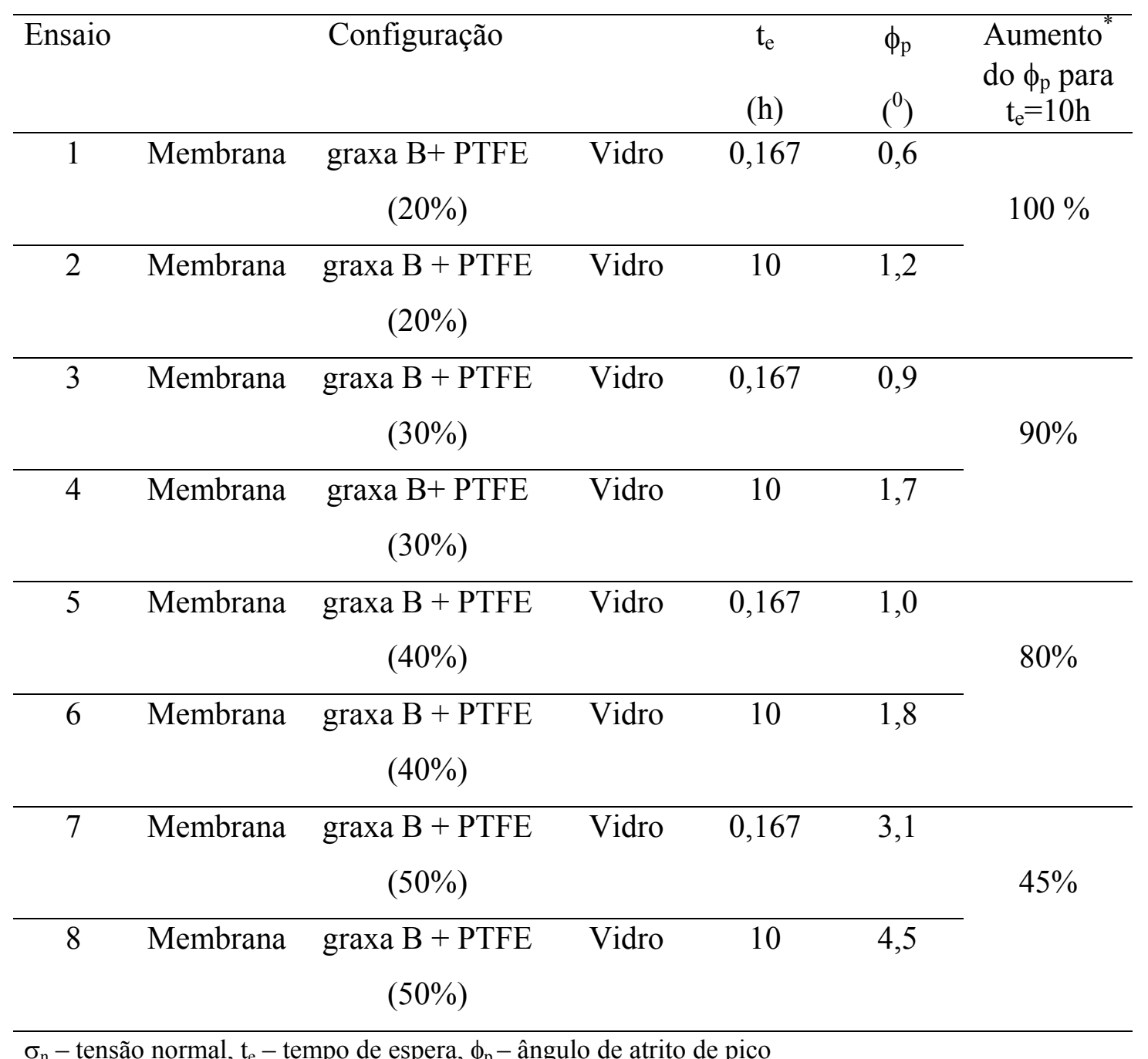

$\sigma_{\mathrm{n}}-$ tensão normal, $\mathrm{t}_{\mathrm{e}}-$ tempo de espera, $\phi_{\mathrm{p}}-$ ângulo de atrito de pico

${ }^{*}$ Aumento do ângulo de atrito para $t_{\mathrm{e}}=10 \mathrm{~h}$ em relação ao ângulo registrado para $\mathrm{t}_{\mathrm{e}}=0,167 \mathrm{~h}$.

Os ensaios mostrados na Tabela 3.7 foram realizados com a proporção de $20 \%$ de PTFE, a fim de fornecer parâmetros para a estimativa de atrito nos ensaios com o elemento de solo reforçado. Nessa investigação, considerou-se ainda a colocação de uma camada de areia sobre a membrana para verificar o acréscimo no ângulo de atrito. Como mostrado por GOTO et al. (1993), a presença de solo sobre a membrana pode modificar o valor do ângulo de atrito da interface. Essa alteração no valor de $\phi$ depende do tamanho e forma das partículas de solo e parece independente da densidade da areia. Os ensaios com areia foram realizados, preparando-se uma 
camada de $5 \mathrm{~mm}$ de areia $\left(\mathrm{D}_{\mathrm{r}}=50 \%\right)$ sobre a membrana (configuração areia/membrana mostrada na Tabela 3.7).

TABELA 3.7 - Ensaios de cisalhamento com graxa B $+20 \%$ de PTFE.

\begin{tabular}{|c|c|c|c|c|c|c|c|}
\hline Ensaio & & Configuração & & $\begin{array}{c}\sigma_{\mathrm{n}} \\
(\mathrm{kPa})\end{array}$ & $\begin{array}{c}\mathrm{t}_{\mathrm{e}} \\
(\mathrm{h})\end{array}$ & $\begin{array}{c}\mathrm{v} \\
(\mathrm{mm} / \mathrm{min})\end{array}$ & $\begin{array}{l}\phi_{\mathrm{p}} \\
\left(^{0}\right.\end{array}$ \\
\hline 1 & Membrana & $\begin{array}{c}\text { graxa B + } \\
\text { PTFE } \\
(20 \%)\end{array}$ & Metal & 25 & 0,167 & 1 & 2,1 \\
\hline 2 & Membrana & $\begin{array}{c}\text { graxa B + } \\
\text { PTFE } \\
(20 \%)\end{array}$ & Metal & 25 & 10 & 1 & 2,8 \\
\hline 3 & Membrana & $\begin{array}{c}\text { graxa B + } \\
\text { PTFE } \\
(20 \%)\end{array}$ & Metal & 10 & 0,167 & 1 & 3,0 \\
\hline 4 & Membrana & $\begin{array}{c}\text { graxa B + } \\
\text { PTFE } \\
(20 \%)\end{array}$ & Metal & 10 & 10 & 1 & 3,6 \\
\hline 5 & $\begin{array}{c}\text { Areia/ } \\
\text { membrana }\end{array}$ & $\begin{array}{c}\text { graxa B + } \\
\text { PTFE } \\
(20 \%)\end{array}$ & Vidro & 25 & 0,167 & 1 & 3,3 \\
\hline 6 & $\begin{array}{c}\text { Areia/ } \\
\text { membrana }\end{array}$ & $\begin{array}{c}\text { graxa B + } \\
\text { PTFE } \\
(20 \%)\end{array}$ & Vidro & 25 & 10 & 1 & 3,8 \\
\hline 7 & $\begin{array}{c}\text { Areia/ } \\
\text { membrana }\end{array}$ & $\begin{array}{c}\text { graxa B+ } \\
\text { PTFE } \\
(20 \%)\end{array}$ & Vidro & 50 & 0,167 & 1 & 1,0 \\
\hline 8 & $\begin{array}{c}\text { Areia/ } \\
\text { membrana }\end{array}$ & $\begin{array}{c}\text { graxa B + } \\
\text { PTFE } \\
(20 \%)\end{array}$ & Vidro & 50 & 10 & 1 & $\overline{1,4}$ \\
\hline
\end{tabular}


TABELA 3.7 - Ensaios de cisalhamento com graxa B + 20\% de PTFE (cont.).

\begin{tabular}{|c|c|c|c|c|c|c|c|}
\hline Ensaio & & Configuraçã & & $\begin{array}{c}\sigma_{\mathrm{n}} \\
(\mathrm{kPa})\end{array}$ & $\begin{array}{c}\mathrm{t}_{\mathrm{e}} \\
(\mathrm{h})\end{array}$ & $\begin{array}{c}\mathrm{V} \\
(\mathrm{mm} / \mathrm{min})\end{array}$ & $\phi_{\mathrm{p}}$ \\
\hline 9 & Membrana & $\begin{array}{c}\text { graxa B + } \\
\text { PTFE } \\
(20 \%)\end{array}$ & Borracha & 100 & 0,167 & 1 & 1,2 \\
\hline 10 & Membrana & $\begin{array}{c}\text { graxa B + } \\
\text { PTFE } \\
(20 \%)\end{array}$ & Borracha & 100 & 10 & 1 & 2,4 \\
\hline 11 & $\begin{array}{c}\text { Areia/ } \\
\text { membrana }\end{array}$ & $\begin{array}{c}\text { graxa B + } \\
\text { PTFE } \\
(20 \%)\end{array}$ & Borracha & 100 & 0,167 & 1 & 2,0 \\
\hline 12 & $\begin{array}{c}\text { Areia/ } \\
\text { membrana }\end{array}$ & $\begin{array}{c}\text { graxa B + } \\
\text { PTFE } \\
(20 \%)\end{array}$ & Borracha & 100 & 10 & 1 & 2,8 \\
\hline 13 & Membrana & $\begin{array}{c}\text { graxa B + } \\
\text { PTFE } \\
(20 \%)\end{array}$ & Borracha & 100 & 0,167 & 0,25 & 1,0 \\
\hline 14 & Membrana & $\begin{array}{c}\text { graxa B + } \\
\text { PTFE } \\
(20 \%)\end{array}$ & Borracha & 100 & 10 & 0,25 & 2,0 \\
\hline 15 & Membrana & $\begin{array}{c}\text { graxa B + } \\
\text { PTFE } \\
(20 \%)\end{array}$ & Borracha & 100 & 0,167 & 5 & 1,8 \\
\hline 16 & $\begin{array}{c}\text { Areia/ } \\
\text { membrana }\end{array}$ & $\begin{array}{c}\text { graxa B + } \\
\text { PTFE } \\
(20 \%)\end{array}$ & Borracha & 200 & 0,167 & 1 & 1,7 \\
\hline 17 & $\begin{array}{c}\text { Areia/ } \\
\text { membrana }\end{array}$ & $\begin{array}{c}\text { graxa B + } \\
\text { PTFE } \\
(20 \%)\end{array}$ & Borracha & 200 & 10 & 1 & 3,2 \\
\hline
\end{tabular}




\subsubsection{Ensaios com o equipamento desenvolvido}

\subsubsection{Procedimentos de ensaio}

\subsection{Ensaios com o elemento de solo reforçado}

O primeiro passo para a realização dos ensaios com o elemento de solo reforçado consistia na preparação do geotêxtil. As hastes para medir a deformação eram posicionadas para então efetuar a fixação do geotêxtil às garras.

Dando seguimento ao processo, a preparação das camadas de solo era iniciada. Primeiro, uma limpeza da caixa era efetuada. Em seguida, todas as superfícies que ficavam em contato com solo, ou seja, paredes de vidro, paredes móveis e borracha da câmaras de ar, eram lubrificadas, aplicando-se uma fina camada do composto graxa de silicone + PTFE (20\%). Após a aplicação do composto, as membranas de látex eram colocadas de modo a abranger a área necessária. Durante todo o processo de preparação do ensaio, as paredes móveis eram impedidas de se movimentar, fixando-se os pórticos à mesa de apoio.

Após a colocação das membranas, iniciava-se o processo de chuva de areia para compor a primeira camada de solo, utilizando-se o equipamento mostrado na Figura 3.26. Com a primeira camada de solo preparada, o geotêxtil era depositado sobre a mesma e as garras eram presas aos pórticos. As chapas superiores das paredes móveis eram posicionadas, instalando-se as membranas em seguida.

A preparação da segunda camada de solo era então efetuada, seguindo o mesmo procedimento descrito para a primeira camada. Após a preparação do solo, a câmara de ar superior era colocada e registravam-se as leituras dos relógios.

O ensaio era iniciado aplicando-se uma pressão na câmara de ar para provocar uma pré-carga no reforço de cerca de $1 \%$ de sua resistência à tração. Após aplicação da pré-carga, as leituras dos relógios comparadores eram registradas. Essas leituras seriam utilizadas para a obtenção do comprimento inicial, a ser considerado no cálculo das deformações ao longo do tempo. Em seguida, a tensão vertical era aumentada até atingir o valor pretendido, em no máximo $60 \mathrm{~s}$, registrando-se a leitura dos relógios comparadores para $1,2,4,8,15,30$ min e para $1,2,4,8,10 \mathrm{~h}$ após a 
aplicação total da tensão vertical. A leitura da célula de carga era efetuada no mesmo intervalo de tempo até 2 horas de ensaio e, em seguida, em intervalos de 1 hora.

\subsection{Ensaios apenas com solo}

O método de preparação do ensaio apenas com solo era semelhante ao descrito anteriormente sendo que, nesse caso, uma única camada de solo era preparada com $200 \mathrm{~mm}$ de espessura.

A preparação do ensaio era iniciada com a lubrificação de todas as superfícies com a graxa de silicone + PTFE (20\%) e posterior instalação das membranas. Logo em seguida, a areia era preparada, em uma única etapa, utilizando-se o processo da chuva de areia.

Dando seguimento ao processo, a câmara de ar superior era instalada e a tensão vertical pretendida, aplicada. Após aplicação da tensão, o motor era acionado, produzindo a movimentação das paredes a uma velocidade constante. As leituras do relógio e da célula de carga eram efetuadas para deslocamentos de 0,$3 ; 0,5 ; 1 \mathrm{~mm}$ e, então, para incrementos de $1 \mathrm{~mm}$ até $18 \mathrm{~mm}$.

\subsubsection{Ensaios realizados}

Os ensaios realizados com o equipamento desenvolvido são apresentados na Tabela 3.8 e 3.9. A etapa de ensaio com o elemento de solo reforçado foi antecedida pela realização de ensaios apenas com solo.

Nos ensaios apenas com solo, duas densidades relativas foram utilizadas para a areia $\left(D_{r}=50 \%\right.$ e $\left.100 \%\right)$ e três valores distintos foram empregados para a velocidade de movimentação das paredes $(0,1 ; 0,7$ e $4 \mathrm{~mm} / \mathrm{min})$. Três valores diferentes foram adotados para a tensão vertical aplicada (100, 150 e $200 \mathrm{kPa})$. Os ensaios com o elemento solo-reforço foram executados com $D_{r}=50 \%$ e $100 \%$, aplicando-se tensões verticais correspondentes a 100 e a $200 \mathrm{kPa}$.

O equipamento desenvolvido também permitiu a realização de ensaios de relaxação do geotêxtil sem a presença de solo. Nos ensaios, o geotêxtil era preso às garras sem a preparação das camadas de areia e as paredes da caixa eram 
movimentadas manualmente até atingir a deformação desejada no período de 1 min. Assim como os ensaios apenas com solo, os ensaios de relaxação foram efetuados para auxiliar as análises dos ensaios com o elemento de solo reforçado.

Alguns dos ensaios mostrados na Tabela 3.8 foram efetuados, especificamente, a fim de avaliar a repetibilidade dos resultados. Com relação à designação dos ensaios, mostrada nas Tabela 3.8 e 3.9, o primeiro caractere corresponde ao tipo de ensaio ( $\mathrm{S}$ - apenas com solo, $\mathrm{SR}$ - elemento solo-reforço, $\mathrm{R}$ relaxação), sendo seguido pelo número do ensaio, acrescido por R no caso de ensaio de repetibilidade.

Todos os ensaios apenas com solo contaram com uma célula de tensão na posição C2, como mostrado na Figura 3.35. Além dos ensaios com a célula nessa posição, um teste (S2T, ver Tabela 3.8) foi realizado com a presença de células de tensão nas posições C1, C2, C3, C4, C5 e C6, como mostrado na Figura 3.35.

TABELA 3.8 - Ensaios e testes realizados com o equipamento desenvolvido.

\begin{tabular}{|c|c|c|c|}
\hline Designação & $\operatorname{Dr}(\%)$ & $\begin{array}{c}\text { Tensão } \\
\text { vertical }(\mathrm{kPa})\end{array}$ & $\begin{array}{l}\text { Velocidade } \\
(\mathrm{mm} / \mathrm{min})\end{array}$ \\
\hline $\mathrm{S} 1$ & 100 & 100 & 0,7 \\
\hline S2T & 100 & 100 & - \\
\hline S3 & 50 & 100 & 0,7 \\
\hline S4 & 50 & 150 & 0,7 \\
\hline S5 & 50 & 200 & 0,7 \\
\hline S6R & 50 & 100 & 0,7 \\
\hline S7R & 50 & 200 & 0,7 \\
\hline S8 & 50 & 100 & 0,1 \\
\hline S9 & 50 & 100 & 4,0 \\
\hline SR1 & 50 & 100 & - \\
\hline SR2R & 50 & 100 & - \\
\hline SR3R & 50 & 100 & - \\
\hline SR4 & 100 & 100 & - \\
\hline SR5 & 50 & 200 & - \\
\hline SR6R & 50 & 200 & - \\
\hline
\end{tabular}


TABELA 3.9 - Ensaios de relaxação

\begin{tabular}{ccc}
\hline Designação & $\varepsilon(\%)$ & Carga $(\mathrm{kN})^{*}$ \\
\hline R1 & 5,8 & 0,82 \\
\hline R2 & 3,4 & 0,46 \\
\hline R3 & 2,6 & 0,38 \\
\hline R4 & 2,1 & 0,34
\end{tabular}

* Carga para $\mathrm{t}=1 \mathrm{~min}$
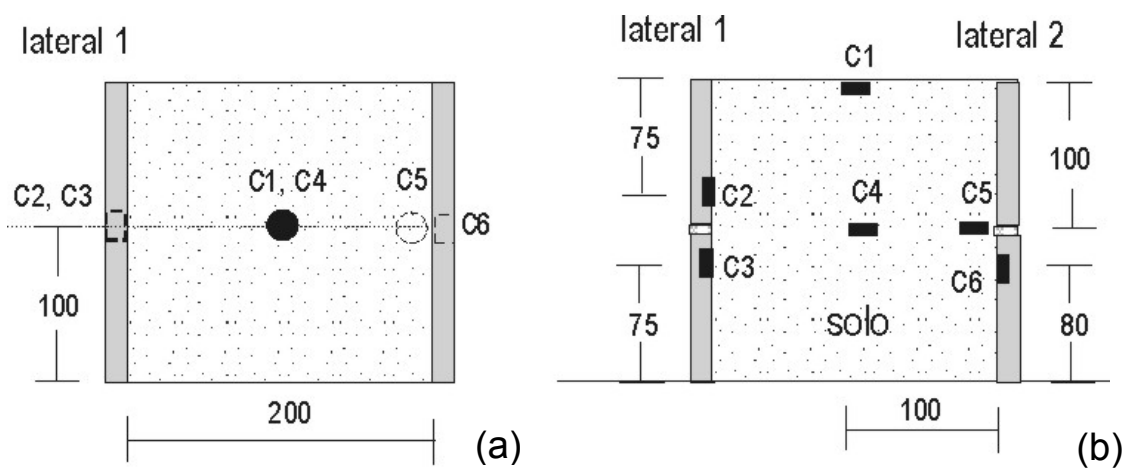

FIGURA 3.35 - Esquema de disposição das células no ensaio S2T (a) vista superior (b) vista lateral.

\subsection{Apresentação e análise dos resultados}

\subsubsection{Ensaios apenas com solo}

As Figuras 3.36 a 3.51 apresentam os resultados obtidos nos ensaios realizados apenas com solo, mostrando os valores para a carga e para a tensão horizontal versus deformação específica do corpo-de-prova. Como mencionado anteriormente, a tensão horizontal mostrada corresponde ao valor registrado pela célula C2 (ver Figura 3.35) enquanto a carga corresponde à força resultante na lateral 1 registrada pela célula de carga. A deformação foi obtida com base no deslocamento de um relógio comparador, posicionado na região central da lateral 1. 


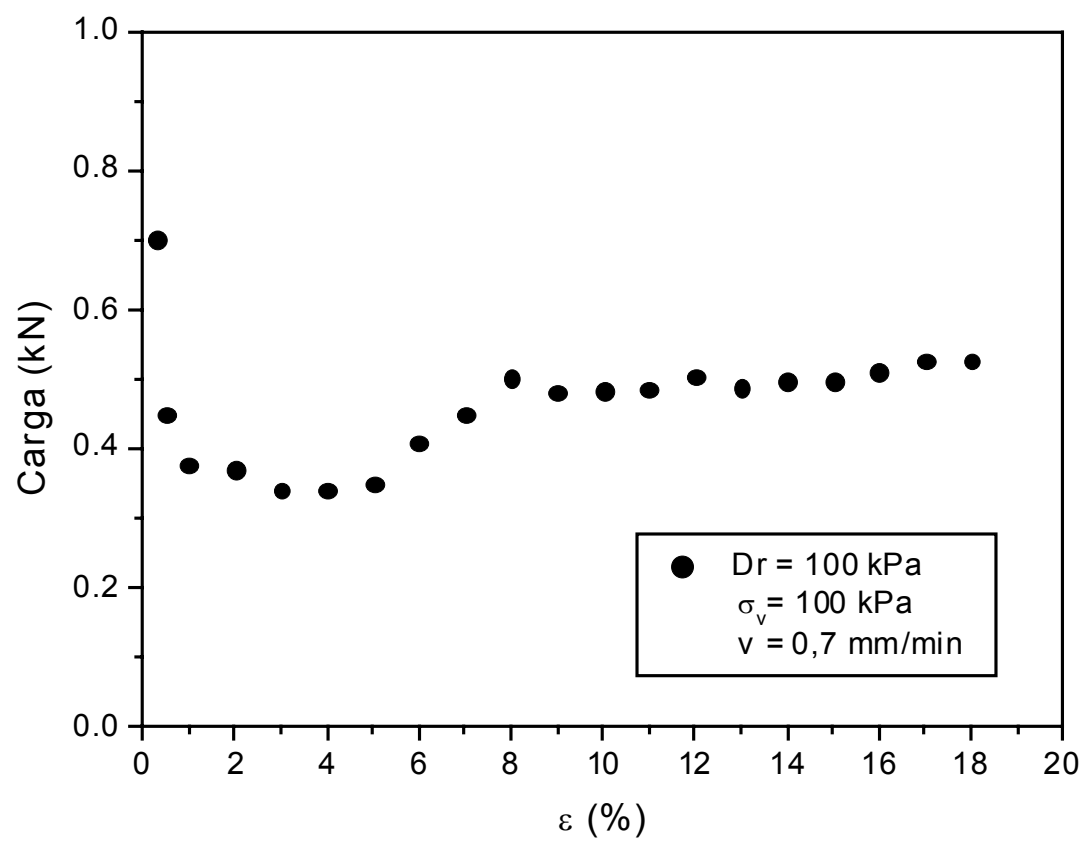

FIGURA 3.36 - Carga x deformação - ensaio S1

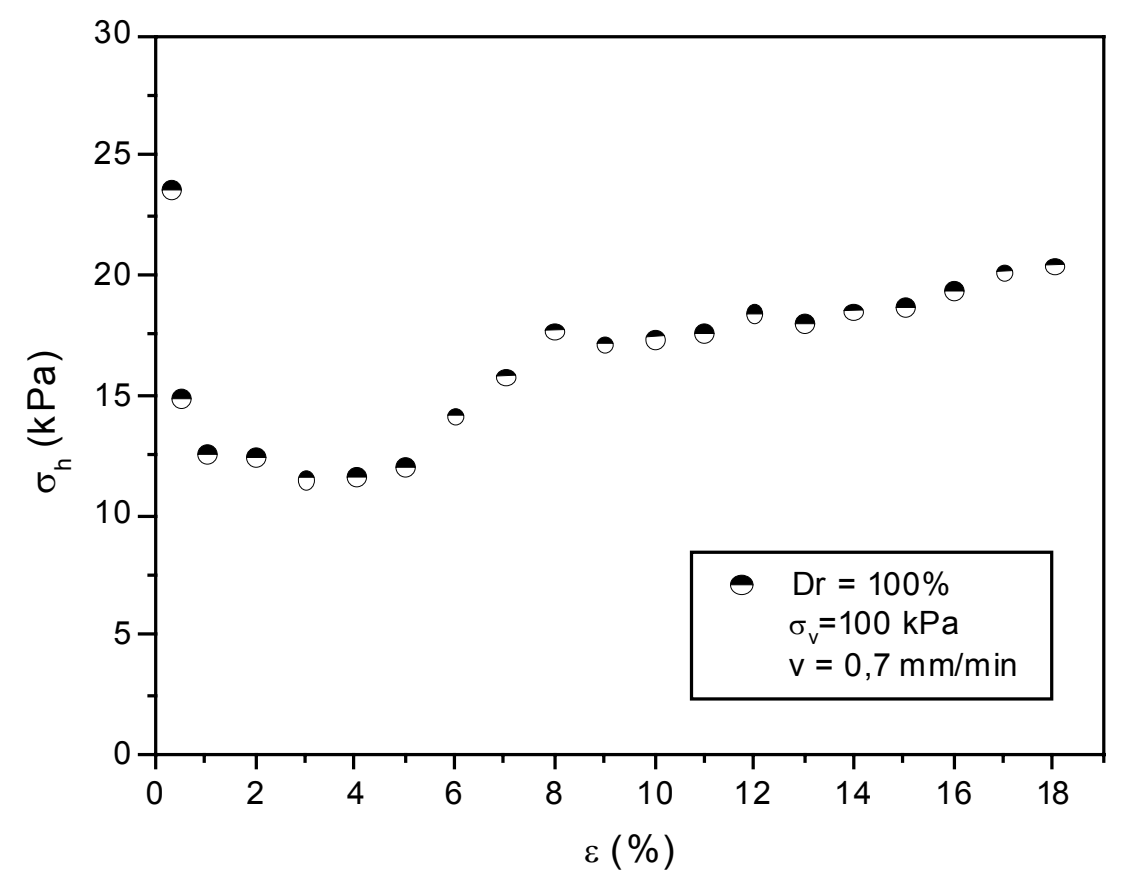

FIGURA 3.37 - Tensão horizontal x deformação - ensaio S1 


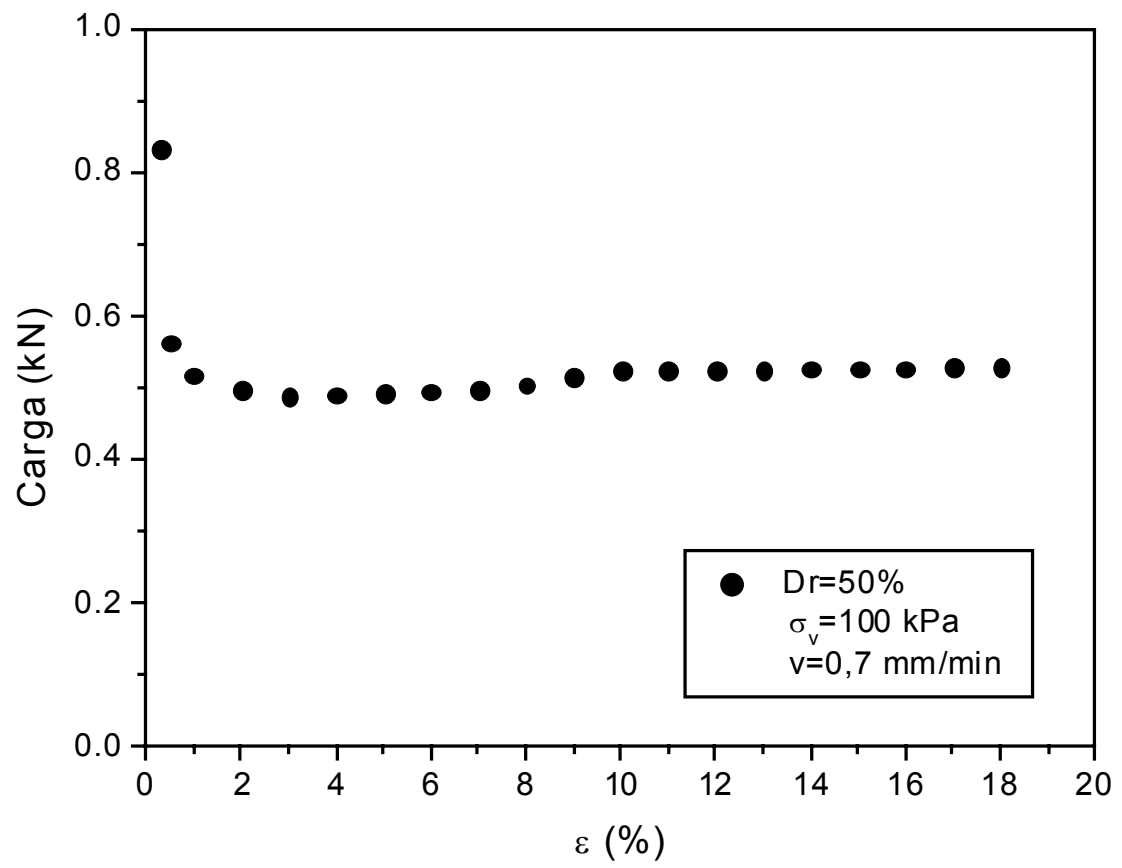

FIGURA 3.38 - Carga x deformação - ensaio S3

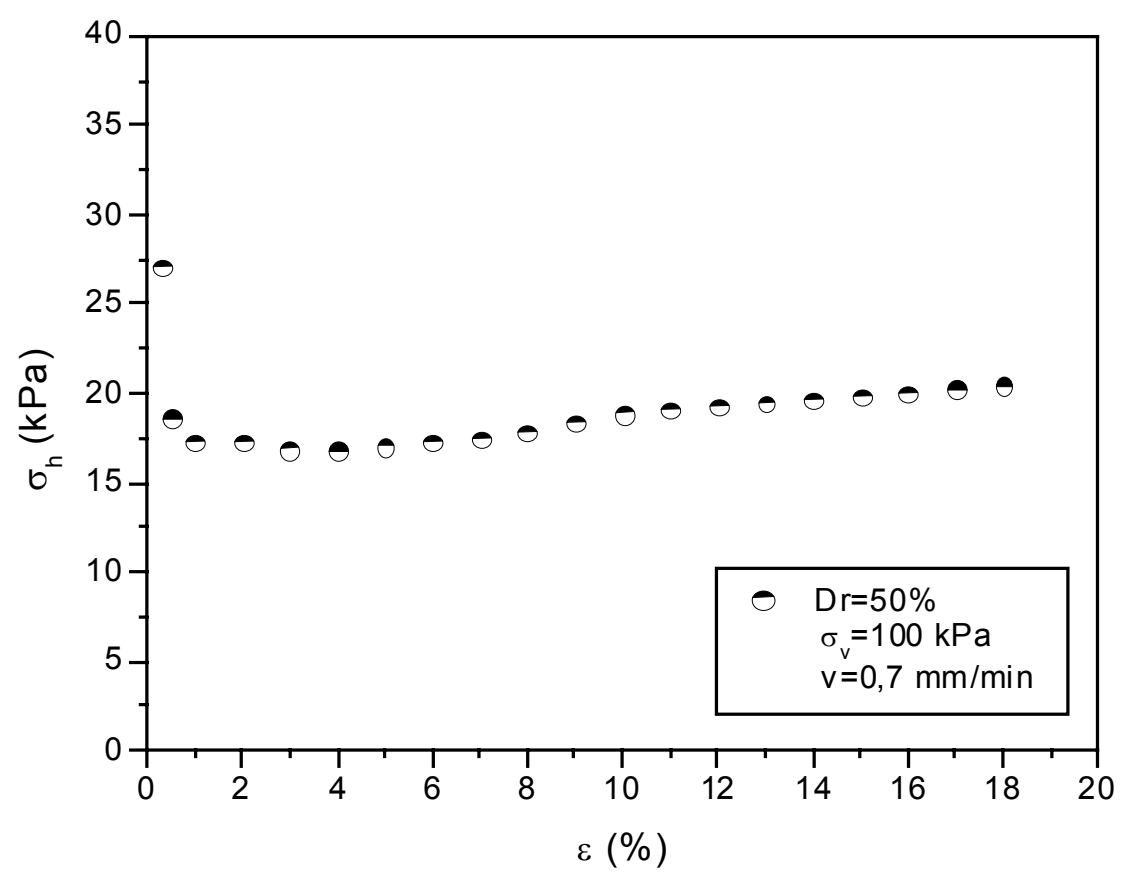

FIGURA 3.39 - Tensão horizontal x deformação - ensaio S3 


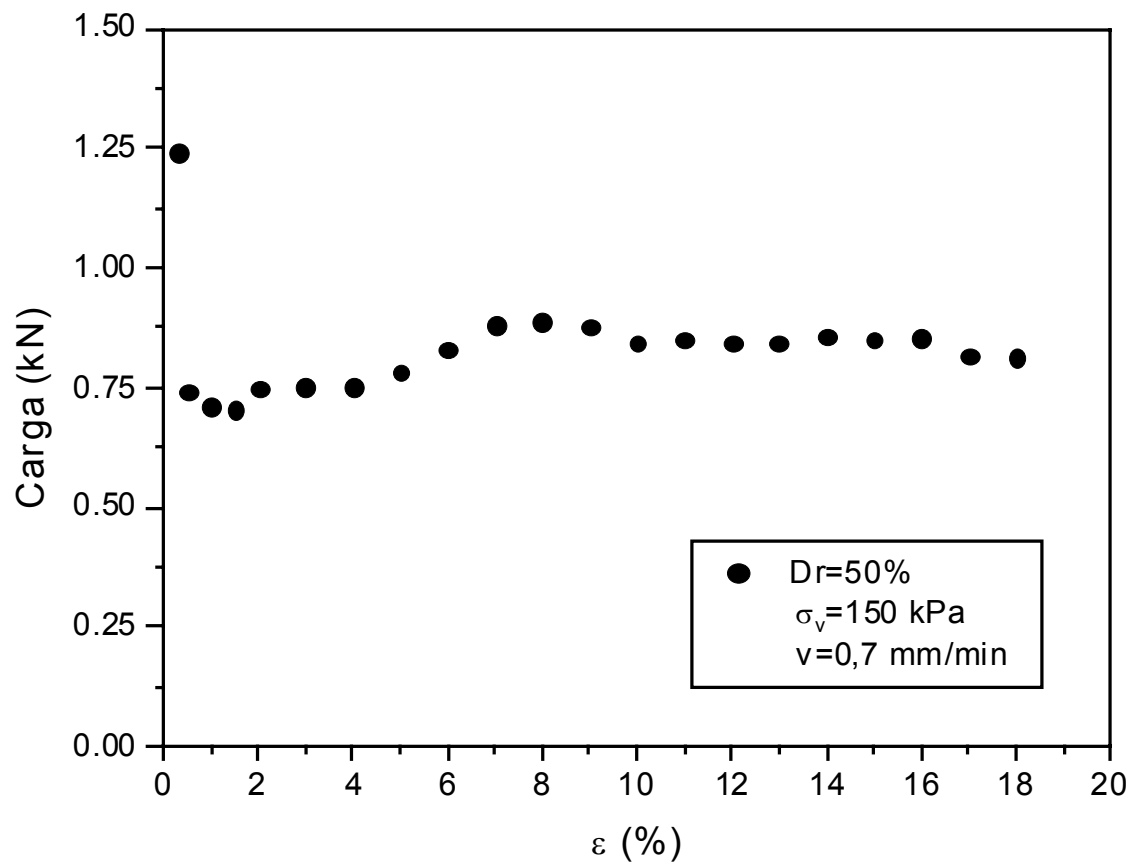

FIGURA 3.40 - Carga x deformação - ensaio S4

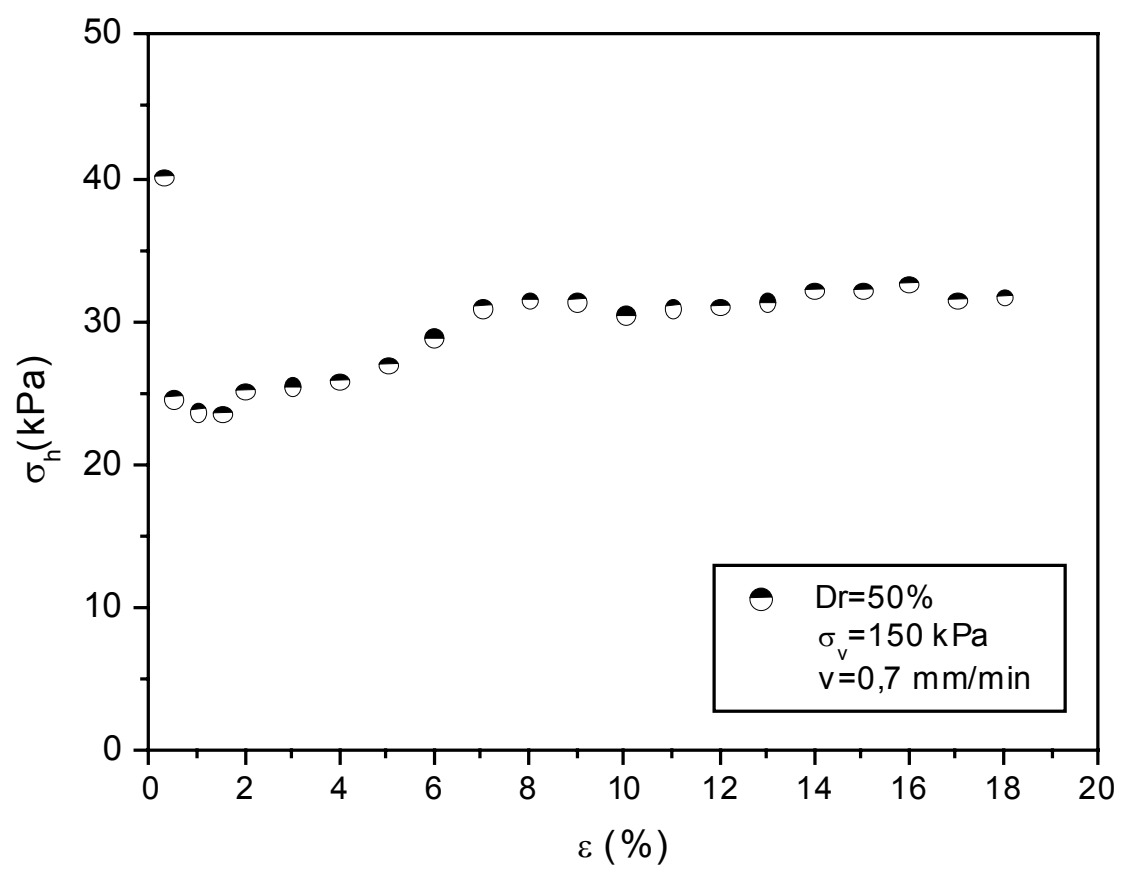

FIGURA 3.41 - Tensão horizontal x deformação - ensaio S4 


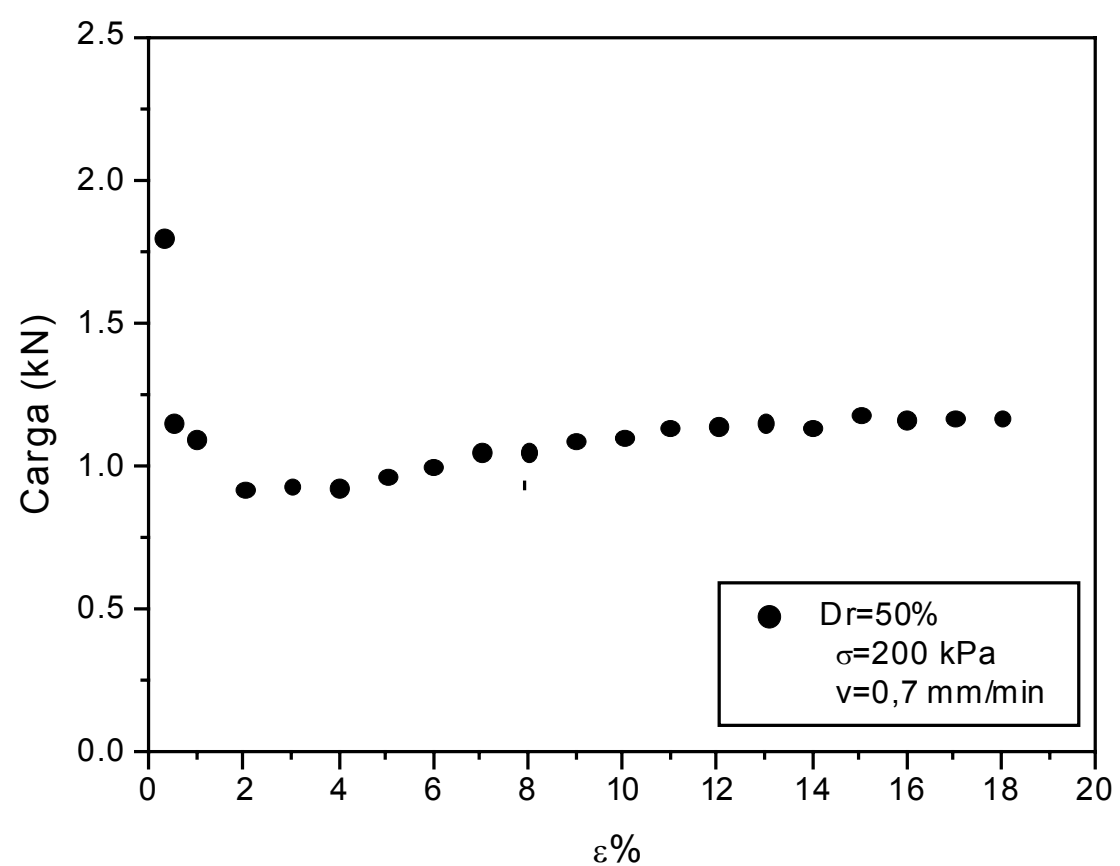

FIGURA 3.42 - Carga x deformação - ensaio S5

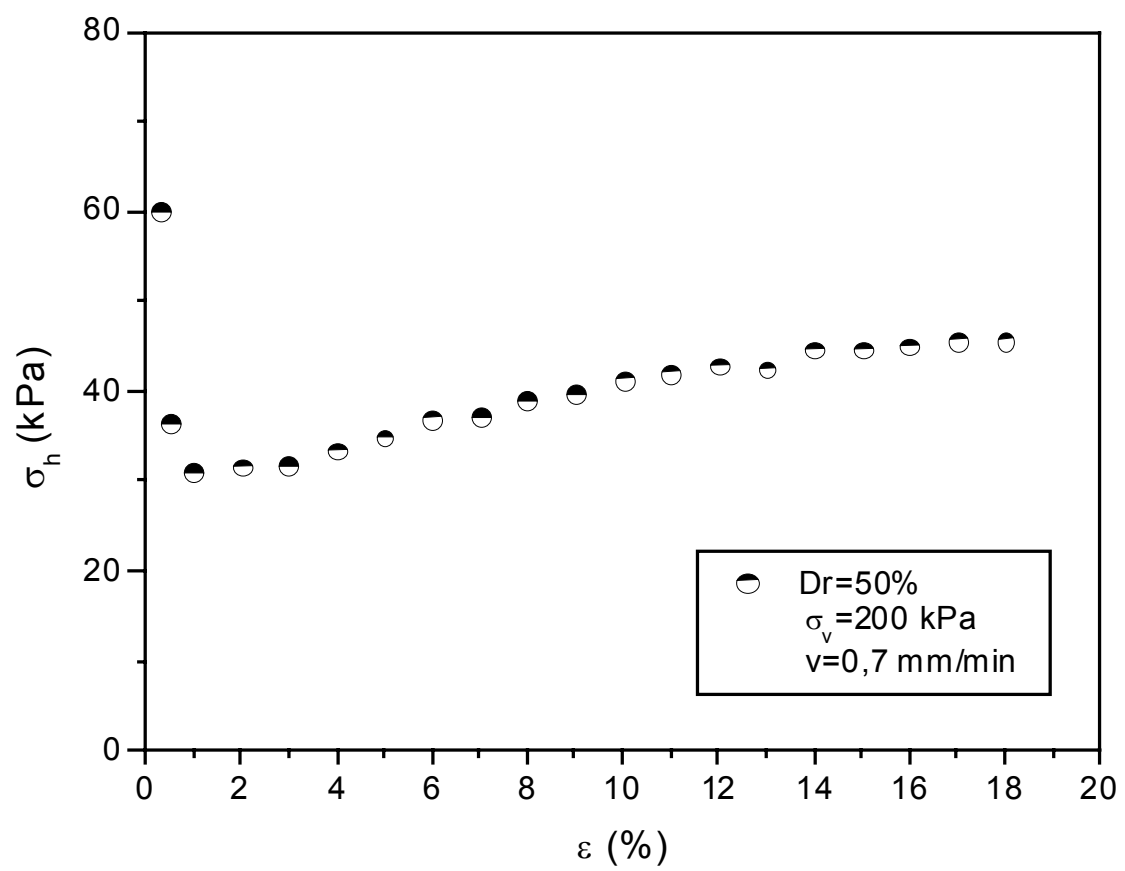

FIGURA 3.43 - Tensão horizontal x deformação - ensaio S5 


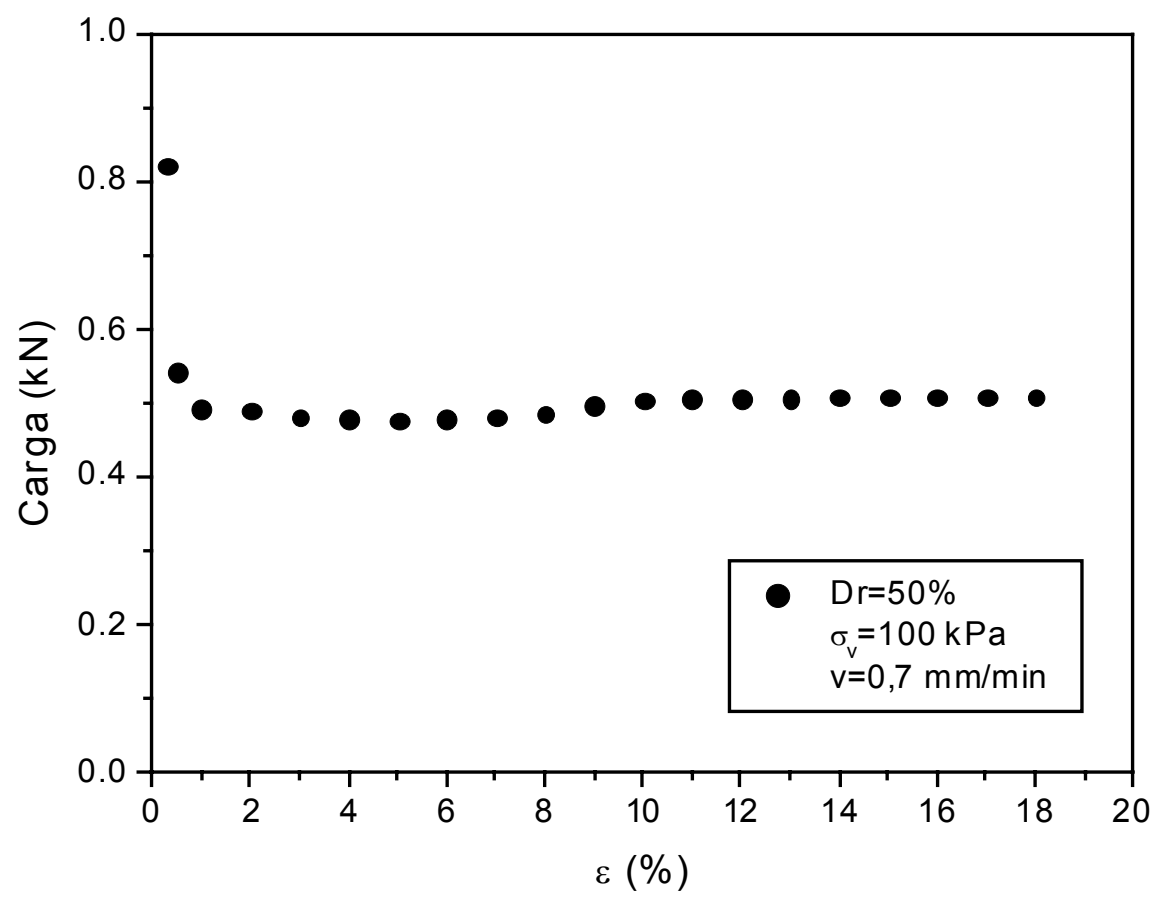

FIGURA 3.44 - Carga x deformação - ensaio SR6

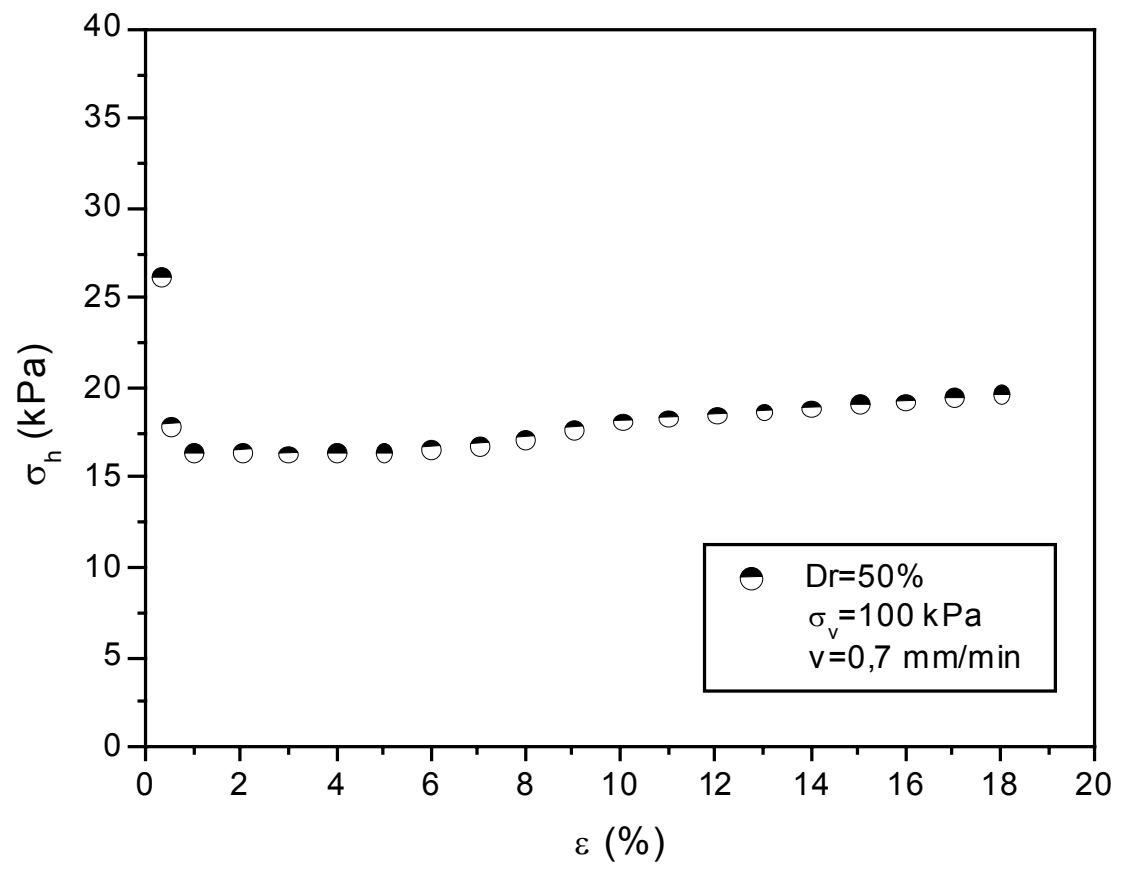

FIGURA 3.45 - Tensão horizontal x deformação - ensaio SR6 


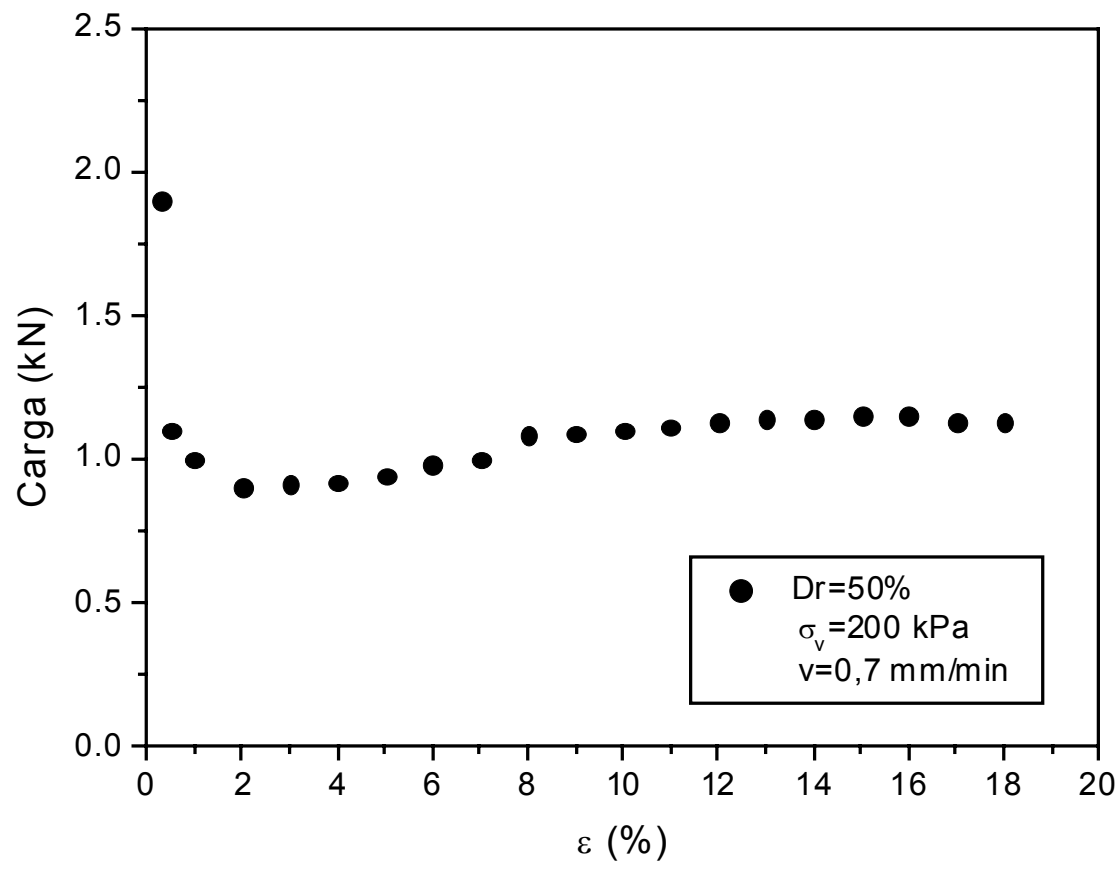

FIGURA 3.46 - Carga x deformação - ensaio SR7

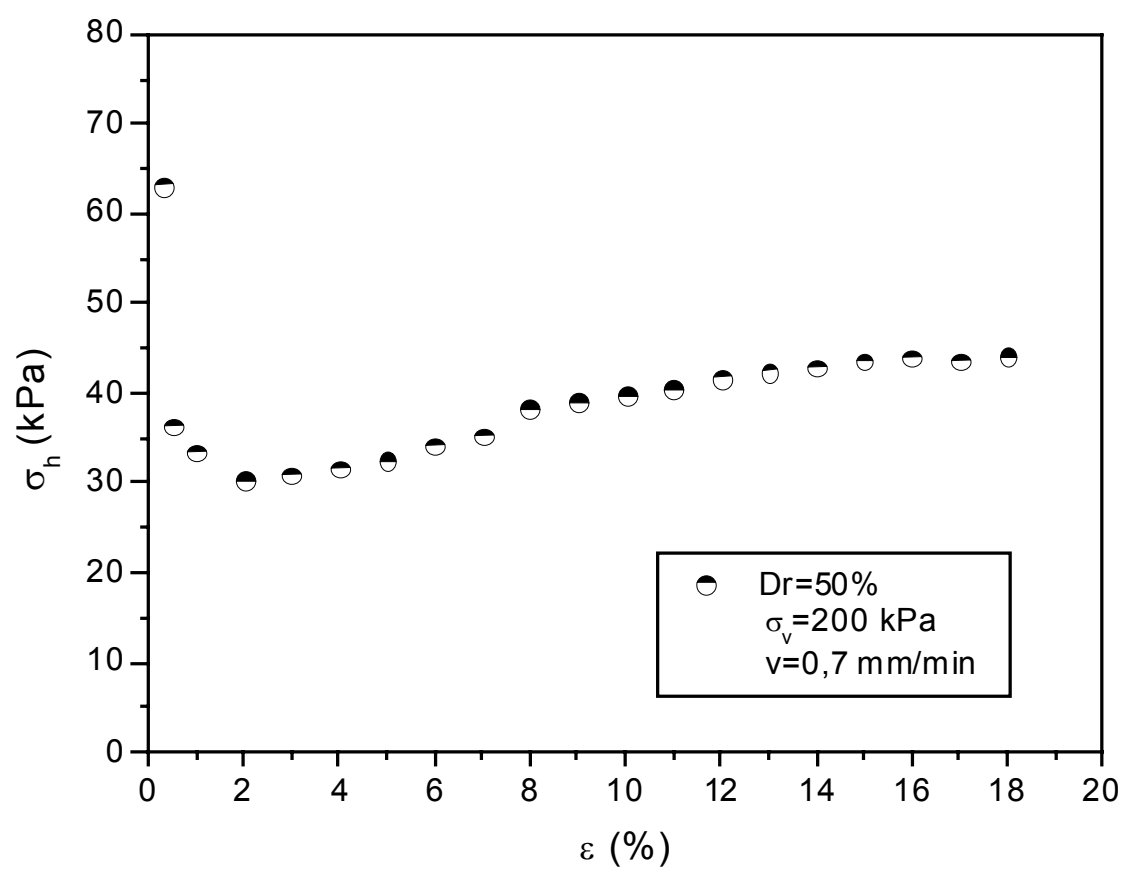

FIGURA 3.47 - Tensão horizontal x deformação - ensaio SR7 


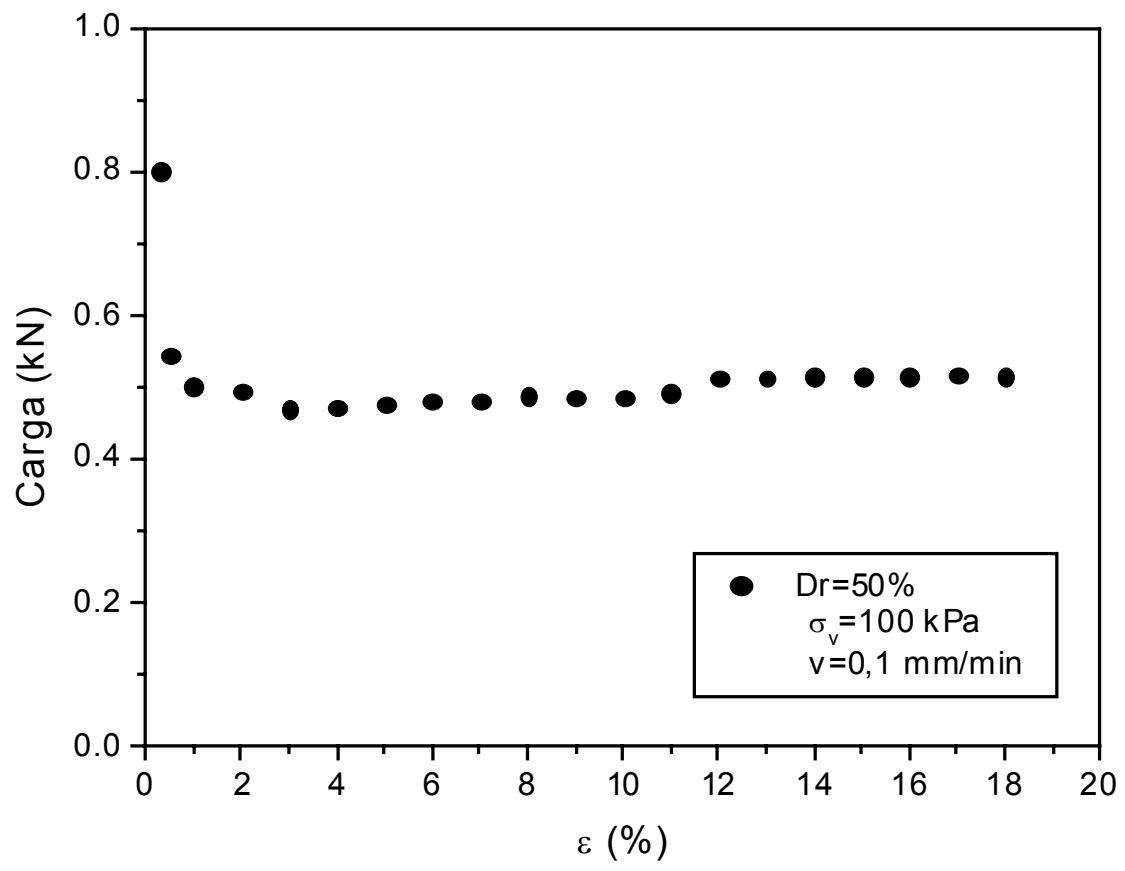

FIGURA 3.48 - Carga x deformação - ensaio S8

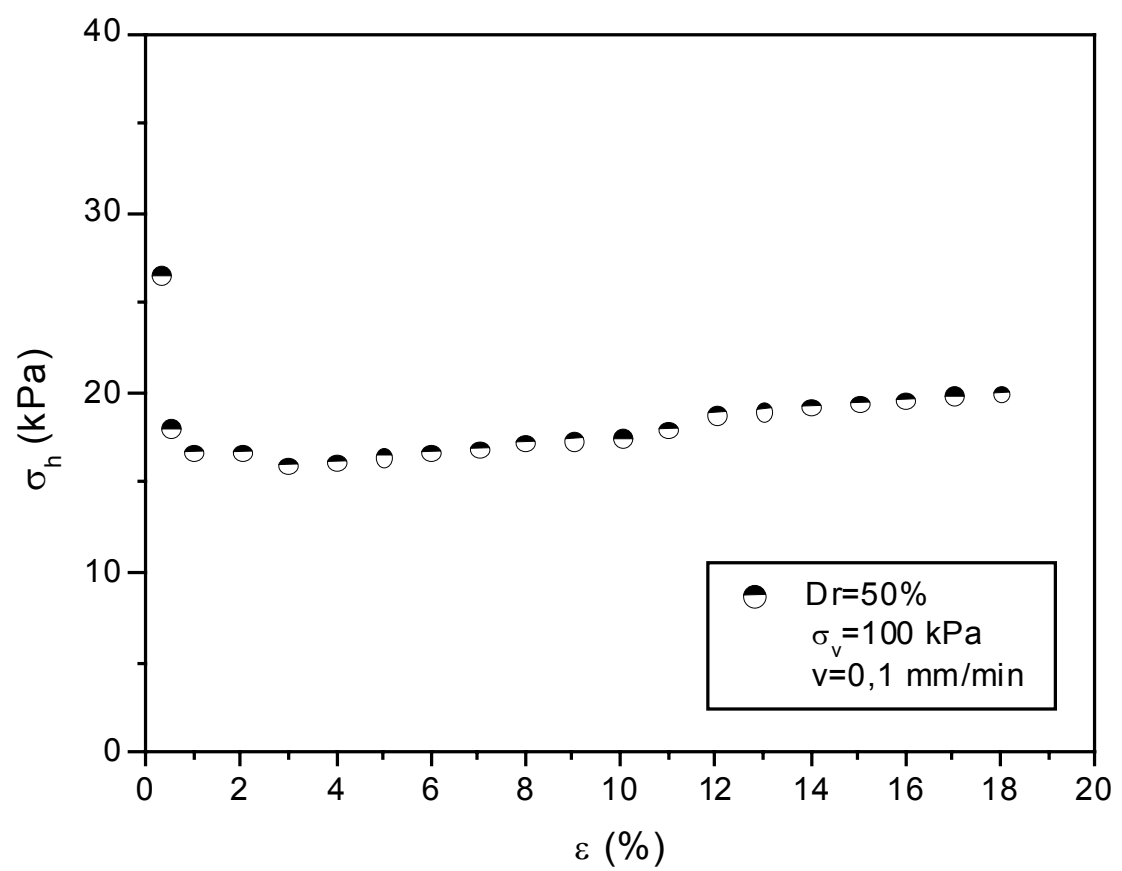

FIGURA 3.49 - Tensão horizontal x deformação - ensaio S8 


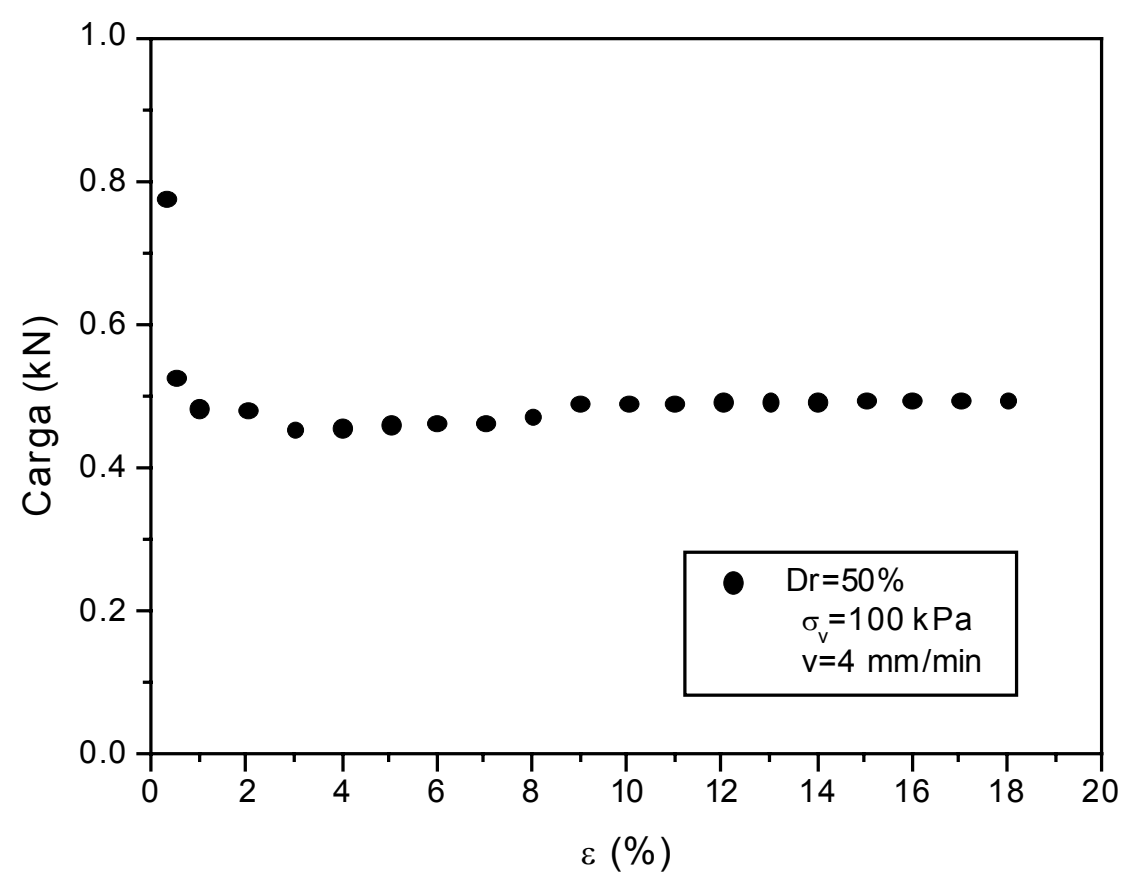

FIGURA 3.50 - Carga x deformação - ensaio S9

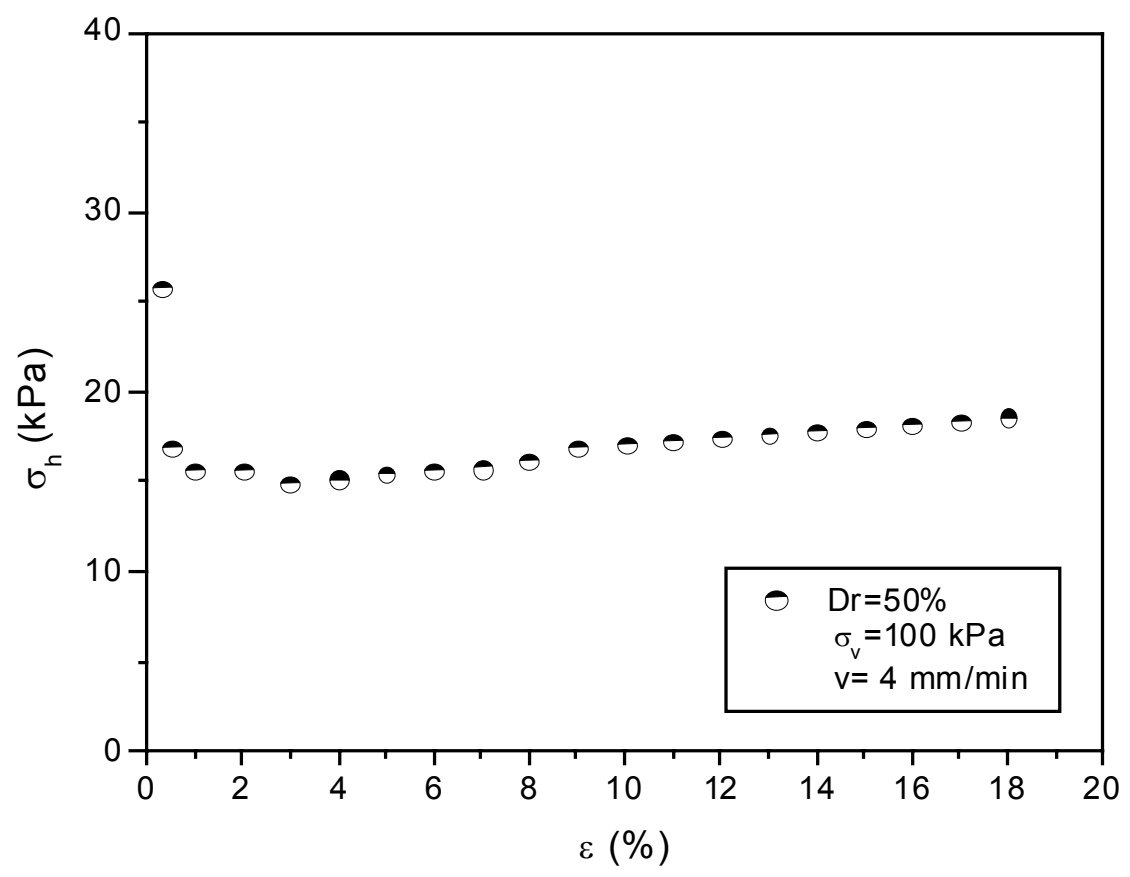

FIGURA 3.51 - Tensão horizontal x deformação - ensaio S9 


\subsubsection{Análise das tensões medidas}

Em todos os ensaios, a tensão horizontal apresentou um decréscimo acentuado com a movimentação inicial da lateral da caixa, seguido por um aumento após uma deformação em torno de $1 \%$ a $2 \%$. Esse comportamento é compatível com o previsto para o solo em termos de mobilização de ângulo de atrito. Inicialmente, o ângulo de atrito mobilizado aumenta com a deformação do corpo-de-prova até atingir o valor de pico que corresponde ao mínimo valor registrado para a tensão horizontal. Com o aumento da deformação, o ângulo de atrito diminui em direção ao estado crítico, provocando, conseqüentemente, o aumento da carga registrada.

De uma forma geral, os resultados confirmam o comportamento tradicionalmente observado em ensaios de cisalhamento de solos. Por exemplo, comparando-se os ensaios S1 e S3 (com Dr=100\% e 50\%, respectivamente), um menor valor foi registrado para a mínima tensão para uma densidade relativa igual a $100 \%$, em virtude do maior ângulo de atrito. Nenhum efeito acentuado das velocidades utilizadas nos ensaios foi detectado, como mostra os resultados dos ensaios S3, S8 e S9. Embora seja um comportamento previsível para uma areia pura, a realização de ensaios com velocidades diferentes foi importante para testar o equipamento desenvolvido. De qualquer forma, essa constatação também é importante para análise dos resultados dos ensaios com o reforço. Verificou-se ainda uma boa repetibilidade dos resultados, como pode ser observado, comparando-se os resultados dos ensaios S3 e S6R e dos ensaios S5 e S7R.

A Tabela 3.10 apresenta os resultados de tensão registrados no ensaio S2T. O valor registrado pela célula $\mathrm{C} 1$ está de acordo com a pressão aplicada pela câmara de ar. As células C4 e C5 apresentaram valores semelhantes, porém, cerca de 15\% inferiores em relação à pressão aplicada. Uma possibilidade inicial para justificar esse resultado poderia ser a presença de atrito lateral na caixa. O papel do atrito no resultado encontrado pode ser avaliado através da expressão (3.3), proposta por BRACHMAN et al. (2000), para verificar a diminuição da tensão aplicada, em virtude de atrito lateral, em caixas utilizadas para ensaios de laboratório. Essa 
expressão foi obtida através da modificação da teoria clássica de arqueamento para considerar a geometria tridimensional de uma caixa de testes.

\begin{tabular}{cc} 
TABELA $3.10-$ Resultado do ensaio S2T & \\
\hline Célula & Tensão $(\mathrm{kPa})$ \\
\hline C1 & 101 \\
C2 & 24 \\
C3 & 22 \\
C4 & 90 \\
C5 & 85 \\
C6 & 24 \\
\hline
\end{tabular}

$\sigma_{v}=\frac{\gamma}{2 K \mu w} \cdot\left(1-e^{-2 k \mu w h}\right)+\sigma_{v 0} \cdot e^{-2 K \mu w h}$

onde,

$\sigma_{\mathrm{vo}}-$ tensão vertical aplicada pela bolsa;

$\mathrm{h}$ - profundidade considerada;

$\mathrm{B}, \mathrm{L}$ - largura e comprimento da caixa, respectivamente;

$\mathrm{W}=1 / \mathrm{B}+1 / \mathrm{L}$;

$\phi$ - ângulo de atrito do solo;

$\mathrm{K}$ - coeficiente de empuxo, $\mathrm{K}_{0}=1$-sen $\phi$;

$\phi_{\mathrm{sp}}-$ ângulo de atrito solo-parede;

$\mu$-coeficiente de atrito na parede, $\mu=\operatorname{tg} \phi_{\mathrm{sp}}$;

$\gamma$ - peso específico.

Adotando-se os valores representativos para a condição correspondente ao ensaio S2T (Tabela 3.11) para a estimativa do efeito do atrito lateral na caixa de ensaios, percebe-se que a tensão atuante na posição das células C4 e C5 deveria corresponder a um valor de 99,5 $\mathrm{kPa}$. O ângulo de atrito para o solo foi estimado para condições de estado plano, $\phi_{\mathrm{ps}}$ (assumindo-se, $\phi_{\mathrm{ps}}=1,1 \phi_{\text {triaxial }}$ ). $\mathrm{O}$ ângulo de atrito na interface solo-parede foi adotado, com base na Tabela 3.8, para uma tensão 
normal correspondente a cerca de $30 \mathrm{kPa}$ (tensão horizontal no repouso estimada na caixa).

TABELA 3.11 -Valores utilizados para estimativa do atrito lateral.

\begin{tabular}{cc}
\hline$\sigma_{\mathrm{vo}}(\mathrm{kPa})$ & 100 \\
$\mathrm{~h}(\mathrm{~m})$ & 0,1 \\
$\mathrm{~B}(\mathrm{~m})$ & 0,2 \\
$\mathrm{~L}(\mathrm{~m})$ & 0,2 \\
$\phi\left(^{0}\right)$ & 43 \\
$\phi_{\mathrm{sp}}\left({ }^{0}\right)$ & 2 \\
$\gamma\left(\mathrm{kN} / \mathrm{m}^{3}\right)$ & 17,7 \\
\hline
\end{tabular}

O resultado fornecido pela expressão (3.3) demonstra que a diferença entre a tensão aplicada e os valores medidos pelas células C4 e C5 não deve ser atribuída ao efeito do atrito. Assim, a menor tensão registrada pelas células C4 e C5 seria uma conseqüência, provavelmente, das dimensões da bolsa para aplicação da tensão. A área da bolsa (efetivamente em contato com o solo) é ligeiramente inferior à área total do corpo-de-prova e corresponde a $0,2 \times 0,18 \mathrm{~m}^{2}$. Essa menor dimensão da bolsa era necessária para evitar seu contato com as laterais móveis da caixa (laterais 1 e 2) e, conseqüentemente, garantir que a tensão horizontal atuante nas laterais fosse transmitida exclusivamente pelo solo.

Fazendo-se uma correção em virtude das dimensões da bolsa, dividindo-se a força vertical resultante do carregamento da bolsa pela área do corpo-de-prova, expressão (3.4), percebe-se que a tensão atuante $\left(\sigma_{\mathrm{vc}}\right)$ na posição das células C4 e C5 deveria corresponder a aproximadamente $90 \mathrm{kPa}$. O valor teórico previsto está de acordo com valores registrados, demonstrando o bom funcionamento do equipamento e a coerência dos resultados obtidos.

$\sigma_{v c}=\sigma_{\text {vaplicado }} \cdot \frac{A_{\text {bolsa }}}{A_{c p}}=0,9 \cdot \sigma_{\text {vaplicado }}$ 
onde,

$\sigma_{\mathrm{vc}}-$ tensão vertical corrigida;

$\mathrm{A}_{\text {bolsa }}$ - área da bolsa de ar pressurizado;

$\mathrm{A}_{\mathrm{cp}}$ - área inicial do corpo-de-prova.

Com relação aos valores de tensão horizontal registrados nos ensaios, destaca-se que o sistema motorizado, utilizado para a movimentação das laterais da caixa, permite uma movimentação de aproximadamente $0,3 \mathrm{~mm}$ quando a tensão vertical é aplicada, antes mesmo do acionamento do motor. Essa movimentação acontece devido a folgas naturais e de difícil eliminação nas roscas dos eixos de movimentação. Assim, o valor da tensão horizontal registrado no ensaio S2T bem como o primeiro valor registrado nos demais ensaios não correspondem a uma condição de fato de "repouso". Os valores obtidos foram cerca de 20 a $25 \%$ inferiores à tensão horizontal estimada através do coeficiente de empuxo no repouso $\left(\mathrm{K}_{0}=1-\operatorname{sen} \phi\right)$.

No que diz respeito à variação da tensão horizontal com a deformação, em todos os ensaios, a tensão inicialmente obtida apresenta um acentuado decréscimo para um intervalo de deformação $(\varepsilon)$ entre 0,3 e 0,5\%. Após esse valor, ocorre um decréscimo bem menor da tensão até uma deformação entre 1\% e 3\%.

Tal comportamento é coerente ao se estabelecer uma analogia com muros de arrimo convencionais. Nesse tipo de estrutura, deslocamentos muito pequenos, da ordem de $0,1 \%$ da altura do muro $(\mathrm{H})$, são suficientes para reduzir drasticamente a tensão horizontal. Porém, após esse patamar, ainda ocorre um pequeno decréscimo da tensão até um deslocamento correspondente a cerca de $1 \%$ da altura do muro (TOYOSAWA et al. 2002). Esse comportamento é semelhante ao observado nos ensaios para a variação da tensão horizontal com a deformação. Considerando-se $\mathrm{H}=200 \mathrm{~mm}$ (altura da lateral móvel da caixa) e estimando-se a tensão horizontal no repouso através de $\sigma_{\mathrm{h}}=\mathrm{K}_{0} \sigma_{\mathrm{v}}$, $\operatorname{com} \mathrm{K}_{0}=1$-sen $\phi$, uma redução na tensão horizontal de até $55 \%$ deve ter ocorrido (em relação à condição de repouso) quando a lateral apresentou uma movimentação igual a apenas $0,25 \% \mathrm{H}(\varepsilon=0,5 \%)$. Quando o 
deslocamento variou de $0,25 \% \mathrm{H}$ a $1 \% \mathrm{H}$, uma redução no valor da tensão bem menor foi verificada (10\%, em média).

Entretanto, em todos os ensaios, o valor mínimo da tensão horizontal foi inferior ao valor teórico, adotando-se um ângulo de atrito de pico no estado plano com base nos ensaios triaxiais realizados $\left(\phi_{\mathrm{ps}}=1,1 \phi_{\text {triaxial }}\right)$. A Figura 3.52 apresenta a mínima tensão obtida nos ensaios e a tensão calculada utilizando a expressão (3.5) para $\mathrm{Dr}=50 \%$.

$$
\sigma_{h}=K_{a} \cdot \sigma_{v c}
$$

onde,

$$
\begin{aligned}
& \mathrm{Ka}=\text { coeficiente de empuxo ativo, } K_{a}=\operatorname{tg}^{2}\left(45-\frac{\phi_{p s}}{2}\right) \\
& \sigma_{\mathrm{vc}}-\text { tensão vertical corrigida, } \sigma_{v c}=\frac{0,9 \cdot \sigma_{\text {vaplicado }}}{\left(1+\varepsilon_{h}\right)} ; \\
& \varepsilon_{\mathrm{h}}-\text { deformação horizontal do corpo-de-prova. }
\end{aligned}
$$

Os valores obtidos nos ensaios foram cerca de $20 \%$ menores para as tensões aplicadas de 100 e $150 \mathrm{kPa}$ e cerca de $28 \%$ menor que o valor teórico previsto para $200 \mathrm{kPa}$. Essa discrepância, no entanto, é admissível, pois pode ser facilmente justificada, caso o ângulo de atrito do solo, nas condições do ensaio, seja até $3^{0}$ superior ao valor adotado. Nesse caso, o valor previsto através da expressão (3.5) igualar-se-ia ao valor medido. O maior ângulo de atrito nos ensaios com o equipamento desenvolvido, em relação aos triaxiais, pode ser decorrente da diferente trajetória de carregamento nas duas condições. Variações no ângulo de atrito de $4^{0}$ entre ensaios de compressão axial e descompressão lateral, por exemplo, são relatadas na literatura (LAMBE \& WHITMAN, 1979). Outros fatores ainda podem ser cogitados para justificar a discrepância observada como, por exemplo, o ângulo de atrito no estado plano ser maior que o estimado com base na expressão adotada $\left(\phi_{\mathrm{ps}}=1,1 \phi_{\text {triaxial }}\right)$. 


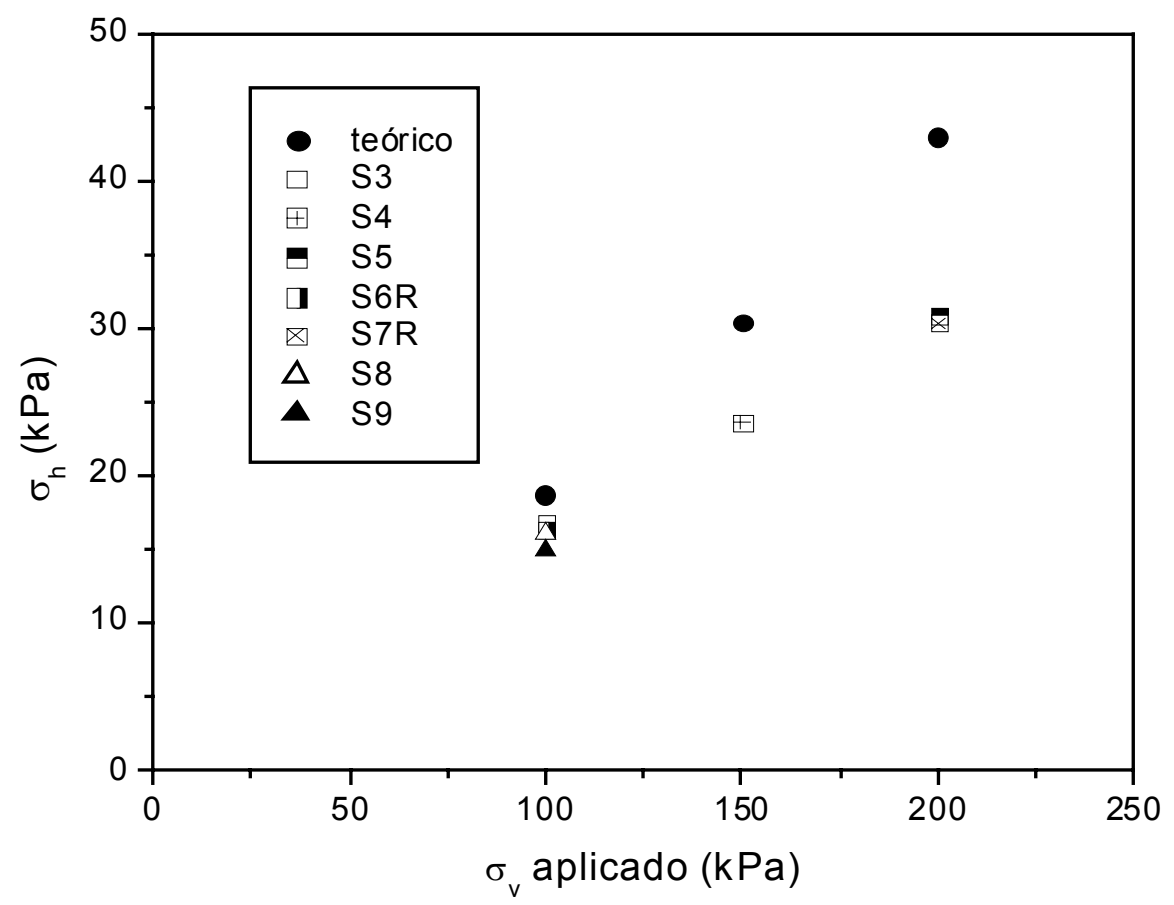

FIGURA 3.52 - Tensão horizontal prevista e obtida nos ensaios.

\subsubsection{Análise da força na lateral móvel}

De forma semelhante à tensão horizontal, a força registrada apresentou um decréscimo acentuado com a movimentação inicial da lateral da caixa, seguido por um aumento após uma deformação de cerca de 1 a $2 \%$. No entanto, uma menor variação após atingir o mínimo valor foi detectada para a força. As Figuras 3.53 e 3.54 ilustram o exposto. Os dados são referentes aos ensaios S3 e S5, mas representam o comportamento típico observado em todos os ensaios. As figuras apresentam a tensão registrada para cada deformação, como uma porcentagem da tensão inicial obtida, $\sigma_{\mathrm{h} 0,3}$ (ou seja, $\sigma_{\mathrm{h}}$ para $\varepsilon=0,3 \%$ ). Apresentam ainda a força em função da deformação como uma porcentagem da força inicialmente registrada, $\mathrm{F}_{\mathrm{h} 0,3}$ (isto é, $\mathrm{F}_{\mathrm{h}}$ para $\varepsilon=0,3 \%$ ). Como se pode observar, a força apresenta uma menor 
variação após atingir o mínimo valor do que a tensão, ficando praticamente constante no caso do ensaio S3.

Ainda ao analisar a carga registrada em todos os ensaios, percebe-se que o valor inicialmente obtido é inferior ao produto entre a tensão medida e a área total da lateral da caixa. Essa diferença deve ocorrer por conta das dimensões da câmara de ar utilizada que fazem com que a tensão aplicada se propague de tal forma que a tensão horizontal não atua em toda a área da lateral móvel da caixa. Como ilustrado no esquema mostrado na Figura 3.55, as extremidades da lateral ficam livres do efeito da tensão vertical aplicada (região sem solicitação), e a área sob influência do carregamento é inferior à área total disponível. A comparação entre os valores de força e tensão registrados, em todos os ensaios, indica que apenas cerca de $80 \%$ da área da lateral móvel da caixa encontra-se inicialmente carregada.

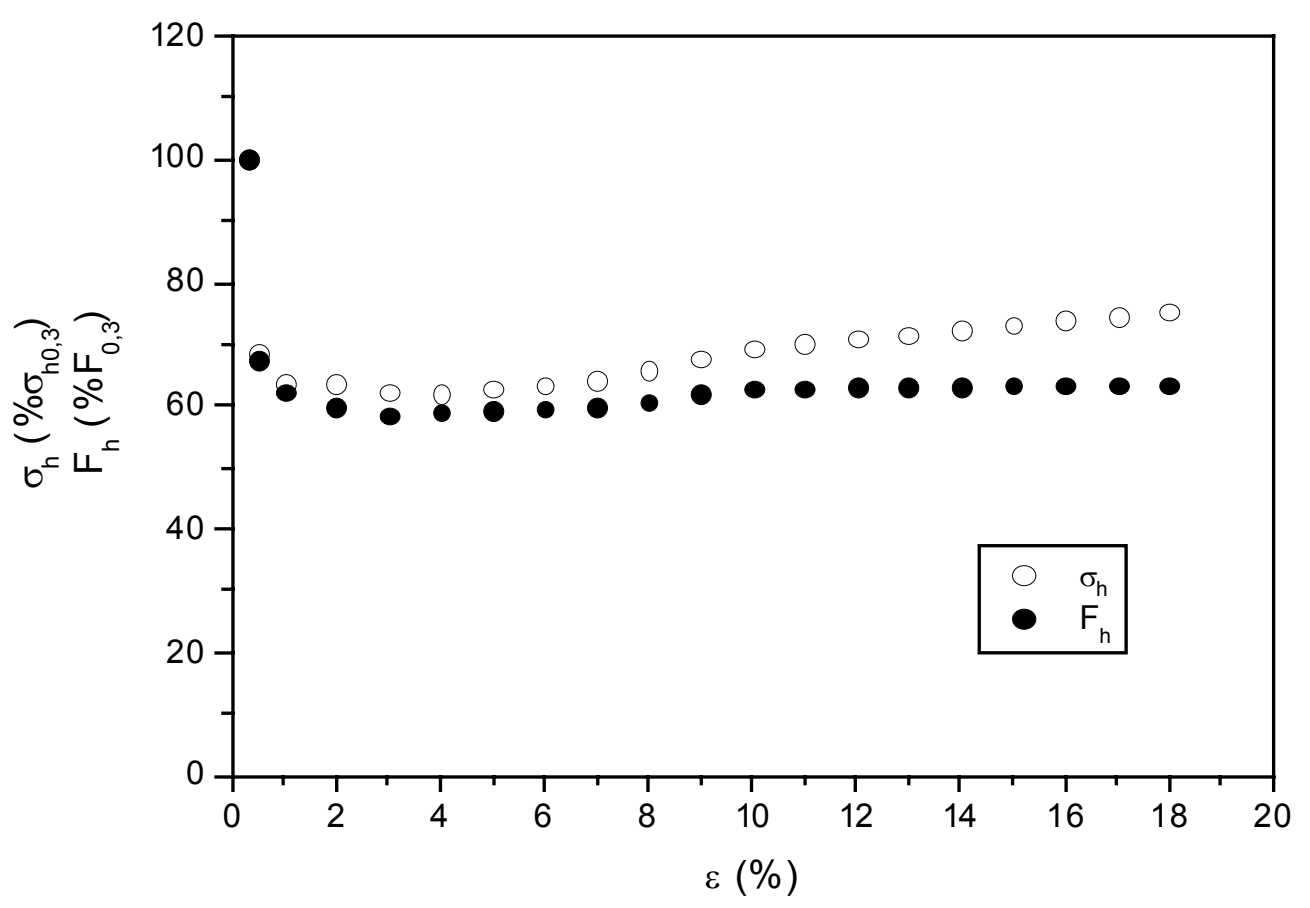

FIGURA 3.53 - Variação da tensão e da força em relação aos valores obtidos para $\varepsilon=0,3 \%$ (ensaio $\mathrm{S} 3$ ). 


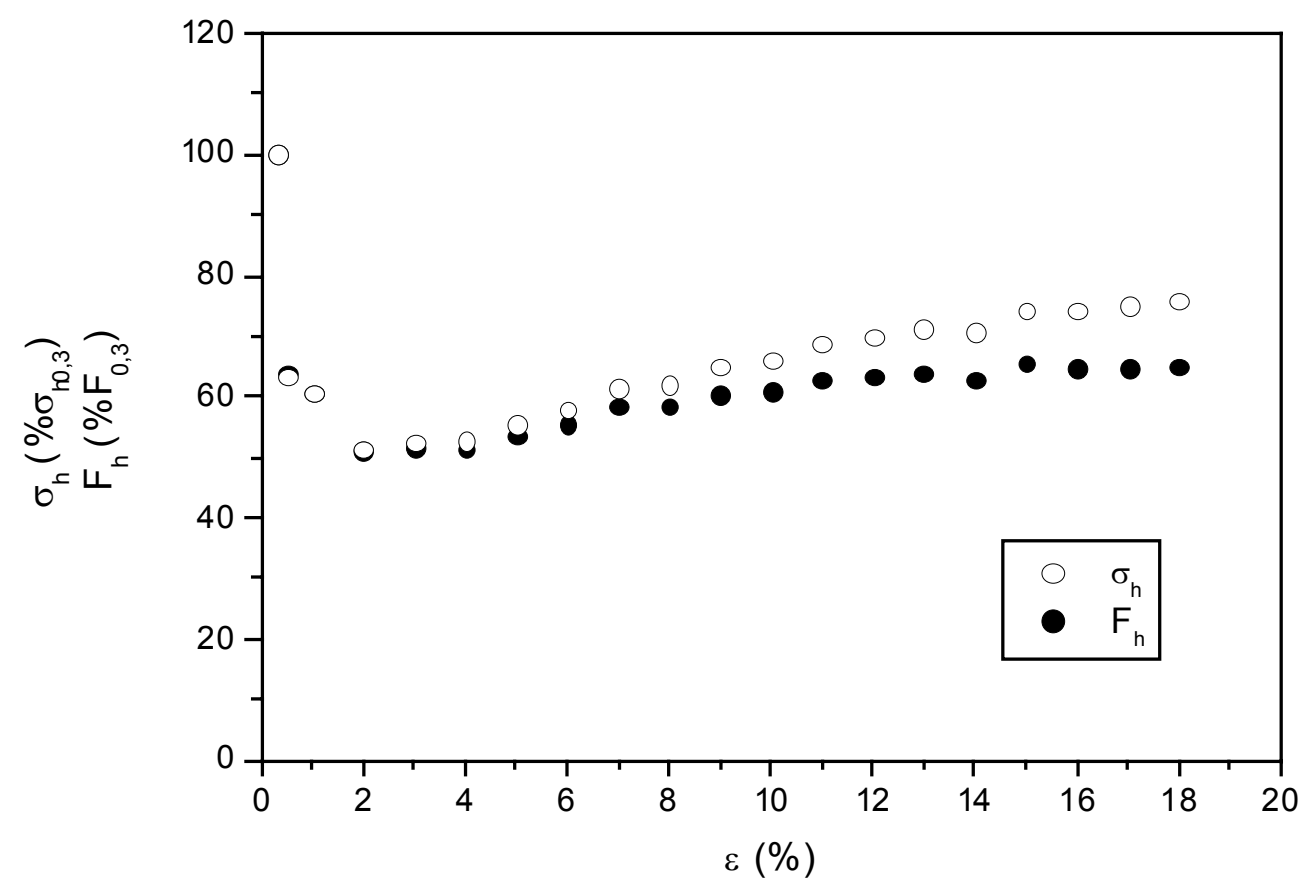

FIGURA 3.54 - Variação da tensão e da força em relação aos valores obtidos para $\varepsilon=0,3 \%$ (ensaio S5).

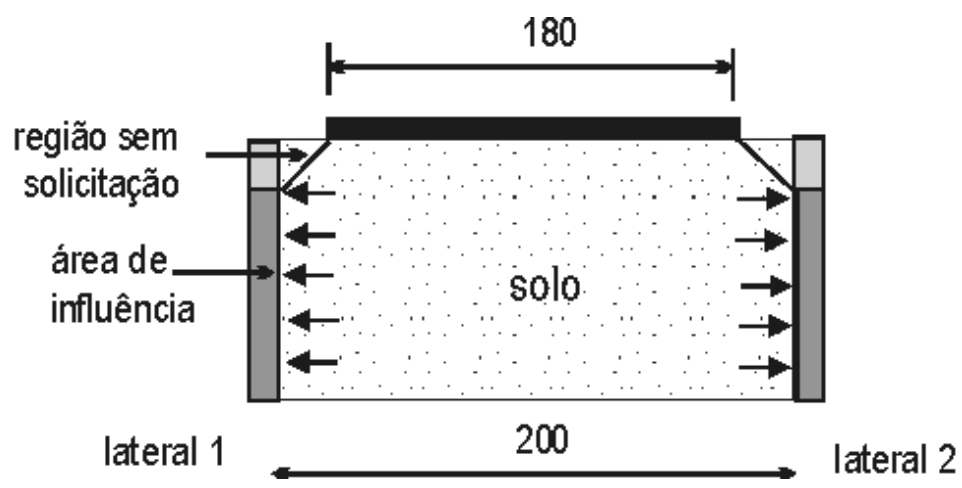

FIGURA 3.55 - Esquema de propagação da tensão vertical aplicada (sem escala, dimensões em mm). 
Essa mesma característica do equipamento, ilustrada na Figura 3.55, pode ser utilizada para justificar o comportamento mostrado nas Figuras 3.53 e 3.54. Na verdade, dois efeitos antagônicos acontecem simultaneamente durante um ensaio, influenciando a carga registrada:

i) À medida que a deformação aumenta, a área de influência do carregamento aplicado tende a diminuir, como ilustrado na Figura 3.56. O decréscimo da área de influência reduz o valor da carga resultante na lateral móvel.

ii) Por outro lado, a diminuição do ângulo de atrito com a deformação após o pico provoca o aumento da tensão horizontal, que tende, conseqüentemente, a aumentar a força na parede. Para fins ilustrativos, a Figura 3.57 mostra o ângulo de atrito mobilizado com a deformação, no ensaio S3, responsável pela tendência de aumento da tensão horizontal mostrada na Figura 3.54. O valor do ângulo de atrito mostrado na Figura 3.57 foi estimado utilizando-se a expressão (3.5), substituindo-se $K_{\mathrm{a}}$ e $\phi_{\mathrm{ps}}$ por k e $\phi$ (mobilizado).

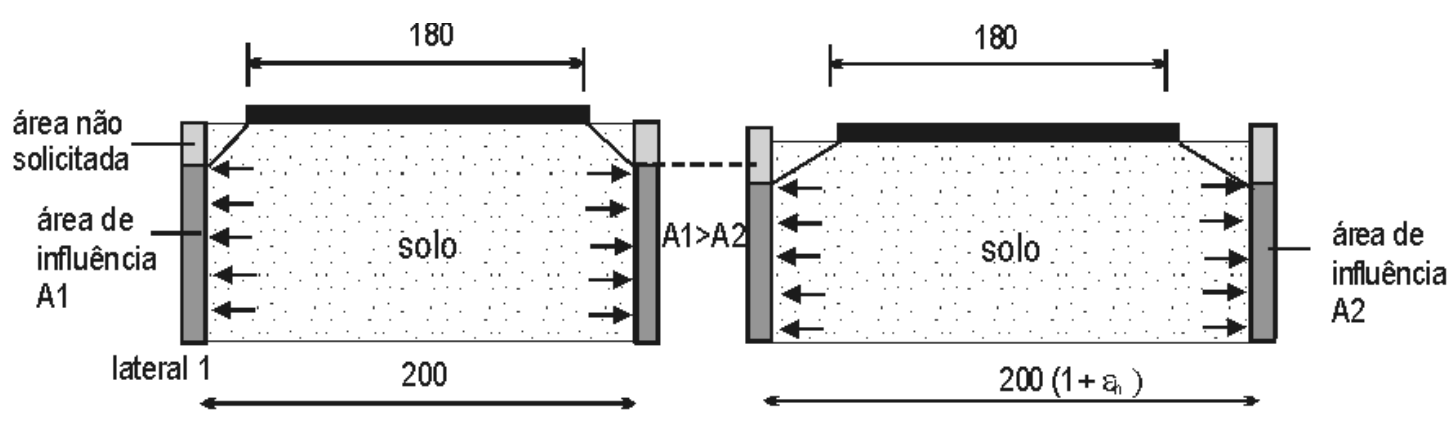

(a)

(b)

FIGURA 3.56 - Esquema de propagação da tensão vertical com a deformação do corpo-de-prova (sem escala, dimensões em mm). 


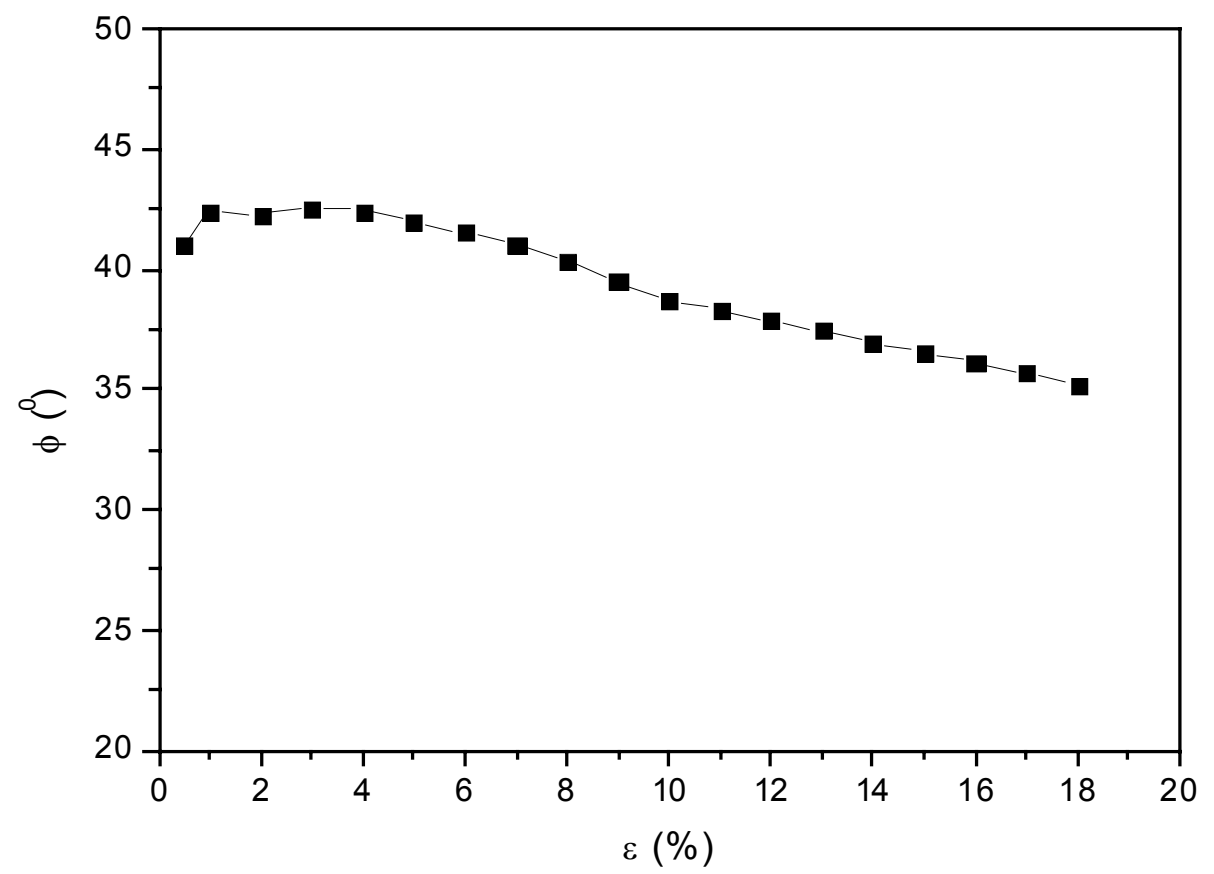

FIGURA 3.57 - Variação do ângulo de atrito mobilizado com a deformação (ensaio S3).

\subsubsection{Ensaios com o elemento de solo reforçado}

As Figuras 3.58 a 3.69 apresentam os resultados obtidos nos ensaios com o elemento de solo reforçado. Os trechos A, B e C, indicados nas curvas deformação versus tempo, correspondem às posições mostradas na Figura 3.17. O termo “externo", nas curvas deformação versus tempo, refere-se à deformação do corpo-deprova com base no deslocamento da lateral móvel, registrado por um relógio comparador apoiado em seu centro.

Em todos os ensaios, foram registradas deformações no decorrer do tempo, evidenciando que a presença do solo não eliminou a fluência do reforço. As deformações obtidas em diferentes trechos do reforço indicaram uma mesma tendência, podendo-se considerar a distribuição de deformação, ao longo do comprimento do corpo-de-prova, praticamente constante. Tal distribuição permite que a força registrada pela célula de carga seja associada à deformação obtida não apenas no trecho A, mas também nos demais trechos observados. 


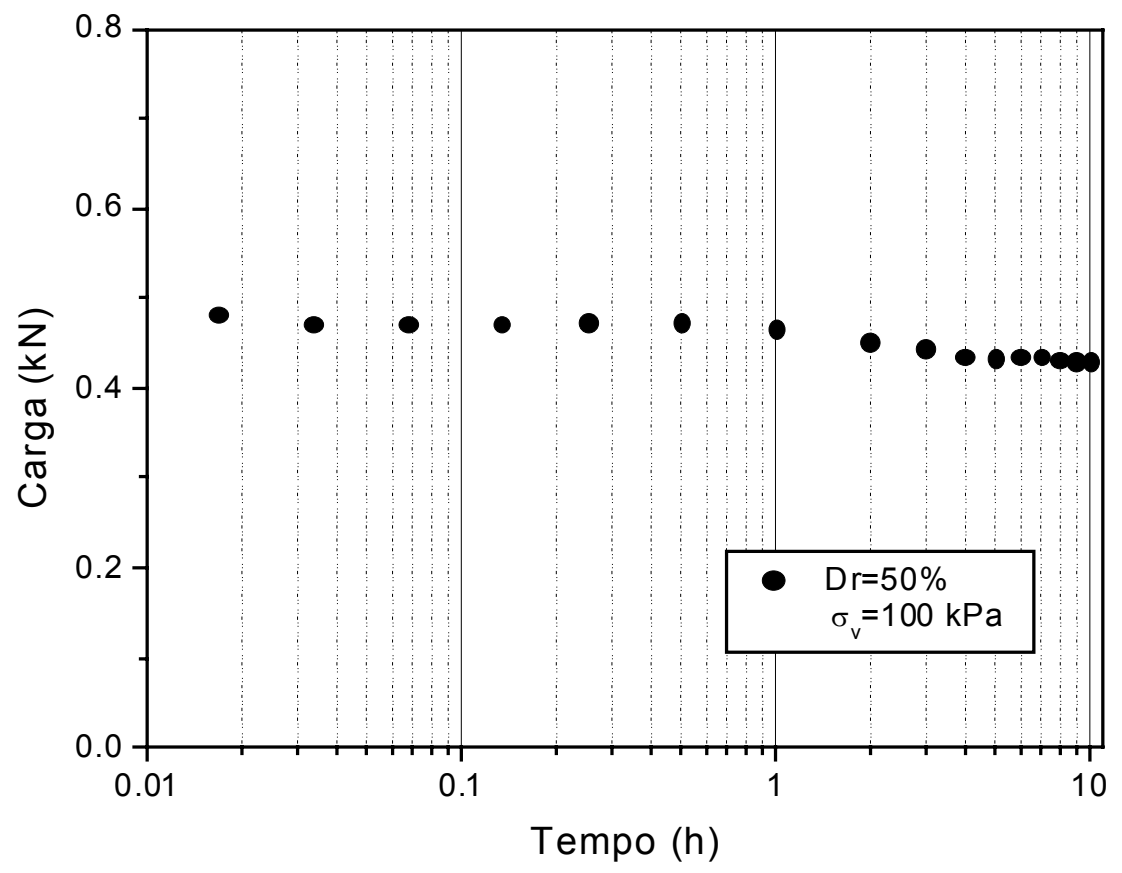

FIGURA 3.58 - Carga x tempo - ensaio SR1

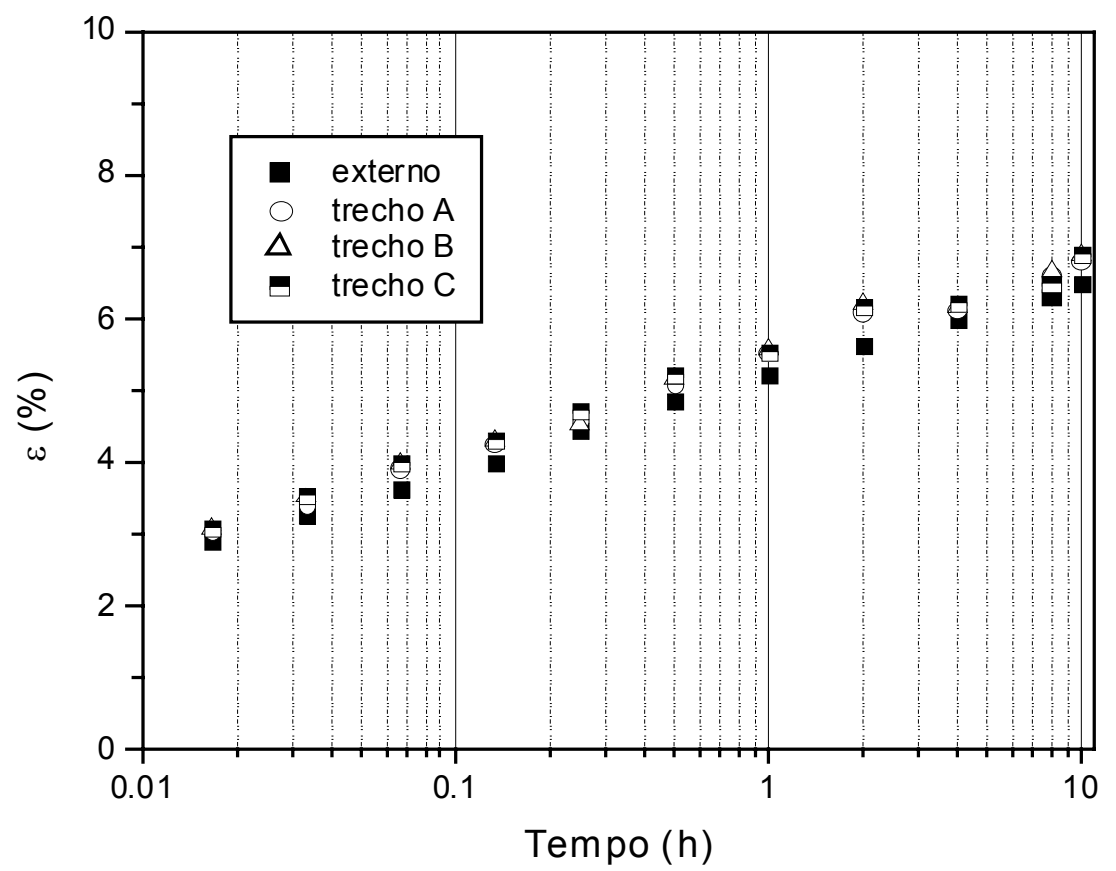

FIGURA 3.59 - Deformação x tempo - ensaio SR1 


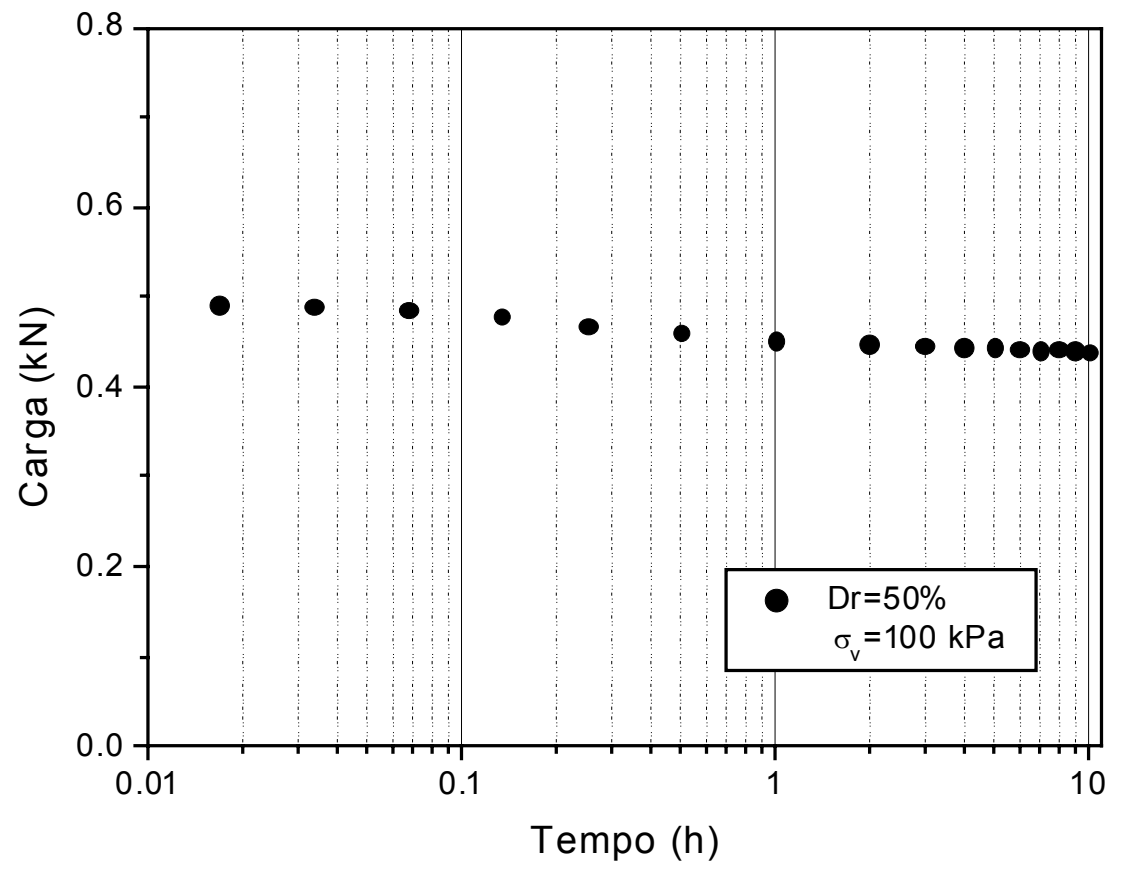

FIGURA 3.60 - Carga x tempo - ensaio SR2R

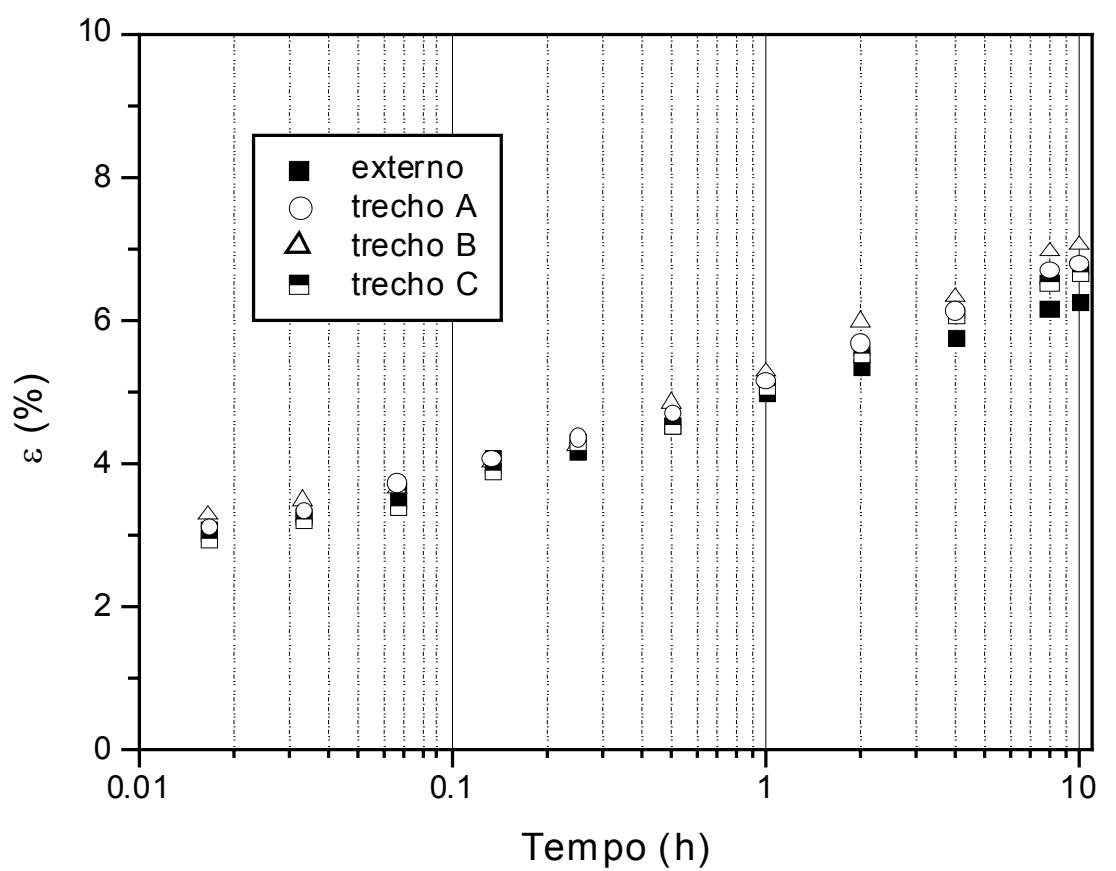

FIGURA 3.61 - Deformação x tempo - ensaio SR2R 


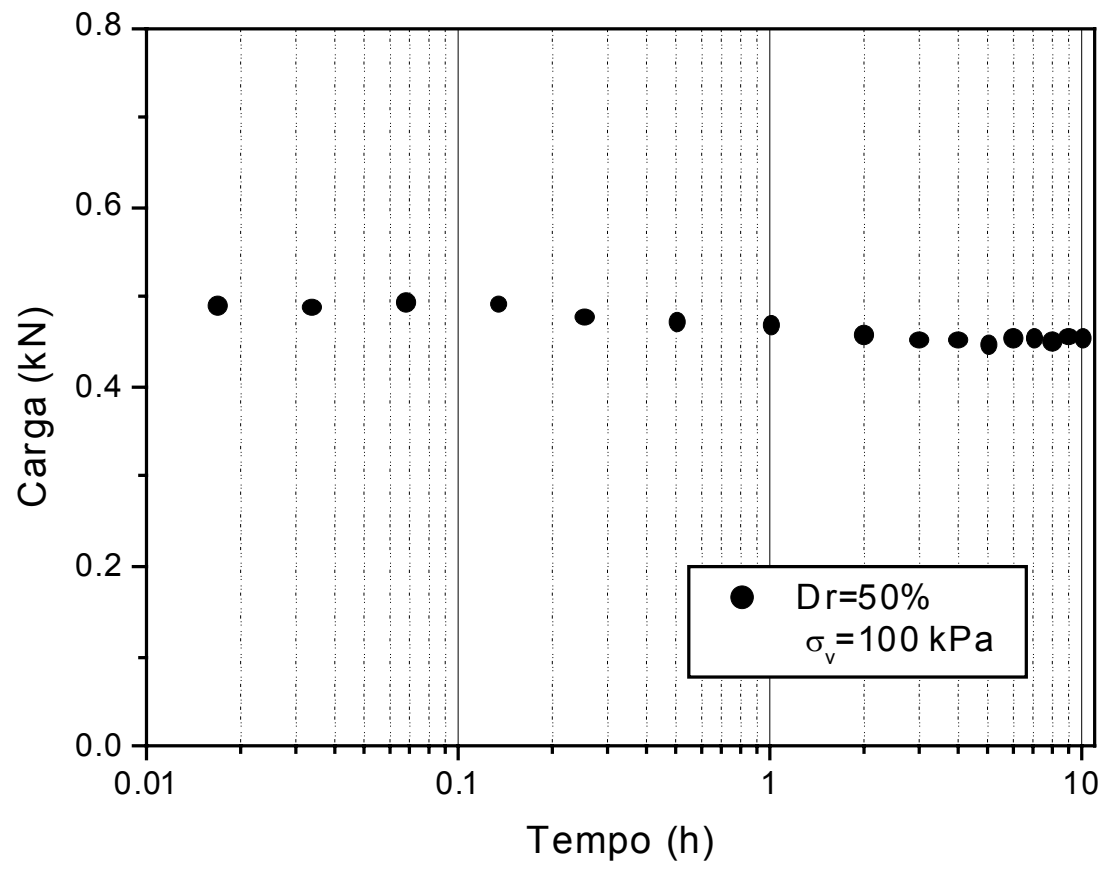

FIGURA 3.62 - Carga x tempo - ensaio SR3R

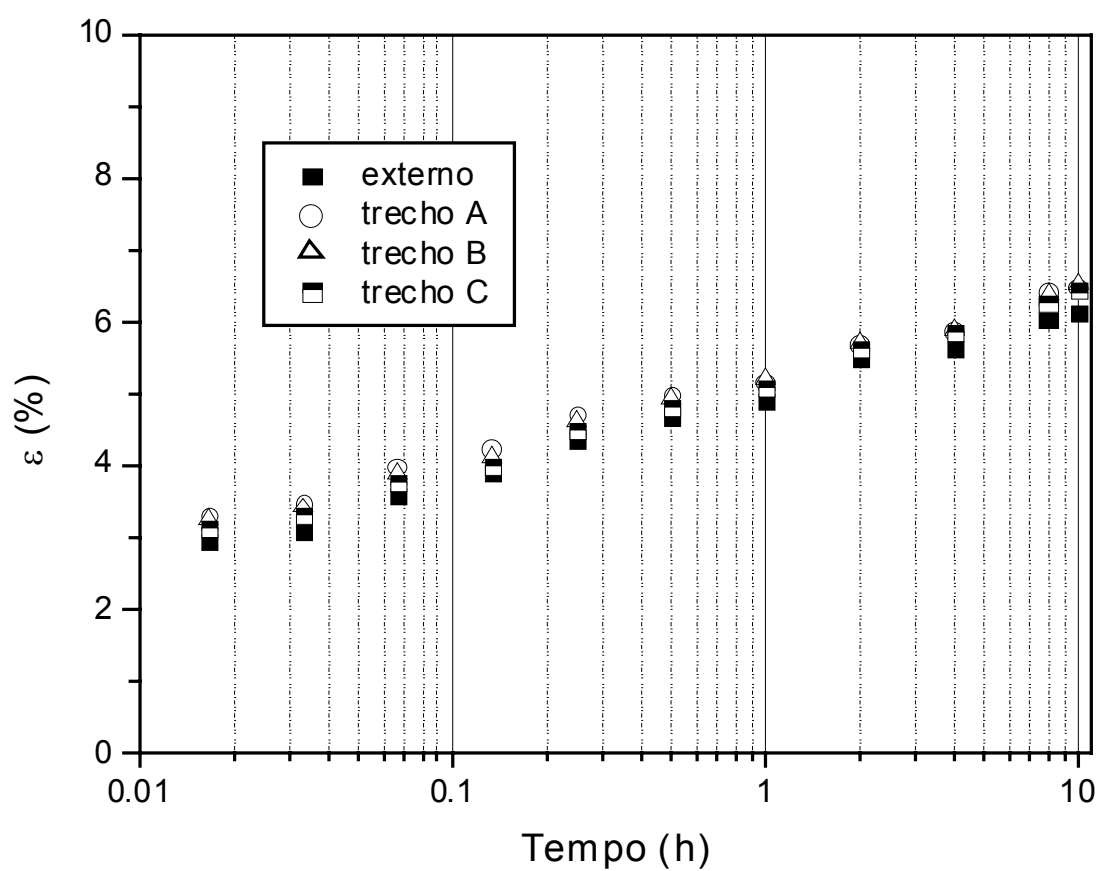

FIGURA 3.63 - Deformação x tempo - ensaio SR3R 


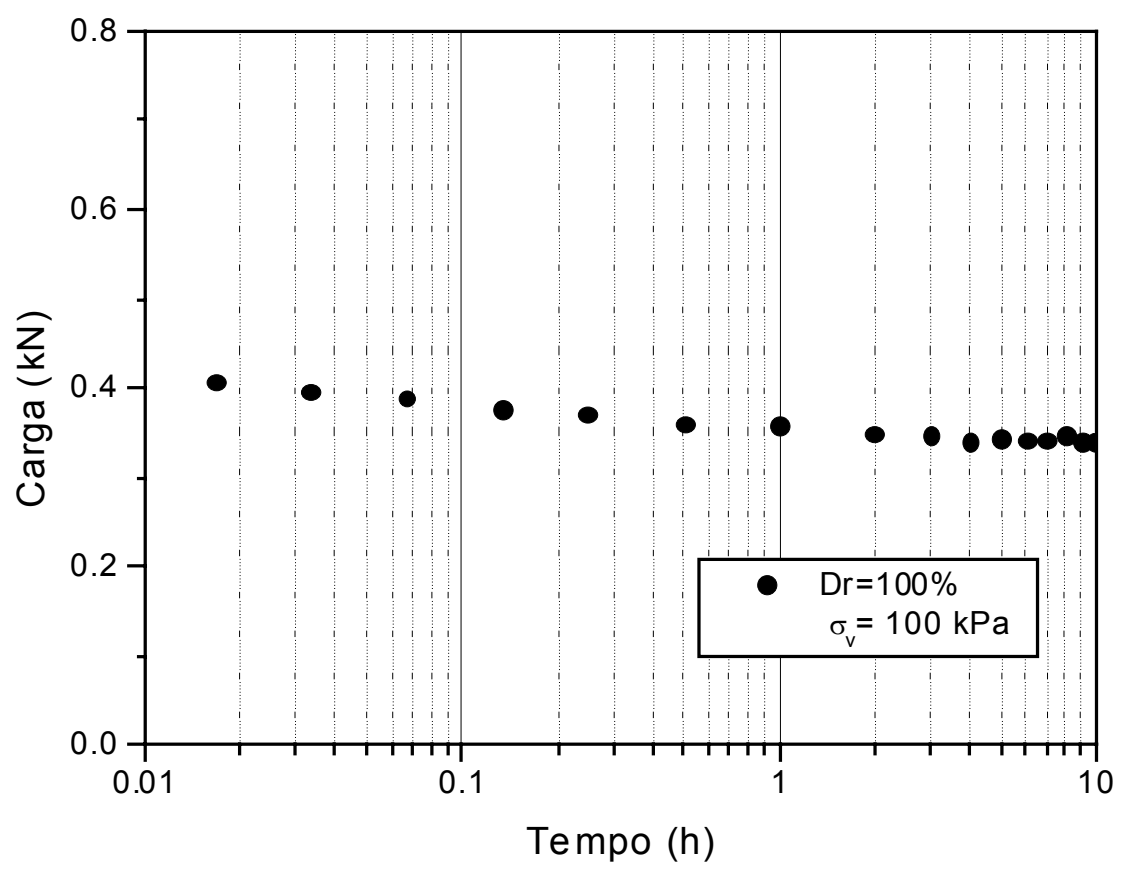

FIGURA 3.64 - Carga x tempo - ensaio SR4

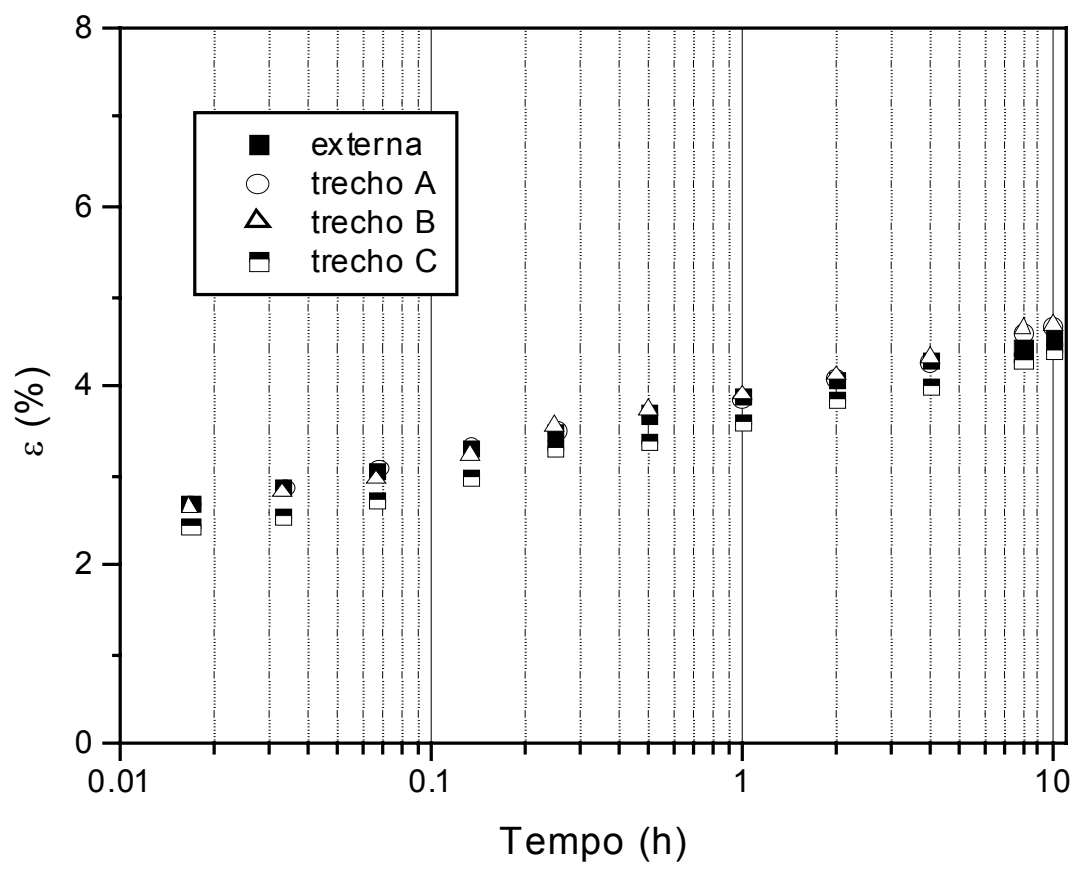

FIGURA 3.65 - Deformação x tempo - ensaio SR4 


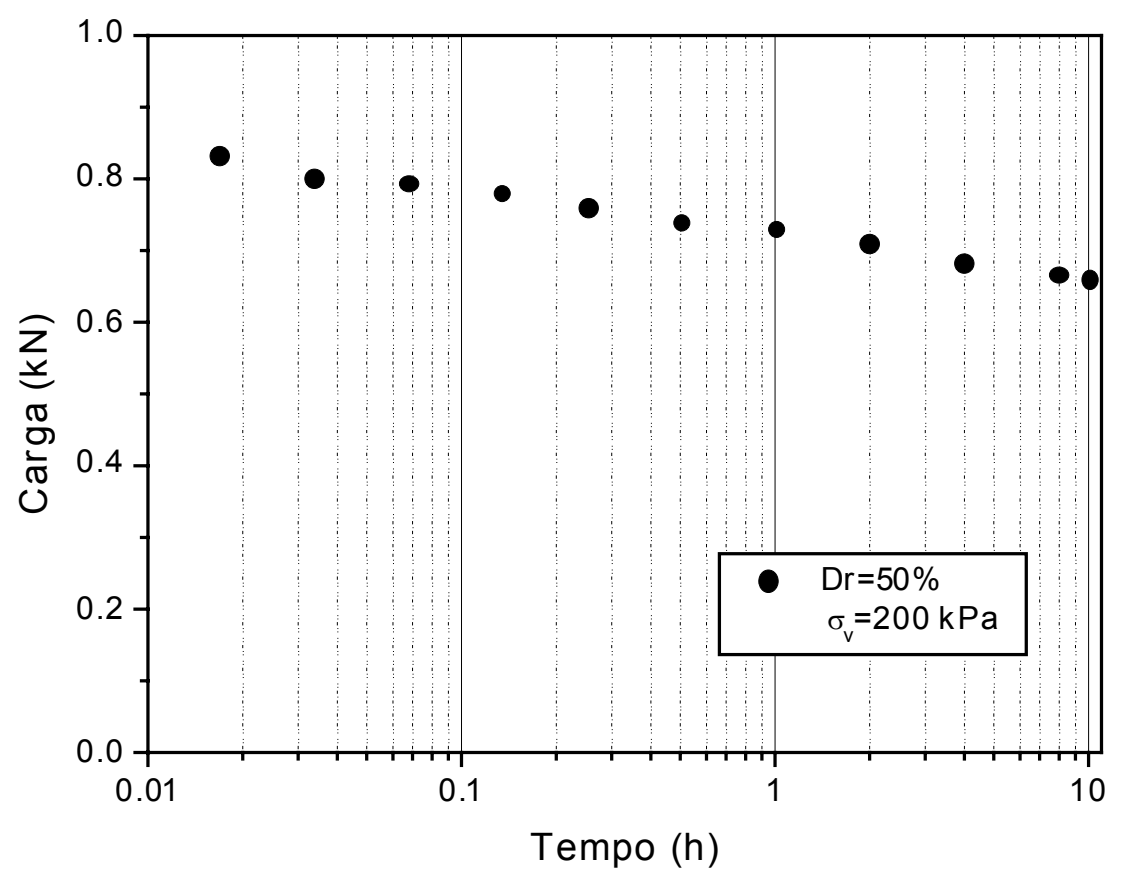

FIGURA 3.66 - Carga x tempo - ensaio SR5

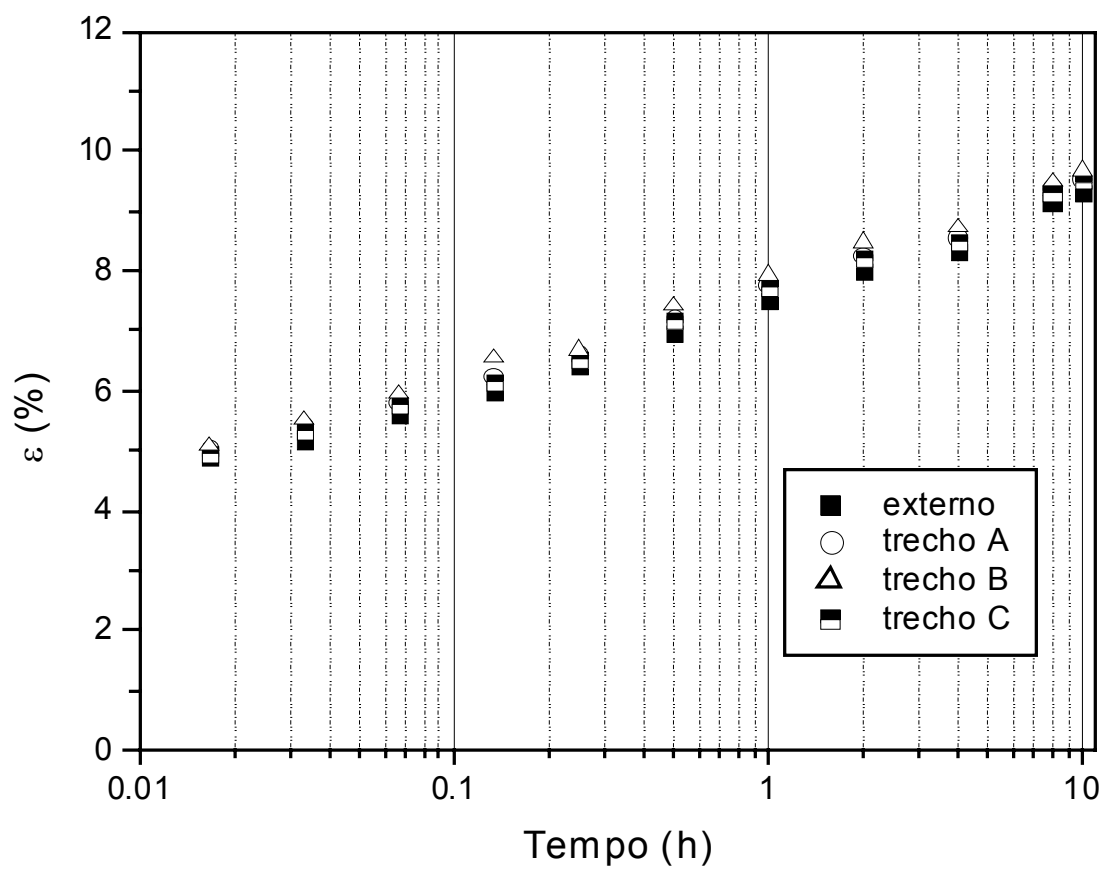

FIGURA 3.67 - Deformação x tempo - ensaio SR5 


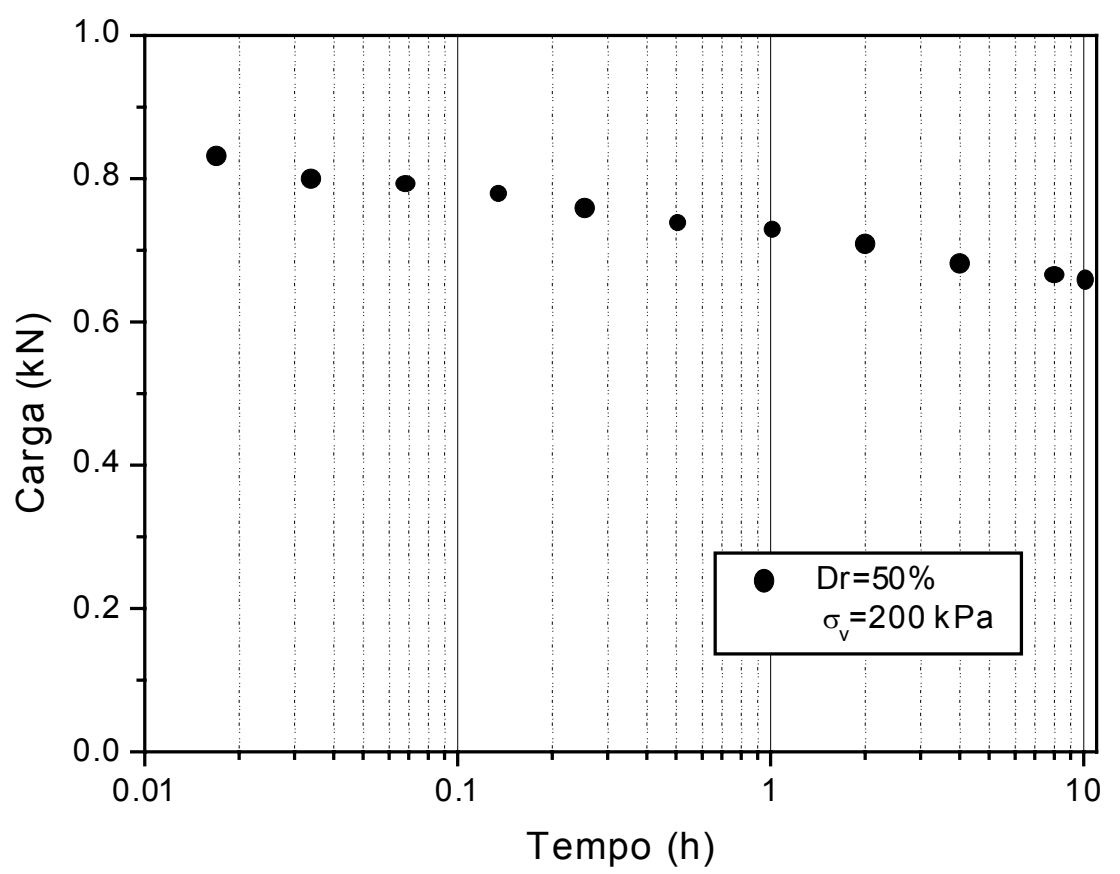

FIGURA 3.68 - Carga x tempo - ensaio SR6R

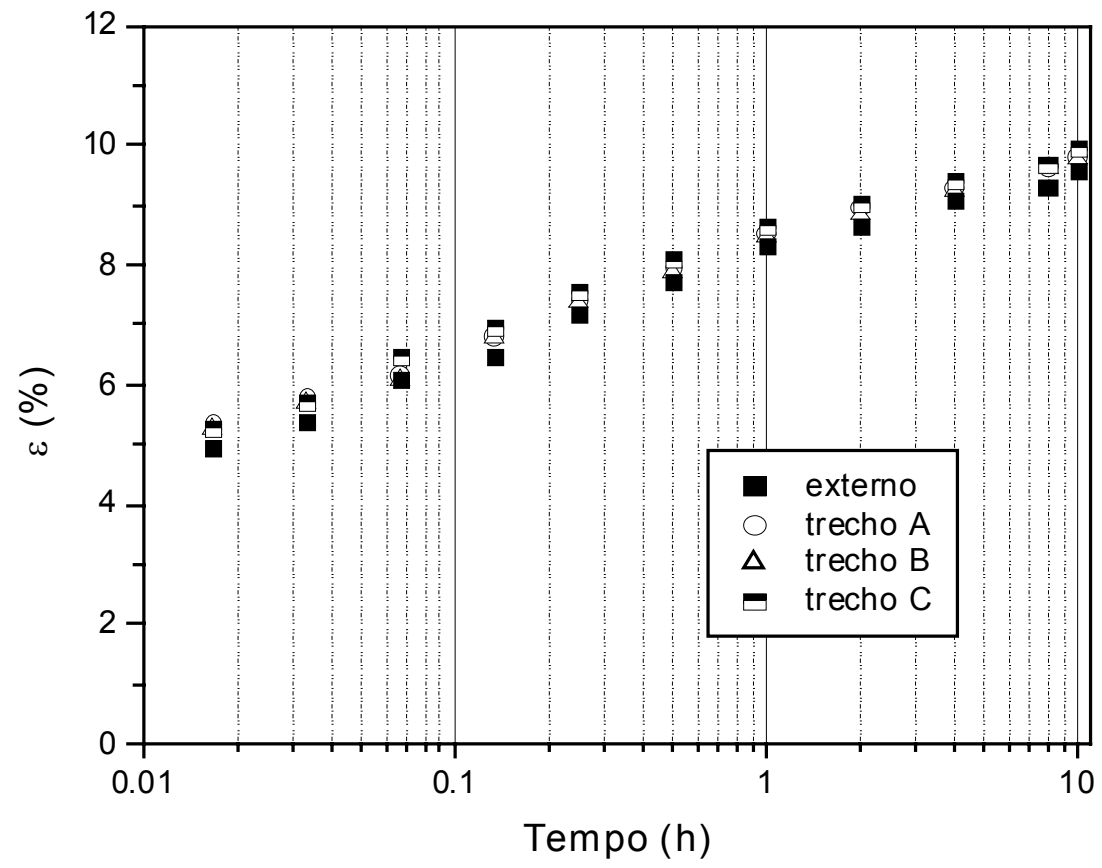

FIGURA 3.69 - Deformação x tempo - ensaio SR6R 
Com relação à carga inicialmente registrada nos ensaios com reforço, o valor obtido foi semelhante ao valor da carga na lateral móvel da caixa, nos ensaios apenas com solo. Nos ensaios SR1, SR2R e SR3R, por exemplo, a carga após 1 min de ensaio foi cerca $0,48 \mathrm{kN}$ enquanto que o valor esperado com base nos ensaios apenas com solo corresponde a $0,47 \mathrm{kN}$ (média entre os ensaios S3, S6R, S8 e S9 para $\varepsilon=3 \%$ ). A carga registrada nos ensaios com o elemento solo-reforço para $\sigma_{\mathrm{v}}=200 \mathrm{kPa}$ apresentou uma maior discrepância, em relação ao valor previsto com base nos ensaios apenas com solo (ensaios S5 e S7R). Nesse caso, a carga nos ensaios com reforço foi aproximadamente $10 \%$ inferior ao valor previsto considerando os ensaios apenas com solo.

Embora a boa concordância obtida para a carga entre ensaios com reforço e apenas com solo demonstre a coerência dos resultados, a questão mais importante a ser discutida diz respeito ao comportamento observado para a força no decorrer do tempo. Nesse sentido, nos ensaios com $\mathrm{Dr}=50 \%$ e $\sigma_{\mathrm{v}}=100 \mathrm{kPa}$ (ensaios SR1, SR2R e SR3R), percebe-se que a carga registrada apresentou uma pequena variação durante o ensaio. A maior variação observada para a carga, em relação ao valor registrado inicialmente ( $\mathrm{t}=1 \mathrm{~min}$ ), ocorreu no ensaio SR2R para o qual houve uma redução de aproximadamente $10 \%$ na carga após $10 \mathrm{~h}$ de ensaio. Nos ensaios com $\sigma_{\mathrm{v}}=200 \mathrm{kPa}$, observou-se uma maior variação ao longo do tempo (uma redução na carga de cerca de $20 \%$ ocorreu após $10 \mathrm{~h}$ ). A Tabela 3.12 mostra a força registrada inicialmente e após $10 \mathrm{~h}$ de ensaio. Os valores mostrados demonstram a boa repetibilidade dos ensaios.

A princípio, os seguintes aspectos poderiam provocar essa redução da carga no reforço ao longo do tempo:

i) aumento no ângulo de atrito mobilizado na massa de solo com o acréscimo de deformação, à medida que o reforço apresenta deformação, em conseqüência de sua tendência à fluência;

ii) variação do ângulo de atrito entre o elemento de solo reforçado e as faces lubrificadas em contato com o mesmo (laterais da caixa e faces em contato com as câmaras de ar). Pois, embora a adição de PTFE à graxa de silicone tenha reduzido, consideravelmente, o aumento do ângulo de atrito 
da graxa com o tempo, alguma variação ainda é possível, como mostrado na Tabela 3.7.

iii) a presença da areia, em contato com o geotêxtil, provoca uma restrição à fluência do reforço, por sua menor tendência à fluência. Essa restrição, por sua vez, resulta em uma diminuição da carga em decorrência do comportamento de relaxação do reforço quando impedido de apresentar deformação.

Para os ensaios com o elemento de solo reforçado aplicando-se $\sigma_{\mathrm{v}}=100 \mathrm{kPa}$ (ensaios SR1, SR2R, SR3R), os resultados dos ensaios apenas com solo realizados sob as mesmas condições (densidade e tensão) afastam a possibilidade citada no item 'i'. Nos ensaios com reforço, a deformação varia aproximadamente de 3,0\% a 6,5\% após 10 h de ensaio. Nesse intervalo de deformação, o ângulo de atrito mobilizado (e conseqüentemente a carga na lateral da caixa) permanece praticamente constante, como pode ser observado nos ensaios apenas com solo (Figuras 3.45, por exemplo). Assim, considera-se que a variação da carga observada nos ensaios não deve ser atribuída à possibilidade descrita no item 'i'.

TABELA 3.12 - Valores registrados para a carga nos ensaios com reforço.

\begin{tabular}{lcccc}
\hline Ensaio & $\sigma_{\mathrm{v}}(\mathrm{kPa})$ & Dr $(\%)$ & Carga inicial $^{*}(\mathrm{kN})$ & Carga após 10h $(\mathrm{kN})$ \\
\hline SR1 & 100 & 50 & 0,48 & 0,44 \\
SR2R & 100 & 50 & 0,49 & 0,44 \\
SR3R & 100 & 50 & 0,49 & 0,46 \\
SR4 & 100 & 100 & 0,41 & 0,34 \\
SR5 & 200 & 50 & 0,84 & 0,66 \\
SR6R & 200 & 50 & 0,85 & 0,68 \\
\hline
\end{tabular}

carga para $\mathrm{t}=1 \mathrm{~min}$.

O segundo aspecto, que poderia provocar a variação da carga com o tempo, relaciona-se à variação do ângulo de atrito do composto graxa + PTFE. O atrito nas faces lubrificadas (tanto nas faces de vidro da caixa, quanto nos contatos com a 
borracha da câmara de ar) limita a movimentação do corpo-de-prova e provoca diminuição da carga registrada em relação à condição de atrito verdadeiramente nulo.

O efeito da variação do ângulo de atrito com o tempo na carga registrada foi estimado, considerando-se que a carga, quando o atrito é nulo $\left(\mathrm{P}_{\mathrm{sa}}\right)$ relaciona-se com a carga registrada $\left(\mathrm{P}_{\mathrm{r}}\right)$ através da expressão (3.6). Embora a carga $\mathrm{P}_{\mathrm{r}}$ possa sofrer alterações em virtude do aumento do ângulo de atrito da graxa, a carga $\mathrm{P}_{\mathrm{sa}}$ deve permanecer constante com o tempo, se a tensão aplicada é mantida constante. Essa asserção é válida desde que a variação do ângulo de atrito da graxa seja o único fator responsável pela variação da carga com o tempo, ou seja, desprezando-se as possibilidades 'i' e 'iii' anteriormente citadas.

$$
\begin{aligned}
& P_{s a}=P_{r}+\tau_{b} A_{b}+\tau_{v} A_{v} \\
& \tau_{b}=\sigma_{n} \cdot \operatorname{tg} \phi_{b} \\
& \tau_{v}=\sigma_{n} \cdot \operatorname{tg} \phi_{v}
\end{aligned}
$$

onde,

$\mathrm{P}_{\mathrm{sa}}-$ Carga sem atrito;

$\mathrm{P}_{\mathrm{r}}$ - Carga registrada pela célula de carga;

$\tau_{\mathrm{b}}, \tau_{\mathrm{v}}-$ tensão cisalhante no contato borracha/membrana de látex e vidro/membrana respectivamente;

$\mathrm{A}_{\mathrm{b}}, \mathrm{A}_{\mathrm{v}}$ - área de atuação de $\tau_{\mathrm{b}}, \tau_{\mathrm{v}}$, respectivamente;

$\sigma_{\mathrm{n}}$ - tensão normal;

$\phi_{\mathrm{b}}, \phi_{\mathrm{v}}$ - ângulo de atrito na interface borracha/membrana e vidro/membrana, respectivamente.

O procedimento utilizado para avaliar o efeito da variação do ângulo de atrito com o tempo na variação da carga registrada envolveu as seguintes etapas: 
1. Estimativa da área de atuação da tensão cisalhante. A inspeção visual do corpo-de-prova indica que ocorreu movimentação relativa (vidro/membrana; borracha/membrana) em grande parte da área total da superfície do corpo-deprova. Assim, considerou-se dois valores para área de atuação da tensão cisalhante, designados doravante: $\mathrm{A}_{1}$ e $\mathrm{A}_{2}$. $\mathrm{A}$ área $\mathrm{A}_{1}$ corresponde ao máximo valor possível, isto é, toda a área do corpo-de-prova $\left(A_{1}=A_{\text {máx }}\right)$. A área $A_{2}$ corresponde à metade da área máxima disponível $\left(\mathrm{A}_{2}=0,5 \mathrm{~A}_{\text {máx }}\right)$.

2. Estimativa da tensão cisalhante, através das expressões (3.7) e (3.8), adotando-se valores de ângulo de atrito com base na Tabela 3.7. A tensão cisalhante foi estimada para duas condições: início e fim do ensaio. Os valores de ângulo de atrito adotados, para o início e para o final do ensaio com o elemento, correspondem a um tempo de espera (ver Tabela 3.7) igual a $0,167 \mathrm{~h}$ e $10 \mathrm{~h}$, respectivamente;

3. Considerando as condições do início do ensaio com o elemento ( $\mathrm{t}=1 \mathrm{~min}$ ), a terceira etapa envolveu o cálculo da carga sem atrito $\left(\mathrm{P}_{\mathrm{sa}}\right)$ através da expressão (3.6). Nesse caso, $\mathrm{P}_{\mathrm{r}}$ corresponde ao valor inicialmente registrado pela célula de carga.

4. Cálculo da carga que seria registrada $\left(\mathrm{P}_{\mathrm{r}}\right)$ após $10 \mathrm{~h}$ de ensaio (carga estimada), também com base na expressão (3.6), adotando-se o valor $\mathrm{P}_{\mathrm{sa}}$ obtido anteriormente na etapa 3 . As tensões de cisalhamento adotadas foram as obtidas na etapa 2, com base nos valores de $\phi$ para um tempo de espera igual a $10 \mathrm{~h}$.

A Tabela 3.13 mostra os valores considerados na estimativa da variação da carga, em virtude do aumento do ângulo de atrito da graxa com o tempo. A Tabela 3.14 apresenta a redução da força registrada pela célula de carga, após $10 \mathrm{~h}$ de ensaios, em relação ao valor inicialmente medido. Essa mesma tabela apresenta também a redução da carga considerando a estimativa efetuada mediante a expressão (3.6). 
TABELA 3.13 - Valores adotados na estimativa de $\mathrm{P}_{\mathrm{r}}$ após $10 \mathrm{~h}$ de ensaio

\begin{tabular}{|c|c|c|}
\hline Interface & $\begin{array}{l}\text { Borracha/ } \\
\text { membrana }\end{array}$ & $\begin{array}{c}\text { Vidro/ } \\
\text { membrana }\end{array}$ \\
\hline Ângulo de atrito inicial, $\phi_{\mathrm{b}}, \phi_{\mathrm{v}}\left({ }^{0}\right)$ & 2,0 & 3,3 \\
\hline Ângulo de atrito após $10 \mathrm{~h}, \phi_{\mathrm{b}}, \phi_{\mathrm{v}}\left(^{0}\right)$ & 2,8 & 3,8 \\
\hline \multirow[t]{2}{*}{ Área, $A_{b}, A_{v}\left(m^{2}\right)$} & 0,04 & 0,04 \\
\hline & 0,02 & 0,02 \\
\hline
\end{tabular}

A comparação entre o valor da redução da carga, com base em estimativas, e o valor, de fato, registrado nos ensaios revela que existe grande possibilidade da variação da carga, com o tempo, ocorrer em virtude do aumento do ângulo de atrito da graxa. A magnitude da redução com base na estimativa efetuada permite ainda supor que toda a variação observada nos ensaios deve-se, exclusivamente, ao efeito do atrito nas faces do corpo-de-prova. Essa constatação reduz a possibilidade de ocorrência do efeito inicialmente cogitado no item 'iii'.

TABELA 3.14 - Redução da carga após 10 h em relação ao valor inicial.

\begin{tabular}{ccc}
\hline $\begin{array}{c}\text { Redução da carga - valores medidos pela } \\
\text { célula de carga }\end{array}$ & $\begin{array}{c}\text { Redução da carga - estimativa para } \\
\text { carga após } 10 \mathrm{~h}\end{array}$ \\
\hline $8 \%$ & Área considerada & Redução \\
& $\mathrm{A}_{1}$ & $15 \%$ \\
$\mathrm{~A}_{2}$ & $5 \%$ \\
\hline
\end{tabular}

* valor médio considerando ensaios SR1, SR2R, SR3R.

O aspecto citado no item 'iii' mesmo que tenha ocorrido, não foi significativo nos ensaios efetuados. Principalmente, analisando-se os resultados obtidos nos ensaios de relaxação do reforço (Figura 3.70). No ensaio de relaxação R2, por exemplo, ocorreu uma redução da força que pode ser suportada pelo reforço após $10 \mathrm{~h}$ de ensaio, igual a $50 \%$, demonstrando o enorme potencial de diminuição da 
carga no reforço quando sua deformação é impedida. A redução da carga nos ensaios com o elemento de solo reforçado foi, no entanto, bem inferior ao que se poderia esperar, se a presença de solo impedisse as deformações no decorrer do tempo. Os resultados observados nos ensaios com o elemento de solo reforçado apresentaram-se mais próximos dos resultados de fluência do reforço do que dos ensaios de relaxação.

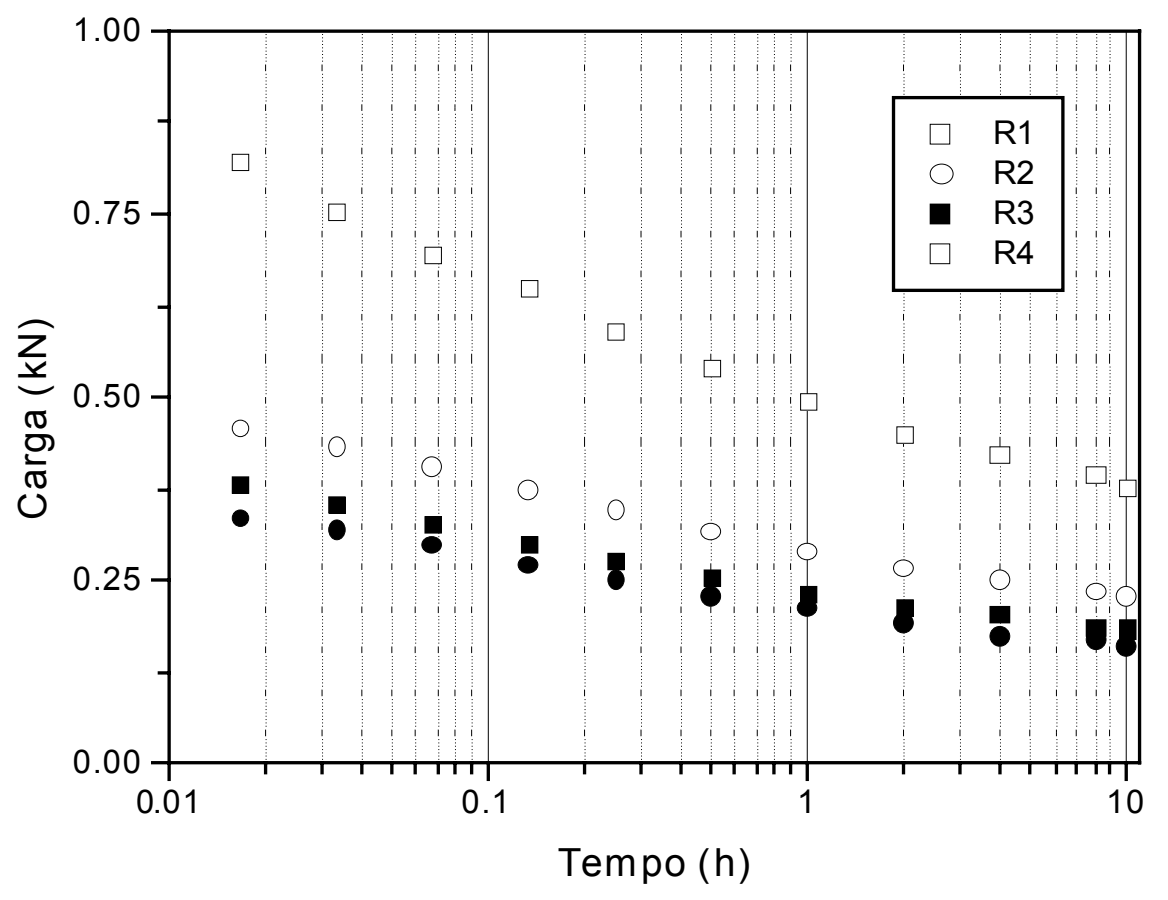

FIGURA 3.70 - Resultados dos ensaios de relaxação

A Figura 3.71 apresenta os valores de deformação obtidos nos ensaios de fluência do reforço e as deformações no ensaio com o elemento de solo reforçado SR3R o qual apresentou a menor variação de carga ao longo do tempo (6\%). A carga aplicada nos ensaios de fluência corresponde a $0,5 \mathrm{kN}$, enquanto que no ensaio com o elemento de solo reforçado, a carga inicialmente registrada foi igual a 0,49 $\mathrm{kN}$. As deformações mostradas para o ensaio SR3R correspondem à média dos valores nos diversos trechos instrumentados. 


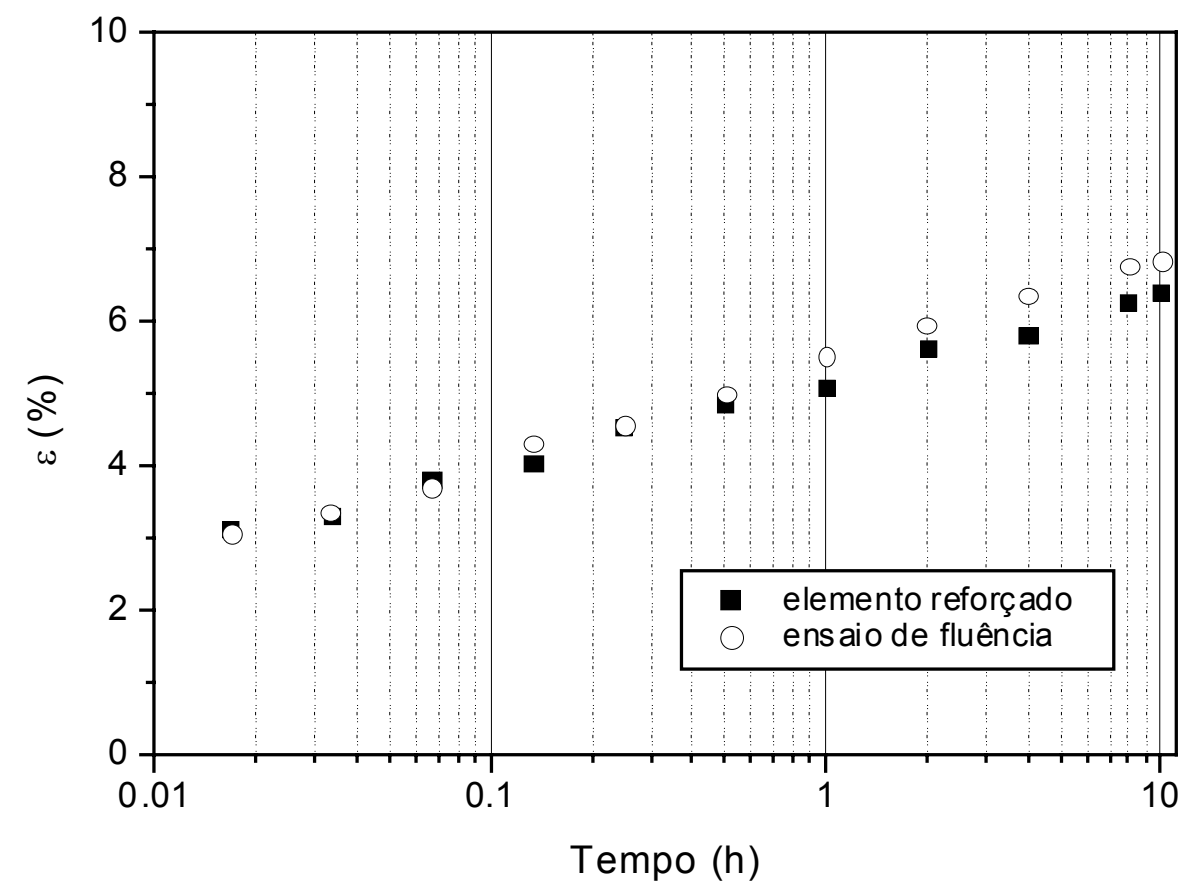

FIGURA 3.71 - Comparação entre as deformações ao longo do tempo, obtidas em diferentes tipos de ensaio.

A Figura 3.71 mostra que o comportamento obtido no ensaio com o elemento de solo reforçado aproxima-se bem do comportamento observado nos ensaios convencionais de fluência do reforço. As diferenças entre os valores de deformação nas duas situações são esperadas, uma vez que a carga no ensaio com o elemento apresenta um decréscimo ao longo do tempo.

Nos ensaios com o elemento de solo reforçado para uma tensão vertical igual a $200 \mathrm{kPa}$ (SR5 e SR6R), a possibilidade de aumento do ângulo de atrito mobilizado na massa de solo com o acréscimo da deformação, como descrito no item 'i', não deve ocorrer. Tal afirmação baseia-se no fato de que, nos ensaios com reforço, a deformação variou de $5 \%$ a $10 \%$, e tomando-se por base os ensaios apenas com solo (S5 e S7R), não seria esperada uma diminuição na carga para esse intervalo de deformação.

O resultado da estimativa do efeito da variação do ângulo de atrito da graxa para os ensaios com $\sigma_{\mathrm{v}}=200 \mathrm{kPa}$, utilizando-se a expressão (3.6) e adotando-se o 
mesmo procedimento descrito anteriormente, é exposto na Tabela 3.15. Os parâmetros adotados na estimativa são mostrados na Tabela 3.16.

Os resultados da Tabela 3.15 demonstram, mais uma vez, a possibilidade do comportamento do ângulo de atrito da graxa ser responsável pela variação da carga com tempo, sem a necessidade de ocorrência da hipótese citada no item 'iii'.

TABELA 3.15 - Redução da carga após 10 h, em relação ao valor inicial para os ensaios SR5 e SR6R.

Redução da carga - valores medidos ${ }^{*} \quad$ Redução da carga - estimativa para carga após $10 \mathrm{~h}$

Área considerada Redução

\begin{tabular}{rcc}
$20,7 \%$ & $\mathrm{~A}_{1}$ & $30 \%$ \\
& $\mathrm{~A}_{2}$ & $15 \%$ \\
\hline
\end{tabular}

* valor médio considerando os ensaios SR5 e SR6R

TABELA 3.16 - Valores adotados na estimativa de $\mathrm{P}_{\mathrm{r}}$ após $10 \mathrm{~h}$ de ensaio.

\begin{tabular}{|c|c|c|}
\hline Interface & $\begin{array}{l}\text { Borracha/ } \\
\text { membrana }\end{array}$ & $\begin{array}{c}\text { Vidro/ } \\
\text { membrana }\end{array}$ \\
\hline Ângulo de atrito inicial, $\phi_{\mathrm{b}}, \phi_{\mathrm{v}}\left({ }^{0}\right)$ & 1,7 & 1,0 \\
\hline Ângulo de atrito após $10 \mathrm{~h}, \phi_{\mathrm{b}}, \phi_{\mathrm{v}}\left({ }^{0}\right)$ & 3,2 & 1,4 \\
\hline \multirow[t]{2}{*}{ Área, $A_{b}, A_{v}\left(m^{2}\right)$} & 0,04 & 0,04 \\
\hline & 0,02 & 0,02 \\
\hline
\end{tabular}

A Figura 3.72 apresenta uma comparação entre as deformações registradas no ensaio SR6R e as obtidas nos ensaios convencionais de fluência do reforço, aplicando-se um carregamento equivalente à carga inicialmente registrada no ensaio SR6R. As deformações do ensaio SR6R correspondem à média dos valores 
registrados nos diversos trechos instrumentados. A diferença entre os dois tipos de ensaios pode ser justificada pela redução da carga em virtude da variação do ângulo de atrito da graxa. Assim, os resultados de todos os ensaios realizados no equipamento desenvolvido indicam que a simples presença de solo confinando o reforço não teve a capacidade de restringir as deformações do reforço, no decorrer do tempo, em virtude de sua, possível, menor tendência à fluência em relação ao reforço.

Considera-se que os resultados presentes na literatura que relatam que a presença de uma areia pura eliminou a fluência do reforço, baseados em equipamentos nos quais o solo solicita o reforço, não foram devidamente interpretados. O equipamento desenvolvido por WU \& HELWANY (1996), por exemplo, não possuía um dispositivo para acompanhar a carga no reforço ao longo do tempo, sendo a mesma estimada apenas no início do ensaio, como base na deformação dos strain gages e nos ensaios de tração do reforço. Contudo, como mostrado no presente trabalho, a manutenção da tensão vertical constante, no decorrer do tempo, não garante que a carga no reforço permanece constante. No ensaio conduzido por WU \& HELWANY (1996), a carga no reforço, certamente, apresentou variações ao longo do tempo, seja por variação do ângulo de atrito mobilizado no solo, seja por variações do ângulo de atrito da graxa de silicone utilizada para lubrificação das faces da caixa. Neste último caso, principalmente, considerando-se que nenhuma medida foi adotada para reduzir as variações do ângulo de atrito da graxa, como a adição de pó de teflon, e a ausência de teflon pode provocar uma variação acentuada da força com o tempo.

A análise conduzida por WU \& HELWANY (1996) consiste em comparar os ensaios convencionais de fluência do geotêxtil e os realizados com o elemento de solo reforçado e atribuir, imediatamente, as diferenças observadas ao fato da menor tendência do solo restringir as deformações do reforço, sem efetuar uma análise mais ampla. Seria o equivalente, no caso deste trabalho, a afirmar que as menores deformações no ensaio com o elemento, observadas na Figura 3.72, são devidas à restrição causada pela menor tendência à fluência do solo. Como já discutido anteriormente, na realidade, a carga diminui com o tempo e provoca as diferenças mostradas na Figura 3.72. O mesmo comportamento observado nos ensaios com o 
reforço confinado entre as camadas de areia poderia ser obtido com o reforço isolado, desde que a mesma trajetória de carregamento fosse aplicada.

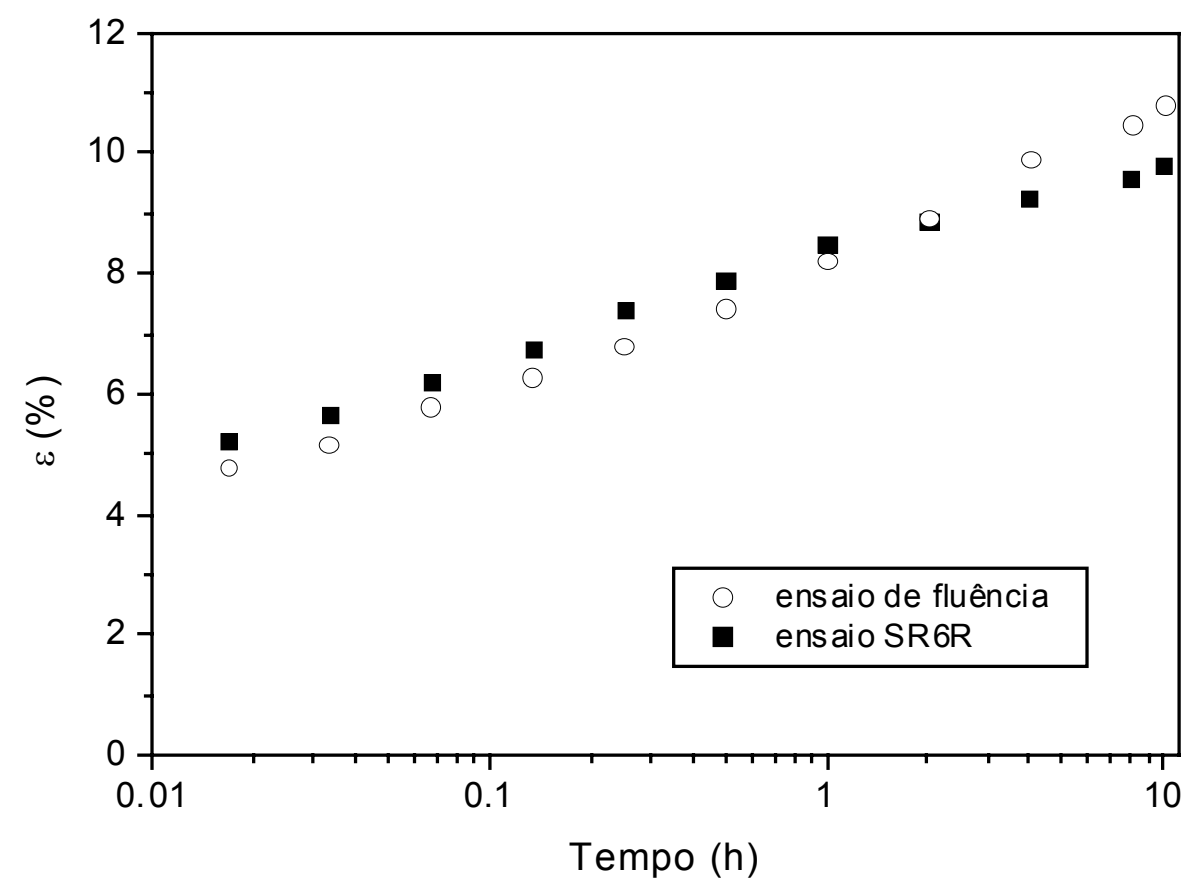

FIGURA 3.72 - Comparação entre as deformações obtidas no ensaio SR6R e em ensaios de fluência.

A Figura 3.73 expõe as deformações obtidas no ensaio SR6R e em um ensaio utilizando o equipamento mostrado na Figura 3.30, como se fosse um ensaio de fluência, a menos pela diminuição da carga com o tempo através da retirada de pesos ao longo do teste. A Figura 3.74 mostra a trajetória da carga adotada no ensaio com descarregamento para simular a redução apresentada no ensaio SR6R. A boa concordância entre os resultados apresentados na Figura 3.73 indica que a diferença observada na Figura 3.72 deve-se ao fato da carga não permanecer constante no ensaio com o elemento. Essa variação da carga ocorre em função do comportamento da graxa e não, por impedimento do solo. 


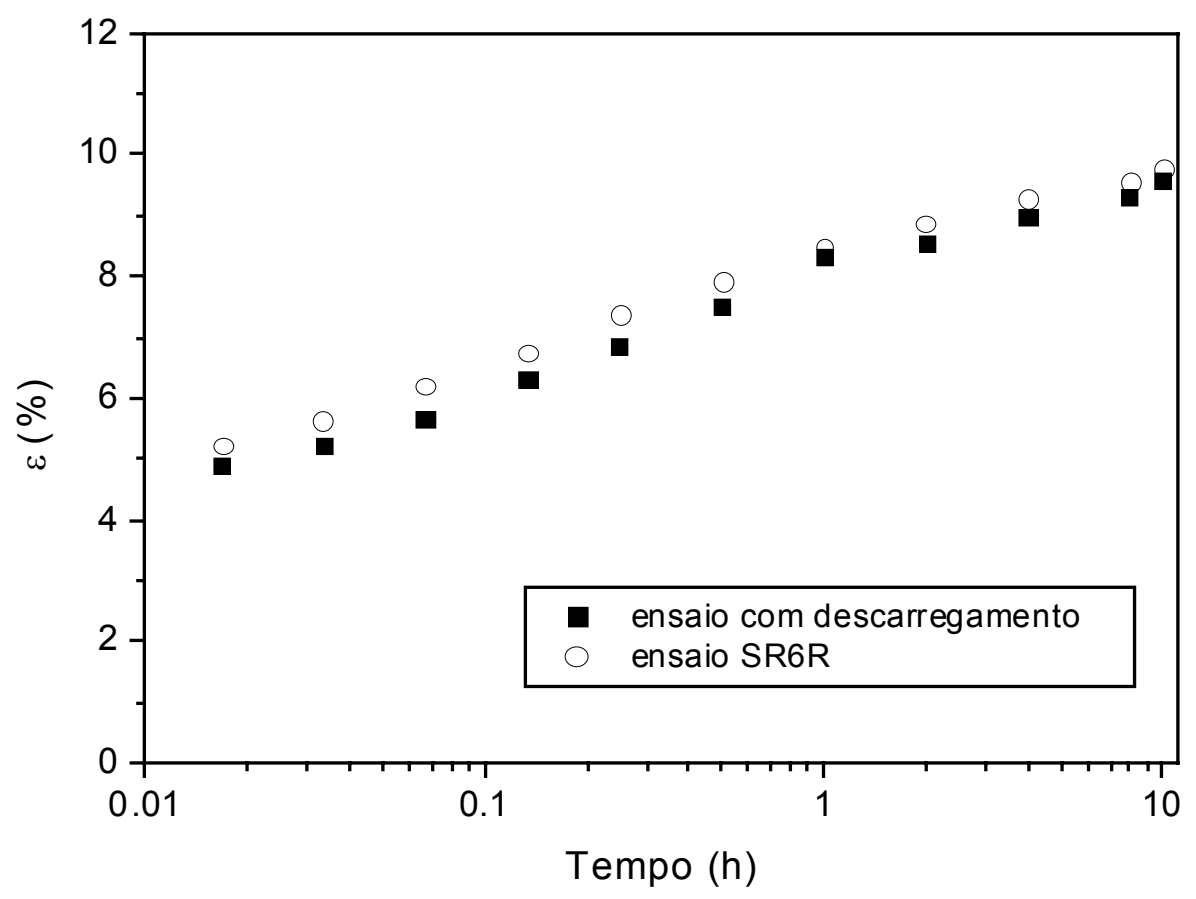

FIGURA 3.73 - Comparação entre ensaio SR6R e ensaio com descarregamento.

Uma outra questão, que, certamente, afasta a hipótese da simples presença do solo restringir a deformação do reforço nos ensaios com o elemento, é o fato da carga no reforço ser o resultado da solicitação do solo. Considerando uma situação hipotética na qual o solo impediria completamente a fluência do geotêxtil (provocando um valor de deformação constante com o tempo) ter-se-ia relaxação no reforço. Sendo assim, a carga que o geotêxtil suportaria diminuiria com o tempo. Por outro lado, desprezando-se os efeitos de atrito nos contatos do corpo-de-prova com a caixa, se a deformação permanecesse constante, a solicitação imposta pelo solo no reforço também permaneceria constante. Essa situação equivale a uma força requerida pelo solo diferente da força no reforço, refutando a hipótese inicialmente considerada.

É importante ainda destacar que as deformações obtidas nos ensaios com o elemento solo-reforço foram próximas às esperadas com base nos ensaios convencionais de fluência. No entanto, isso não corresponde ao comportamento típico que deve ser esperado em ensaios com equipamentos semelhantes ao 
desenvolvido neste trabalho. Esse resultado deve-se ao comportamento do solo, do reforço, das condições escolhidas para os ensaios e, principalmente, do cuidado na redução da variação do ângulo de atrito da graxa com o tempo. Os resultados de ensaios com elementos de solo reforçado podem apresentar uma elevada diminuição da carga no reforço, ao longo do tempo, como mostrado em alguns trabalhos (BOYLE, 1995; HELWANY \& SHIH, 1998).

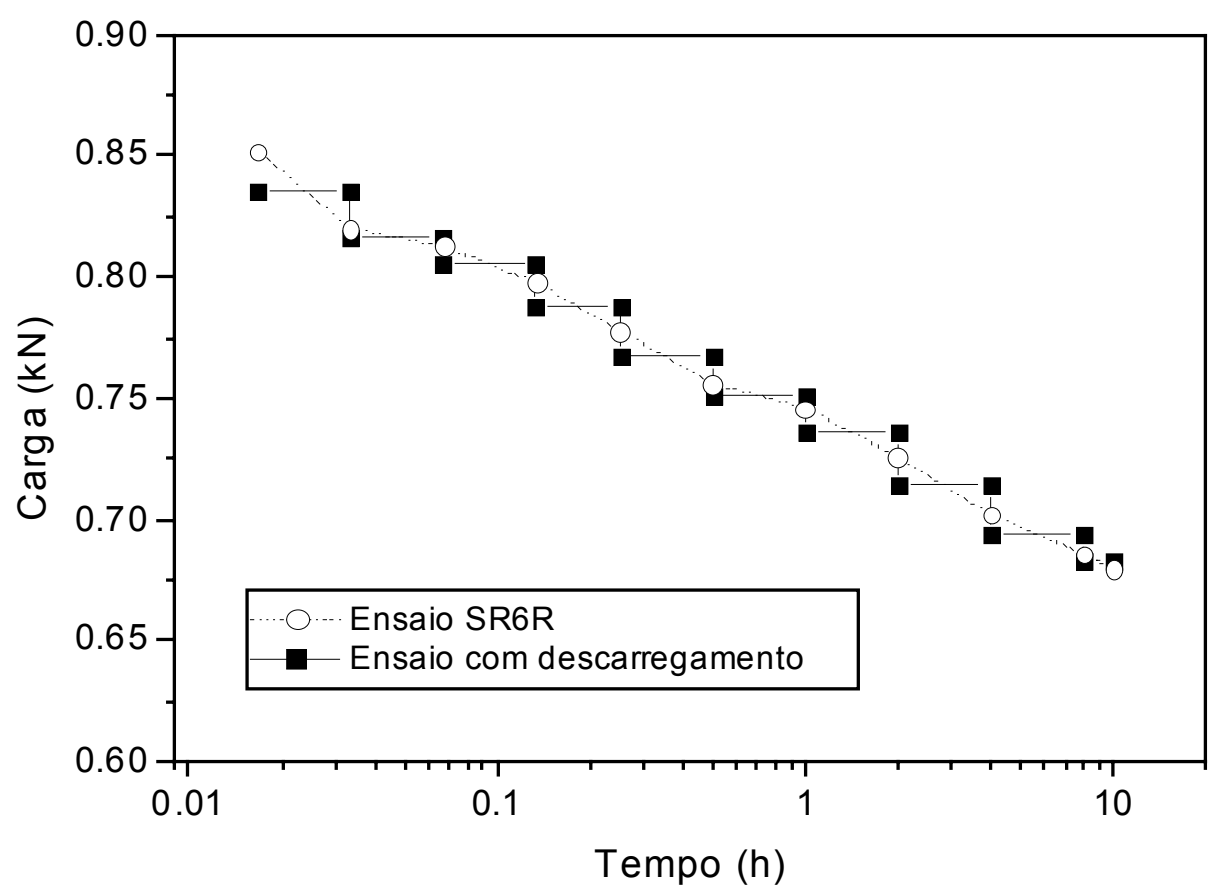

FIGURA 3.74 - Variação da carga no ensaio SR6R e no ensaio com descarregamento.

A Figura 3.75 mostra, por exemplo, a redução da carga no reforço obtida por BOYLE (1995) em um ensaio com o equipamento anteriormente descrito no capítulo 2 (Figura 2.16). Nesse ensaio, utilizou-se uma areia e um geotêxtil tecido de PP, sendo a tensão vertical $\left(\sigma_{1}\right)$ aumentada e então mantida constante por um determinado intervalo de tempo. Com a tensão constante, a deformação lateral do corpo-de-prova $\left(\varepsilon_{3}\right)$ aumentou e a carga no reforço sofreu uma diminuição de $13 \%$ em apenas 25 min. Essa redução é bem maior que a verificada no presente trabalho e, certamente, a comparação da deformação lateral, ao longo do tempo, com resultados 
de ensaios de fluência do reforço, embora não realizada pelos autores, indicaria resultados bastante discrepantes.

Em resultados como os mostrados na Figura 3.75, o importante é reconhecer que se houve uma diminuição da carga dessa magnitude é porque, com o acréscimo de deformação com o tempo, o solo aumentou sua resistência, mobilizando um maior ângulo de atrito, e/ou houve um aumento da força de atrito nas faces da caixa resultando, conseqüentemente, no decréscimo da carga reforço. A hipótese de que apenas a presença de uma areia pura confinando o reforço é suficiente para reduzir suas deformações, no decorrer do tempo, não está de acordo com os resultados encontrados neste trabalho.

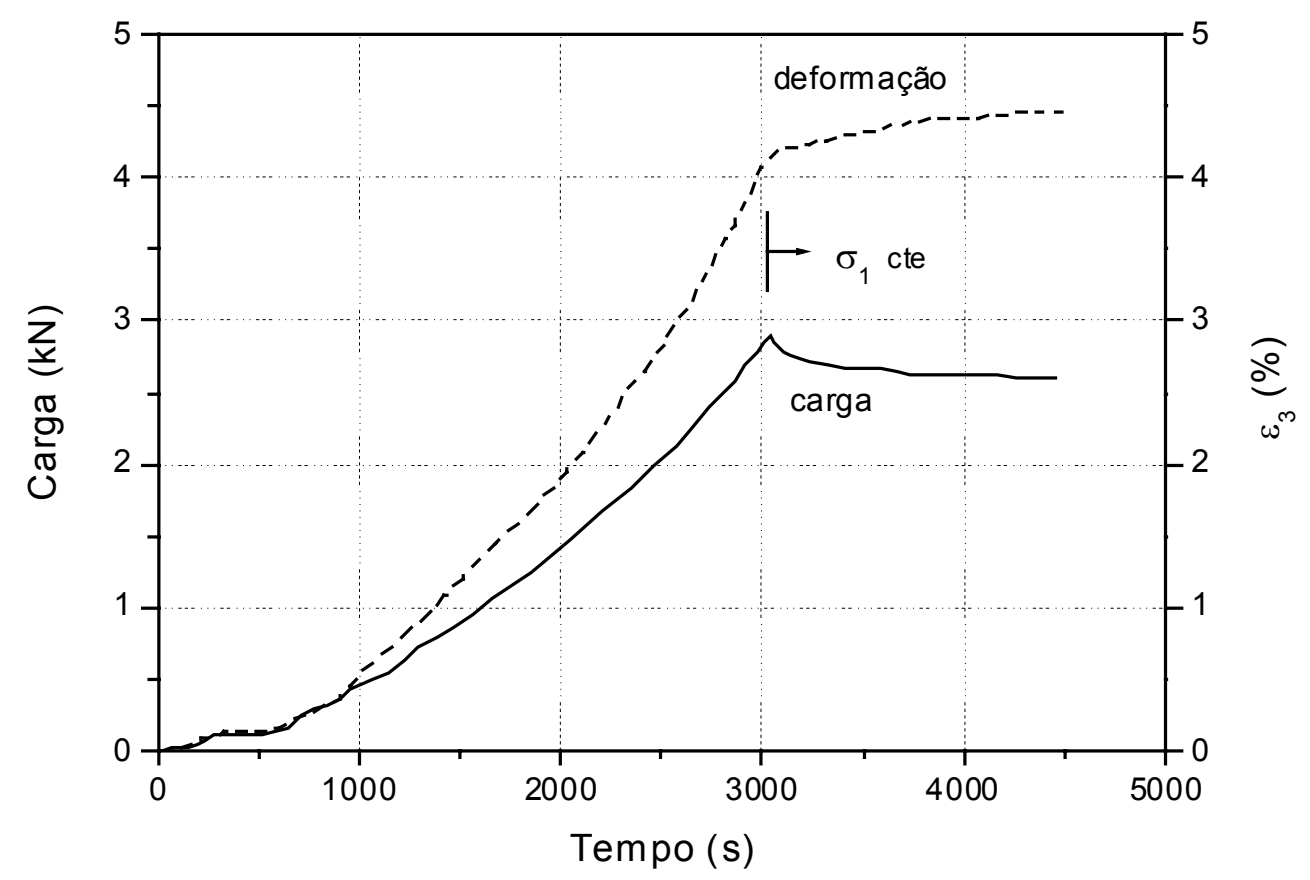

FIGURA 3.75 - Resultado obtido em um ensaio utilizando o equipamento desenvolvido por BOYLE (1995).

Possivelmente, conforme relatado anteriormente, o mecanismo de deformação presente em estruturas de solo reforçado deve envolver deformações, ao longo do tempo, com variação da carga no reforço, como observado nos ensaios 
conduzidos por BOYLE (1995). Por essa razão, HELWANY \& SHIN (1998) consideram essencial a realização de ensaios em longo prazo, em laboratório, com elementos de solo reforçado. Nesse sentido, o aparelho desenvolvido foi de suma importância para esclarecer e facilitar as discussões sobre os mecanismos que podem se desenvolver no decorrer do tempo. A utilização desse tipo de equipamento como ferramenta para a previsão do comportamento de uma determinada estrutura de solo reforçado ao longo do tempo constitui uma questão importante e será discutida posteriormente no capítulo 5 . 


\section{Investigação das deformações ao longo do tempo em muros de solo reforçado através de ensaios em centrífuga}

Este capítulo apresenta as atividades relativas à segunda parte do trabalho conduzida na Universidade do Colorado. No programa experimental desenvolvido, modelos de muros de solo reforçado foram construídos e ensaiados em centrífuga para investigar os efeitos do comportamento dependente do tempo do reforço nas deformações da estrutura. A fim de elucidar a abordagem utilizada nessa etapa da pesquisa, uma breve discussão sobre princípios de modelagem em centrífuga é inicialmente efetuada. Os materiais e métodos utilizados nos ensaios são descritos em seguida e os resultados apresentados e discutidos.

\subsection{Princípios e limitações de modelos físicos em centrífuga}

Uma grande variedade de problemas geotécnicos pode ser adequadamente investigada através da construção de modelos físicos em centrífuga. E naturalmente, estudos utilizando centrífugas geotécnicas têm contribuído significativamente para o entendimento do comportamento de estruturas de solo reforçado com geossintéticos (ex. MITCHELL et al., 1988; PORBANA \& GOODINGS, 1994; BARKER et al., 1996; SHAHAR \& FRYDMAN, 2002; ZHANG et al., 2002; ARRIAGA, 2003, WOODRUFF, 2003). 
A importância da modelagem em centrífuga em problemas geotécnicos devese principalmente ao fato do comportamento do solo ser dependente do estado de tensão. A utilização de modelos reduzidos sob as condições normais de gravidade (1 g), por exemplo, não permite que o comportamento do solo seja devidamente simulado, pela impossibilidade de reprodução da distribuição de tensão que ocorre devido ao peso próprio do solo presente na estrutura em escala real (protótipo). Em oposição, os modelos ensaiados dentro de uma centrífuga são submetidos a uma aceleração radial que simula um campo de aceleração gravitacional muitas vezes superior ao campo gravitacional exercido pela terra, permitindo uma reprodução mais adequada das tensões presentes no protótipo (TAYLOR, 1995).

\subsubsection{Leis de escala}

Para que um modelo reduzido possa simular adequadamente o comportamento de um determinado protótipo, algumas leis de escala precisam ser observadas. A tensão no modelo $\left(\sigma_{\mathrm{m}}\right)$, por exemplo, deve ser igual à tensão no protótipo $\left(\sigma_{\mathrm{p}}\right)$. A Figura 4.1 mostra a tensão vertical no protótipo atuante a uma profundidade $z_{p}$ e a tensão no modelo no ponto correspondente a uma profundidade $\mathrm{Z}_{\mathrm{m}}$.

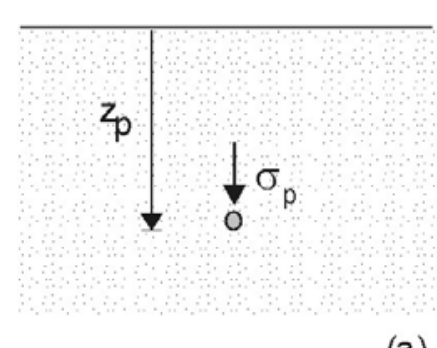

(a)

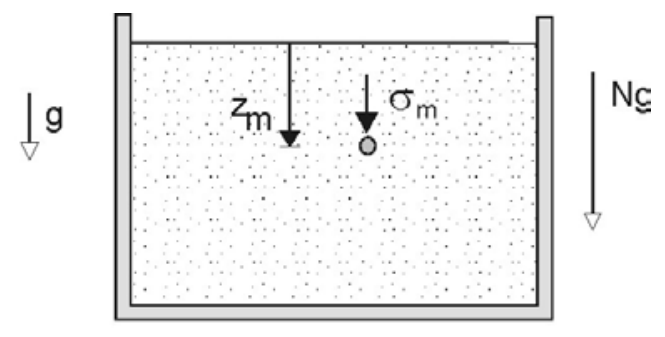

(b)

FIGURA 4.1 - Tensões verticais (a) no protótipo (b) no modelo 
Nos modelos, se uma aceleração $\mathrm{N}$ vezes superior à aceleração gravitacional (g) exercida pela terra atua na centrífuga, a tensão vertical $\left(\sigma_{\mathrm{m}}\right)$ no modelo a uma profundidade $\mathrm{z}_{\mathrm{m}}$ é dada pela expressão (4.1). Por outro lado, no protótipo, a tensão vertical $\left(\sigma_{\mathrm{p}}\right)$ a uma profundidade $\mathrm{z}_{\mathrm{p}}$ é dada pela expressão (4.2).

$$
\begin{aligned}
& \sigma_{\mathrm{m}}=\rho \cdot \mathrm{N} \cdot \mathrm{g} \cdot \mathrm{z}_{\mathrm{m}} \\
& \sigma_{\mathrm{p}}=\rho \cdot \mathrm{g} \cdot \mathrm{z}_{\mathrm{p}}
\end{aligned}
$$

onde,

$\rho$ - massa específica do material (o mesmo material é utilizado no modelo e no protótipo).

Como a tensão no modelo deve ser igual à tensão no protótipo $\left(\sigma_{\mathrm{m}}=\sigma_{\mathrm{p}}\right)$, para que o comportamento do modelo seja representativo do comportamento do protótipo, a relação indicada na expressão (4.3) precisa ser obedecida, ou seja, as dimensões do modelo precisam ser reduzidas e o fator de escala a ser aplicado entre as dimensões do modelo e do protótipo corresponde a $1 / \mathrm{N}$.

$$
\mathrm{Z}_{\mathrm{m}}=\frac{\mathrm{Z}_{\mathrm{p}}}{\mathrm{N}}
$$

Alguns fatores de escala, de caráter geral, utilizados em modelos em centrífuga são mostrados na Tabela 4.1. Maiores detalhes sobre leis de escala e modelagem em centrífuga podem ser encontrados em TAYLOR (1995) e SCHOFIELD (1980). 
TABELA 4.1 - Fatores de escala utilizados em modelagem em centrífuga ${ }^{*}$

\begin{tabular}{lc}
\hline \multicolumn{1}{c}{ Grandeza } & Modelo \\
\cline { 2 - 2 } Tensão & Prótipo \\
Deformação & 1 \\
Comprimento & $1 / \mathrm{N}$ \\
Massa & $1 / \mathrm{N}^{3}$ \\
Massa Específica & 1 \\
Força & $1 / \mathrm{N}^{2}$ \\
Aceleração inercial & $\mathrm{N}$
\end{tabular}

\section{Consolidação}

Tempo

$1 / \mathrm{N}^{2}$

Taxa de deformação

$1 / \mathrm{N}^{2}$

\section{Fluência}

Deformação 1

Taxa de deformação 1

Assumindo-se que o mesmo solo é utilizado no modelo e no protótipo

A Tabela 4.2 apresenta os fatores de escala utilizados na modelagem de estruturas de solo reforçado e que podem ser deduzidos das relações gerais mostradas na Tabela 4.1. Nessas relações, está implícito que o mesmo solo é utilizado no modelo e no protótipo e os reforço utilizados são elementos planos para os quais a resistência é dada em força por unidade de comprimento. Destaca-se que para garantir as condições de similitude, o reforço precisa ser substituído no modelo por uma material bem menos resistente, com resistência $\mathrm{N}$ vezes inferior à resistência do reforço no protótipo. 
TABELA 4.2 -Fatores de escala para estruturas de solo reforçado (ZORNBERG et al., 1997).

\begin{tabular}{|c|c|}
\hline Grandeza & $\frac{\text { Modelo }}{\text { Protótipo }}$ \\
\hline \multicolumn{2}{|l|}{ Parâmetros do solo } \\
\hline $\begin{array}{l}\text { Parâmetros de resistência ao cisalhamento } \\
(\mathrm{c}, \phi)\end{array}$ & 1 \\
\hline Comportamento tensão - deformação & 1 \\
\hline \multicolumn{2}{|l|}{ Parâmetros do reforço } \\
\hline Resistência à tração ( $\left.\mathrm{T}_{\text {ult }}\right)$ & $1 / \mathrm{N}^{*}$ \\
\hline Módulo de rigidez (J) & $1 / N^{*}$ \\
\hline \multicolumn{2}{|l|}{ Propriedades da interface } \\
\hline Resistência ao cisalhamento de interface & 1 \\
\hline
\end{tabular}

*Para o caso de reforços planos

\subsubsection{Limitações dos ensaios em centrifuga}

Obviamente, nem todas as condições presentes em uma situação real podem ser adequadamente simuladas nos modelos em centrífuga. Como em qualquer outra abordagem utilizada para investigar uma determinada situação, existem algumas limitações associadas à modelagem em centrífuga. A reprodução de alguns aspectos construtivos é uma dessas limitações. É muito difícil, por exemplo, simular etapas de escavação do maciço de solo com o modelo em movimento na centrífuga. Tal aspecto é particularmente importante no caso de estruturas de solo reforçado. A trajetória de tensão durante o processo construtivo considerando, por exemplo, o efeito da compactação nas tensões desenvolvidas no reforço não pode ser convenientemente reproduzida. Os modelos são construídos previamente a $1 \mathrm{~g}$ e só então carregados na centrífuga, impossibilitando a análise das tensões desenvolvidas no protótipo durante a etapa construtiva.

Um outro fator capaz de limitar a modelagem em centrífuga diz respeito ao efeito escala que ocorre, por exemplo, devido ao tamanho relativo das partículas de solo no modelo e no protótipo. A dificuldade de simular o solo faz com que o mesmo solo do protótipo seja utilizado no modelo o que pode provocar problemas, 
dependendo da situação. No caso de um modelo com dimensões reduzidas utilizando pedregulho e ensaiado a uma aceleração elevada, por exemplo, o tamanho das partículas em relação às dimensões do modelo pode provocar efeitos locais fazendo com que o solo não se comporte mais como um meio contínuo. Nesse caso, diferenças entre modelo e protótipo devem ocorrer.

Alguns efeitos de borda podem ainda limitar a validade dos resultados como a presença de atrito lateral na caixa utilizada para o modelo. Esse feito, que na verdade encontra-se presente em quase todos os tipos de ensaio, deve ser minimizado mediante, por exemplo, a adoção de procedimentos de lubrificação das laterais da caixa.

Embora não seja possível reproduzir nos modelos em centrífuga todas as condições a que uma estrutura real fica submetida (nesse sentido a realização de ensaios com estruturas em grande dimensão é mais adequada), os modelos em centrífuga constituem, mesmo assim, uma ferramenta extremamente útil, principalmente, para a investigação de mecanismos de ruptura e/ou deformação. Em relação à realização de ensaios de grande dimensão, a modelagem em centrífuga apresenta como vantagens: o baixo custo, a facilidade de repetição dos ensaios, o menor tempo de montagem do ensaio e a conseqüente possibilidade de realização de um maior número de ensaios (que na verdade são vantagens de modelos reduzidos de uma forma geral).

\subsubsection{Objetivos da modelagem em centrífuga}

A realização de modelos em centrífuga embora tradicionalmente associada à modelagem de um determinado protótipo não se restringe unicamente a esse objetivo. Segundo KO (1988a) a modelagem em centrífuga é utilizada também com os seguintes propósitos:

i) Investigação de novos fenômenos: os modelos não necessariamente representam um protótipo e são ensaiados para a investigação de um determinado fenômeno. Essa investigação fornece informações para a elaboração de novas teorias a fim de justificar as observações experimentais. 
ii) Validação de métodos numéricos: os modelos são construídos para representar um determinado tipo de protótipo, mas com o objetivo de avaliar ferramentas de análise numérica.

iii) Estudos paramétricos: os modelos são usados para gerar sensibilidade a respeito de um determinado parâmetro relevante para projeto.

Destaca-se que os modelos realizados no presente trabalho foram conduzidos tendo em vista o objetivo destacado no item 'i'. Sendo assim, é imperativo considerar que os modelos foram realizados com o objetivo de avaliar o mecanismo de deformação ao longo do tempo em muros de solo reforçado para a discussão e elaboração de teorias a respeito, sem nenhum protótipo específico a ser modelado. $\mathrm{Na}$ verdade, a centrífuga foi usada como uma ferramenta eficaz para aplicar o carregamento nos modelos (carregamento devido ao peso próprio). As comparações devem ser estabelecidas entre os modelos (que constituem o universo de estudo) e nenhuma tentativa deve ser feita no sentido de relacionar os modelos a um determinado protótipo.

\subsection{Descrição geral dos modelos construídos}

Os modelos de muro de solo reforçado foram construídos utilizando-se uma areia pura e mantas poliméricas com gramatura bastante reduzida para simular os geotêxteis. Uma caixa com dimensões internas de 419 x 203 x 300 mm (comprimento, largura e altura) foi utilizada para a confecção dos modelos cuja configuração pode ser observada na Figura 4.2.

Os muros apresentavam face envelopada com uma inclinação correspondente a $85^{\circ}$ com a horizontal, com exceção do primeiro modelo construído (teste preliminar) para o qual o valor adotado foi $90^{\circ}$. Todos os muros possuíam uma altura de 228,6 mm (9in) e foram apoiados sobre uma camada de fundação com 25,4 $\mathrm{mm}$ (1in) de espessura. Os reforços tinham $200 \mathrm{~mm}$ de comprimento e $76 \mathrm{~mm}$ de comprimento para envelopamento, com exceção da última camada para a qual se adotou $100 \mathrm{~mm}$ de comprimento para envelopamento. 


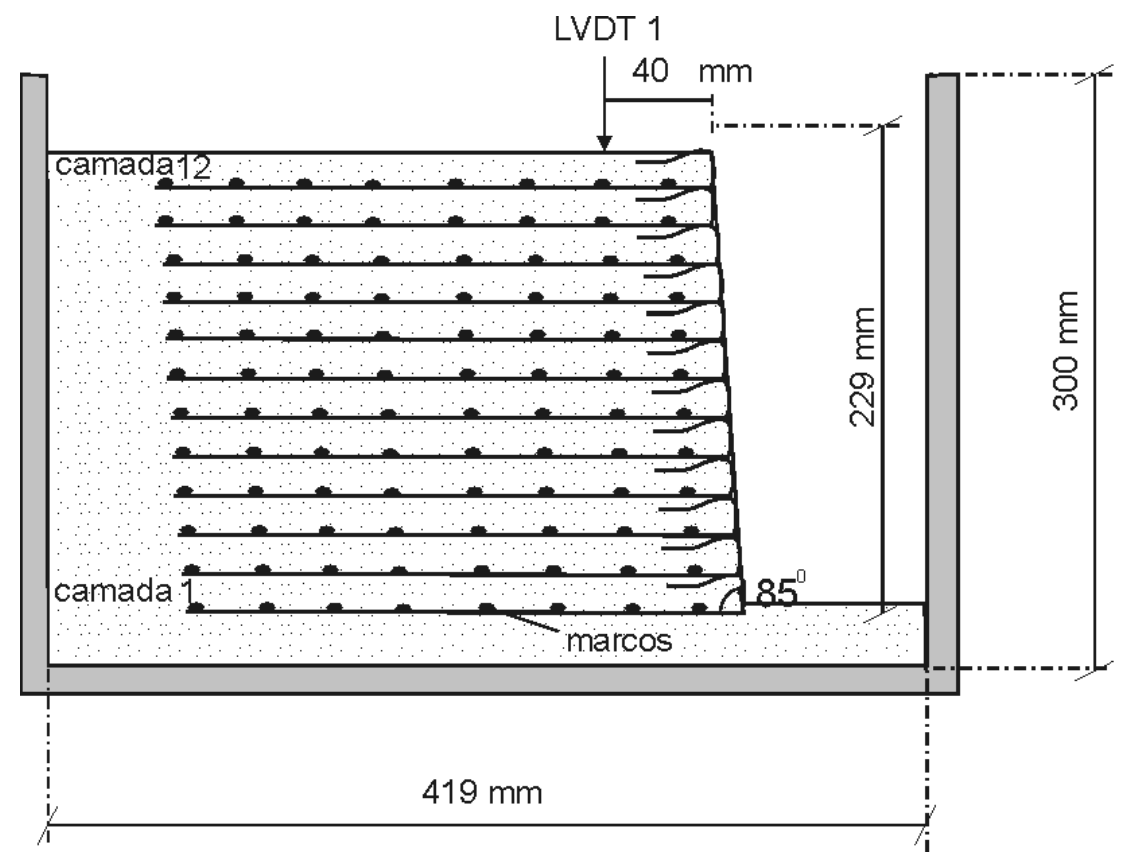

FIGURA 4.2 - Configuração dos modelos, corte esquemático sem escala.

Um espaçamento igual a $19,05 \mathrm{~mm}(0,75 \mathrm{in})$ foi adotado entre camadas resultando em um total de 12 camadas. Apenas em um dos testes preliminares o espaçamento adotado foi de 25,4 mm (1in). A designação das camadas utilizada no presente trabalho é mostrada na Figura 4.2, a camada próxima à fundação será designada por camada 1 , enquanto a camada mais próxima ao topo corresponde à camada 12.

Durante a construção dos modelos, marcos de areia colorida eram posicionados ao longo das camadas de reforço a fim de registrar a movimentação da estrutura durante o ensaio. Uma câmera fotográfica posicionada dentro da centrífuga permitia a aquisição de imagens do modelo. A movimentação dos muros também foi acompanhada através de LVDT's posicionados no topo da estrutura. Alguns termopares foram ainda utilizados a fim de permitir o registro da temperatura durante os ensaios.

A seguir, as características dos modelos e os equipamentos empregados são descritos com detalhes. 


\subsection{Materiais e equipamentos utilizados}

\subsubsection{Caixa utilizada}

A caixa utilizada para a confecção dos modelos é mostrada na Figura 4.3. Como se pode observar, a mesma dispõe de uma lateral em acrílico a fím de possibilitar a visualização do modelo enquanto as demais faces são de alumínio. Essa caixa possui dimensões internas de 419 × 203 x $300 \mathrm{~mm}$ (comprimento, largura e altura) e rigidez suficiente para a manutenção do estado plano de deformação, já tendo sido utilizada em outras pesquisas de estrutura de solo reforçado com geossintéticos (ex. ZORNBERG, 1994; ARRIAGA, 2003).

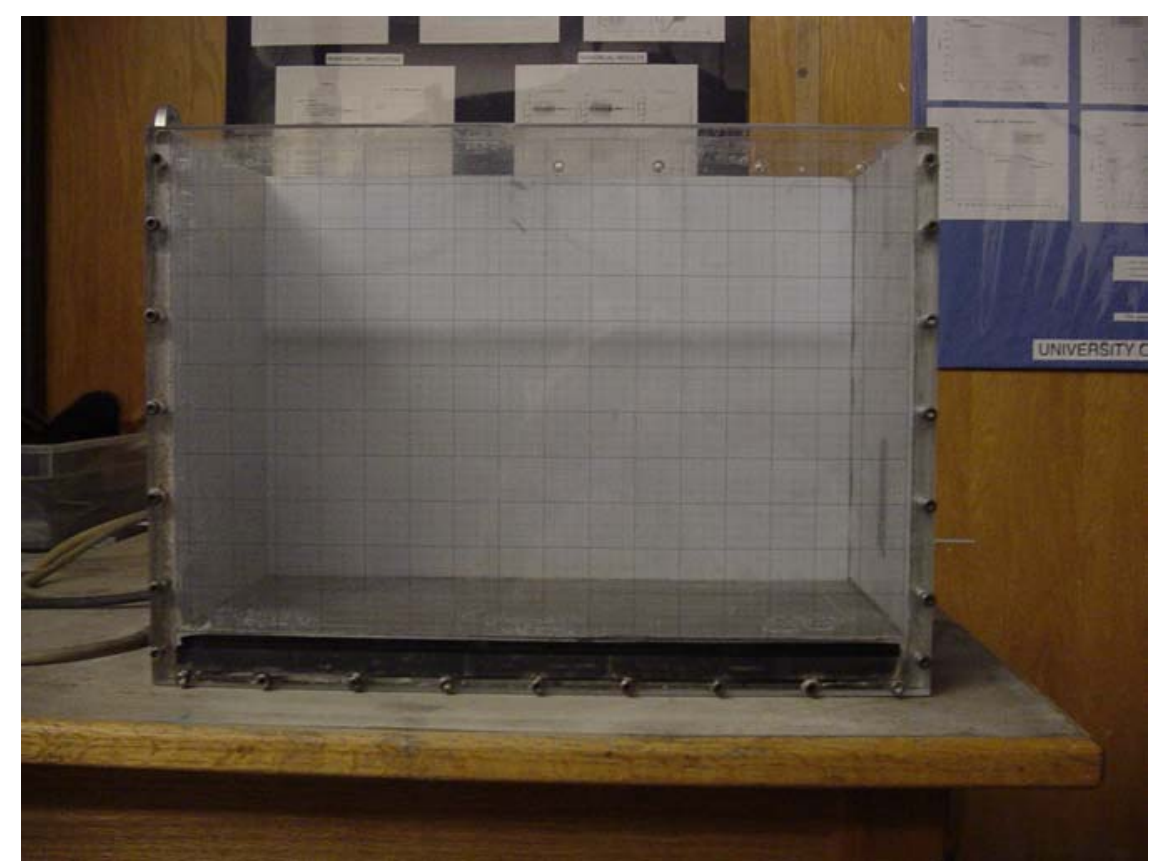

FIGURA 4.3 - Caixa utilizada para a confecção dos modelos

Para reduzir o atrito lateral, as faces de alumínio em contato com o modelo foram revestidas com teflon enquanto a parede de acrílico foi revestida com duas camadas de filme transparente de poliéster comercialmente conhecido como mylar sheet. Um dos filmes de PET possuía uma malha impressa que auxiliava a 
construção dos modelos e servia de referência para acompanhar as deformações no modelo.

A utilização de teflon e mylar tem se mostrado suficiente para reduzir o atrito como mostrado por ZORNBERG (1998b) ao ensaiar modelos de taludes reforçados com geotêxteis em centrífuga. O autor afirma que o efeito do atrito resultante é desprezível baseado nos seguintes aspectos:

i) os rasgos observados nos reforços após ensaio não apresentam curvatura em direção às bordas;

ii) Boa concordância entre os deslocamentos observados através da face de acrílico e os observados dentro da massa de solo quando o modelo foi umedecido e dissecado após ensaio;

iii) Boa concordância entre a superfície de ruptura observada através da face de acrílico e a obtida a partir dos rasgos nos reforços.

Além disso, recentemente, WOODRUFF (2003) duplicou um dos modelos desenvolvidos neste trabalho utilizando, porém, uma caixa de $500 \mathrm{~mm}$ de largura (2,5x maior que a largura da caixa utilizada no presente trabalho). Uma outra centrífuga (440g-ton), também disponível na Universidade do Colorado, foi utilizada para acomodar o modelo com essas dimensões. Os mesmos procedimentos para redução de atrito relatados anteriormente foram adotados. Mesmo utilizando uma caixa com largura bem maior, a aceleração na ruptura constatada por WOODRUFF (2003) foi a mesma obtida neste trabalho.

\subsubsection{Centrífuga utilizada}

A centrífuga utilizada no presente trabalho é mostrada na Figura 4.4. Trata-se de uma centrífuga geotécnica modelo Genisco 1230, 15g-ton, com raio de 1,36m. A capacidade da centrífuga é geralmente limitada ao espaço disponível aos modelos que corresponde a 457 × 457 × $305 \mathrm{~mm}$. A mesma possui braços de rotação simétricos com berços articulados, como mostrado na Figura 4.5, e um total de 56 slip rings. Um motor com $19 \mathrm{~kW}$ de potência é responsável por seu funcionamento, sendo controlada manualmente (KO, 1988b). 


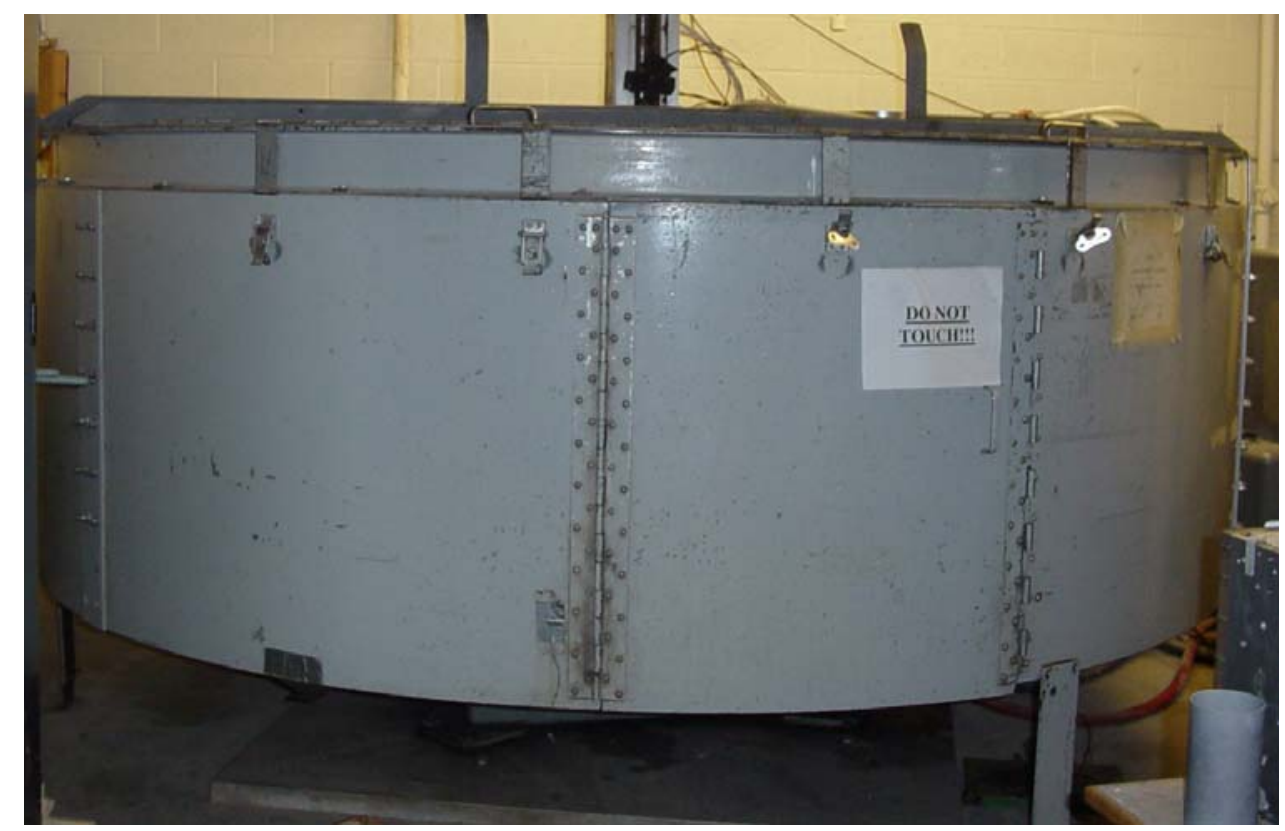

FIGURA 4.4 - Centrífuga utilizada

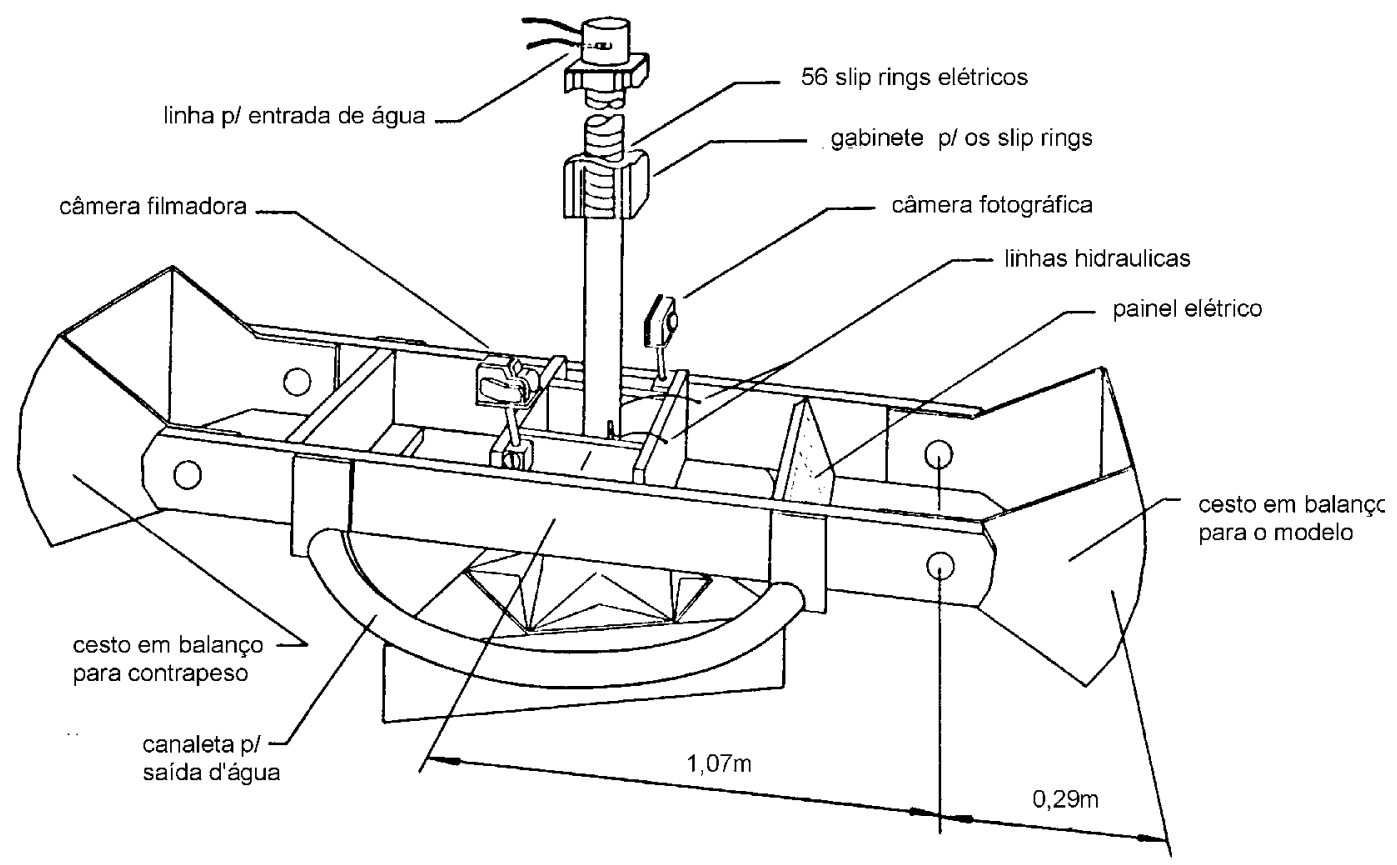

FIGURA 4.5 - Esquema da centrífuga utilizada (KO, 1988b). 


\subsubsection{Instrumentação dos ensaios}

\subsubsection{LVDT's}

O deslocamento vertical no topo dos muros foi acompanhado através de LVDT's fabricados pela Schaevitz Sensors (modelo DC-EC500, curso de 25,4 mm). Dois LVDT's, posicionados no centro em relação à largura do muro, foram empregados em alguns ensaios para registrar os recalques a cerca de 40 e $100 \mathrm{~mm}$ da crista do muro. O LVDT a $40 \mathrm{~mm}$ (LVDT 1, ver Figura 4.2) foi empregado em todos os ensaios e os dados registrados foram utilizados para auxiliar a detecção do momento de ruptura, como será visto no item 4.8.1.1.

O sinal do LVDT era transmitido através dos slip rings para um sistema de aquisição externo à centrífuga que permitiu o registro dos deslocamentos com uma resolução de $0,01 \mathrm{~mm}$.

\subsubsection{Sistema de aquisição de imagens}

Como as mantas utilizadas neste trabalho eram extremamente frágeis, devido à necessidade de baixa resistência imposta pelas leis de escala, a instrumentação das mantas era impossível. A instrumentação com strain gages, por exemplo, provocaria um enrijecimento considerável na região de fixação e uma conseqüente concentração de tensão que invalidaria os dados obtidos.

Assim, o procedimento adotado para avaliar a deformação da estrutura foi baseado na aquisição de imagens do modelo, possível pela existência da face transparente da caixa de ensaios. O movimento de marcos de areia colorida, distribuídos ao longo dos reforços, foi obtido através de uma câmera fotográfica posicionada dentro da centrífuga em uma plataforma presa ao berço (ver Figura 4.6).

As imagens foram enviadas através dos slip rings para um computador externo equipado com uma placa de vídeo podendo então ser visualizadas durante o ensaio e gravadas em tempos pré-determinados.

A câmera utilizada, produzida pela JAI cameras, é monocromática e possui resolução de 1300 (h) x 1030 (v) pixels, o que permite uma resolução de 0,15 mm para obtenção de deslocamentos no modelo. 


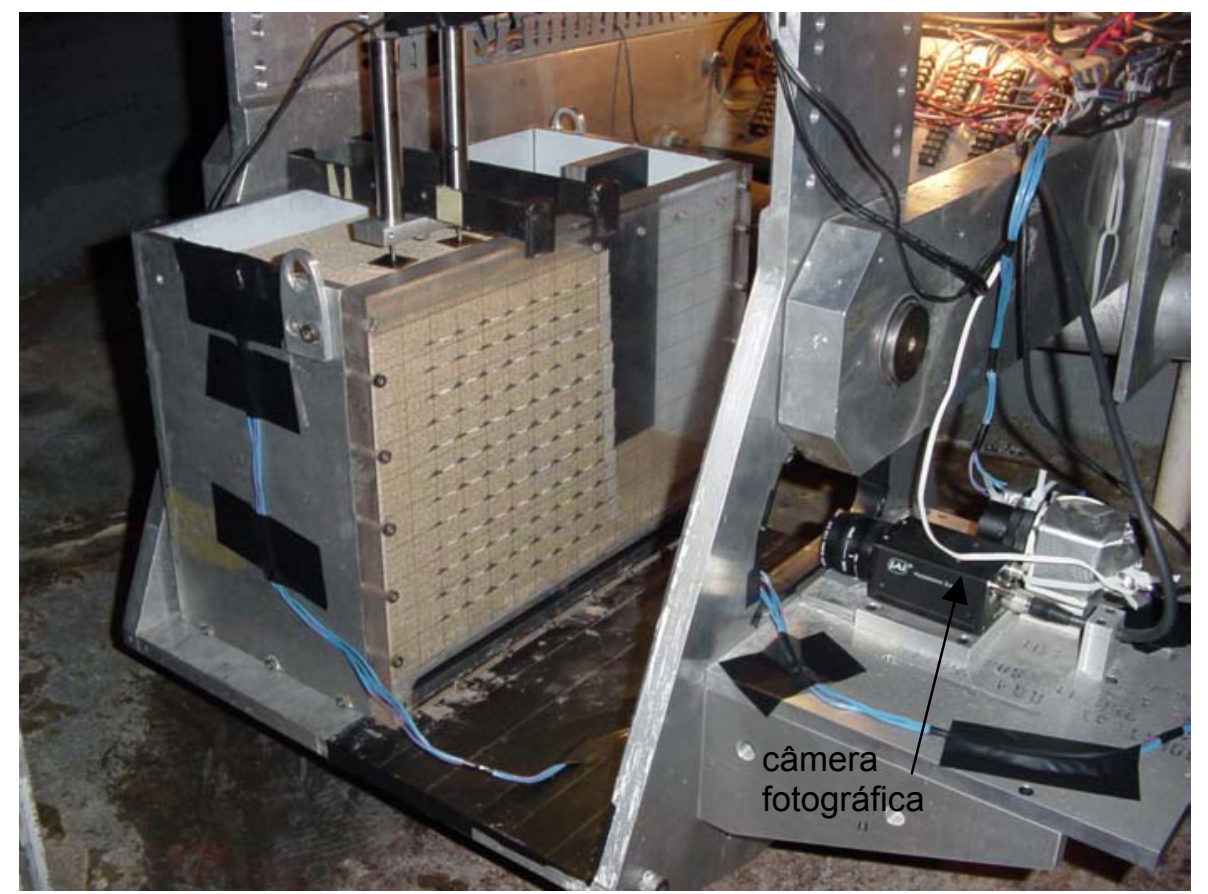

FIGURA 4.6 - Modelo posicionado dentro da centrífuga pronto para ensaio.

\subsubsection{Sistema para obtenção da temperatura}

Como as mantas poliméricas utilizadas nos modelos podiam ter o comportamento alterado devido a variações de temperatura, a mesma foi monitorada em todos os ensaios. Essa questão poderia ser relevante para a análise dos dados pela possibilidade de aquecimento do ambiente em virtude do funcionamento prolongado da centrífuga em alguns ensaios.

Como não existia um sistema para medir temperatura dentro na centrífuga, tornou-se necessário desenvolver tal sistema. Com relação a essa questão, a utilização do sistema de aquisição disponível (utilizado para os LVDT's) não foi possível, pois o mesmo não permitia a implementação de um módulo com essa finalidade.

O sistema de aquisição utilizado foi um sistema remoto da National Instruments ainda em fase de implementação na centrífuga. Nesse dispositivo, os módulos de aquisição, localizados dentro da centrífuga, eram ligados a um computador também localizado dentro da centrífuga. Os sinais eram enviados através 
de um sistema remoto para um computador externo, podendo ser monitorados durante os ensaios.

Além de termopares, dois módulos extra foram adquiridos para permitir o registro de temperatura, os módulos SCXI-1102 e SCXI SCXI-1300, responsáveis, respectivamente, pela leitura dos termopares e pela leitura da temperatura utilizada para a compensação da junta fria. Uma rotina utilizando-se o software LabVIEW 7 foi ainda desenvolvida, como parte do presente trabalho, para permitir o controle dos módulos de aquisição.

A Figura 4.7 mostra os termopares tipo $\mathrm{T}$, produzidos pela Omega Engineering Inc., que foram utilizados. A distribuição dos quatro termopares (T1 a T4) adotada nos modelos é mostrada na Figura 4.7. A temperatura do ambiente externo próximo à centrífuga foi acompanhada em todos os ensaios através de um termômetro digital.

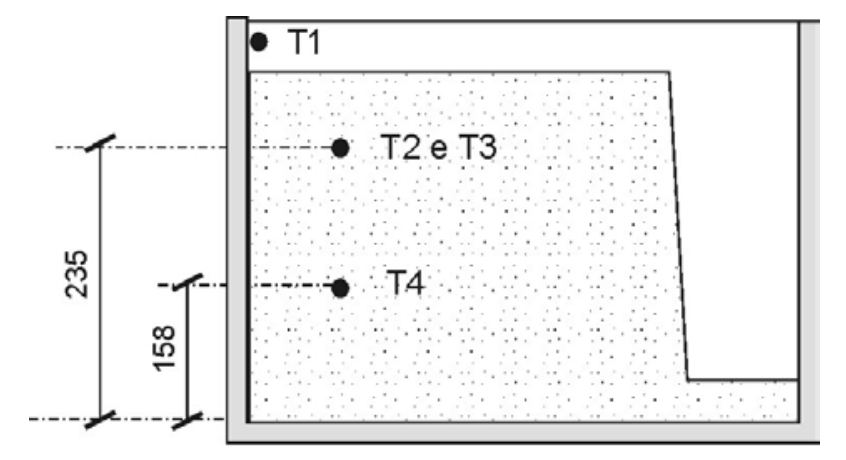

(a)

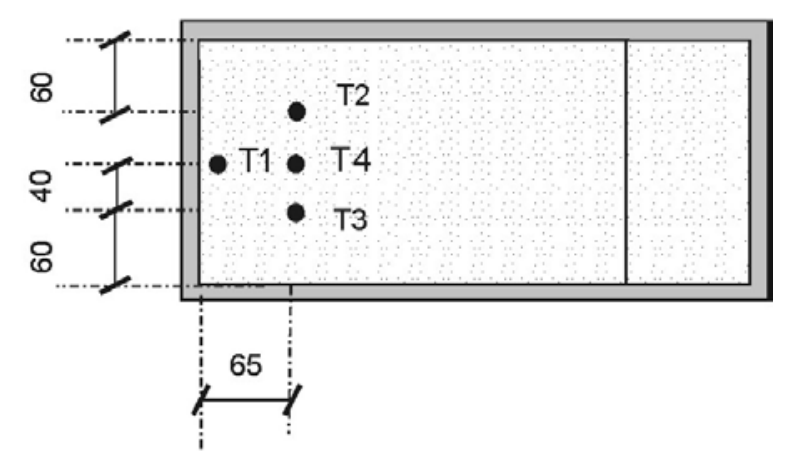

(b)

FIGURA 4.7 - Distribuição dos termopares no modelo, sem escala - dimensões em mm (a) corte esquemático (b) vista superior. 


\subsubsection{Solo utilizado}

Como citado, em todos os modelos utilizou-se uma areia pura (Monterey n.30) que apresenta grãos esféricos a semi-esféricos, sendo composta predominantemente por grãos de quartzo com pequenas quantidades de feldspatos.

A Figura 4.8 apresenta a curva granulométrica da areia utilizada. Como se pode observar, trata-se de um solo mal graduado, com coeficiente de não uniformidade igual a 1,8. Os valores correspondentes aos índices de vazios mínimo e máximo, encontrados para a areia, são $\mathrm{e}_{\min }=0,56\left(\gamma_{\operatorname{máx}}=16,7 \mathrm{kN} / \mathrm{m}^{3}\right)$ e $\mathrm{e}_{\text {máx }}=0,76$ $\left(\gamma_{\min }=14,76 \mathrm{kN} / \mathrm{m}^{3}\right)$.

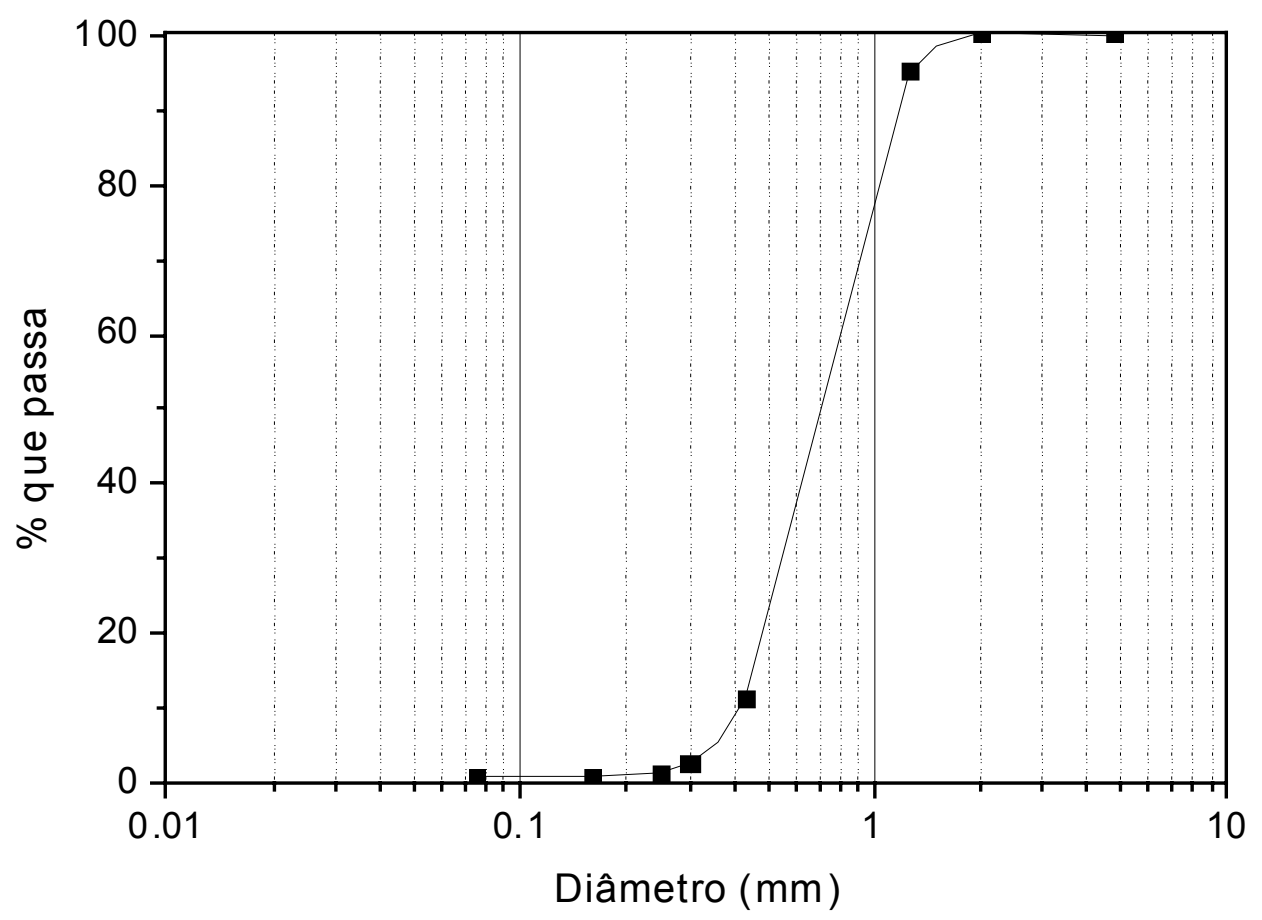

FIGURA 4.8 - Curva granulométrica da areia Monterey n. 30.

Os dados de resistência disponíveis para a referida areia são provenientes de ensaios triaxiais, realizados na Universidade do Colorado. Para a densidade relativa usada na preparação dos modelos $\left(\mathrm{D}_{\mathrm{r}}=70 \%\right)$, a areia possui um ângulo de atrito de pico $\left(\phi_{\mathrm{p}}\right)$ correspondente a $36,4^{0}$ e um ângulo estimado no estado crítico $\left(\phi_{\mathrm{cr}}\right)$ 
correspondente a $32,5^{\circ}$. No entanto, como os modelos de muro de solo reforçado encontram-se em condições de estado plano, o ângulo de atrito sob essa condição $\left(\phi_{\mathrm{ps}}\right)$ apresenta-se mais adequado para a análise dos resultados. Com base em correlações reportadas na literatura, especificamente para a areia Monterey (LADE \& DUNCAN, 1973; MARACHI et al., 1981), um valor de pico $\phi_{\mathrm{ps}}=42^{0}$ foi adotado para uma densidade correspondente a $70 \%$.

\subsubsection{Materiais empregados como reforço}

Duas mantas poliméricas com reduzida gramatura (uma 100\% poliéster, outra $100 \%$ polipropileno) foram utilizadas no trabalho. Esses materiais são empregados, principalmente, na indústria de confecção e ainda como filtros, e simulam bem características de geotêxteis não tecidos. Embora os materiais utilizados não sejam, de fato, geotêxteis, os mesmos serão assim referidos em algumas ocasiões, já que representam geotêxteis nos modelos. Ressalta-se que a magnitude da fluência do material de poliéster, no entanto, não deve ser considerada representativa de geotêxteis de poliéster. O mesmo é válido para o material de polipropileno utilizado.

Convém destacar ainda que a necessidade de resistência à tração bastante reduzida, a fim de atender à escala do modelo, limita bastante a disponibilidade de materiais a serem empregados como reforço. $\mathrm{O}$ emprego de materiais tecidos poderia, por exemplo, facilitar as análises dos resultados por evitar questões como o conhecido efeito de confinamento encontrado para geotêxteis não tecidos. No entanto, embora inicialmente pretendido, o emprego de mantas tecidas não foi possível pela inexistência de material com resistência adequada para os modelos. De qualquer forma, o material utilizado simula bem alguns aspectos de geotêxteis disponíveis no mercado e possui a característica considerada mais importante para este trabalho, ou seja, é composto por polímeros, apresentando assim, fluência.

\subsubsection{Geotêxtil de poliéster}

O material de poliéster utilizado, comercialmente conhecido por Pellon Sewin, é produzido pela Pellon Division of Freudenberg Nonwovens e possui gramatura 
de $23 \mathrm{~g} / \mathrm{m}^{2}$. Esse material já foi utilizado com sucesso em trabalhos anteriores para simular geotêxteis em modelos reduzidos (ex. GULER \& GOODINGS, 1992; ARRIAGA, 2003).

Ensaios de tração de faixa larga foram realizados para o material no laboratório de geossintéticos da EESC-USP de acordo com a NBR-12824. Devido à reduzida resistência dos geotêxteis utilizados nos modelos, tornou-se necessário além de adquirir uma nova célula de carga, projetar e confeccionar garras especiais a fim de evitar danos e deslizamentos do corpo-de-prova. A Figura 4.9 mostra as garras de alumínio desenvolvidas que são recobertas internamente com uma camada de lixa para impedir deslizamentos.

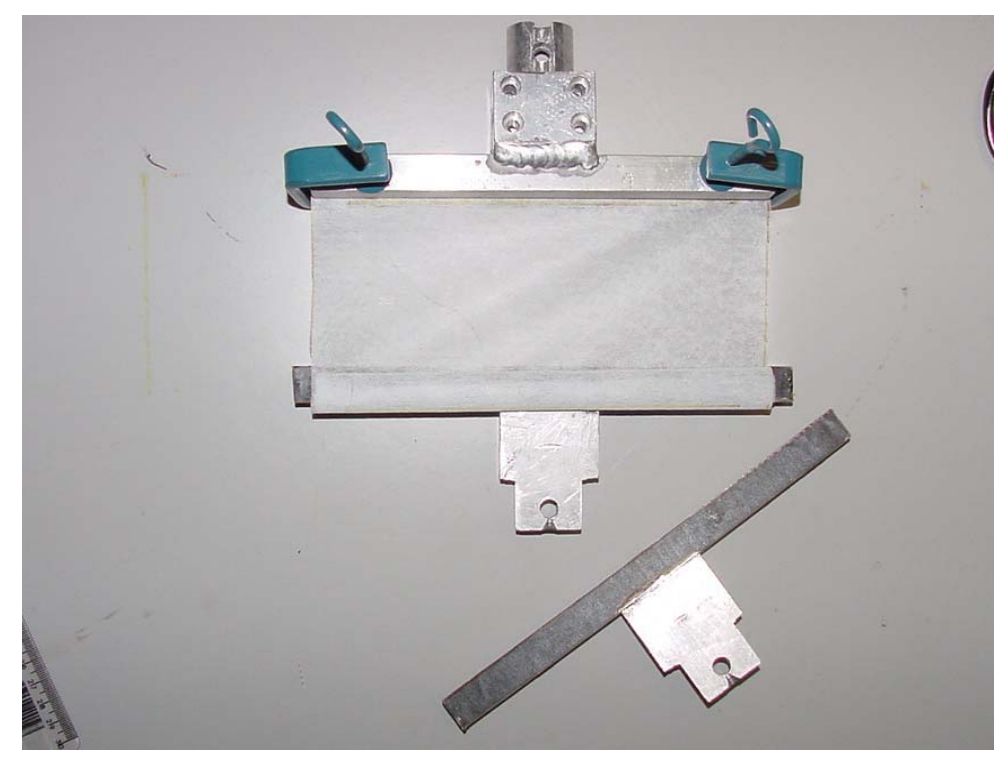

FIGURA 4.9 - Garras confeccionadas para os ensaios de tração

A Figura 4.10 apresenta as curvas força $\mathrm{x}$ deformação encontradas nos ensaios de tração, enquanto a Tabela 4.3 expõe os valores médios de resistência à tração e deformação na ruptura. 


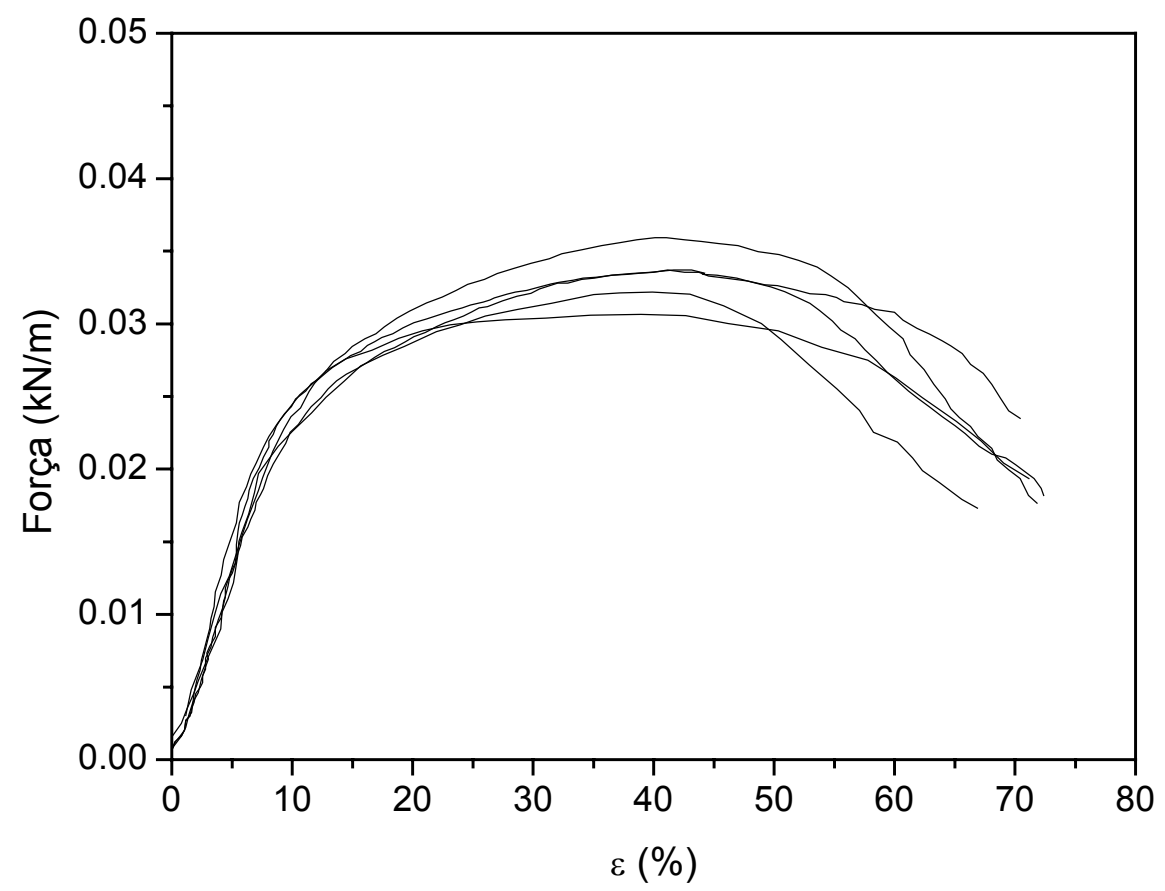

FIGURA 4.10 - Resultados dos ensaios de tração para o geotêxtil de PET.

TABELA 4.3 - Resistência à tração e deformação na ruptura para o geotêxtil de PET.

\begin{tabular}{ccc}
\cline { 3 - 3 } & & $\mathrm{CV}^{(1)}(\%)$ \\
\hline Força $(\mathrm{kN} / \mathrm{m})$ & 0,0332 & 6,4 \\
$\varepsilon^{(2)}(\%)$ & 41,0 & 4,9 \\
\hline${ }^{(1)}$ Coeficiente de variação; ${ }^{(2)}$ Deformação na ruptura.
\end{tabular}

O material utilizado é altamente anisotrópico. Os valores mostrados na Figura 4.10 e na Tabela 4.3 correspondem à direção transversal da manta. Essa direção foi utilizada nos modelos por apresentar a menor resistência. A resistência na direção transversal é cerca de 9x vezes inferior ao valor na direção longitudinal.

As Figuras 4.11 e 4.12 apresentam os resultados obtidos nos ensaios convencionais de fluência (sem confinamento, ASTM D5262) para o material de PET, realizados na Universidade do Colorado. Para $80 \%$ da resistência à tração, observou-se ruptura após cerca de 4,9;1,9 e 3,2 horas para os CP's 1, 2 e 3, respectivamente. 


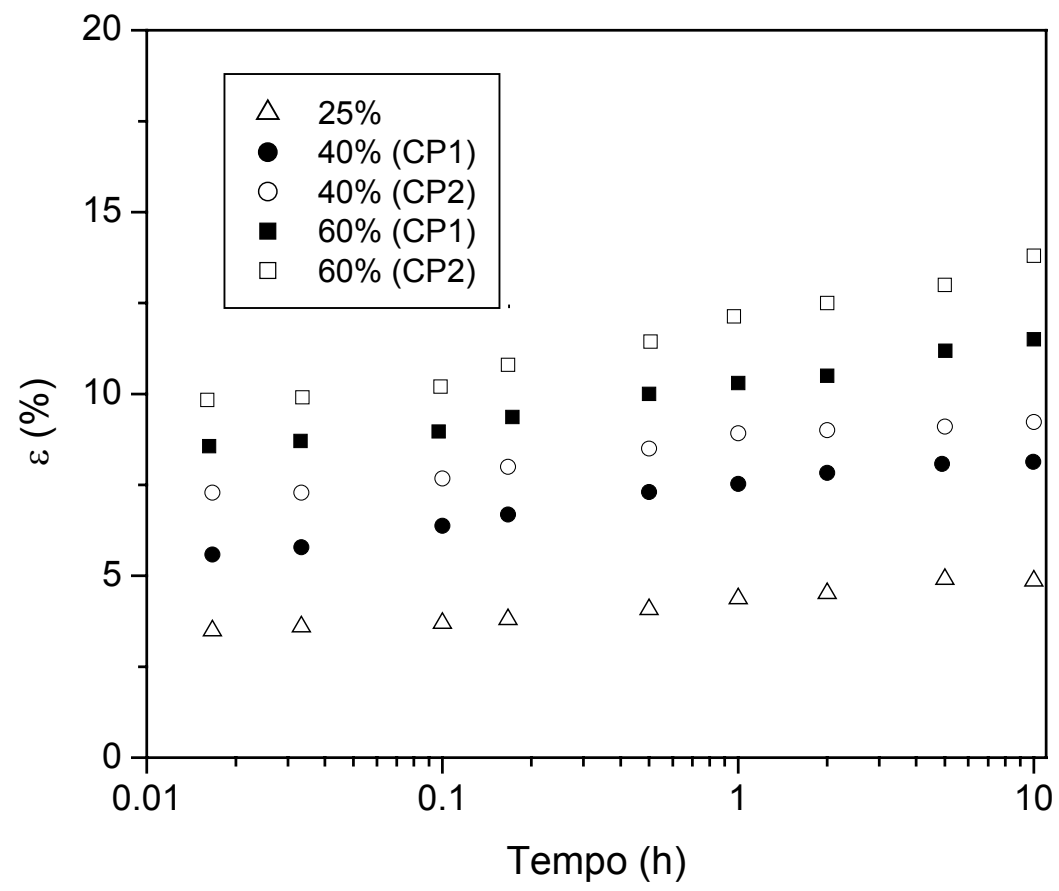

FIGURA 4.11 - Curvas deformação x tempo obtidas para o material de PET para 25,40 e $60 \%$ da resistência à tração

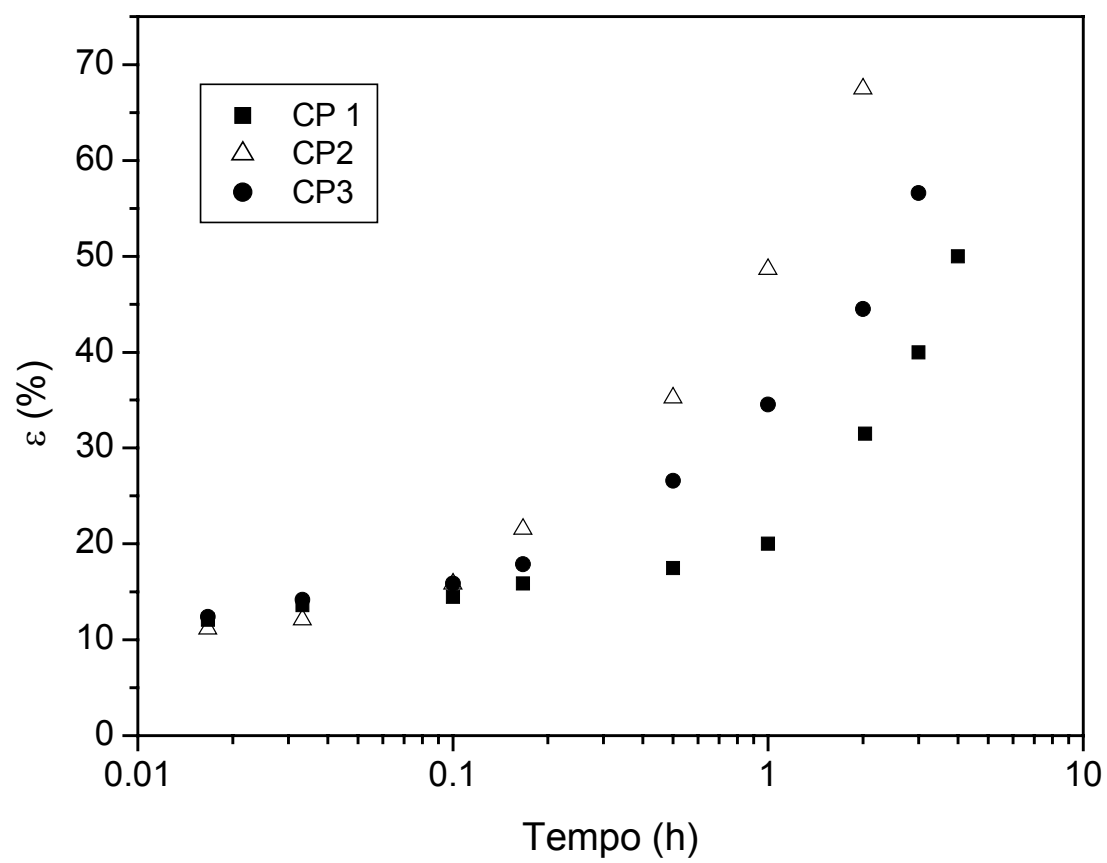

FIGURA 4.12 - Curvas deformação x tempo obtidas para o material de PET para $80 \%$ da resistência à tração 


\subsubsection{Geotêxtil de polipropileno}

A obtenção de um material de PP com características adequadas para os modelos constituiu uma tarefa difícil. A utilização de mantas de PP em modelos em centrífuga, inclusive, não é reportada na literatura. A grande maioria dos materiais comercialmente disponíveis possuía resistência pelo menos 10x superior a desejada e após uma extensa e longa procura, apenas um único material não tecido de PP possuía resistência adequada para os ensaios.

A manta não tecida de PP empregada nos ensaios é produzida pela $B B A$ Nonwovens, sendo comercialmente designada por Celestra. Trata-se de um geotêxtil termoligado que possui gramatura de $12 \mathrm{~g} / \mathrm{m}^{2}$. O material não faz parte da linha de produção habitual da empresa tendo sido produzido sob encomenda para este trabalho.

O geotêxtil de PP é menos anisotrópico com relação à resistência à tração que o de PET. A resistência na direção transversal é cerca de $2 x$ inferior ao valor na direção longitudinal. Mais uma vez a direção transversal foi empregada nos modelos por apresentar o menor valor. A Figura 4.13 apresenta os resultados encontrados nos ensaios de tração (NBR- 12824) e a Tabela 4.4 mostra os valores médios de resistência à tração e deformação na ruptura.

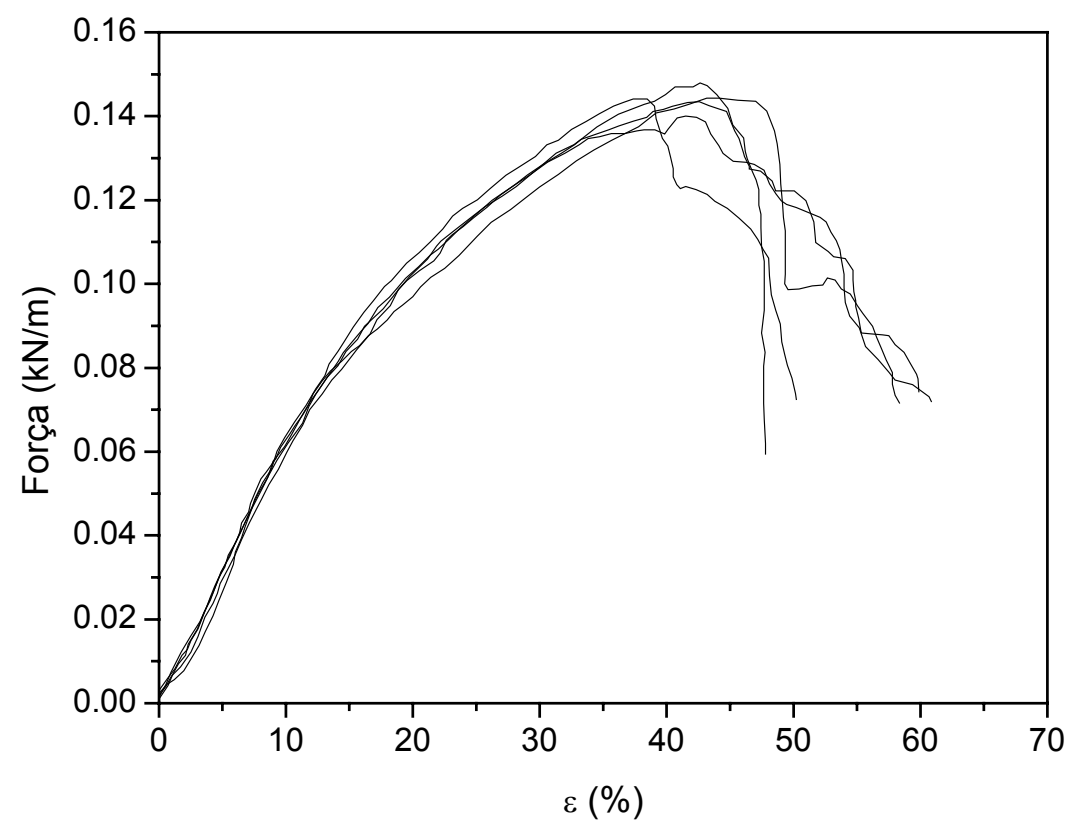

FIGURA 4.13 - Resultados dos ensaios de tração para o geotêxtil de PP. 
TABELA 4.4 - Resistência à tração e deformação na ruptura para o geotêxtil de PP.

\begin{tabular}{ccc}
\cline { 3 - 3 } & & $\mathrm{CV}^{(1)}(\%)$ \\
\hline Força $(\mathrm{kN} / \mathrm{m})$ & 0,144 & 1,75 \\
$\varepsilon^{(2)}(\%)$ & 41,8 & 5,4 \\
\hline${ }^{(1)}$ Coeficiente de variação; ${ }^{(2)}$ Deformação na ruptura.
\end{tabular}

Os resultados obtidos nos ensaios de fluência convencionais, também realizados na Universidade do Colorado, são mostrados na Figura 4.14. Para 80\% da resistência à tração, observou-se ruptura após 53min, 1,4 e 1,6 horas para os CP's 1, 2 e 3 , respectivamente.

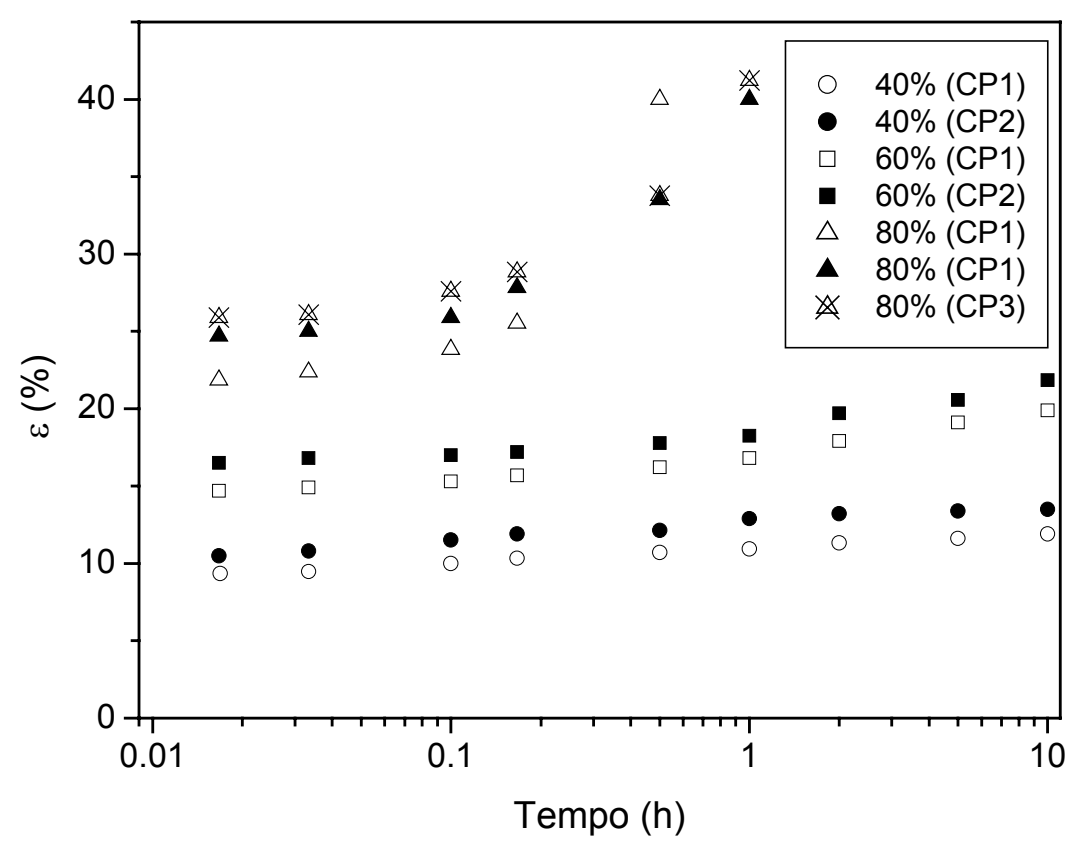

FIGURA 4.14 - Curvas deformação x tempo obtidas para o material de PP para 40, 60 e $80 \%$ da resistência à tração

\subsection{Procedimento de montagem dos modelos}

A montagem dos modelos era iniciada pela preparação da fundação passando então à construção das camadas do muro de solo reforçado. Em ambos os casos, o solo foi preparado através da técnica de chuva de areia utilizando-se um funil. A abertura de descarga do funil bem como a altura de queda foram selecionadas a fim 
de obter a densidade pretendida. A seqüência detalhada do processo é descrita a seguir.

1. Preparação da camada de fundação. A areia era lançada através do funil, removendo-se o excesso de material através de um tubo de alumínio ligado a um sistema de vácuo. $\mathrm{O}$ processo de sucção era mantido até se obter uma camada de solo com 25,4 mm de espessura.

2. Colocação de suportes de madeira como mostrado na Figura 4.15. Os suportes horizontais possibilitavam a contenção das camadas de solo durante a preparação do modelo além de permitir a construção da face de acordo com a inclinação desejada. Dois suportes verticais serviam de apoio aos suportes horizontais.

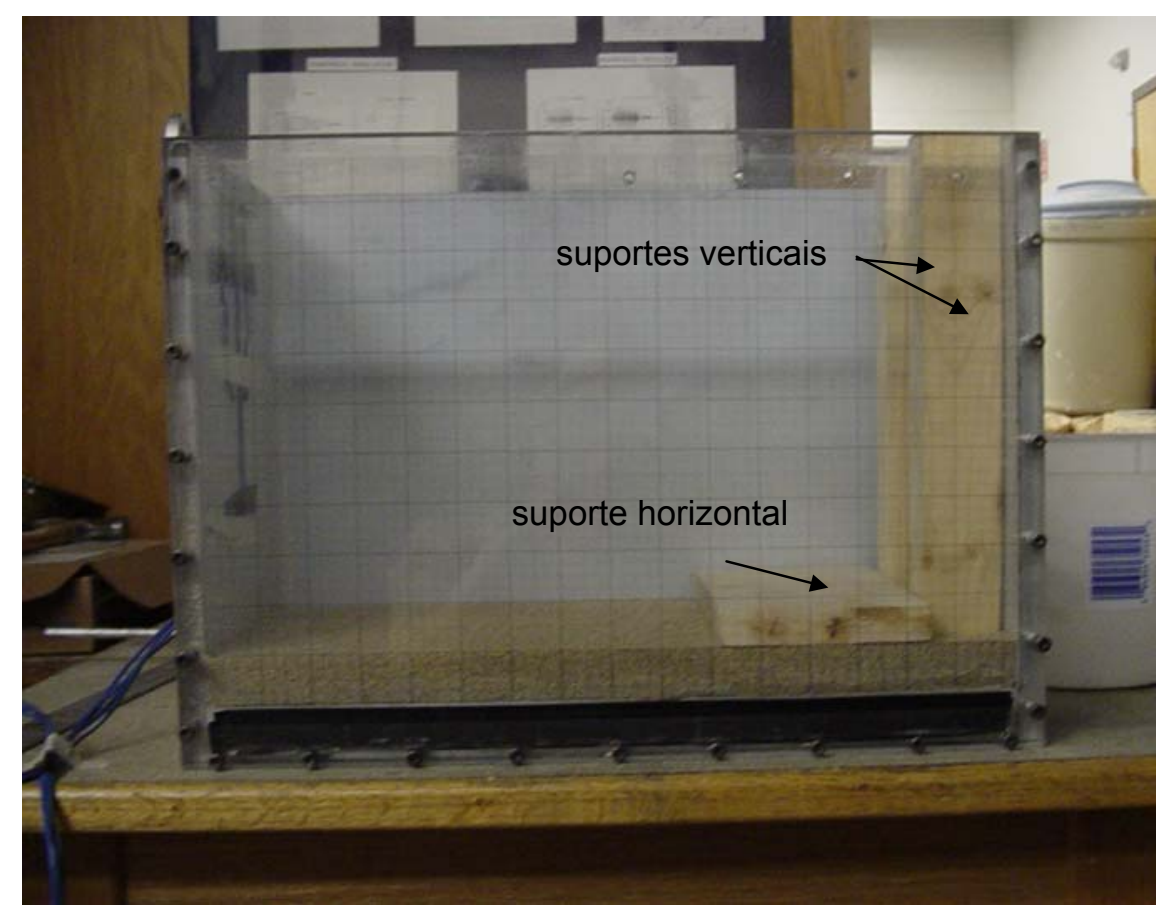

FIGURA 4.15 - Modelo com camada de fundação preparada e com suportes de apoio colocados

3. Instalação da camada de reforço. O reforço era colocado na posição pretendida e então preso com uma fita adesiva ao suporte horizontal. A região 
da manta utilizada como face era pressionada contra o suporte horizontal através de uma espátula, para obter a inclinação desejada. O reforço era ainda cortado de modo a permitir a dobra mostrada na Figura 4.18, evitando assim perda de material.

4. Colocação dos marcos de areia. A areia foi colorida para possibilitar a confecção de marcos na massa de solo. Marcos pretos foram distribuídos ao longo do reforço e intercalados com a colocação de uma fina camada de areia branca.

5. Execução de chuva-de-areia para compor a camada de solo reforçado. A areia era lançada, mantendo-se a altura de queda constante $(\mathrm{h}=127 \mathrm{~mm})$ e o excesso de areia era removido por sucção, utilizando-se o tubo de alumínio ligado ao sistema de vácuo, até se obter a espessura pretendida para a camada (Figura 4.16).

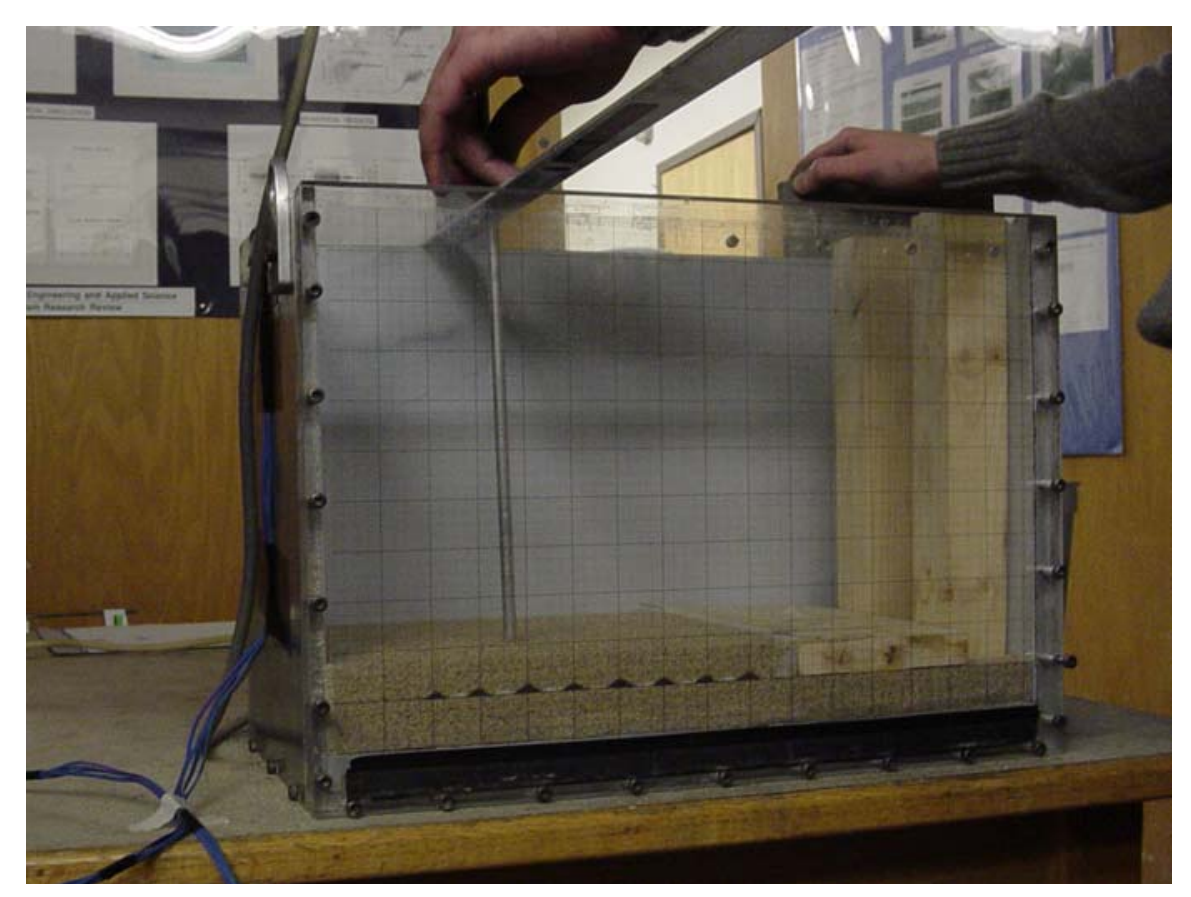

FIGURA 4.16 - Sucção do excesso de areia. 
6. Para permitir o envelopamento, uma trincheira era construída através da sucção da areia na área desejada (Figura 4.17). A trincheira possuía 6,3 mm de profundidade, estendendo-se por toda a largura da caixa.

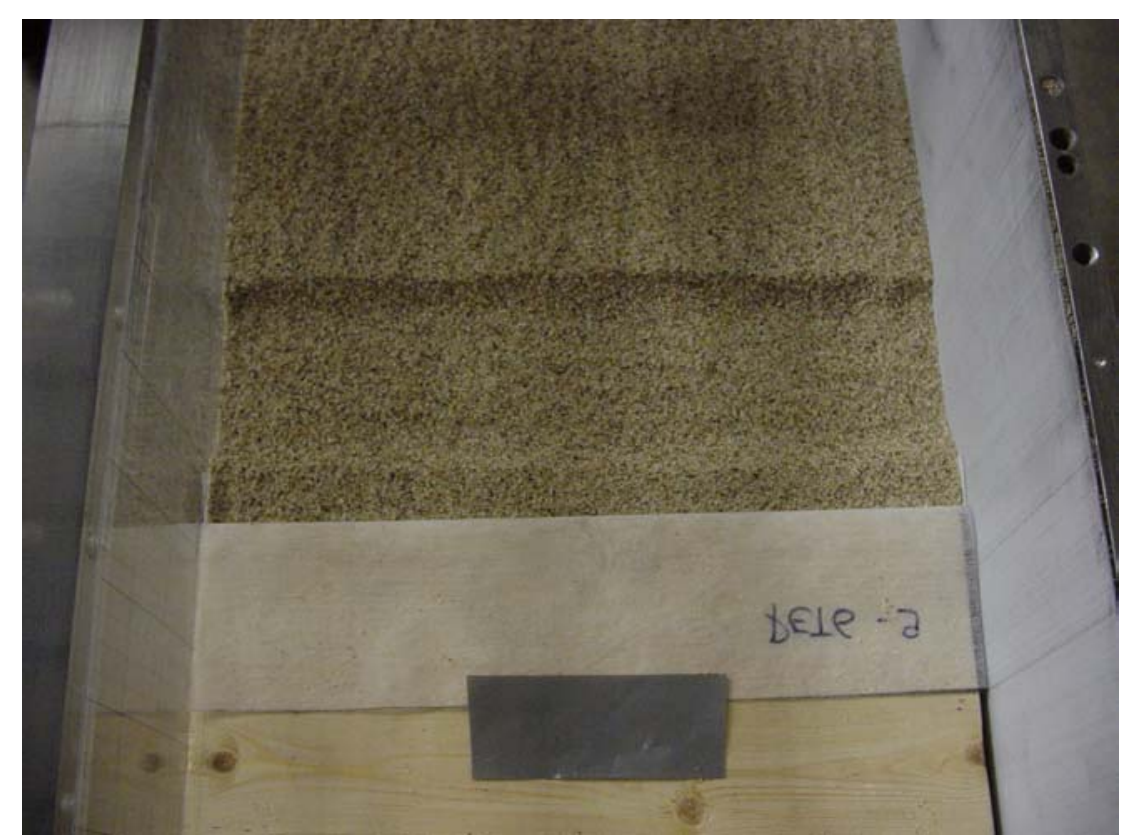

FIGURA 4.17 - Trincheira preparada para envelopamento.

7. O trecho para envelopamento era posicionado dentro da trincheira, preenchendo-se a mesma com solo mediante chuva-de-areia. $\mathrm{O}$ excesso de material era removido até obter a espessura da camada.

8. Os passos 3 a 7 são repetidos após a colocação do novo suporte horizontal, até que a altura final do modelo ser alcançada. No caso dos modelos instrumentados com termopares, o passo 3 era seguido pela instalação dos mesmos.

As Figuras 4.18 e 4.19 apresentam o modelo durante e após o término do processo de construção, respectivamente. 


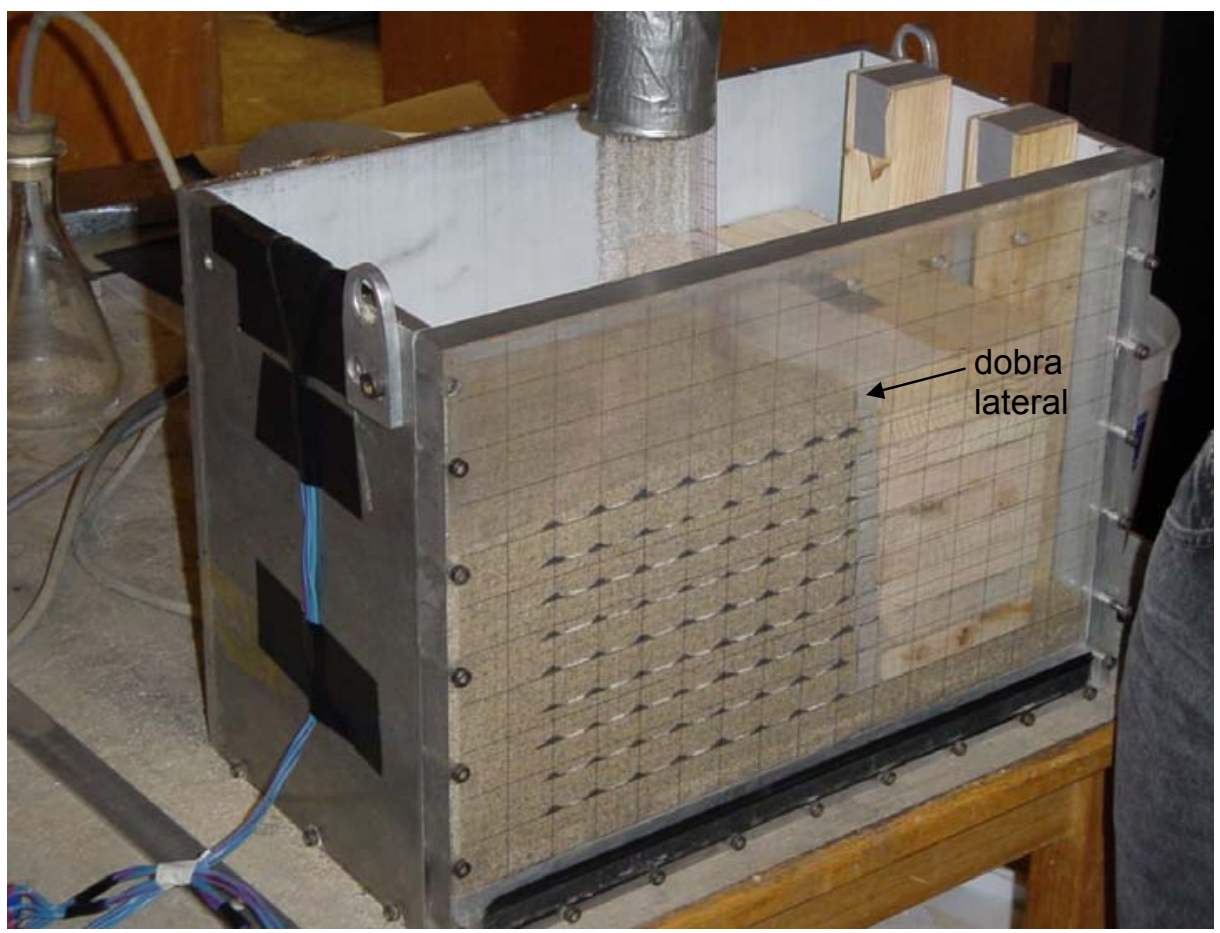

FIGURA 4.18 - Modelo sendo preparado (chuva-de-areia)

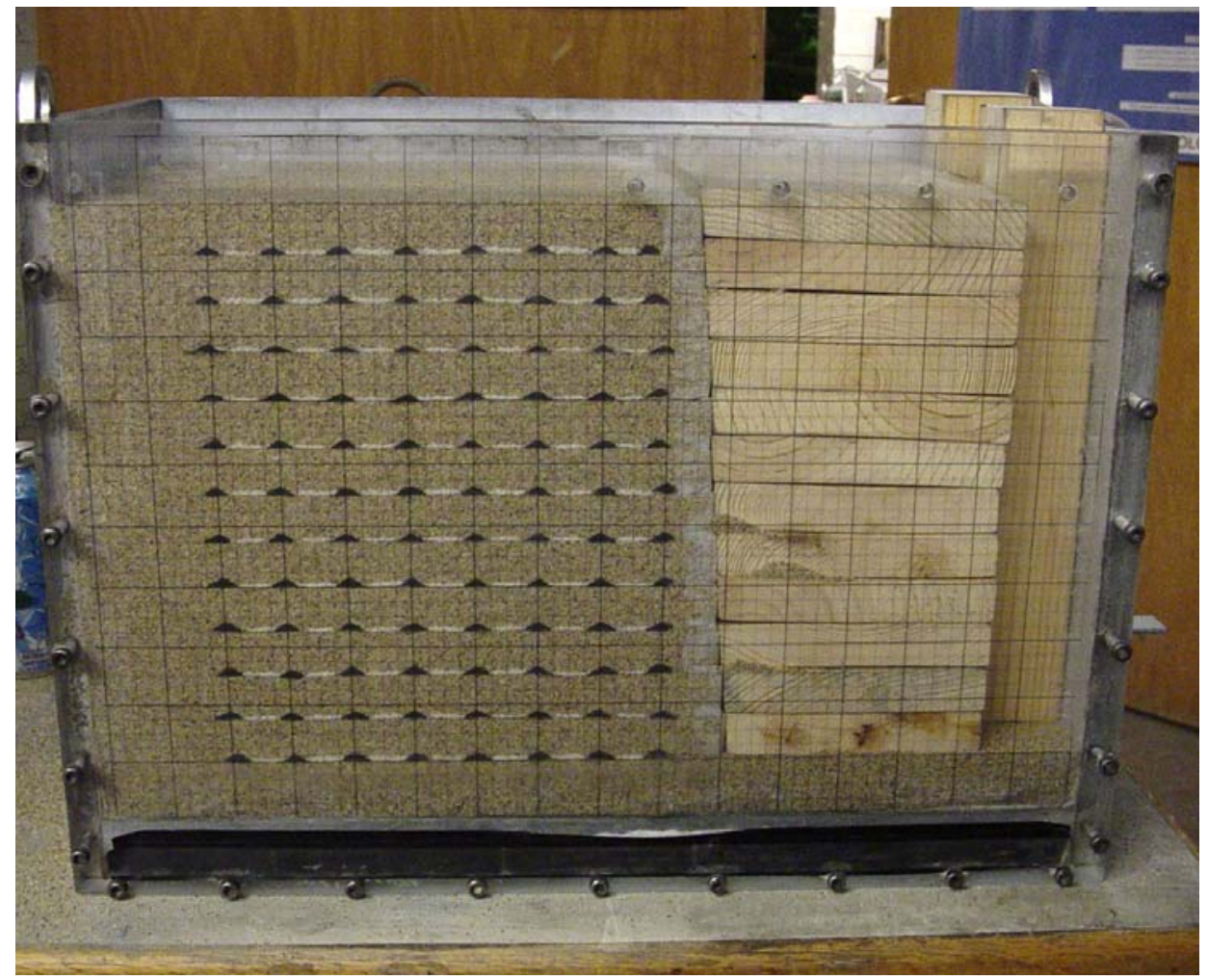

FIGURA 4.19 - Modelo finalizado 


\subsection{Procedimento de execução dos ensaios}

\subsubsection{Ensaios de ruptura}

Nesse tipo de ensaio, a aceleração era aumentada manualmente em incrementos aproximadamente iguais até a observação de ruptura do modelo. Tal procedimento é freqüentemente utilizado para a investigação de ruptura de modelos em centrífuga (ex. MITCHELL, 1988; RAGHEB \& ELGAMAL, 1991; KAWAMURA \& OKABAYASHI, 1998; ZHANG et al., 2002; ARRIAGA, 2003, WOODRUFF, 2003). As imagens do modelo, bem como as leituras do LVDT e dos termopares eram registradas automaticamente em intervalos pré-estabelecidos.

Cada incremento para aumento da aceleração era aplicado em cerca de $2 \mathrm{~min}$. Após a aplicação do incremento desejado, a aceleração era mantida constante por 3 min para garantir a estabilização do valor pretendido. O tempo de espera para a aplicação do próximo incremento de aceleração era importante para a tomada de decisões e para o acompanhamento visual do modelo durante a execução do ensaio. Esse tempo permitia também o registro manual do número da imagem armazenada e o correspondente tempo, para posterior conferência com os dados registrados automaticamente pelo sistema de aquisição.

\subsubsection{Ensaios de fluência}

Nos ensaios de fluência, o mesmo procedimento dos ensaios de ruptura era adotado até atingir um determinado nível de aceleração (fase de carregamento). Quando a aceleração desejada era alcançada, a mesma era mantida constante por cerca de 10 horas ou até a observação de ruptura, seguindo-se com o registro das imagens e leituras dos LVDT's e termopares.

O termo "ensaio de fluência" foi utilizado no sentido da aceleração ser mantida constante. Isso não implica, a princípio, ocorrência de fluência pura nos reforços, ou seja, a carga no reforço constante ao longo de todo o ensaio o que irá depender da interação solo-reforço. 


\subsection{Ensaios realizados}

\subsubsection{Programa de ensaios}

Os ensaios realizados podem ser observados na Tabela 4.5. Como descrito no item 4.2, todos os modelos foram construídos com uma mesma altura, utilizando-se uma densidade relativa igual a $70 \%$ para a areia e uma inclinação para a face correspondente a $85^{\circ}$ com a horizontal (com exceção do modelo R-PET-1P para o qual o valor adotado foi $90^{\circ}$ ).

Um total de 16 ensaios, distribuídos em duas séries básicas, foi realizado. A série 1 corresponde aos modelos construídos com o geotêxtil de poliéster, enquanto a série 2 abrange os modelos nos quais o geotêxtil de polipropileno foi empregado.

TABELA 4.5 - Ensaios realizados

\begin{tabular}{|c|c|c|c|c|c|}
\hline $\begin{array}{c}\text { Série / } \\
\text { Geotêxtil }\end{array}$ & Tipo & $\begin{array}{c}\mathrm{S}_{\mathrm{V}} \\
(\mathrm{mm})\end{array}$ & $\begin{array}{c}\text { Nível de } \\
\text { Carregamento } \\
\left(\% \mathrm{a}_{\mathrm{r}}{ }^{*}\right)\end{array}$ & Designação & Obs. \\
\hline \multirow{2}{*}{$\begin{array}{c}\text { SÉRIE } 1 \\
\text { PET }\end{array}$} & Ruptura & 19,05 & - & $\begin{array}{c}\text { R-PET-1P } \\
\text { R-PET-1 } \\
\text { R-PET-2 } \\
\text { R-PET-3 } \\
\text { R-PET-4 }\end{array}$ & $\begin{array}{l}\text { - Teste preliminar } \\
\text { - Definitivo } \\
\text { - Repetibilidade } \\
\text { - Repetibilidade } \\
\text { - Investigação do } \\
\text { mecanismo de } \\
\text { ruptura }\end{array}$ \\
\hline & Fluência & 19,05 & $\begin{array}{l}25 \% \\
40 \% \\
60 \% \\
80 \%\end{array}$ & $\begin{array}{l}\text { F-PET-1 } \\
\text { F-PET-2 } \\
\text { F-PET-3 } \\
\text { F-PET-4 }\end{array}$ & - \\
\hline \multirow{3}{*}{$\begin{array}{c}\text { SÉRIE } 2 \\
\text { PP }\end{array}$} & \multirow[t]{2}{*}{ Ruptura } & 25,4 & - & R-PP-1P & - Teste preliminar \\
\hline & & 19,05 & - & $\begin{array}{l}\text { R-PP-1 } \\
\text { R-PP-2 }\end{array}$ & $\begin{array}{l}\text {-Definitivo } \\
\text {-Repetibilidade }\end{array}$ \\
\hline & Fluência & 19,05 & $\begin{array}{l}25 \% \\
40 \% \\
60 \% \\
80 \%\end{array}$ & $\begin{array}{l}\text { F-PP-1 } \\
\text { F-PP-2 } \\
\text { F-PP-3 } \\
\text { F-PP-4 }\end{array}$ & - \\
\hline
\end{tabular}

$\mathrm{a}_{\mathrm{r}}$ - aceleração na ruptura $=$ média dos ensaios de ruptura; $\mathrm{S}_{\mathrm{v}}$ - espaçamento vertical. 
Cada série foi iniciada pela execução de um modelo preliminar com o intuito de verificar os procedimentos de ensaio, bem como para auxiliar a seleção da configuração final dos modelos. O modelo R-PP-1P, por exemplo, foi importante para a definição do espaçamento vertical dos modelos da série 2. Antes de sua execução, com base nas resistências não confinadas do geotêxtil de PET e de PP, acreditava-se que a adoção do mesmo espaçamento da série 1 para os modelos da série 2 não seria adequada para atingir a ruptura. No entanto, o ensaio R-PP-1P revelou a possibilidade de continuar adotando o mesmo espaçamento, o que foi confirmado pelo modelo R-PP-1.

Com relação aos ensaios de ruptura, alguns modelos foram construídos para averiguar a repetibilidade dos resultados. O modelo R-PET-4 foi ainda construído a fim de suprimir algumas dúvidas referentes ao mecanismo de ruptura, bem como com relação à movimentação dos marcos, como será visto em seguida.

\subsection{Resultados obtidos}

\subsubsection{Curvas aceleração $x$ recalque}

A Figura 4.20 apresenta o comportamento típico "aceleração x recalque" encontrado para os modelos da série 1. Observando-se a Figura 4.20, pode-se identificar um comportamento aproximadamente bi-linear. No trecho $\mathrm{AB}$, os incrementos de aceleração resultaram em um incremento de recalque praticamente constante enquanto no trecho $\mathrm{BC}$, um incremento de recalque bem mais pronunciado foi registrado. Após o ponto $\mathrm{C}$, um novo acréscimo de aceleração resultava no colapso geral do modelo (a massa instável, indicada na Figura 4.21 pela região $\mathrm{ABC}$, se separava do resto do modelo, causando o desmoronamento completo da estrutura). Devido à elevada magnitude, o recalque correspondente ao o colapso não pôde ser monitorado em nenhum ensaio pela perda de curso do LVDT.

A Figura 4.22 apresenta o comportamento aceleração x recalque observado para os modelos da série 2. Embora seja possível admitir um comportamento bilinear também para esses modelos, a taxa de recalque não permanece tão constante antes de atingir o ponto $\mathrm{B}$, como no caso dos modelos da série 1 . Um acréscimo na 
taxa de recalque no trecho B'B pode ser observado. Após o ponto B, assim como para os modelos da série 1 , a taxa de recalque aumenta consideravelmente. No entanto, o recalque correspondente ao ponto $\mathrm{C}$, ponto que antecede o colapso, é menor no caso dos modelos da série 2 .

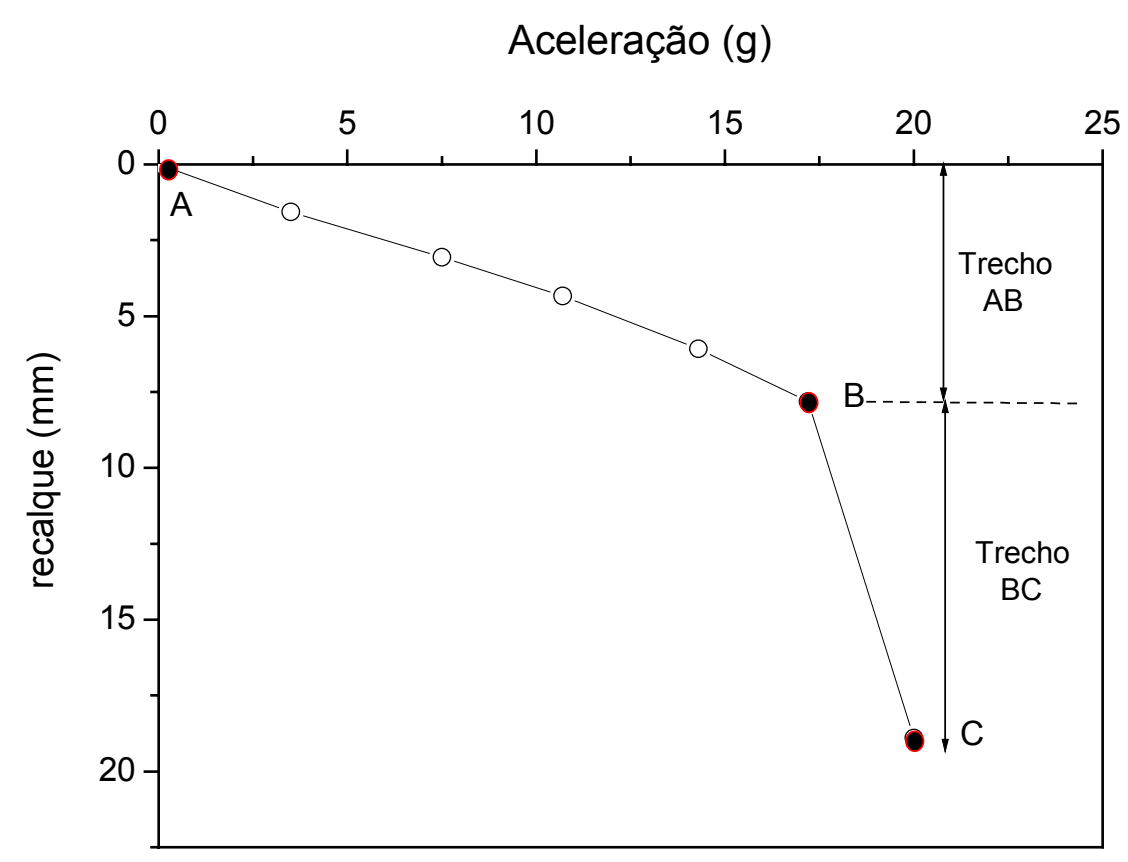

FIGURA 4.20 - Comportamento aceleração x recalque (LVDT 1) obtido para os modelos da série 1.

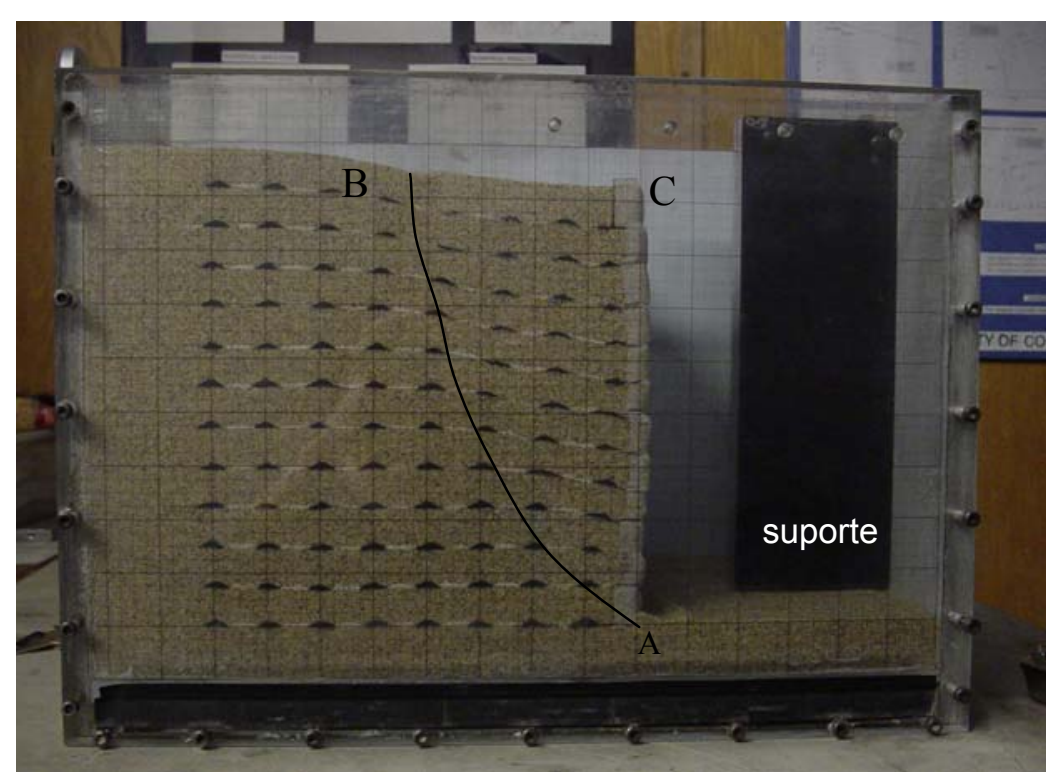

FIGURA 4.21 - Modelo R-PET-4 após ensaio 
As curvas aceleração $\mathrm{x}$ recalque obtidas em cada ensaio de ruptura podem ser observadas nas Figuras 4.23 a 4.26. O recalque mostrado nas curvas corresponde ao valor observado através do LVDT 1 (ver Figura 4.2) após 3 min da aplicação do nível de aceleração pretendido.

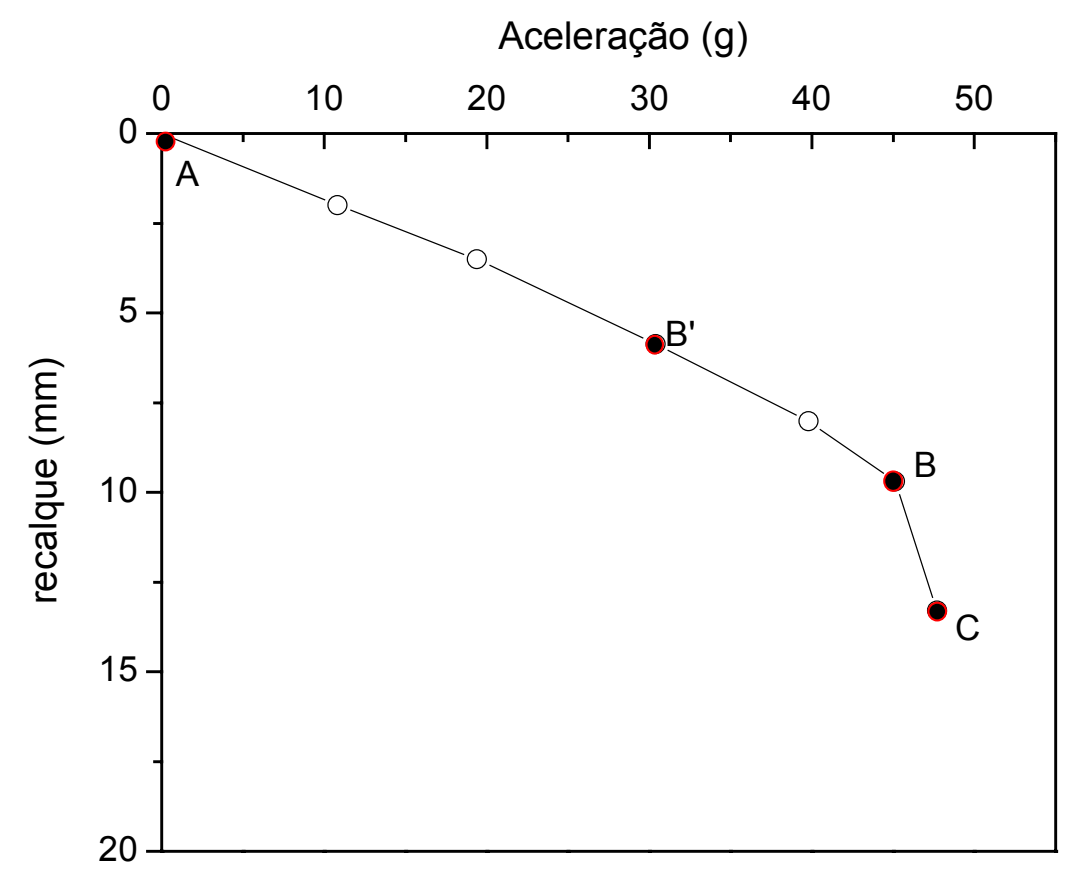

FIGURA 4.22 - Comportamento aceleração x recalque (LVDT 1) obtido para os modelos da série 2.

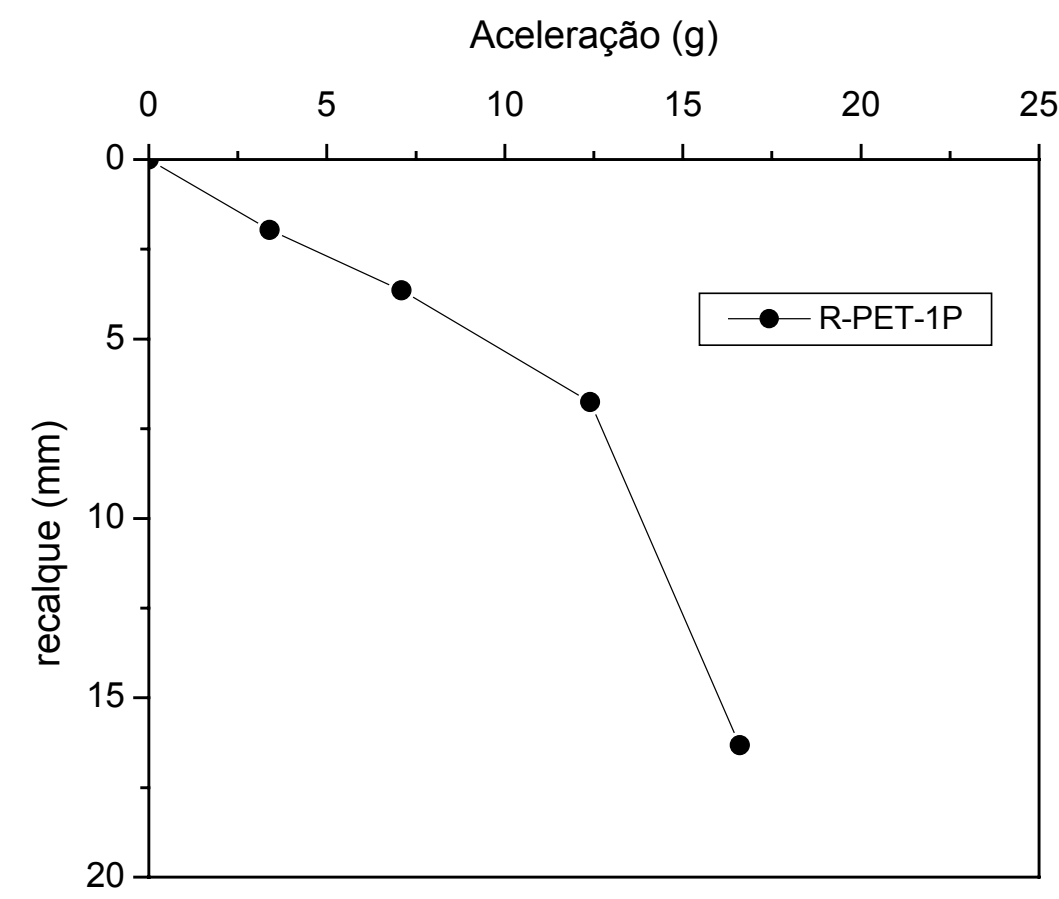

FIGURA 4.23 - Curva Aceleração x recalque (ensaio R-PET-1P). 
Aceleração (g)

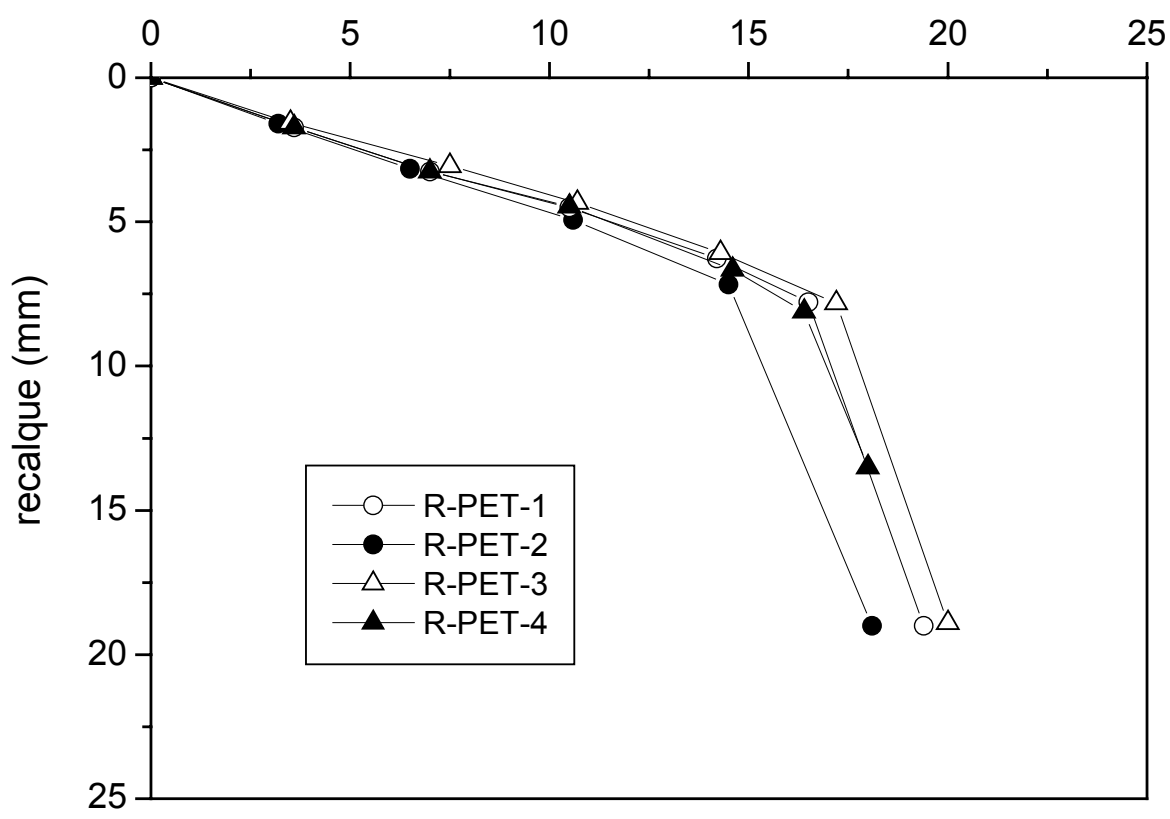

FIGURA 4.24 - Curva Aceleração x recalque (ensaios R-PET-1, 2, 3 e 4)

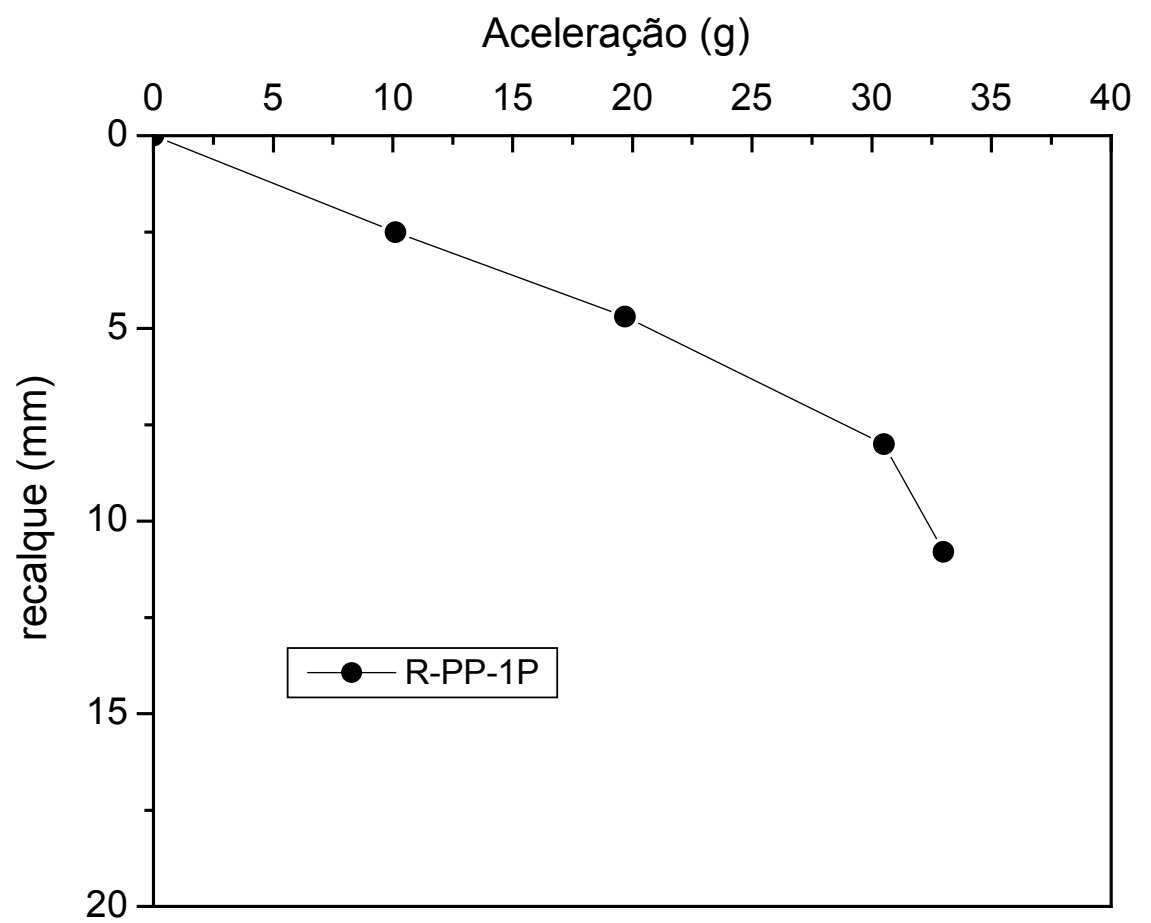

FIGURA 4.25 - Curva Aceleração x recalque (ensaio R-PP-1P) 


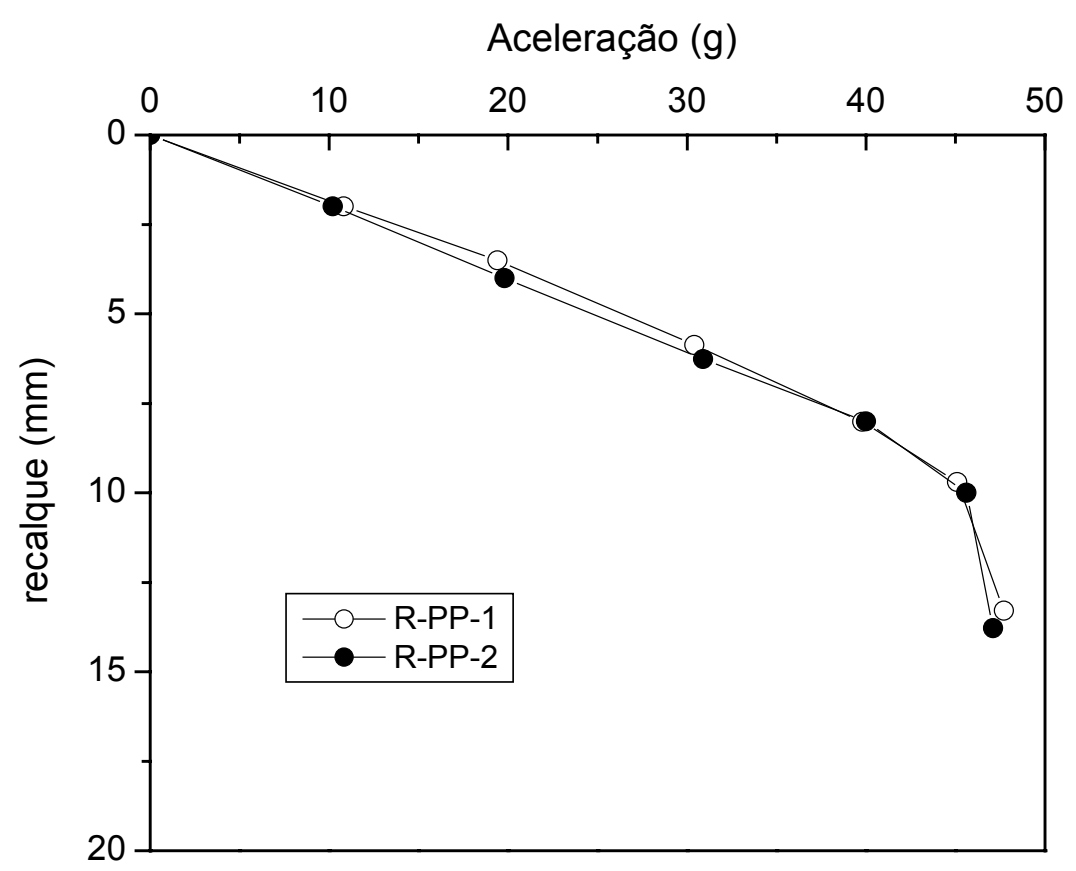

FIGURA 4.26 - Curva Aceleração x recalque (ensaios R-PP-1 e 2)

As Figuras 4.27 e 4.28 apresentam as curvas aceleração x recalque obtidas para os ensaios de fluência durante a fase de carregamento até o nível de aceleração desejado após o qual a mesma foi mantida constante.

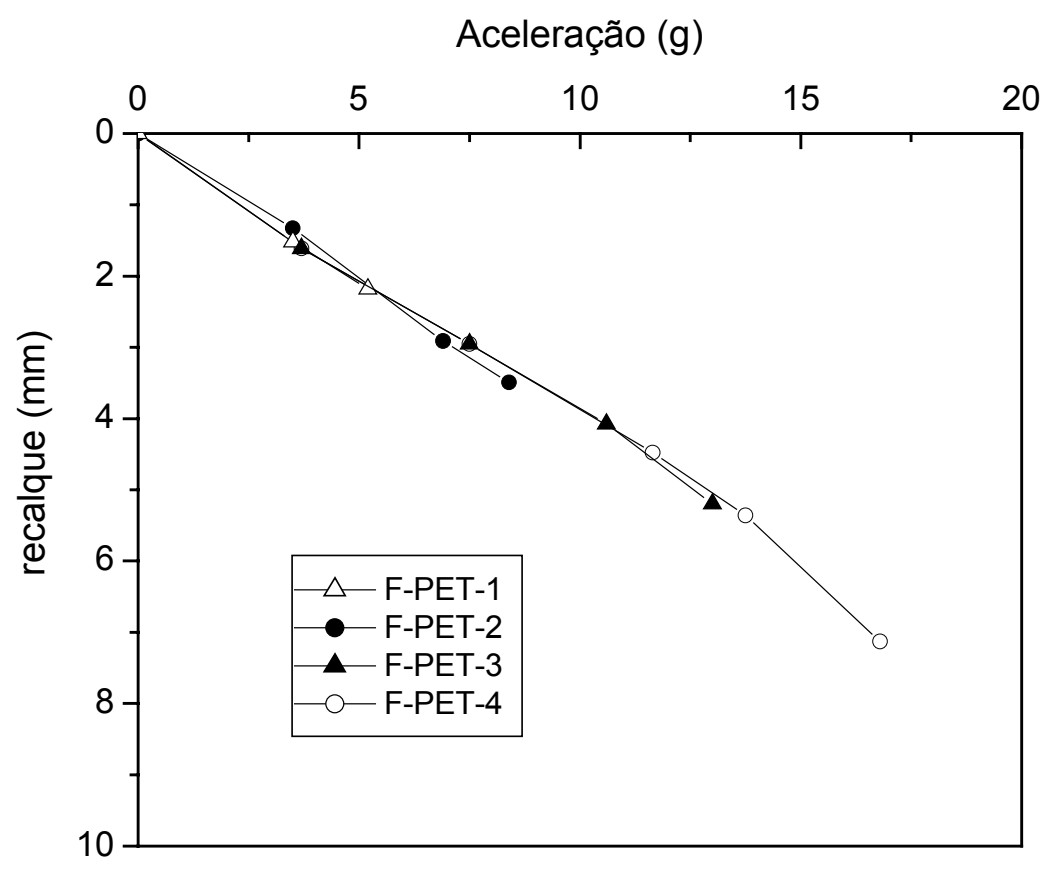

FIGURA 4.27 - Curva Aceleração x recalque (ensaios F-PET-1, 2, 3 e 4) 


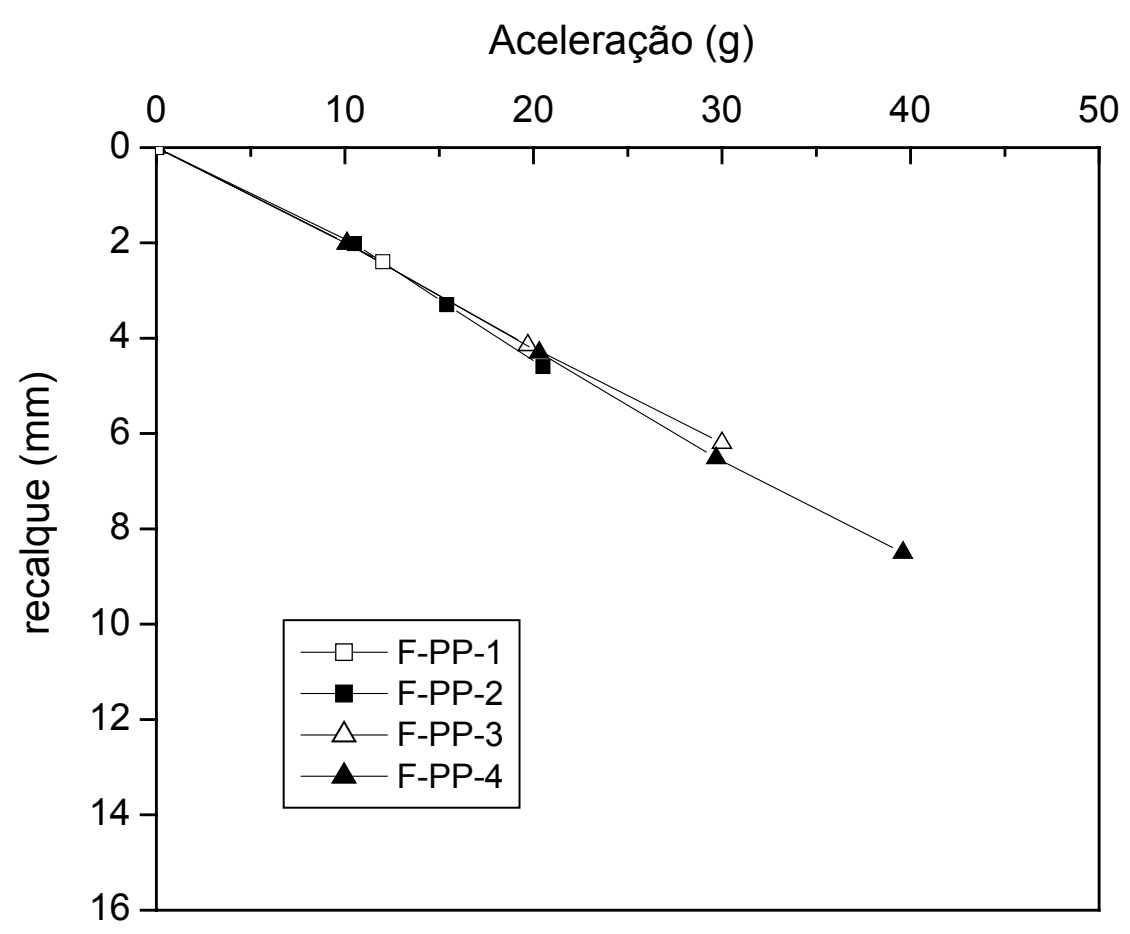

FIGURA 4.28 - Curva Aceleração x recalque (ensaios F-PP-1, 2, 3 e 4)

\subsubsection{Curvas tempo $x$ recalque}

As Figuras 4.29 e 4.30 mostram os recalques com tempo no topo dos muros (LVDT 1) para os modelos das séries 1 e 2, respectivamente, com a aceleração mantida constante. O tempo mostrado nas figuras corresponde ao tempo decorrido após os 3 min de estabilização da aceleração aplicada.

Em todos os ensaios, ocorreram movimentações ao longo do tempo cuja intensidade aumentou com o acréscimo do nível de aceleração na ruptura aplicado. Para os ensaios com aceleração $a=80 \% a_{r}$, observou-se, inclusive, a ruptura da estrutura após cerca de $4,3 \mathrm{~h}$ e $1,8 \mathrm{~h}$ para os modelos das séries 1 e 2 , respectivamente. 
Tempo (h)

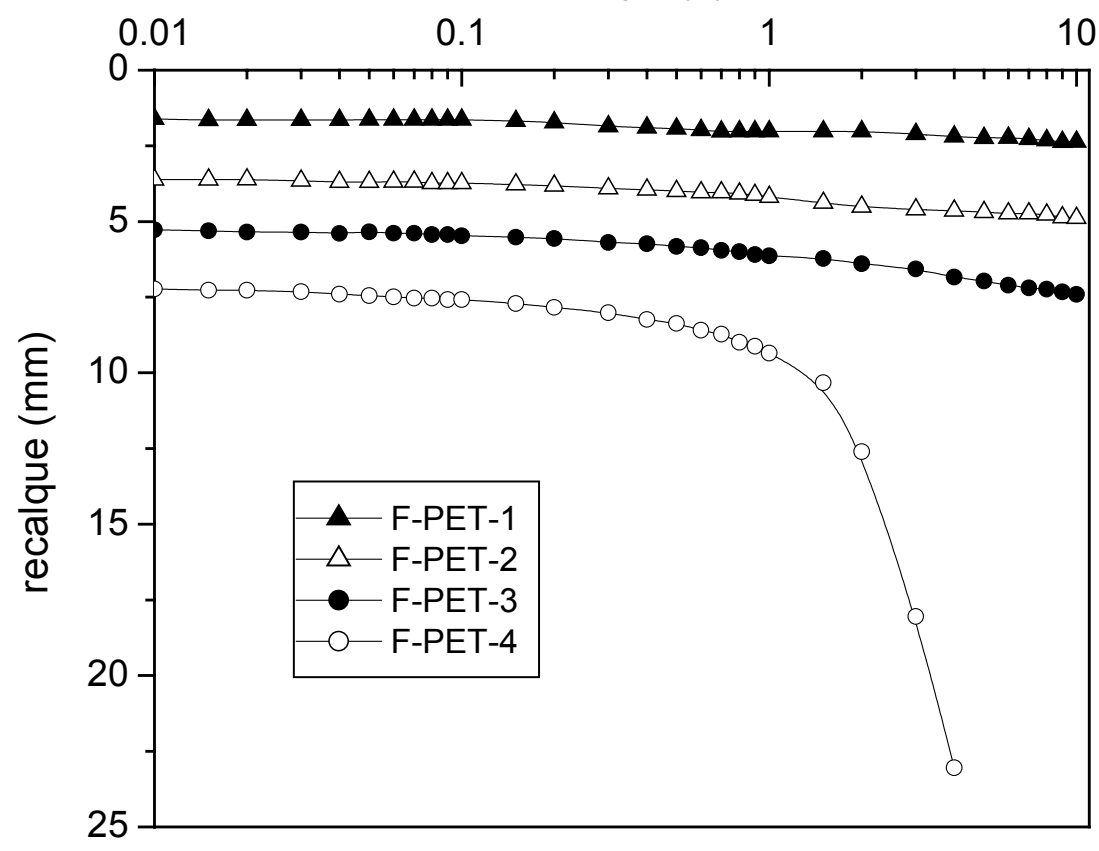

FIGURA 4.29 - Recalque x tempo para os modelos da série 1.

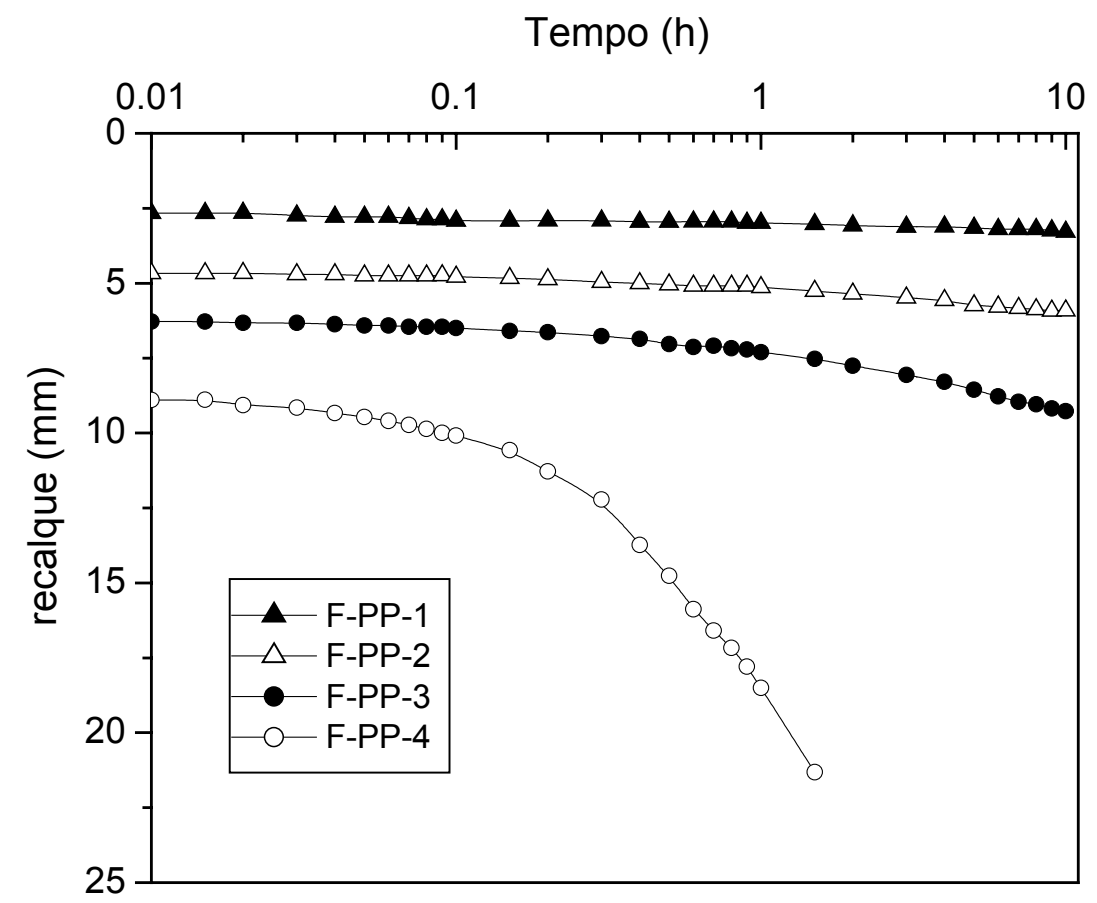

FIGURA 4.30 - Recalque x tempo para os modelos da série 2. 


\subsubsection{Resultados obtidos através da aquisição de imagens - deslocamentos e deformações}

Os deslocamentos dos marcos de areia foram obtidos através do tratamento das fotos registradas durante o ensaio utilizando o software SigmaScan, aplicativo dedicado à análise digital de imagens.

Como os marcos podem se deformar durante o ensaio, o centróide de cada marco foi utilizado para a obtenção dos deslocamentos em relação à face. O cálculo de cada centróide foi efetuado automaticamente pelo programa após a delimitação manual de cada marco com o auxílio do mouse.

Com os deslocamentos e assumindo-se compatibilidade de deformação na interface solo-reforço, as deformações no reforço foram calculadas. O procedimento adotado consistiu em aproximar uma função aos deslocamentos encontrados e efetuar o cálculo da deformação derivando-se tal função.

A função sigmóide apresentada na expressão (4.4) foi utilizada para a regressão dos dados de deslocamentos. A Figura 4.31 ilustra o comportamento da função adotada.

$d=\frac{1}{a+b \cdot e^{-c x}}$

onde,

$\mathrm{d}$ - deslocamento do marco até a face;

$\mathrm{x}$ - distância do marco até face;

e - base do logaritmo neperiano;

a, b, c - constantes obtidas após o ajuste da curva.

Esse procedimento foi utilizado anteriormente por ZORNBERG (1994) para a obtenção de deformações em estruturas de solo reforçado, apresentando resultados satisfatórios. A distribuição de deformação resultante da função adotada (Figura 4.32) está de acordo com o comportamento observado em muros de solo reforçado com face flexível. Ou seja, a deformação na face é nula, cresce até atingir um valor máximo e então decresce tornando-se novamente igual a zero. 


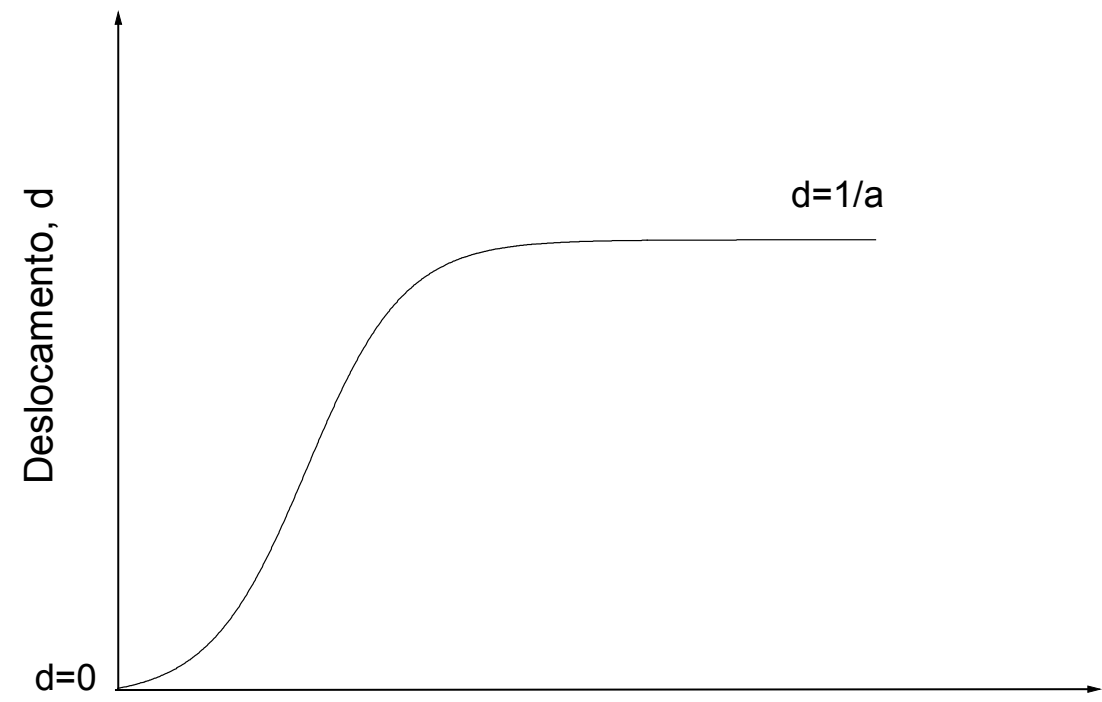

Distância à face, $\mathrm{x}$

FIGURA 4.31 - Comportamento da função sigmóide utilizada

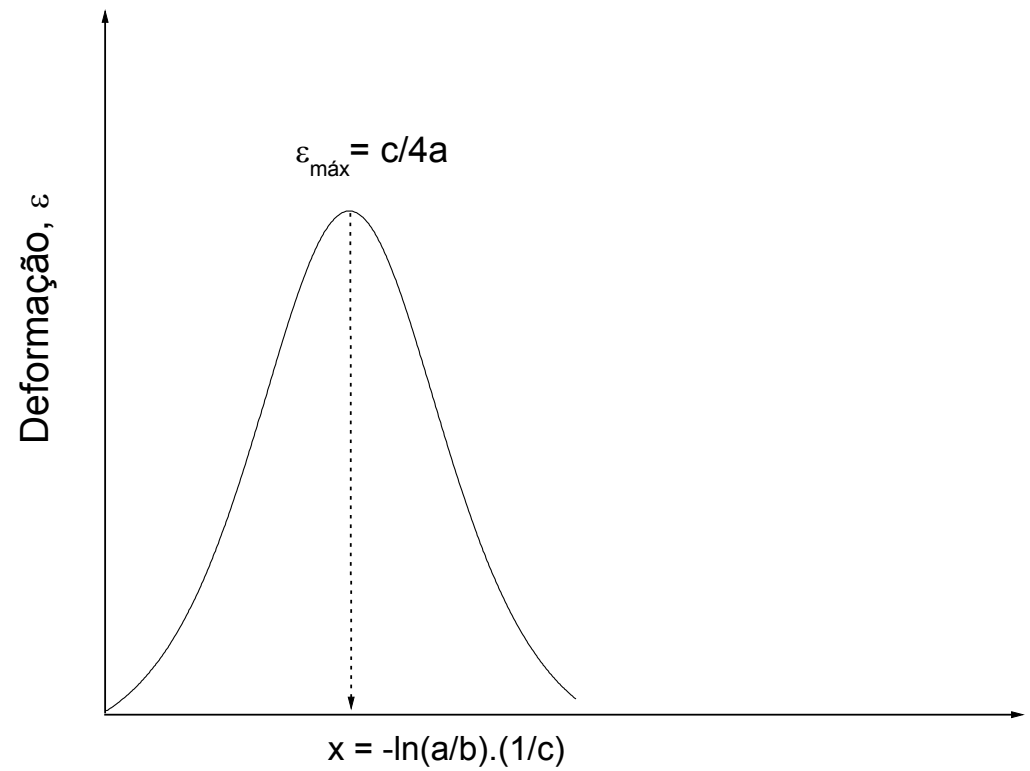

Distância à face, $x$

FIGURA 4.32 - Distribuição de deformação resultante da função de deslocamento adotada. 
A função sigmóide bem como a distribuição de deformação obtida para o ensaio R-PET-3 são mostradas nas Figuras 4.33 e 4.34. Como se pode observar, a função utilizada descreve muito bem o comportamento dos dados obtidos.

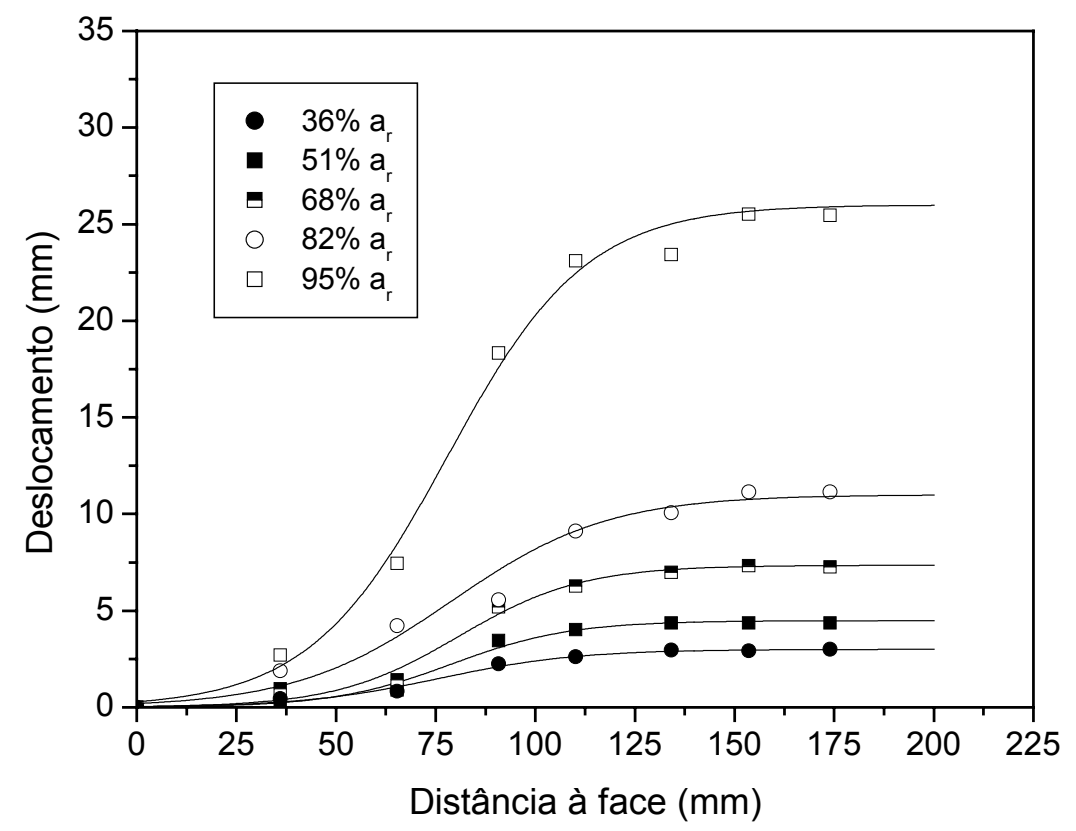

FIGURA 4.33 - Deslocamentos dos marcos de areia obtidos para o ensaio R-PET-3, camada 10.

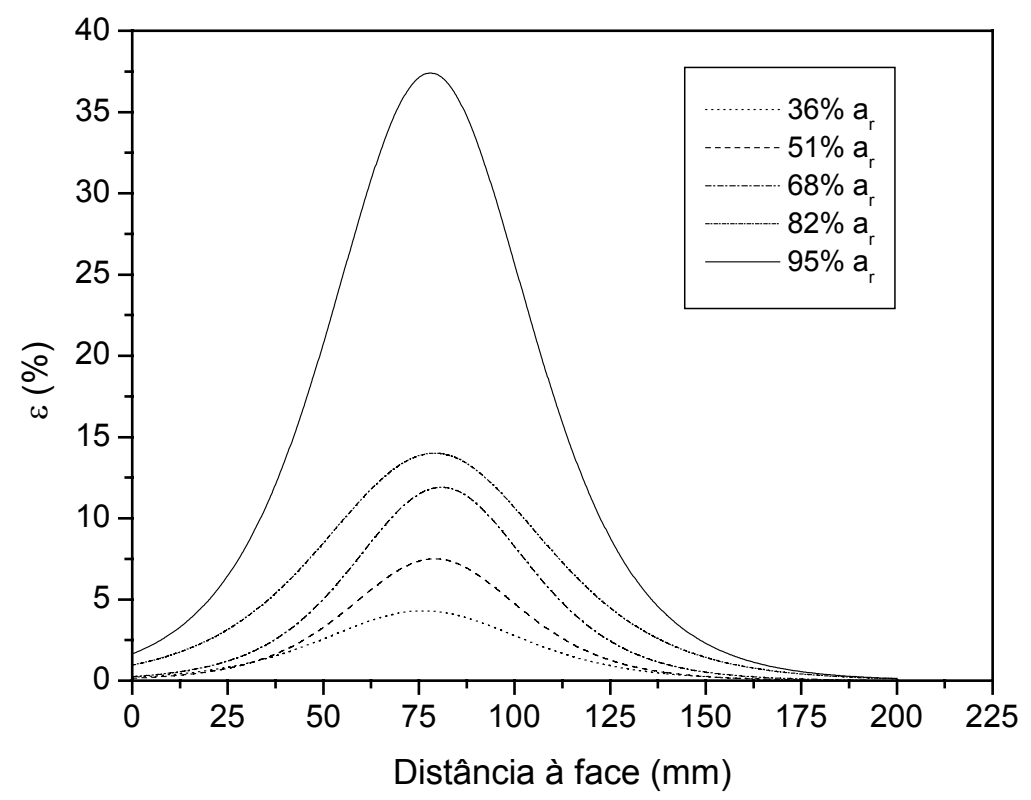

FIGURA 4.34 - Deformação no reforço para o ensaio R-PET-3, camada 10. 
$\mathrm{O}$ anexo A apresenta as curvas de deslocamento para os demais ensaios, bem como tabelas com os coeficientes de determinação $\left(R^{2}\right)$ encontrados nos ajustes. $O$ anexo B apresenta as deformações resultantes para cada ensaio. De uma forma geral, o resultado obtido através da análise das imagens foi satisfatório. Apenas quando os deslocamentos apresentados por uma determinada camada eram inferiores a 1 ou $2 \mathrm{~mm}$ os dados ficavam dispersos (geralmente com $\mathrm{R}^{2}<0,90$ ), impossibilitando a determinação de um comportamento bem definido.

Diante disso, o coeficiente de determinação foi adotado como critério para estabelecer se um determinado conjunto de dados deveria ou não ser considerado na fase de análise dos resultados. Assim, apenas as curvas com coeficiente de determinação superior a 0,90 foram consideradas nos ensaios de ruptura, sendo mostradas no anexo A. No caso dos ensaios de fluência, curvas com $\mathrm{R}^{2}<0,97$ foram desconsideradas nas análises.

Como a fase de tratamento das fotos, ou seja, obtenção das coordenadas do centróide de cada marco é extremamente laboriosa e demorada. Os ensaios piloto e de repetibilidade não tiverem as imagens tratadas, sendo excluídos das análises de deformação. Apenas um ensaio de repetibilidade foi tratado (R-PET-3) para averiguar a repetibilidade em termos de deformação. Tal procedimento foi adotado por considerar que o esforço dispensado à análise de tais resultados não seria justificável por não trazer nenhuma contribuição relevante à análise dos resultados.

\subsubsection{Temperatura}

Os valores de temperatura registrados durante os ensaios são mostrados na Tabela 4.6. Para não comprometer o cronograma do trabalho, inicialmente, apenas a temperatura do ambiente externo próximo à centrífuga foi acompanhada com um termômetro, enquanto o sistema para medidas internas de temperatura era desenvolvido.

Observando-se a Tabela 4.6, percebe-se que não houve variação significativa da temperatura durante os ensaios. O máximo acréscimo de temperatura no ambiente foi $4^{0} \mathrm{C}$, possivelmente, pelo aquecimento do motor responsável pelo funcionamento 
da centrífuga. Nos modelos, a variação detectada foi menor, no máximo $2^{0} \mathrm{C}$ (ensaio F-PP-3), provavelmente, devido ao resfriamento causado pela presença de uma corrente de ar gerada durante a rotação do modelo. Nos ensaios de ruptura e na fase de carregamento dos ensaios de fluência, detectou-se uma diminuição na temperatura. Enquanto nos ensaios de fluência, com a aceleração mantida, um acréscimo de temperatura foi registrado.

A Figura 4.35 mostra a temperatura registrada pelos termopares durante todo o ensaio F-PP-3. A temperatura registrada pelo termopar T1 (localizado acima do muro) apresentou a maior variação enquanto uma menor oscilação foi verificada para T4 (posicionado a uma maior profundidade dentro do modelo).

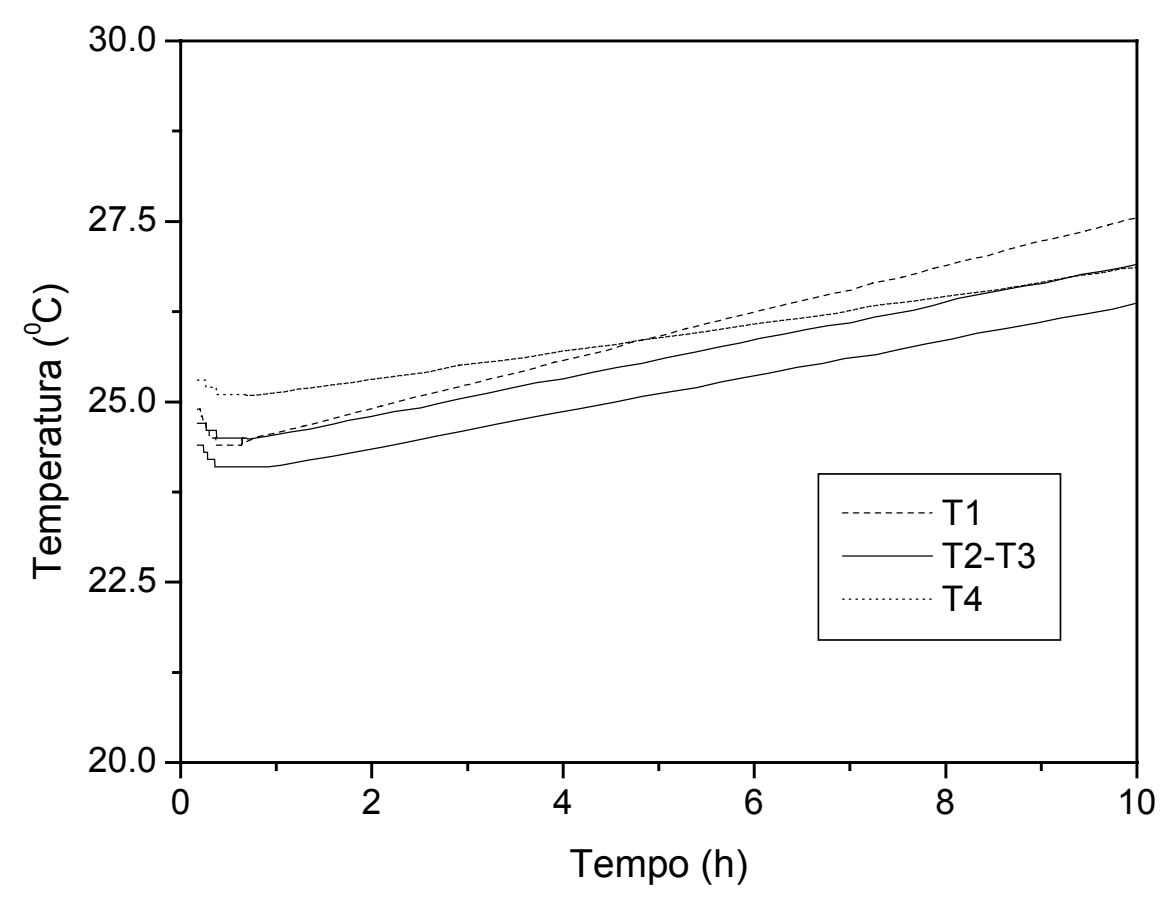

FIGURA 4.35 - Temperatura medida no ensaio F-PP-3 através dos termopares T1, T2, T3 e T4.

Em virtude da pequena variação de temperatura registrada nos ensaios F-PET-1 e F-PET-2 (dentro da faixa estabelecida pela ASTM D5262, por exemplo, para ensaios de fluência), os termopares foram empregados apenas em alguns ensaios para facilitar a execução dos mesmos. A temperatura externa foi monitorada em todos os ensaios. 
TABELA 4.6 - Temperaturas registradas nos ensaios

\begin{tabular}{|c|c|c|c|c|c|}
\hline \multirow[t]{2}{*}{ Ensaio } & \multicolumn{2}{|c|}{$\begin{array}{l}\text { Temperatura externa } \\
\left({ }^{0} \mathrm{C}\right)\end{array}$} & \multicolumn{2}{|c|}{$\begin{array}{c}\text { Temperatura Interna } \\
\left({ }^{0} \mathrm{C}\right)\end{array}$} & \multirow{2}{*}{$\begin{array}{c}\text { Duração do } \\
\text { ensaio } \\
\text { (h) } \\
0,58\end{array}$} \\
\hline & Inicial & Final & Inicial & Final & \\
\hline R-PET-1 & 21,3 & 21,0 & - & - & 0,50 \\
\hline R-PET-2 & 21,5 & 21,6 & - & - & 0,58 \\
\hline R-PET-3 & 22,0 & 22,1 & 23,2 & 22,80 & 0,58 \\
\hline R-PET-4 & 21,0 & 21,0 & - & - & 0,50 \\
\hline F-PET-1 & 21,2 & 23,0 & 23,0 & 24,9 & 10 \\
\hline F-PET-2 & 21,4 & 24,3 & 23,1 & 24,8 & 10 \\
\hline F-PET-3 & 21,3 & 22,4 & - & - & 10 \\
\hline F-PET-4 & 21,1 & 22,7 & - & - & 4 \\
\hline R-PP-1 & 23,2 & 23,4 & - & - & 0,58 \\
\hline R-PP-2 & 23,2 & 23,5 & - & - & 0,58 \\
\hline F-PP-1 & 23,5 & 26,0 & 23,5 & 24,2 & 10 \\
\hline F-PP-2 & 23,0 & 26,0 & - & - & 10 \\
\hline F-PP-3 & 23,1 & 27,0 & 24,7 & 26,7 & 10 \\
\hline F-PP-4 & 23,0 & 24,9 & - & - & 1,8 \\
\hline
\end{tabular}

\subsection{Análise dos resultados}

\subsubsection{Ensaios de ruptura}

\subsubsection{Definição da aceleração na ruptura}

A aceleração correspondente à ruptura foi definida através da interpretação da curva aceleração x recalque e pela observação visual do modelo através da câmera instalada dentro da centrífuga. Para os modelos da série 1, uma primeira possibilidade para a adoção da aceleração na ruptura com base na curva aceleração $\mathrm{x}$ recalque (Figura 4.36) consiste em considerar que a ruptura ocorre para um nível de aceleração correspondente ao ponto A. Essa definição seria absolutamente compatível com procedimentos normalmente adotados para definir ruptura em provas de cargas, por exemplo, em análises de fundações.

No entanto, essa definição não parece adequada no caso do presente trabalho. É preciso analisar a curva mostrada na Figura 4.36 como referente a uma estrutura de 
solo reforçado. A presença de recalques elevados após o ponto A não significa, necessariamente, que a estrutura atingiu seu limite de resistência, já que a resistência à tração do reforço é mobilizada para um nível de deformação bem mais elevado que o normalmente associado à ruptura para solos. Na verdade, convém destacar que o limite de utilização da estrutura pode ser considerado bem antes do ponto A, em virtude da magnitude dos recalques observados. O que se discute é o limite de resistência da estrutura.

Comparando-se o comportamento obtido nos ensaios de resistência à tração com o comportamento mostrado nas curvas aceleração x recalque, percebe-se uma semelhança. A Figura 4.37 apresenta uma curva obtida nos ensaios de tração do material e como se pode observar, após o ponto 1, o reforço apresenta maiores incrementos de deformação para um mesmo incremento de carga. Assim, a maior taxa de recalque após o ponto A, mostrado na Figura 4.36, deve-se ao fato do reforço ter ultrapassado o limite mostrado pelo ponto 1, na Figura 4.37. Portanto, o modelo pode ainda dispor de mais resistência após o ponto A e o comportamento mostrado após esse ponto deve-se ao comportamento força $\mathrm{x}$ deformação característico do geotêxtil de PET utilizado.

A inspeção visual do modelo R-PET-4 corrobora essa hipótese. O modelo foi ensaiado até um recalque correspondente a $14 \mathrm{~mm}$ (valor compreendido entre os pontos A e B) e então descarregado. A inspeção visual de todas as camadas de reforço revelou a ausência de rasgos ou de fibra rompidas que certamente deveriam estar presentes se algum dos geotêxteis tivesse atingido sua resistência à tração. Assim, o comportamento mostrado após o ponto $\mathrm{B}$ deve-se, de fato, ao comportamento força $\mathrm{x}$ deformação do material utilizado e não à ruptura de alguma camada de reforço.

Ainda com relação à definição da aceleração na ruptura, deve-se considerar que o objetivo primordial deste trabalho consiste em estudar a movimentação nos modelos ao longo do tempo em virtude do comportamento do reforço. Assim, quanto mais próximo o mesmo estiver de sua resistência à tração maior a susceptibilidade à fluência, facilitando a visualização das deformações. Nesse sentido, a aceleração para a qual o colapso se manifesta garante que o reforço já atingiu sua resistência à tração. 


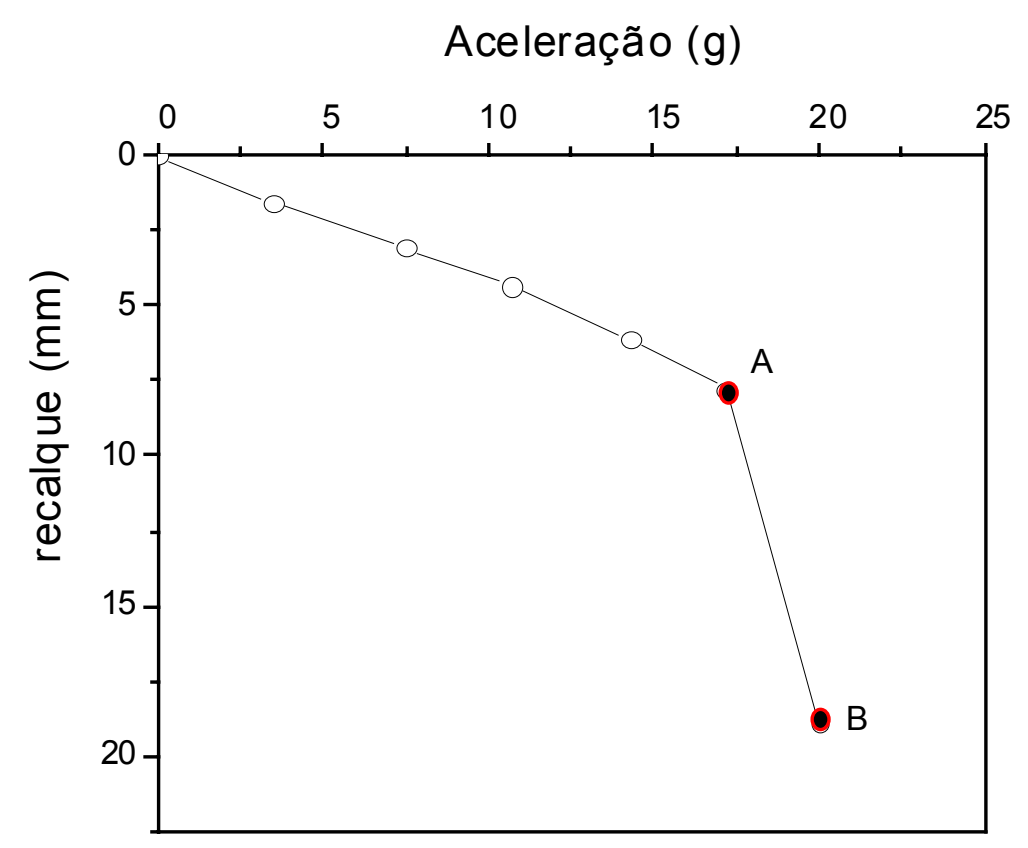

FIGURA 4.36 - Comportamento típico "aceleração x recalque" obtido para os modelos da série 1.

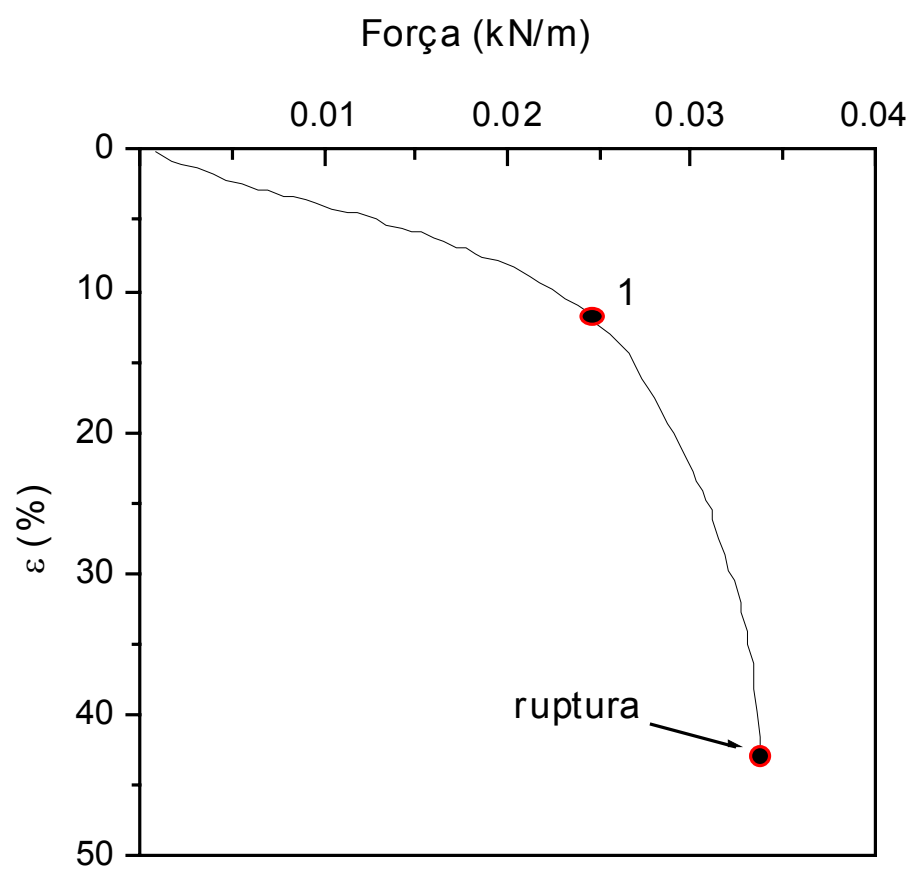

FIGURA 4.37 - Resultado típico obtido no ensaio de tração para o PET.

Com base nos aspectos discutidos, a aceleração na ruptura $\left(a_{r}\right)$ foi definida como a média entre a aceleração apresentada no ponto $B\left(a_{B}\right)$ e o valor da aceleração 
seguinte, para o qual o colapso da estrutura é observado ( $\mathrm{a}_{\text {colapso }}$ ). Ressalta-se mais uma vez, que pela elevada magnitude, o recalque final resultante do incremento de aceleração para o qual o colapso se manifesta não pôde ser monitorado em nenhum ensaio pela perda de curso do LVDT utilizado, não sendo possível assim sua representação na curva mostrada na Figura 4.36.

Para os modelos da série 2, a adoção de $\mathrm{a}_{\mathrm{A}}, \mathrm{a}_{\mathrm{B}}$ ou $\mathrm{a}_{\text {colapso }}$ não é muito relevante em virtude da menor diferença relativa entre os três valores, em comparação aos modelos da série 1 . De qualquer forma, a aceleração na ruptura $\left(a_{r}\right)$ foi novamente

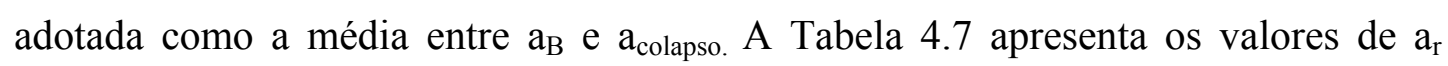
adotados para cada ensaio.

TABELA 4.7 - Valores de $\mathrm{a}_{\mathrm{r}}$ adotados em cada ensaio.

\begin{tabular}{cc}
\hline Ensaio & Aceleração na ruptura $\left(\mathrm{a}_{\mathrm{r}}\right)$ \\
\hline R-PET-1 & $20 \mathrm{~g}$ \\
R-PET-2 & $19 \mathrm{~g}$ \\
R-PET-3 & $21 \mathrm{~g}$ \\
R-PP-1 & $48 \mathrm{~g}$ \\
R-PP-2 & $49 \mathrm{~g}$ \\
\hline
\end{tabular}

\subsubsection{Localização da superfície de ruptura}

A inspeção visual dos modelos após os ensaios de ruptura revelou a presença de rasgos em todas as camadas, com exceção da primeira camada. Esse fato foi observado tanto para os modelos da série 1 quanto para os modelos da série 2. Os rasgos desenvolvidos foram praticamente perpendiculares ao comprimento do reforço. A localização da superfície de ruptura foi então considerada, primeiramente, com base nos rasgos observados nos geotêxteis.

A Figura 4.38 apresenta o padrão de rasgos observados para ambos geotêxteis. Para o geotêxtil de PP, o comprimento final do reforço foi praticamente igual ao comprimento inicial e os rasgos se estenderam ao longo de toda a largura do reforço, com separação completa das partes. Já o geotêxtil de PET apresentou um 
alongamento considerável após o ensaio, com o rasgo compreendido entre regiões bastante deformadas. Nem sempre a separação completa das partes foi observada.
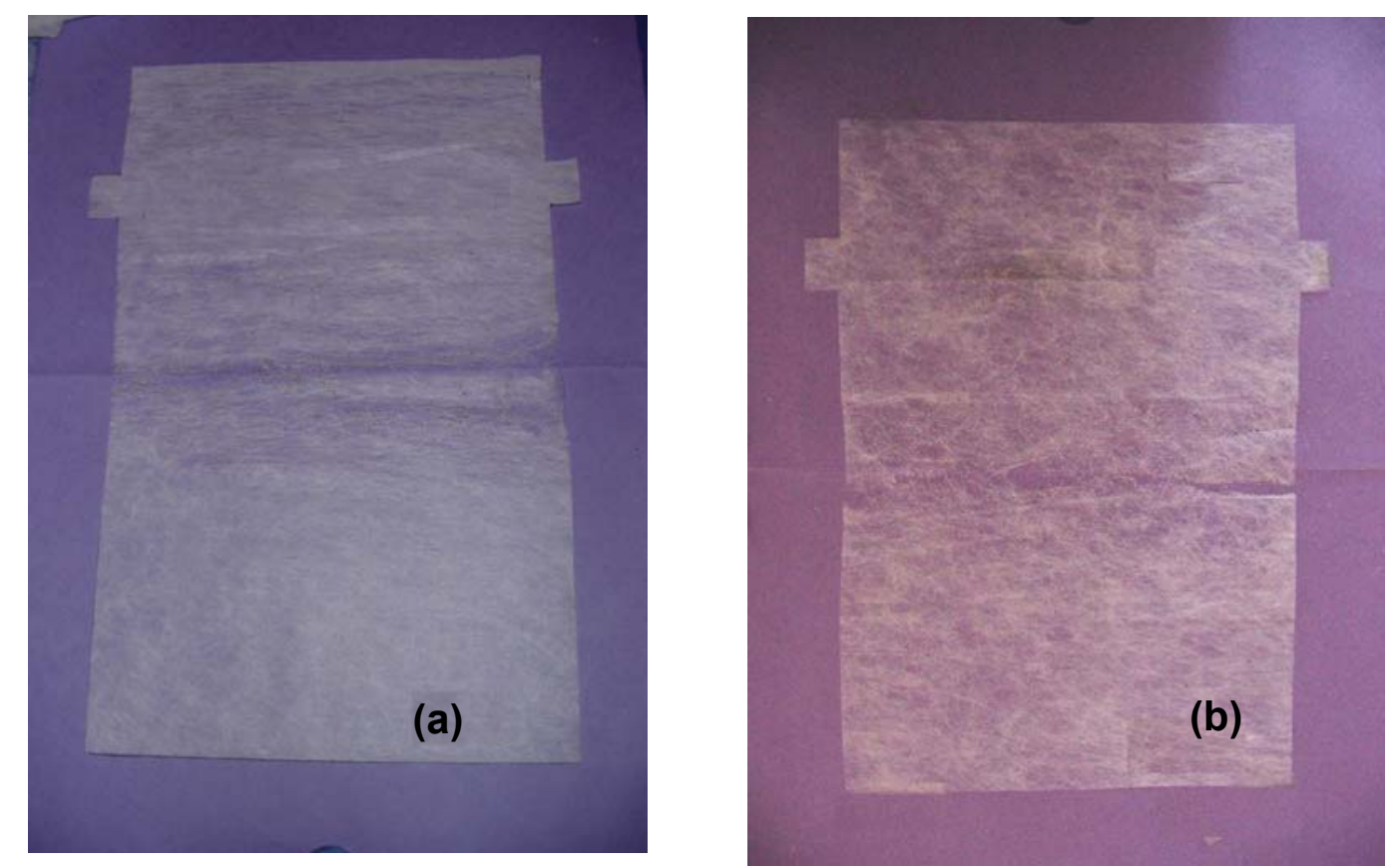

FIGURA 4.38 - Rasgos nos geotêxteis (a) PET, ensaio R-PET-2 - camada 6 (b) PP, ensaio R-PP-2 - camada 9.

Como o geotêxtil de PET apresentou um alongamento considerável após ensaio, a distância inicial do rasgo até a face não pôde ser medida diretamente, sendo então estimada através da expressão (4.5). Com o uso dessa expressão, assume-se que metade da variação de comprimento observada após ensaio foi resultante de deformação entre o rasgo e a face.

$\mathrm{d}_{\mathrm{i}}=\mathrm{d}_{\mathrm{f}}-\frac{\left(\mathrm{L}_{\mathrm{f}}-\mathrm{L}_{\mathrm{i}}\right)}{2}$

Onde,

$\mathrm{d}_{\mathrm{i}}$ - distância inicial do rasgo à face;

$\mathrm{d}_{\mathrm{f}}$ - distância final do rasgo à face (medida após ensaio);

$\mathrm{L}_{\mathrm{i}}$ - comprimento inicial do reforço;

$\mathrm{L}_{\mathrm{f}}$ - comprimento final do reforço (medido após ensaio). 
As Figuras 4.39 e 4.40 apresentam a superfície de ruptura obtida com base na localização dos rasgos para os modelos das séries 1 e 2, respectivamente. Pode-se observar a boa repetibilidade encontrada entre os ensaios R-PET-2 e 3. Como relatado na literatura, o tipo de reforço (desde que flexível) não afetou a localização da superfície. Praticamente, a mesma superfície foi encontrada para ambos geotêxteis. A posição da máxima deformação no reforço obtida através das curvas mostradas no Anexo B foi ainda considerada para a localização da superfície de ruptura, como mostrado nas Figuras 4.39 e 4.40.

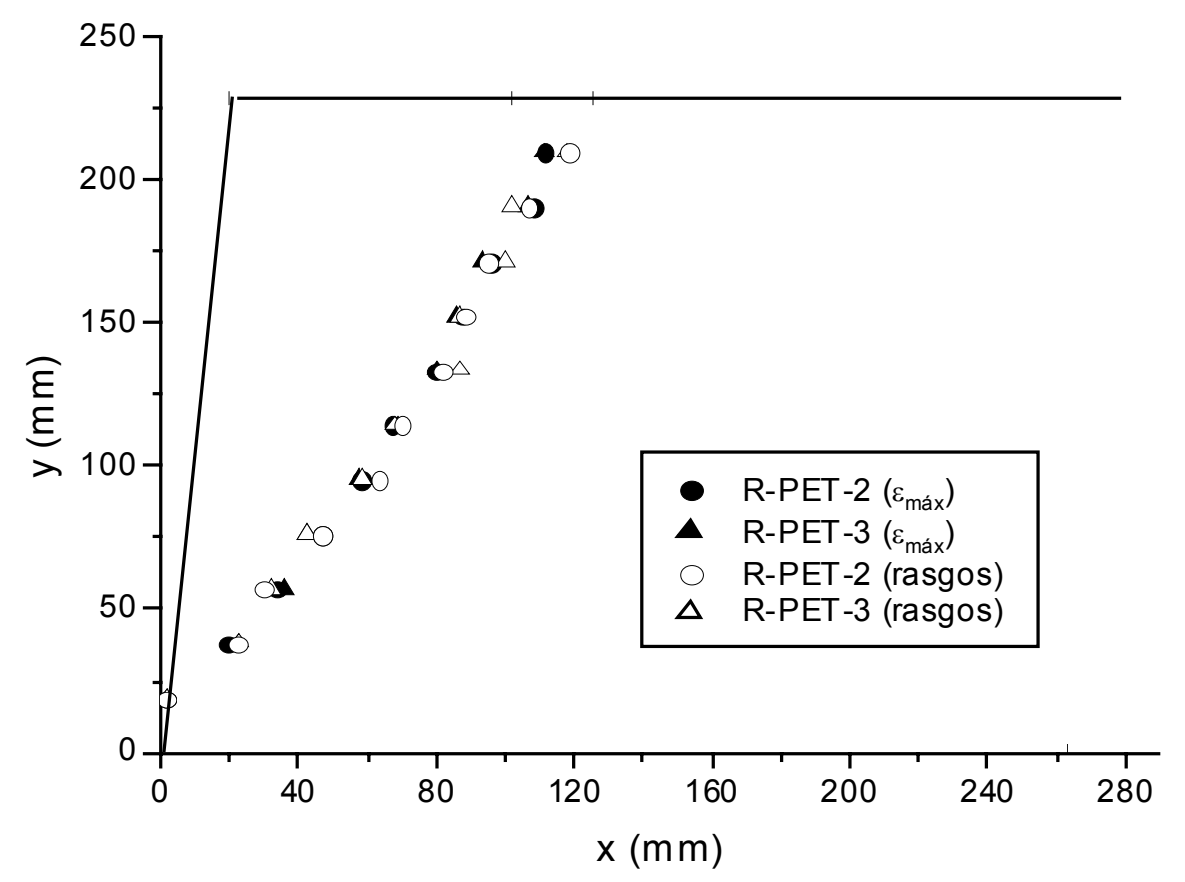

FIGURA 4.39 - Localização da superfície de ruptura para os modelos R-PET-2 e R-PET-3.

Observando-se as Figuras 4.39 e 4.40, percebe-se que ambas abordagens (rasgos e máxima deformação) produziram resultados bastante semelhantes, reforçando, de certa forma, a coerência da distribuição de deformação encontrada no presente trabalho. 


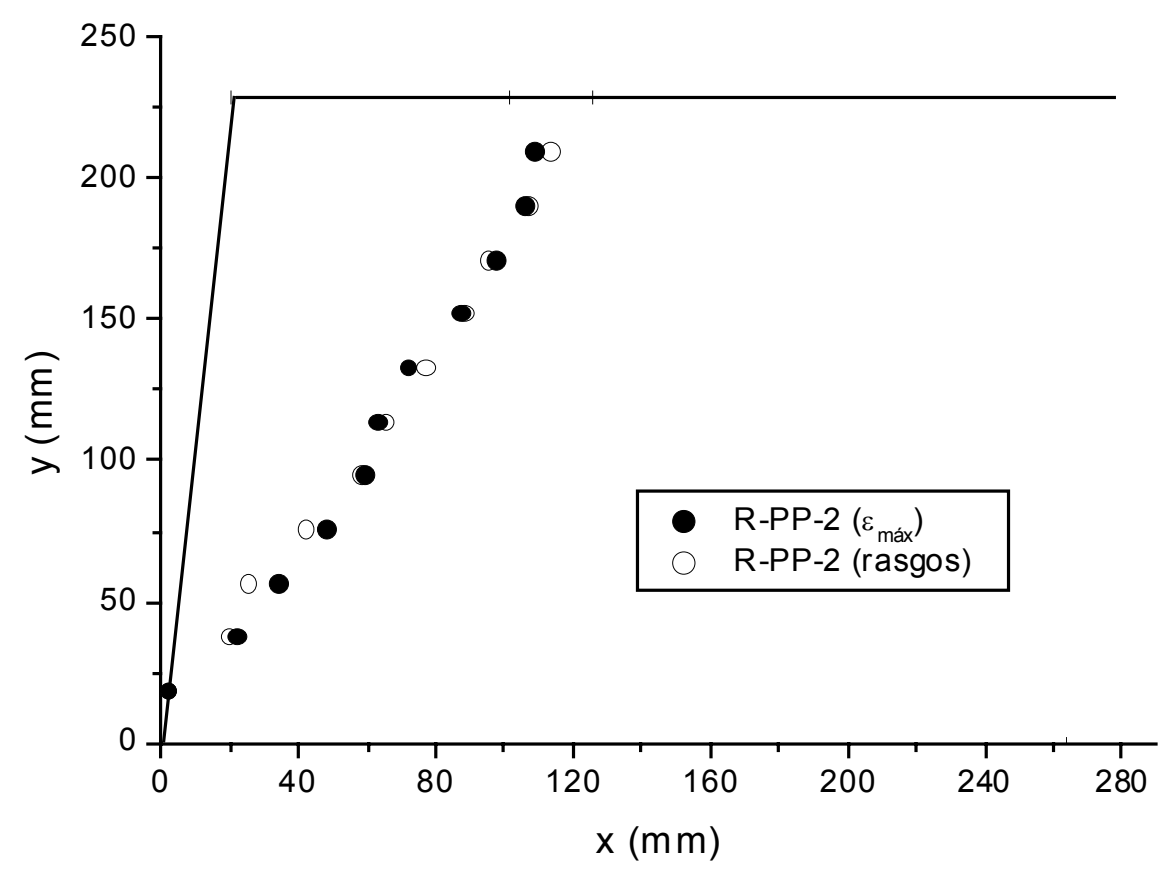

FIGURA 4.40 - Localização da superfície de ruptura para modelo R-PP-2.

\subsubsection{Efeito do confinamento}

Como os geotêxteis utilizados nos modelos são não tecidos, o efeito do confinamento na redução da estricção da manta precisa ser considerado. Esse efeito para o mesmo material de PET utilizado neste trabalho foi investigado anteriormente por ARRIAGA (2003). A investigação foi realizada através da retro-análise da ruptura de uma série de modelos de taludes de solo reforçado em centrífuga. A retroanálise teve por objetivo determinar o valor da força no reforço no momento da ruptura (resistência confinada), assumindo-se o ângulo de atrito de pico para o solo. Em todos os casos, um mesmo valor para a resistência confinada foi obtido, embora os modelos tenham configurações bastante distintas (ex. diferentes: inclinação do talude, espaçamento vertical, densidade relativa do solo, etc). A resistência confinada obtida foi cerca de 3,7 vezes superior ao valor não confinado.

O efeito do confinamento reportado por ARRIAGA (2003) é maior do que o normalmente encontrado para geotêxteis não tecidos. Uma relação entre a resistência confinada e não confinada em torno de 1,2 foi obtida por LEVACHER et al. (1994) e 
BALLEGEER \& WU (1993) para uma tensão confinante de 100 e 78,5 kPa, respectivamente. WU \& HONG (1994) encontraram uma relação igual a 1,6 para um geotêxtil não tecido agulhado confinado a $200 \mathrm{kPa}$, enquanto YUAN et al. (1998) reportam um valor de 1,9 para $138 \mathrm{kPa}$ de confinamento.

No entanto, é preciso considerar que o efeito do confinamento na resistência varia a depender do material e equipamento utilizados. Assim, algumas características específicas do material empregado podem justificar um maior efeito do confinamento. Nesse sentido, ressalta-se que o material utilizado possui uma gramatura bastante reduzida (até $25 \mathrm{x}$ menor) em relação à gramatura do material não tecido que é normalmente, de fato, utilizado como geotêxtil. Adicionalmente, é possível que o efeito da redução da estricção pelo confinamento, e a conseqüente restrição ao re-alinhamento das fibras, seja mais intenso para o material empregado pela alta anisotropia do mesmo em termos de resistência. Anisotropia essa, bem superior à normalmente verificada para geotêxteis disponíveis no mercado.

Um outro aspecto importante com relação ao material empregado, é que a resistência confinada parece ser a mesma independente do valor da tensão confinante aplicada. Esse comportamento foi constatado tanto por ZORNBERG et al. (1998a) quanto por ARRIAGA (2003) nos modelos de taludes de solo reforçado em centrífuga.

O comportamento mostrado na Figura 4.41, obtido por ZORNBERG et al. (1998a) e ARRIAGA (2003), demonstra tal aspecto. A Figura 4.41 mostra a aceleração na ruptura obtida para modelos de talude de solo reforçado exatamente com as mesmas características (mesma altura, solo, reforço, etc), com exceção do número de reforços, i.e, diferentes espaçamentos. Na ruptura, a tensão vertical a uma mesma profundidade para o modelo que apresenta dezessete inclusões $(n=17)$, por exemplo, é cerca 2,8x maior do que para o modelo com seis inclusões $(n=6)$, já que o primeiro apresenta ruptura para $a_{\mathrm{r}}=60 \mathrm{~g}$ e o segundo, para $\mathrm{a}_{\mathrm{r}}=21 \mathrm{~g}$. Se a resistência confinada dependesse do nível de tensão, o modelo com maior número de inclusões deveria apresentar uma maior aceleração na ruptura, não apenas pelo aumento do número de reforços, mas também por ganho de resistência em cada camada de reforço pelo aumento da tensão confinante. Pode-se observar, no entanto, que a aceleração na ruptura para o modelo com um número de reforços (n) igual a 17 é 
cerca de 2,8x maior que o valor esperado para um modelo com número de reforços $2,8 x$ menor ( $n=6)$, ou seja, apenas o suficiente pelo aumento do número de reforços. Se o valor da tensão confinante interferisse na resistência, $a_{r}$ para $n=17$ teria que ser bem maior que o valor verificado, já que a tensão confinante em cada nível de reforço é cerca de 2,8x maior.

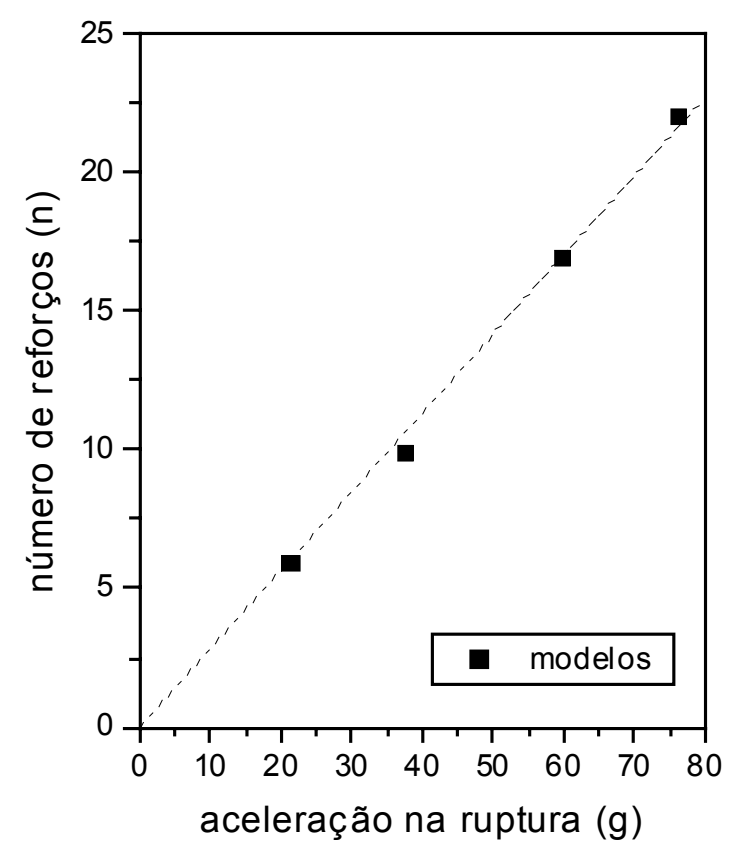

FIGURA 4.41 - Variação da aceleração na ruptura com o número de camadas no modelo (ZORNBERG et al., 1998a)

Esse comportamento deve-se possivelmente a algumas características peculiares do material empregado como reforço. Como discutido no capítulo 2, o efeito do confinamento em geotêxteis não tecidos deve-se à redução da estricção em virtude de alguns aspectos como, por exemplo, uma possível impregnação de solo na manta. A Figura 4.42 ilustra o efeito da impregnação de partículas em uma manta idealizada composta por duas fibras f1 e f2. Quando uma carga (P) é aplicada à manta, as fibras tendem a se reorientar na direção de aplicação da carga e a estricção ocorre (Figura 4.42a). Com a impregnação de uma partícula de solo entre as fibras, as mesmas não têm a mesma liberdade de movimentação que tinham anteriormente e a estricção da manta é reduzida (Figura 4.42b). 


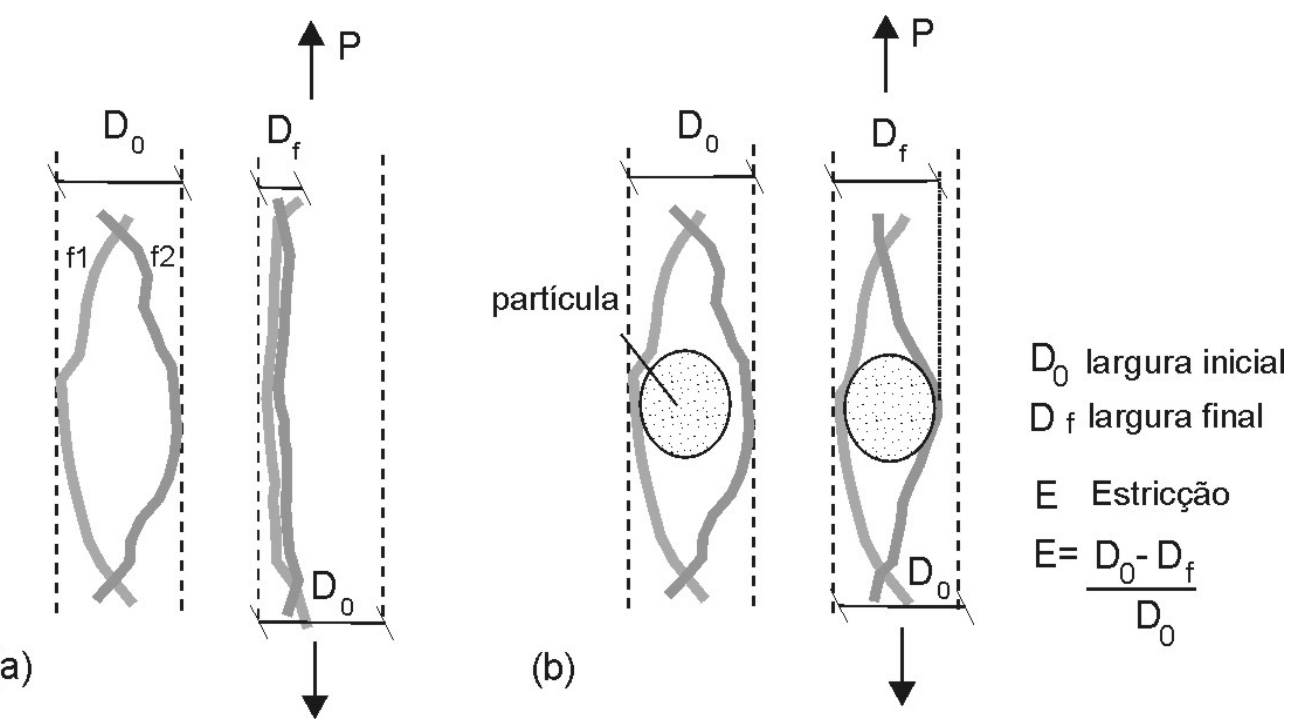

FIGURA 4.42 - Mecanismo de estriccão (a) sem impregnação de partículas (b) com impregnação.

No caso do material utilizado como reforço nos modelos, a baixa gramatura e a conseqüente espessura reduzida em comparação ao material de fato utilizado como geotêxtil pode provocar um efeito diferente com relação à impregnação de partículas na manta. No caso de geotêxteis, a imbricação de partículas se restringe à região superficial da manta e o efeito de travamento das fibras proporcionado pelas partículas não atinge todas as fibras que compõem a manta (Figura 4.43a). O aumento da tensão confinante tende a aumentar a impregnação de partículas como mostrado na Figura 4.43b.

No caso do material utilizado como reforço nos modelos, a impregnação de partículas pode facilmente atingir toda a espessura da manta (Figura 4.43c), mesmo para um baixo valor de tensão, e garantir o travamento da maioria das fibras. Como mostrado na Figura 4.43c, as partículas de solo inferior e superior já se encontram praticamente em contato em virtude da pequena espessura da manta, portanto o aumento da tensão confinante não provoca uma maior penetração das partículas (Figura 4.43d). Isso evita que a variação da tensão aplicada interfira no processo. 


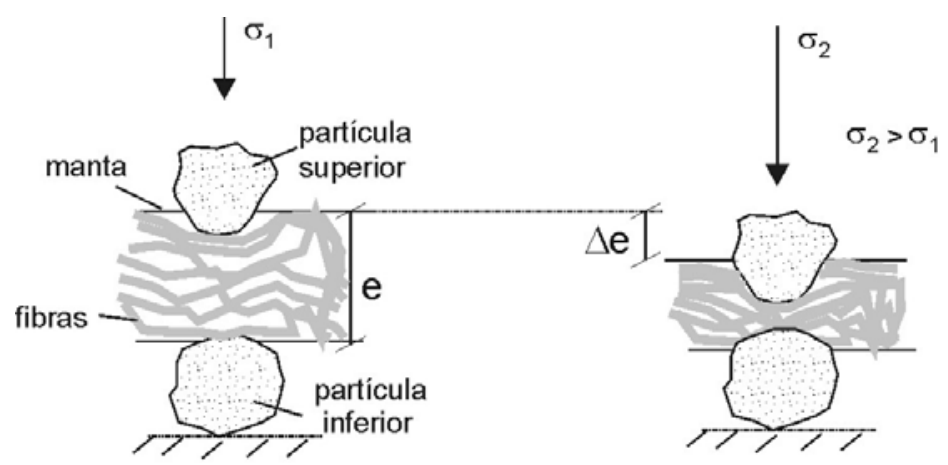

e - espessura

(a)

(b)

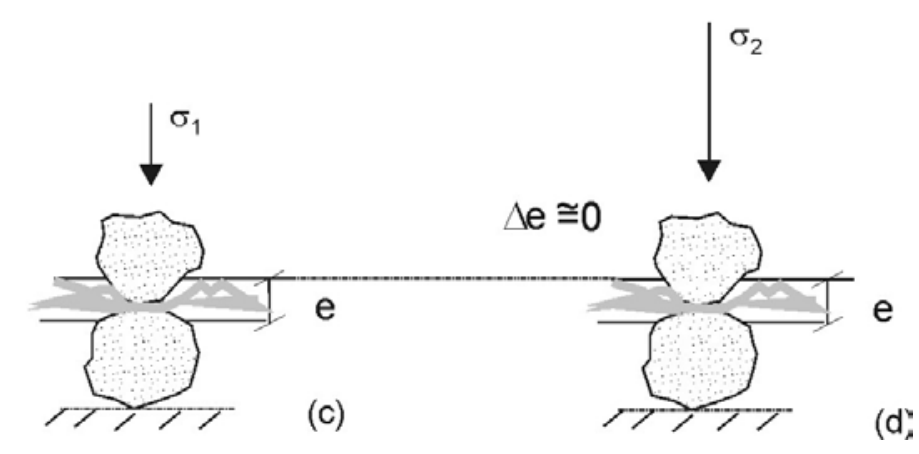

FIGURA 4.43 - (a) Impregnação de partículas em geotêxteis (b) Impregnação de partículas em geotêxteis com o aumento da tensão (c) Impregnação de partículas no material dos modelos (d) Impregnação de partículas no material dos modelos com o aumento de tensão.

Assim, para o material utilizado nos modelos, a presença do solo mesmo com a aplicação de uma tensão confinante de pequeno valor, já pode garantir uma maior resistência em relação aos ensaios sem confinamento devido ao travamento causado pela presença das partículas. O efeito da impregnação de partículas deve ser preponderante em relação a outros fatores que também podem diminuir a estricção do reforço. Como tal efeito tende a não apresentar variação com o aumento da tensão confinante, todas as camadas de reforço no modelo podem manifestar uma mesma resistência confinada apesar de submetidas a tensões confinantes diferentes.

\subsubsection{Distribuição da força máxima no reforço com a profundidade}

Uma outra questão importante, principalmente antes de efetuar comparações entre o comportamento observado e previsões teóricas, diz respeito à distribuição da força máxima em cada camada de reforço com a profundidade. $\mathrm{Na}$ grande maioria 
dos métodos disponíveis considera-se que a última de camada de reforço é a mais solicitada em virtude da distribuição de tensão horizontal adotada em estruturas de contenção convencionais, isto é, linearmente crescente com a profundidade. Essa distribuição resulta na distribuição da força máxima em cada reforço, em função da profundidade, mostrada na Figura 4.44 (distribuição triangular).

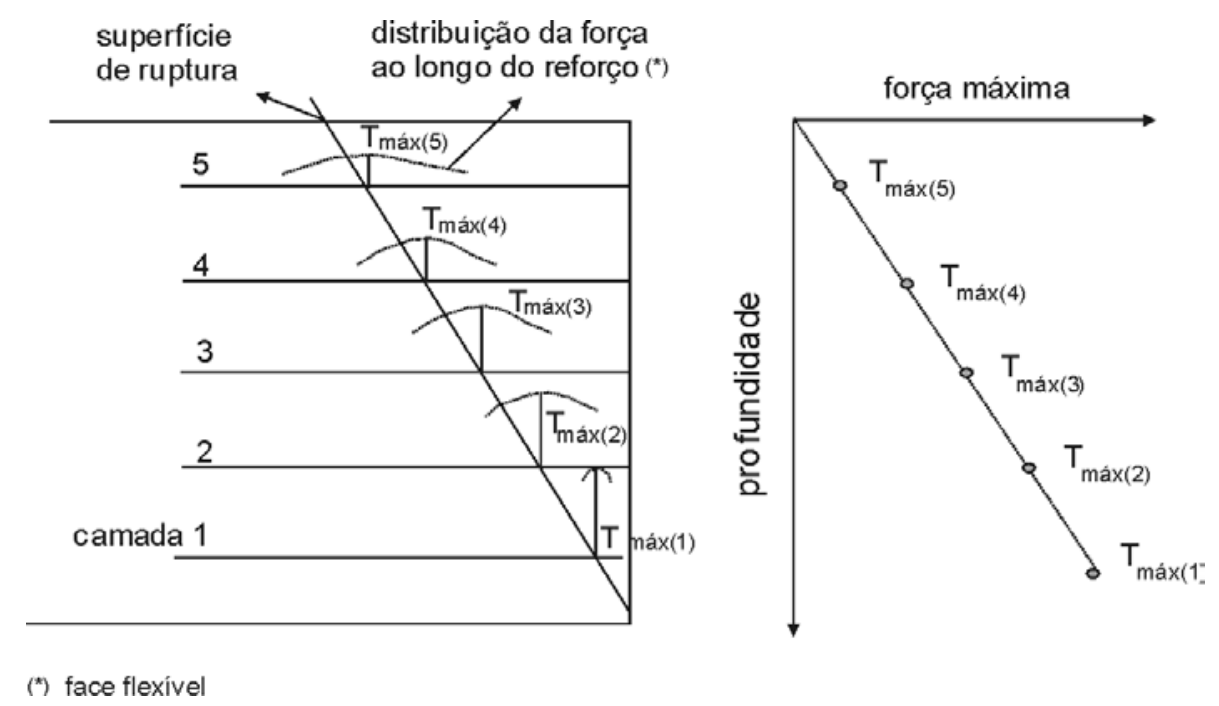

FIGURA 4.44 - Distribuição da força máxima com a profundidade adotada em projetos

A distribuição mostrada na Figura 4.44, no entanto, nem sempre é observada em muros de solo reforçado com geossintéticos. Se, por exemplo, o efeito da compactação for considerado, a distribuição mostrada na Figura 4.44 não é necessariamente válida. Como discutido no capítulo 2, a consideração das tensões induzidas durante a compactação pode provocar uma distribuição diferente da mostrada na Figura 4.44. Segundo EHRLICH \& MITCHELL (1994), para muros de pequena altura, nos quais as tensões induzidas pela compactação ultrapassam as tensões geostáticas, e considerando ainda, solos não coesivos e geotêxteis, as tensões horizontais no solo e a força no reforço mantêm-se praticamente constantes com a profundidade, como mostrado na Figura 4.45.

Outros fatores também podem provocar uma distribuição diferente em relação à distribuição mostrada na Figura 4.44. A restrição causada pela fundação bem como o atrito entre o solo e a face têm sido freqüentemente citados como possíveis 
responsáveis pelo fato da última camada de reforço não ser a mais solicitada (ex. ROWE \& HO, 1998; JABER, 1989).

Com relação à distribuição da força máxima com a profundidade, praticamente não se encontram na literatura relatos dessa distribuição, em condições semelhantes aos modelos estudados no presente trabalho. Embora exista um número razoável de obras instrumentadas através das quais se pode obter a distribuição da força no reforço com a profundidade, essas estruturas encontram-se em condições de trabalho, e assim sendo, com reforços muito pouco solicitados, ao contrário dos modelos ensaiados nesta pesquisa.

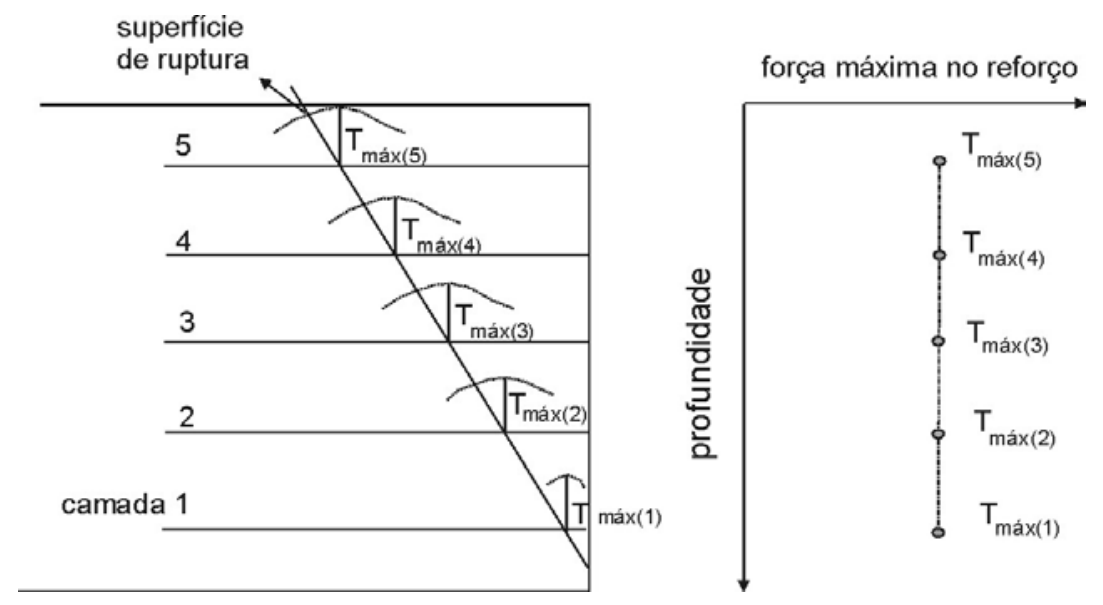

FIGURA 4.45 - Distribuição retangular da força no reforço

No que diz respeito especificamente a ensaios em centrífuga, poucos trabalhos apresentam a distribuição da força com a profundidade. A título de ilustração, como base em uma revisão da literatura realizada por ARRIAGA (2003), de 13 trabalhos relatados na literatura sobre muros de solo reforçado em centrífuga, apenas na pesquisa desenvolvida por JABER (1989) alguns muros foram instrumentados, possibilitando a obtenção da distribuição da força no reforço. Nesse trabalho, um comportamento importante, com relação à distribuição da força nos reforços, foi verificado em um muro de solo reforçado com tiras de papel alumínio: ocorreu uma redistribuição de tensão entre os reforços. Inicialmente, a estrutura apresentou uma distribuição de força máxima no reforço com a tendência mostrada na Figura 4.44, com exceção de uma redução da força para as duas últimas camadas. No entanto, a cerca de $85 \%$ da aceleração na ruptura iniciou-se uma redistribuição de 
tensão entre reforços e, próximo à ruptura, todas as camadas estavam igualmente solicitadas (ou seja, distribuição retangular da força com a profundidade, ver Figura 4.45). Segundo ZORNBERG (1994) e ARRIAGA (2003), a distribuição retangular também é mais coerente com o comportamento que foi observado para os modelos de taludes de solo reforçado ensaiados pelos autores.

A Figura 4.46 apresenta a deformação máxima em cada camada de reforço em função da profundidade observada no presente trabalho para os modelos de ruptura e de fluência. Apesar do possível efeito de confinamento na rigidez para geotêxteis não tecidos, acredita-se que essa distribuição de deformação corresponde a uma distribuição de carga nos reforços constante com a profundidade, como mostrado na Figura 4.46. Nesse sentido, os seguintes aspectos foram considerados:

(i) o aumento de resistência devido ao confinamento mostrou-se independente do valor da tensão confinante atuante em cada camada, como discutido anteriormente;

(ii) resultados descritos na literatura mostram que, para geotêxteis não tecidos, ocorre uma variação significativa da rigidez com a tensão confinante aplicada para pequenas deformações (ex. módulo tangente inicial, módulo secante a 1\% e 2\%). No entanto, para o nível de deformação nos modelos ensaiados $(\varepsilon>5 \%)$, a variação da rigidez com a tensão confinante é bem menor, como mostrado por CHRISTOPHER et al. (1986), e tende a diminuir à medida que a deformação aumenta.

(iii) A variação de deformação com a profundidade para $\mathrm{a}=95 \% \mathrm{a}_{\mathrm{r}}$ (que mostra uma tendência parabólica com a profundidade) não implica variações significativas da força atuante nos reforços. Como se pode observar na Figura 4.37, próximo à ruptura, uma variação significativa na deformação corresponde a uma pequena variação na carga. Assim, a distribuição da força ainda pode ser assumida constante com a profundidade para $\mathrm{a}=95 \% \mathrm{a}_{\mathrm{r}}$, como mostrado na Figura 4.46.

Ainda com relação à distribuição de força com a profundidade, como o último reforço (camada 1) não apresentou ruptura, é possível que ocorra uma tendência de decréscimo da força próximo à fundação como freqüentemente relatado na literatura (linha tracejada na Figura 4.46). 


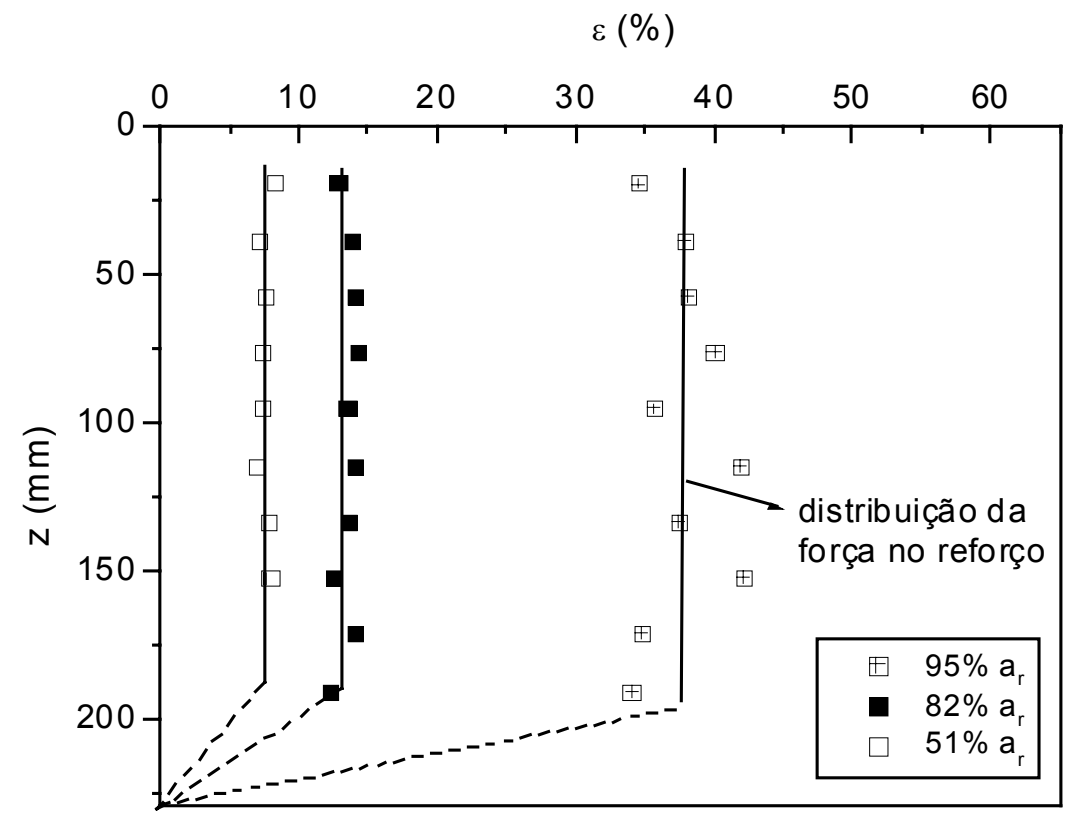

FIGURA 4.46 - Distribuição da deformação máxima em cada camada com a profundidade (z) observada no modelo R-PET-3

Ressalta-se que a distribuição de força verificada nos modelos (força máxima constante com a profundidade) é representativa de situações verificadas em campo. Como discutido, as estruturas reais podem apresentar o mesmo tipo de distribuição devido, por exemplo, ao efeito do processo de compactação. Destaca-se ainda que esse tipo de distribuição também já foi detectada em modelos por outros autores (JABER, 1989; ZORNBERG, 1994; ARRIAGA, 2003). No entanto, a intensidade e a forma de desenvolvimento do mecanismo de redistribuição de força deve depender das características de cada estrutura.

No modelo com tiras metálicas estudado por JABER (1989), a redistribuição foi iniciada a cerca de $85 \%$ da aceleração que provocou o colapso da estrutura. Nos taludes de solo reforçado reportados por ARRIAGA (2003) essa redistribuição é iniciada a cerca de 50, 60\% da aceleração que provoca o colapso. Assim, o mecanismo de redistribuição tal qual observado nos modelos realizados no presente trabalho resulta da combinação das características específicas do modelo (face flexível, reforço bastante extensível, etc) e da forma de carregamento na centrífuga. 


\subsubsection{5 Ângulo de atrito mobilizado}

O ângulo de atrito do solo mobilizado na ruptura é um aspecto importante na análise dos resultados obtidos. Alguns autores (ex. McGOWN et al., 1998; JEWELL, 1991) acreditam que sendo alguns geossintéticos bastante extensíveis, o ângulo de atrito mobilizado na ruptura corresponderia a uma condição pós-pico. A adoção do ângulo correspondente ao estado crítico corresponderia a uma abordagem mais conservadora. Outros autores (ex. ZORNBERG et al., 1998a; ARRIAGA, 2003) consideram que o ângulo de atrito mobilizado na ruptura corresponde ao valor de pico, mesmo com a utilização de geotêxteis. Essa asserção tem por base resultados de ensaios em centrífuga de taludes de solo reforçado nos quais modelos idênticos foram preparados utilizando-se duas densidades relativas diferentes para o solo de aterro. Como os modelos com densidade mais elevada (ou seja, maior ângulo de pico) atingiram a ruptura para uma aceleração bem superior, o ângulo de pico foi adotado na condição de ruptura do modelo, apesar do elevado nível de deformação nos reforços $(\varepsilon=40 \%)$.

Com relação a essa questão, a Figura 4.47 apresenta o padrão de deformação na massa de solo observado no ensaio R-PET-3 próximo à condição de ruptura. A figura corresponde a um deslocamento no topo da ordem de $10 \%$ da altura do muro. Para fins ilustrativos, a Figura 4.48 apresenta o padrão clássico de deformação na massa de solo encontrado em estudos de estruturas de contenção convencionais (sem reforço). O padrão mostrado foi obtido através da rotação do paramento em torno do topo para um deslocamento na base igual a $4 \%$ da altura do muro de contenção.

Observando-se a Figura 4.47 e 4.48, fica nítida a diferença de mecanismo devido à presença dos reforços. Na Figura 4.48, percebe-se a presença de deformações cisalhantes na massa de solo bem mais acentuadas na região da superfície de deslizamento que as mostradas na Figura 4.47, mesmo com o elevado valor de deformação no reforço, em torno de 40\%. O padrão de deformação observado na Figura 4.47 sugere uma grande deformação lateral da estrutura, devido à deformação dos geotêxteis. Ou seja, é possível que o reforço apresente uma deformação elevada sem que existam deformações acentuadas em termos de cisalhamento no solo. Em outras palavras, o ângulo de atrito mobilizado nos modelos 
pode ser correspondente a um valor superior ao do ângulo de atrito no estado crítico, apesar do alto valor de deformação dos geotêxteis.

Com base no exposto, a comparação dos resultados dos ensaios de ruptura com previsões teóricas (item 4.8.1.6) será feita utilizando-se também o valor do ângulo de atrito de pico para a consideração da resistência mobilizada no solo.

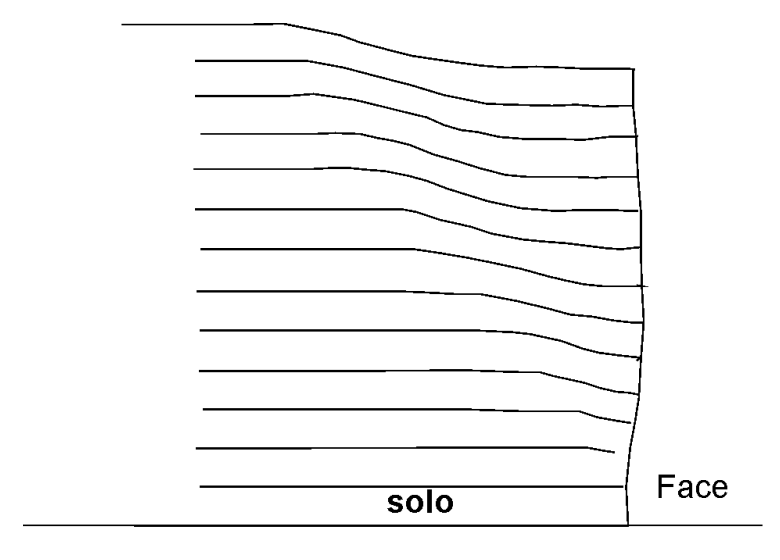

FIGURA 4.47 - Padrão de deformação observado nos modelos - ensaio R-PET-3

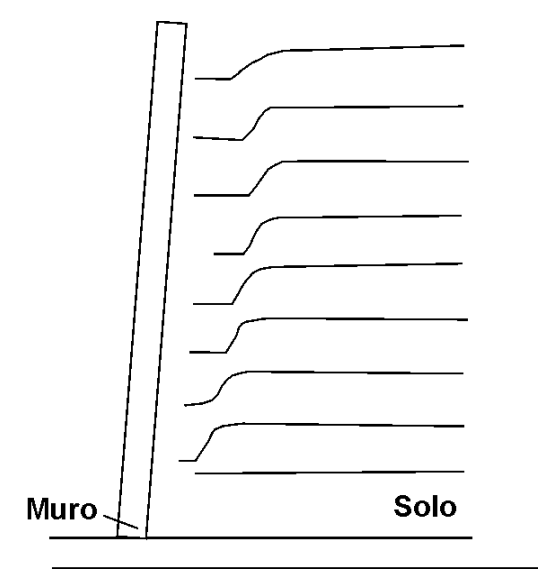

FIGURA 4.48 - Padrão de deformação observado em um muro de contenção convencional (modificado de TOYOSAWA et al. 2002). 


\subsubsection{Comparação dos resultados obtidos com previsões teóricas}

O método conhecido como Tieback Wedge (US Forest Service) largamente empregado no dimensionamento de muros de solo reforçado com geossintéticos foi utilizado para comparar os resultados encontrados com previsões teóricas. Nesse método, considera-se, para fins de estabilidade interna, que a estrutura é flexível o suficiente para mobilizar o empuxo ativo. O coeficiente de empuxo ativo $\left(\mathrm{k}_{\mathrm{a}}\right)$ é então adotado para obter a tensão horizontal a partir da tensão vertical. Em seguida, assume-se que o reforço deve resistir à tensão horizontal correspondente a sua área de influência.

De acordo com o referido método, a aceleração na ruptura prevista para os modelos pode ser obtida através da expressão (4.6).

$\mathrm{F}_{\mathrm{h}}=\mathrm{k}_{\mathrm{a}} \cdot \mathrm{N} \cdot \gamma \cdot \mathrm{z} \cdot \mathrm{S}_{\mathrm{v}}$

onde,

$\mathrm{F}_{\mathrm{h}}$ - força no reforço;

$\mathrm{k}_{\mathrm{a}}$ - coeficiente de empuxo ativo, $\mathrm{k}_{\mathrm{a}}=\operatorname{tg}^{2}(45-\phi / 2)$;

$\phi$ - ângulo de atrito;

$\mathrm{N}$ - fator de escala (na ruptura $\mathrm{N}=\mathrm{a}_{\mathrm{r}}$ );

$\gamma$ - peso específico do solo $\left(\gamma=16,08 \mathrm{kN} / \mathrm{m}^{3}\right)$;

$\mathrm{Z}$ - profundidade do reforço considerado;

$\mathrm{S}_{\mathrm{v}}$ - espaçamento vertical entre camadas $\left(\mathrm{S}_{\mathrm{v}}=19,05 \mathrm{~mm}\right)$.

A Tabela 4.8 apresenta os valores de aceleração utilizando-se a expressão (4.6), de acordo com a abordagem normalmente adotada em projetos. Ou seja, a força no reforço foi assumida igual ao valor da resistência não confinada. A expressão (4.6) foi utilizada ainda adotando, para fins de comparação, tanto o ângulo de atrito de pico considerando estado plano $\left(\phi_{\mathrm{ps}}\right)$, quanto o correspondente ao estado crítico $\left(\phi_{\mathrm{cr}}\right)$. 
TABELA 4.8 - Aceleração prevista através da expressão 4.6 para os modelos.

\begin{tabular}{ccccccc}
\hline Abordagem & Modelo & $\begin{array}{c}\text { Camada } \\
\text { mais } \\
\text { solicitada }\end{array}$ & $\begin{array}{c}\text { Angulo } \\
\text { de atrito }\end{array}$ & $\begin{array}{c}\mathrm{F}_{\mathrm{h}} \\
(\mathrm{kN} / \mathrm{m})\end{array}$ & $\begin{array}{c}\mathrm{a}_{\mathrm{r}-\text { previsto }} \\
(\mathrm{g})\end{array}$ & ${ }^{*} \mathrm{a}_{\mathrm{r}-\mathrm{obtido}} / \mathrm{a}_{\mathrm{r}-\text { previsto }}$ \\
\hline 1 & Série 1 -PET & 1 & $42,0^{0}$ & 0,033 & 2,4 & 8,3 \\
2 & Série 1 -PET & 1 & $32,5^{0}$ & 0,033 & 1,6 & 12,5 \\
3 & Série 2 -PP & 2 & $42,0^{0}$ & 0,144 & 11,3 & 4,3 \\
\hline
\end{tabular}

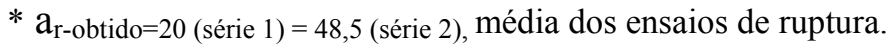

Observando-se a Tabela 4.8, percebe-se que os valores previstos para aceleração na ruptura para os modelos da série 1 foram bem inferiores aos observados. Adoção de $\phi_{\text {cr, }}$, obviamente, provoca uma discrepância ainda maior, cerca de $1,5 x$ superior à adoção de $\phi_{\text {ps. }}$.

Inúmeros trabalhos na literatura afirmam que os métodos de dimensionamento normalmente utilizados são conservadores (ex. RESL, 1990; THAMM, 1990; JABER \& MITCHELL, 1990; ROWE \& HO, 1992). Especificamente, com relação ao método utilizado (Tieback Wedge), ALLEN \& BATHURST (2002a), ao revisarem o comportamento de 16 muros instrumentados, relatam que a carga prevista no reforço foi em média de 4 a 5 vezes superior à observada. Convém destacar que tal diferença não leva em conta os fatores de redução para a resistência à tração e coeficientes de segurança utilizados em projetos que aumentariam ainda mais esse valor.

Especificamente para os modelos da série 1, a primeira abordagem (ver Tabela 4.8) foi considerada mais adequada e escolhida para avaliar as diferenças entre a aceleração prevista e obtida nos modelos, pelos motivos discutidos no item 4.8.1.5 e por facilitar comparações com outros trabalhos presentes na literatura. Acredita-se que a diferença entre o valor de $a_{r}$ previsto na abordagem 1 e o valor observado deve-se principalmente aos seguintes fatores:

i) A expressão 4.6 assume que a camada 1 é a mais solicitada. No entanto, devido possivelmente à restrição da fundação, a superfície de ruptura observada nos modelos não interceptou a última camada. Considerando a 
penúltima camada como a mais solicitada, a relação entre o valor de $a_{r}$ obtido e previsto seria reduzido para 7,4 ;

ii) Aumento da resistência à tração do reforço devido ao confinamento. Como mostrado no item 4.8.1.3, estima-se que a resistência confinada seja cerca de 3,7 vezes superior ao valor da resistência sem confinamento;

iii) Redistribuição de tensão entre reforços, provocando uma força máxima nos geotêxteis praticamente uniforme com a profundidade, como discutido no item 4.8.1.4.

Com efeito, se todos esses fatores forem considerados percebe-se que a aceleração na ruptura poderia atingir o valor observado nos modelos. Os aspectos acima discutidos são de extrema importância e serão incorporados nas análises seguintes.

Para os modelos da série 2, a discrepância entre o valor previsto e o observado é menor. Como os aspectos discutidos nos itens 'i' e 'iii' são também válidos para os modelos da série 2 , a diferença deve-se provavelmente a um menor efeito do confinamento na resistência para o geotêxtil de PP. Considerando a redistribuição de tensão, o valor de $\mathrm{a}_{\mathrm{r} \text {-previsto }}$ seria duas vezes superior ao mostrado na Tabela 4.8. Uma resistência confinada 2 vezes superior à não confinada justificaria assim, a ruptura dos modelos para a aceleração observada.

\subsubsection{Ensaios de fluência}

Como citado, em todos os ensaios de fluência, constatou-se que a estrutura apresentou deformações ao longo do tempo, tanto através do LVDT como através do tratamento das imagens. Em alguns ensaios, observou-se ainda ruptura da estrutura após algumas horas com a aceleração constante.

Os resultados demonstram claramente a interferência do comportamento dependente do tempo dos reforços utilizados. A grande questão, no entanto, consiste em avaliar se a magnitude da movimentação observada está de acordo com o que poderia ser previsto com base no reforço isolado, ou se uma possível interação com o solo afetou o comportamento do geotêxtil. 
A identificação do nível de carga nos reforços no momento em que a aceleração é mantida constante, constitui o primeiro aspecto a ser considerado para as análises. A princípio, 25, 40, 60 e $80 \%$ da aceleração na ruptura não significa necessariamente que todos os geotêxteis estão a 25, 40, 60 e $80 \%$ de sua resistência à tração. O nível de carga atuante dependeria da distribuição de carga entre as camadas durante o ensaio. No entanto, como discutido no item 4.8.1.4, a distribuição de força máxima nos reforços parece ser constante com a profundidade, mesmo antes da ruptura. Esse comportamento permite que os níveis de aceleração em relação à aceleração na ruptura possam ser adotados, para todas as camadas, como os níveis de carga nos reforços em relação à resistência à tração do material.

As Figuras 4.49 a 4.51 apresentam as deformações obtidas para os modelos da série 1 nos ensaios de fluência e as deformações ao longo do tempo registradas nos ensaios de fluência não confinada para o geotêxtil de PET. As deformações nos modelos estão em geral compreendidas no intervalo observado nos ensaios não confinados e uma mesma tendência em termos de taxa de deformação foi verificada para as duas situações. A variação entre camadas de reforço pode ser justificada pela própria variabilidade do material já identificada nos ensaios não confinados. Essa boa concordância foi observada também em termos de ruptura. O tempo de ruptura para o modelo com $\mathrm{a}=80 \% \mathrm{a}_{\mathrm{r}}$ foi cerca de $4 \mathrm{~h}$ e o tempo encontrado nos ensaios não confinados variou de $1 \mathrm{a} 5 \mathrm{~h}$.

Os diferentes tempos de carregamento entre os ensaios de fluência convencionais e os modelos ( 1 min para os ensaios não confinados e até 30 min nos modelos) não compromete essa comparação, pois embora a velocidade de carregamento possa influenciar consideravelmente a taxa inicial de fluência, as taxas observadas tendem a apresentar um mesmo valor ao longo do tempo (ALLEN \& BATHURST, 2002b). As diferenças já são bastante reduzidas após a carga, no ensaio com menor velocidade de carregamento, ser mantida constante por um tempo equivalente ao de carregamento (RIMOLDI \& MONTANELLI, 1993; GOTTARDI \& SIMONINI, 2000). No caso dos modelos, no máximo em 30 min após a aceleração ser mantida constante, a velocidade de carregamento não provocaria diferenças na taxa de deformação. 


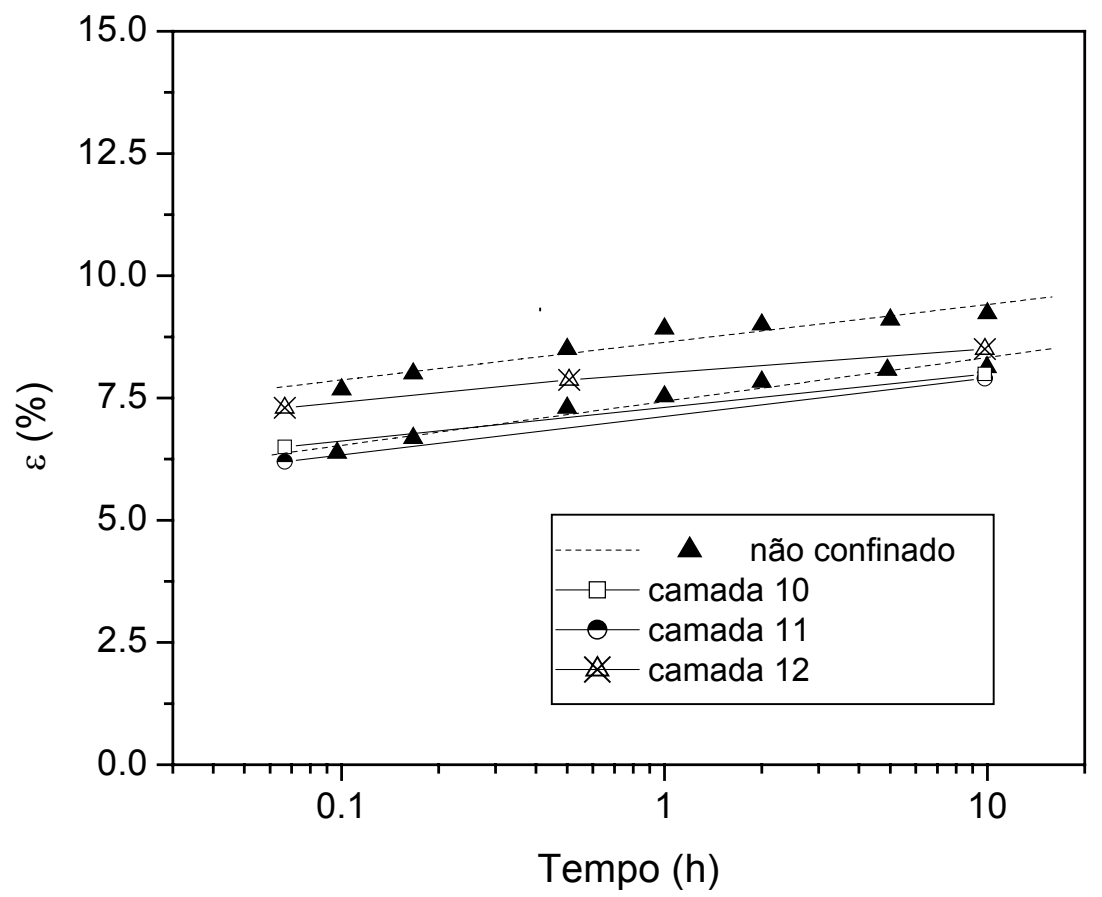

FIGURA 4.49 - Comparação entre as deformações obtidas nos modelos $\left(40 \% \mathrm{a}_{\mathrm{r}}\right)$ e as obtidas nos ensaios de fluência não confinada $\left(40 \% \mathrm{~T}_{\mathrm{ult}}\right)$, geotêxtil de PET.

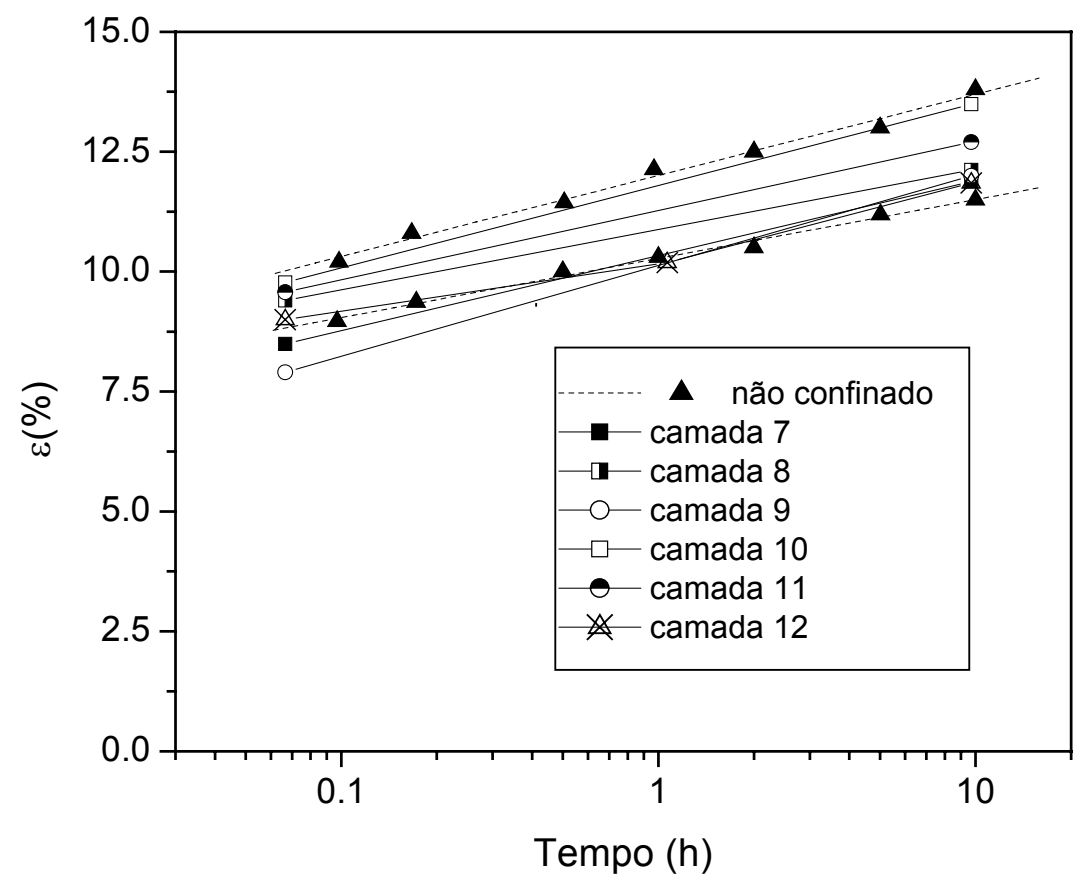

FIGURA 4.50 - Comparação entre as deformações obtidas nos modelos $\left(60 \% \mathrm{a}_{\mathrm{r}}\right)$ e as obtidas nos ensaios de fluência não confinada $\left(60 \% \mathrm{~T}_{\mathrm{ult}}\right)$, geotêxtil de PET. 


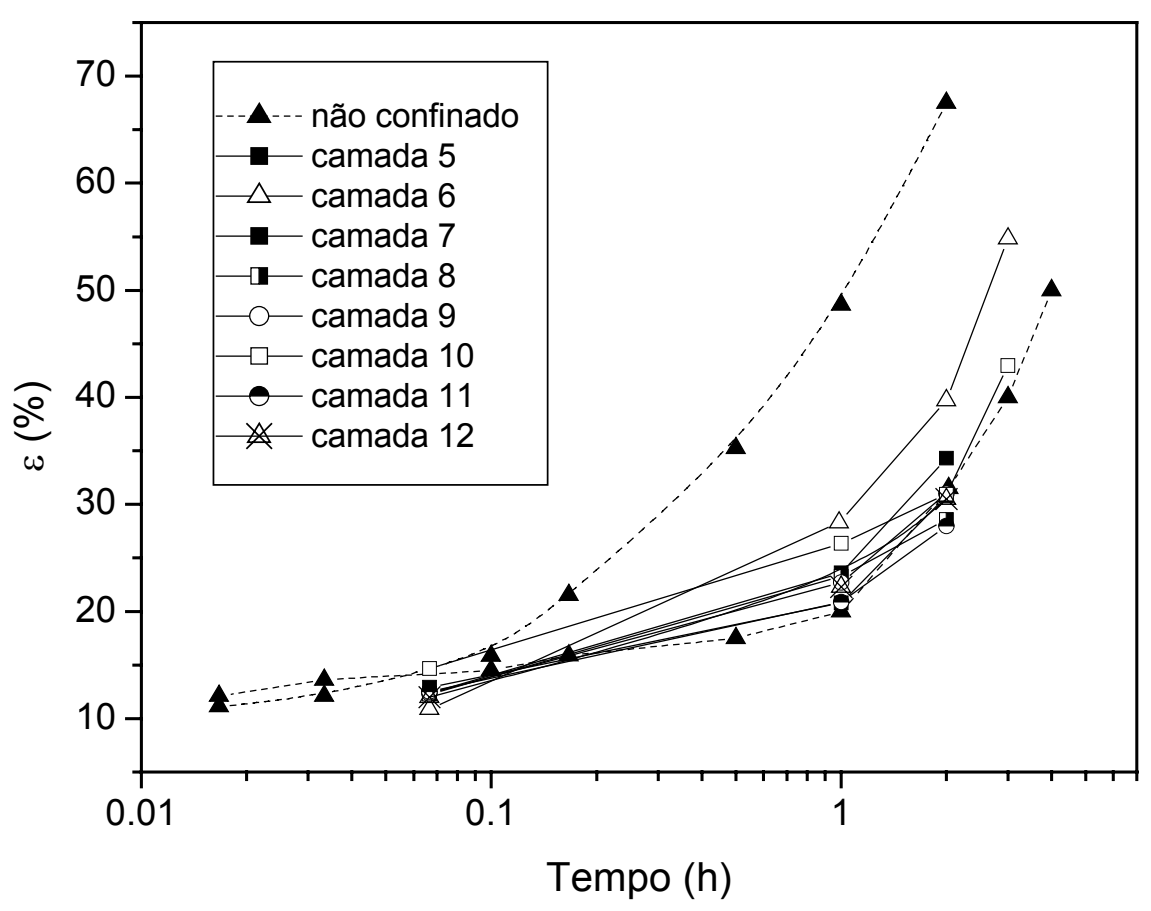

FIGURA 4.51 - Comparação entre as deformações obtidas nos modelos $\left(80 \% \mathrm{a}_{\mathrm{r}}\right)$ e as obtidas nos ensaios de fluência não confinada $\left(80 \% \mathrm{~T}_{\mathrm{ult}}\right)$, geotêxtil de PET.

A princípio, o fato das deformações ao longo do tempo no modelo estarem de acordo com o comportamento do reforço em isolamento surpreende, principalmente, pelo fato dos geotêxteis serem não tecidos. No que diz respeito a essa questão, devese considerar que a maioria dos trabalhos na literatura relatam diferenças entre fluência confinada e não confinada de geotêxteis não tecidos (ex. LEVACHER et al., 1994; COSTA, 1999), porém, bem menos pronunciadas do que as encontradas em ensaios de tração. Deve-se notar ainda que a abordagem tradicional para averiguar o efeito do confinamento na fluência consiste em aplicar uma mesma carga em condições confinadas e não confinadas e comparar os resultados. Assim, os níveis de carga aplicada, em relação à resistência à tração, seriam diferentes nas duas situações já que a resistência confinada pode ser maior do que a não confinada. Essa diferença entre os níveis de carga pode ser responsável por grande parte da diferença observada entre ensaios de fluência confinada e sem confinamento relatada na literatura. A comparação efetuada nas Figuras 4.49 a 4.51, no entanto, corresponde, por exemplo, a $40 \%$ da resistência não confinada versus $40 \%$ da resistência confinada, no caso dos 
modelos. Essa abordagem pode justificar a boa concordância observada nas Figuras 4.49 a 4.51 (entre os geotêxteis sem confinamento e sob condições de confinamento nos modelos).

As Figuras 4.52 a 4.54 apresentam comparações semelhantes efetuadas para os modelos da série 2 , mostrando as deformações com o tempo nos modelos e a deformações nos ensaios de fluência sem confinamento realizados com o geotêxtil. Embora as deformações iniciais tenham sido menores no caso dos modelos, possivelmente por efeito de confinamento, a fluência observada foi bastante semelhante em todos os casos. As maiores diferenças em termos de deformação, observadas na Figura 4.54, são justificadas pela própria variabilidade do material característica para o nível do carregamento. Em termos de tempo de ruptura, o comportamento também foi semelhante, para os ensaios convencionais variou de 53 min a $1,6 \mathrm{~h}$ e no modelo ocorreu a $1,8 \mathrm{~h}$.

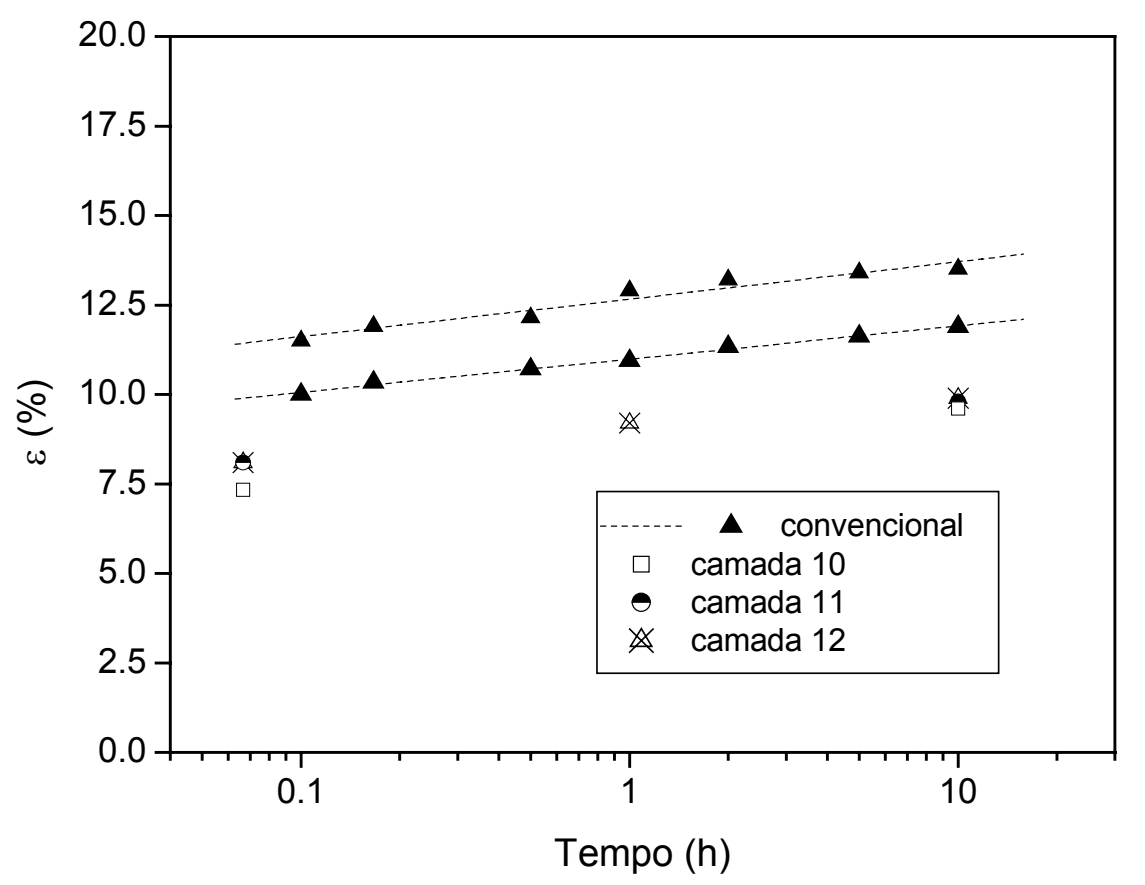

FIGURA 4.52 - Comparação entre as deformações obtidas nos modelos $\left(40 \% \mathrm{a}_{\mathrm{r}}\right)$ e as obtidas nos ensaios de fluência não confinada $\left(40 \% \mathrm{~T}_{\text {ult }}\right)$, geotêxtil de PP. 


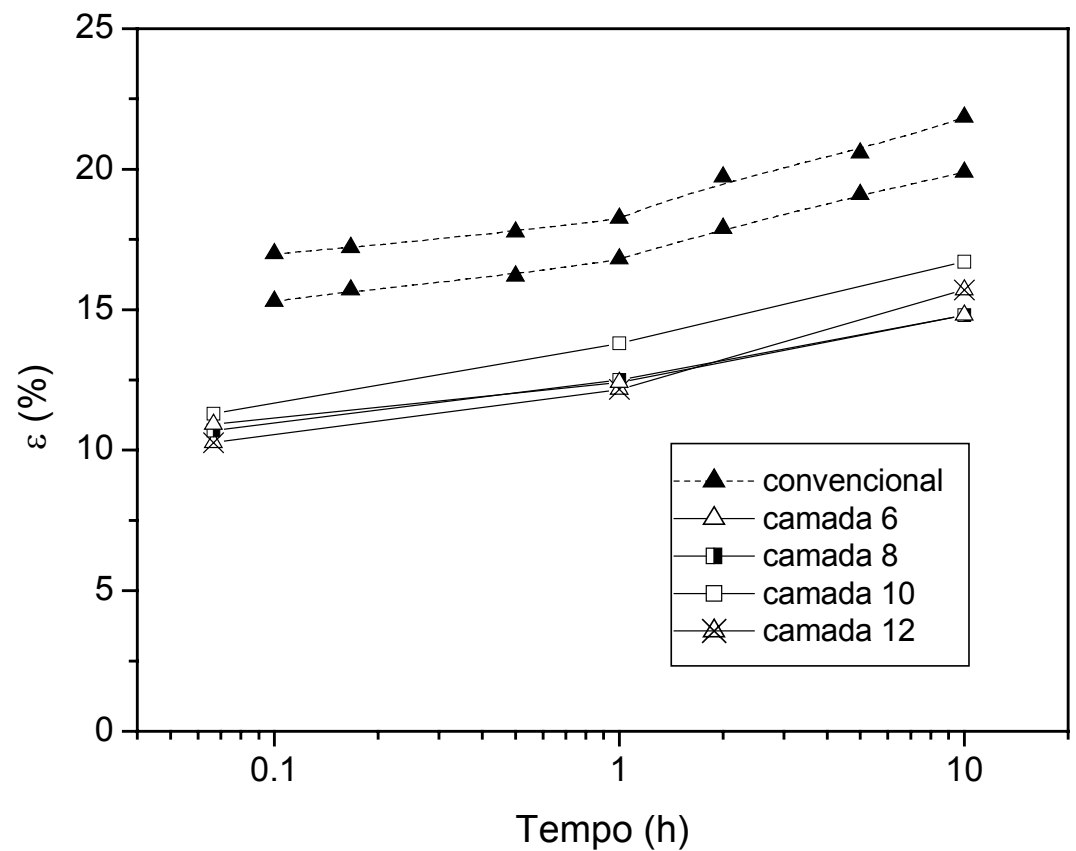

FIGURA 4.53 - Comparação entre as deformações obtidas nos modelos $\left(60 \% \mathrm{a}_{\mathrm{r}}\right)$ e as obtidas nos ensaios de fluência não confinada $\left(60 \% \mathrm{~T}_{\text {ult }}\right)$, geotêxtil de PP.

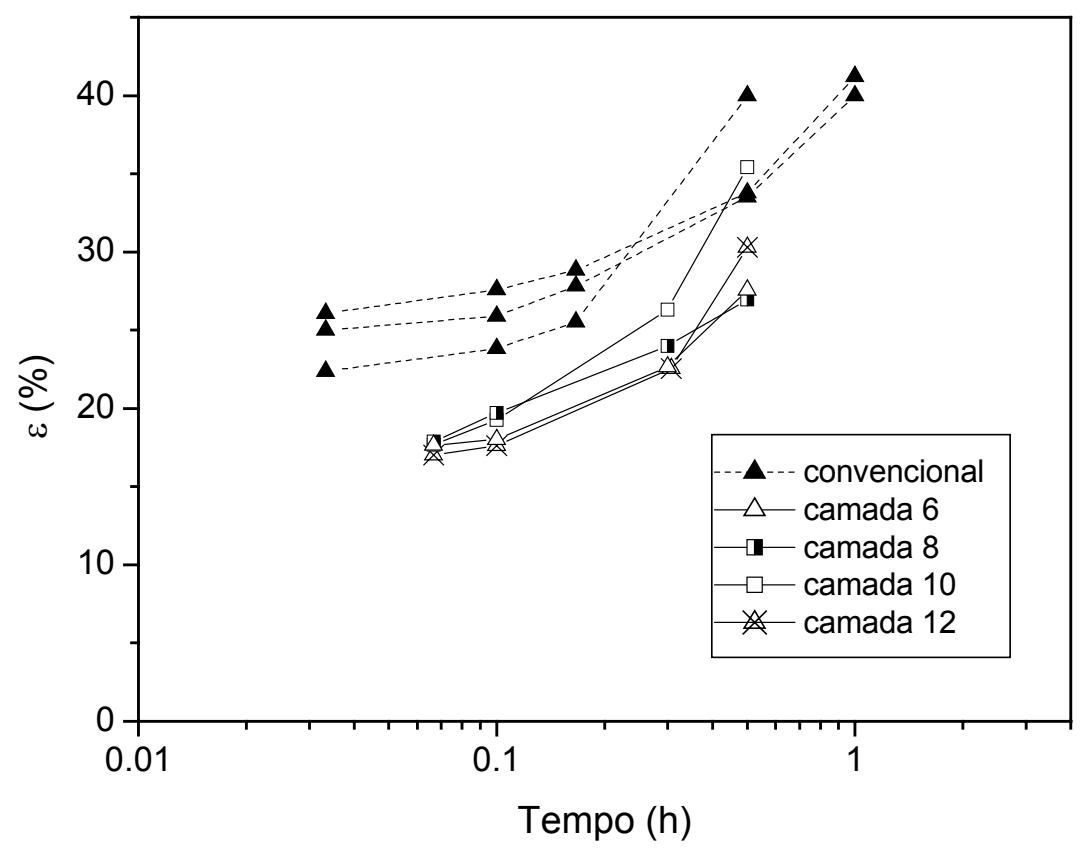

FIGURA 4.54 - Comparação entre as deformações obtidas nos modelos $\left(80 \% \mathrm{a}_{\mathrm{r}}\right)$ e as obtidas nos ensaios de fluência não confinada $\left(80 \% \mathrm{~T}_{\mathrm{ult}}\right)$, geotêxtil de PP. 
Os resultados encontrados em todos os modelos, série 1 ou 2, demonstraram aspectos importantes com relação a uma possível interação com o solo. A presença de uma areia não evitou a manifestação das deformações do reforço no decorrer do tempo. Tal comportamento ocorreu mesmo sendo as areias consideradas, geralmente, solos cuja fluência é admitida como insignificante e que, portanto, teriam um grande potencial para reduzir a fluência do reforço. Deformações em função do tempo ocorreram em todos os níveis de aceleração considerados, e de acordo com o nível esperado com base nos ensaios não confinados, ocorrendo, inclusive, ruptura.

Considerando o comportamento com relação ao ângulo de atrito mobilizado discutido no item 4.8.1.5, é bem possível que a carga no reforço não tenha apresentado grandes variações durante o processo de deformação, o que também contribuiu para a boa concordância observada nas Figuras 4.49 a 4.54.

Um outro aspecto importante com relação à análise dos resultados diz respeito à distribuição típica de força ao longo de uma camada de reforço para faces flexíveis. Como a força assume maiores valores nas proximidades da superfície de ruptura e decresce em direção à face, a menor tendência à fluência em direção à face (ver Figura 4.55) poderia reduzir a movimentação ao longo do tempo. A deformação na seção AA mostrada na Figura 4.55, por exemplo, poderia ser reduzida pela menor tendência à fluência do reforço entre os pontos 1 e 2 , devido a menor carga nessas posições. No entanto, tal mecanismo não deve ter ocorrido nos modelos, em virtude do nível de fluência observado. Os dados obtidos suportam que a fluência na seção AA não foi reduzida pela menor tendência à fluência entre esta seção e a face.

Com base nos resultados obtidos, acredita-se que a ausência ou a reduzida fluência em obras instrumentadas, freqüentemente relatada na literatura, deve-se à reduzida solicitação no reforço. No caso dos modelos estudados no presente trabalho, a ruptura da estrutura foi averiguada antes dos ensaios de fluência dos modelos, permitindo que os reforços fossem bem solicitados e possibilitando a manifestação de fluência. As menores deformações ao longo do tempo apresentadas pelos geossintéticos em obras, em comparação aos ensaios de fluência em laboratório, resultam de uma avaliação incorreta da solicitação no reforço devido a dificuldades relativas às condições de fato encontradas em obras, como efeito de confinamento, ângulo de atrito mobilizado, entre outras. Essas questões serão discutidas em maiores 
detalhes no capítulo 5 que apresenta, ainda, análises adicionais dos ensaios em centrífuga, no sentido de estabelecer o significado e as implicações dos mesmos em projetos de estruturas de solo reforçado, de uma forma geral.

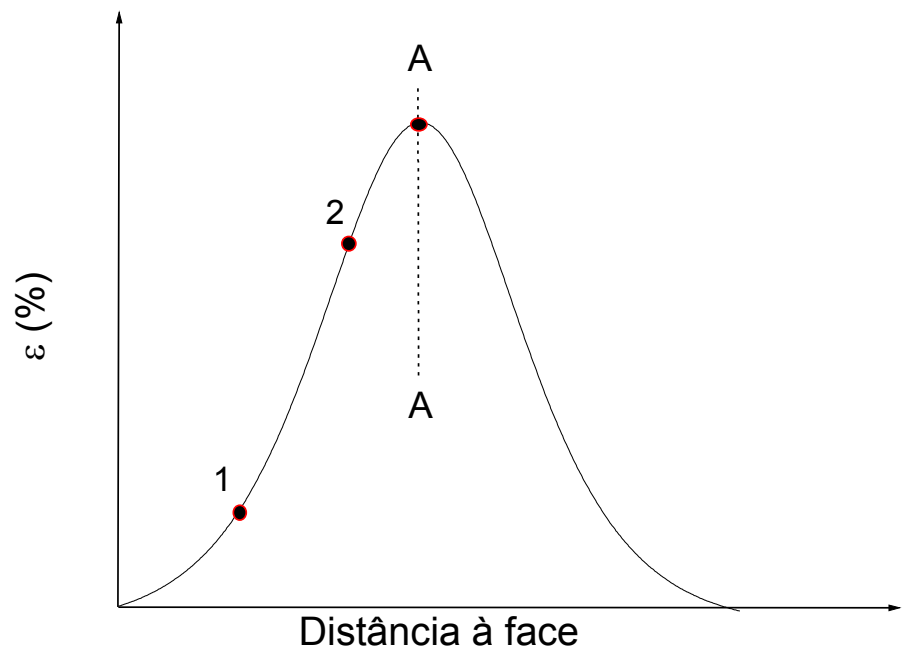

FIGURA 4.55 - Distribuição de deformação para faces flexíveis. 
Capítulo 5

\section{Discussão geral dos resultados e mecanismos de deformação em longo prazo em muros de solo reforçado}

Os resultados obtidos no presente trabalho indicam a ocorrência de elevadas deformações ao longo do tempo em geotêxteis confinados em uma areia. Indicam ainda que a fluência do reforço confinado em solo foi semelhante à fluência estimada com base nos ensaios sem confinamento. No presente capítulo, o significado e as implicações desses resultados são analisados, apresentando-se também uma avaliação do comportamento verificado nos ensaios em relação a investigações anteriores reportadas na literatura. Possíveis mecanismos de deformação ao longo do tempo em muros de solo reforçado com geossintéticos são ainda apresentados e discutidos.

5.1 Avaliação dos resultados obtidos com relação a investigações anteriores reportadas na literatura

\subsubsection{Considerações sobre o comportamento observado em obras instrumentadas}

Como discutido no capítulo 2, a instrumentação de obras tem indicado que as deformações ao longo do tempo em muros de solo reforçado são inexistentes ou 
bastante reduzidas. Como também já discutido anteriormente, esse comportamento é bastante justificável, em virtude do caráter conservador dos métodos de cálculo tradicionalmente utilizados no dimensionamento de muros de solo reforçado.

No entanto, o freqüente relato da ausência de deformações ao longo do tempo nos muros nos quais o reforço está necessariamente confinado em solo, mesmo com a ressalva de que a carga estimada no reforço é baixa, provoca muitas vezes uma associação de idéias entre confinamento no solo e redução da fluência. Esse tipo de apreciação, embora represente um equívoco, resulta em uma certa resistência à aceitação de uma elevada fluência quando o reforço encontra-se na presença de solo.

Essa associação pode ocorrer ainda mais facilmente, caso a fluência observada nos muros instrumentados seja comparada aos resultados de ensaios de fluência sem confinamento. Isso ocorre porque nesse tipo de comparação, destaca-se freqüentemente que as deformações ao longo do tempo nos muros instrumentados são menores que as previstas considerando os ensaios do reforço sem a presença de solo. Tal comparação, comumente estabelecida, é ilustrada na Figura 5.1. Como a força atuante no reforço não pode ser facilmente medida nos muros, a mesma é estimada através da deformação no reforço registrada no muro $\left(\varepsilon_{\text {muro }}\right)$, com base nos ensaios de tração do material (carga $\mathrm{T}_{\mathrm{a} 1}$ mostrada na Figura 5.1a). Depois dessa estimativa, as deformações do reforço no muro, após a sua construção, são comparadas com as obtidas em ensaios de fluência para uma força correspondente ao valor estimado no muro, $\mathrm{T}_{\mathrm{a} 1}$ (Figura 5.1b).

No muro reforçado reportado por ALLEN et al. (1992), anteriormente descrito no capítulo 2 (Tabela 2.3), por exemplo, os autores destacam que as taxas de fluência obtidas foram inferiores, em uma ordem de magnitude, às taxas obtidas nos ensaios de fluência sem confinamento para níveis de carga semelhantes. Mesmo sendo os geotêxteis utilizados tecidos, esse comportamento, segundo os autores, deve-se principalmente ao efeito do confinamento do solo, ou seja, o comportamento no muro é diferente do obtido nos ensaios sem confinamento, principalmente pela presença do solo. Assim, esse tipo de comparação "fluência em ensaio sem confinamento versus fluência observada em muros instrumentados" tem ajudado, de certa forma, a promover e a perpetuar a idéia de que a fluência é reduzida pela presença do solo. Ressalta-se que, como os geotêxteis utilizados são tecidos, o termo 
"efeito do confinamento" refere-se à interferência do comportamento mecânico do solo no processo.

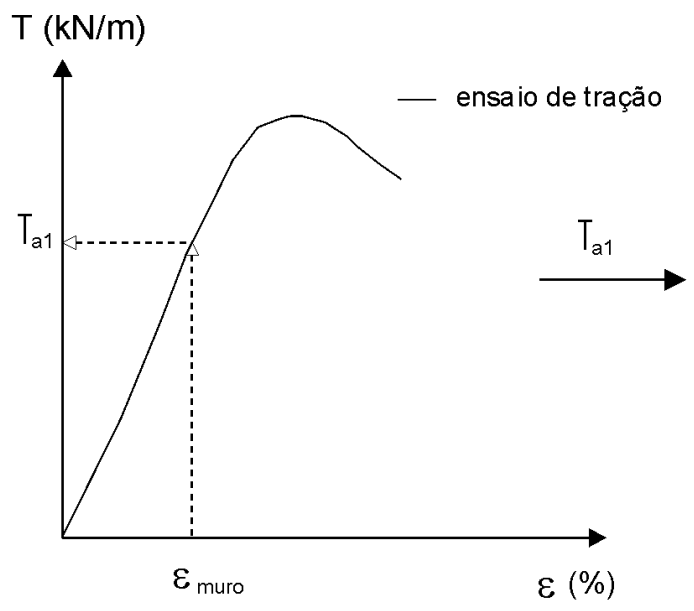

(a)

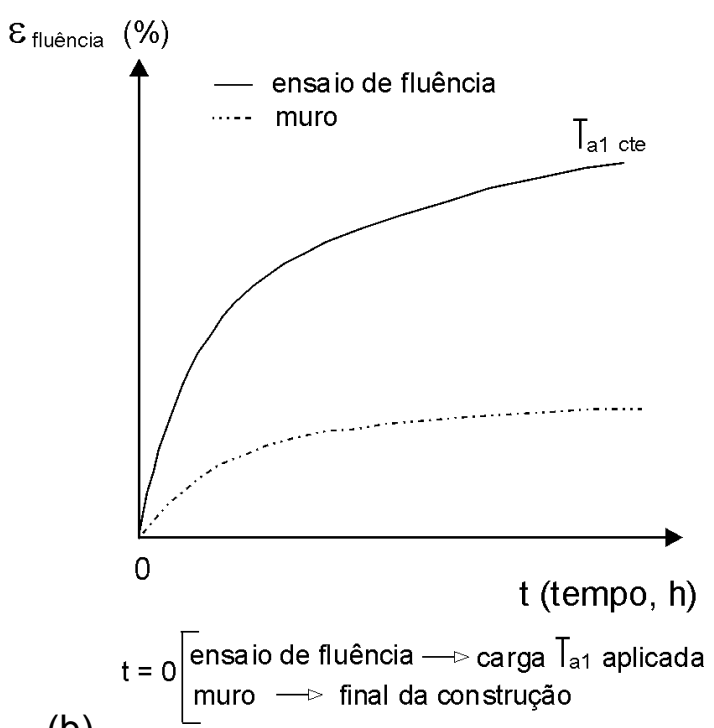

(b)

FIGURA 5.1 - (a) Estimativa da carga no reforço no muro com base em ensaios de tração (b) fluência em laboratório para a carga $\mathrm{T}_{\mathrm{a} 1}$ e deformações com o tempo no muro.

Esse tipo de comparação, no entanto, não deve ser estabelecida, podendo resultar em erros significativos, caso algumas correções não sejam efetuadas. Não se pode sempre comparar as deformações observadas nos muros ao longo do tempo com os ensaios de fluência sem confinamento, de acordo com o procedimento ilustrado na Figura 5.1, pois a velocidade de carregamento nas duas situações pode ser muito diferente. O período de carregamento do reforço em um muro reforçado pode ser consideravelmente superior ao tempo de carregamento nos ensaios de tração. Nesse último caso, inferior a 10 min e durante a construção do muro geralmente superior a $500 \mathrm{~h}$. No caso da estrutura descrita por ALLEN et al. (1992), por exemplo, cerca de $1500 \mathrm{~h}$ (aproximadamente dois meses).

A velocidade de carregamento interfere na rigidez e na resistência do reforço, que tendem a aumentar com o acréscimo da velocidade. Esse efeito é bem pronunciado em geossintéticos de polipropileno. A Figura 5.2 mostra, por exemplo, o 
comportamento obtido, em ensaios de tração, para o geotêxtil tecido de PP utilizado no muro reportado por ALLEN et al. (1992). Fica evidente a diferença na rigidez do reforço em função da velocidade de carregamento.

BOYLE (1995) já alertava para a dificuldade em estimar a carga atuante no muro reportado por ALLEN et al. (1992) com base em ensaios de tração (ASTM, D4595), cuja velocidade de deformação é $10 \% / \mathrm{min}$, enquanto nesse muro a velocidade não excedeu $0,00001 \% / \mathrm{min}$. No entanto, apenas recentemente a influência e a importância da velocidade de carregamento na rigidez de geossintéticos tornou a ser discutida (ex. KONGKITKUL et al. 2004).

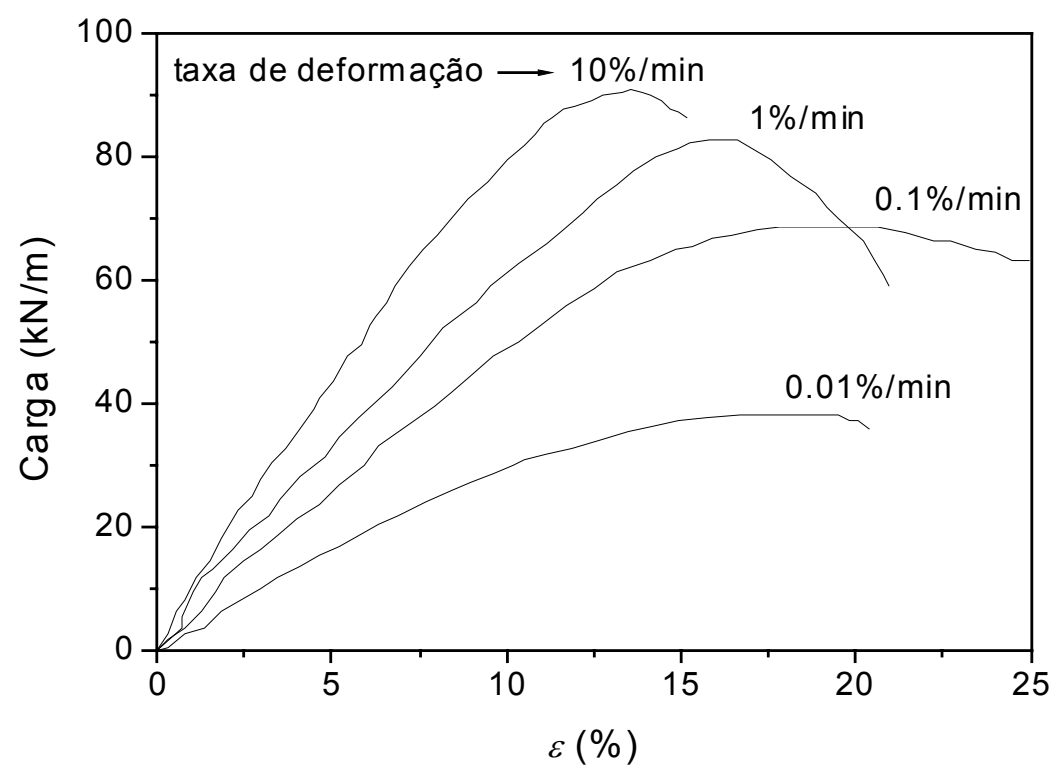

FIGURA 5.2 - Ensaios de tração realizados com diferentes taxas de deformação (BOYLE, 1996).

A utilização da curva com maior velocidade de deformação resulta na adoção de um valor de carga no reforço $\left(\mathrm{T}_{\mathrm{a} 1}\right)$ maior que a carga de fato atuante $\left(\mathrm{T}_{\mathrm{a} 2}\right)$, conforme indicado na Figura 5.3. Para uma melhor estimativa da carga atuante seria preciso utilizar uma curva com uma velocidade semelhante à verificada durante a construção do muro. O que seria, de qualquer forma, uma estimativa, já que a taxa de 
deformação durante a construção do muro sofre variações, não permanecendo de fato constante como nos ensaios de tração.

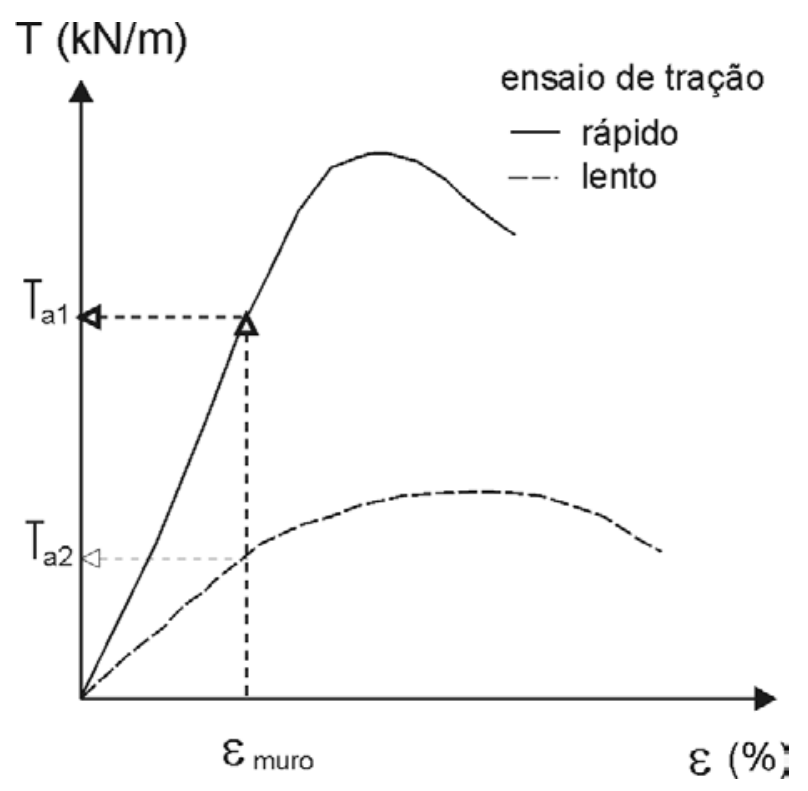

FIGURA 5.3 - Efeito da taxa de deformação na avaliação da carga no reforço com base na deformação verificada no muro.

Além desse aspecto, deve-se considerar ainda que a velocidade de aplicação da carga em um ensaio de fluência interfere na taxa de deformação ao longo do tempo, como discutido no item 2.1.3.3 (capítulo 2). Quando a carga é aplicada lentamente, as deformações dependentes do tempo já se manifestam durante o tempo de carregamento. Quanto maior o tempo de aplicação da carga, menor a taxa de fluência após a carga ser mantida constante, como mostrado na Figura 5.4. Segundo GOTTARDI \& SIMONINI (2000), a taxa de fluência (inclinação da reta tangente às curvas mostradas na Figura 5.4), no ensaio com carregamento mais lento, tende a ser semelhante à obtida no ensaio com carregamento rápido depois de decorrido um período de tempo com a carga constante, pelo menos superior ao tempo de carregamento do ensaio mais lento. 


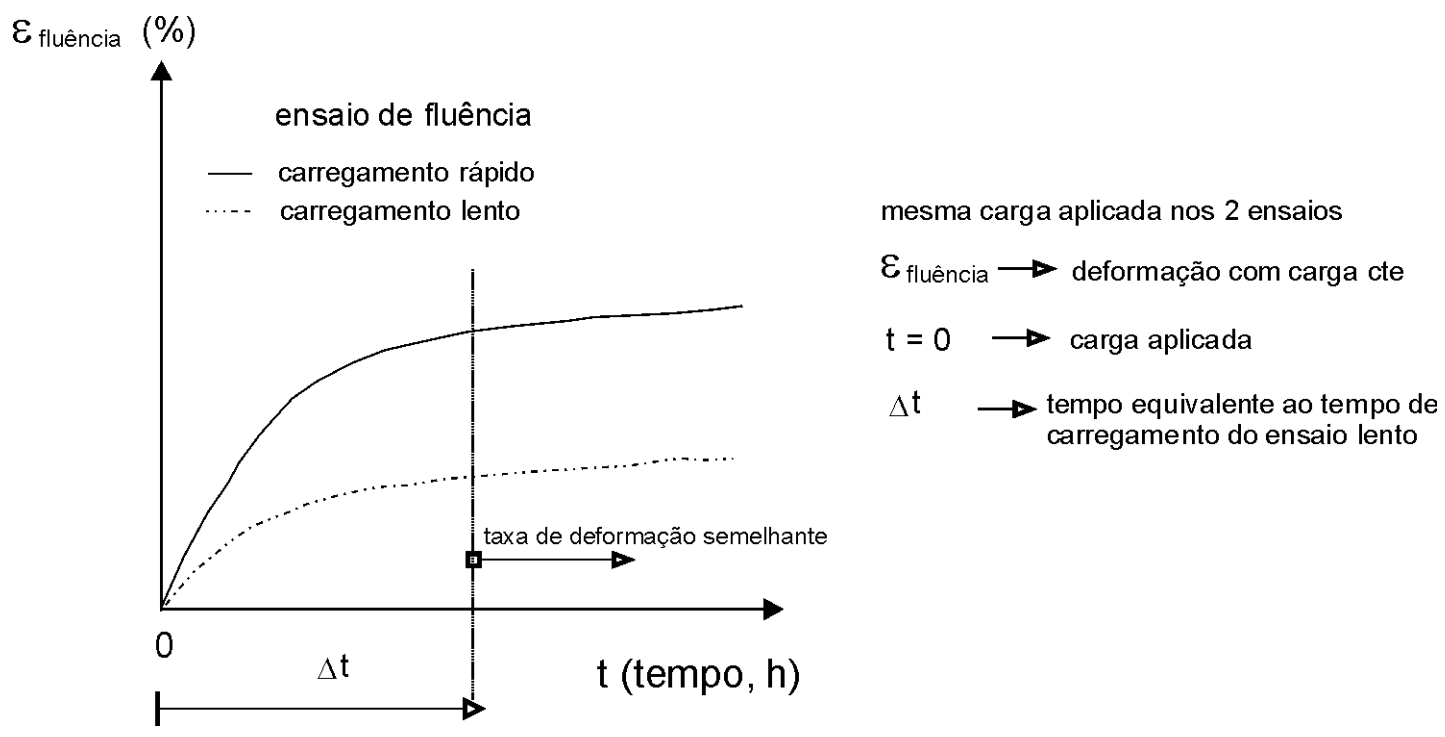

FIGURA 5.4 - Diferença entre ensaios de fluência com tempos de carregamento diferentes.

Com relação à velocidade de carregamento, em um ensaio de fluência sem confinamento, realizado segundo as normas em vigência (ex. ISO 13431), a carga é aplicada em um intervalo de tempo igual a, no máximo, 1 min. Esse mesmo intervalo nos muros, embora não usual, pode atingir, por exemplo, $1500 \mathrm{~h}$. Assim, as deformações ao longo do tempo observadas após a construção no muro não devem ser comparadas diretamente às dos ensaios de fluência, considerando o mesmo intervalo de tempo. Considera-se que os resultados só devem ser comparados para tempos superiores ao intervalo de tempo correspondente à construção do muro. A Figura 5.5 ilustra esse aspecto, indicando o procedimento proposto como o mais adequado em relação ao tradicionalmente adotado (mostrado anteriormente na Figura 5.1) para efetuar comparações entre a taxa de deformação observada em muros e em ensaios de laboratório.

É importante observar que os erros cometidos no procedimento mostrado na Figura 5.1, tanto com relação à estimativa da carga, quanto em relação ao tempo de aplicação da carga nos ensaios de fluência contribuem para que a fluência nos muros seja menor que a estimada com base nos ensaios. Ou seja, esses erros promovem a idéia que as deformações do reforço ao longo do tempo são menores na presença do solo, quando, na verdade, essas diferenças deveriam ser esperadas tendo em vista as velocidades de carregamento diferentes nas duas situações. 

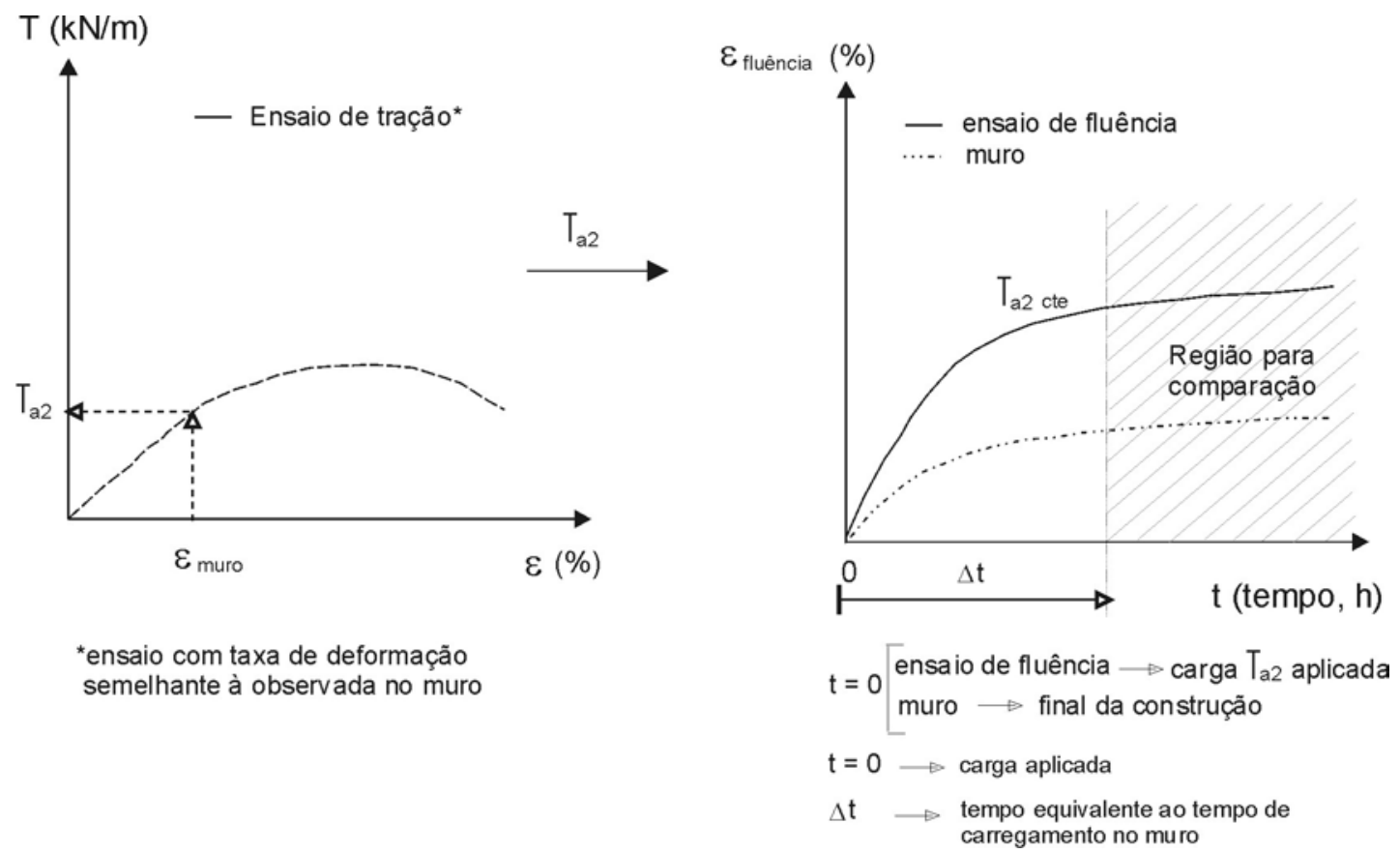

FIGURA 5.5 - Procedimento mais adequado para a comparação das deformações ao longo do tempo em muros com resultados de ensaios.

Tendo em vista o exposto, a reduzida magnitude das deformações ao longo do tempo relatada em muros instrumentados não impõe nenhuma resistência à aceitação dos resultados obtidos no presente trabalho, que indicam fluência elevada do reforço confinado em solo e, ainda, sendo compatível a dos ensaios sem confinamento.

Considera-se que a instrumentação de obras constitui, naturalmente, a melhor abordagem para a confirmação do desempenho adequado desse tipo de estrutura, considerando os métodos de dimensionamento utilizados. No entanto, a instrumentação de obras não representa uma abordagem muito adequada para a elucidação de mecanismos de interação ao longo do tempo entre reforço e demais componentes da estrutura. Isso se deve não apenas à freqüente baixa solicitação do reforço, mas principalmente, às dificuldades em estabelecer comparações entre o comportamento do reforço isolado, com base em ensaios em laboratório, e o comportamento observado na estrutura real. Dificuldades relativas, por exemplo, à velocidade de carregamento e à trajetória de carga ao longo do tempo nas duas situações. As variações de temperatura em campo, e muitas vezes, a presença de 
solos coesivos tendem a dificultar ainda mais a elucidação do comportamento observado ao longo do tempo em muros de solo reforçado cujo comportamento e interações, mesmo em curto prazo, não são ainda bem compreendidos.

\subsubsection{Comparação com resultados obtidos em protótipos}

A comparação dos resultados deste trabalho com os obtidos através de protótipos em laboratório é importante, pois estes últimos reproduzem mais adequadamente algumas condições presentes em estruturas reais e, semelhantemente aos modelos em centrífuga, podem ser carregados até a ruptura, possibilitando a manifestação dos efeitos da fluência. No entanto, na maioria dos trabalhos com utilização de protótipos publicados na literatura, o comportamento da estrutura não é observado ao longo do tempo ou as informações apresentadas não são suficientes para analisar adequadamente o comportamento da estrutura ao longo do tempo.

Uma exceção a esse fato é o trabalho publicado por ALLEN \& BATHURST (2002b). Esses autores realizaram uma nova análise do trabalho publicado por BENJAMIN (1989) relativo ao comportamento de dois protótipos de muros de solo reforçado em laboratório. A análise corrobora os resultados encontrados no presente trabalho, no sentido de que as deformações ao longo do tempo observadas nos protótipos foram elevadas, não ocorrendo redução das taxas de fluência, previstas com base nos ensaios de fluência do reforço sem confinamento.

A Figura 5.6 mostra a configuração dos dois protótipos, diferentes apenas pelo tipo de face empregada. No primeiro protótipo, P1, utilizou-se uma face composta por painéis de alumínio contínuos e no segundo, $\mathrm{P} 2$, painéis segmentados de alumínio. Em ambos os casos, a face foi escorada durante todo o processo de construção. Os protótipos possuíam uma altura de $3 \mathrm{~m}$ e espaçamento entre reforços igual a $0,75 \mathrm{~m}$. Uma areia com presença de alguns pedregulhos e peso específico igual a $18 \mathrm{kN} / \mathrm{m}^{3}$ foi utilizada para a construção dos muros. O ângulo de atrito adotado para a referida areia, obtido através de ensaios de cisalhamento direto, corresponde a $40^{\circ}$. Uma geogrelha de $\mathrm{PP}$, com resistência à tração igual a $12 \mathrm{kN} / \mathrm{m}$, foi empregada como reforço. 


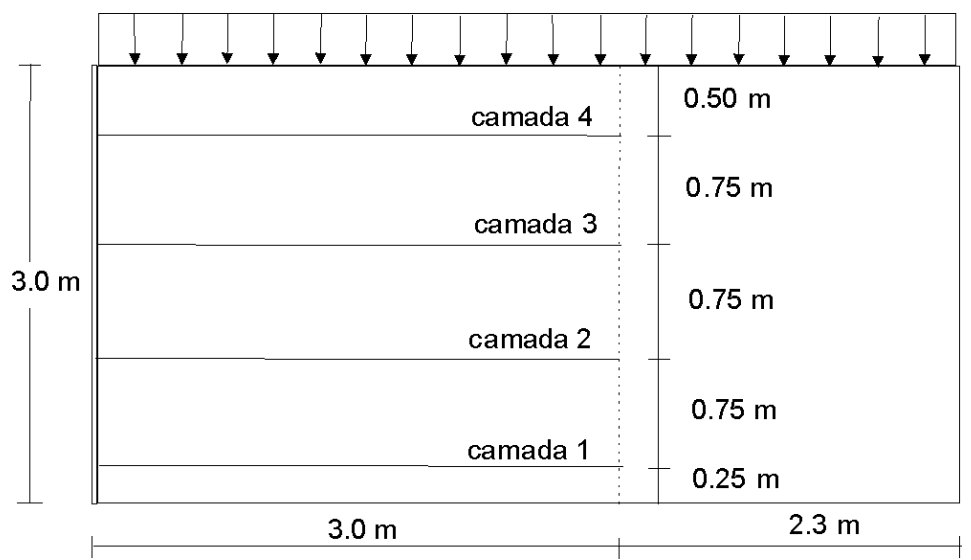

FIGURA 5.6 - Configuração dos protótipos (ALLEN \& BATHURST, 2002b)

Após a construção, os protótipos foram submetidos a uma sobrecarga crescente, aplicada através de uma bolsa de ar pressurizado, até um valor correspondente a $80 \mathrm{kPa}$ e $70 \mathrm{kPa}$, no caso dos protótipos $\mathrm{P} 1$ e $\mathrm{P} 2$, respectivamente. Durante os ensaios, após a aplicação de cada incremento de pressão, a mesma foi mantida constante por um intervalo de, no mínimo, $100 \mathrm{~h}$ e as deformações no reforço foram observadas ao longo do tempo.

Para o protótipo P1, após a retirada do escoramento e antes da aplicação da sobrecarga, o máximo deslocamento observado na face foi igual a $0,33 \% \mathrm{H}(\mathrm{H}-$ altura do muro) e a máxima deformação nas geogrelhas foi igual a 1\%. Após cerca de $250 \mathrm{~h}$ da aplicação da sobrecarga correspondente a $80 \mathrm{kPa}$, observou-se a formação de fendas no solo e após cerca de $350 \mathrm{~h}$, com esse valor de sobrecarga mantido constante, a primeira camada de reforço apresentou ruptura. Próximo à ruptura, o máximo deslocamento na face correspondia a $3,4 \% \mathrm{H}$ e a máxima deformação no reforço era cerca de $12 \%$, nas proximidades da conexão face-reforço.

Para o protótipo P2, após a retirada do escoramento e antes da aplicação da sobrecarga, o máximo deslocamento observado na face foi igual a $0,43 \% \mathrm{H}$ e a máxima deformação no reforço igual a 1\%. Cerca de 100h após a aplicação de uma sobrecarga equivalente a $70 \mathrm{kPa}$, observou-se a formação de fendas no solo e após cerca de $380 \mathrm{~h}$ com a sobrecarga mantida constante, a primeira camada de reforço apresentou ruptura. Próximo à ruptura, o máximo deslocamento na face correspondia $3,4 \% \mathrm{H}$ e a máxima deformação no reforço era igual a $10 \%$. 
Conforme relatado anteriormente, os resultados foram recentemente reavaliados por ALLEN \& BATHURST (2002b). Esses autores fizeram uma estimativa da carga atuante no reforço logo após aplicação da sobrecarga, considerando algumas correções devido às diferenças entre o tempo de carregamento nos ensaios de tração e nos ensaios de fluência do reforço e o tempo de construção dos protótipos, conforme discutido no item 5.1.1. A Tabela 5.1 mostra o nível de carga atuante estimado para o reforço logo após a aplicação de uma determinada sobrecarga e o período de observação com a sobrecarga constante. A Tabela 5.1 apresenta ainda o valor médio, observado durante um determinado intervalo de tempo, da relação (RT) entre a taxa de deformação nos ensaios convencionais de fluência sem confinamento ( $\left.\alpha_{\text {ensaio}}\right)$ e a taxa de fluência observada nos protótipos $\left(\alpha_{\text {protótipo }}\right)$.

Tabela 5.1 - Relação entre a taxa de fluência nos ensaios convencionais e nos protótipos.

\begin{tabular}{cccccc}
\hline Protótipo & Geogrelha & $\begin{array}{c}\text { Sobrecarga } \\
(\mathrm{kPa})\end{array}$ & $\begin{array}{c}\text { Carga } \\
\text { estimada } \\
\% \mathrm{~T}_{\text {ult }}{ }^{*}\end{array}$ & $\begin{array}{c}\text { Tempo de } \\
\text { observação (h) }\end{array}$ & $\mathrm{RT}=\frac{\alpha_{\text {ensaio }}}{\alpha_{\text {protótipo }}}$ \\
\hline P1 & camada 4 & 20 & 13 & $0-100$ & 0,8 \\
& 80 & 26 & $0-100$ & 0,6 \\
& 80 & 26 & $100-200$ & 0,15 \\
\hline P2 & camada 3 & 20 & 7 & $0-100$ & 0,8 \\
& 70 & 23 & $0-380$ & 0,12 \\
${ }^{*} \mathrm{~T}_{\text {ult }}-$ resistência à tração & & &
\end{tabular}

Com base na Tabela 5.1, para os valores mais reduzidos de sobrecarga $(20 \mathrm{kPa})$, pode-se considerar que a taxa de deformação ao longo do tempo nos protótipos foi semelhante à taxa obtida nos ensaios de fluência (RT próximo a 1,0 ). Para os valores mais elevados de sobrecarga, no entanto, a taxa de fluência nos protótipos foi consideravelmente superior aos valores previstos com base nos ensaios de fluência. Inclusive, a ruptura por fluência não pode ser justificada com base nos 
ensaios convencionais de fluência para o nível de carga inicialmente estimado para o reforço (26 e 23\% $\mathrm{T}_{\text {ult }}$ para $\mathrm{P} 1$ e P2, respectivamente).

ALLEN \& BATHURST (2002b) justificam esse comportamento afirmando que a carga no reforço não permanece igual ao valor inicialmente estimado, provocando as discrepâncias observadas entre ensaios e protótipos, com relação à taxa de deformação. À medida que as deformações ocorrem ao longo do tempo, a resistência do solo diminui cada vez mais em direção ao valor de resistência residual. Essa redução da resistência do solo provoca o aumento da carga do reforço, aumentando a taxa de deformação e provocando a ruptura da estrutura.

No caso do protótipo P2, com a aplicação da sobrecarga equivalente a $70 \mathrm{kPa}$, ocorreu ruptura da camada de reforço número 4, decorridas 90h após a aplicação da sobrecarga. Essa ruptura, segundo ALLEN \& BATHURST (2002b), também deve ter provocado a redistribuição de carga para as outras camadas, ajudando a acelerar a taxa de deformação no protótipo e reduzindo valor de RT mostrado na Tabela 5.1 para a camada $3(\mathrm{RT}=0,12)$.

O comportamento observado nesses protótipos está de acordo com o resultado geral obtido com base nos ensaios realizados no presente trabalho. Por serem protótipos, essas estruturas puderam ser submetidas a carregamentos elevados que possibilitam a manifestação de deformações intensas ao longo do tempo, que não foram reduzidas pela presença da areia confinando o reforço.

\subsubsection{Comparação com resultados obtidos através de outros modelos reduzidos}

Apesar do número razoável de pesquisas sobre o comportamento de muros de solo reforçado utilizando modelos reduzidos, a quantidade de trabalhos para investigar o comportamento do reforço a longo prazo é bastante reduzida. Apenas dois trabalhos foram identificados nesse sentido: MITCHELL et al. (1988) e GOTTARDI \& SIMONINI (2000). De forma semelhante aos resultados do presente trabalho, as pesquisas por esses autores também mostram uma intensa deformação em estruturas ensaiadas ao longo do tempo. 
MITCHELL et al. (1988) investigaram o comportamento de muros de solo reforçado realizando ensaios com modelos reduzidos em centrífuga. Embora o objetivo primordial do trabalho não tenha sido o estudo do comportamento da estrutura ao longo do tempo, dois modelos foram ensaiados mantendo-se a aceleração constante por um determinado intervalo de tempo. Esses modelos foram construídos utilizando-se uma areia e mantas não tecidas de poliéster como reforço.

Embora não fosse possível medir as deformações do reforço, a observação visual do modelo revelou a presença de deformações excessivas ao longo do tempo. Um dos modelos apresentou ruptura após cerca de $1 \mathrm{~h}$ com a aceleração mantida constante. O valor dessa aceleração correspondia a 70\% da aceleração na ruptura detectada anteriormente, em ensaios de curto prazo, para o modelo. Esse comportamento permitiu aos autores, já em 1988, alertar sobre os efeitos prejudiciais da fluência na estabilidade da estrutura. No entanto, os resultados da instrumentação de obras que se seguiram a partir de então, nas quais as deformações pós-construtivas foram sempre bastante reduzidas, acabaram, de certa forma, por ofuscar essa questão.

GOTTARDI \& SIMONINI (2000) realizaram ensaios em modelos reduzidos a $1 \mathrm{~g}$, construídos utilizando-se uma areia como aterro e uma geogrelha de polipropileno como reforço. O comportamento do modelo foi investigado aplicandose uma carga crescente no topo da estrutura até a ocorrência de ruptura $\left(\mathrm{P}_{\text {máx }}\right)$. Em seguida, alguns ensaios foram realizados, mantendo-se uma carga (P) constante, equivalente a uma porcentagem da carga de ruptura. Também nesse caso, os reforços não foram instrumentados para obtenção das deformações, mas o acompanhamento dos recalques do topo da estrutura revelou a presença de movimentações ao longo do tempo. De forma semelhante aos modelos realizados no presente trabalho, GOTTARDI \& SIMONINI (2000) também constataram a ruptura da estrutura, após manter a carga aplicada constante por um determinado período de tempo. A carga que provocou ruptura por fluência era equivalente a $75 \%$ do valor obtido nos ensaios em curto prazo $\left(\mathrm{P}=0,75 \mathrm{P}_{\text {máx }}\right)$. 


\subsection{Discussão geral sobre mecanismos de interação ao longo do tempo}

Os resultados encontrados no presente trabalho mostram deformações ao longo do tempo com o reforço confinado em areia semelhantes às estimadas com base nos ensaios de fluência do reforço isolado. Tal comportamento deve ser entendido como o resultado de um dos mecanismos que pode se desenvolver ao longo do tempo, isto é, constitui um caso particular e não, a regra geral.

No entanto, esses resultados foram extremamente importantes para mostrar que algumas idéias freqüentemente citadas na literatura sobre fluência de geossintéticos devem ser revistas. Como por exemplo, a afirmação de que se o solo confinante apresenta uma menor tendência para apresentar deformações ao longo do tempo em relação ao geossintético, o solo irá restringir a fluência do reforço.

Como base na análise conjunta dos resultados obtidos nesta pesquisa e de outros trabalhos relacionados com o tema presentes na literatura, considera-se que a interferência da tendência à fluência do solo confinante na fluência do reforço não ocorre necessariamente assim e deve ser analisada de forma mais abrangente. As seguintes situações podem ocorrer:

Caso 1 - o solo apresenta mesma tendência à fluência em relação ao reforço;

Caso 2 - o solo apresenta menor tendência à fluência;

Caso 3 - o solo apresenta uma maior tendência à fluência em relação ao reforço.

Os três casos determinam diferentes mecanismos de interação solo-reforço ao longo do tempo, que se desenvolvem de acordo com as características do reforço e do solo confinante. Considerando um elemento de solo composto por um geossintético confinado entre duas camadas de solo, os mecanismos se desenvolvem da seguinte forma:

- Caso 1 - Solo e reforço com mesma tendência à fluência

Solo e reforço apresentam deformações ao longo do tempo e esse acréscimo de deformação não provoca nenhuma variação no valor da carga no reforço. A 
resistência mobilizada no solo também permanece constante e as deformações observadas, de fato, podem ser consideradas como fluência (deformações ao longo do tempo sob carga constante).

- Caso 2 - Solo apresenta menor tendência à fluência

A menor taxa de fluência do solo em relação ao reforço não constitui condição suficiente para o solo restringir a fluência do reforço. Outros fatores precisam ainda ser considerados, entre os quais a resistência mobilizada pelo solo ao longo do tempo.

Se, por exemplo, o valor da deformação, após a aplicação do carregamento, for inferior à deformação correspondente à resistência ao cisalhamento de pico do solo, existe a possibilidade do solo restringir as deformações do reforço ao longo do tempo. Caso contrário, o solo não é capaz de restringir as deformações ao longo do tempo, apesar da menor tendência à fluência em relação ao reforço.

A Figura 5.7 ilustra o exposto. Se a deformação do solo após a aplicação da tensão vertical $\left(\varepsilon_{0}\right)$ for superior à deformação correspondente à máxima resistência do solo $\left(\varepsilon_{\mathrm{p}}\right)$, este não tem capacidade de restringir a fluência do reforço. Quando a deformação inicial é menor que $\varepsilon_{\mathrm{p}}$, o solo pode restringir a fluência do reforço, pois é possível mobilizar uma maior resistência com o aumento da deformação com o tempo, pelo menos até um valor próximo ao valor de pico. Esses mecanismos são discutidos em maiores detalhes a seguir.

- Mecanismo desenvolvido para $\varepsilon_{0}<\varepsilon_{\mathrm{p}}$

A deformação, com o passar do tempo, de um elemento solo-reforço após a aplicação de uma determinada tensão vertical, obviamente, será resultado da interação entre esses dois elementos de forma a tornar compatível o comportamento ao longo do tempo esperado para o solo e para o reforço, separadamente. 


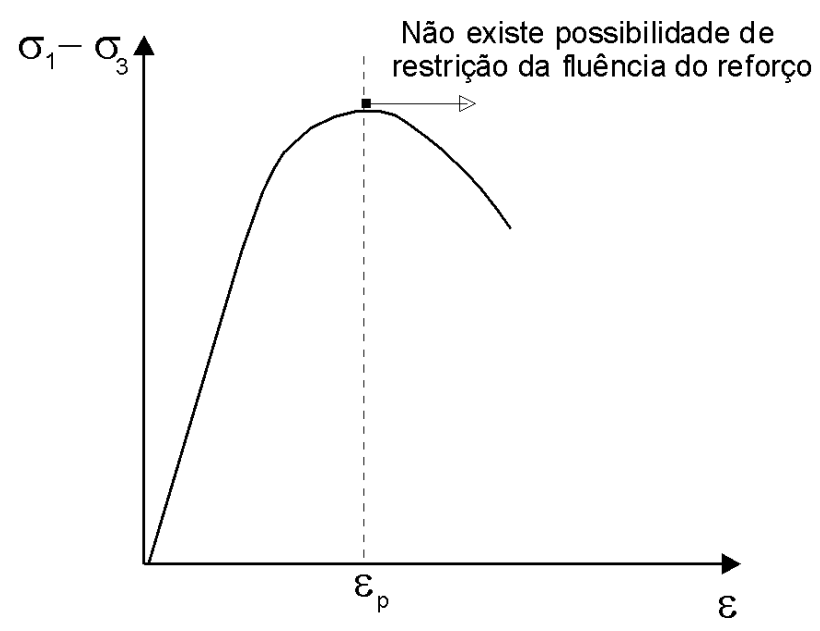

FIGURA 5.7 - Curva tensão x deformação do solo com indicação da possibilidade de restrição da fluência do reforço pela presença do solo.

Os mecanismos descritos a seguir referem-se a um elemento de solo reforçado submetido, inicialmente, a uma tensão vertical $\left(\sigma_{v}\right)$, conforme ilustrado na Figura 5.8. Esse elemento solo-reforço equivale a um elemento de solo sujeito a uma tensão vertical e horizontal iguais a $\sigma_{v}$ e $\sigma_{h i}$, respectivamente, e a um reforço submetido a uma força inicial $\mathrm{T}_{\mathrm{i}}$. Considera-se um elemento com dimensões reduzidas e com força no reforço constante ao longo do comprimento $L$. A força $T_{i}$ corresponde ao produto da tensão horizontal no solo pela área de influência do reforço. Considerando um valor de força por unidade de comprimento na direção z, indicada na Figura 5.8, $\mathrm{T}_{\mathrm{i}}=\sigma_{\mathrm{hi}} \cdot \mathrm{H}$.
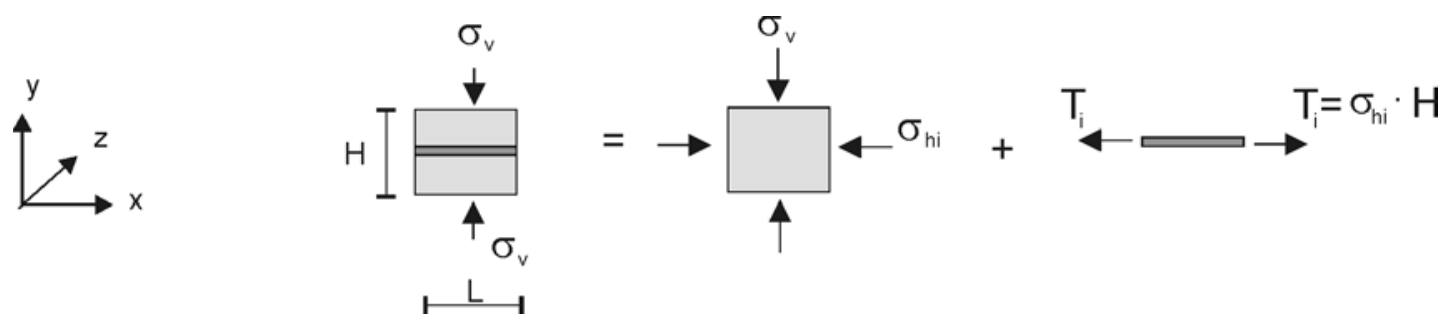

FIGURA 5.8 - Elemento de solo reforçado 
O mecanismo que pode se desenvolver quando a deformação inicial $\varepsilon_{0}$ é menor do que o valor $\varepsilon_{\mathrm{p}}$ pode ser compreendido com o auxílio da Figura 5.9, a qual ilustra o comportamento esperado para o elemento reforçado, considerando as interações solo-reforço. A força requerida pelo solo $\left(\sigma_{\mathrm{hi}} \cdot \mathrm{H}\right)$ e a força no reforço $\left(\mathrm{T}_{\mathrm{i}}\right)$, indicadas na Figura 5.9a, correspondem ao valor imediatamente após a aplicação da tensão vertical.

A Figura 5.9b indica o comportamento ao longo do tempo esperado, com base apenas no elemento de solo mostrado na Figura 5.8. Se a tensão $\sigma_{\text {hi }}$ é mantida constante por um determinado intervalo de tempo $(\Delta \mathrm{t})$, o solo apresenta fluência (trajetória 1), resultando em um incremento de deformação correspondente a $\Delta \varepsilon_{\mathrm{AS}}$, como ilustrado na Figura $5.9 \mathrm{~b}\left(\Delta \varepsilon_{\mathrm{AS}}\right.$ corresponde à fluência prevista, considerando apenas o solo).

Por outro lado, se a carga inicial no reforço $T_{i}$ permanece constante por esse mesmo intervalo de tempo (Figura 5.9c), o reforço, sem a presença do solo, irá apresentar fluência (trajetória 1), provocando um incremento de deformação correspondente a $\Delta \varepsilon_{\mathrm{AR}}$. Como o solo apresenta uma menor tendência à fluência (menor taxa de fluência), $\Delta \varepsilon_{\mathrm{AS}}<\Delta \varepsilon_{\mathrm{AR}}$

Considerando agora o comportamento do elemento solo-reforço, para o solo restringir a deformação do reforço é preciso que este apresente um incremento de deformação na presença do solo $\left(\Delta \varepsilon_{\mathrm{SR}}\right)$, para o mesmo intervalo de tempo, menor que $\Delta \varepsilon_{\mathrm{AR}}$ (ver Figura 5.9c). Se isso ocorre, a carga no reforço diminui pela tendência de relaxação do reforço (trajetória 2, Figura 5.9c). A carga só pode ser mantida constante se o reforço apresentar todo o incremento $\Delta \varepsilon_{\mathrm{AR}}$. Por outro lado, se a carga no reforço diminui com o tempo, então a tensão no solo $\sigma_{\mathrm{h}}$ também diminui $\left(\sigma_{\mathrm{h}}=\mathrm{T} /\right.$ H). Como $\sigma_{\mathrm{v}}$ permanece constante com o tempo, a diminuição de $\sigma_{\mathrm{h}}$ implica aumento da tensão de cisalhamento e, assim, o solo precisa mobilizar uma maior resistência, a fim de possibilitar o equilíbrio. 


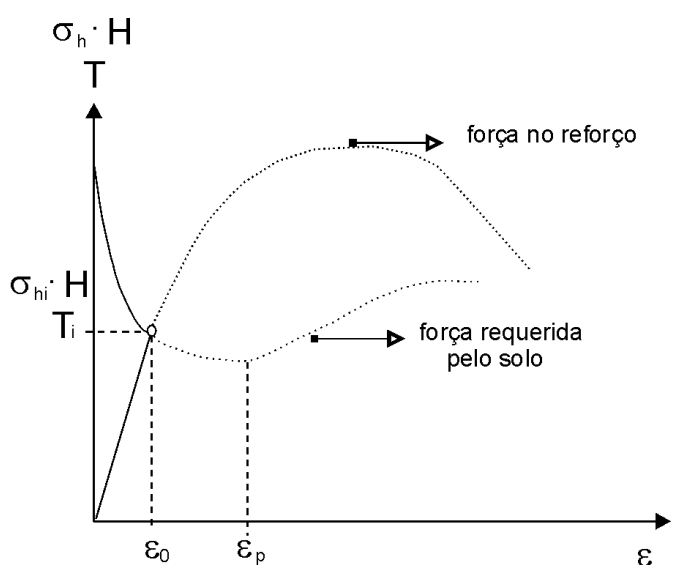

(a)

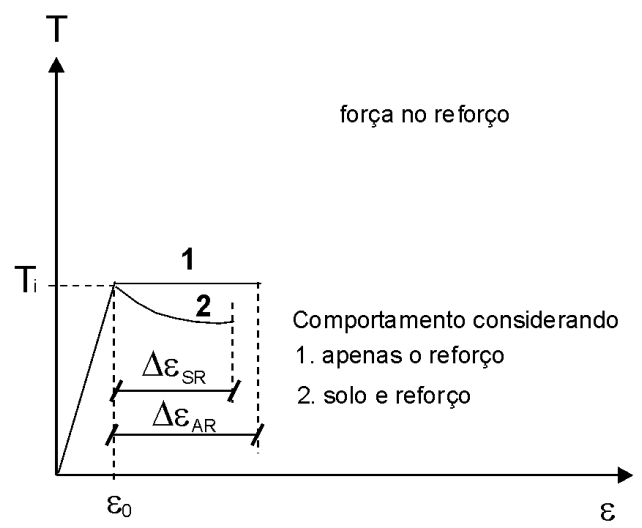

(c)

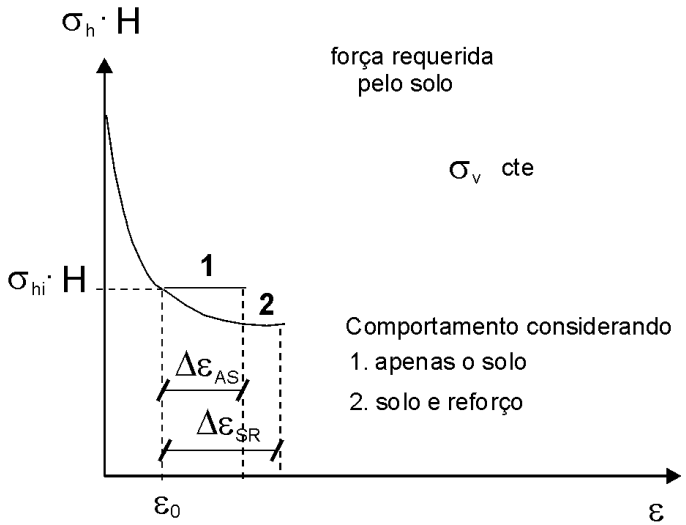

(b)

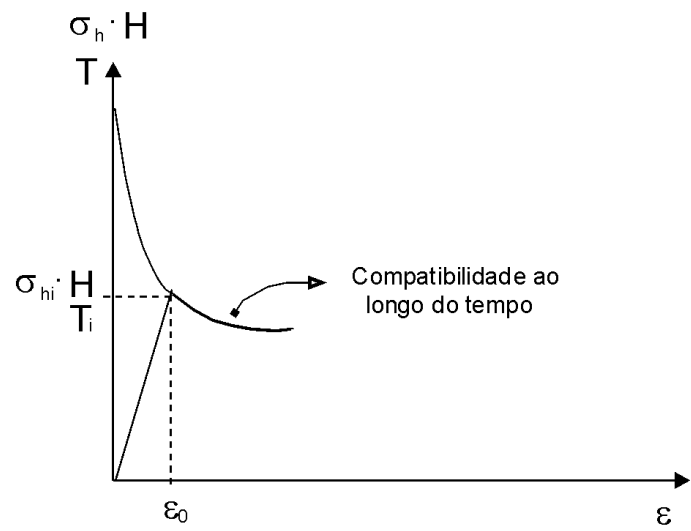

(d)

FIGURA 5.9 - Mecanismo quando o solo apresenta menor tendência à fluência $\left(\varepsilon_{0}<\varepsilon_{\mathrm{p}}\right)(\mathrm{a})$ Força requerida pelo solo e tensão no reforço imediatamente após a aplicação de $\sigma_{\mathrm{v}}$ (b) força requerida pelo solo ao longo do tempo (c) força no reforço ao longo do tempo (d) compatibilidade entre carga requerida e força no reforço ao longo do tempo.

Como o solo ainda não tinha atingido sua resistência máxima após a aplicação da tensão vertical, o valor da carga no reforço pode diminuir, desde que o incremento de deformação no solo seja diferente do valor $\Delta \varepsilon_{\mathrm{AS}}$, a fim de possibilitar a mobilização de um maior valor de ângulo de atrito. As necessidades do solo e do reforço ao longo do tempo podem então ser compatibilizadas (Figura 5.9d). Destacase que o incremento de deformação no solo não pode ser igual a $\Delta \varepsilon_{\mathrm{AS}}$, pois, se for igual, $\sigma_{\mathrm{h}}$ permanece constante e igual a $\sigma_{\mathrm{hi}}$ e pelas necessidades do reforço, $\sigma_{\mathrm{h}}$ precisa diminuir. 
Assim, quando o valor da deformação após a aplicação do carregamento é inferior à deformação correspondente ao ângulo de atrito de pico, existe a possibilidade do solo restringir as deformações do reforço ao longo do tempo. Salienta-se mais uma vez que essa possibilidade de restrição só é possível pela capacidade do solo mobilizar uma maior resistência com o tempo, em função do incremento de deformação, possibilitando assim a diminuição de carga no reforço. De uma forma geral, essa restrição causada pelo solo é possível sempre que o solo possa adquirir uma maior resistência com o tempo, seja através da mobilização de um maior ângulo de atrito com as deformações ao longo do tempo (caso ilustrado na Figura 5.9) ou por algum outro motivo, como um possível acréscimo de sucção com o tempo, no caso de solos não-saturados.

- Mecanismo desenvolvido para $\varepsilon_{0}>\varepsilon_{\mathrm{p}}$

Se o estado de tensão inicial no solo corresponder a uma situação após a mobilização do ângulo de atrito de pico e não existir nenhuma outra possibilidade de aumento da resistência do solo com o tempo, mesmo que o solo tenha uma menor tendência à fluência, como mencionado, não é possível ocorrer a restrição da fluência do reforço causada pelo solo. O solo não tem mais como mobilizar uma maior resistência, a fim de compensar a perda de carga no reforço, necessária caso o incremento de deformação com o tempo seja inferior a $\Delta \varepsilon_{\mathrm{AR}}$. (Figura $5.10 \mathrm{c}$ ). Qualquer incremento de deformação ao longo do tempo maior que o valor $\Delta \varepsilon_{\mathrm{AS}}$ provoca um aumento no valor de $\sigma_{\mathrm{h}}$ (Figura 5.10b) o que significa, conseqüentemente, uma maior solicitação no reforço. As necessidades do solo e do reforço não podem ser compatibilizadas (Figura 5.10d).

Assim, para compatibilizar as necessidades entre solo e reforço, este, na verdade, passa a apresentar acréscimo de carga com o tempo. Esse acréscimo deve resultar em uma deformação no reforço ao longo do tempo maior que o valor esperado apenas com base no reforço, conforme indicado na Figura 5.11. Na verdade, não existem ensaios na literatura considerando esse tipo de trajetória. 


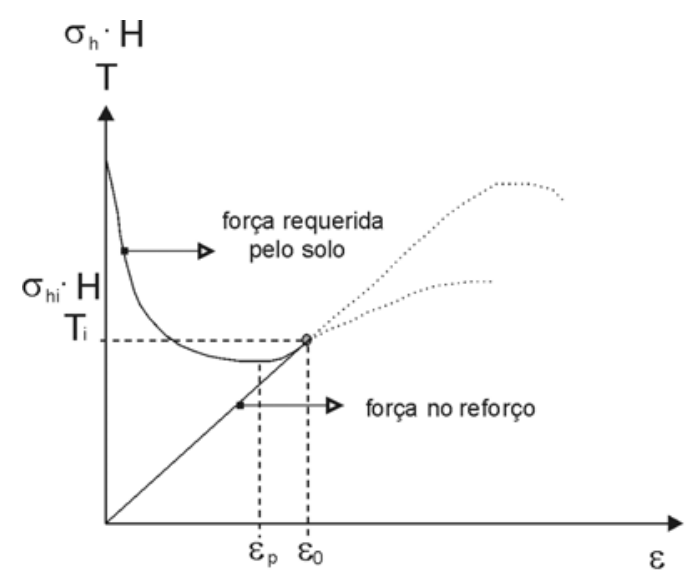

(a)

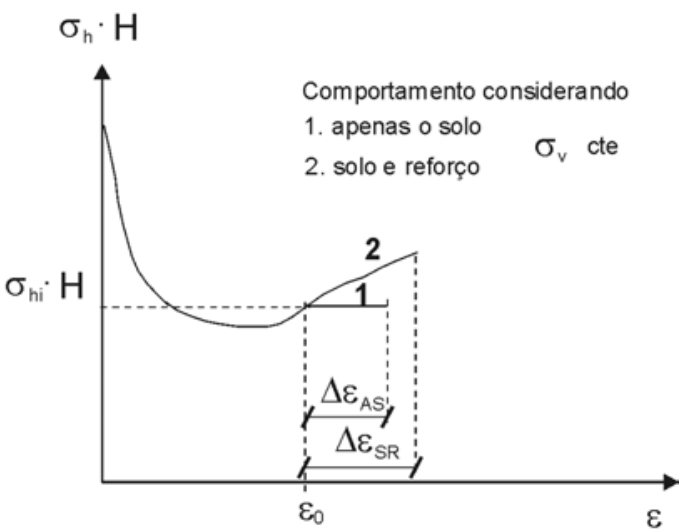

(b)
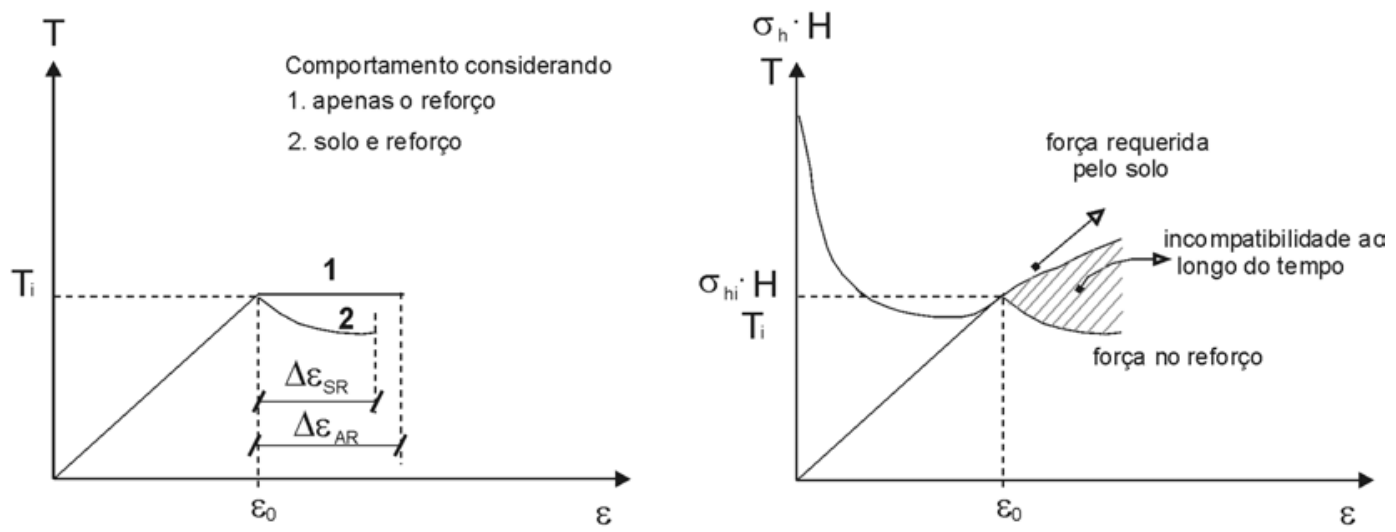

(c)

(d)

FIGURA 5.10 - Mecanismo quando o solo apresenta menor tendência à fluência $\left(\varepsilon_{0}>\varepsilon_{\mathrm{p}}\right)(\mathrm{a})$ Força requerida pelo solo e tensão no reforço imediatamente após a aplicação de $\sigma_{\mathrm{v}}(\mathrm{b})$ força requerida pelo solo ao longo do tempo (c) força no reforço ao longo do tempo (d) compatibilidade entre carga requerida e força no reforço ao longo do tempo.

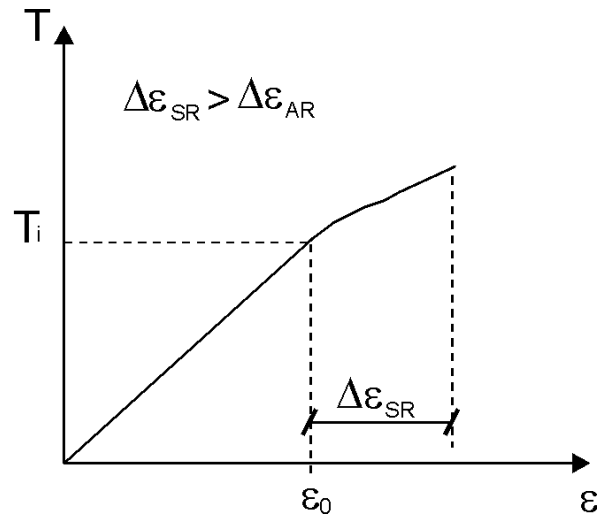

FIGURA 5.11 - Força x deformação no reforço para compatibilizar as necessidades entre solo e reforço quando $\varepsilon_{0}>\varepsilon_{\mathrm{p}}$ 
- Caso 3 - o solo apresenta uma maior tendência à fluência em relação ao reforço

Quando o solo apresenta uma maior tendência à fluência, a presença do reforço pode restringir a deformação do solo ao longo do tempo. Ao contrário do caso anterior (solo com menor tendência à fluência), um mesmo tipo de mecanismo pode ser idealizado, independente da deformação inicial $\left(\varepsilon_{0}\right)$ ser ou não inferior ao valor de deformação correspondente ao ângulo de atrito de pico $\left(\varepsilon_{\mathrm{p}}\right)$.

A Figura 5.12 ilustra o mecanismo nesse caso, mostrando o incremento de deformação ao longo do tempo previsto apenas com base no solo e apenas com base no reforço, $\Delta \varepsilon_{\mathrm{AS}}$ e $\Delta \varepsilon_{\mathrm{AR}}$, respectivamente. Como a taxa de fluência do solo é maior que a do reforço, $\Delta \varepsilon_{\mathrm{AS}}>\Delta \varepsilon_{\mathrm{AR}}$

Para o reforço restringir a deformação do solo, é preciso que este último apresente um incremento de deformação na presença do reforço $\left(\Delta \varepsilon_{\mathrm{SR}}\right)$, para o mesmo intervalo de tempo, menor que $\Delta \varepsilon_{\mathrm{AS}}$ (Figura 5.12b). Se isso ocorre, o valor $\left(\sigma_{\mathrm{v}}-\sigma_{\mathrm{h}}\right)$ diminui pela tendência de relaxação do solo (a tensão só pode permanecer constante caso o solo apresente todo o incremento $\Delta \varepsilon_{\mathrm{AS}}$ ). Sendo assim, como $\sigma_{\mathrm{v}}$ permanece constante, a tensão no solo $\sigma_{\mathrm{h}}$ tem que aumentar. Por outro lado, se a tensão $\sigma_{\mathrm{h}}$ aumenta, então a carga no reforço precisa aumentar com o tempo $\left(\mathrm{T}=\sigma_{\mathrm{h}} \cdot \mathrm{H}\right)$.

Como o nível de deformação após a aplicação do carregamento $\left(\varepsilon_{0}\right)$ é sempre inferior à deformação de ruptura do reforço $\left(\varepsilon_{\text {rup }}\right)$, este tem sempre possibilidade de mobilizar uma maior resistência com o tempo (ver Figura 5.12c), e assim suprir a necessidade do solo no sentido de aumentar o valor da tensão $\sigma_{\mathrm{h}}$. A compatibilidade de necessidades pode ser estabelecida (Figura 5.12d).

É importante destacar que os mecanismos de interação solo-reforço, conforme discutidos, permitem uma análise mais adequada das deformações observadas em estruturas de solo reforçado. Obviamente, algumas simplificações foram adotadas. Não se considerou, por exemplo, algumas particularidades do comportamento de solos sob carga constante, como a possibilidade de ganho ou perda de resistência após fluência em relação à resistência obtida em curto prazo. 
Considerou-se ainda a fluência do solo apenas em virtude de tensões cisalhantes. No entanto, esses mecanismos são bem mais abrangentes que os mecanismos idealizados anteriormente na literatura, e mostram que alguns aspectos, freqüentemente dissociados, devem ser considerados conjuntamente, como a tendência à fluência do solo confinante e o ângulo de atrito do solo mobilizado após a aplicação do carregamento.

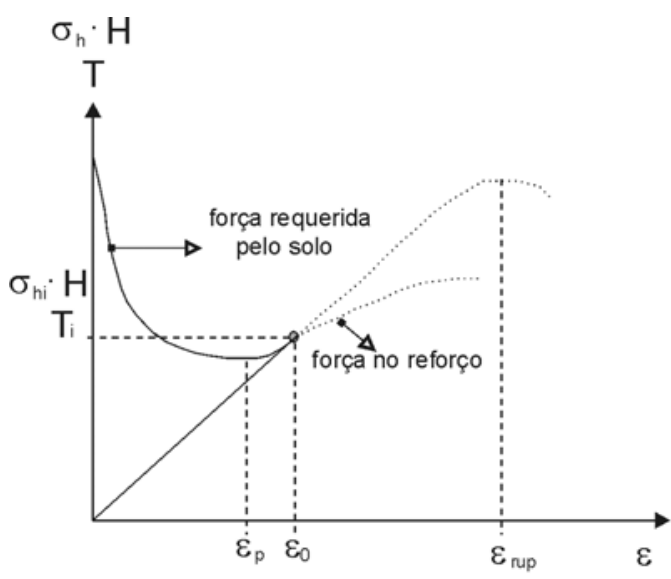

(a)

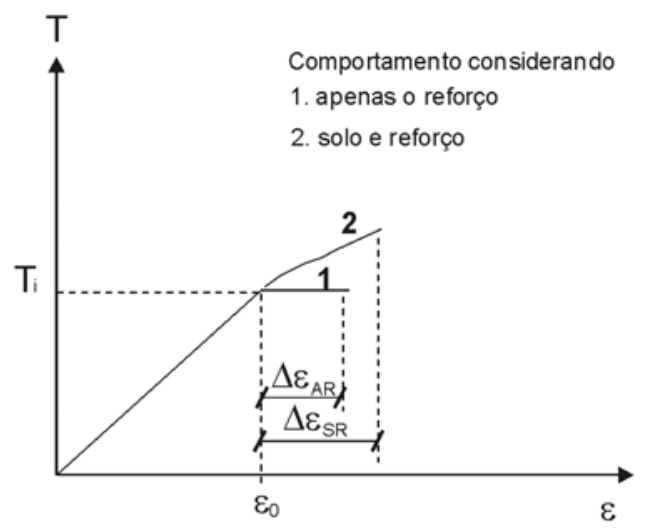

(c)

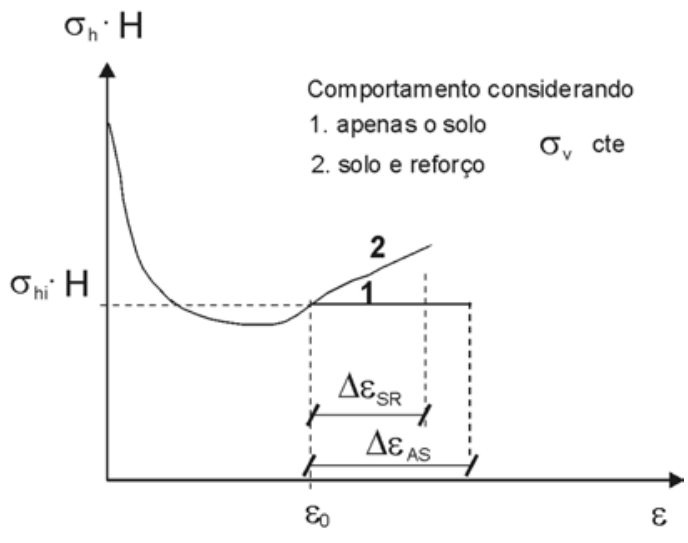

(b)

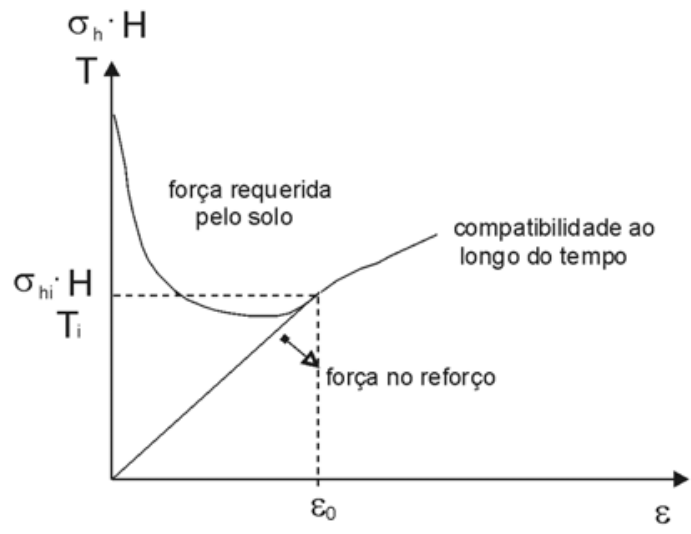

(d)

FIGURA 5.12 - Mecanismo quando o solo apresenta uma maior tendência à fluência em relação ao reforço (a) Força requerida pelo solo e tensão no reforço imediatamente após a aplicação de $\sigma_{v}$ (b) força requerida pelo solo ao longo do tempo (c) força no reforço ao longo do tempo (d) compatibilidade entre carga requerida e força no reforço ao longo do tempo.

Com relação à tendência à fluência do solo em relação ao reforço, é importante observar ainda que, apesar da fluência das areias ser tradicionalmente considerada desprezível, a taxa de fluência de uma areia nas condições encontradas 
em um muro de solo reforçado pode não ser consideravelmente inferior à taxa de fluência dos geossintéticos. Esse comportamento pode ser observado analisando-se resultados de ensaios de fluência de uma areia e de geossintéticos, como os mostrados na Figura 5.13 e 5.14, respectivamente.

A Figura 5.13 apresenta valores de taxa de deformação ao longo do tempo, tipicamente observada para areias, segundo KUHN \& MITCHELL (1993). Os valores foram obtidos por MURAYAMA et al (1984) para uma areia pura submetida a uma diferença de tensão principal $\left(\sigma_{1}-\sigma_{3}\right)$ constante. Essa Figura apresenta a taxa de deformação $\mathrm{d} \gamma / \mathrm{dt}$ ao longo do tempo (t), onde $\gamma=\varepsilon_{1}-\varepsilon_{3}$. Os valores são referentes a diversos níveis de tensão, em relação à máxima tensão cisalhante $\left(\tau_{\text {máx }}\right)$ obtida em ensaios de compressão triaxial.

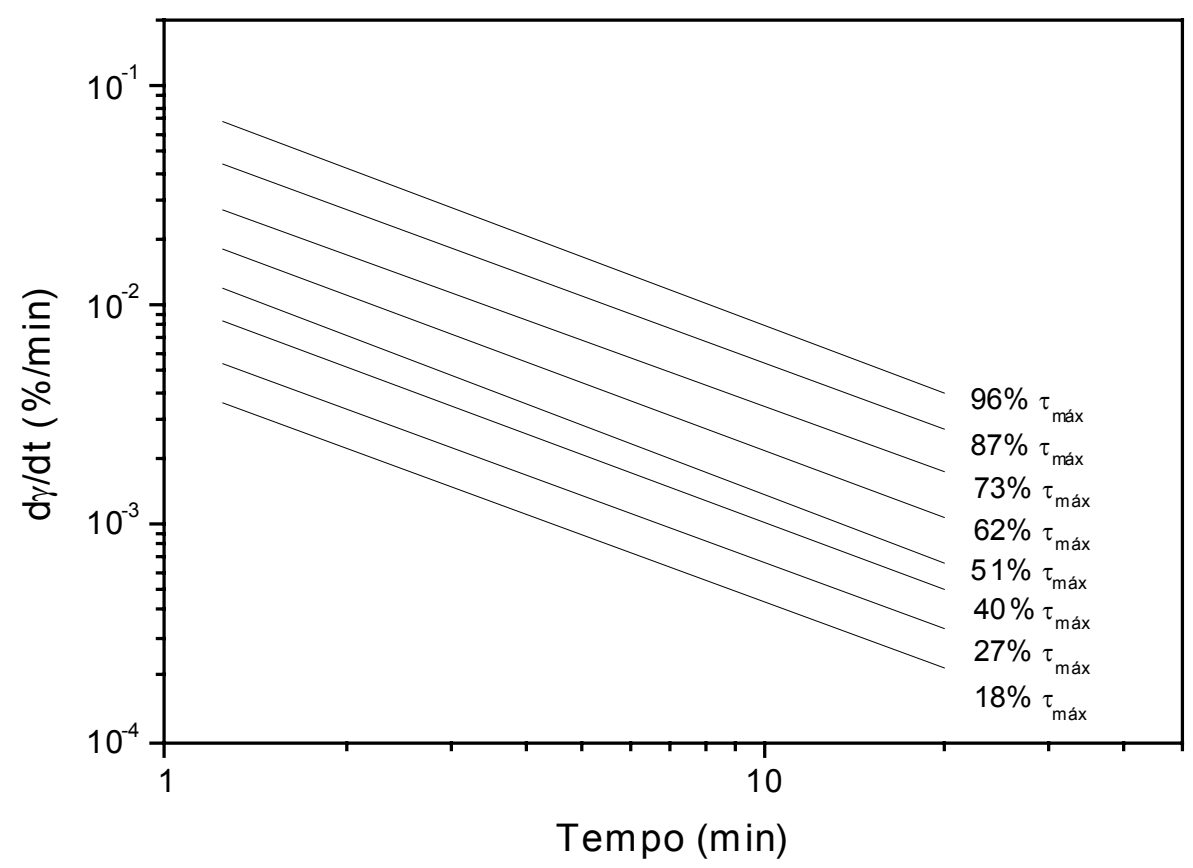

FIGURA 5.13 - Taxa de fluência tipicamente observada para areias (MURAYAMA et al., 1984).

A Figura 5.14 apresenta valores de taxa de fluência para vários tipos de geossintéticos. Esses valores foram calculados neste trabalho com base em dados 
presentes na literatura. Para um mesmo material, são apresentadas taxas de fluência para diferentes níveis de carregamento em relação à resistência à tração de cada geossintético $\left(\% \mathrm{~T}_{\mathrm{ult}}\right)$. Obviamente, considerando um determinado geossintético, quanto maior o nível de carregamento, maior a taxa de deformação para um mesmo tempo.

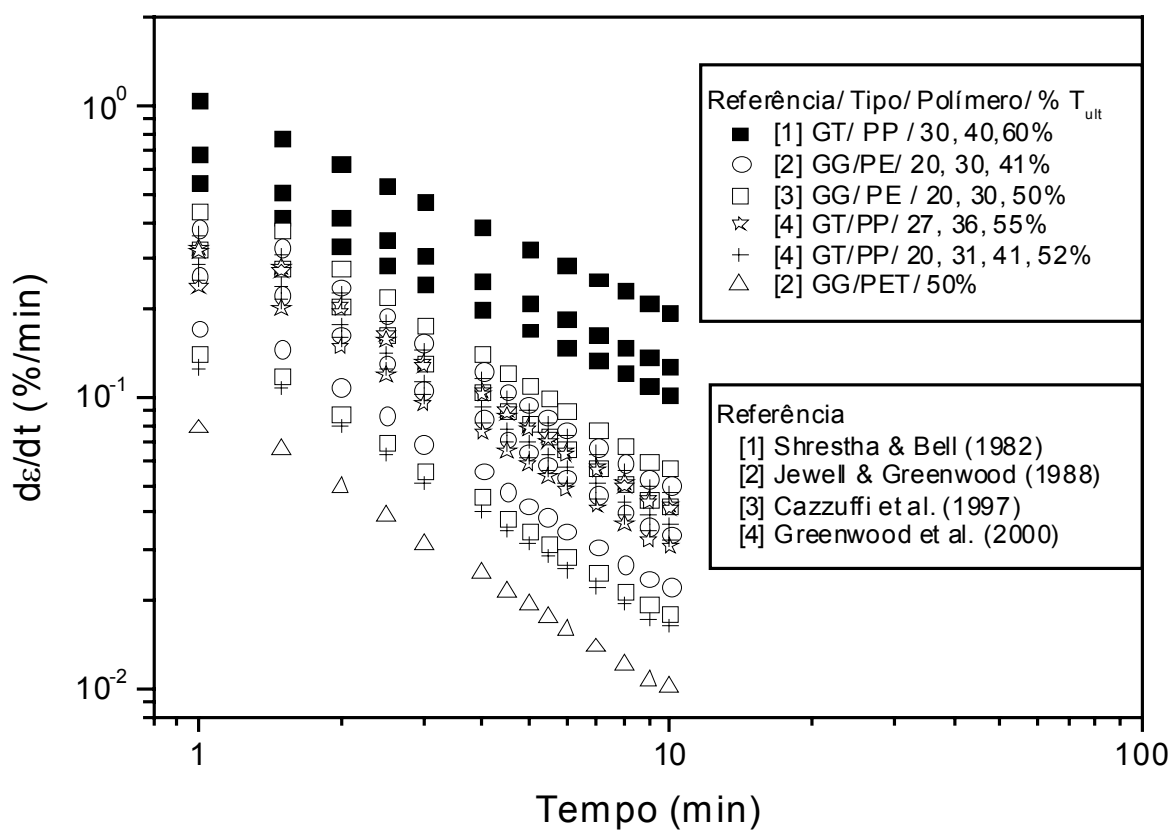

FIGURA 5.14 - Taxa de fluência observada em geossintéticos (GT - geotêxtil tecido, GG geogrelha).

Comparando-se a magnitude das taxas de fluência mostradas nas Figura 5.13 e 5.14, para um mesmo nível de solicitação, percebe-se que a fluência da areia é consideravelmente menor que a apresentada por geossintéticos. A Figura 5.15 apresenta esse tipo de comparação, considerando $40 \%$ de $\tau_{\text {máx }}$ e $40 \%$ de $\mathrm{T}_{\text {ult }}$, para solo e reforço, respectivamente, e esse mesmo tipo de comparação para e $20 \%$ de $\tau_{\text {máx }}$ e $20 \%$ de $T_{\text {ult. }}$ A faixa de valores indicada na Figura 5.15, no caso de geossintéticos, corresponde à variação identificada para os diferentes tipos de 
geossintéticos mostrados na Figura 5.14, submetidos a $40 \%$ e a $20 \%$ da resistência à tração.

Ressalta-se que certamente seria mais adequado comparar a taxa de fluência de areias em termos de $\mathrm{d} \varepsilon_{3} / \mathrm{dt}$, já que a deformação $\varepsilon_{3}$ é associada à deformação na direção do reforço. No entanto, a taxa de fluência para solos é, geralmente, apresentada em termos de variação de deformação cisalhante. Mesmo assim, comparações estabelecidas com base nas Figuras 5.13 e 5.14 são válidas para avaliar a ordem de grandeza da tendência à fluência de uma areia em relação à fluência de geossintéticos.

Observando-se a Figura 5.15, percebe-se que a taxa de fluência do solo é mais de uma ordem de magnitude inferior à taxa de fluência dos geossintéticos (geotêxteis e geogrelhas), considerando um mesmo nível de solicitação. No entanto, deve-se considerar que tal situação não corresponde à condição normalmente presente em estruturas de solo reforçado. Para o nível de deformação máxima freqüentemente verificado nos reforços em estruturas instrumentadas $(\varepsilon=1$ a $3 \%$ ), o nível de carregamento no geossintético é bastante reduzido, ao passo que o nível de tensão no solo é, possivelmente, bem mais elevado.

Para geogrelhas e geotêxteis tecidos, considerando a Figura 2.45 (capítulo 2), uma deformação correspondente a 1 e $2 \%$ corresponde a cerca de 10 e $20 \% \mathrm{~T}_{\text {ult }}$, respectivamente. Por outro lado, para esse mesmo nível de deformação, o solo pode, inclusive, mobilizar um ângulo de atrito correspondente ao valor de pico, ou seja, nível de carregamento correspondente a $100 \% \tau_{\text {máx }}$.

Ressalta-se que esse nível de carga no reforço, $10 \%-20 \% \mathrm{~T}_{\text {ult }}$ para $\varepsilon=1 \%$ $2 \%$, foi obtido com base em ensaios de tração convencionais e, como o tempo de carregamento nos muros é maior que o dos ensaios, o nível de carga de fato atuante no reforço no muro deve ser ainda menor, conforme discutido no item 5.1.1. No entanto, a omissão de informações importantes nos trabalhos publicados sobre muros de solo reforçado, como curvas de tração e fluência dos geossintéticos utilizados, impede uma avaliação mais adequada no nível de carga atuante nos geossintéticos em estruturas de solo reforçado.

Com relação a essa questão, ALLEN \& BATHURST (2002a), ao revisarem o comportamento de 6 muros instrumentados, considerando o tempo de carregamento 
da estrutura, mostram por exemplo, que a força máxima registrada nos reforços variou de 1 a 7\% da resistência à tração.

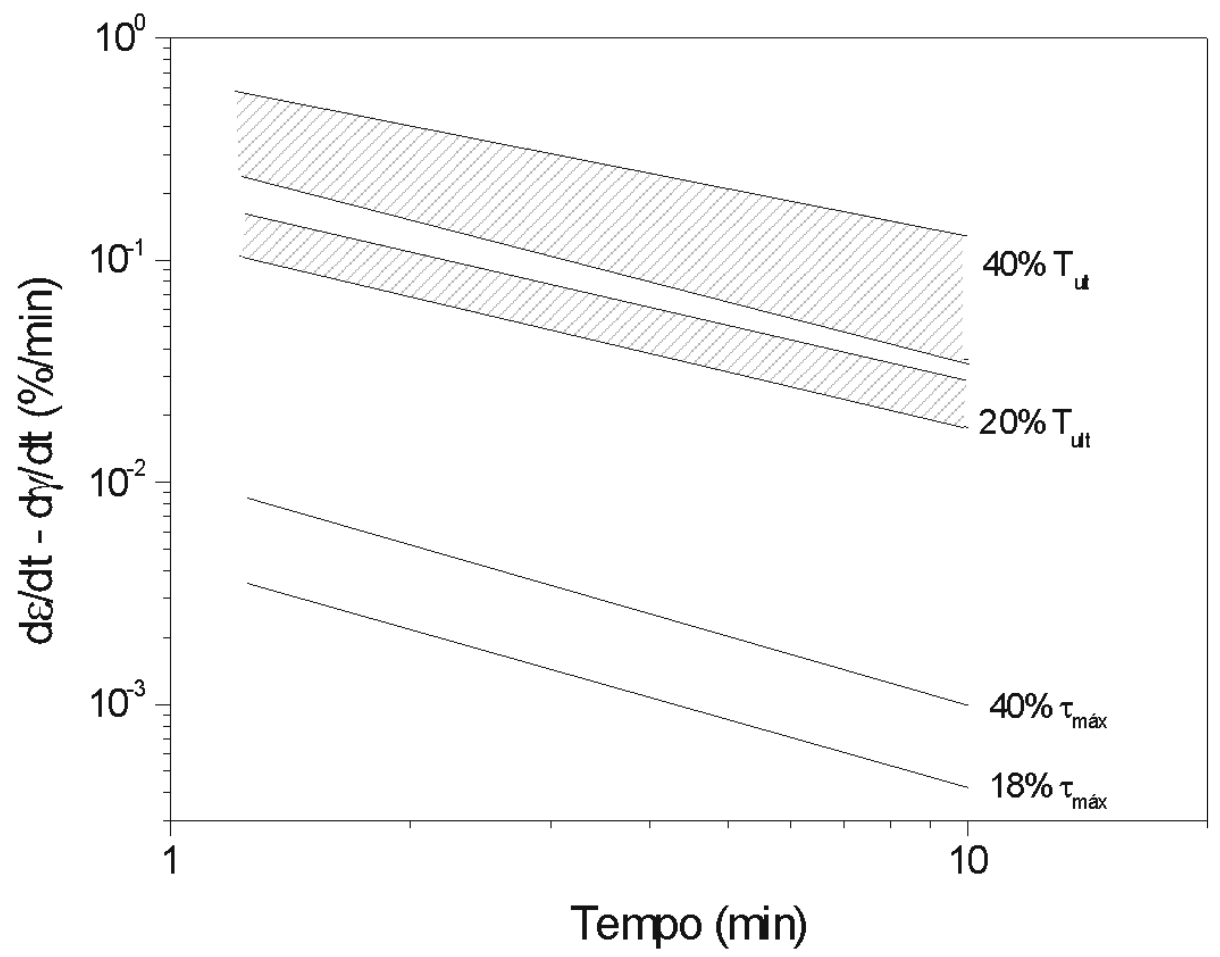

FIGURA 5.15 - Comparação entre tendência à fluência de areias e geossintéticos para um mesmo nível de solicitação (valores obtidos nas Figuras 5.13 e 5.14 para solo e geossintéticos, respectivamente).

Assim, uma condição representativa de estruturas de solo reforçado, para comparar a taxa de fluência de areias em relação aos geossintéticos, corresponde ao reforço com um nível de carregamento bastante reduzido ao passo que o solo apresenta níveis mais elevados. Por exemplo, enquanto o reforço está submetido a um nível de solicitação igual a $10 \% \mathrm{~T}_{\text {ult }}$ o solo estaria sujeito a $60-90 \% \tau_{\text {máx }}$.

A Figura 5.16 apresenta a faixa de valores para a taxa de fluência mostrada na Figura 5.13 , considerando $62 \%$ a $96 \% \tau_{\text {máx }}$ para o solo, e a faixa de valores para a taxa de fluência de geossintéticos de PE e PP a 20\% $\mathrm{T}_{\text {ult }}$ mostrada na Figura 5.14 (o nível de $20 \%$ foi considerado pela inexistência de dados correspondentes a um menor nível de solicitação). A Figura 5.16 também mostra a taxa de fluência para uma 
geogrelha de PET a 50\% $\mathrm{T}_{\text {ult. }}$ Considerando um nível de carregamento até $10 \% \mathrm{~T}_{\text {ult }}$ para o reforço, percebe-se que a taxa de fluência, mesmo de uma areia, pode ser semelhante à taxa de fluência de um geossintético.

Assim, apesar da fluência das areias ser tradicionalmente considerada desprezível, a taxa de fluência de uma areia nas condições encontradas em um muro de solo reforçado pode não ser consideravelmente inferior à taxa de fluência dos geossintéticos. Isso implica que o caso 1 (solo e reforço com mesma tendência à fluência) não é improvável, mesmo considerando uma areia como aterro. Além do mais, mesmo que a taxa de fluência da areia seja inferior a do reforço (caso 2) a diferença pode não ser elevada e, portanto, a restrição da fluência do reforço pode não ser muito significativa.

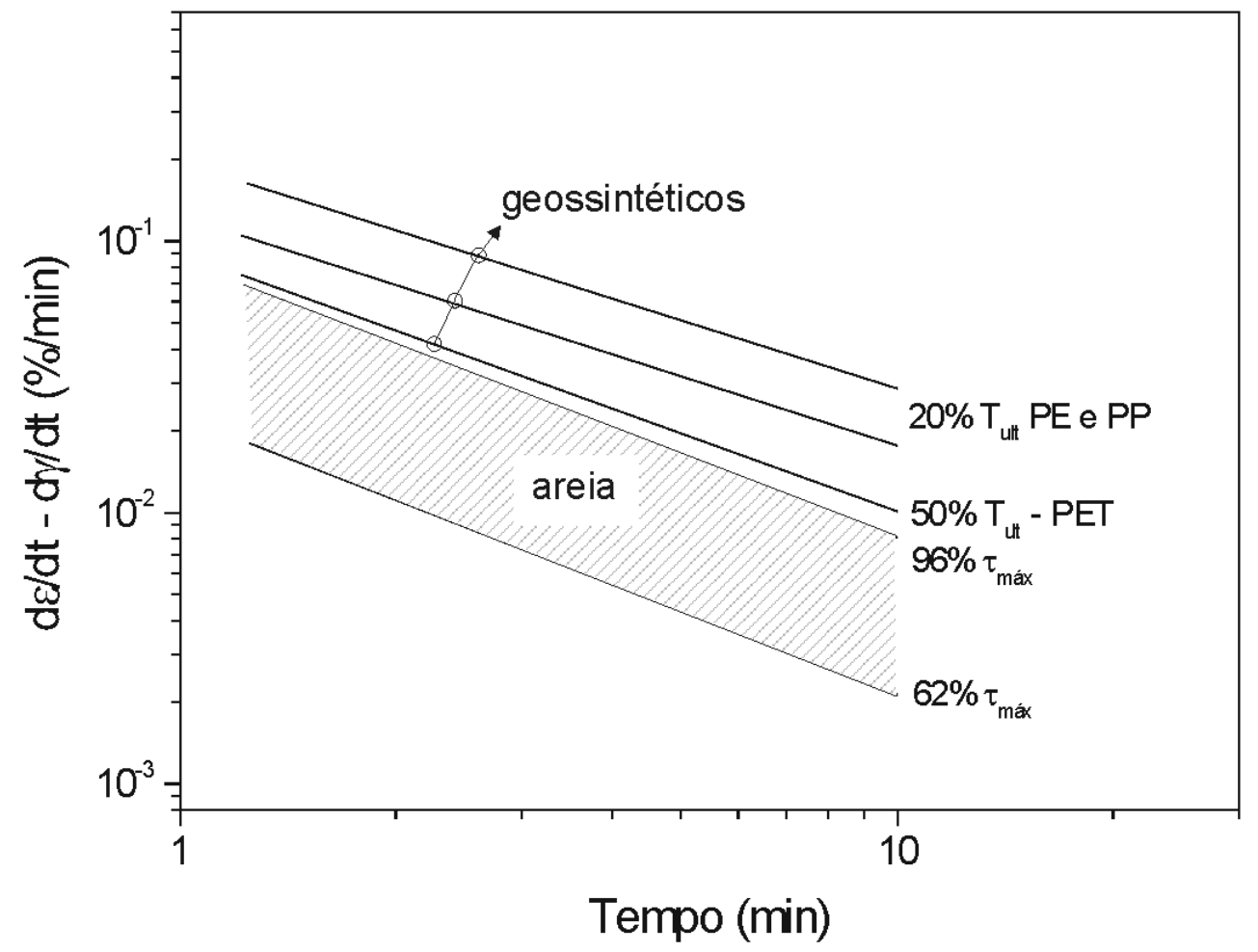

FIGURA 5.16 - Comparação entre tendência à fluência de areias e geossintéticos para níveis de solicitação diversos (valores obtidos nas Figuras 5.13 e 5.14 para solo e geossintéticos, respectivamente). 
É importante salientar ainda que os mecanismos discutidos anteriormente são referentes a um elemento de solo reforçado composto por um único reforço confinado entre duas camadas de solo. Deve-se considerar, ainda, que existe possibilidade de uma interação entre camadas de reforço nos muros de solo reforçado e entre os demais componentes da estrutura.

A redistribuição de força entre reforços, identificada nos modelos realizados em centrífuga no presente trabalho, bem com a redistribuição de força entre reforços em outros trabalhos presente na literatura sugere que pode haver uma interação entre camadas ao longo do tempo. A fluência de uma camada mais solicitada, por exemplo, pode ser reduzida pela interação com uma camada menos solicitada. Esse mecanismo pode ocorrer da seguinte forma: se a fluência do reforço mais solicitado é parcialmente impedida, ocorre redução na sua carga (pela tendência de relaxação do reforço), tal redução pode ser compensada, caso a camada menos solicitada mobilize uma maior força a fim de garantir o equilíbrio da estrutura. Assim, a camada inicialmente mais solicitada apresenta deformações ao longo do tempo com diminuição de carga e a camada inicialmente menos solicitada apresenta deformações ao longo do tempo com acréscimo de carga.

\subsection{Considerações finais com relação à previsão de deformações ao longo do tempo em muros de solo reforçado}

Considerando todo o mecanismo anteriormente discutido, a presença do solo, de fato, pode afetar a fluência do reforço, mas não no sentido de alterar as propriedades do material. Com exceção dos geotêxteis não tecidos, a diferença entre o comportamento de geossintéticos confinados no solo e sem confinamento, submetidos a um mesmo carregamento inicial, ocorre devido às diferentes trajetórias de carregamento a que o material é submetido ao longo do tempo nas duas situações.

No caso de geossintéticos sob confinamento em muros de solo reforçado, os mecanismos de deformação ao longo do tempo podem se desenvolver de formas diversas, a depender das características de cada estrutura, como tipo de solo e reforço. Pode ocorrer fluência de fato, isto é, deformações ao longo do tempo sob carga constante ou deformações ao longo do tempo com diminuição e/ou com 
acréscimo de carga. É possível inclusive que, em uma mesma estrutura, para algumas camadas de reforço ocorra diminuição de carga com o tempo e para outras, aumento.

Sendo assim, nem sempre a previsão das deformações ao longo do tempo de uma estrutura com base em ensaios de fluência convencionais do reforço estará de acordo com o comportamento observado, mesmo que a carga inicial no reforço seja conhecida. A realização de ensaios com elementos de solo reforçado, semelhantes aos realizados no presente trabalho, é mais adequada e muito importante no sentido de investigação de possíveis mecanismos, mas diante da complexidade do problema, não necessariamente garante uma boa concordância entre previsão e comportamento observado nas estruturas. O comportamento observado nas estruturas ainda pode ser diferente devido às interações com outras camadas de reforço e demais componentes da estrutura, interações inexistentes nos ensaios com o elemento de solo reforçado.

Diante de tal situação, uma previsão adequada das deformações ao longo do tempo em muros de solo reforçado com base em resultados de ensaios de laboratório não é simples e essa questão, certamente, ainda constitui tema de pesquisa. $\mathrm{Na}$ ausência de um outro procedimento mais adequado, impor uma carga limite no reforço para a qual a deformação ao longo do tempo não é excessiva, com base em ensaios de fluência convencionais, ainda é a alternativa mais viável.

Tendo em vista os mecanismos discutidos, considera-se que pesquisas para a caracterização de geossintéticos disponíveis comercialmente, considerando diferentes possibilidades carga-deformação-tempo, são necessárias e podem contribuir consideravelmente para a realização de previsões mais adequadas. As investigações devem envolver a realização de ensaios de fluência e relaxação sem confinamento, além de ensaios para avaliar as deformações, considerando trajetórias com aumento e diminuição de carga em função do tempo. Pesquisas nesse sentido devem auxiliar o desenvolvimento de novos procedimentos para uma melhor previsão do comportamento das estruturas.

Com relação ao dimensionamento de muros de solo reforçado, os resultados encontrados no presente trabalho suportam que, embora os métodos utilizados em projeto sejam extremamente conservadores com relação à ruptura, muita cautela deve ser tomada antes de adotar procedimentos menos conservadores, já que as deformações ao longo do tempo podem comprometer a utilização da estrutura. Sem 
uma caracterização adequada do comportamento do reforço ao longo do tempo, considerando diversas trajetórias de carga, o mais prudente é não permitir um nível de deformação no reforço em curto prazo muito superior ao nível de deformação correspondente ao ângulo de atrito de pico do solo. Como citado, após esse valor, o reforço apresenta deformações sob aumento de carga com o tempo e a trajetória de carregamento deve resultar em deformações maiores que as estimadas com base em ensaios de fluência. Nesse caso, a adoção, em projetos, de parâmetros obtidos em ensaios de fluência estaria contra a segurança da estrutura. Devido ao caráter conservador dos métodos de dimensionamento empregados, tal situação não tem representado um problema, mas caso os procedimentos de cálculo sejam revistos, essa situação passaria a constituir um potencial problema. 
Capítulo 6

\section{Conclusões}

A presente tese apresentou uma investigação sobre o comportamento dependente do tempo de geotêxteis em muros de solo reforçado. O programa experimental conduzido foi elaborado considerando duas etapas de investigação distintas, a fim de fomentar discussões sobre o tema. Na primeira etapa, desenvolveu-se um equipamento para a observação das deformações de um elemento de solo reforçado em função do tempo. No que diz respeito a essa fase do trabalho, as seguintes conclusões devem ser ressaltadas:

- A configuração final do equipamento apresentou um desempenho adequado durante a fase de calibração e, de forma semelhante a outros equipamentos presentes na literatura, apresenta as seguintes vantagens:

i) o elemento de solo reforçado é ensaiado sob condições de estado plano, condição que tipicamente prevalece em estruturas de solo reforçado com geossintéticos;

ii) a carga atuante no reforço é transmitida pelo solo e ambos podem deformar de forma interativa, assim como em estruturas de solo reforçado.

- O equipamento desenvolvido representa um avanço com relação aos tipos de equipamentos presentes na literatura para o mesmo fim, pois tanto a carga quanto a deformação no reforço podem ser observadas em função do tempo. O equipamento permite também a realização de ensaios apenas com solo para 
a caracterização prévia da solicitação a ser transmitida pelo solo nos ensaios solo-reforço, além de possibilitar a realização de ensaios de relaxação do reforço;

- Muitos obstáculos foram encontrados durante a fase de desenvolvimento do equipamento. $\mathrm{O}$ projeto e a execução do sistema para a aplicação da tensão vertical, bem como a adoção de um procedimento de lubrificação eficiente para as laterais da caixa apresentaram-se como os principais entraves para a confecção do equipamento.

- A utilização de graxa de silicone pura para a lubrificação das faces do corpode-prova não relevou bons resultados ao longo do tempo. Embora o ângulo de atrito da graxa, imediatamente após a aplicação da tensão confinante, fosse pequeno, o mesmo apresentava um substancial acréscimo no decorrer do tempo, provocando a deterioração da lubrificação;

- A adição de pó de PTFE (Poly Tetra Fluoro Ethylene) à graxa reduziu o escoamento da graxa e a conseqüente variação do ângulo de atrito com o tempo. Entre as diversas proporções testadas, o composto formado por graxa de silicone e $20 \%$ de pó de PTFE apresentou o melhor desempenho.

- Todos os ensaios realizados para a verificação da repetibilidade dos resultados, tanto os ensaios apenas com solo, quanto os ensaios com o elemento solo-reforço, demonstraram que os procedimentos adotados para preparação e execução dos ensaios foram satisfatórios;

- Nos ensaios realizados para testar o equipamento e verificar a interferência do comportamento mecânico de uma areia na fluência do reforço, a carga no geotêxtil apresentou uma pequena variação com o tempo. Para os ensaios com $\mathrm{Dr}=50 \%$ e $\sigma_{\mathrm{v}}=100 \mathrm{kPa}$, a maior variação observada corresponde a uma redução em torno de $10 \%$ da força registrada, inicialmente, e após $10 \mathrm{~h}$ de ensaio. Nos ensaios com $\sigma_{\mathrm{v}}=200 \mathrm{kPa}$, observou-se uma maior variação da carga ao longo do tempo. Após $10 \mathrm{~h}$ de ensaio, ocorreu uma redução na carga inicial em torno de $20 \%$. Em ambos os casos, a magnitude da variação da carga observada no decorrer do ensaio pôde ser justificada pela variação estimada, ao longo do tempo, para o ângulo de atrito do composto graxa + PTFE; 
- As deformações ao longo do tempo nos ensaios com o elemento de solo reforçado foram semelhantes às deformações estimadas com base nos ensaios convencionais de fluência do reforço.

- A presença de areia confinando o reforço não provocou restrição da fluência do geotêxtil, apesar da areia constituir um material com menor tendência à fluência, em relação ao geotêxtil, sob um mesmo nível de solicitação.

Na segunda etapa do trabalho, a realização de ensaios, em centrífuga, para a investigação do desempenho de muros de solo reforçado constituiu uma abordagem importante para a auxiliar a elucidação do comportamento desse tipo de estrutura em função do tempo (principalmente, pela facilidade de visualização do mecanismo de deformação desenvolvido durante os ensaios). Os resultados obtidos demonstraram claramente a interferência do comportamento dependente do tempo dos reforços nos muros investigados. As seguintes conclusões relativas a essa fase da pesquisa devem ser destacadas:

- O mecanismo de deformação na massa de solo, encontrado nos ensaios de ruptura, apresentou-se diferente do mecanismo observado tradicionalmente em estruturas de contenção convencionais. Não se percebeu deformações acentuadas em termos de cisalhamento no solo. O padrão de deformação possibilitou a mobilização de um ângulo de atrito com valor superior ao ângulo de atrito no estado crítico, apesar do elevado nível de deformação nos reforços;

- Os resultados indicaram a ocorrência de uma distribuição para força máxima no reforço, com a profundidade, diferente da distribuição freqüentemente assumida em projeto. Mesmo antes da iminência de ruptura, a força máxima em cada camada de reforço apresentou valores semelhantes, em virtude da redistribuição de tensão entre as inclusões;

- A utilização de procedimentos comumente empregados no dimensionamento de muros para prever a aceleração na ruptura dos modelos revelou valores bastante inferiores aos obtidos nos ensaios de ruptura. Tal discrepância 
ocorreu, possivelmente, em virtude da redistribuição de força entre reforços e ao efeito do confinamento na resistência à tração do reforço;

- Deformações ao longo do tempo foram observadas em todos os modelos realizados para investigação de fluência, ocorrendo, inclusive, a manifestação de ruptura, após algumas horas de ensaio, em alguns modelos.

- A taxa de deformação ao longo do tempo observada nos modelos foi semelhante à observada nos ensaios convencionais de fluência dos materiais utilizados como reforços. Essa semelhança é válida, considerando o nível de solicitação dos geotêxteis nos modelos em relação à resistência confinada do reforço.

- Nos ensaios de fluência, considerando o mecanismo de deformação observado nos modelos (isto é, ausência de deformações acentuadas em termos de cisalhamento no solo), é bem possível que não tenham ocorrido grandes variações do ângulo de atrito do solo no decorrer do tempo. Assim, apesar da deformação imposta pelo reforço ao longo do tempo, a carga no reforço pode ter permanecido praticamente constante durante a maioria dos ensaios, possibilitando a ocorrência de fluência "pura" no reforço (carga constante);

Com base na parte experimental desenvolvida e nas discussões apresentadas nesta tese, os seguintes aspectos devem ainda ser destacados com respeito ao comportamento de muros de solo reforçado de uma forma geral:

- A ausência ou a reduzida fluência comumente relatada na literatura em estruturas instrumentadas deve-se, principalmente, à reduzida solicitação no reforço.

- A análise do comportamento dependente do tempo do reforço mediante a observação de estruturas instrumentadas tem, freqüentemente, resultado em interpretações indevidas do comportamento observado. Os erros de interpretação devem-se, principalmente, às dificuldades em estabelecer comparações entre o comportamento do reforço isolado, com base em ensaios em laboratório, e o comportamento observado na estrutura. Dificuldades 
relativas, por exemplo, à velocidade de carregamento e à trajetória de carga, no decorrer do tempo, nas duas situações. As variações de temperatura em campo e, muitas vezes, a presença de solos coesivos tendem a dificultar ainda mais a elucidação do comportamento do reforço em muros de solo reforçado cujo comportamento e interações, mesmo em curto prazo, ainda não são bem compreendidos.

- Os equívocos geralmente cometidos ao analisar a fluência do reforço através da observação de estruturas, tanto com relação à estimativa da carga inicial, quanto com relação à comparação com ensaios convencionais de fluência, contribuem para que a fluência nos muros seja menor que a estimada com base nos ensaios em laboratório. Tendo em vista a possibilidade desses erros de interpretação, recomenda-se que a interpretação do comportamento do reforço mediante dados de estruturas instrumentadas seja conduzida com muita acuidade.

- A interferência da tendência à fluência do solo confinante na fluência do reforço não ocorre, necessariamente, como descrito na literatura. Os mecanismos de interação solo-reforço apresentados nesta tese são mais abrangentes que os discutidos anteriormente e mostram que alguns aspectos, antes dissociados, devem ser considerados conjuntamente, como a tendência à fluência do solo confinante e o ângulo de atrito mobilizado após a aplicação do carregamento. Nesse sentido, os seguintes mecanismos devem ser considerados:

i) Quando o solo e o reforço apresentam a mesma tendência à fluência, ambos apresentam deformações ao longo do tempo, e esse acréscimo de deformação não provoca nenhuma variação no valor da carga no reforço com o tempo. A resistência mobilizada no solo também permanece constante e as deformações observadas, de fato, podem ser consideradas como fluência (deformações sob carga constante).

ii) Quando o solo apresenta menor tendência à fluência, a menor taxa de deformação em relação ao reforço não constitui condição suficiente para o solo restringir a fluência do reforço. Necessário se faz, ainda, analisar a possibilidade do solo apresentar uma maior resistência com o tempo. 
Considerando o comportamento de uma areia compacta, duas situações distintas podem ser identificadas em função do ângulo de atrito mobilizado:

ii.1) Quando o valor da deformação, após a aplicação do carregamento, é inferior à deformação correspondente ao ângulo de atrito de pico, o solo restringe as deformações do reforço ao longo do tempo. Nesse caso, a carga no reforço apresenta uma diminuição com o tempo;

ii.2) Quando o estado de tensão inicial no solo corresponde a uma situação após a mobilização do ângulo de atrito de pico, a restrição da fluência do reforço, causada pelo solo, não é possível. Para compatibilizar as necessidades entre solo e reforço, este apresenta acréscimo de deformação com aumento de carga com o tempo.

iii) Quando o solo apresenta uma maior tendência à fluência em relação ao reforço, a presença do reforço restringe a deformação do solo ao longo do tempo. Tal fato ocorre porque a deformação inicial (curto prazo) é sempre inferior à deformação de ruptura do reforço, logo, o reforço tem possibilidade de mobilizar uma maior resistência com o tempo e as necessidades de ambos os materiais podem ser compatibilizadas.

- Não obstante a fluência das areias ser tradicionalmente considerada desprezível, a taxa de fluência de uma areia nas condições encontradas em um muro de solo reforçado pode não ser significativamente inferior à taxa de fluência dos geossintéticos. Uma condição representativa de estruturas de solo reforçado para comparar a taxa de fluência de areias, em relação aos geossintéticos, corresponde ao reforço com um baixo nível de carregamento, enquanto o solo apresenta níveis mais elevados (por exemplo, 10\% $\mathrm{T}_{\text {ult }}$ para geossintéticos e 60 a $90 \% \tau_{\text {máx }}$ para o solo). Nessa situação, a taxa de fluência de uma areia, pode ser semelhante a de um geossintético.

- Não é simples efetuar uma previsão adequada das deformações em muros de solo reforçado, em função do tempo, mediante resultados de ensaios de laboratório. Diante da complexidade do problema, considera-se que adotar uma carga limite no reforço, considerando ensaios de fluência convencionais, 
por meio, por exemplo, de curvas isócronas, ainda constitui o procedimento mais recomendável para evitar deformações excessivas.

- Embora os métodos utilizados para o dimensionamento de muros de solo reforçado sejam conservadores com respeito à ruptura, considera-se que qualquer reavaliação dos métodos atuais ou proposição de novas rotinas de cálculo não deve ser estabelecida sem uma análise criteriosa sobre os efeitos do comportamento dependente do tempo do reforço no desempenho da estrutura. 


\section{ANEXO A: Deslocamentos dos marcos de areia}

\section{A.1 - Curvas deslocamento $x$ distância à face}

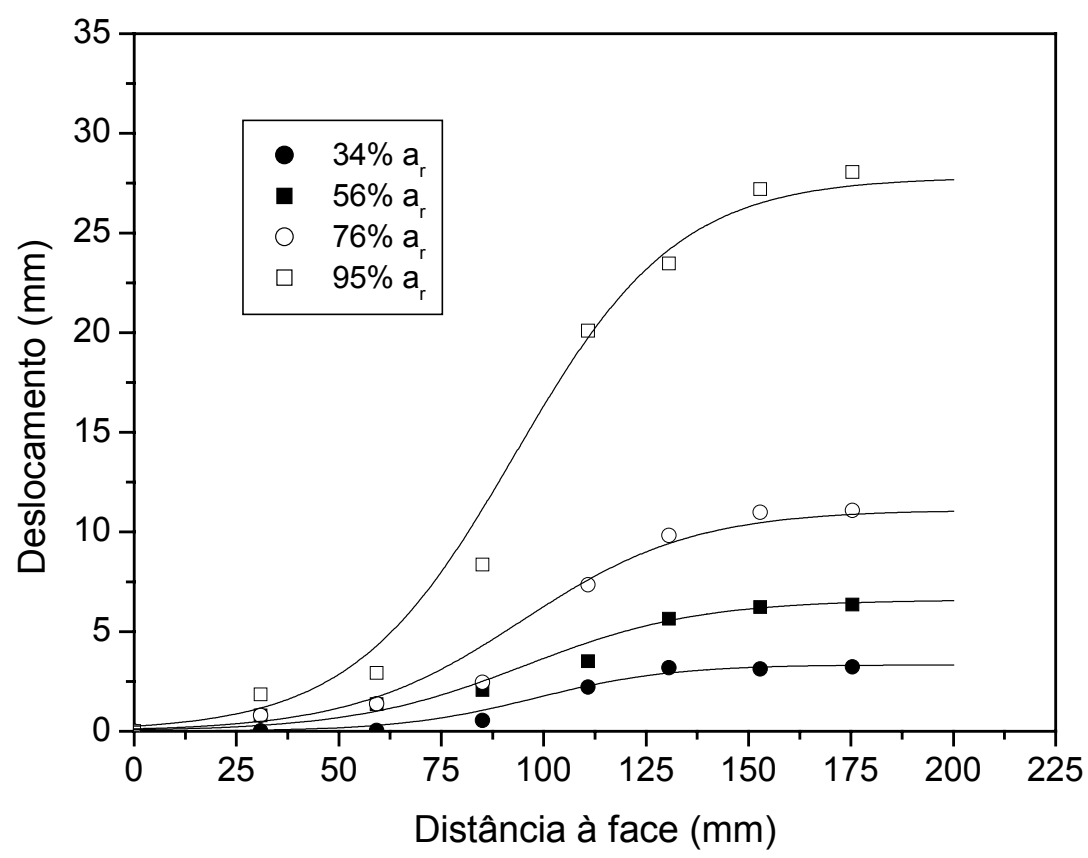

FIGURA A1 - Deslocamentos obtidos para o ensaio R-PET-2, camada 12, $a_{r}$ - Aceleração na ruptura obtida para o ensaio.

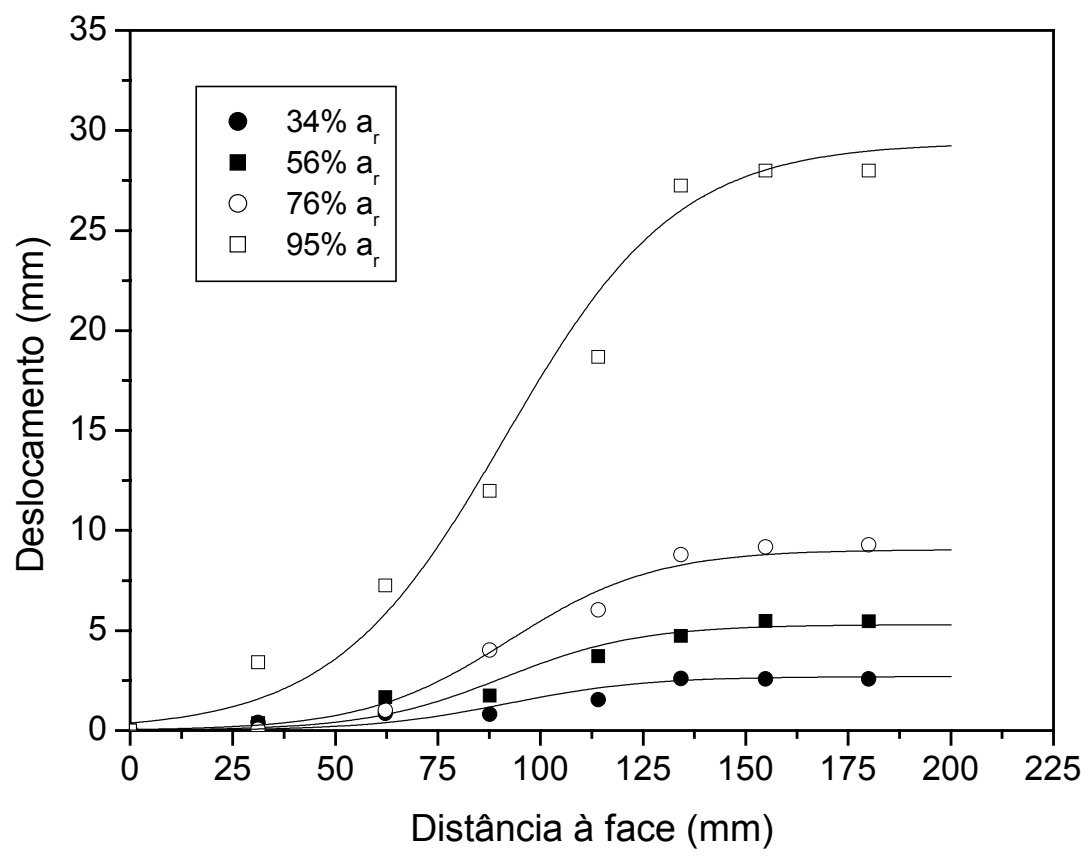

FIGURA A2 - Deslocamentos obtidos para o ensaio R-PET-2, camada 11. 


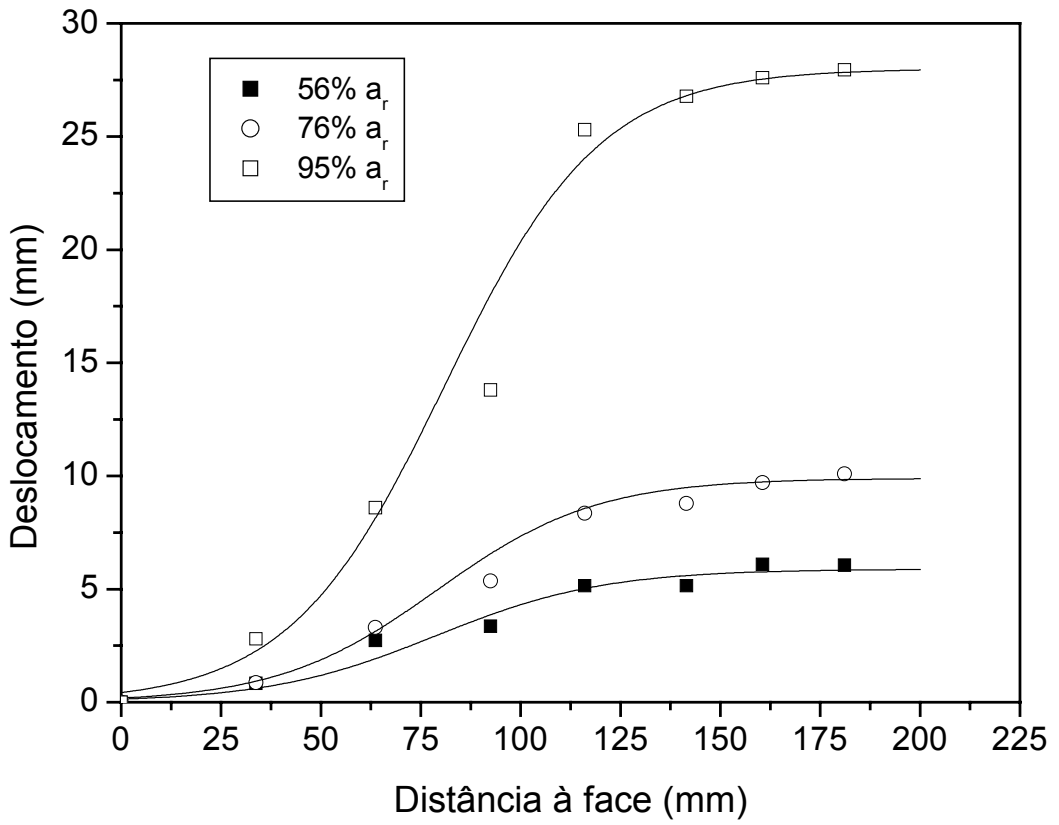

FIGURA A3 - Deslocamentos obtidos para o ensaio R-PET-2, camada 10.

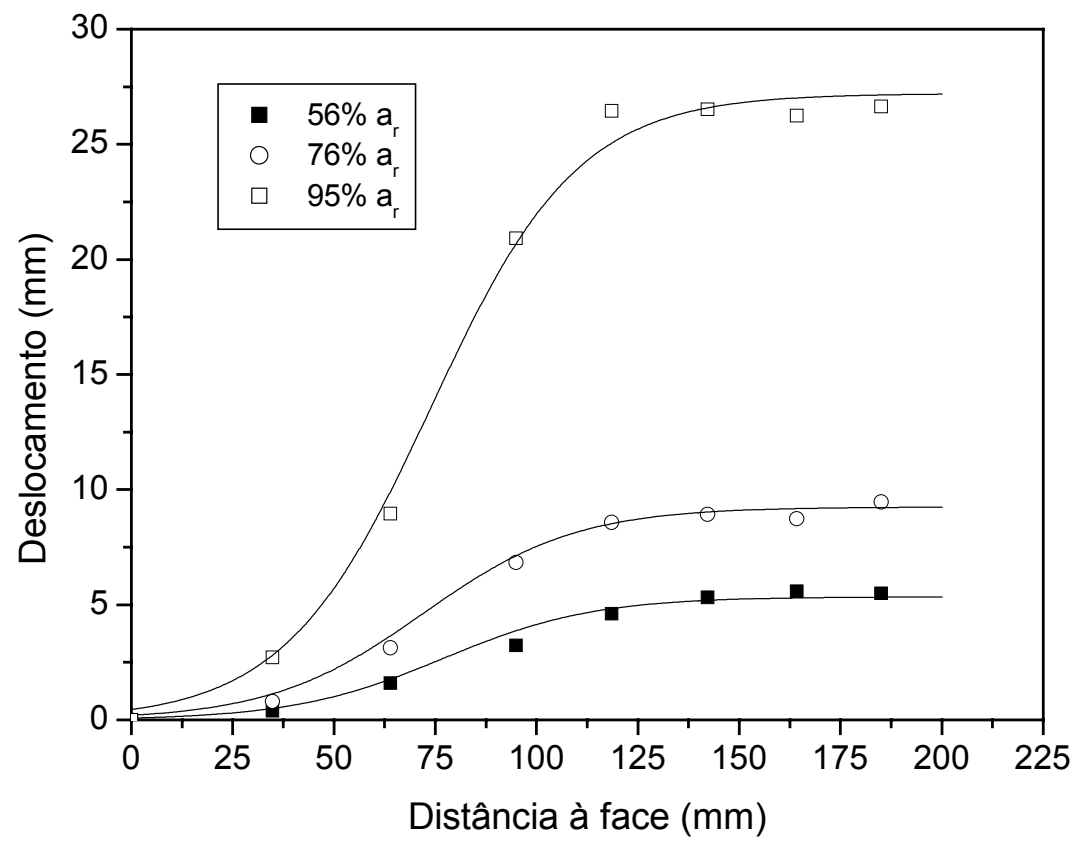

FIGURA A4 - Deslocamentos obtidos para o ensaio R-PET-2, camada 9. 


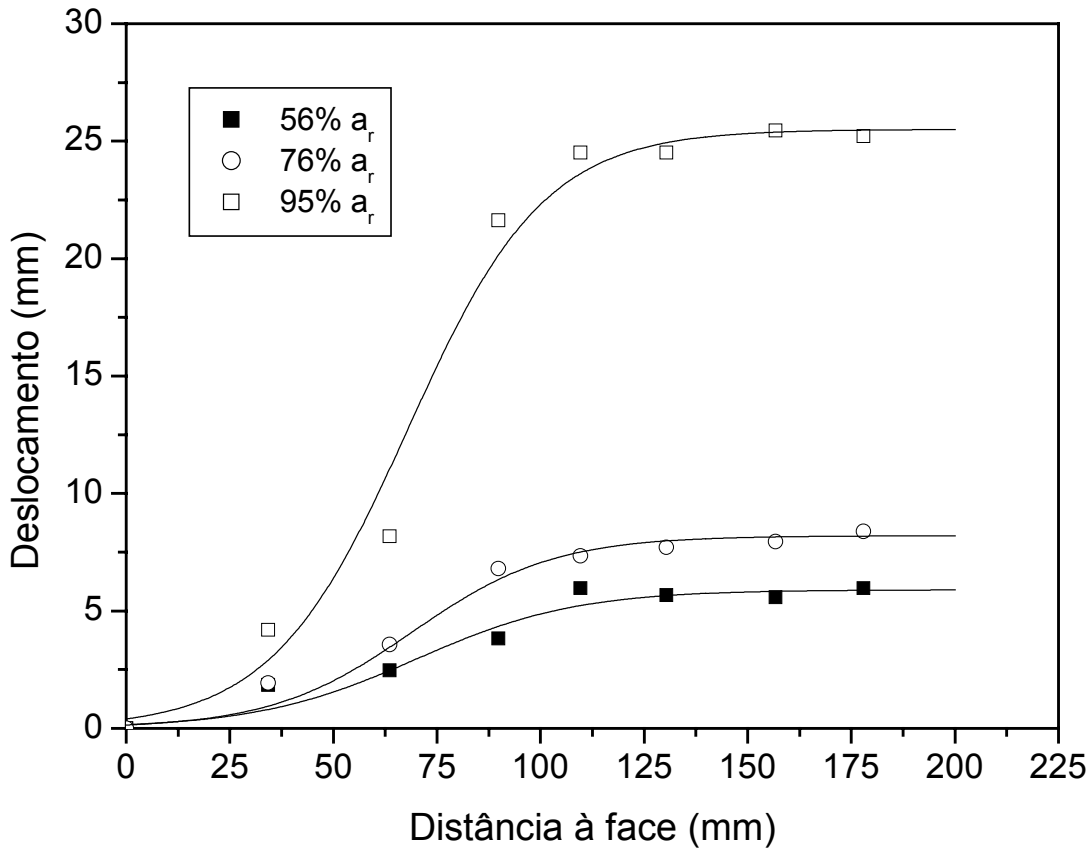

FIGURA A5 - Deslocamentos obtidos para o ensaio R-PET-2, camada 8.

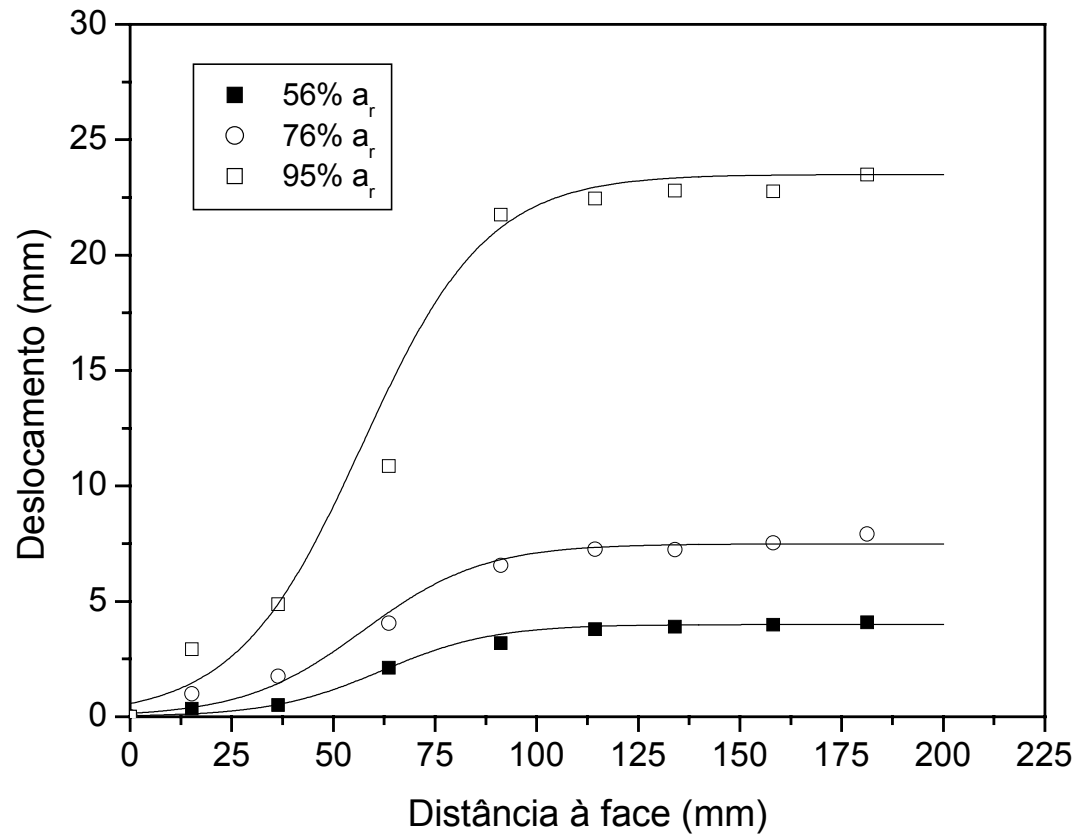

FIGURA A6 - Deslocamentos obtidos para o ensaio R-PET-2, camada 7. 


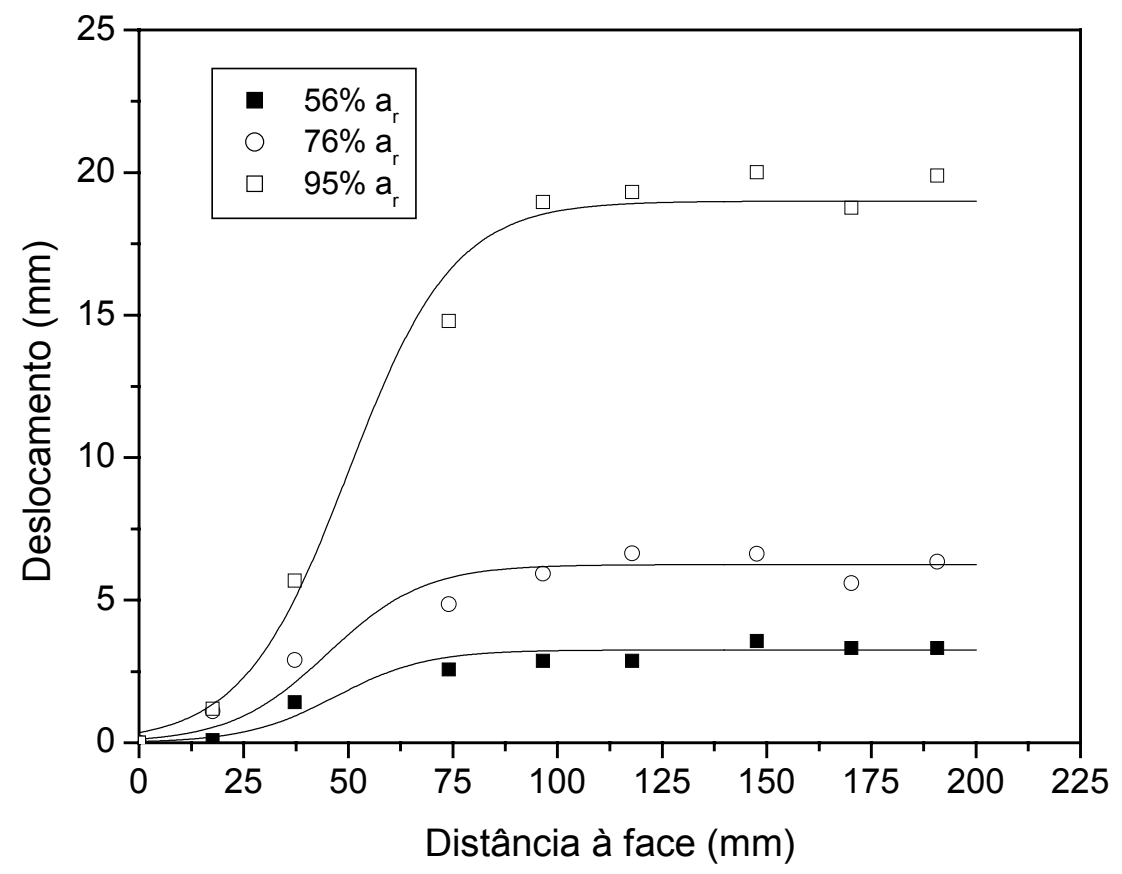

FIGURA A7 - Deslocamentos obtidos para o ensaio R-PET-2, camada 6.

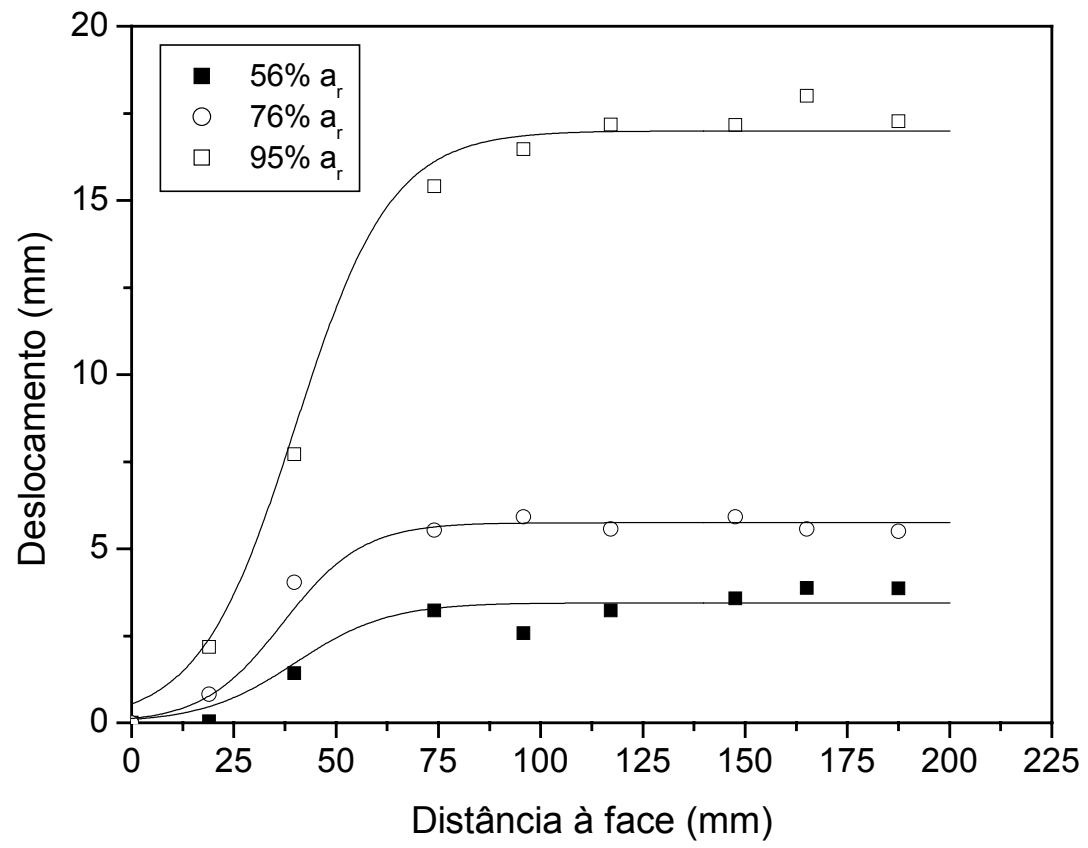

FIGURA A8 - Deslocamentos obtidos para o ensaio R-PET-2, camada 5. 


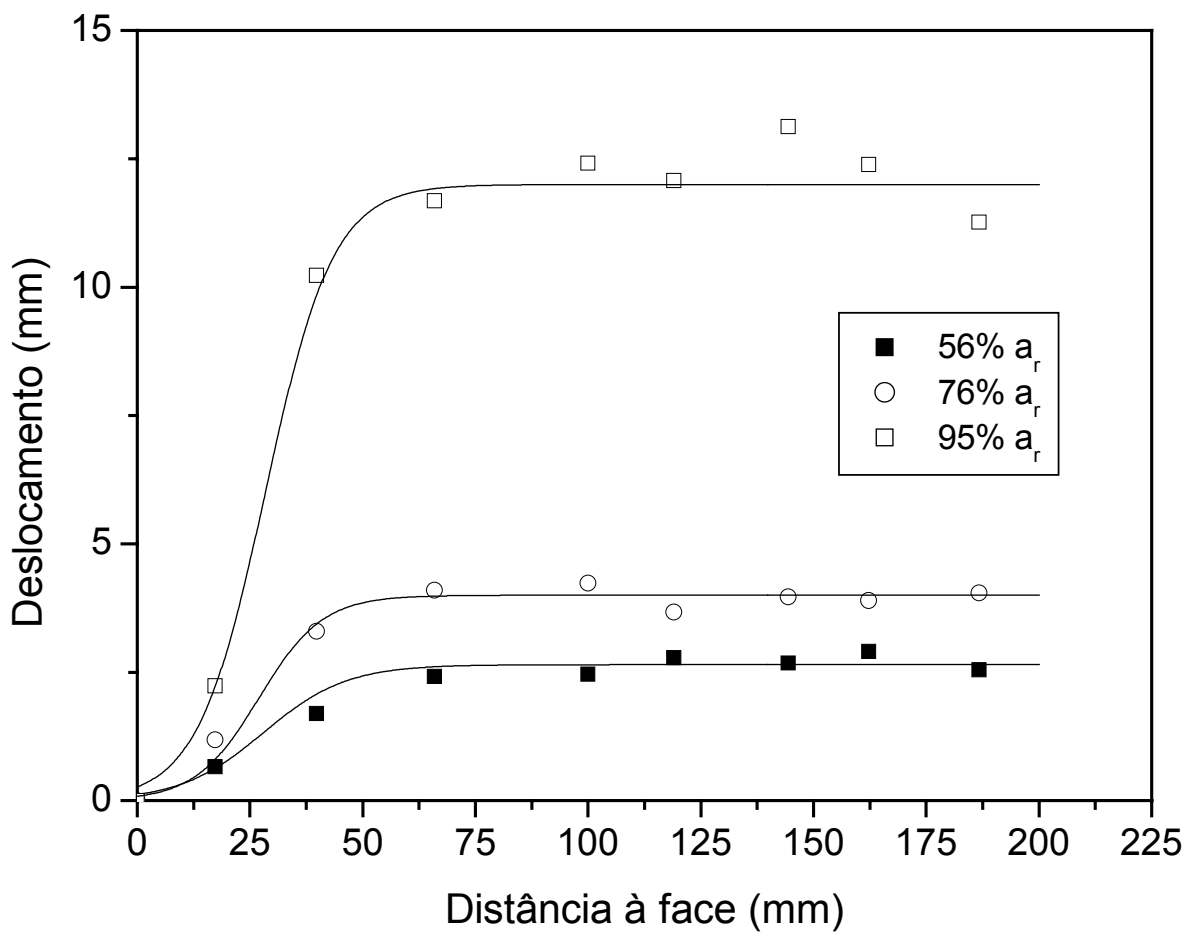

FIGURA A9 - Deslocamentos obtidos para o ensaio R-PET-2, camada 4.

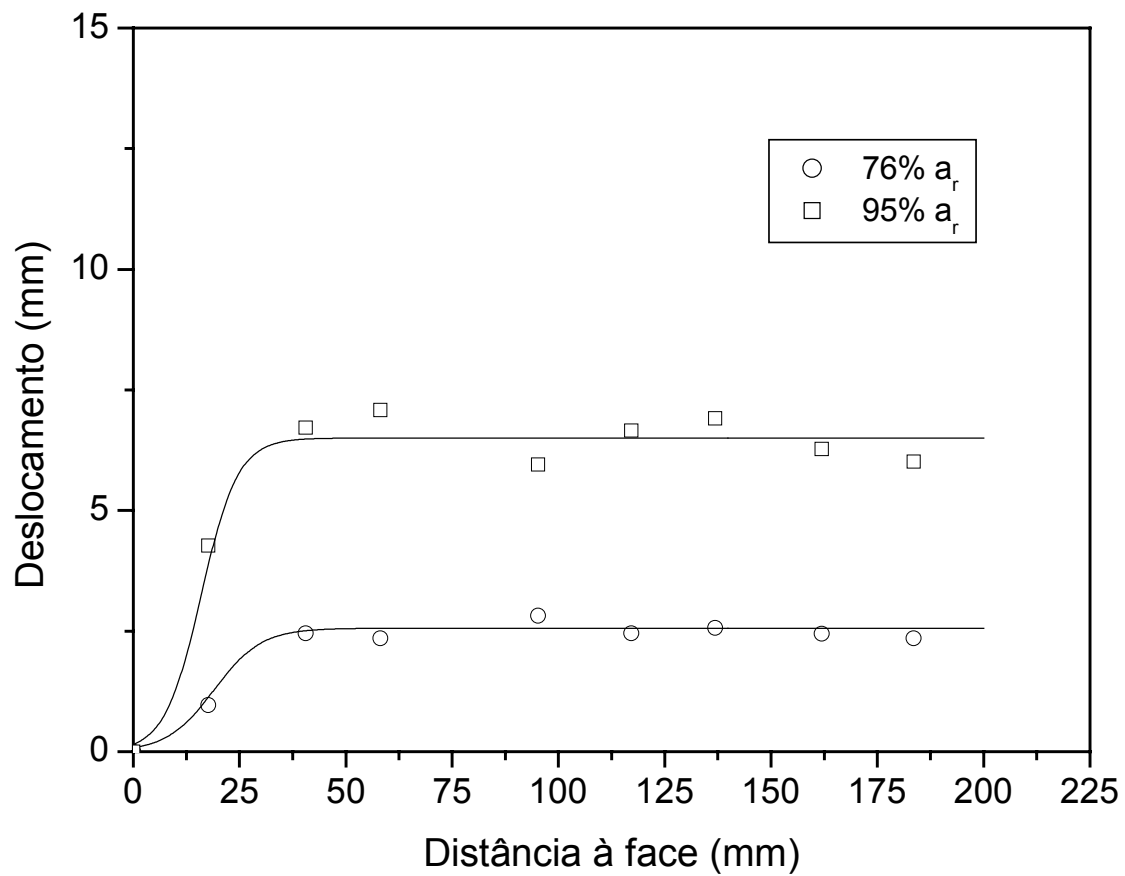

FIGURA A10 - Deslocamentos obtidos para o ensaio R-PET-2, camada 3. 


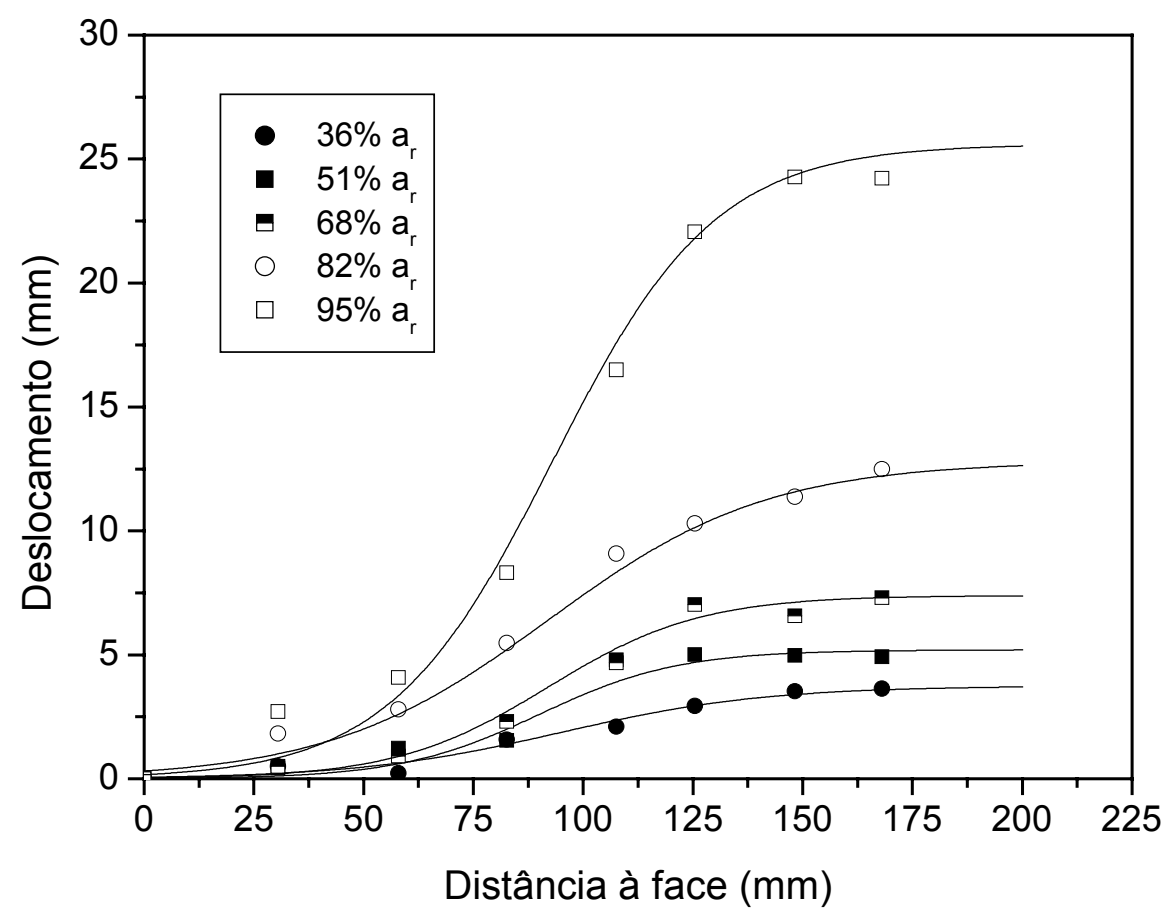

FIGURA A11 - Deslocamentos obtidos para o ensaio R-PET-3, camada 12.

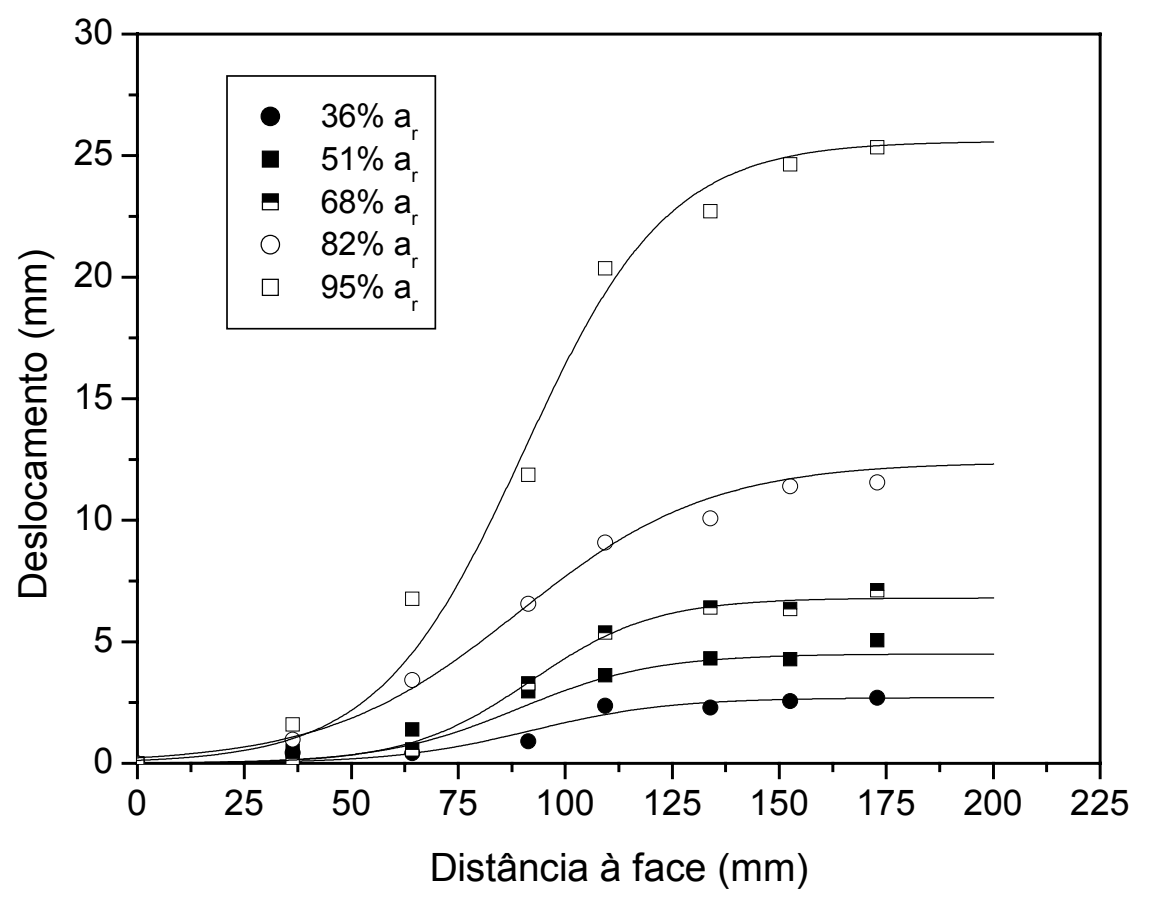

FIGURA A12 - Deslocamentos obtidos para o ensaio R-PET-3, camada 11. 


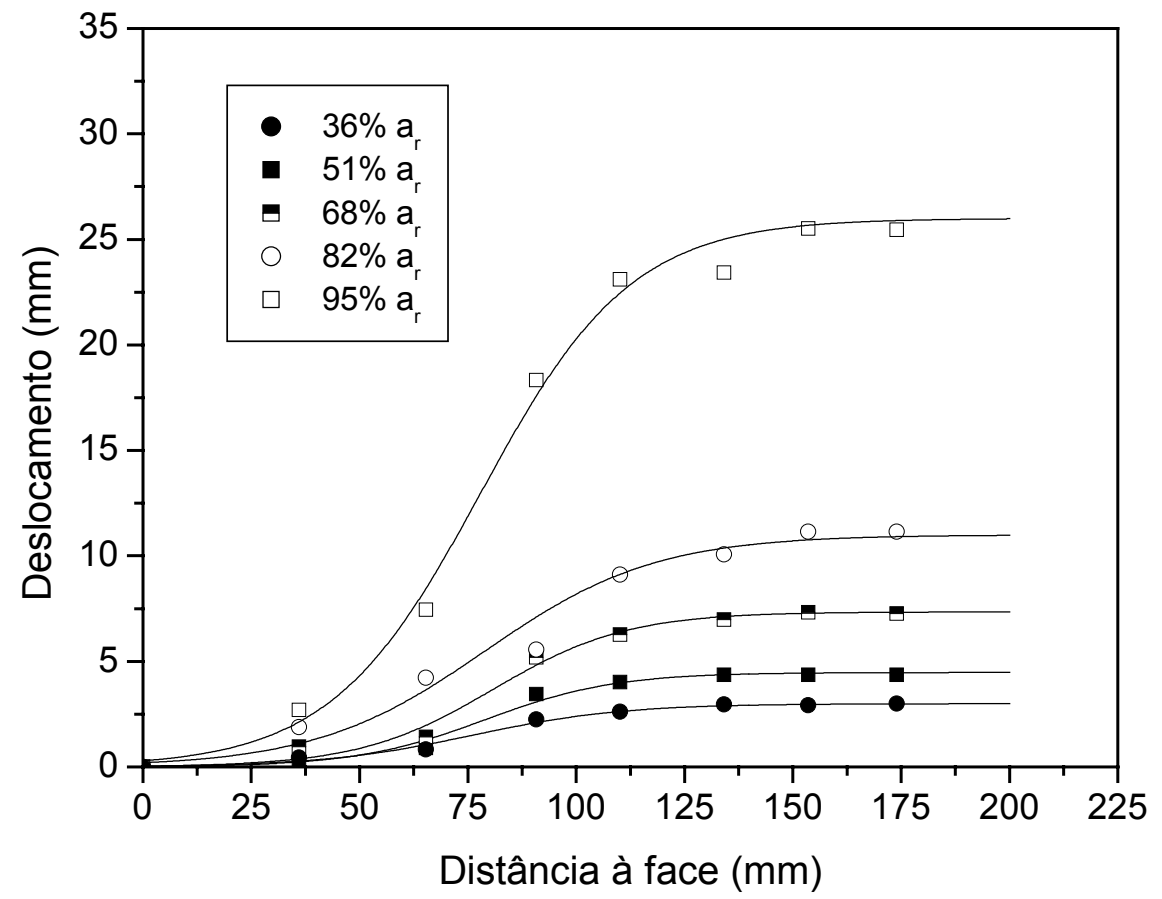

FIGURA A13 - Deslocamentos obtidos para o ensaio R-PET-3, camada 10.

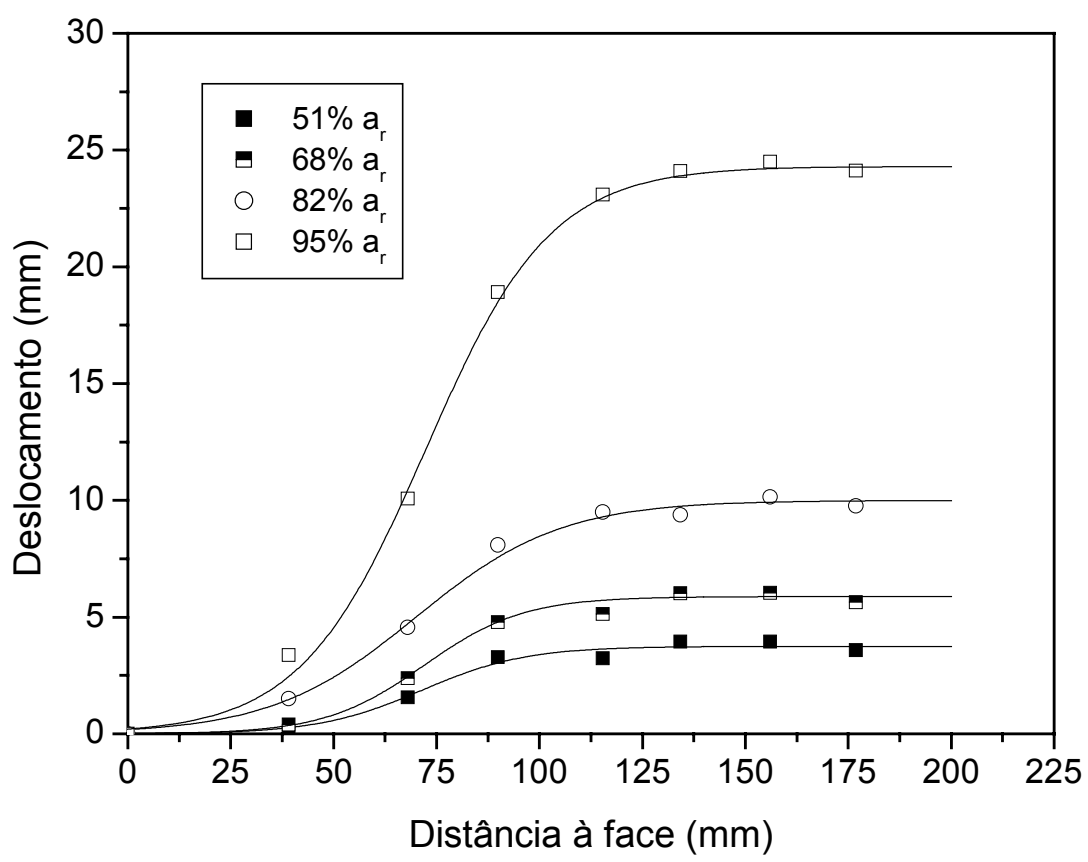

FIGURA A14 - Deslocamentos obtidos para o ensaio R-PET-3, camada 9. 


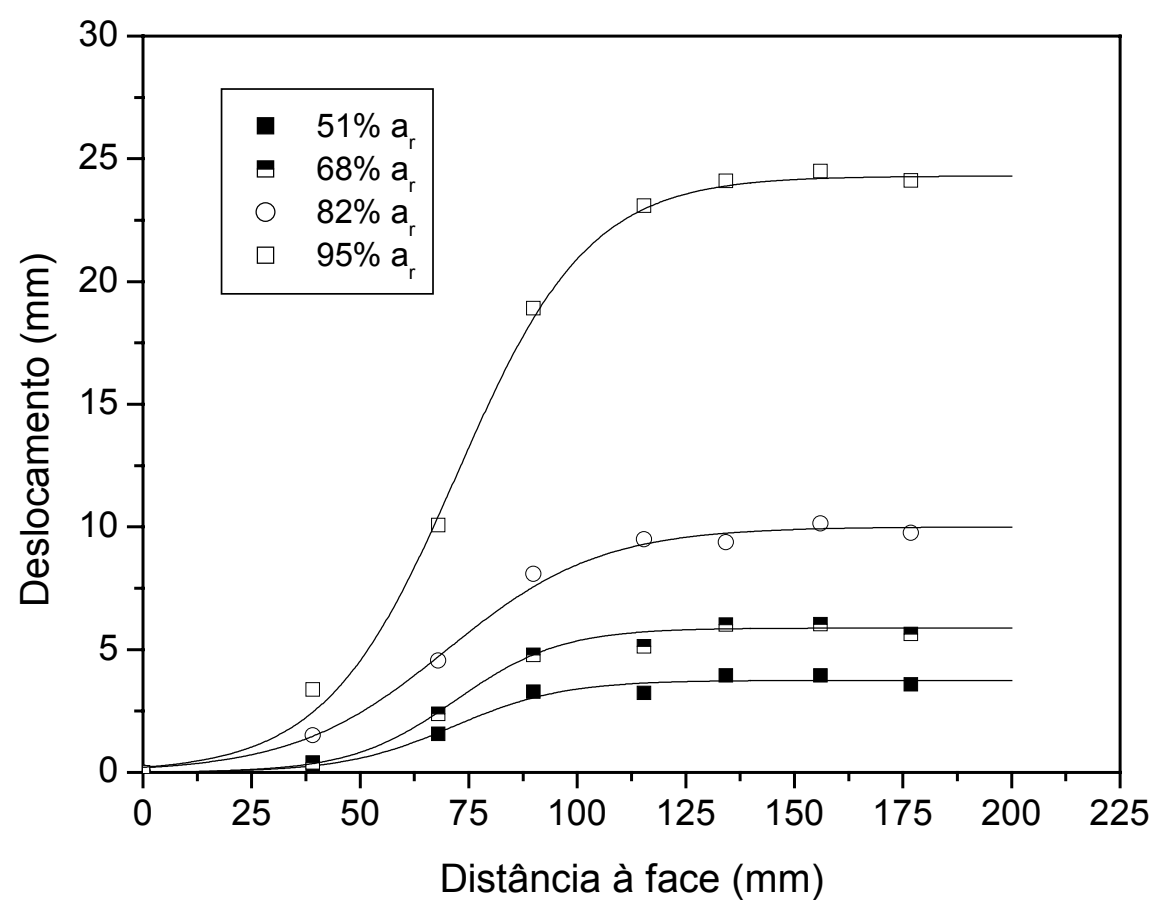

FIGURA A15 - Deslocamentos obtidos para o ensaio R-PET-3, camada 8.

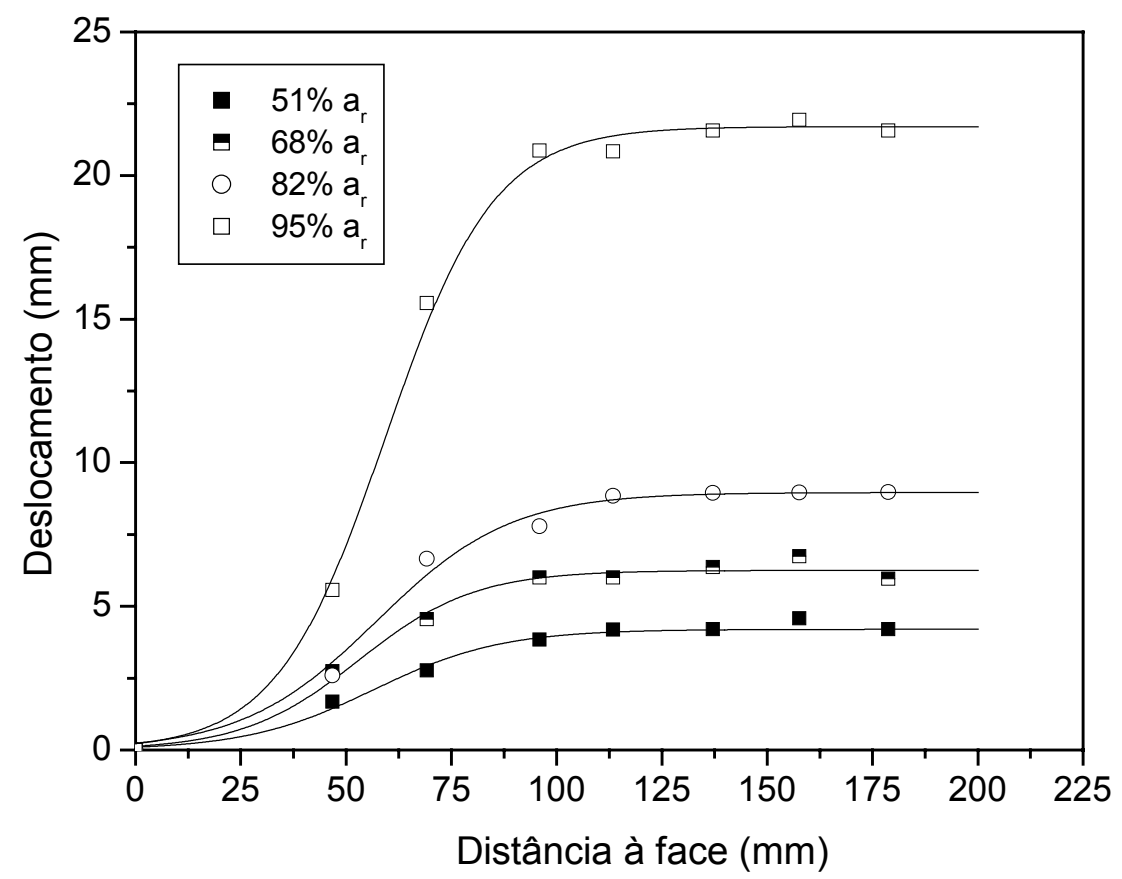

FIGURA A16 - Deslocamentos obtidos para o ensaio R-PET-3, camada 7. 


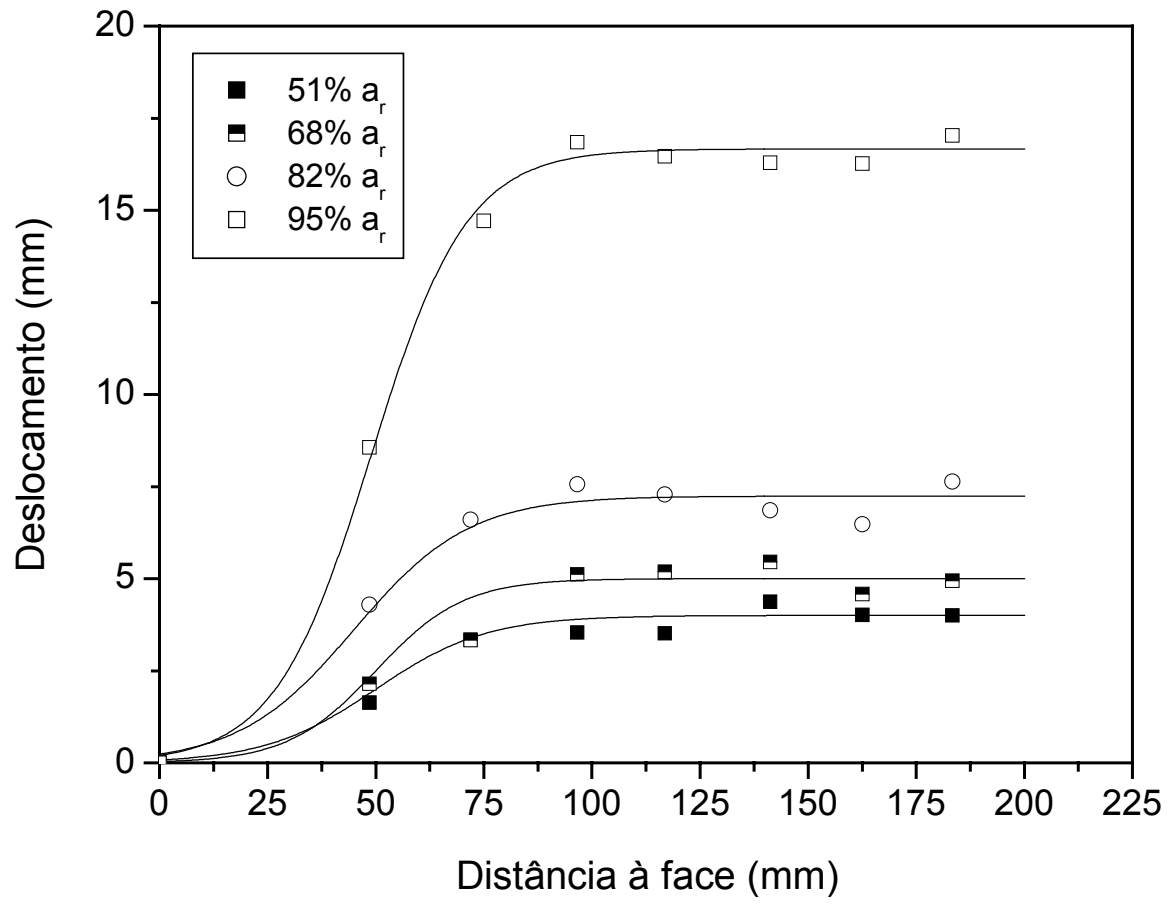

FIGURA A17 - Deslocamentos obtidos para o ensaio R-PET-3, camada 6.

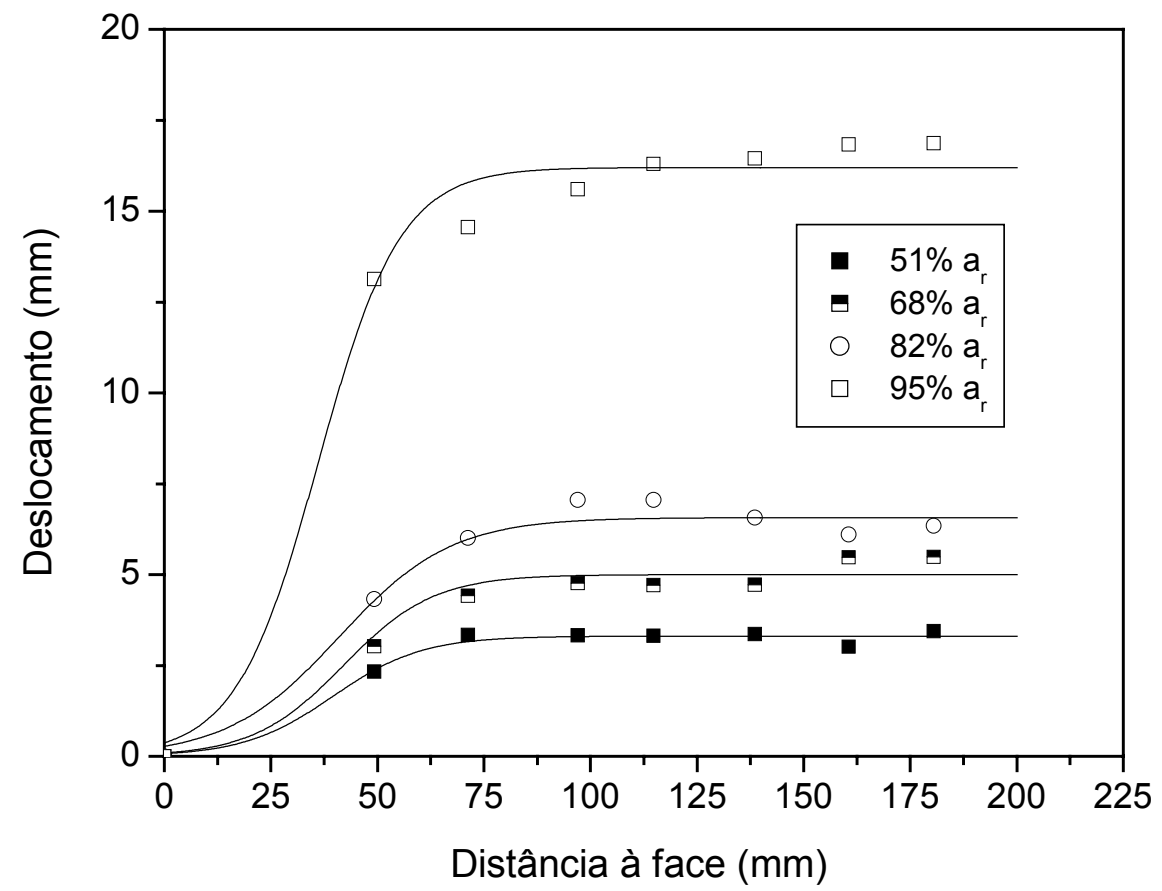

FIGURA A18 - Deslocamentos obtidos para o ensaio R-PET-3, camada 5. 


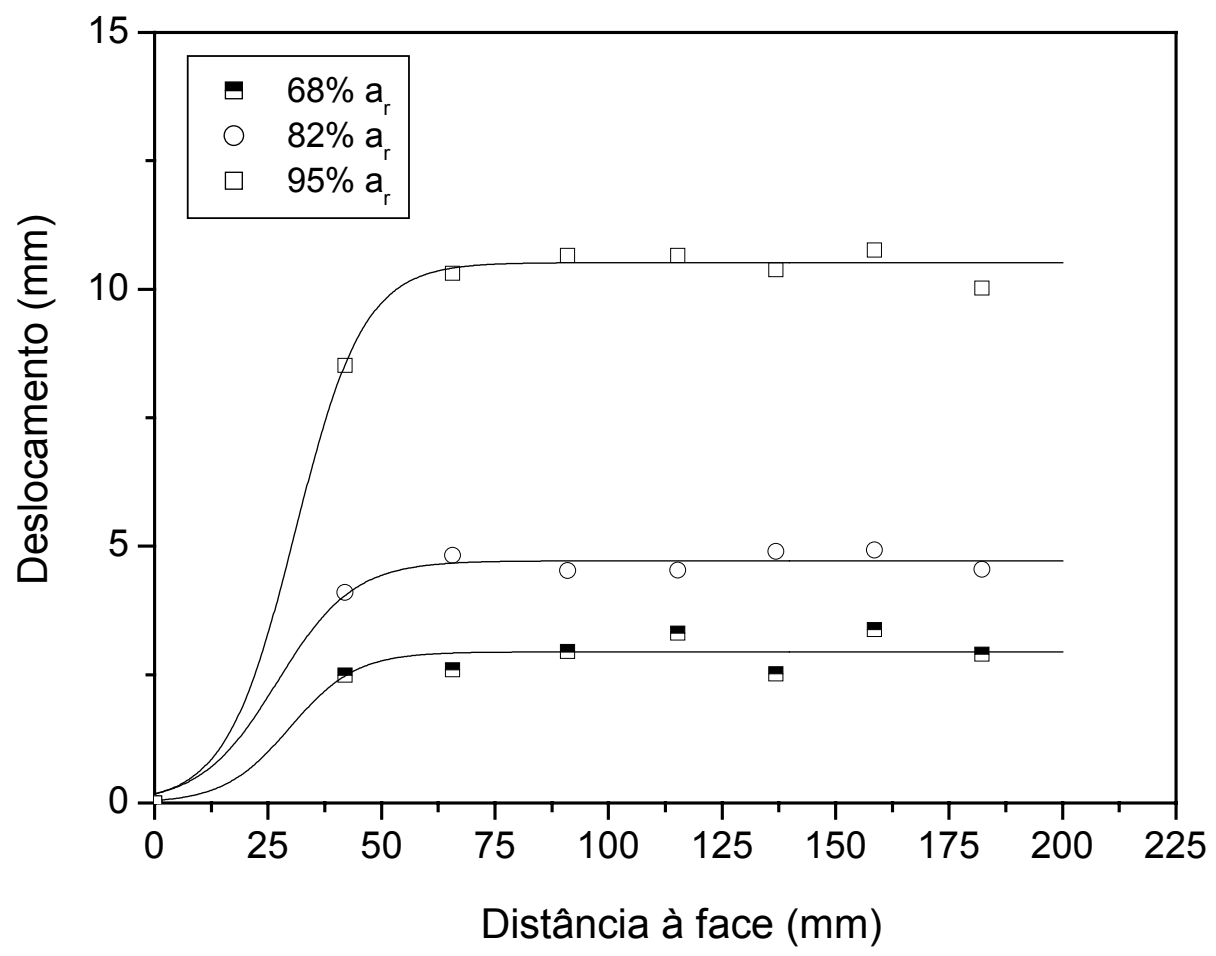

FIGURA A19 - Deslocamentos obtidos para o ensaio R-PET-3, camada 4.

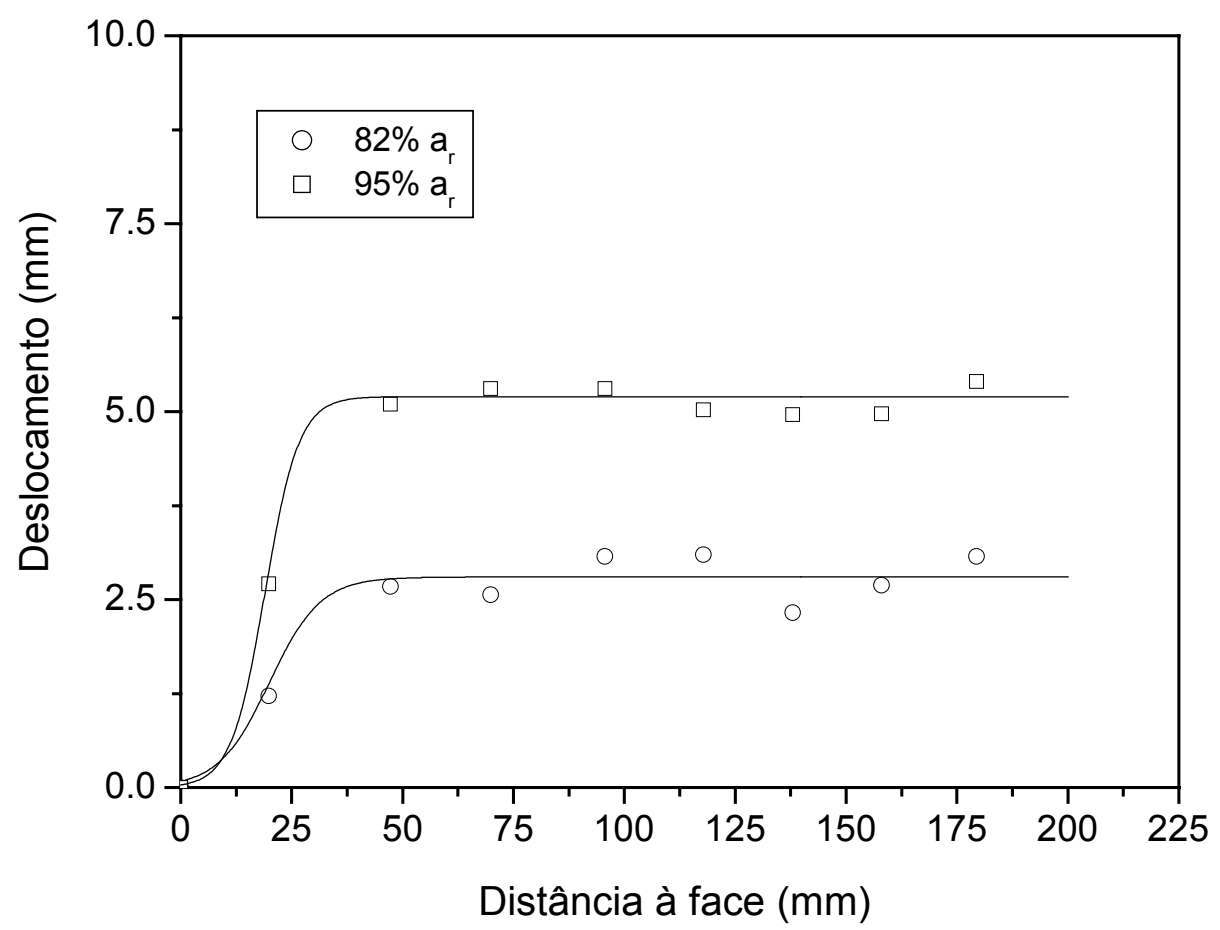

FIGURA A20 - Deslocamentos obtidos para o ensaio R-PET-3, camada 3. 


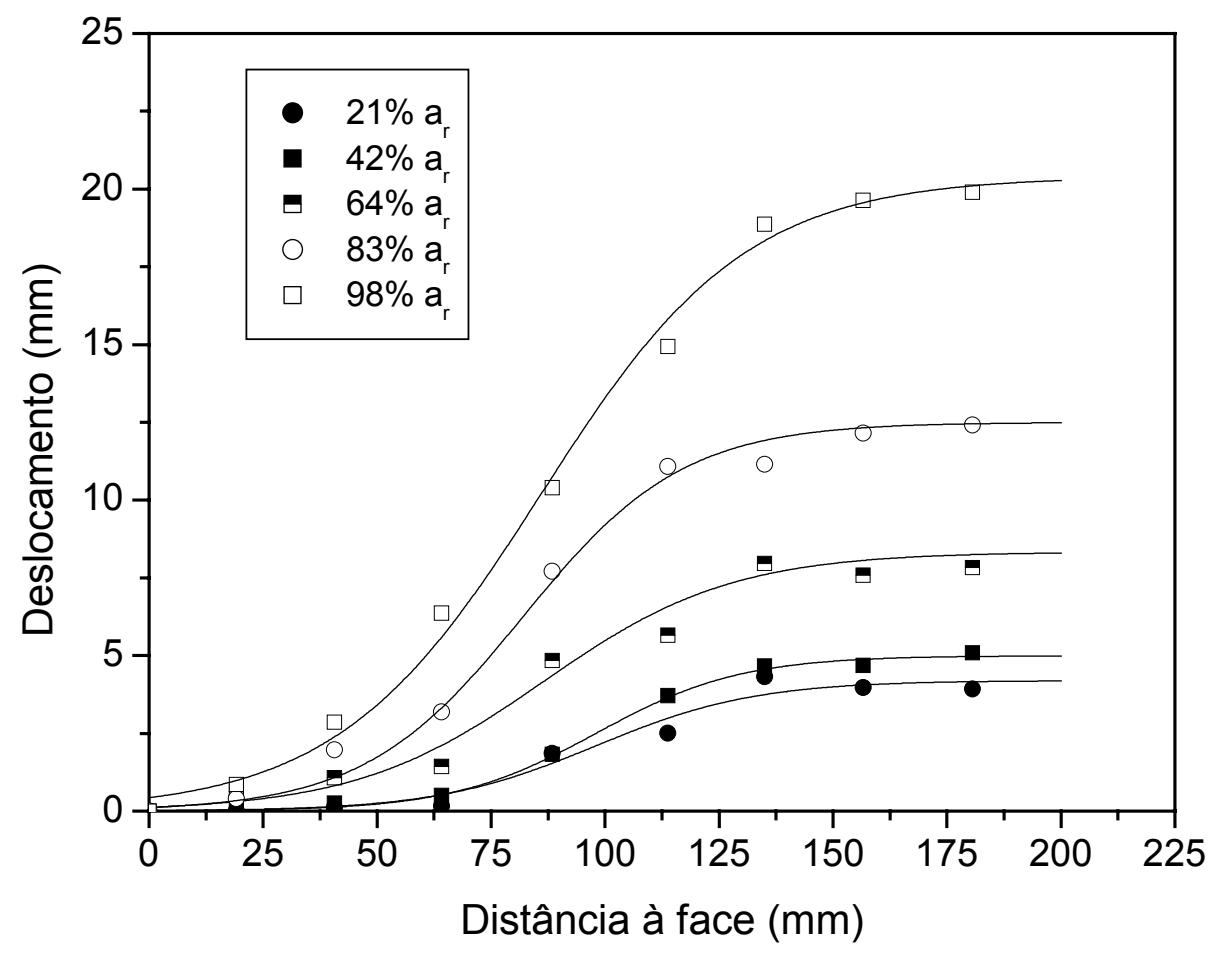

FIGURA A21 - Deslocamentos obtidos para o ensaio R-PP-1, camada 12.

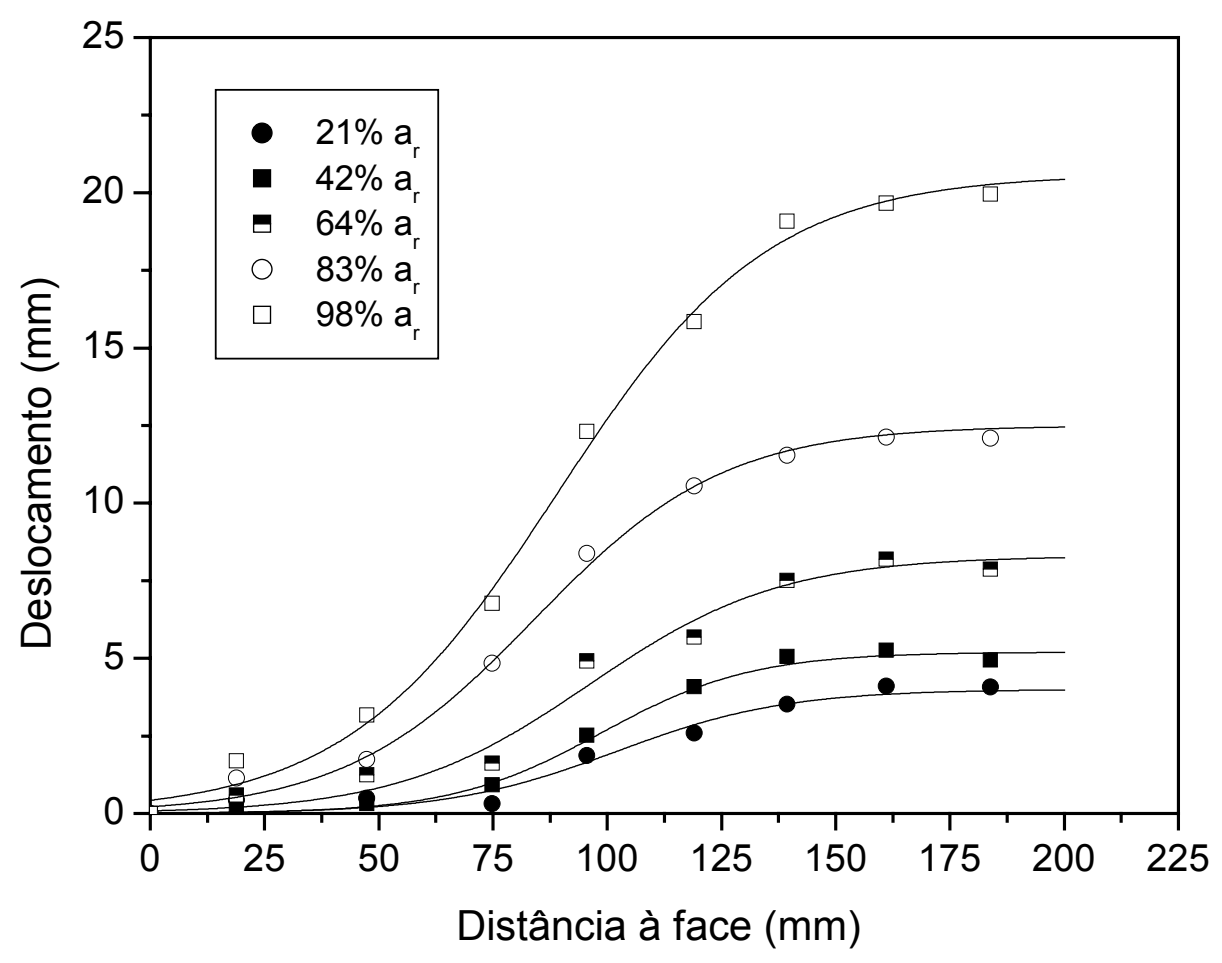

FIGURA A22 - Deslocamentos obtidos para o ensaio R-PP-1, camada 11. 


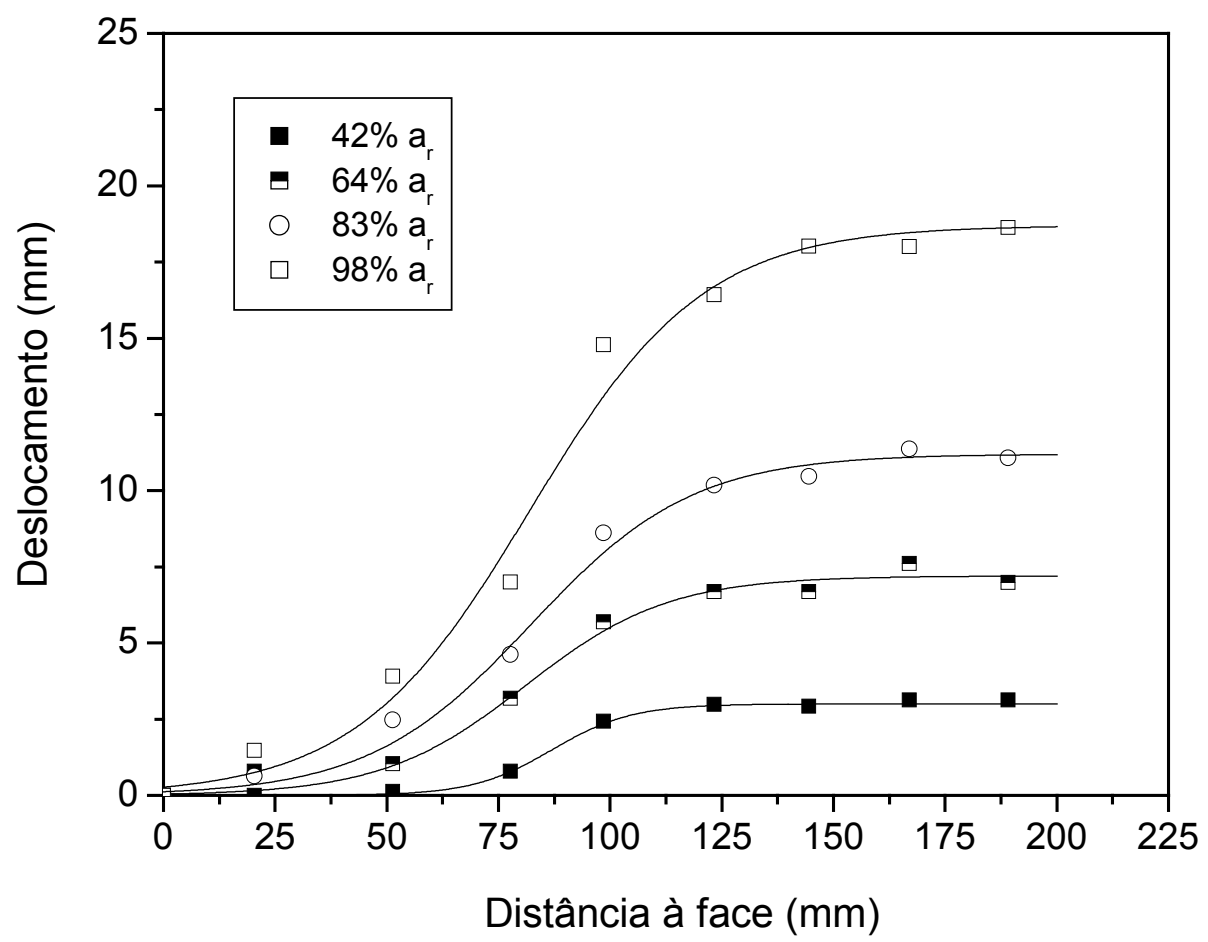

FIGURA A23 - Deslocamentos obtidos para o ensaio R-PP-1, camada 10.

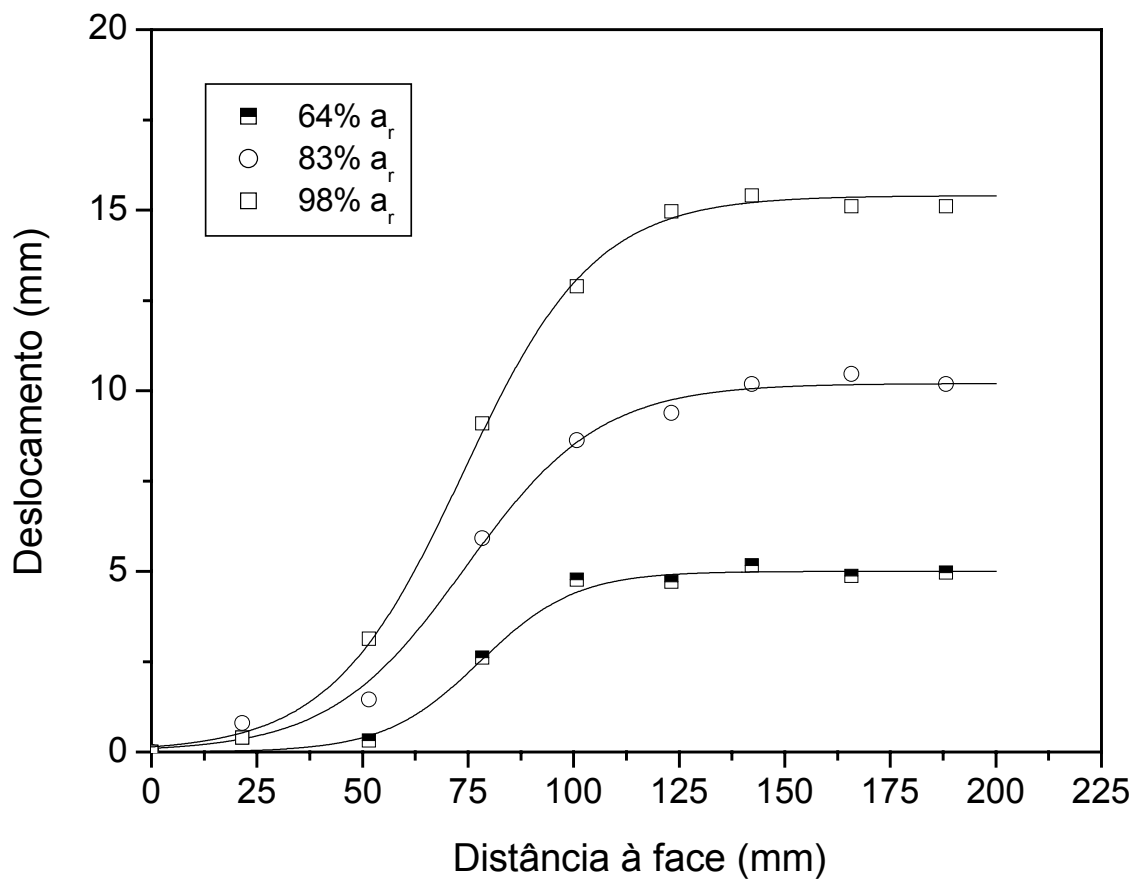

FIGURA A24 - Deslocamentos obtidos para o ensaio R-PP-1, camada 9 


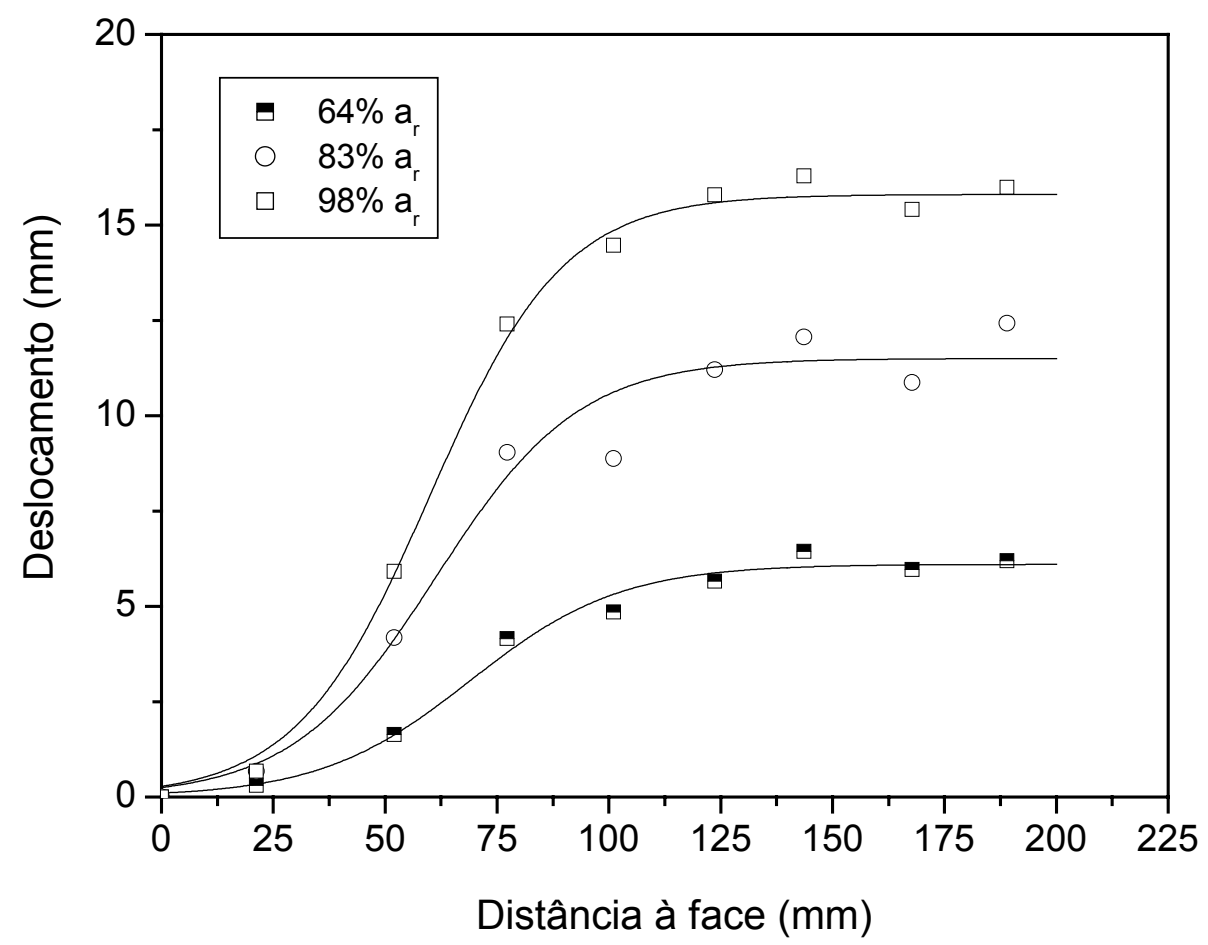

FIGURA A25 - Deslocamentos obtidos para o ensaio R-PP-1, camada 8.

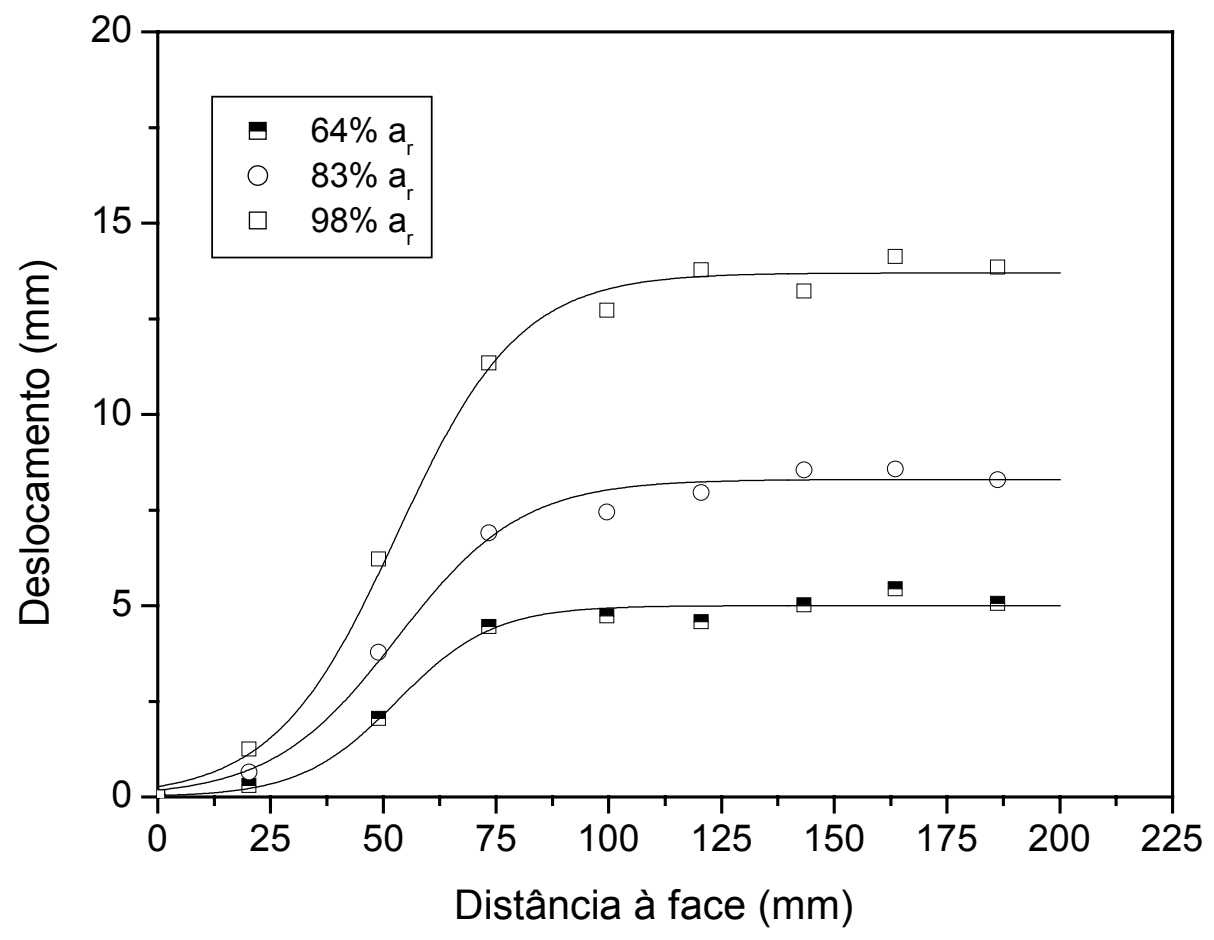

FIGURA A26 - Deslocamentos obtidos para o ensaio R-PP-1, camada 7. 


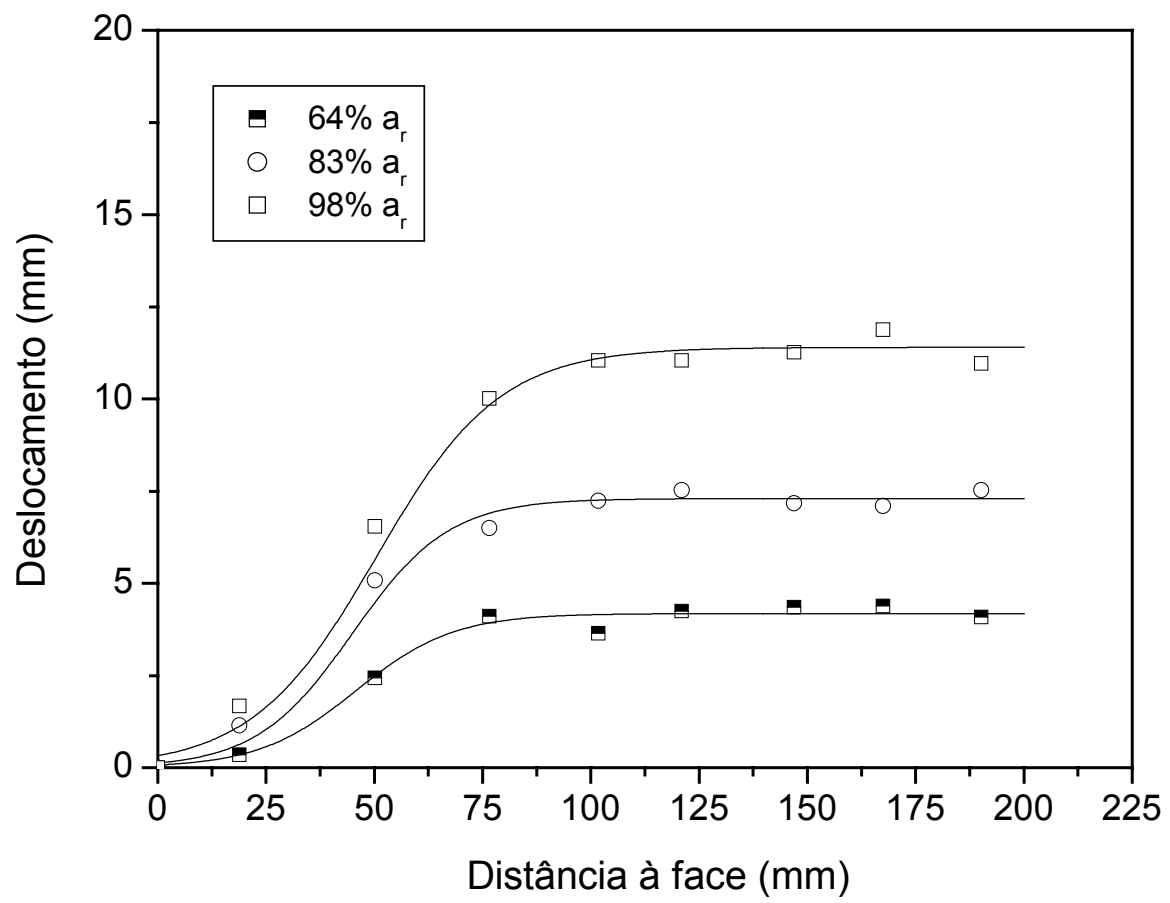

FIGURA A27 - Deslocamentos obtidos para o ensaio R-PP-1, camada 6.

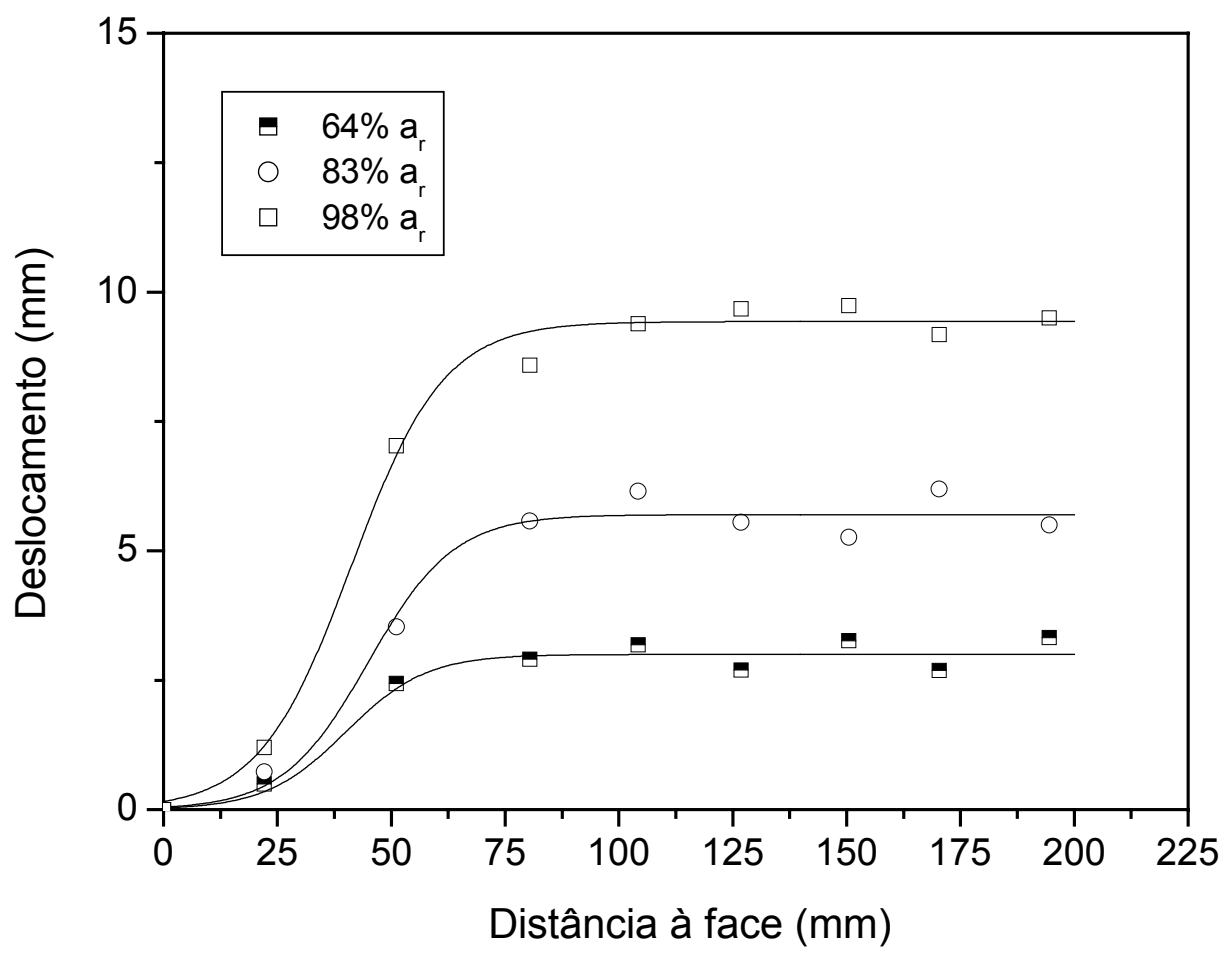

FIGURA A28 - Deslocamentos obtidos para o ensaio R-PP-1, camada 5. 


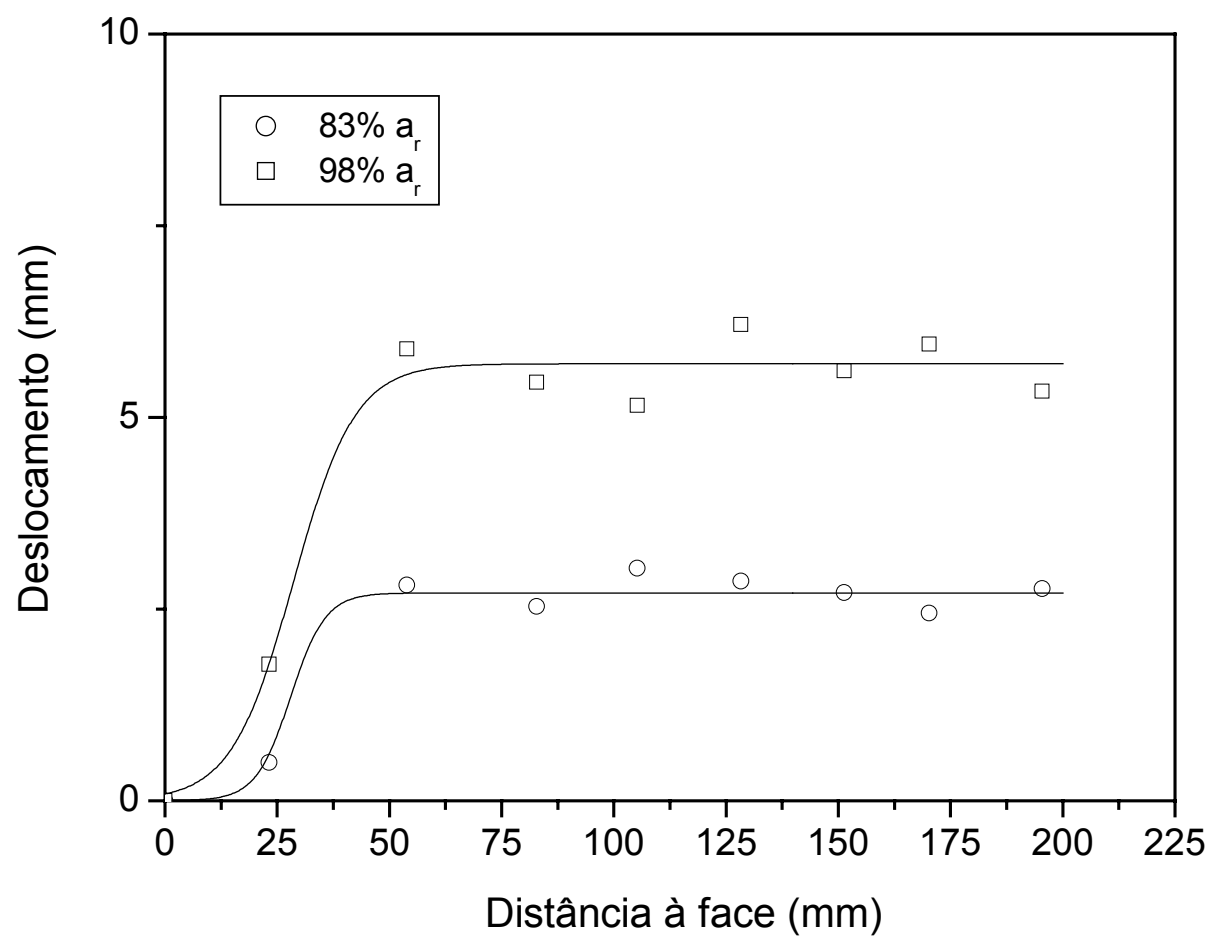

FIGURA A29 - Deslocamentos obtidos para o ensaio R-PP-1, camada 4.

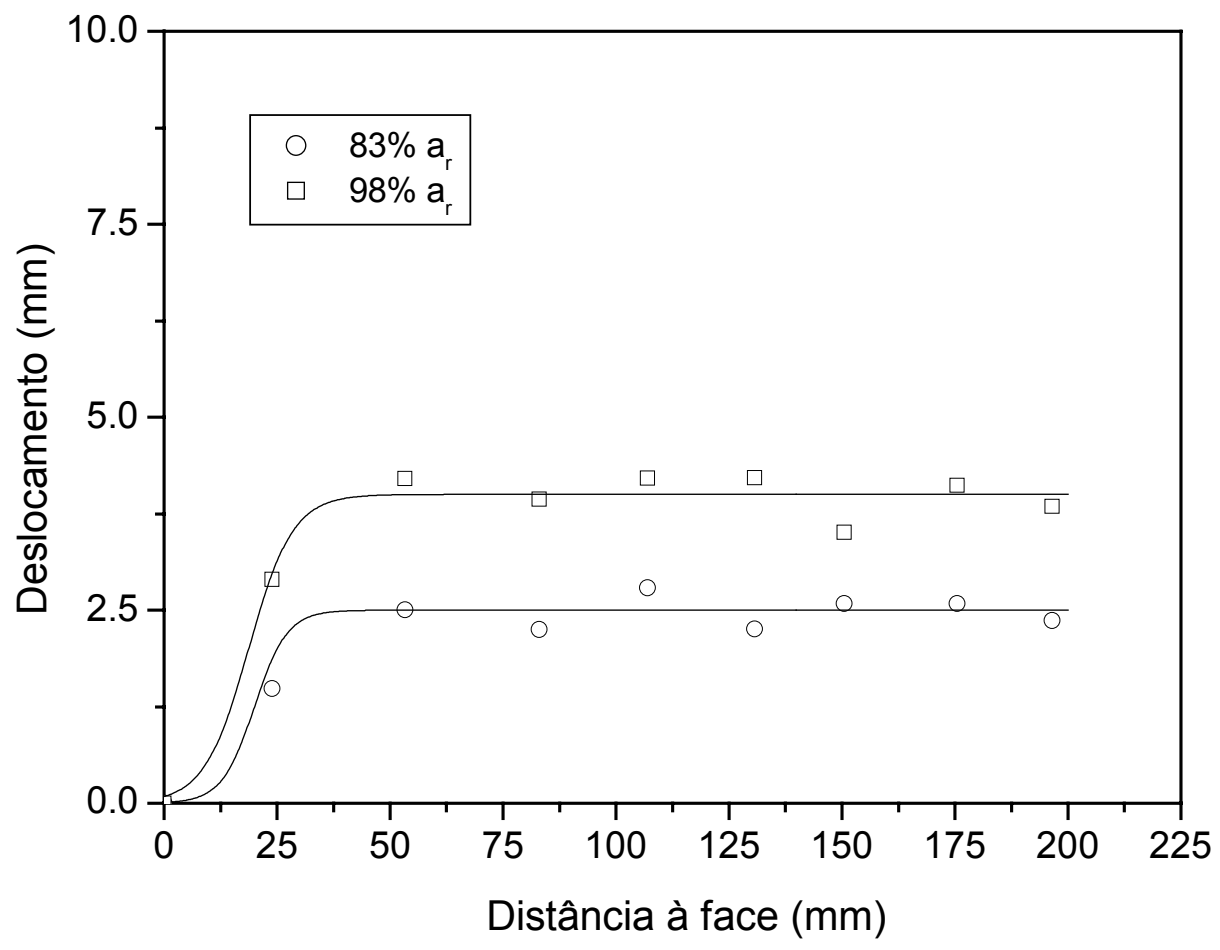

FIGURA A30 - Deslocamentos obtidos para o ensaio R-PP-1, camada 3. 


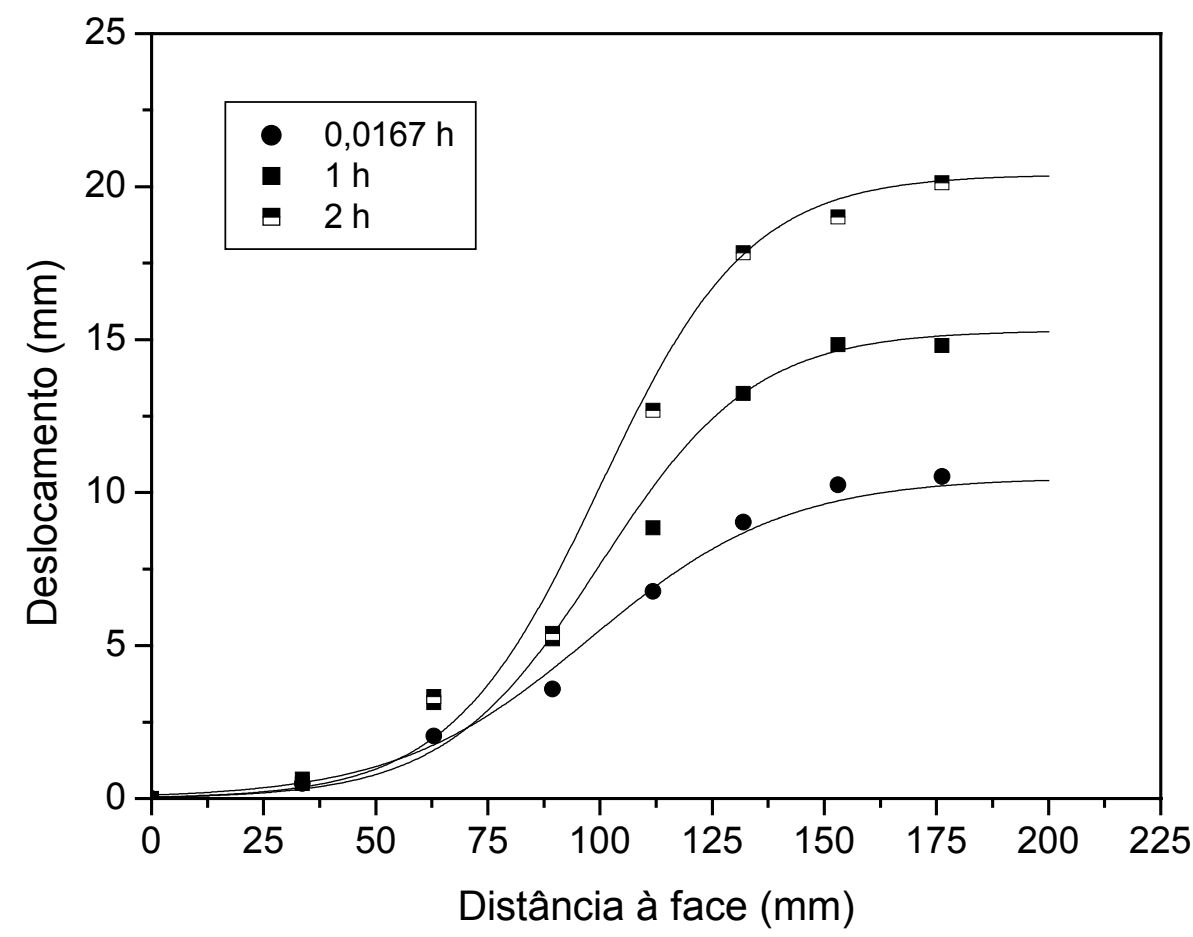

FIGURA A31 - Deslocamentos obtidos para o ensaio F-PET-4, camada 12.

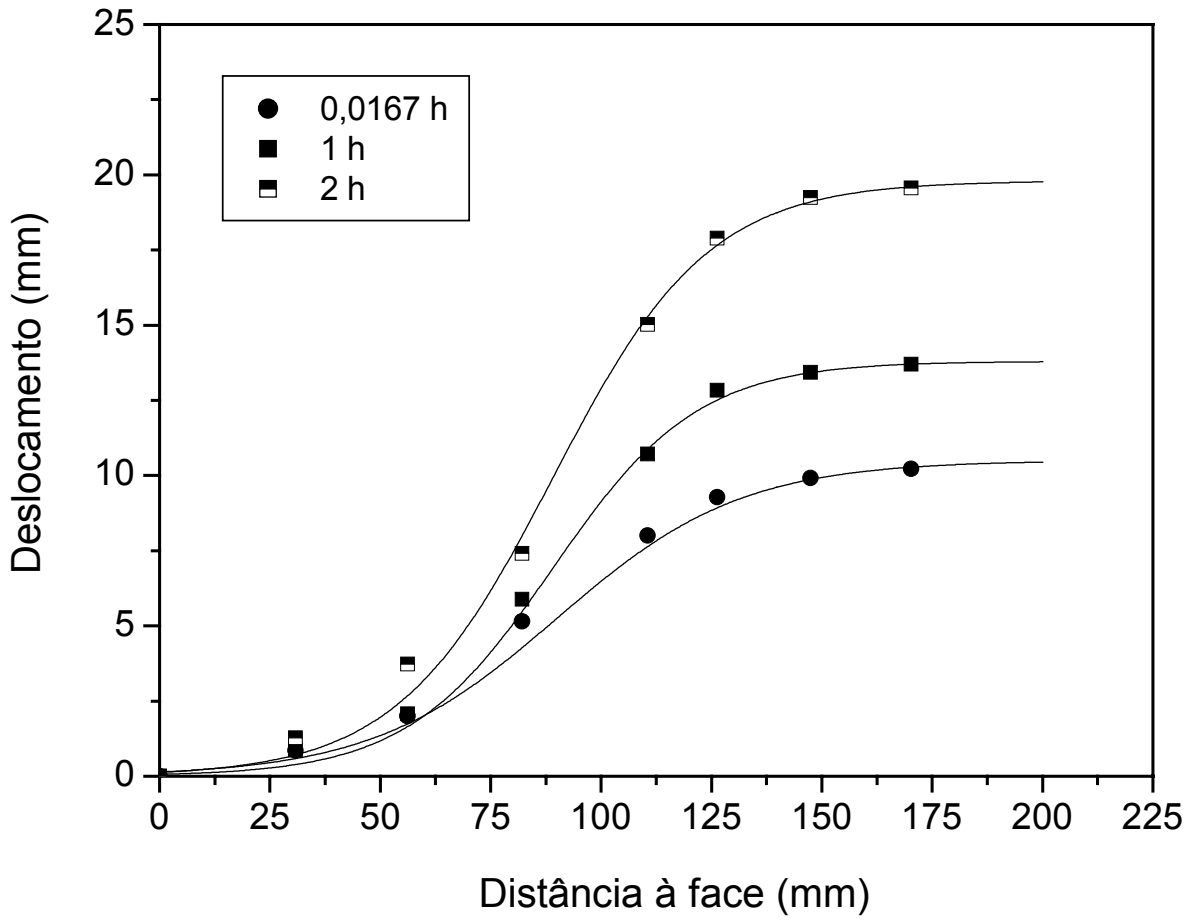

FIGURA A32 - Deslocamentos obtidos para o ensaio F-PET-4, camada 11. 


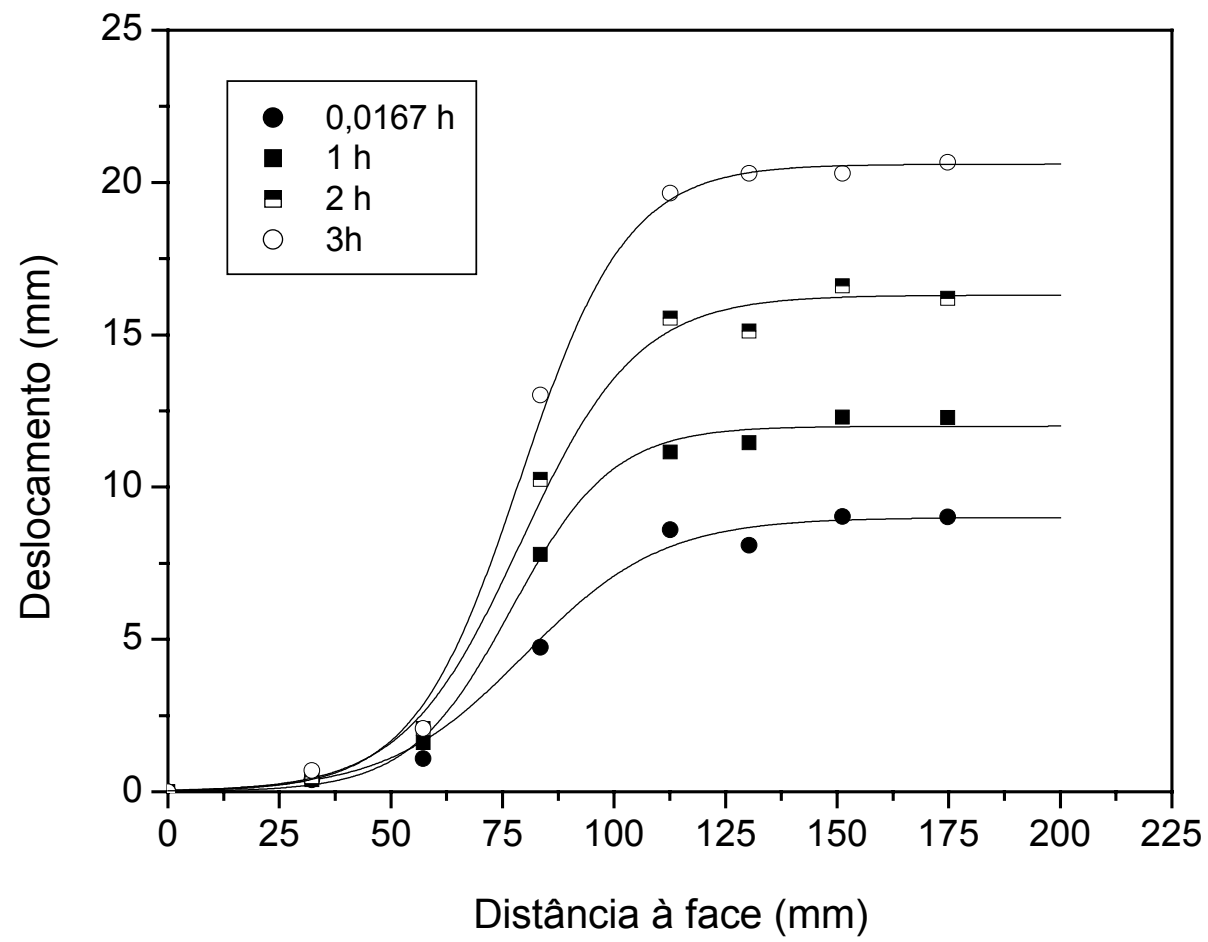

FIGURA A33 - Deslocamentos obtidos para o ensaio F-PET-4, camada 10.

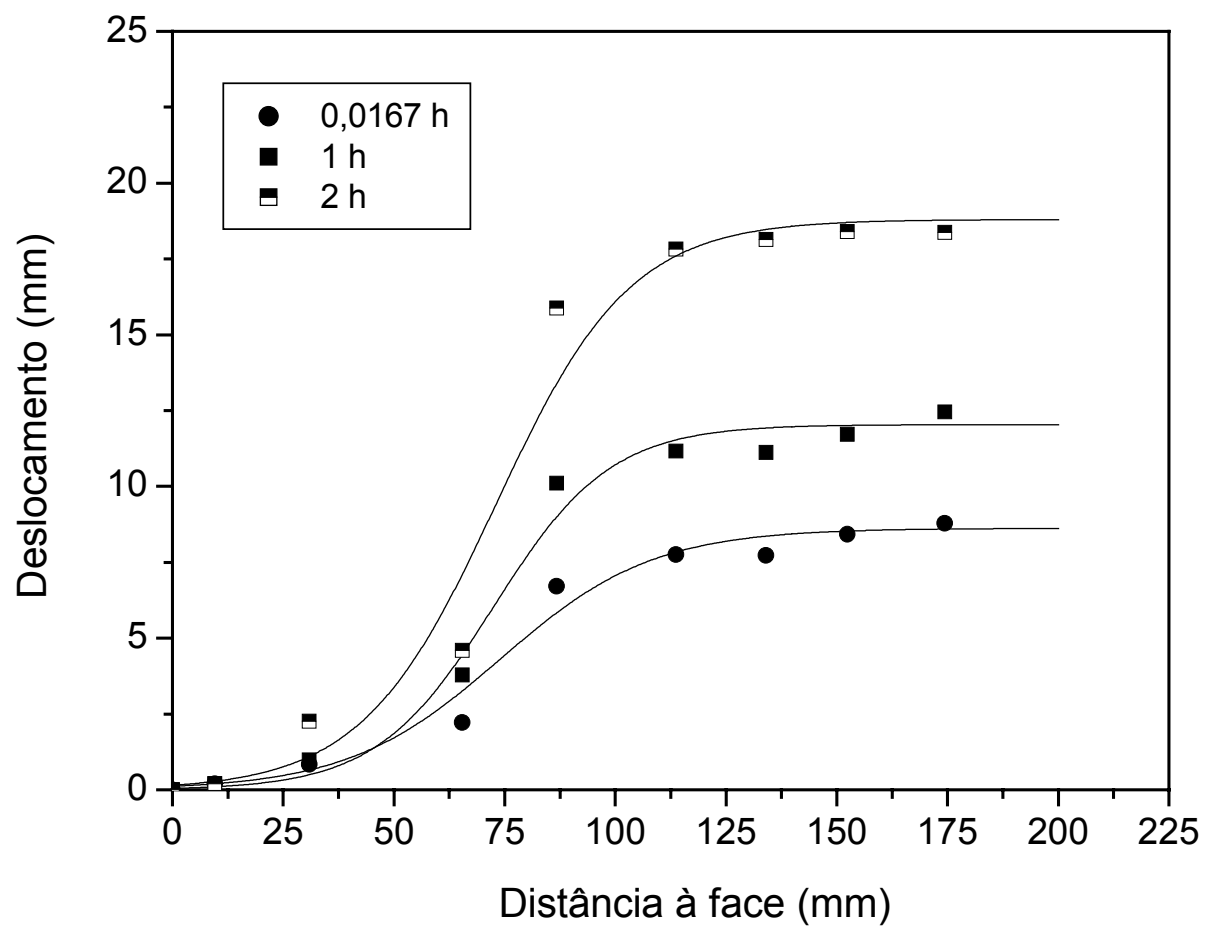

FIGURA A34 - Deslocamentos obtidos para o ensaio F-PET-4, camada 9. 


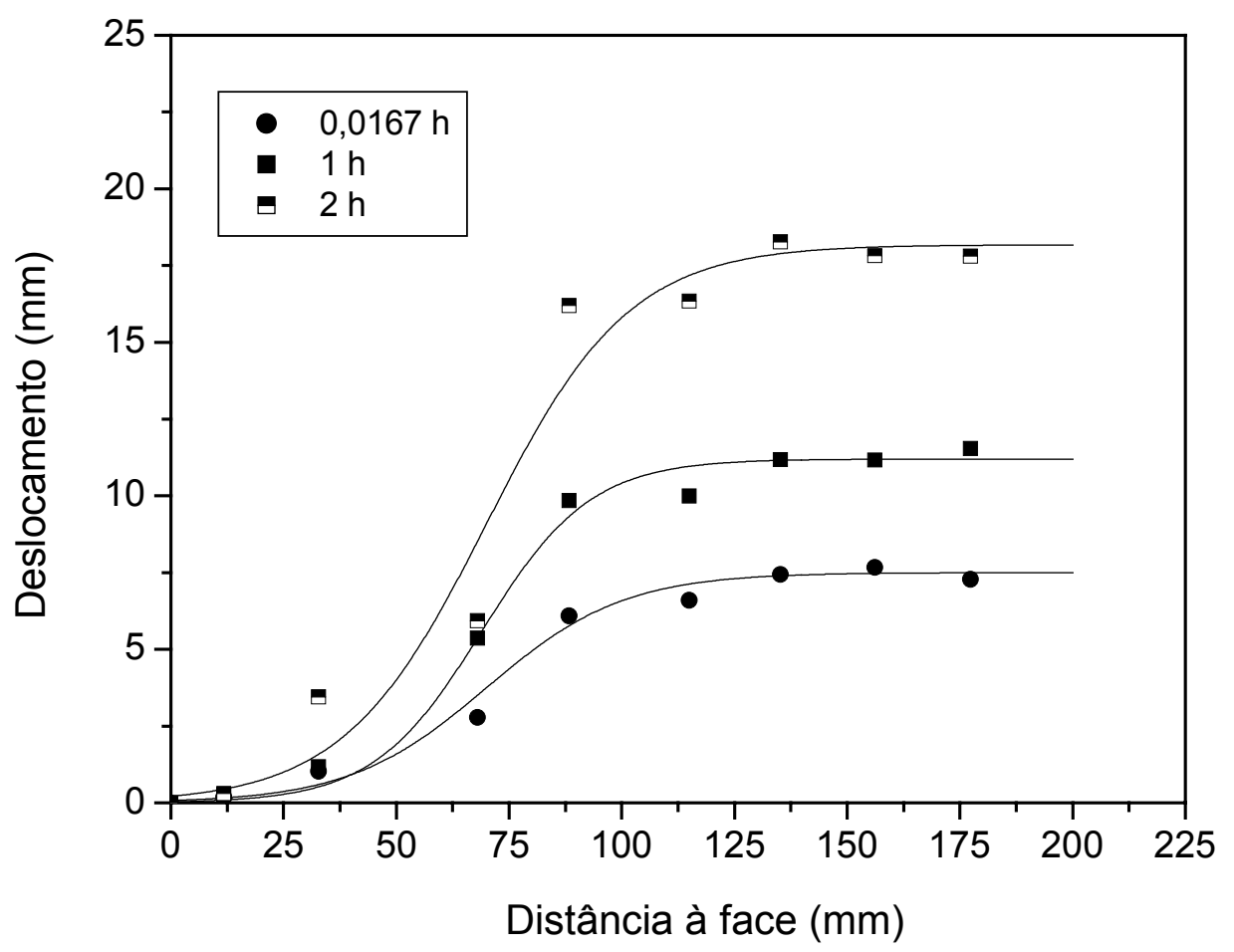

FIGURA A35 - Deslocamentos obtidos para o ensaio F-PET-4, camada 8.

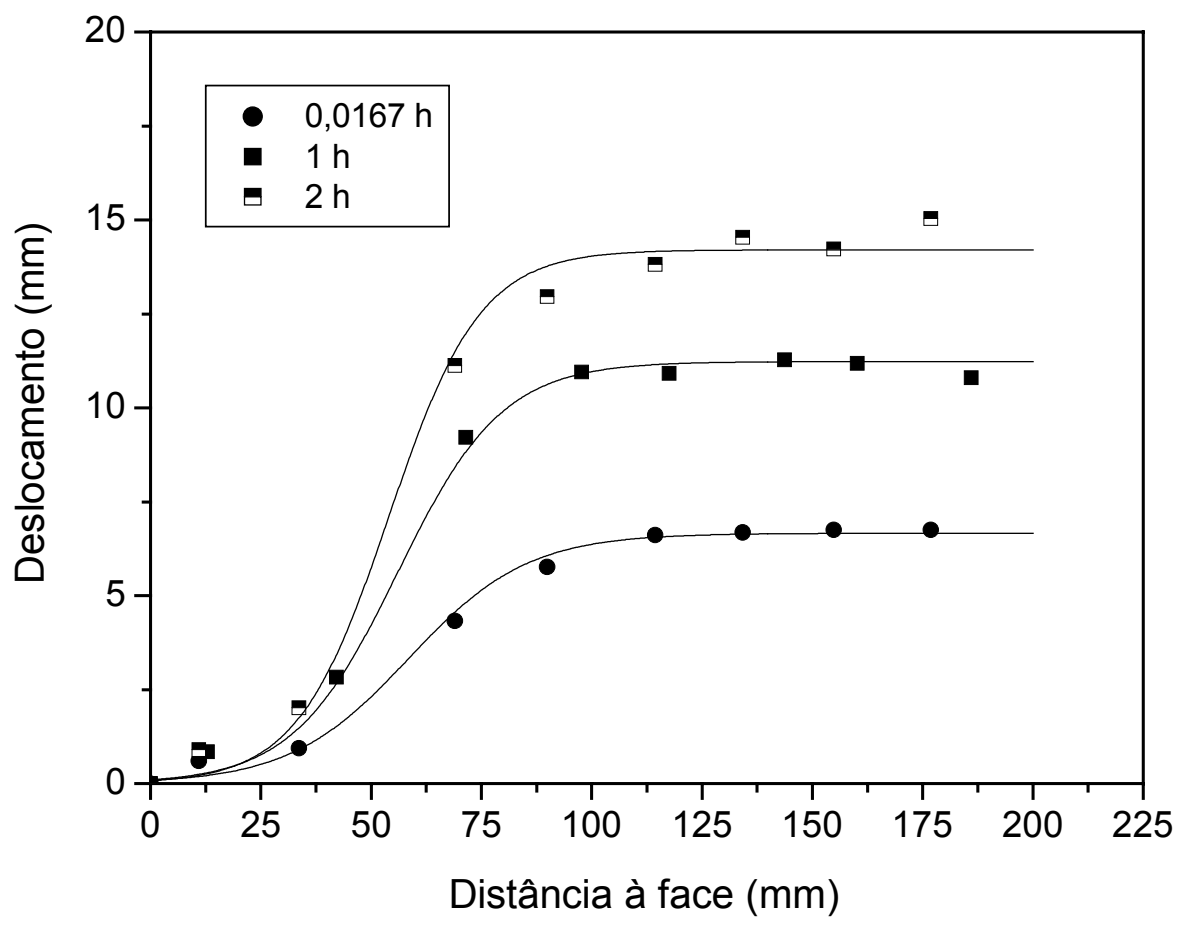

FIGURA A36 - Deslocamentos obtidos para o ensaio F-PET-4, camada 7. 


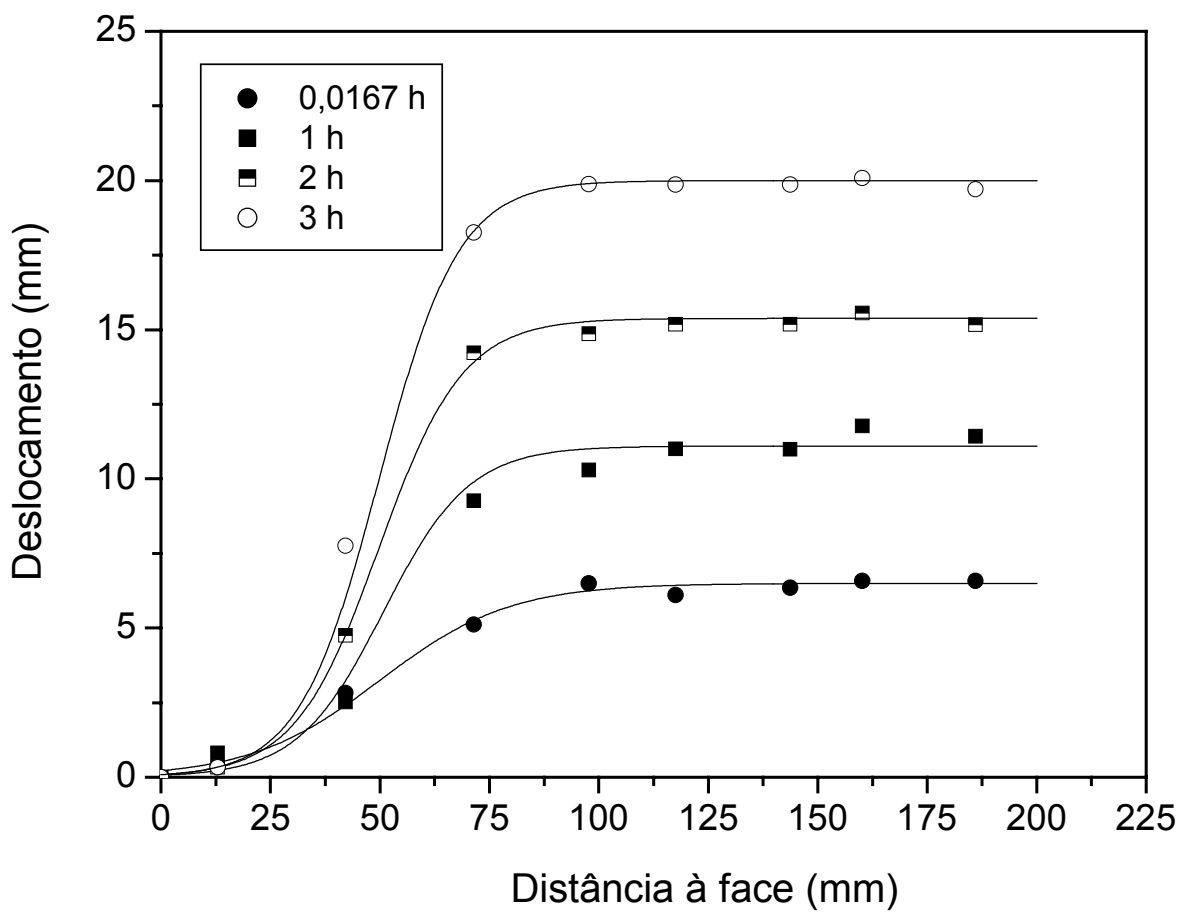

FIGURA A37 - Deslocamentos obtidos para o ensaio F-PET-4, camada 6.

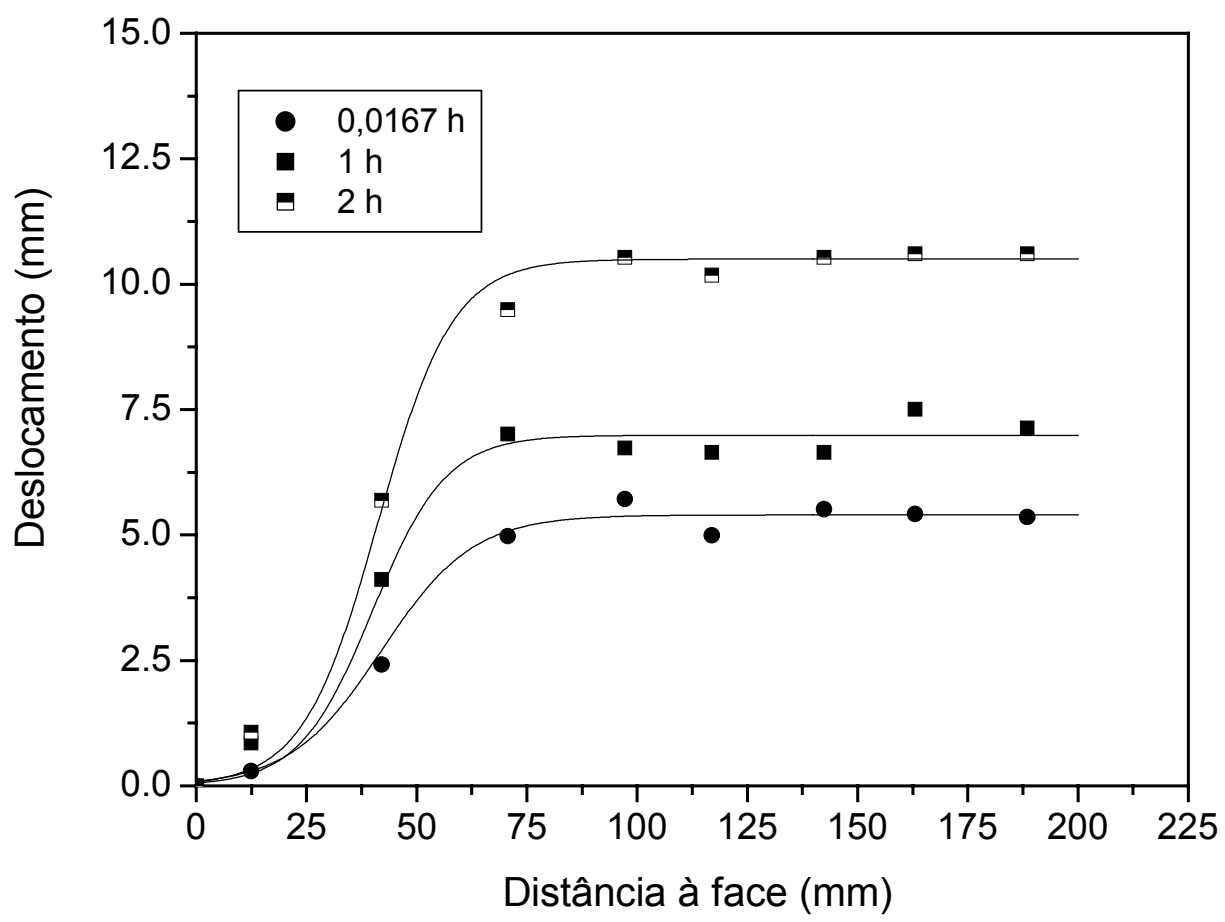

FIGURA A38 - Deslocamentos obtidos para o ensaio F-PET-4, camada 5. 


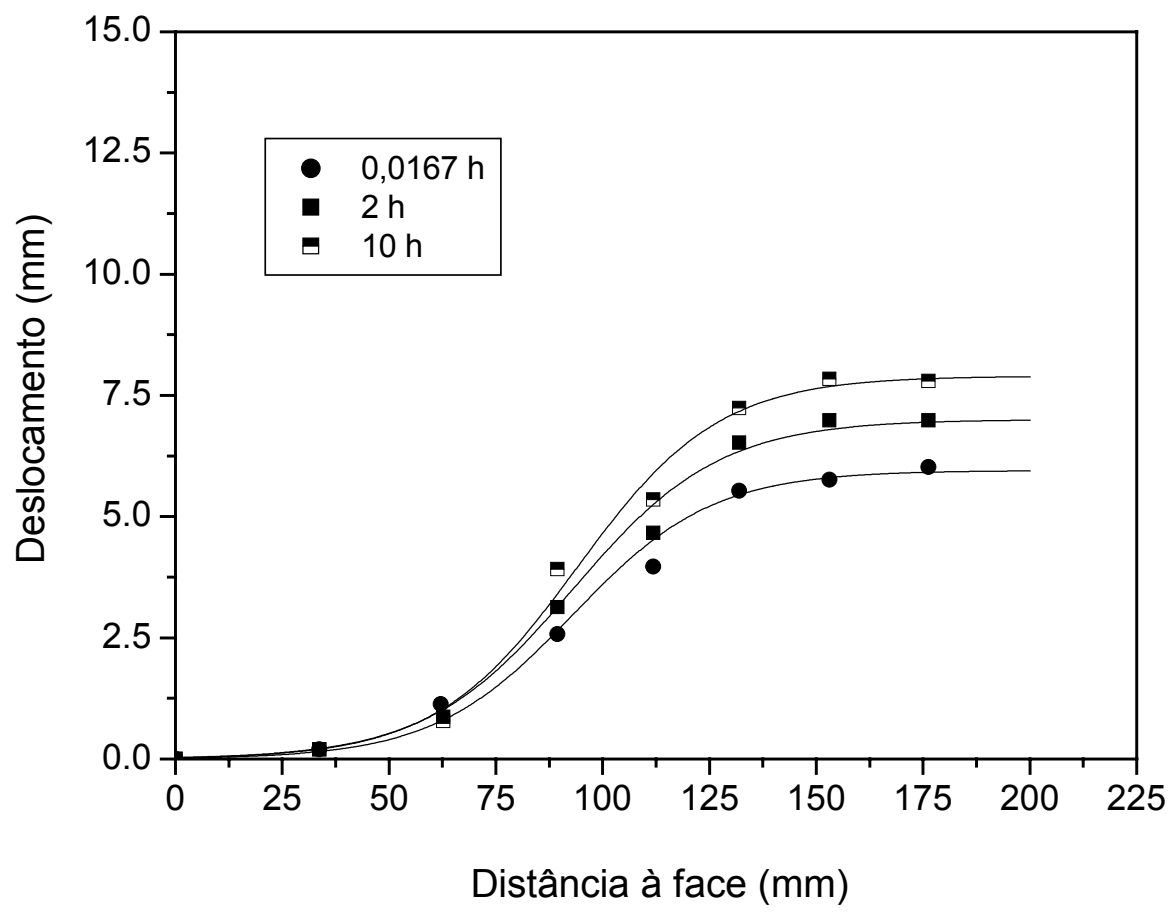

FIGURA A39 - Deslocamentos obtidos para o ensaio F-PET-3, camada 12.

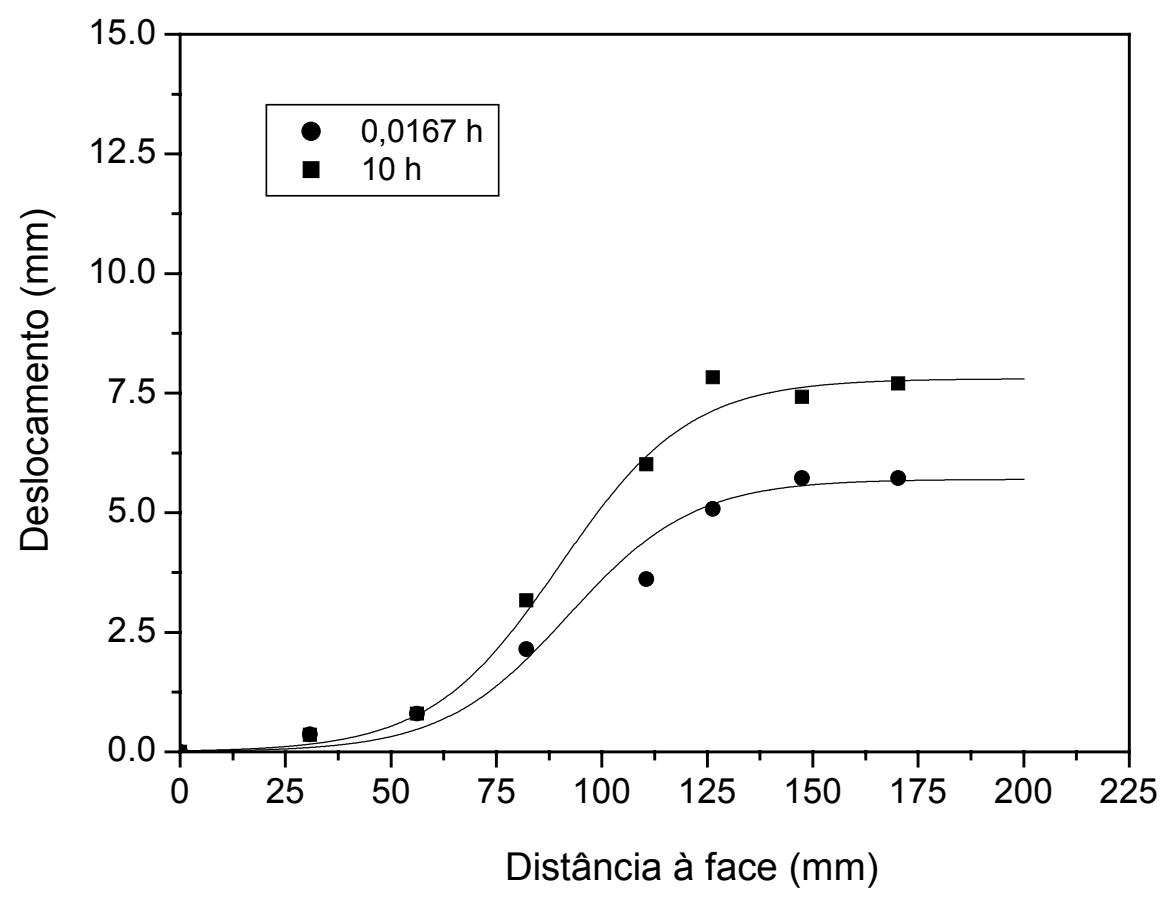

FIGURA A40 - Deslocamentos obtidos para o ensaio F-PET-3, camada 11 


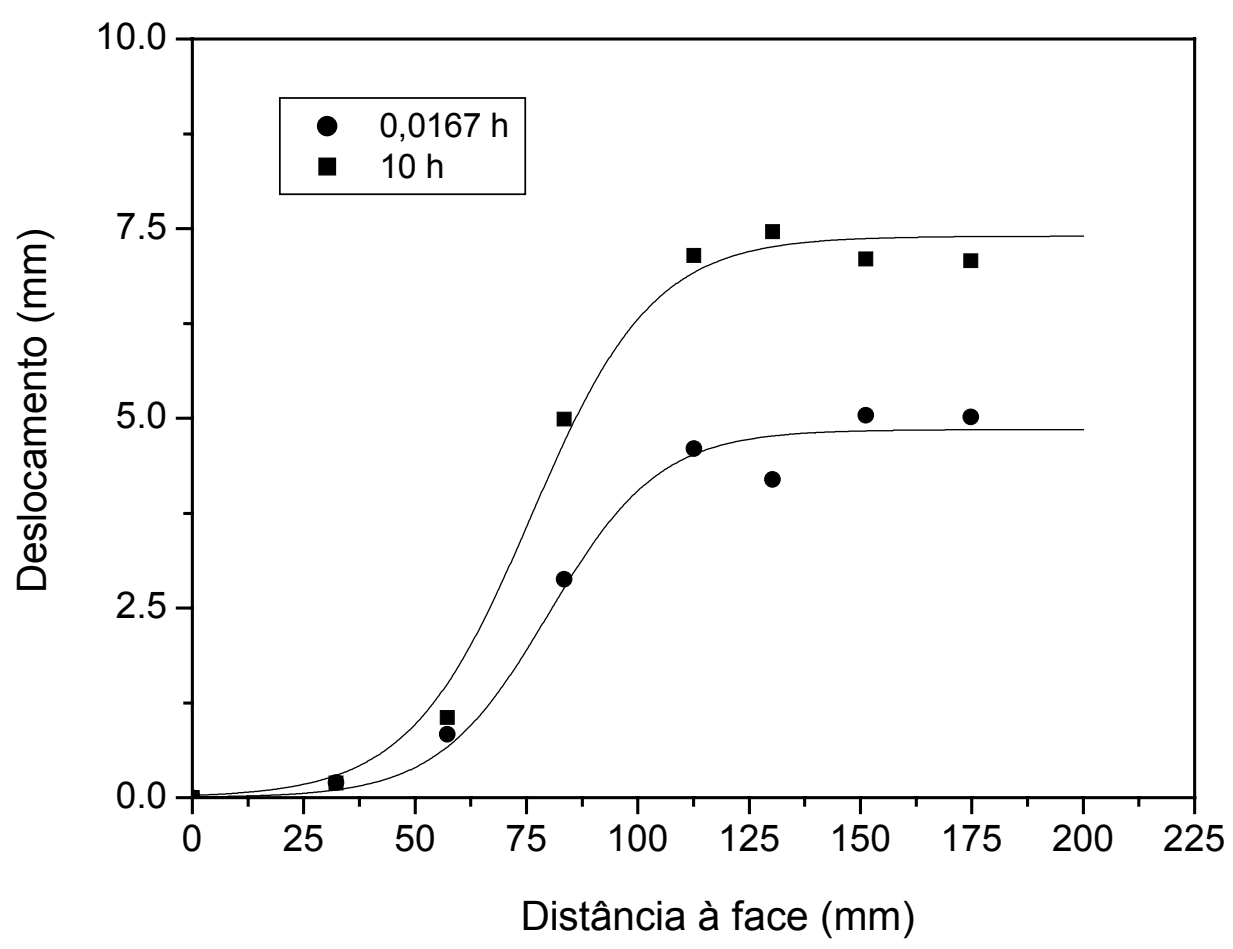

FIGURA A41 - Deslocamentos obtidos para o ensaio F-PET-3, camada 10.

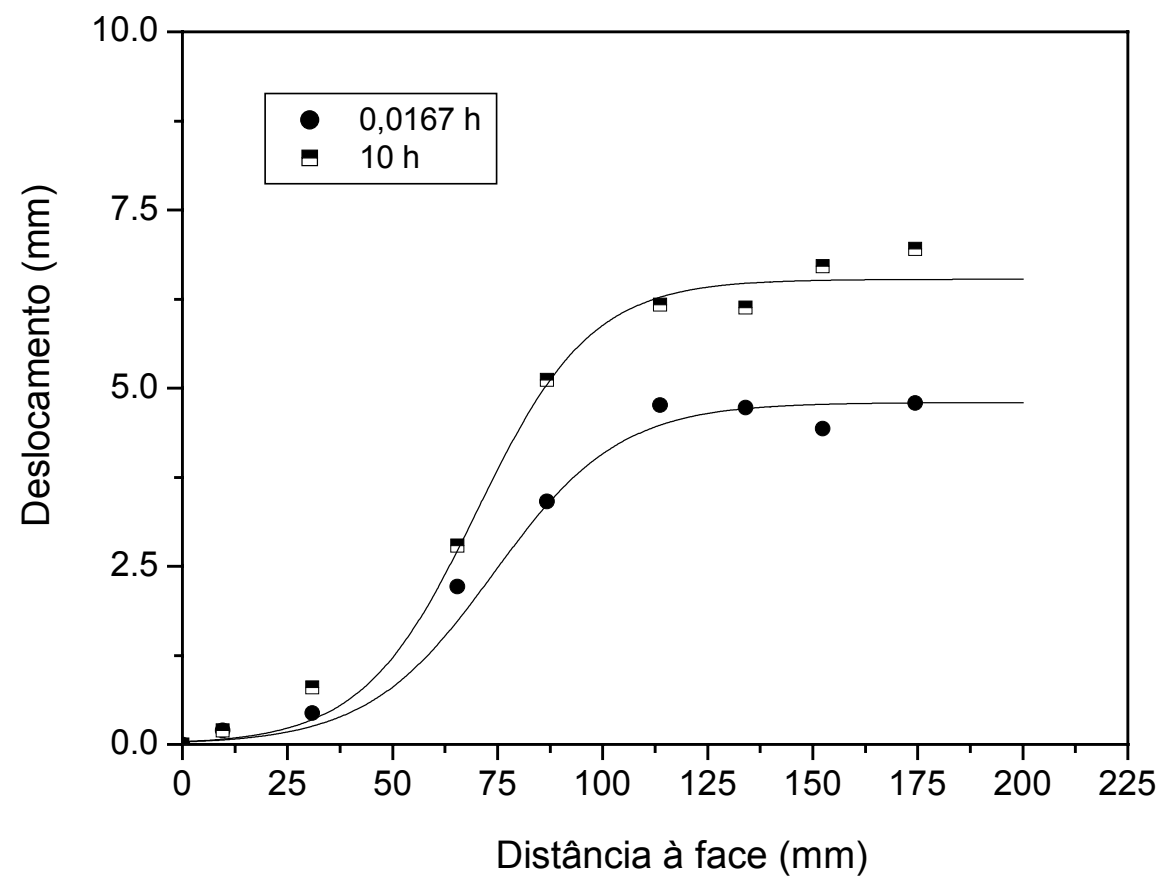

FIGURA A42 - Deslocamentos obtidos para o ensaio F-PET-3, camada 9. 


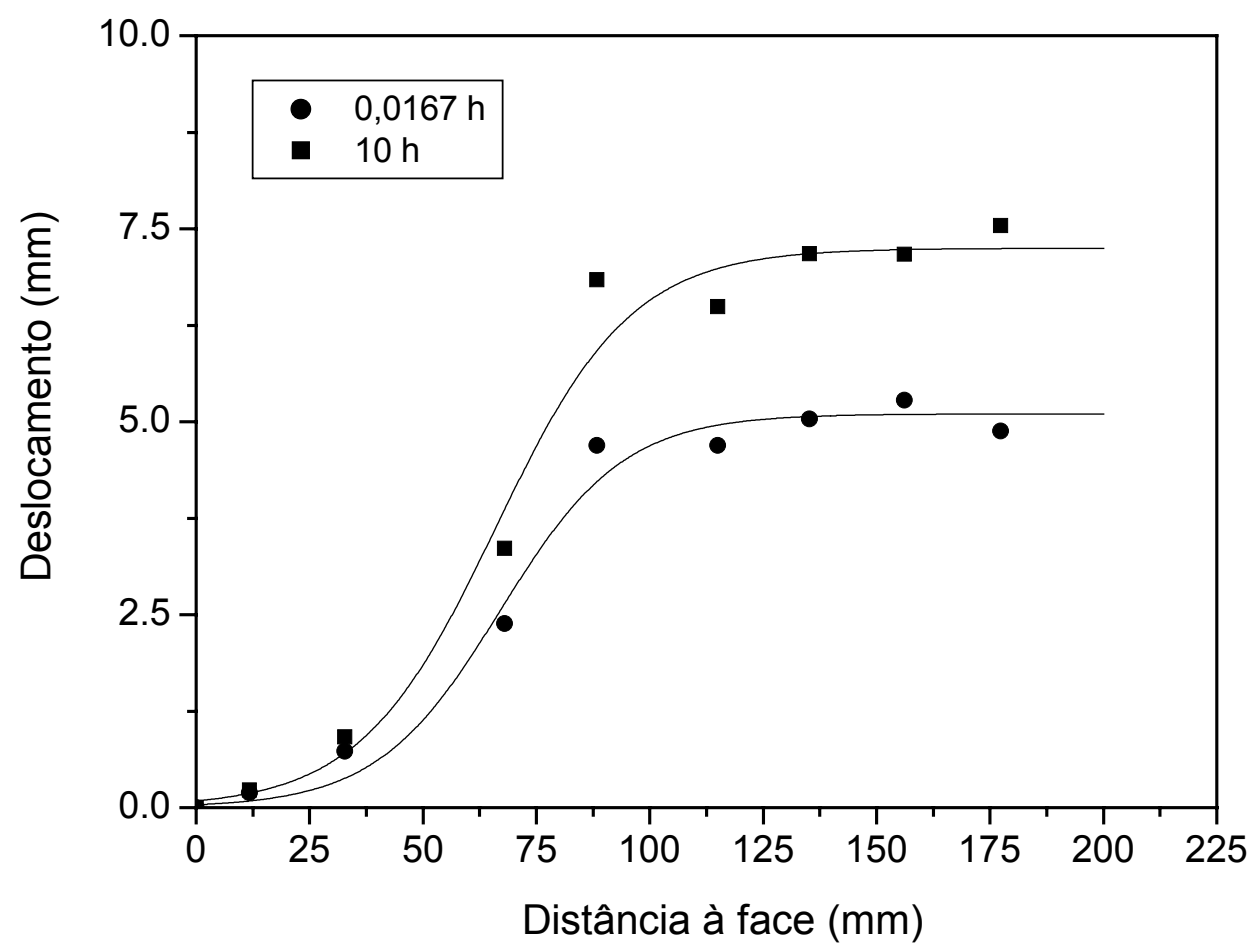

FIGURA A43 - Deslocamentos obtidos para o ensaio F-PET-3, camada 8.

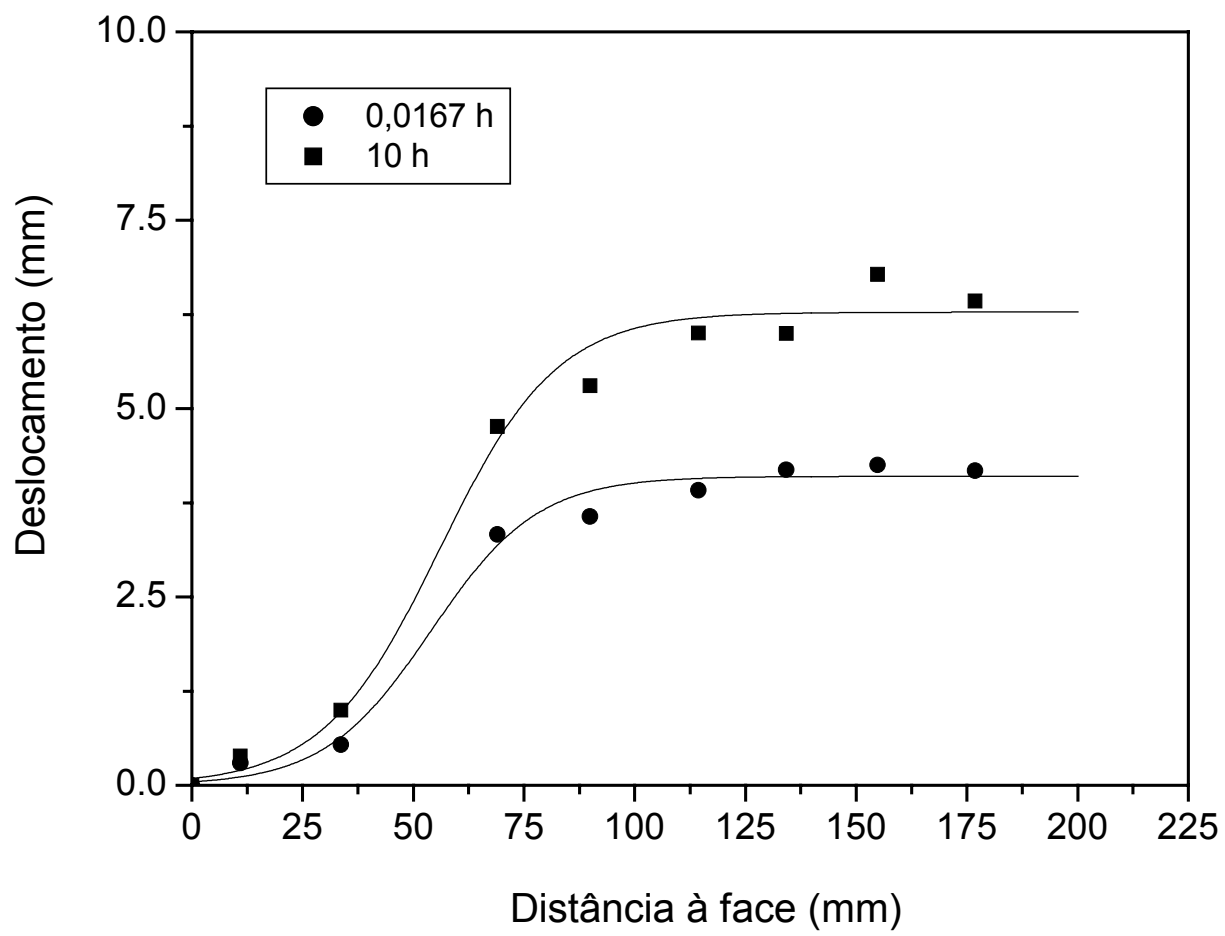

FIGURA A44 - Deslocamentos obtidos para o ensaio F-PET-3, camada 7. 


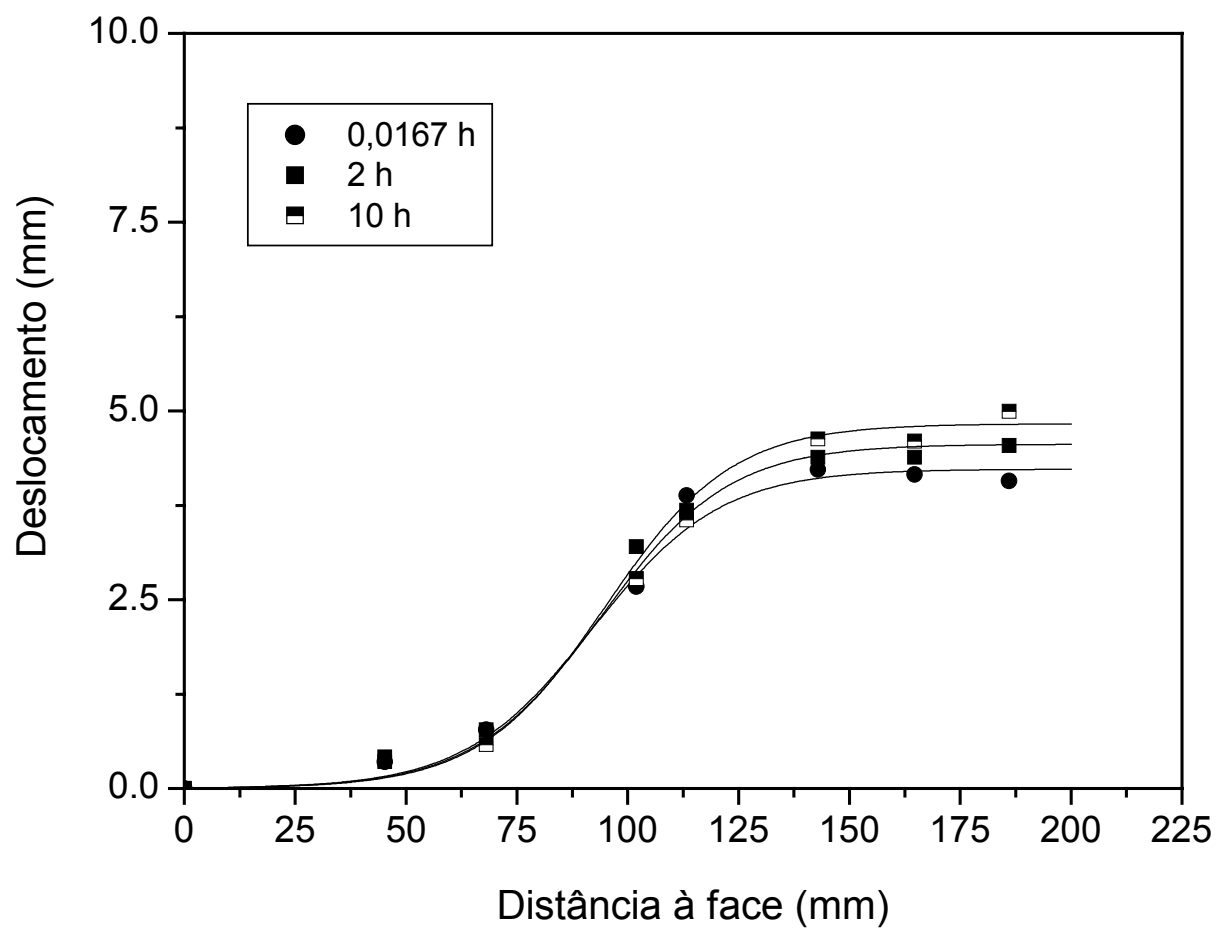

FIGURA A45 - Deslocamentos obtidos para o ensaio F-PET-2, camada 12.

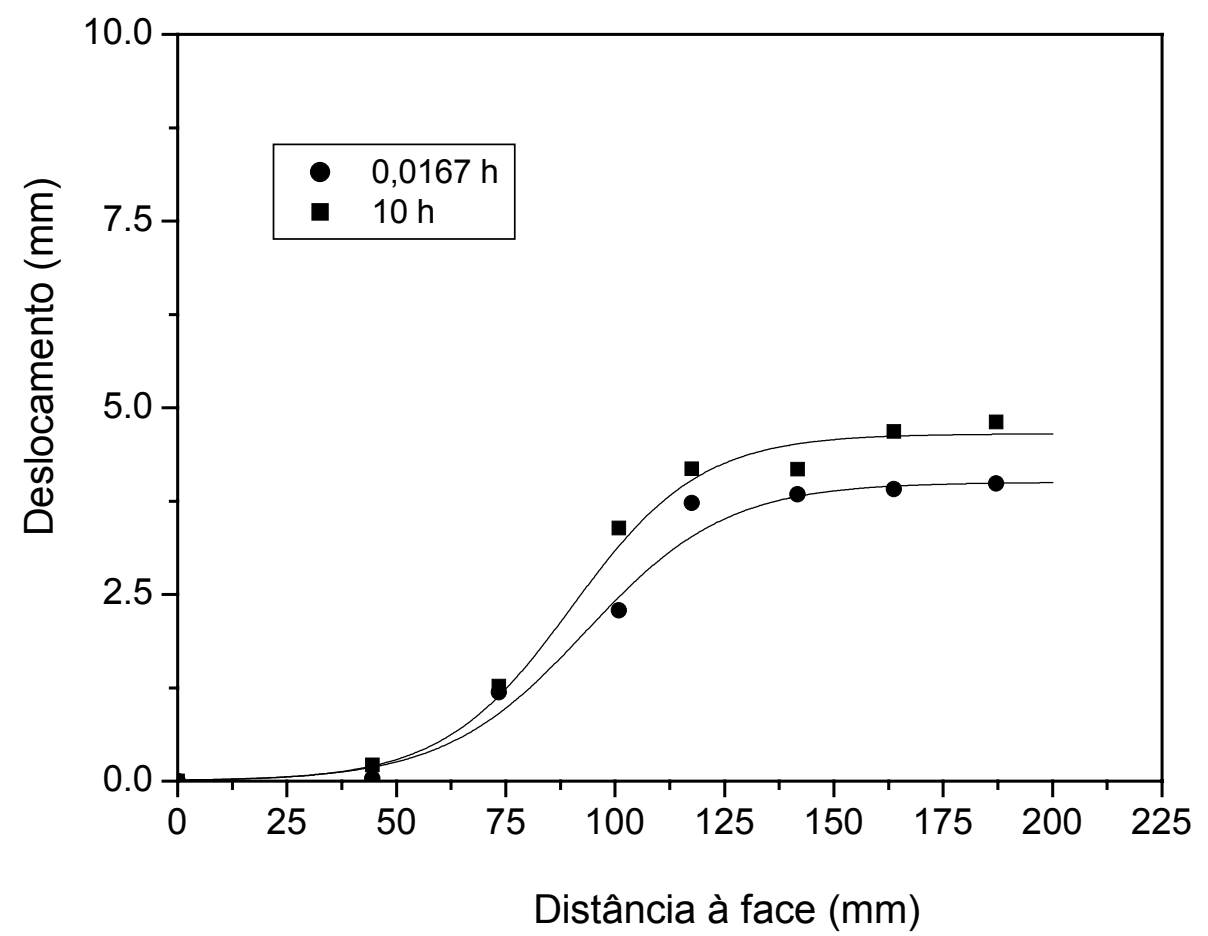

FIGURA A46 - Deslocamentos obtidos para o ensaio F-PET-2, camada 11. 


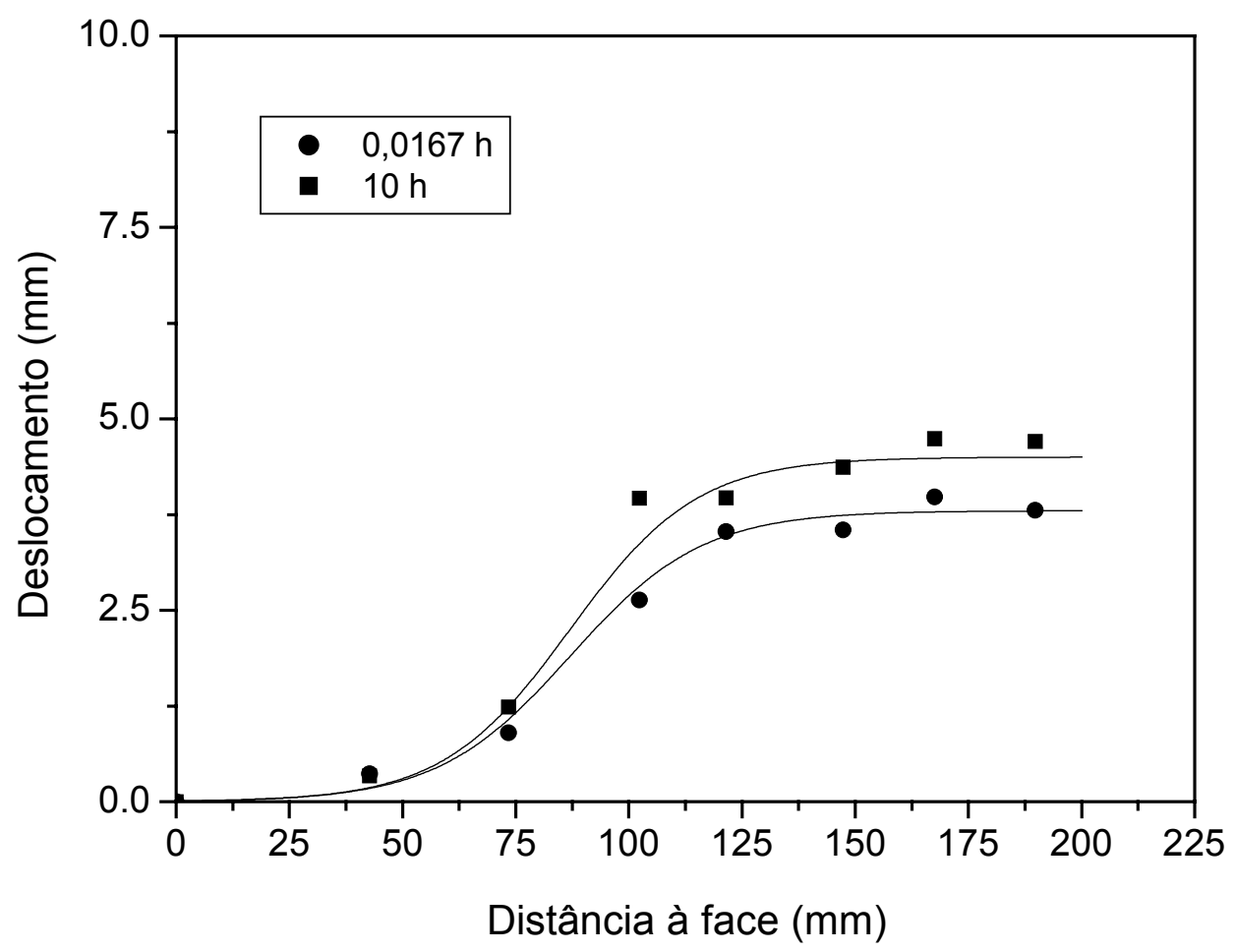

FIGURA A47 - Deslocamentos obtidos para o ensaio F-PET-2, camada 10.

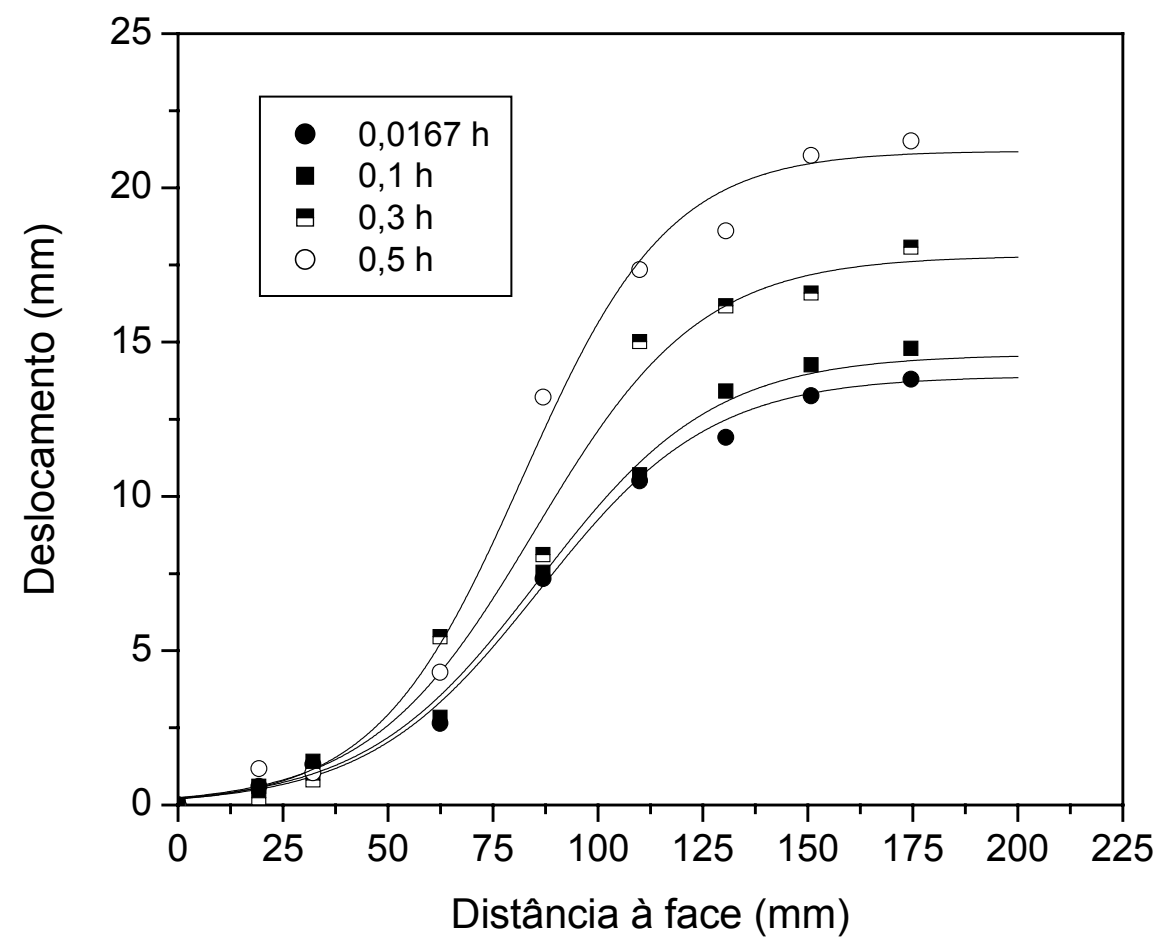

FIGURA A48 - Deslocamentos obtidos para o ensaio F-PP-4, camada 12. 


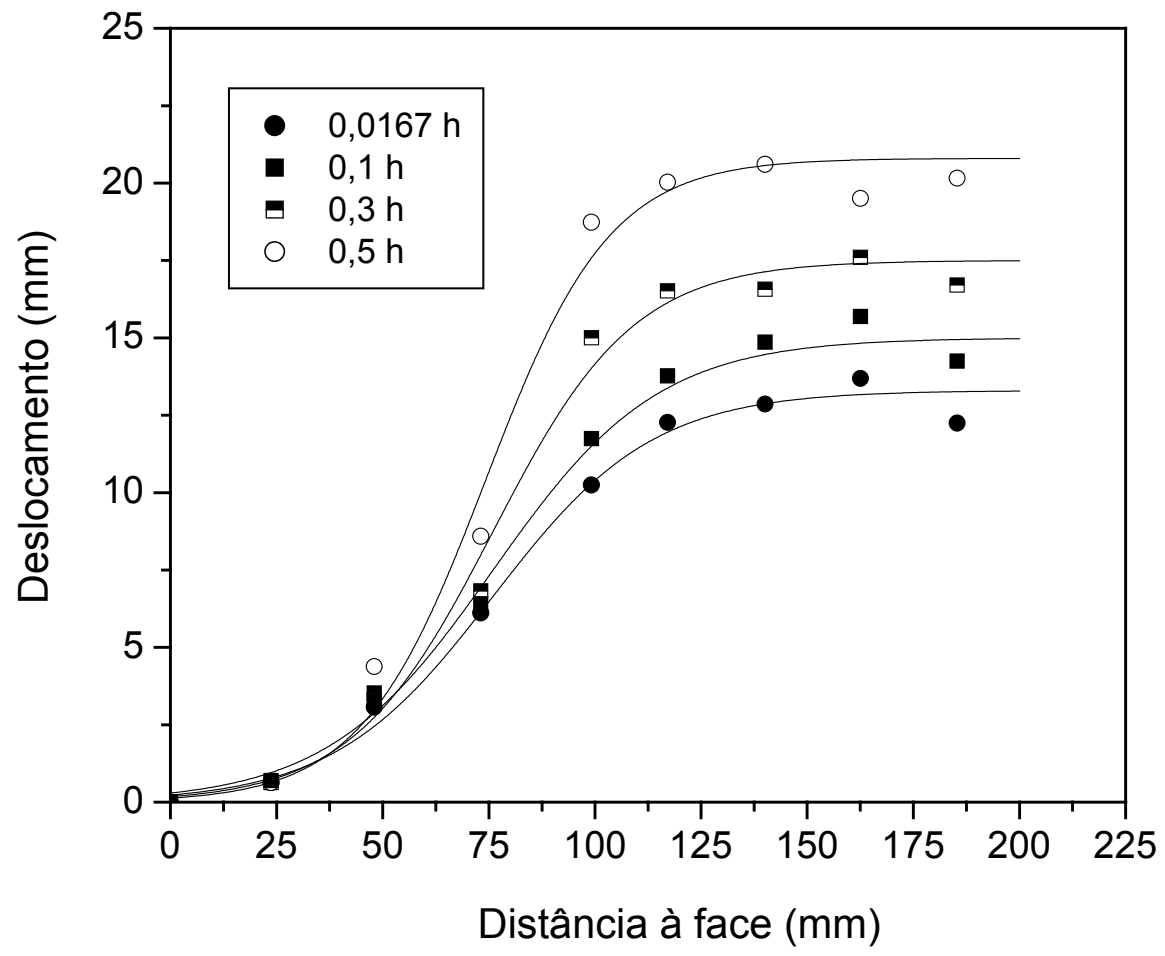

FIGURA A49 - Deslocamentos obtidos para o ensaio F-PP-4, camada 10.

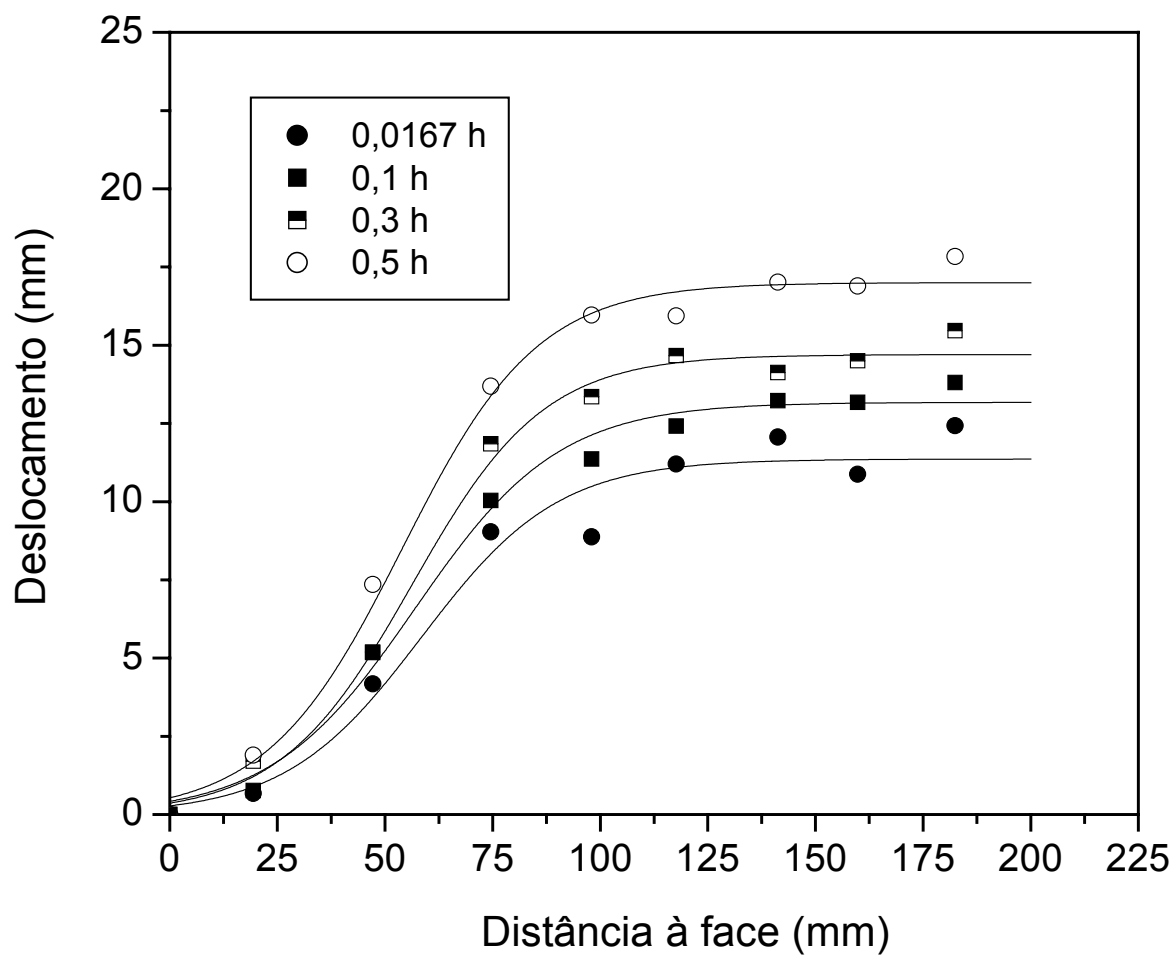

FIGURA A50 - Deslocamentos obtidos para o ensaio F-PP-4, camada 8. 


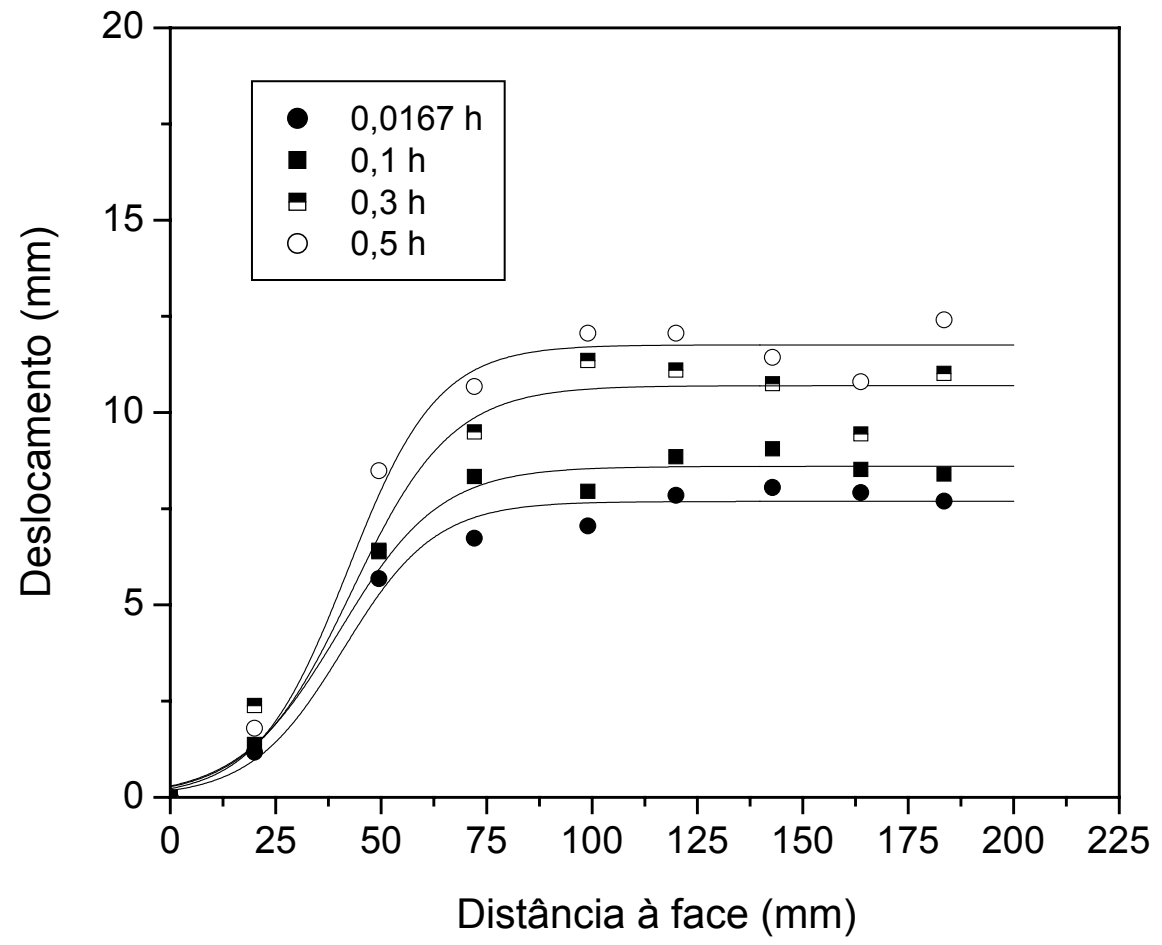

FIGURA A51 - Deslocamentos obtidos para o ensaio F-PP-4, camada 6.

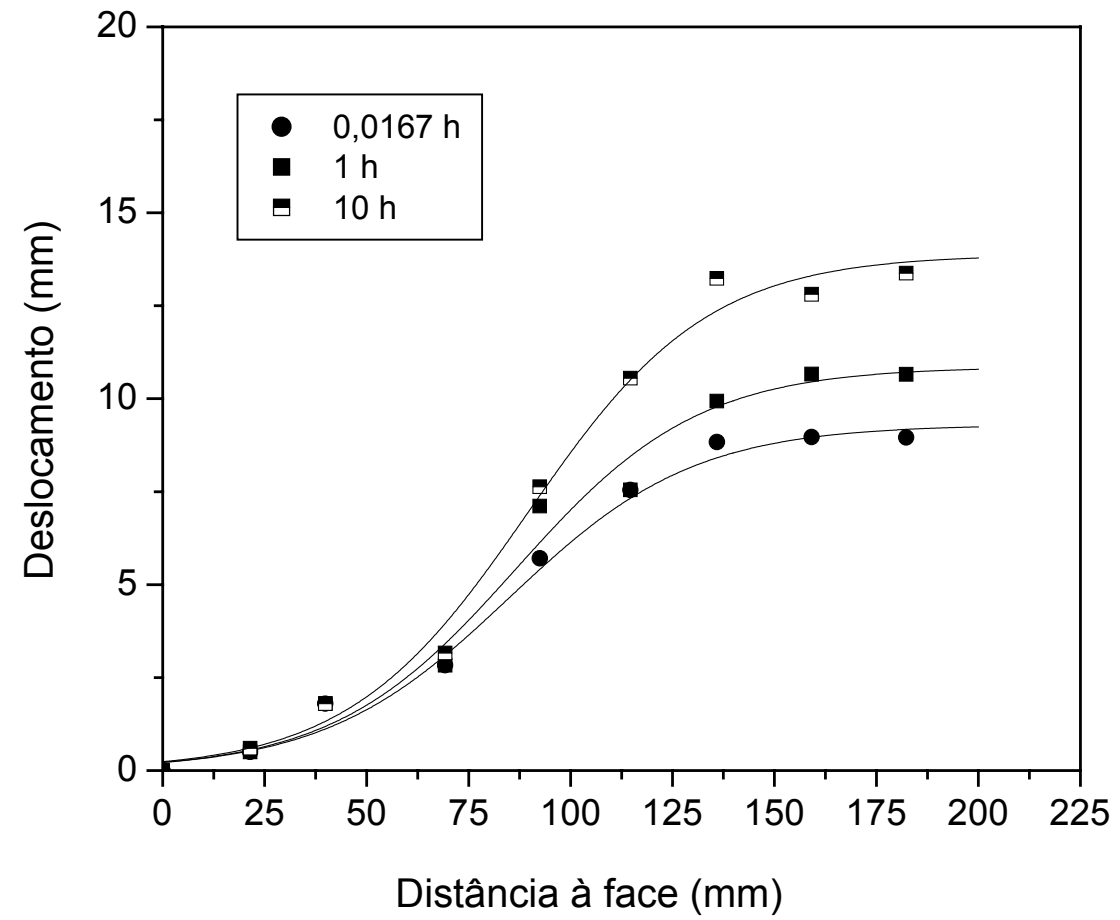

FIGURA A52 - Deslocamentos obtidos para o ensaio F-PP-3, camada 12. 


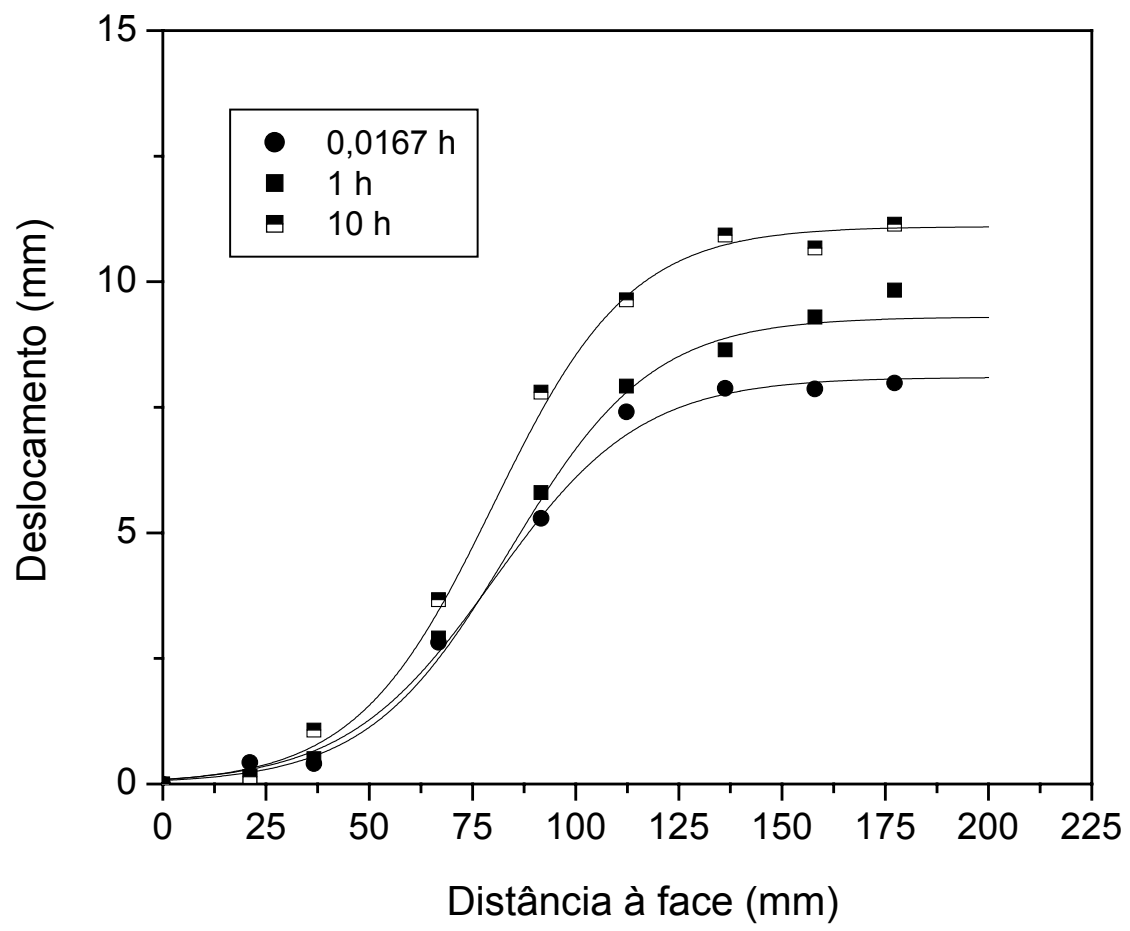

FIGURA A53 - Deslocamentos obtidos para o ensaio F-PP-3, camada 10.

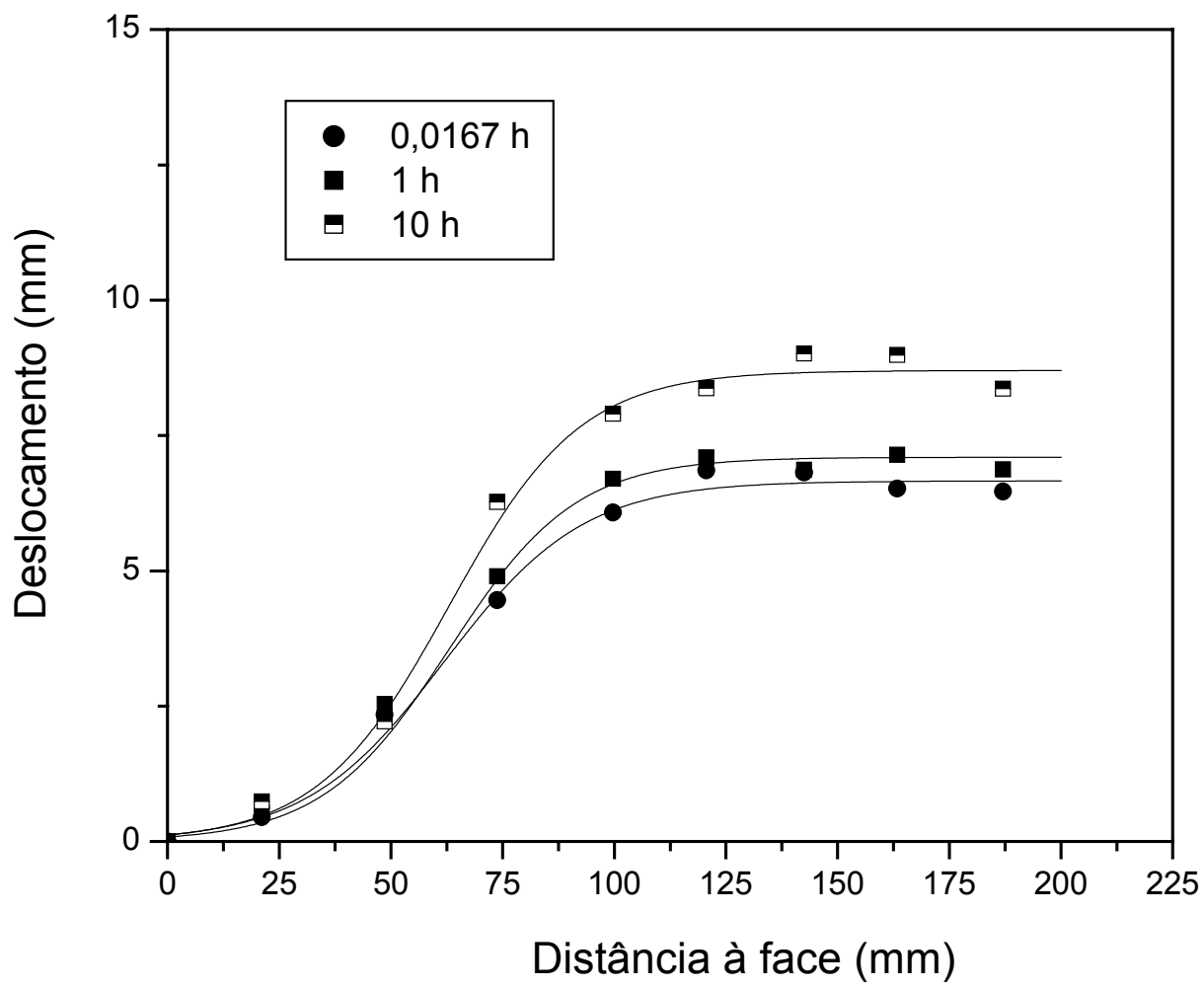

FIGURA A54 - Deslocamentos obtidos para o ensaio F-PP-3, camada 8. 


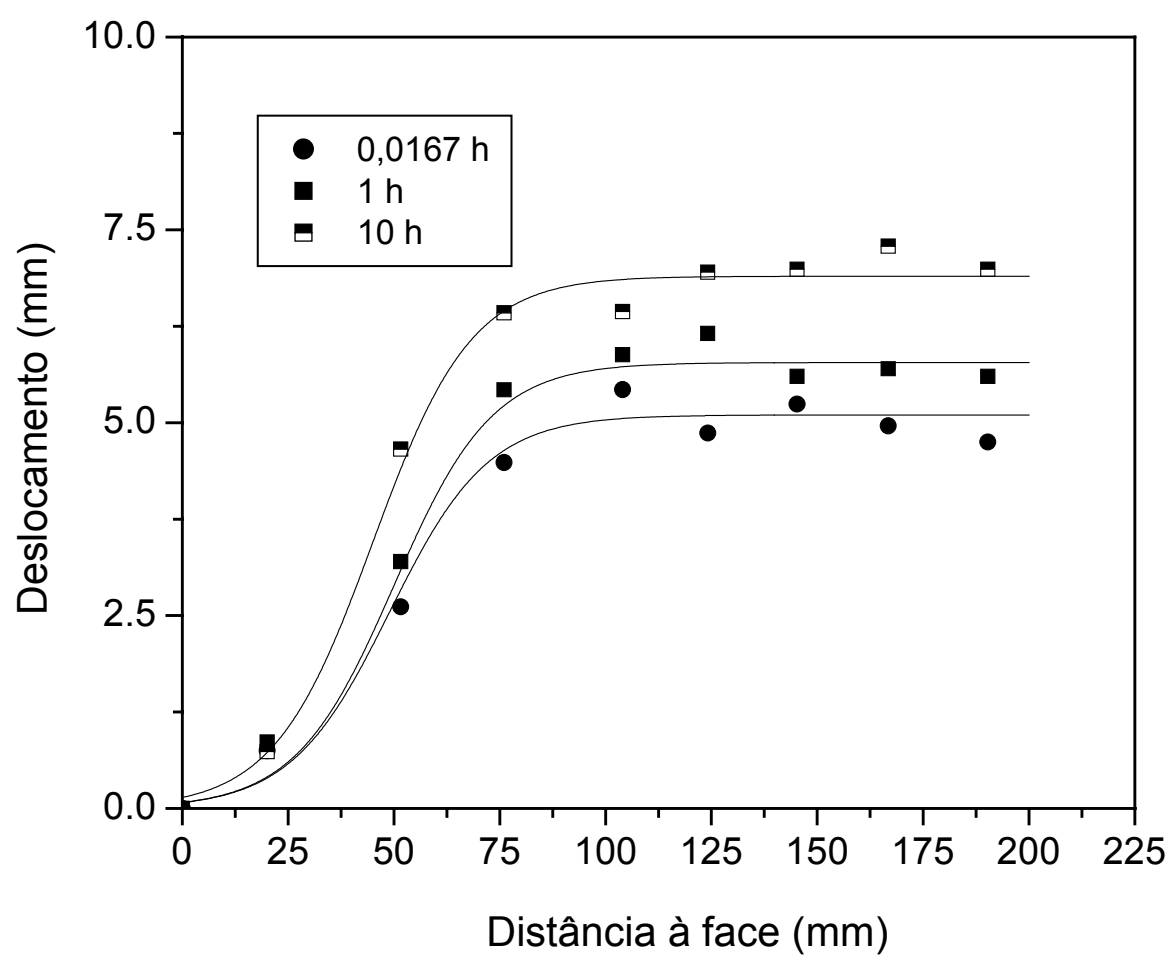

FIGURA A55 - Deslocamentos obtidos para o ensaio F-PP-3, camada 6.

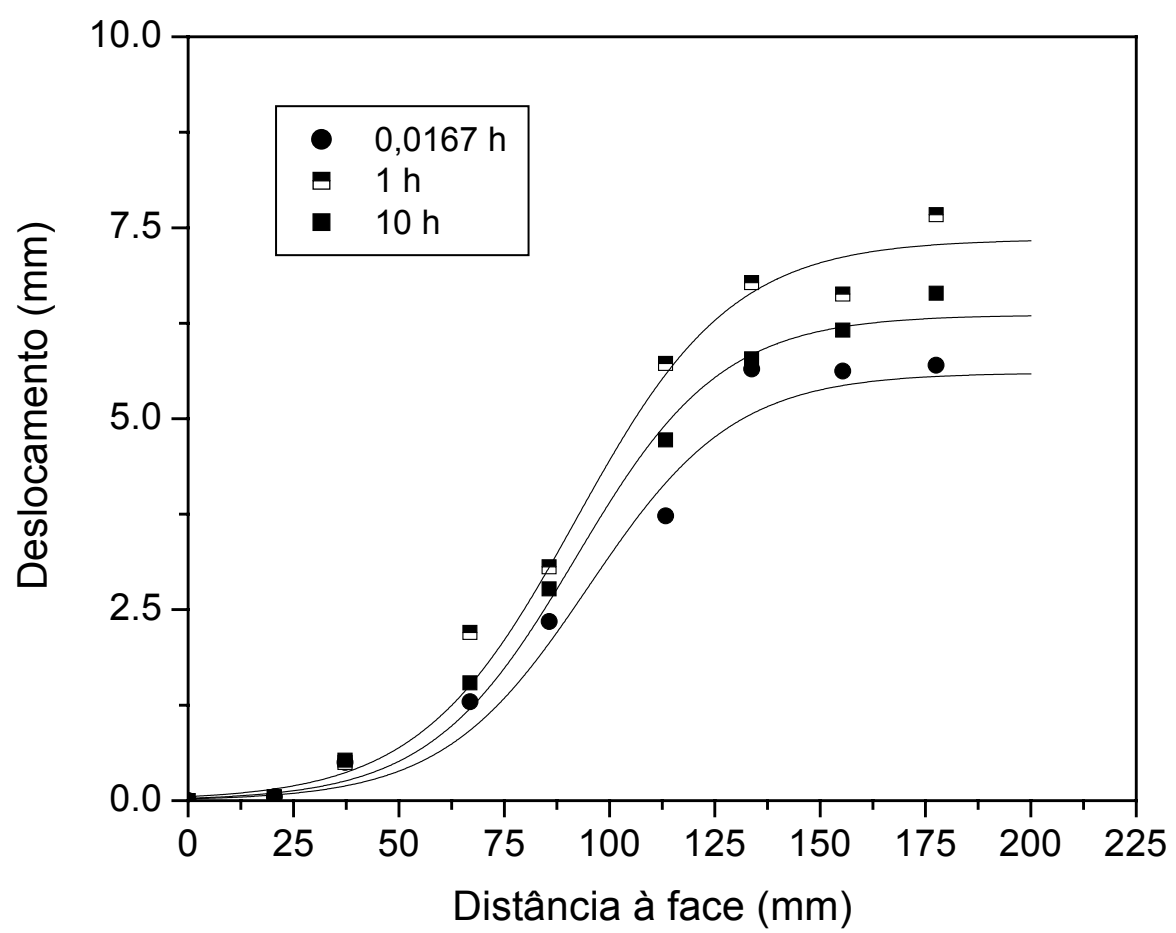

FIGURA A56 - Deslocamentos obtidos para o ensaio F-PP-2, camada 12. 


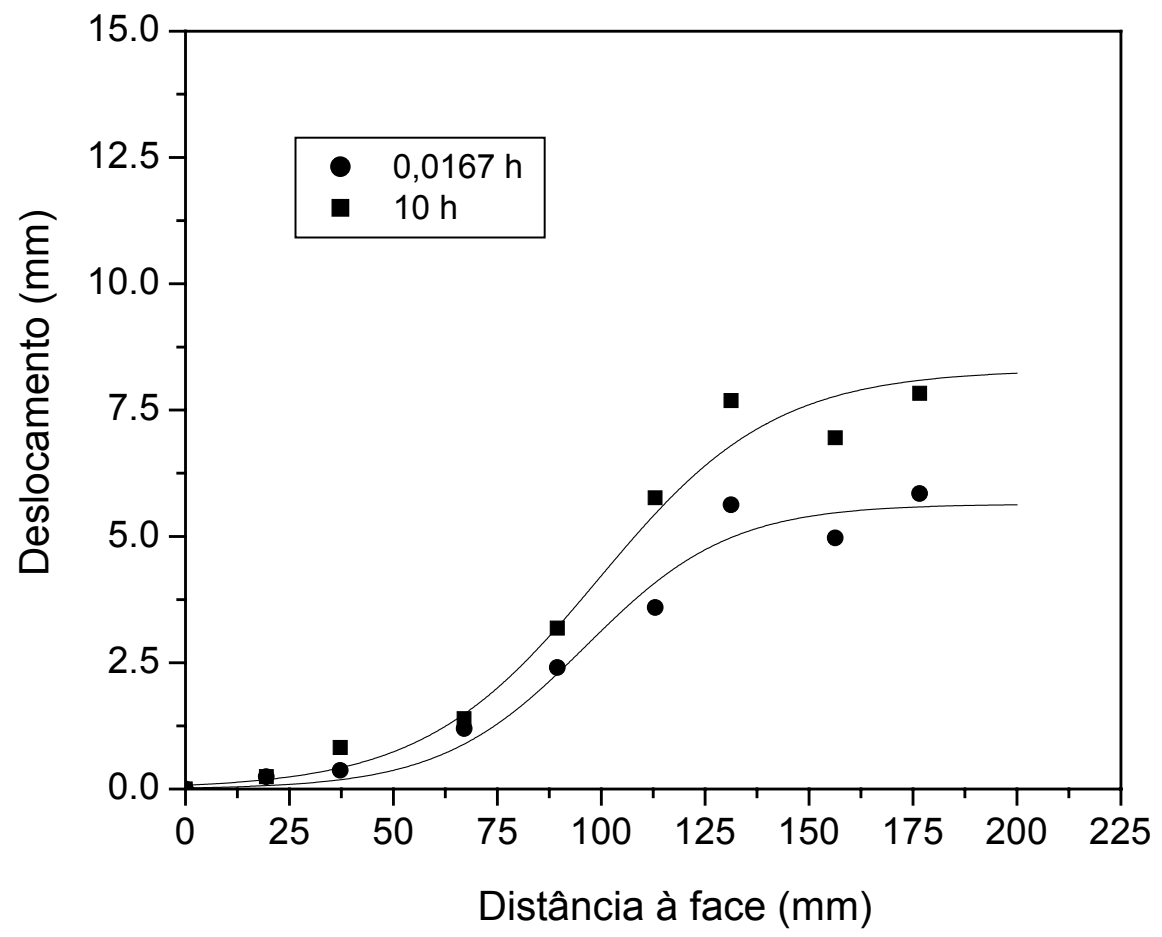

FIGURA A57 - Deslocamentos obtidos para o ensaio F-PP-2, camada 11.

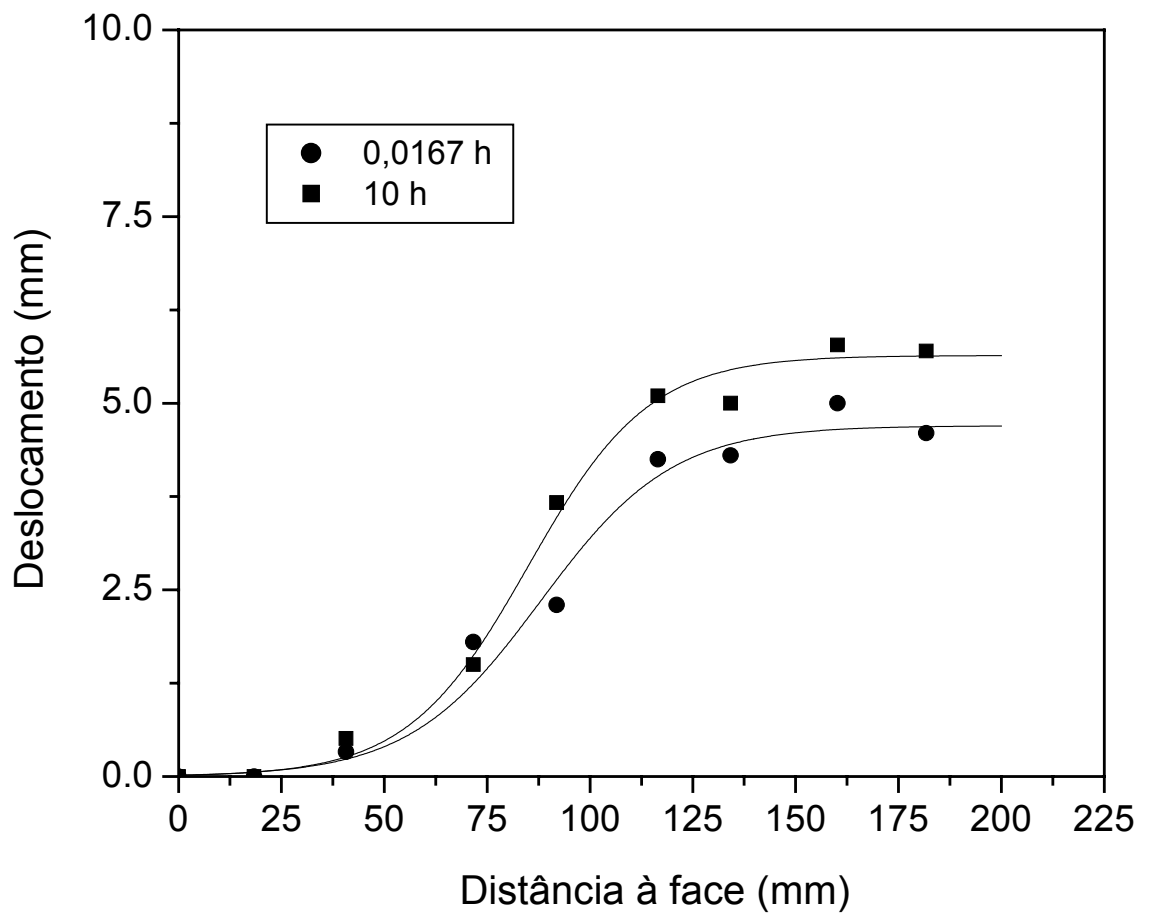

FIGURA A58 - Deslocamentos obtidos para o ensaio F-PP-2, camada 10. 


\section{A. 2 - Coeficientes de determinação $\left(R^{2}\right)$ obtidos nos ajustes}

\section{A.2.1 Ensaios de Ruptura}

TABELA A1 - Ensaio R-PET-2

\begin{tabular}{|c|c|c|c|c|c|c|c|c|c|c|}
\hline \multirow{2}{*}{$\begin{array}{c}\text { Aceleração } \\
\left(\% \mathrm{a}_{\mathrm{r}}^{*}\right)^{2}\end{array}$} & \multicolumn{10}{|c|}{ Camada } \\
\hline & 3 & 4 & 5 & 6 & 7 & 8 & 9 & 10 & 11 & 12 \\
\hline 95 & 0,96 & 0,98 & 0,99 & 0,99 & 0,98 & 0,97 & 0,99 & 0,98 & 0,97 & 0,99 \\
\hline 76 & 0,97 & 0,98 & 0,98 & 0,96 & 0,98 & 0,97 & 0,99 & 0,98 & 0,98 & 0,98 \\
\hline 56 & - & 0,97 & 0,94 & 0,95 & 0,99 & 0,97 & 0,98 & 0,96 & 0,95 & 0,97 \\
\hline 34 & - & - & - & - & - & - & - & - & 0,92 & 0,97 \\
\hline
\end{tabular}

TABELA A2- Ensaio R-PET-3

\begin{tabular}{cccccccccc}
$\begin{array}{c}\text { Aceleração } \\
\left(\% \mathrm{a}_{\mathrm{r}}^{*}\right)\end{array}$ & 4 & 5 & 6 & 7 & 8 & 9 & 10 & 11 & 12 \\
\hline 95 & 0,99 & 0,98 & 0,99 & 0,98 & 0,98 & 0,99 & 0,99 & 0,99 & 0,97 \\
82 & 0,98 & 0,97 & 0,97 & 0,98 & 0,97 & 0,99 & 0,97 & 0,99 & 0,99 \\
68 & 0,93 & 0,96 & 0,95 & 0,98 & 0,98 & 0,99 & 0,98 & 0,99 & 0,98 \\
51 & - & 0,98 & 0,97 & 0,98 & 0,98 & 0,98 & 0,99 & 0,96 & 0,96 \\
36 & - & - & - & - & - & - & 0,99 & 0,95 & 0,97 \\
${ }_{*}^{*}-$ a $_{\mathrm{r}}$ obtida no ensaio R-PET-3 & & & & & & & &
\end{tabular}

TABELA A3 - Ensaio R-PP-1

\begin{tabular}{|c|c|c|c|c|c|c|c|c|c|c|}
\hline \multirow{2}{*}{$\begin{array}{c}\text { Aceleração } \\
\left(\% \mathrm{a}_{\mathrm{r}}{ }^{*}\right)\end{array}$} & \multicolumn{10}{|c|}{ Camada } \\
\hline & 3 & 4 & 5 & 6 & 7 & 8 & 9 & 10 & 11 & 12 \\
\hline 98 & 0,97 & 0,97 & 0,99 & 0,99 & 0,99 & 0,99 & 0,99 & 0,98 & 0,99 & 0,99 \\
\hline 83 & 0,96 & 0,97 & 0,98 & 0,97 & 0,99 & 0,97 & 0,99 & 0,99 & 0,99 & 0,99 \\
\hline 64 & - & - & 0,96 & 0,98 & 0,98 & 0,98 & 0,98 & 0,98 & 0,98 & 0,98 \\
\hline 42 & - & - & - & - & - & - & - & 0,99 & 0,98 & 0,98 \\
\hline 21 & - & - & - & - & - & - & - & - & 0,97 & 0,97 \\
\hline
\end{tabular}

\section{A.2.2 Ensaios de Fluência}

TABELA A4 - Ensaio F-PET-4

\begin{tabular}{ccccccccc}
\hline Tempo $^{(1)}(\mathrm{h})$ & \multicolumn{8}{c}{ Camada } \\
& 5 & 6 & 7 & 8 & 9 & 10 & 11 & 12 \\
\hline 0,0167 & 0,98 & 0,98 & 0,98 & 0,98 & 0,98 & 0,99 & 0,99 & 0,98 \\
1,0 & 0,98 & 0,99 & 0,99 & 0,99 & 0,98 & 0,99 & 0,99 & 0,98 \\
2,0 & 0,99 & 0,99 & 0,98 & 0,97 & 0,97 & 0,99 & 0,98 & 0,99 \\
3,0 & - & 0,99 & - & - & - & 0,99 & - & - \\
\hline
\end{tabular}


TABELA A5 - Ensaio F-PET-3

\begin{tabular}{ccccccc}
\hline Tempo $(\mathrm{h})$ & 7 & 8 & 9 & 10 & 11 & 12 \\
\hline 0,0167 & 0,99 & 0,98 & 0,98 & 0,98 & 0,97 & 0,98 \\
2,0 & - & - & - & - & - & 0,99 \\
10,0 & 0,98 & 0,98 & 0,98 & 0,99 & 0,98 & 0,99 \\
\hline
\end{tabular}

TABELA A6 - Ensaio F-PET-2

\begin{tabular}{cccc}
\hline Tempo $(\mathrm{h})$ & 10 & Camada & 11 \\
\hline 0,0167 & 0,97 & 0,98 & 0,98 \\
0,5 & - & - & 0,99 \\
10,0 & 0,98 & 0,98 & 0,99 \\
\hline
\end{tabular}

TABELA A7 - Ensaio F-PP-4

\begin{tabular}{ccccc}
\hline Tempo $(\mathrm{h})$ & 6 & 8 & 10 & 12 \\
\hline 0,0167 & 0,98 & 0,97 & 0,99 & 0,99 \\
0,1 & 0,98 & 0,99 & 0,99 & 0,99 \\
0,3 & 0,97 & 0,99 & 0,99 & 0,98 \\
0,5 & 0,98 & 0,99 & 0,98 & 0,98 \\
\hline
\end{tabular}

TABELA A8 - Ensaio F-PP-3

\begin{tabular}{ccccc}
\hline Tempo $(\mathrm{h})$ & 6 & 8 & 10 & 12 \\
\hline 0,0167 & 0,97 & 0,99 & 0,99 & 0,99 \\
1,0 & 0,98 & 0,98 & 0,99 & 0,98 \\
10,0 & 0,99 & 0,99 & 0,99 & 0,98 \\
\hline
\end{tabular}

TABELA A9 - Ensaio F-PP-2

\begin{tabular}{cccc}
\hline Tempo $(\mathrm{h})$ & \multicolumn{3}{c}{ Camada } \\
& 10 & 11 & 12 \\
\hline 0,0167 & 0,98 & 0,98 & 0,98 \\
1,0 & - & - & 0,99 \\
10,0 & 0,99 & 0,97 & 0,98 \\
\hline
\end{tabular}


ANEXO B: Distribuição de deformação no reforço

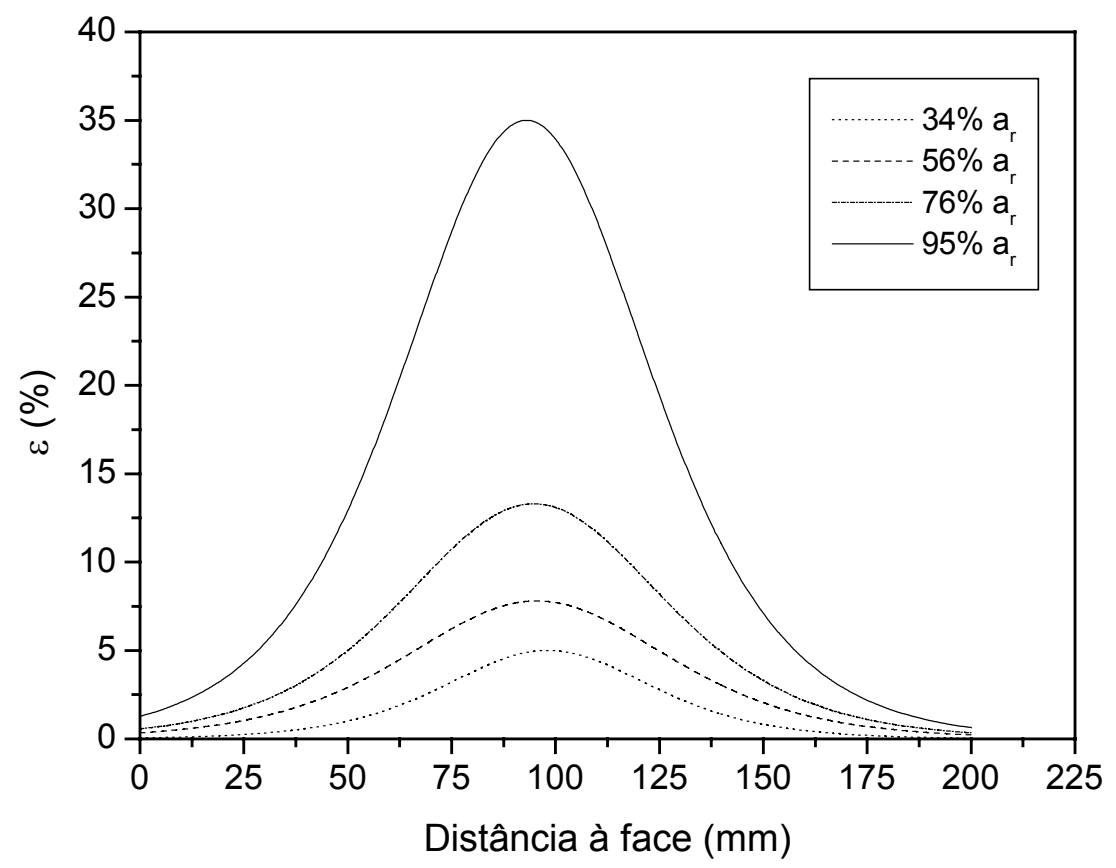

FIGURA B1 - Deformações obtidas para o ensaio R-PET-2, camada 12.

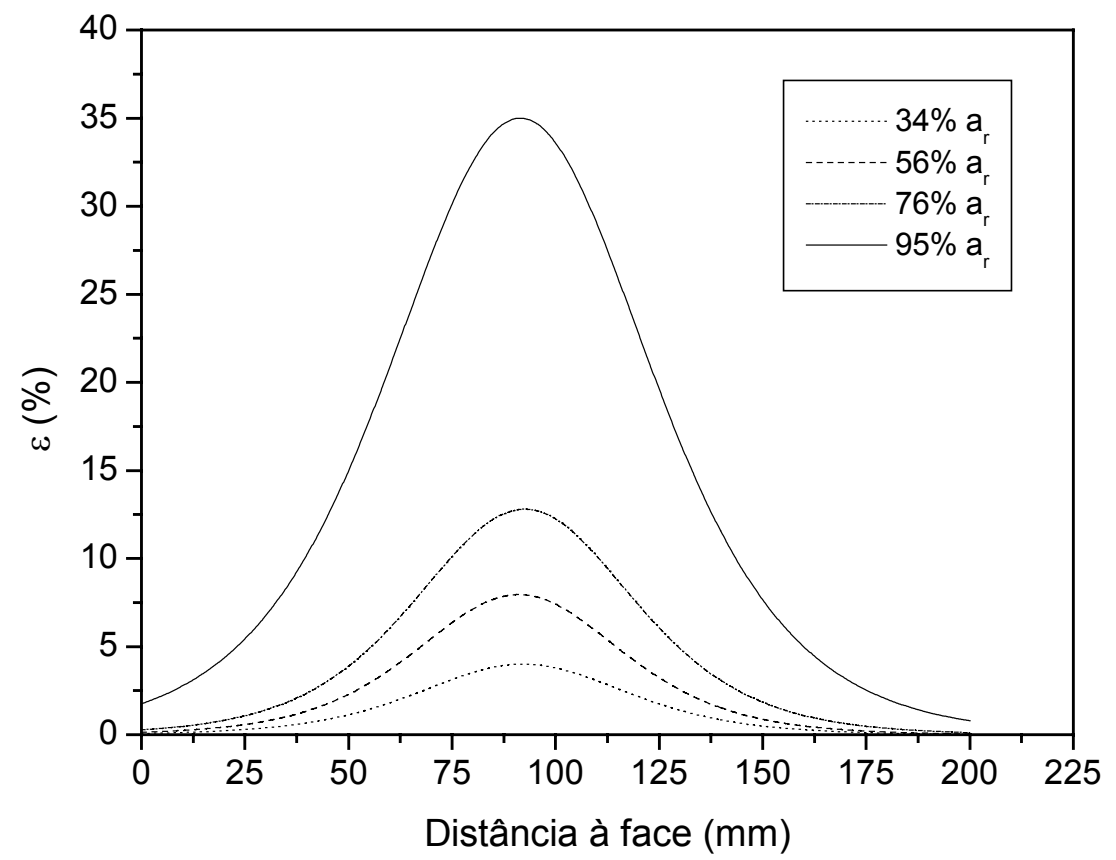

FIGURA B2 - Deformações obtidas para o ensaio R-PET-2, camada 11. 


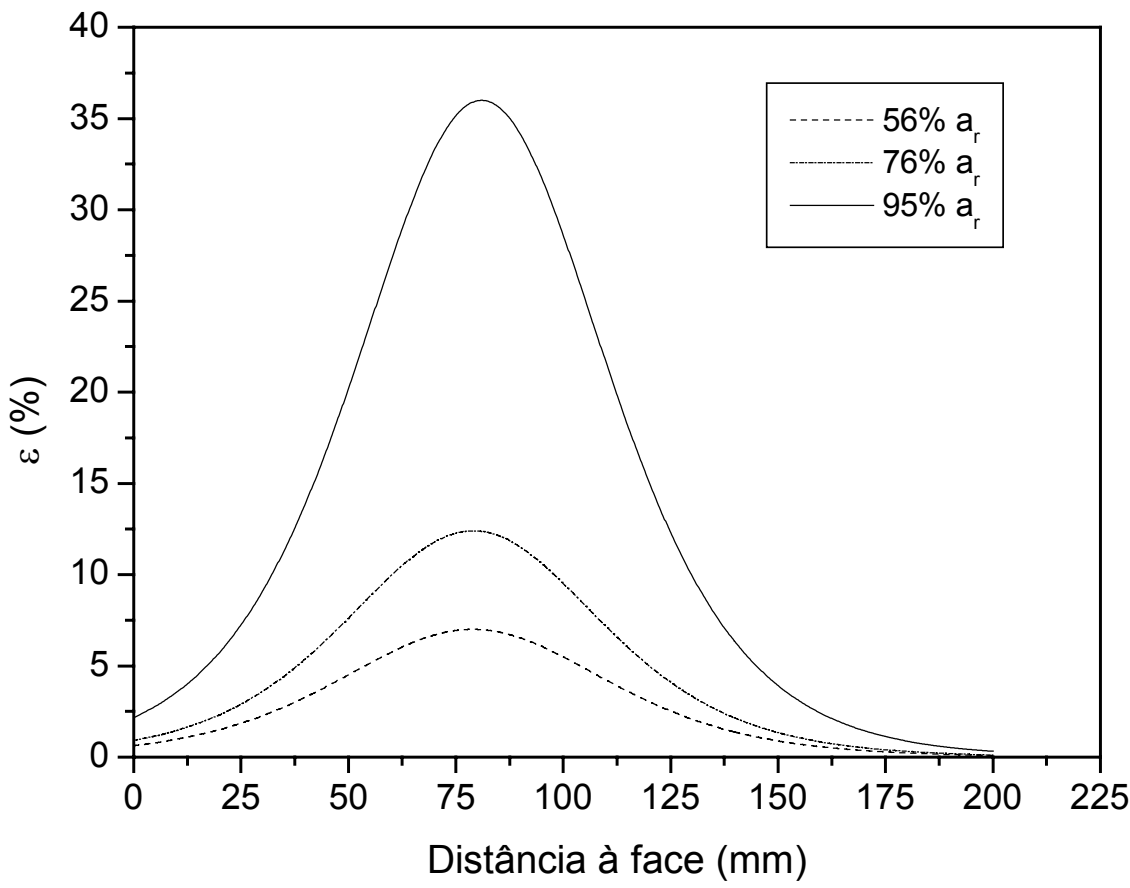

FIGURA B3 - Deformações obtidas para o ensaio R-PET-2, camada 10.

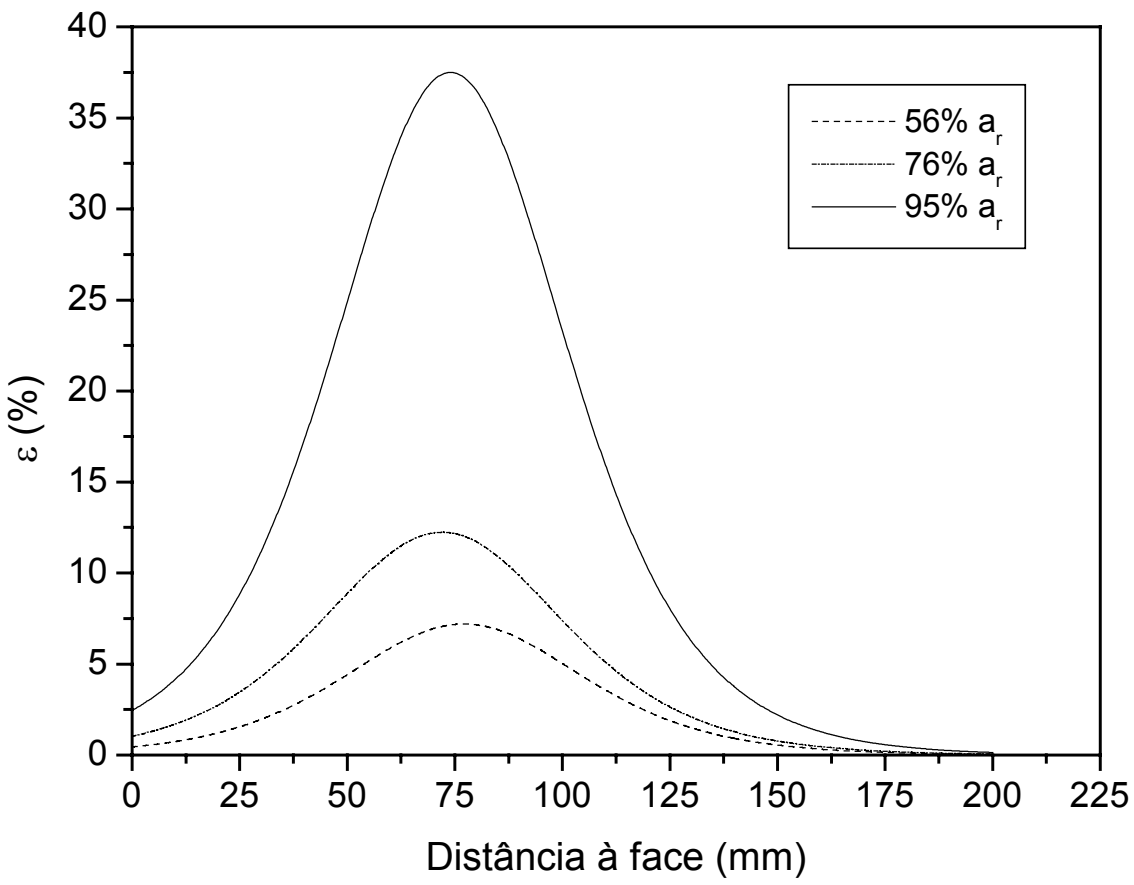

FIGURA B4 - Deformações obtidas para o ensaio R-PET-2, camada 9. 


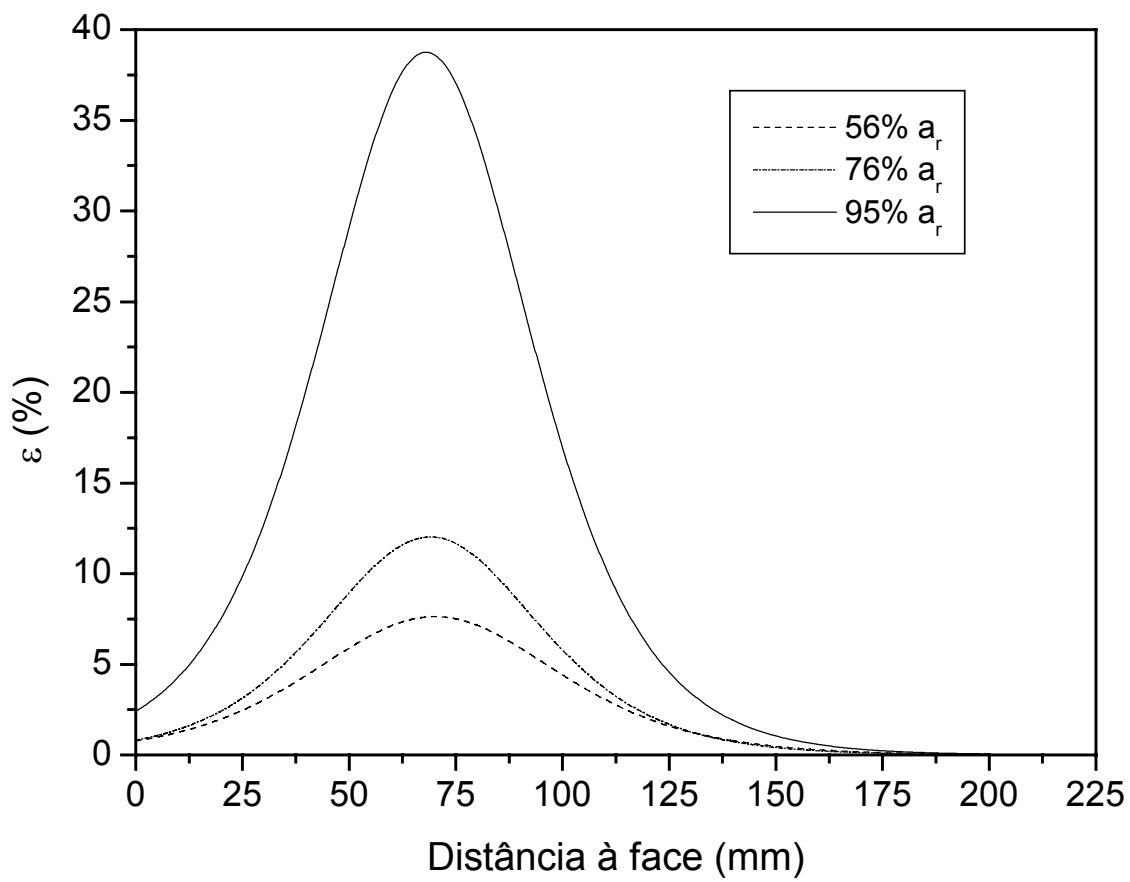

FIGURA B5 - Deformações obtidas para o ensaio R-PET-2, camada 8.

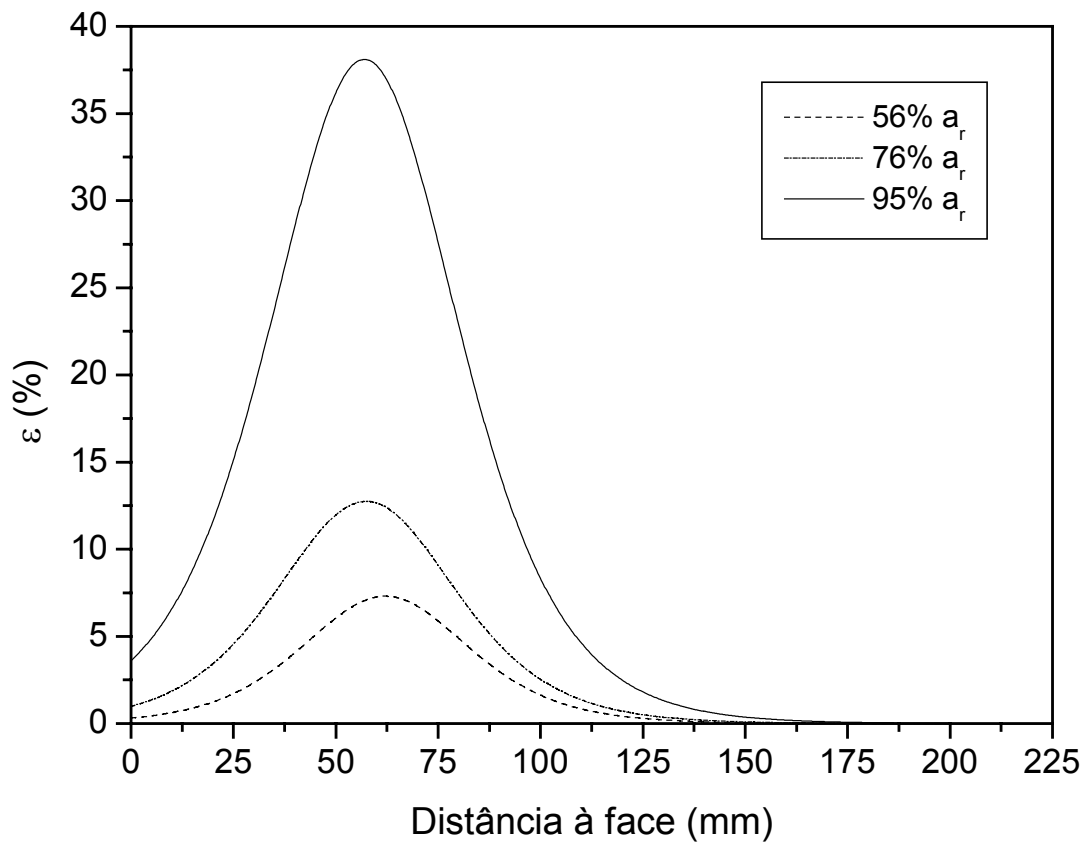

FIGURA B6 - Deformações obtidas para o ensaio R-PET-2, camada 7. 


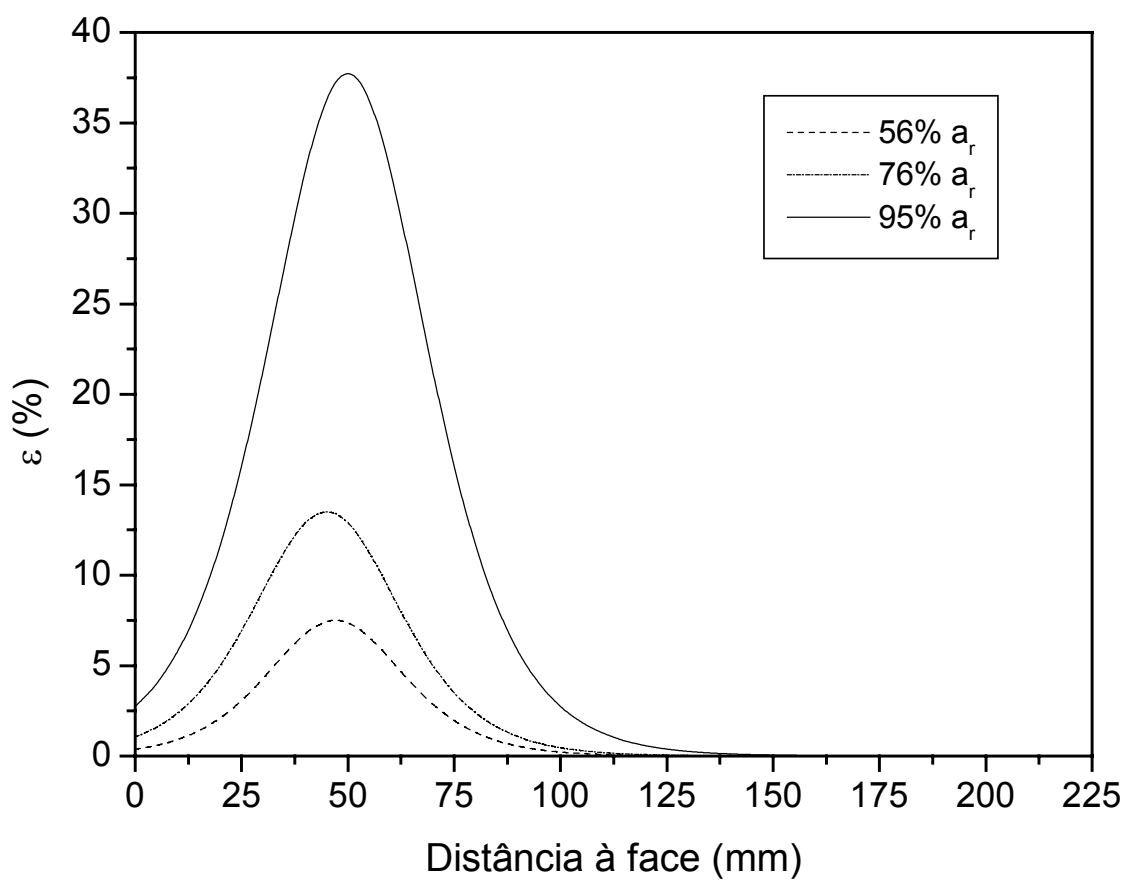

FIGURA B7 - Deformações obtidas para o ensaio R-PET-2, camada 6.

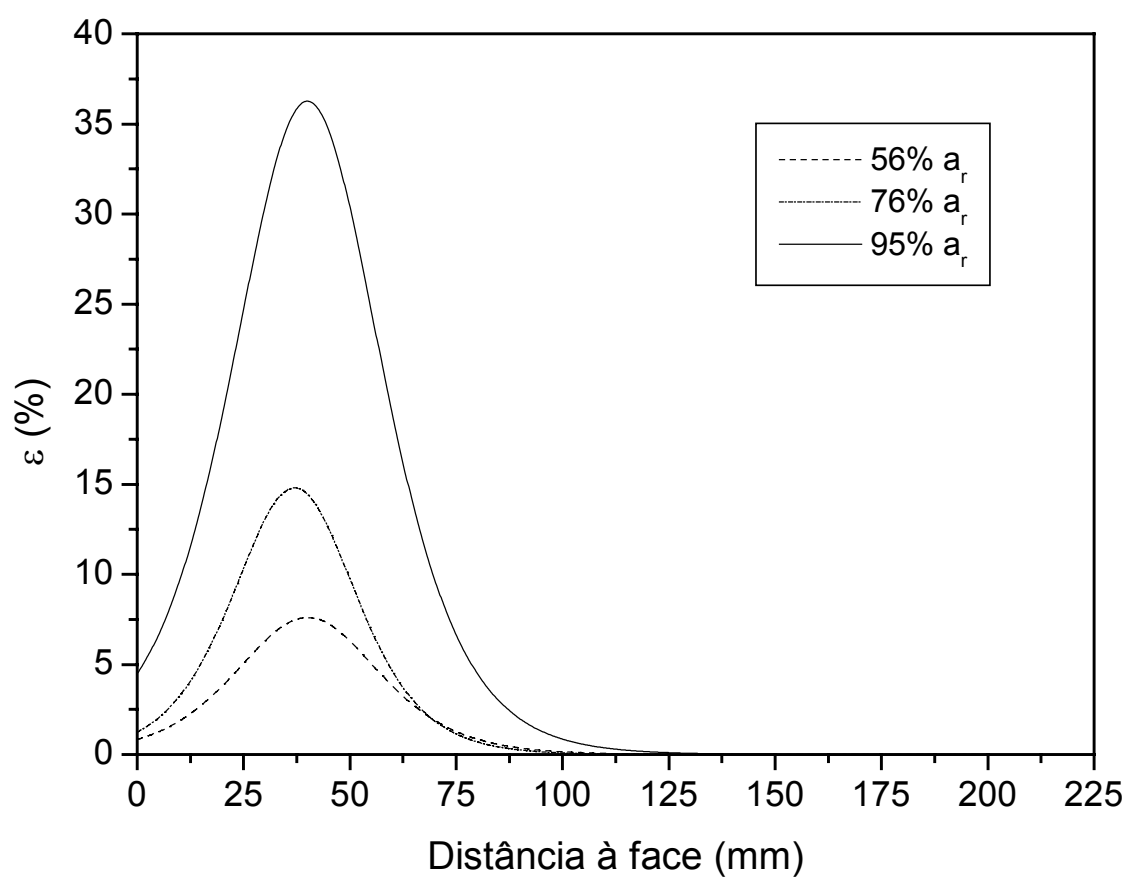

FIGURA B8 - Deformações obtidas para o ensaio R-PET-2, camada 5. 


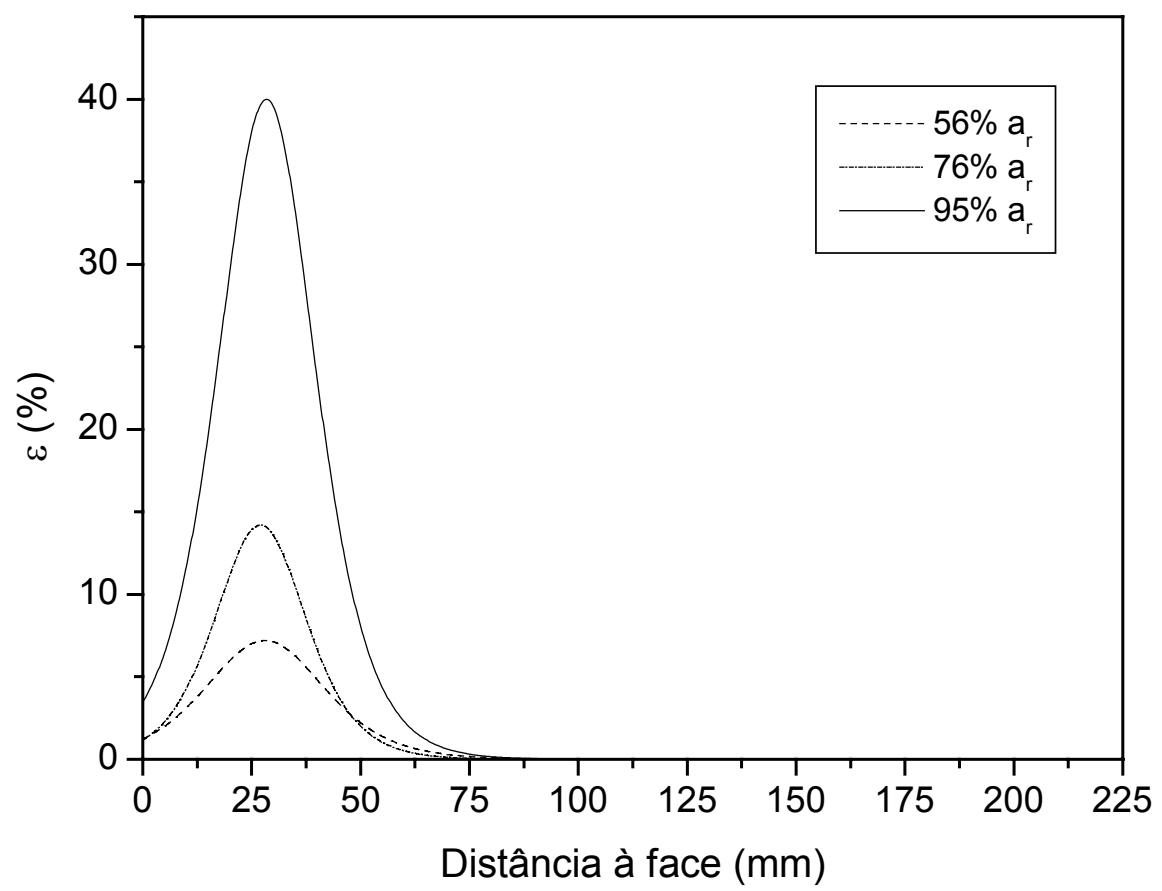

FIGURA B9 - Deformações obtidas para o ensaio R-PET-2, camada 4.

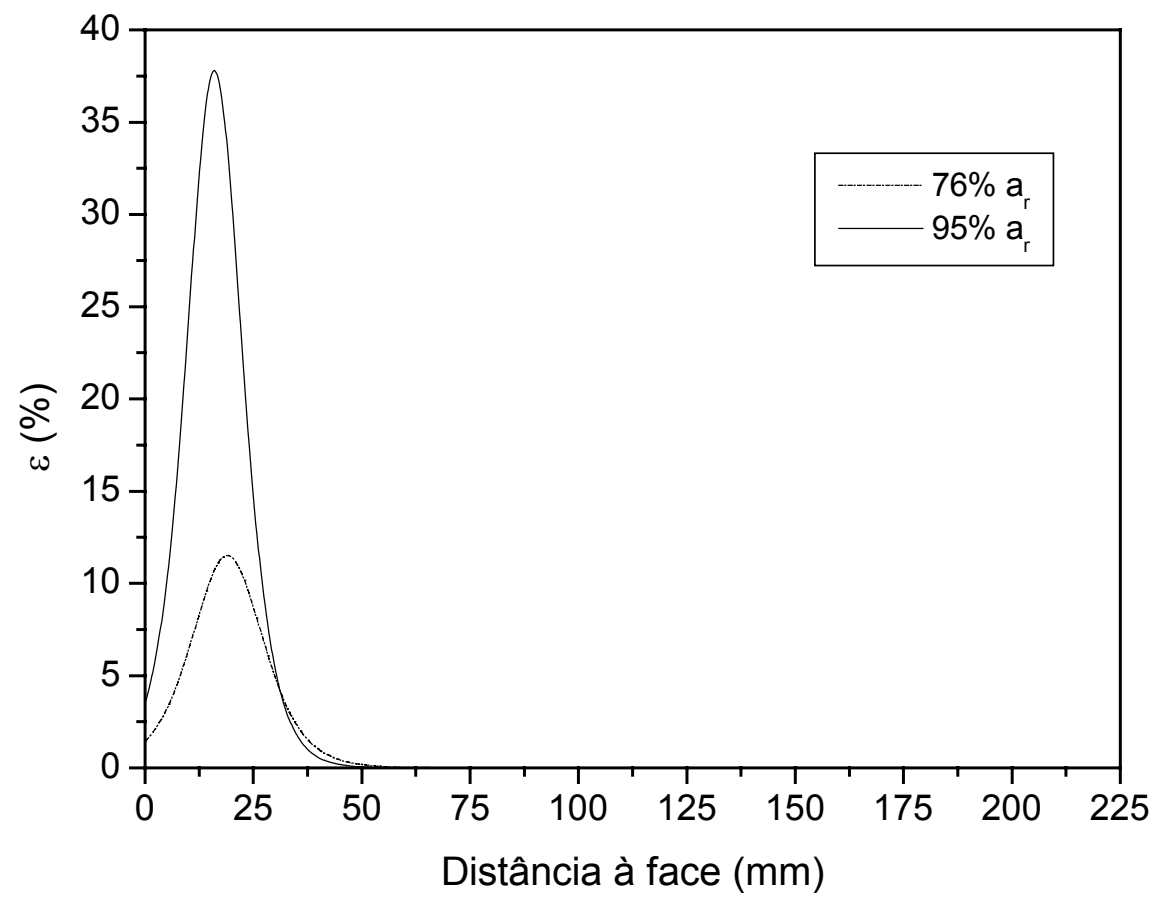

FIGURA B10 - Deformações obtidas para o ensaio R-PET-2, camada 3. 


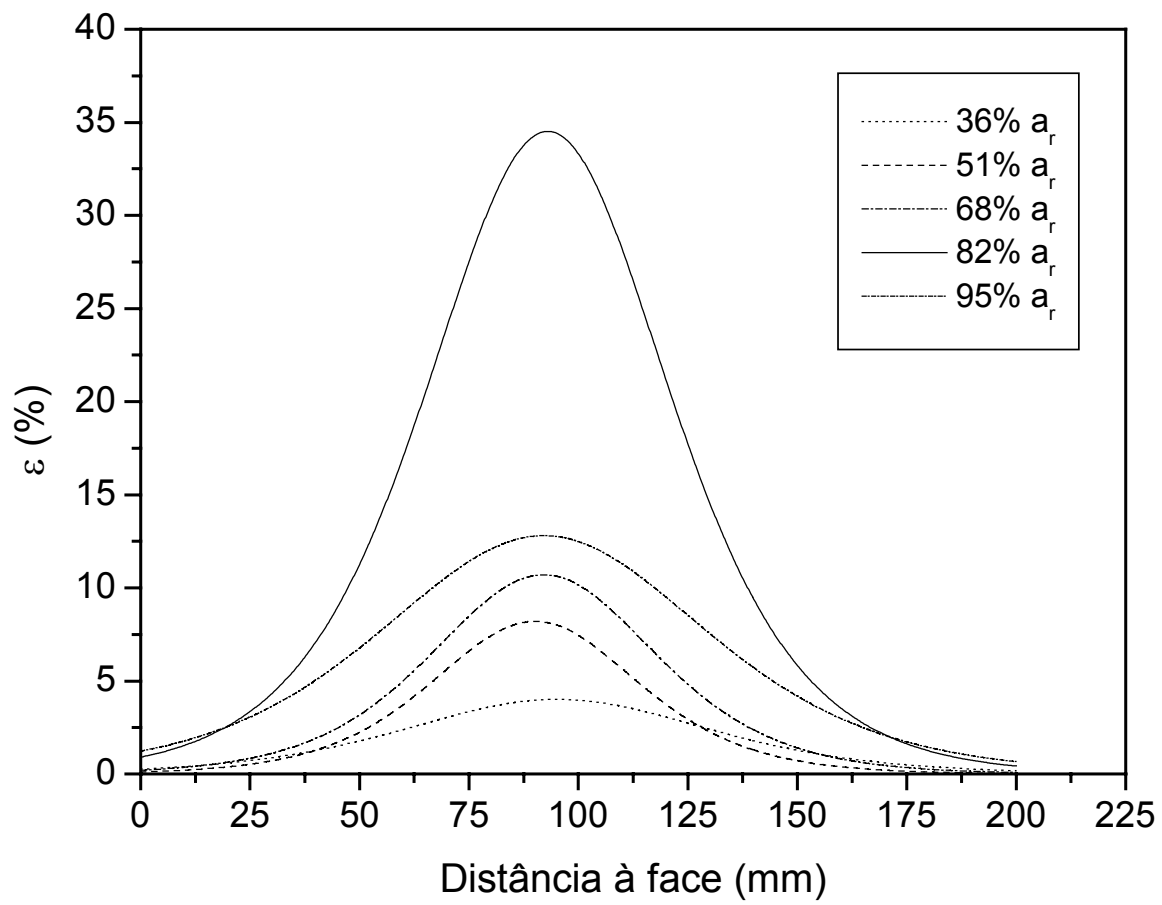

FIGURA B11 - Deformações obtidas para o ensaio R-PET-3, camada 12.

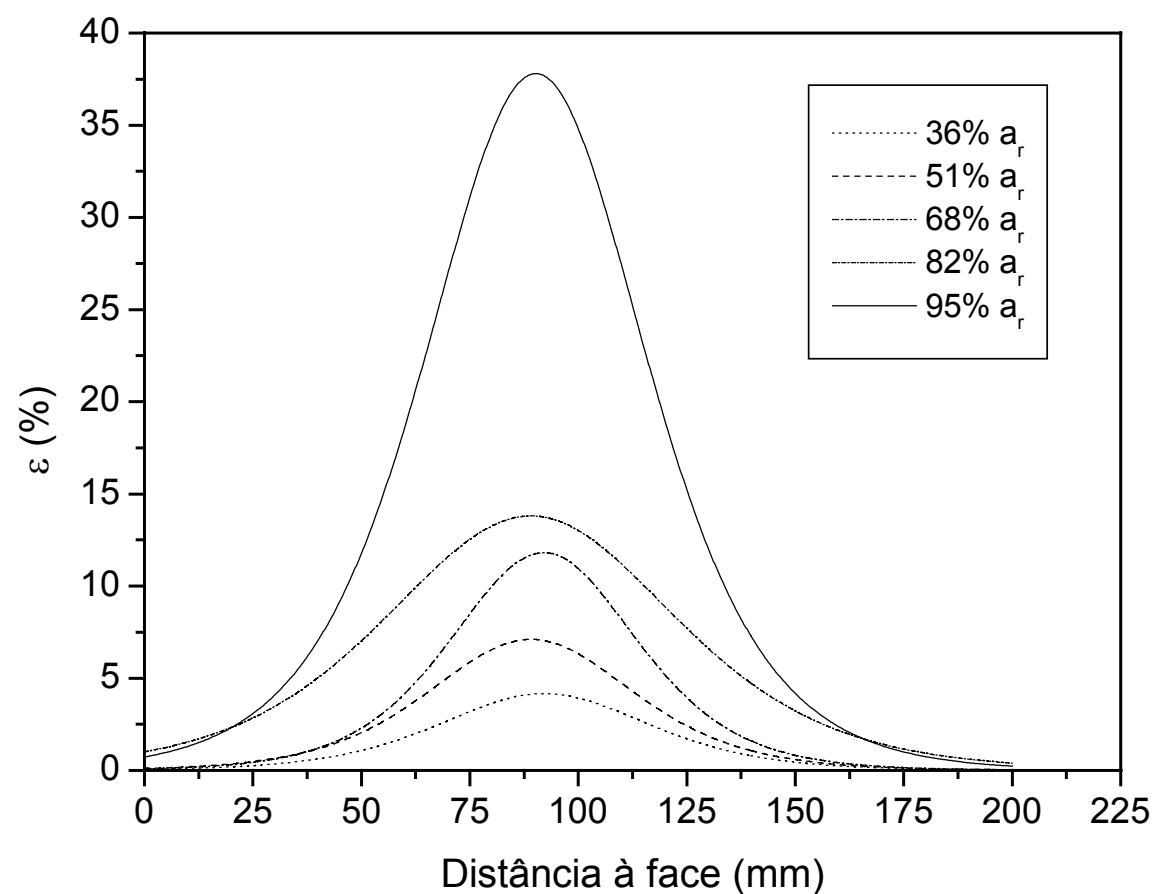

FIGURA B12 - Deformações obtidas para o ensaio R-PET-3, camada 11. 


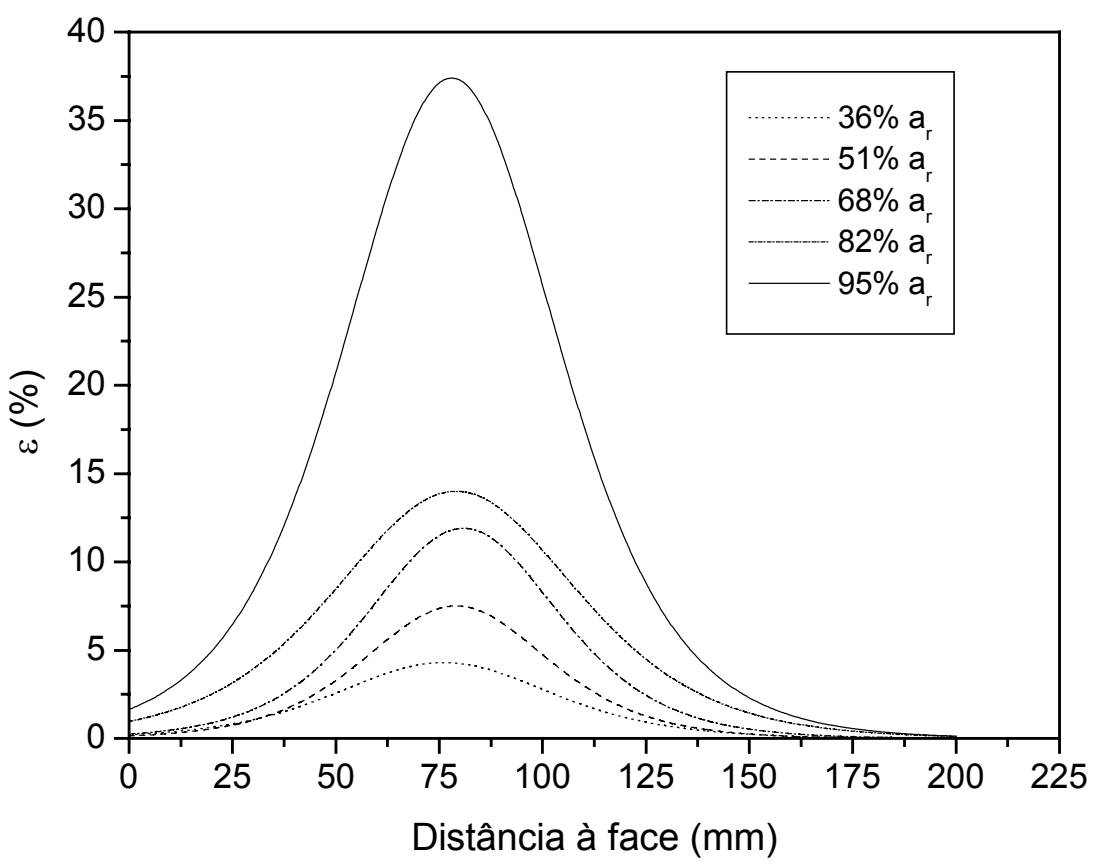

FIGURA B13 - Deformações obtidas para o ensaio R-PET-3, camada 10.

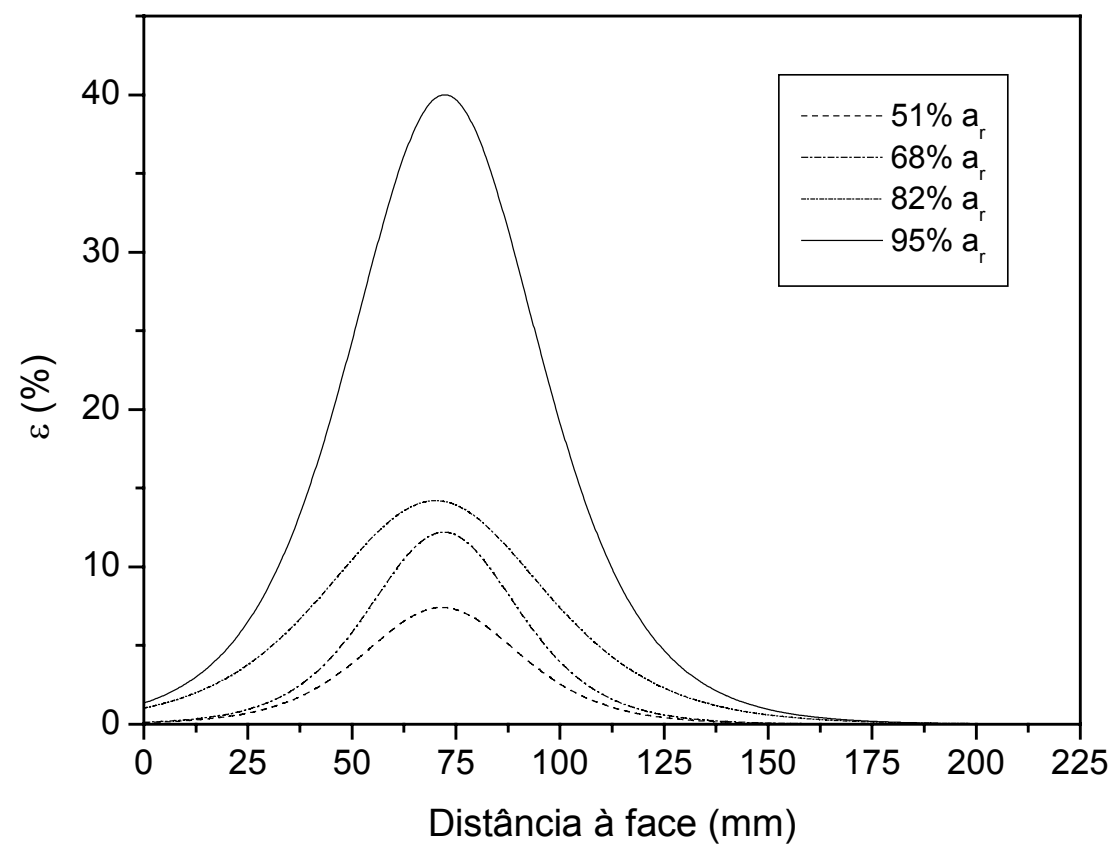

FIGURA B14 - Deformações obtidas para o ensaio R-PET-3, camada 9. 


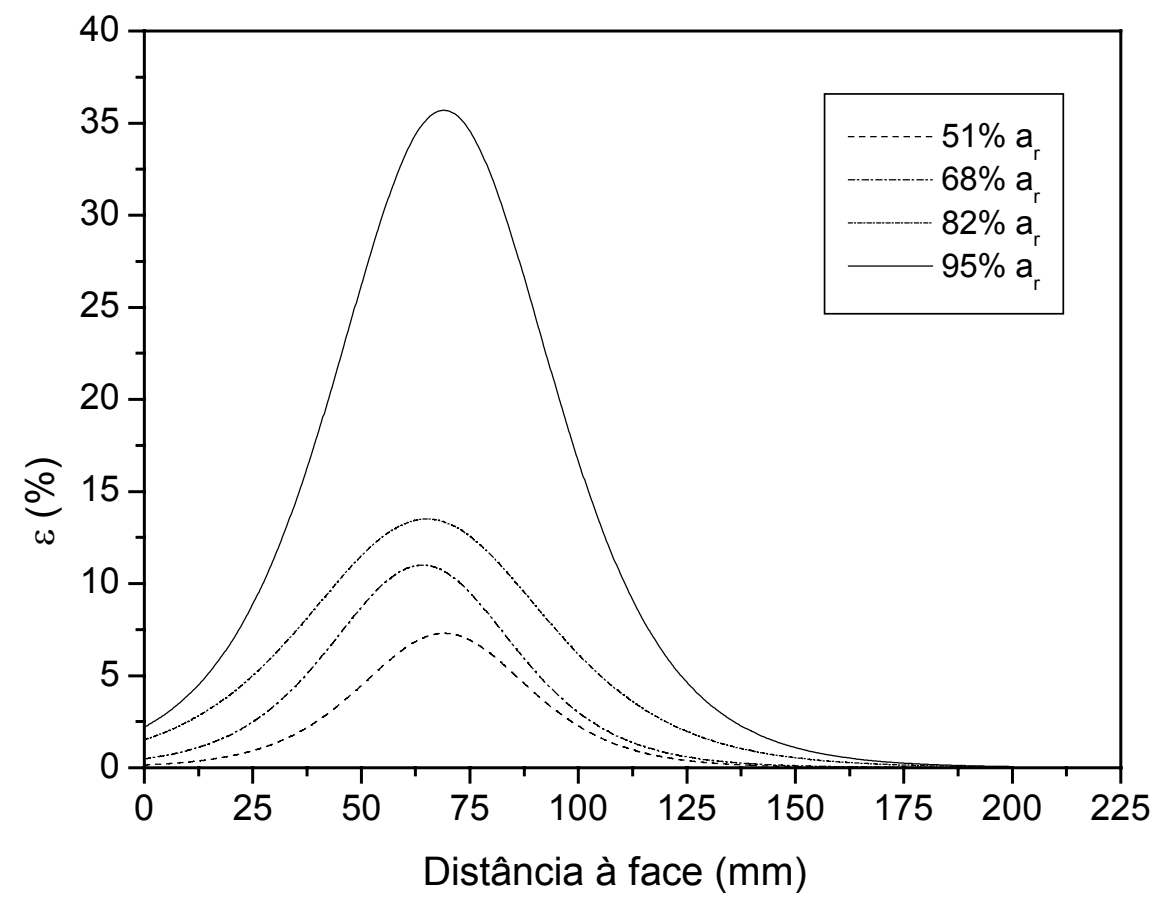

FIGURA B15 - Deformações obtidas para o ensaio R-PET-3, camada 8.

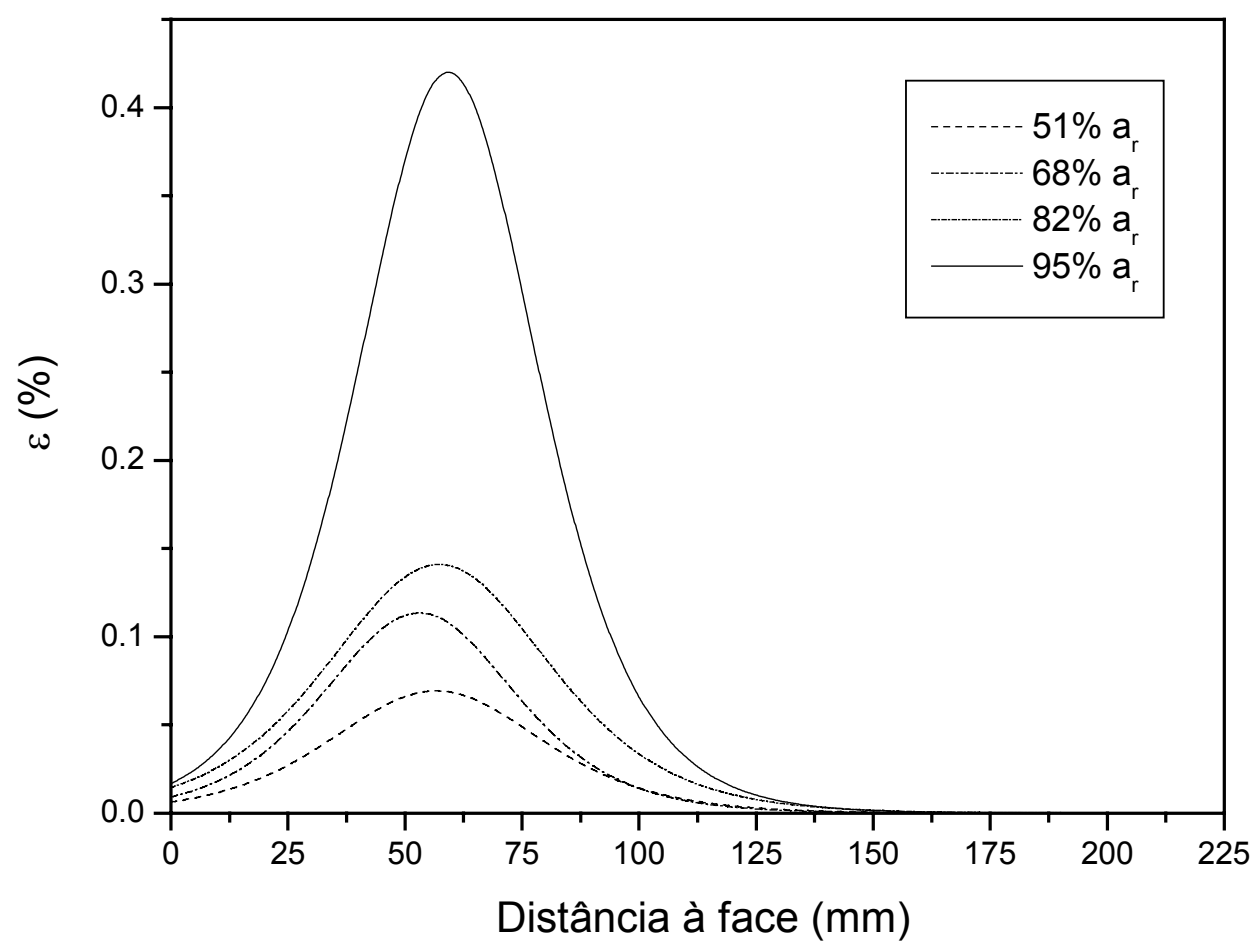

FIGURA B16 - Deformações obtidas para o ensaio R-PET-3, camada 7. 


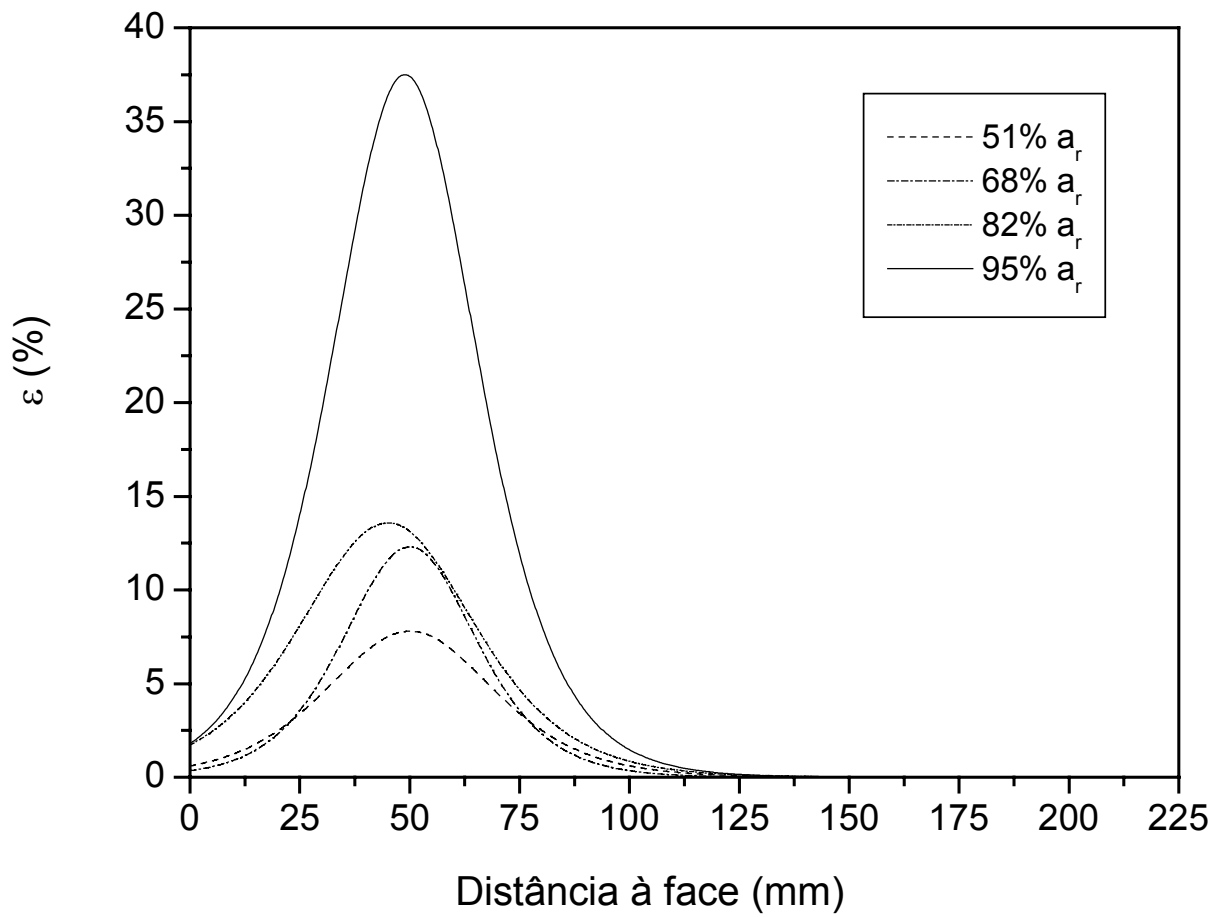

FIGURA B17 - Deformações obtidas para o ensaio R-PET-3, camada 6.

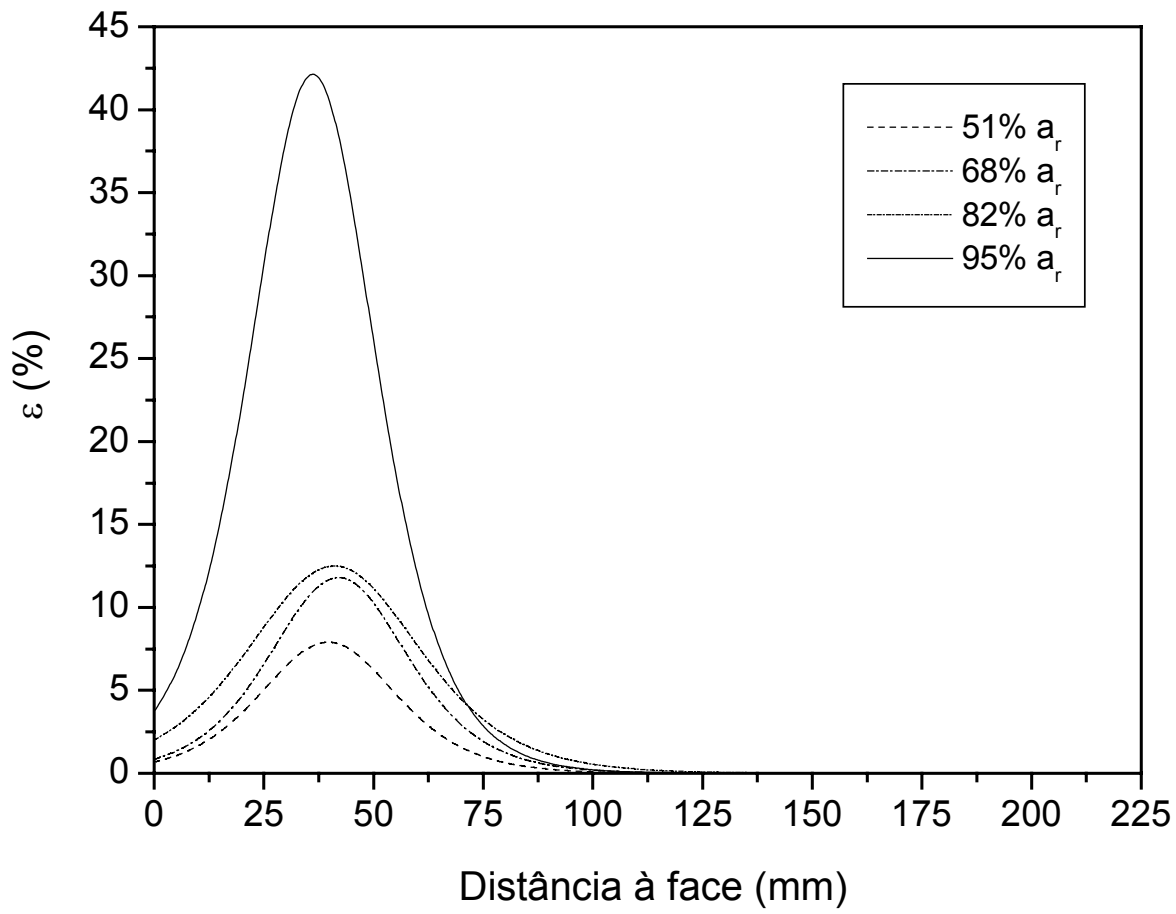

FIGURA B18 - Deformações obtidas para o ensaio R-PET-3, camada 5. 


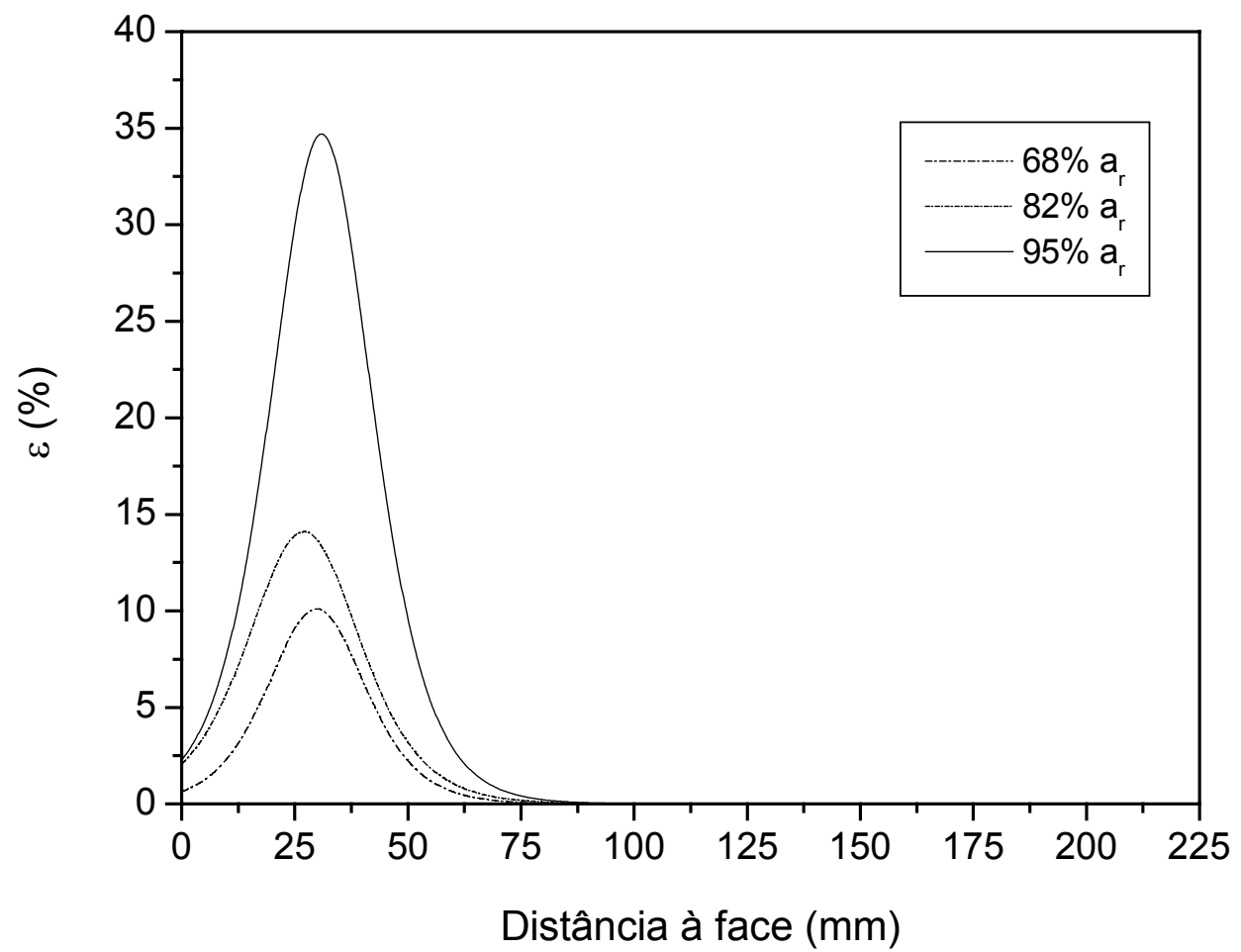

FIGURA B19 - Deformações obtidas para o ensaio R-PET-3, camada 4.

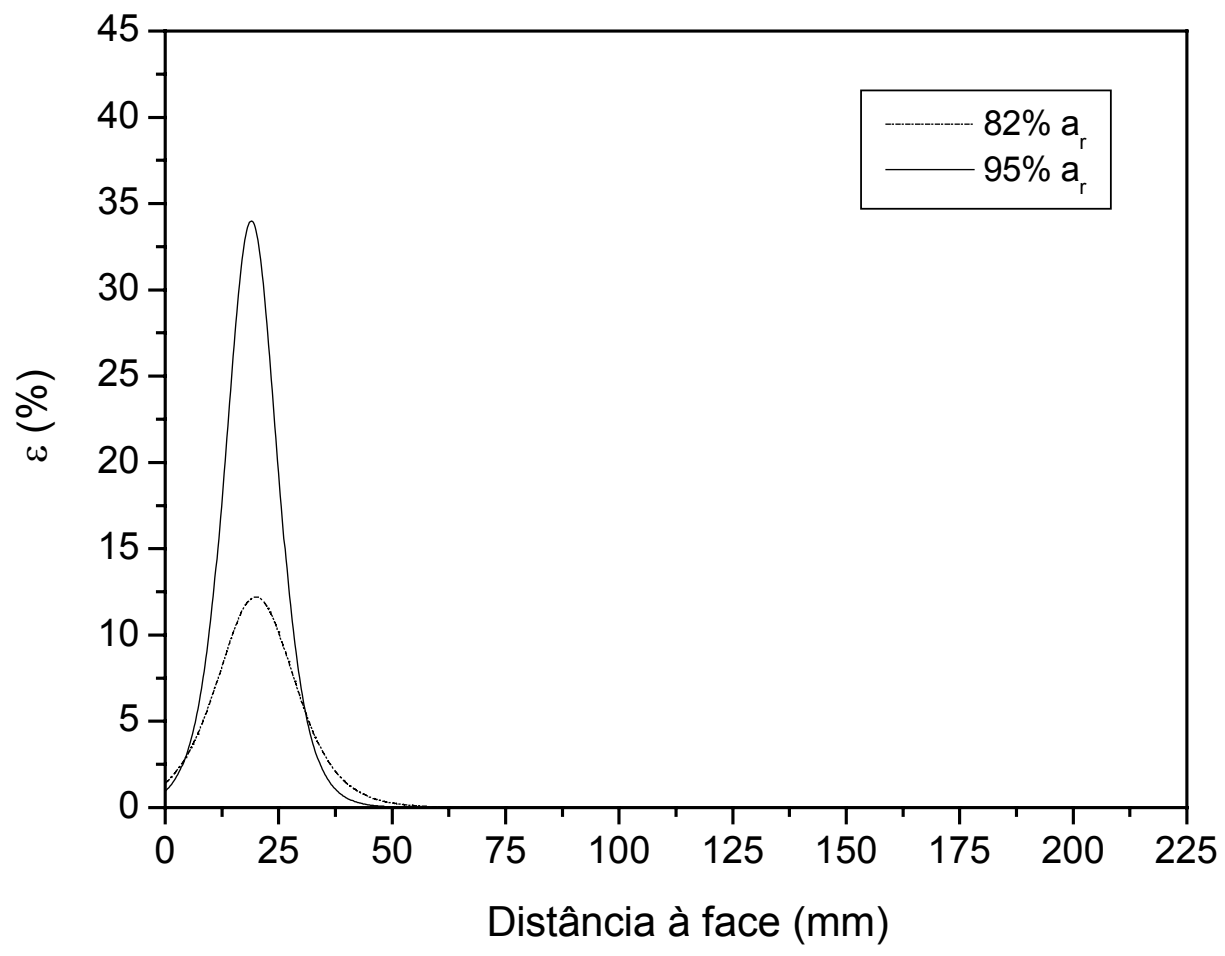

FIGURA B20 - Deformações obtidas para o ensaio R-PET-3, camada 3. 


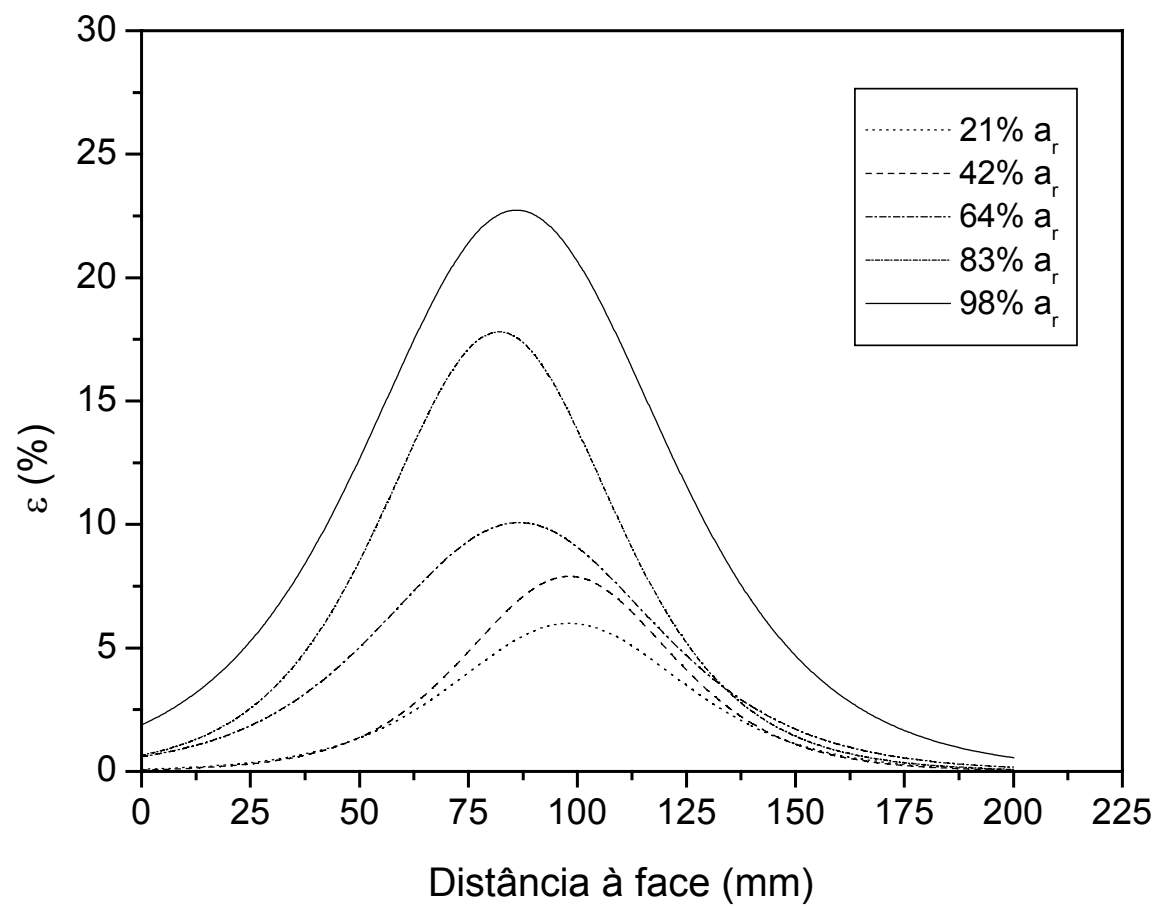

FIGURA B21 - Deformações obtidas para o ensaio R-PP-1, camada 12.

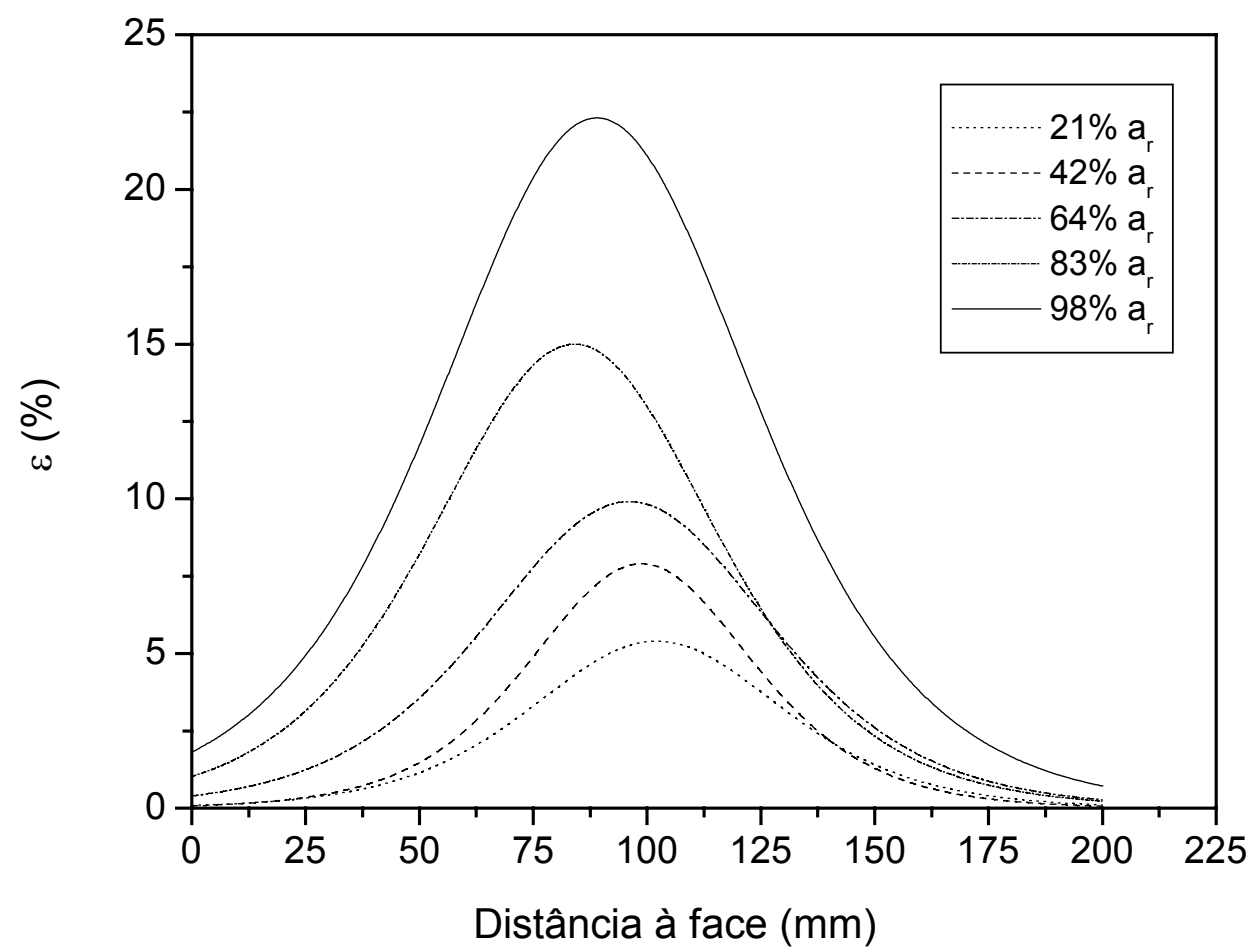

FIGURA B22- Deformações obtidas para o ensaio R-PP-1, camada 11. 


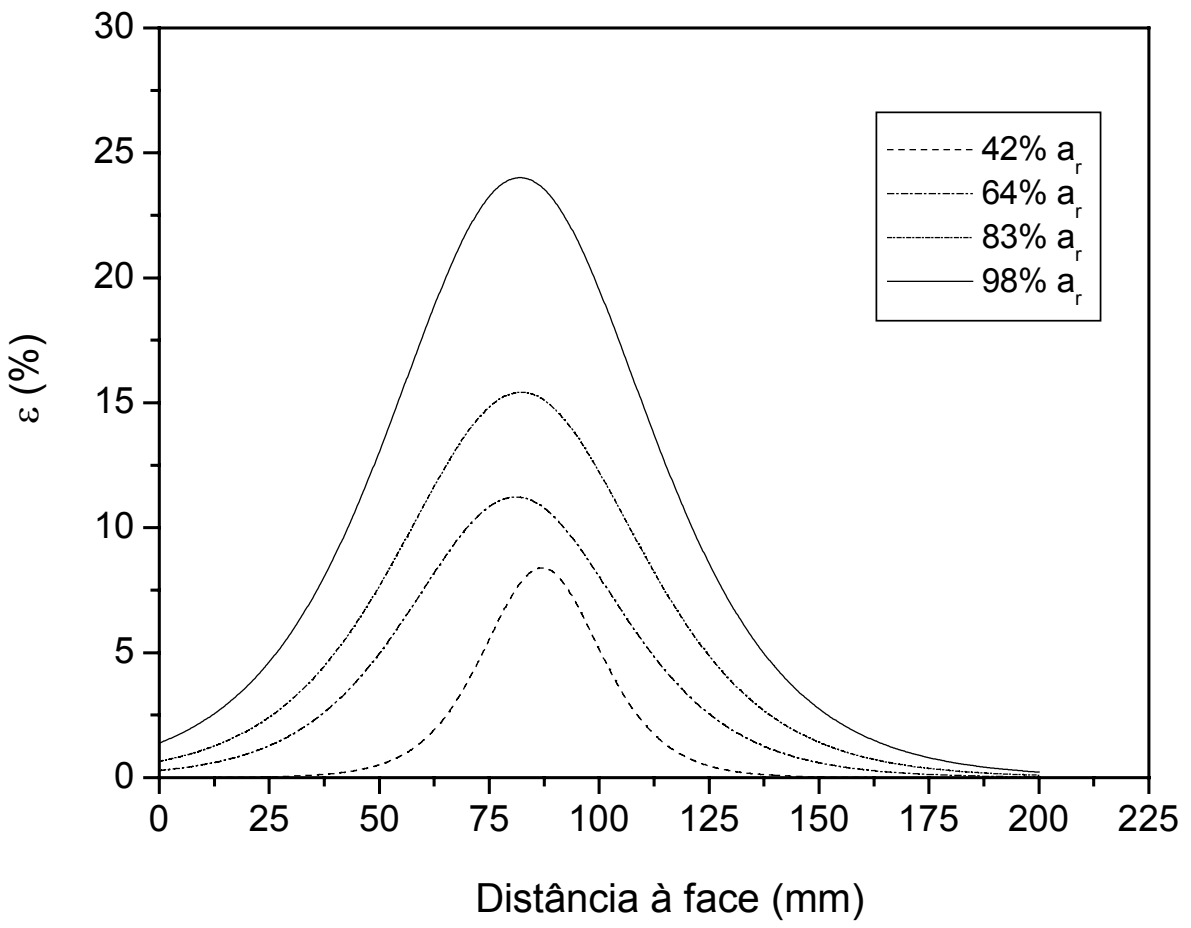

FIGURA B23- Deformações obtidas para o ensaio R-PP-1, camada 10.

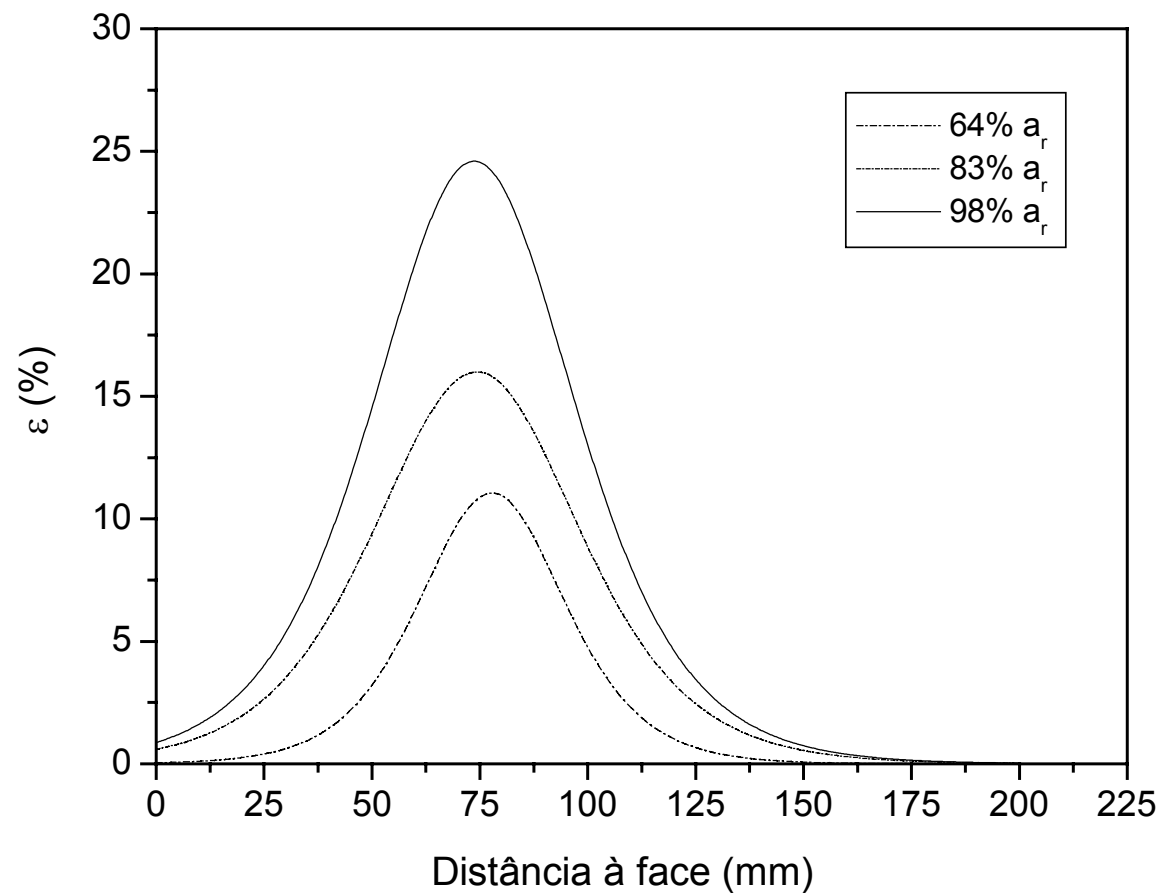

FIGURA B24- Deformações obtidas para o ensaio R-PP-1, camada 9. 


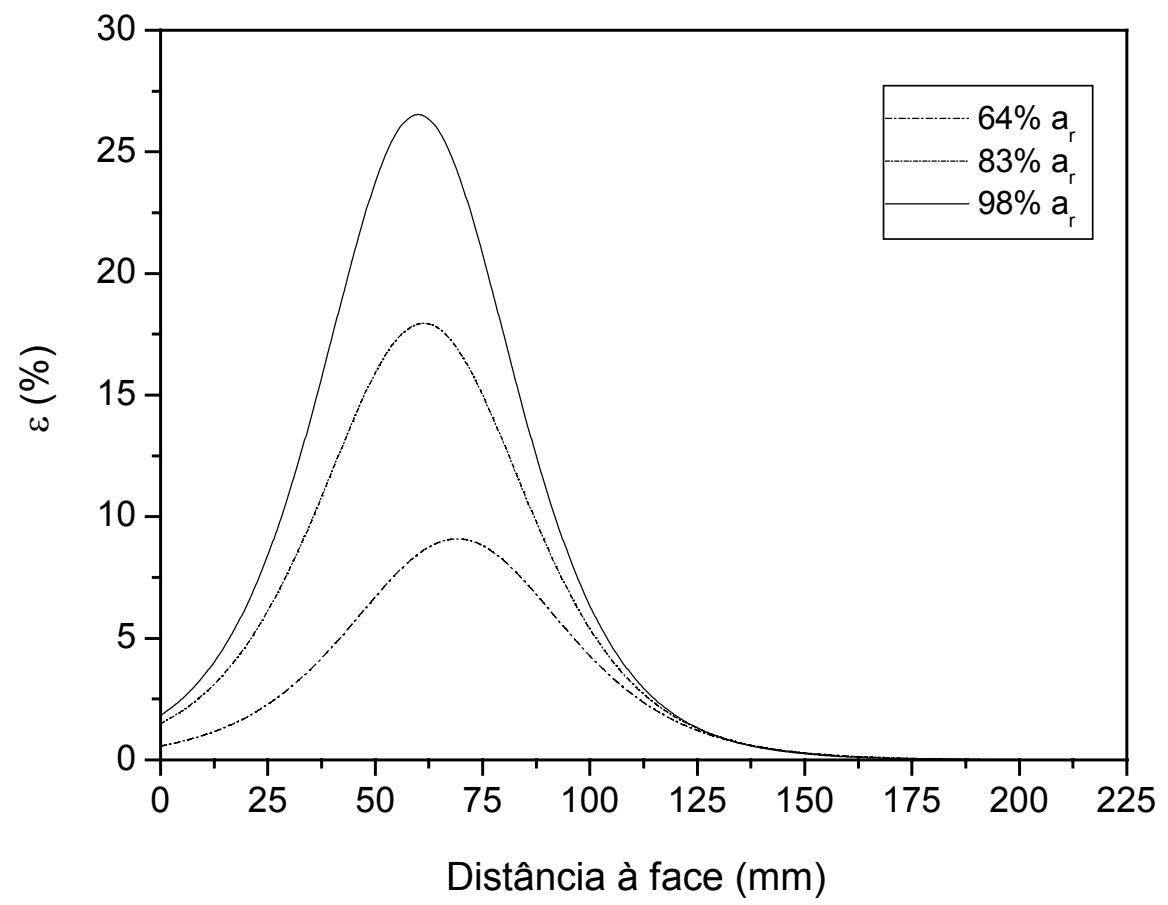

FIGURA B25- Deformações obtidas para o ensaio R-PP-1, camada 8.

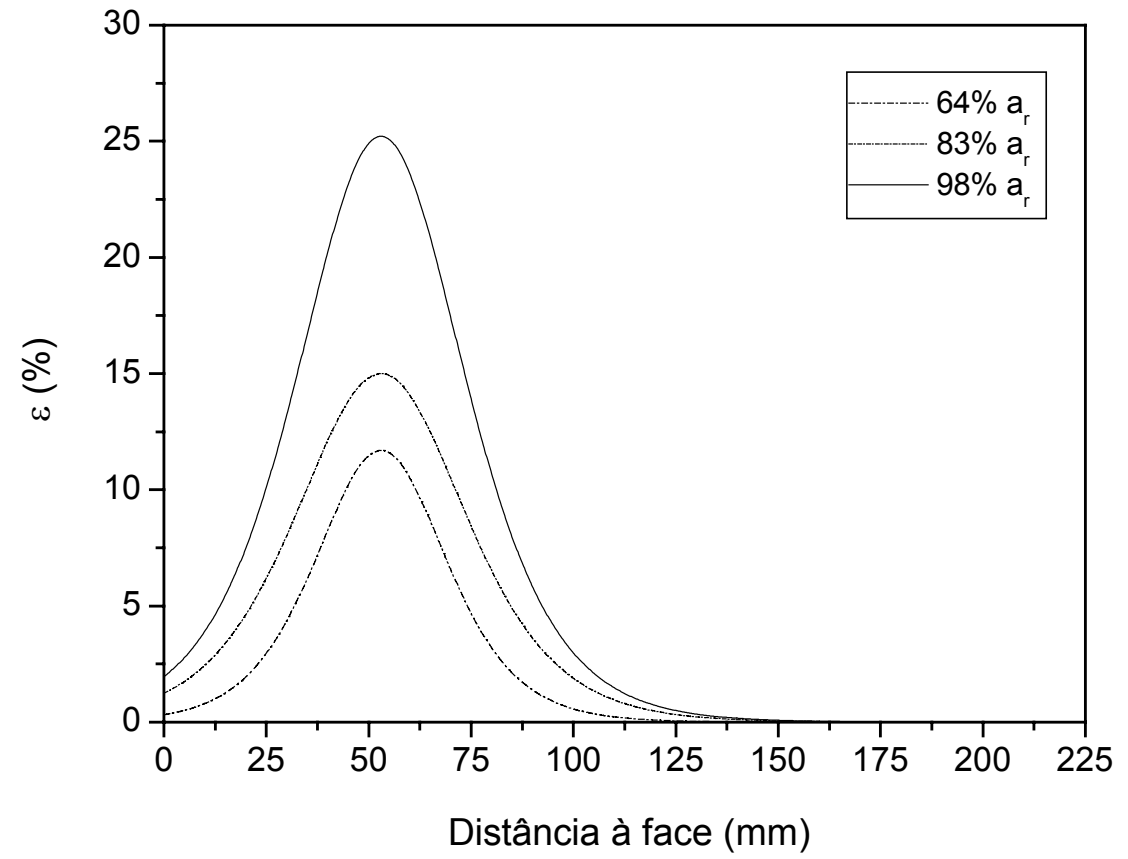

FIGURA B26- Deformações obtidas para o ensaio R-PP-1, camada 7. 


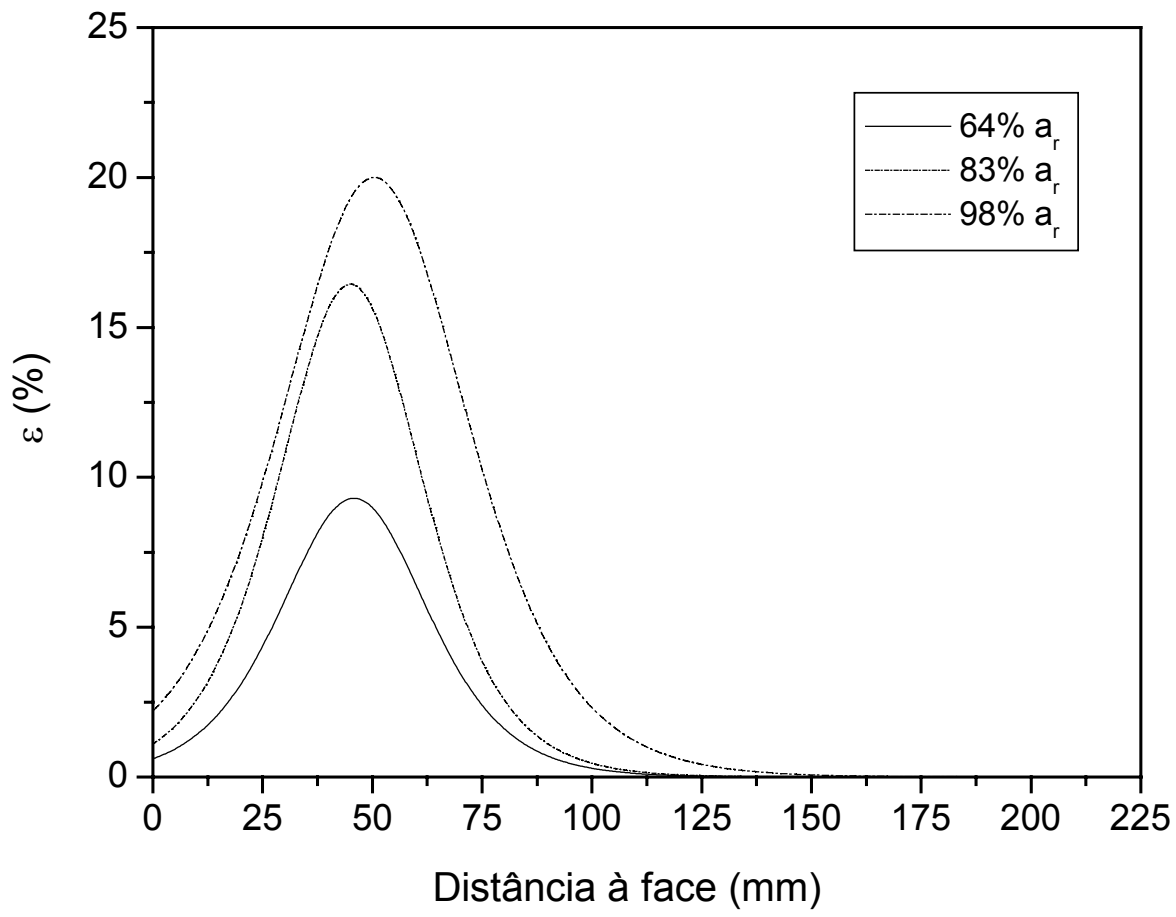

FIGURA B27- Deformações obtidas para o ensaio R-PP-1, camada 6.

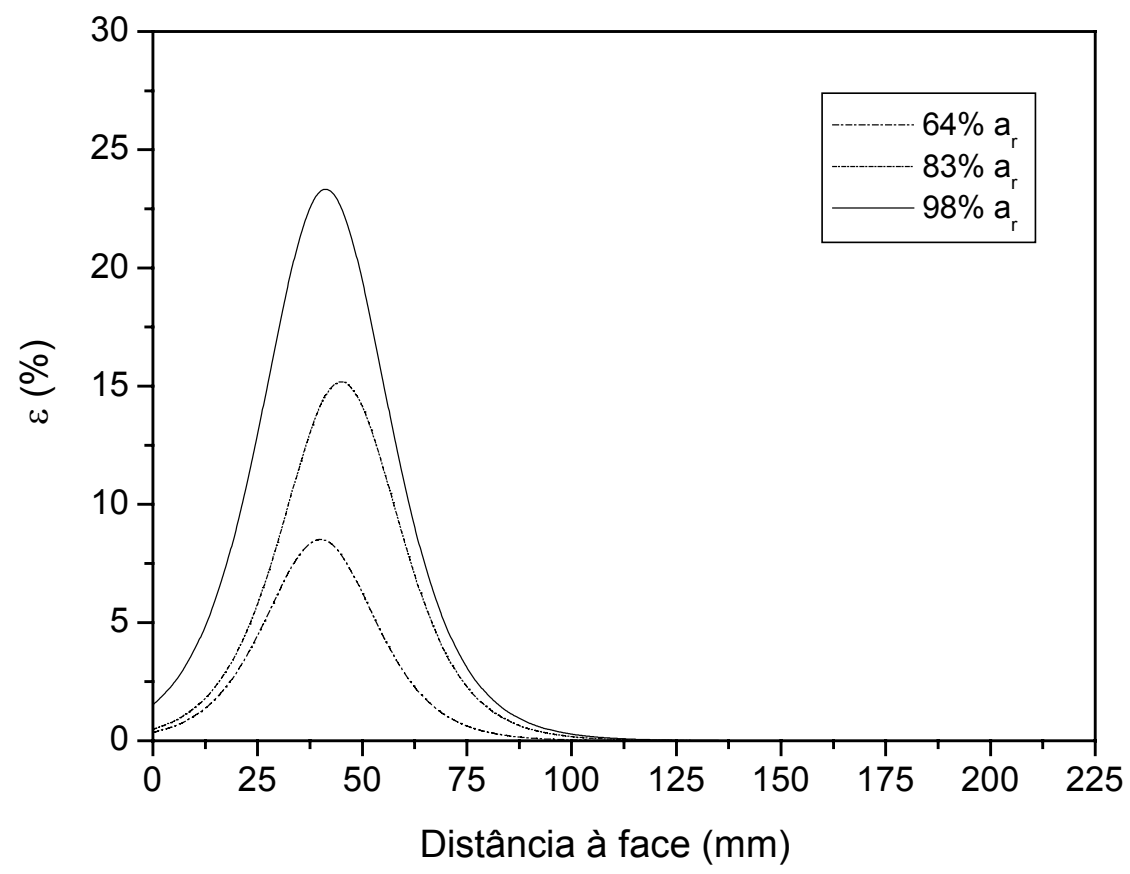

FIGURA B28- Deformações obtidas para o ensaio R-PP-1, camada 5. 


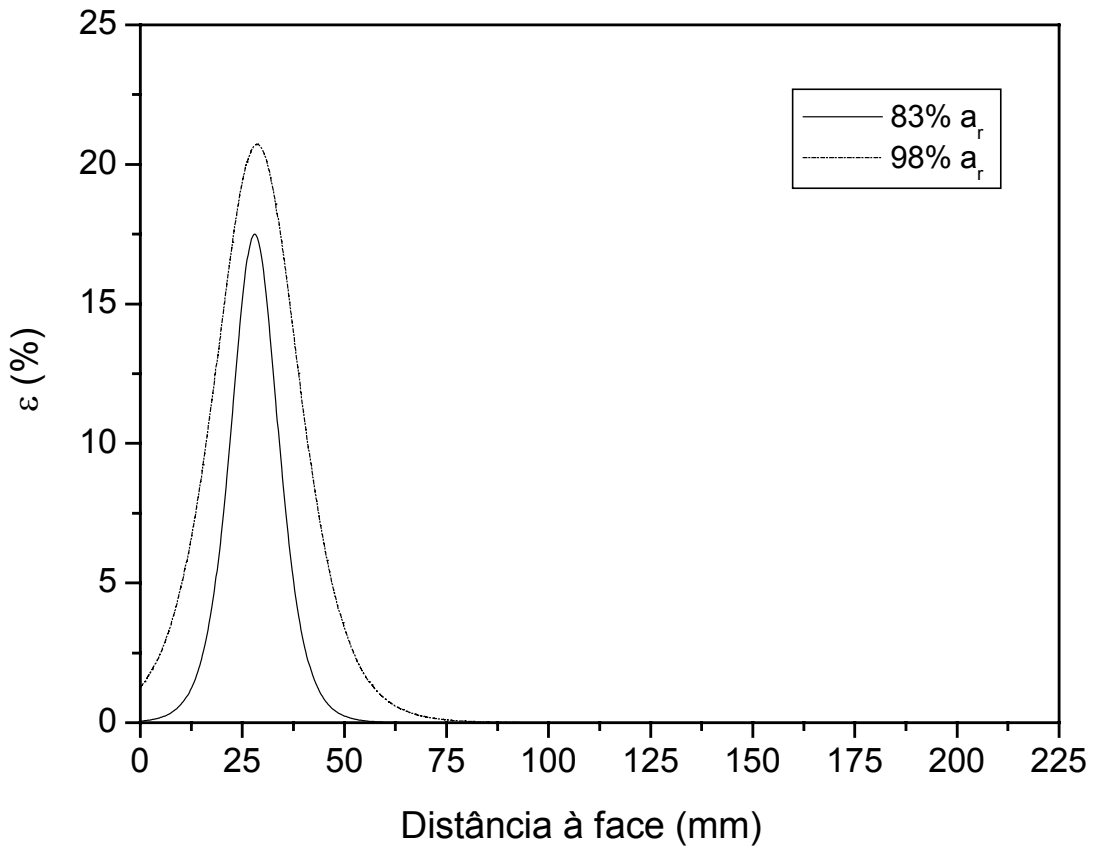

FIGURA B29- Deformações obtidas para o ensaio R-PP-1, camada 4.

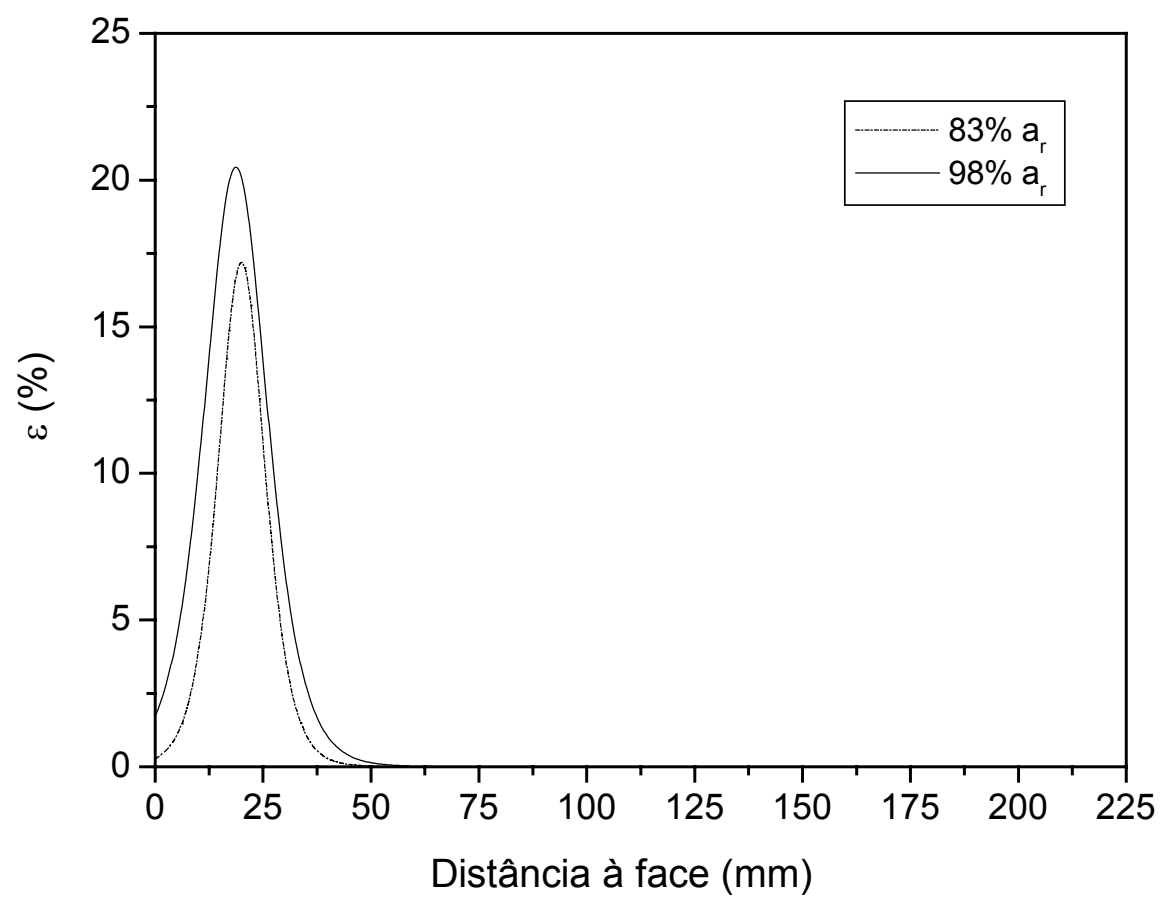

FIGURA B30- Deformações obtidas para o ensaio R-PP-1, camada 3. 


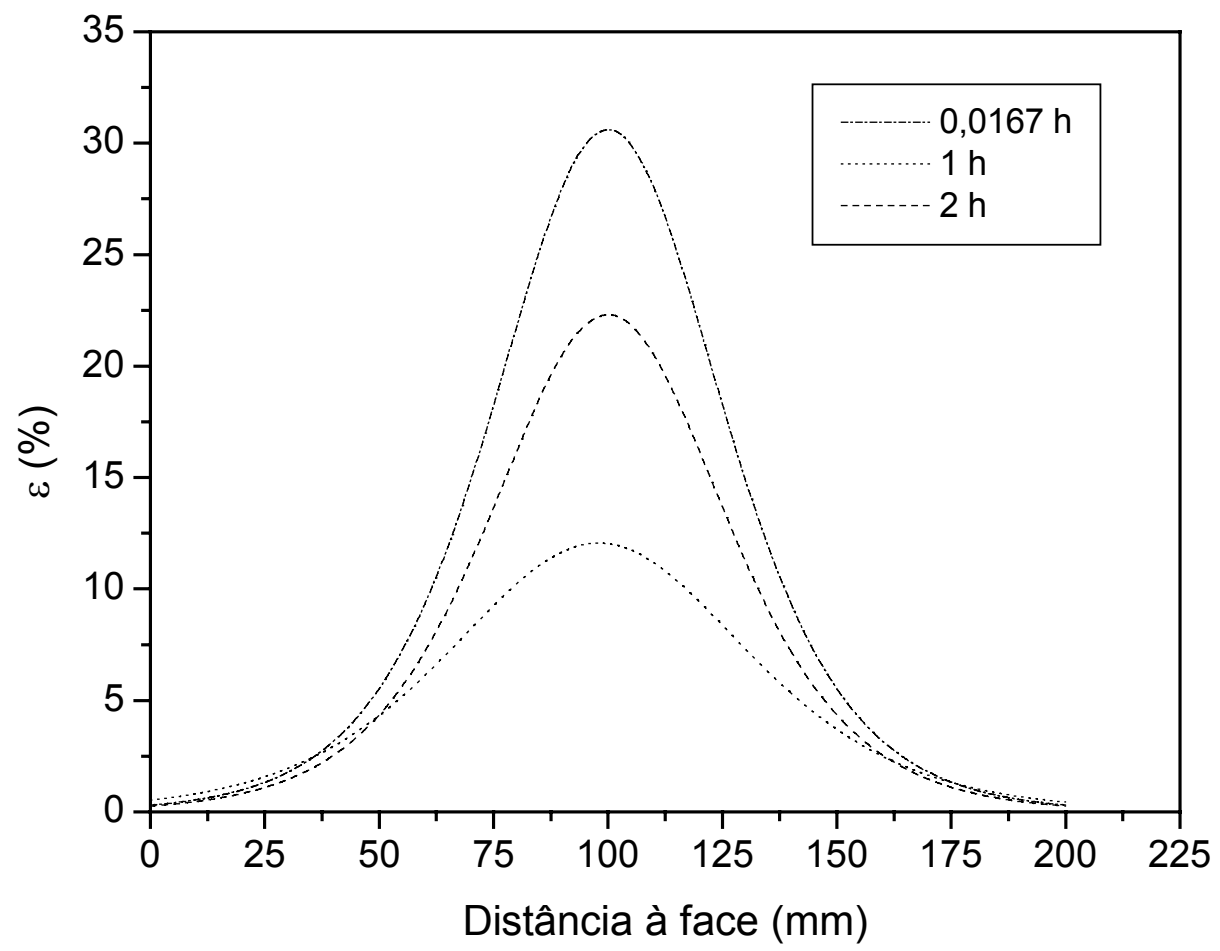

FIGURA B31- Deformações obtidas para o ensaio F-PET-4, camada 12.

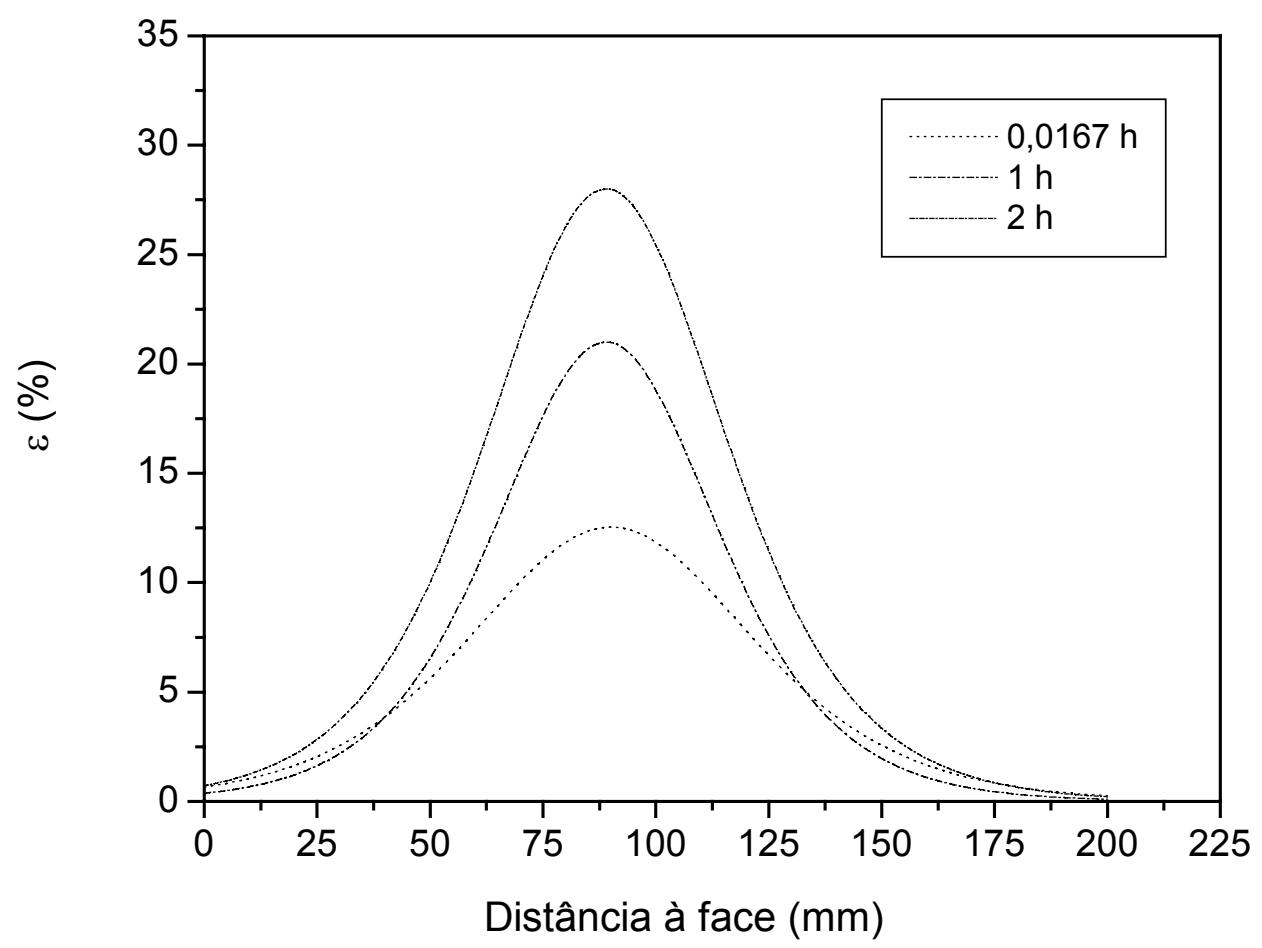

FIGURA B32- Deformações obtidas para o ensaio F-PET-4, camada 11 


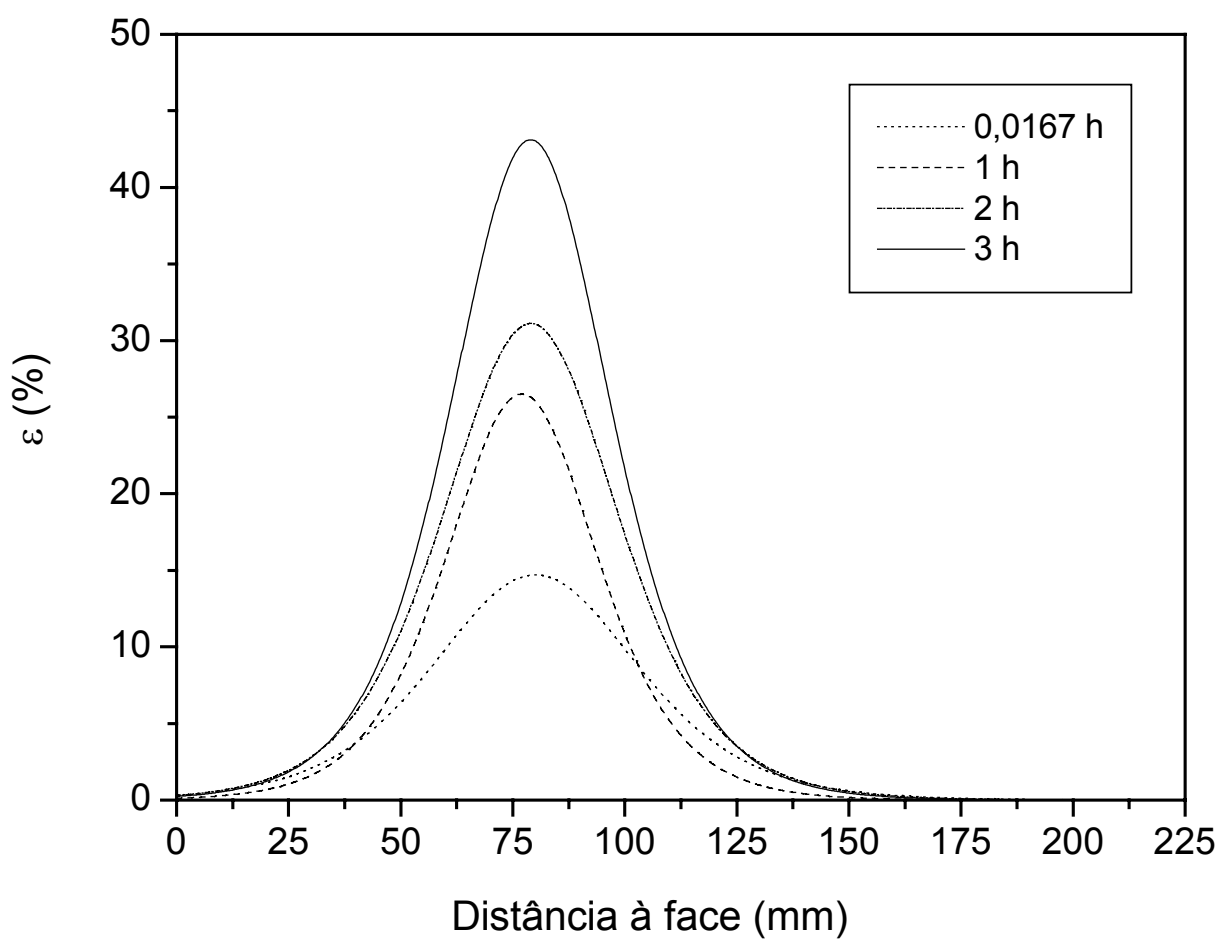

FIGURA B33- Deformações obtidas para o ensaio F-PET-4, camada 10

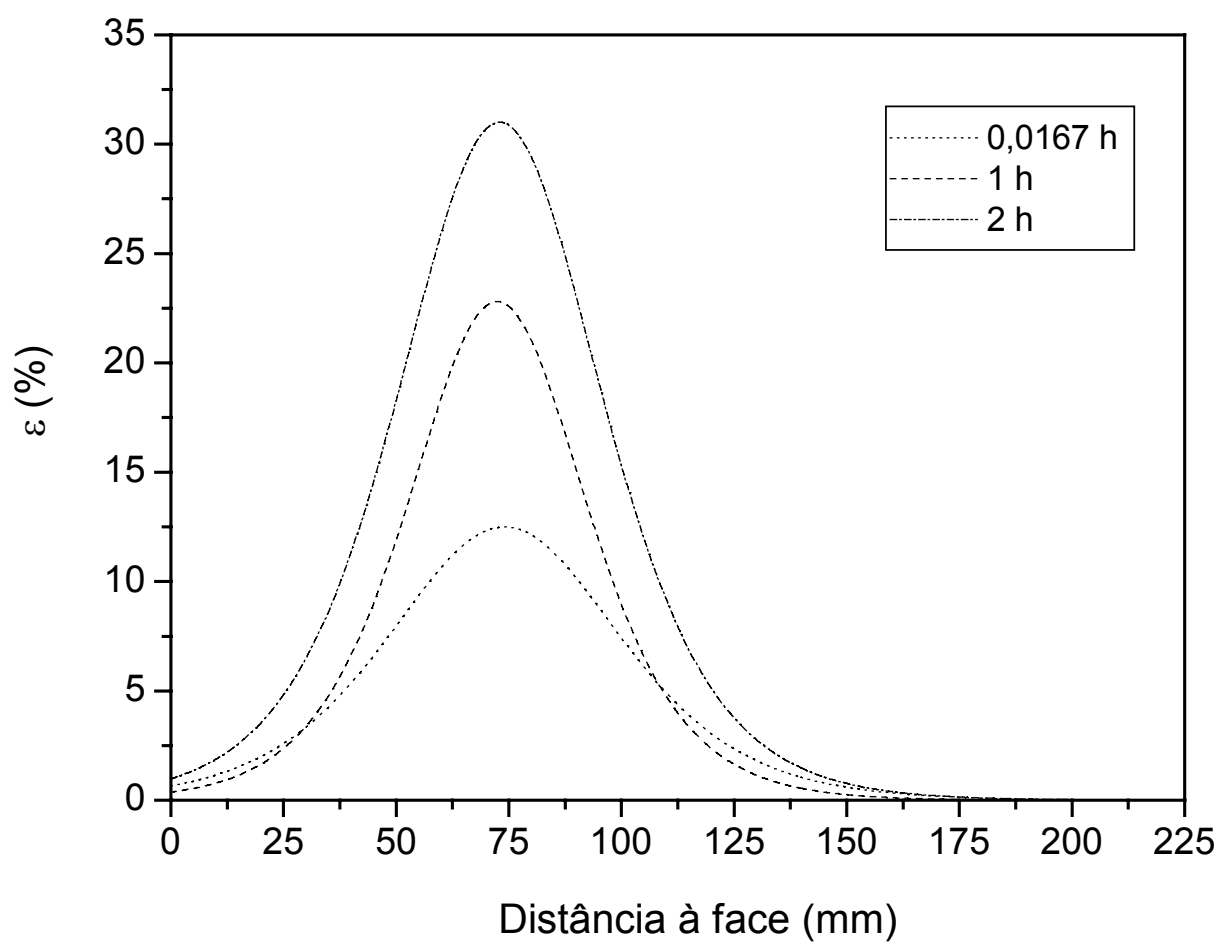

FIGURA B34- Deformações obtidas para o ensaio F-PET-4, camada 9 


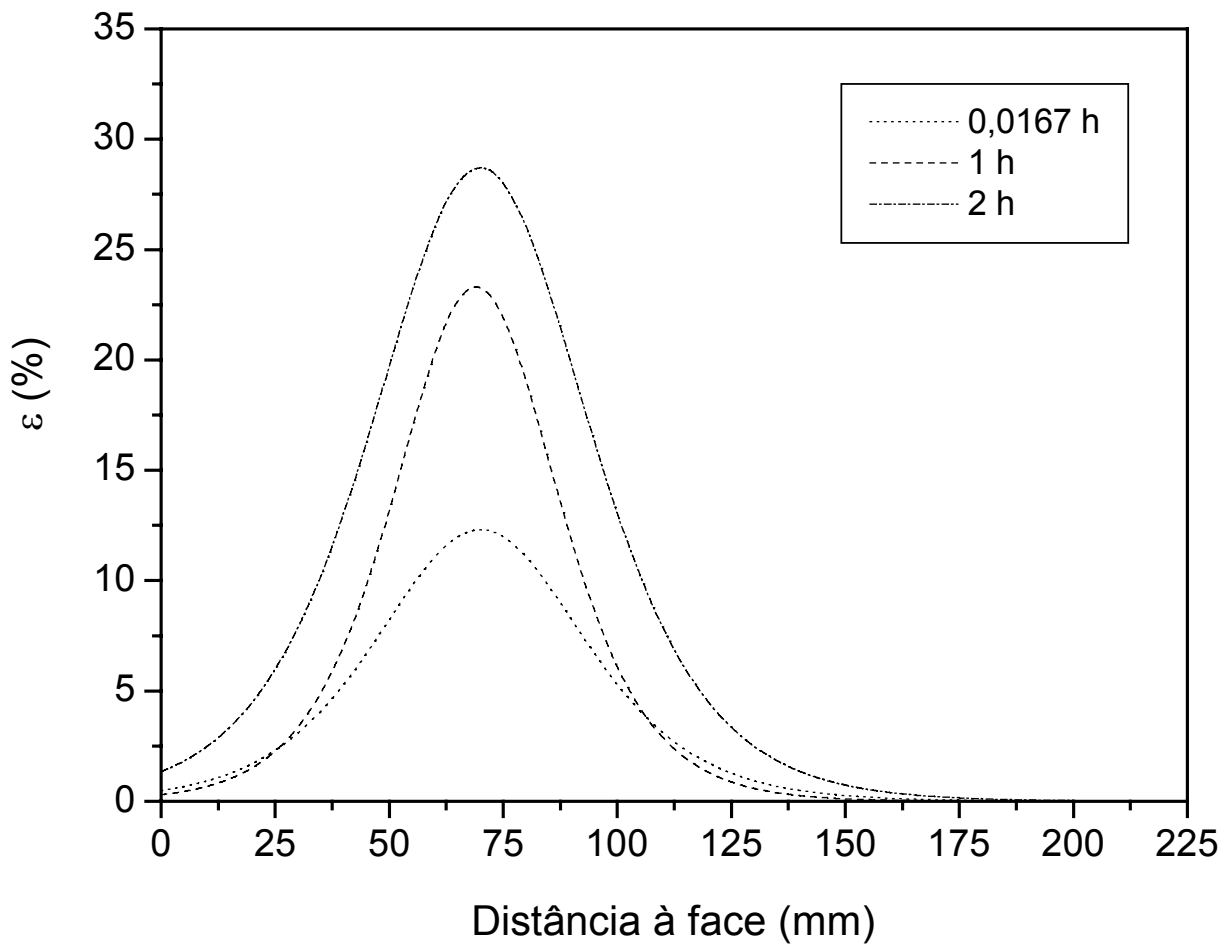

FIGURA B35- Deformações obtidas para o ensaio F-PET-4, camada 8

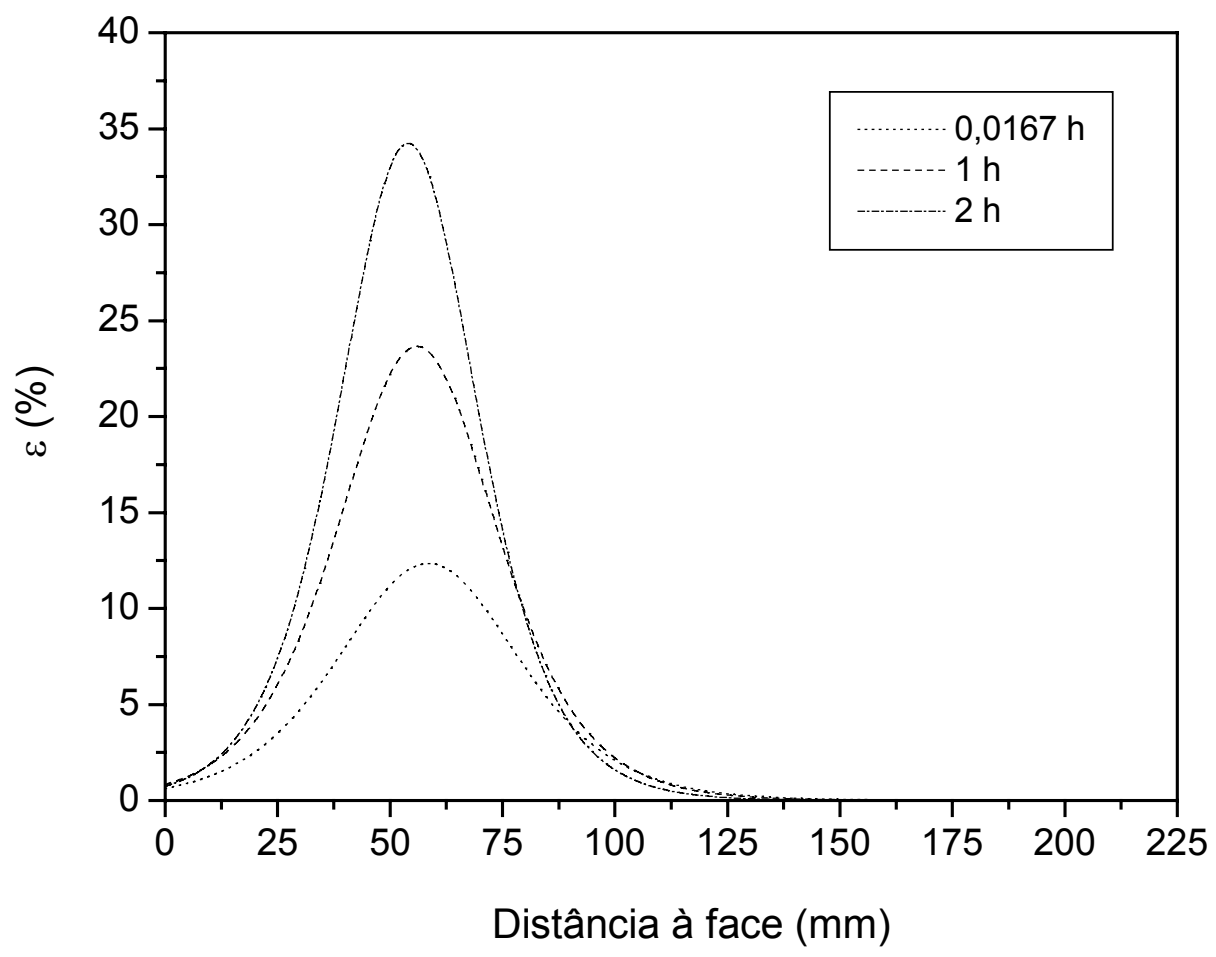

FIGURA B36- Deformações obtidas para o ensaio F-PET-4, camada 7. 


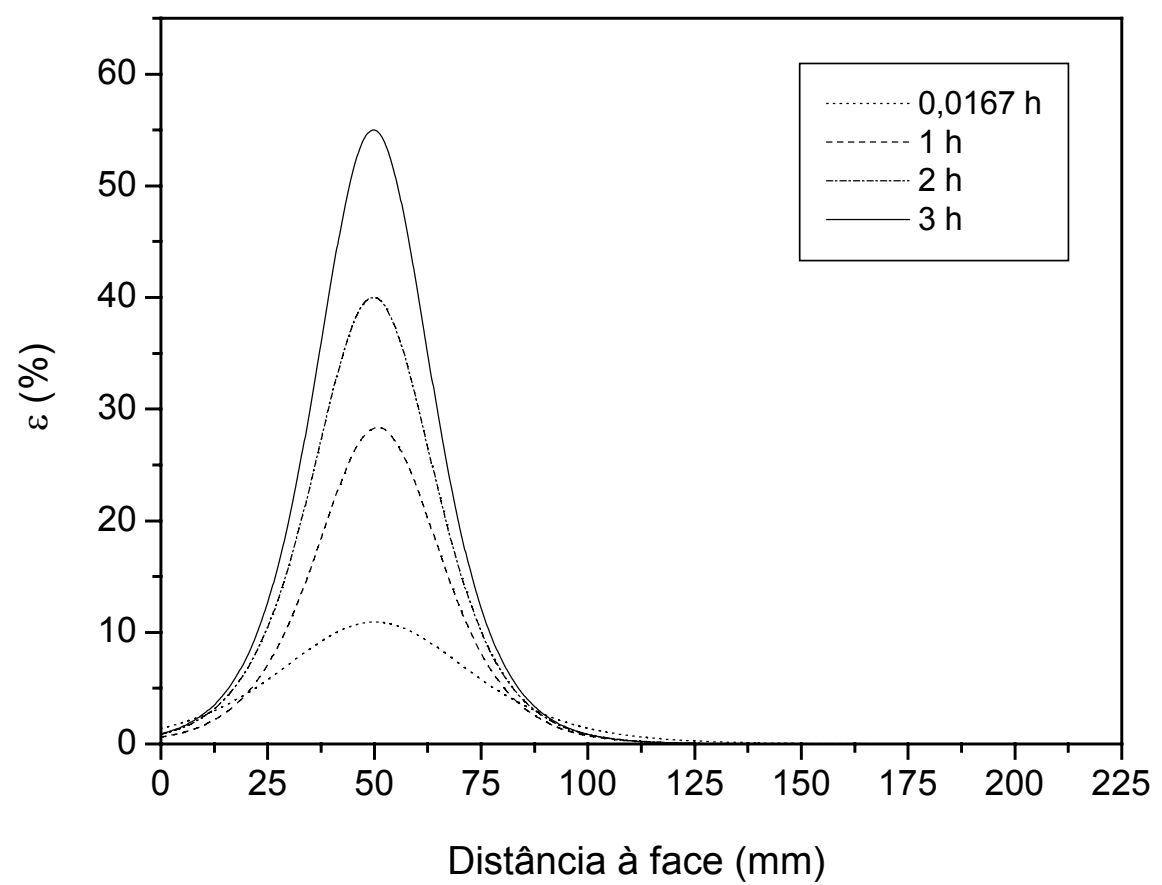

FIGURA B37 - Deformações obtidas para o ensaio F-PET-4, camada 6.

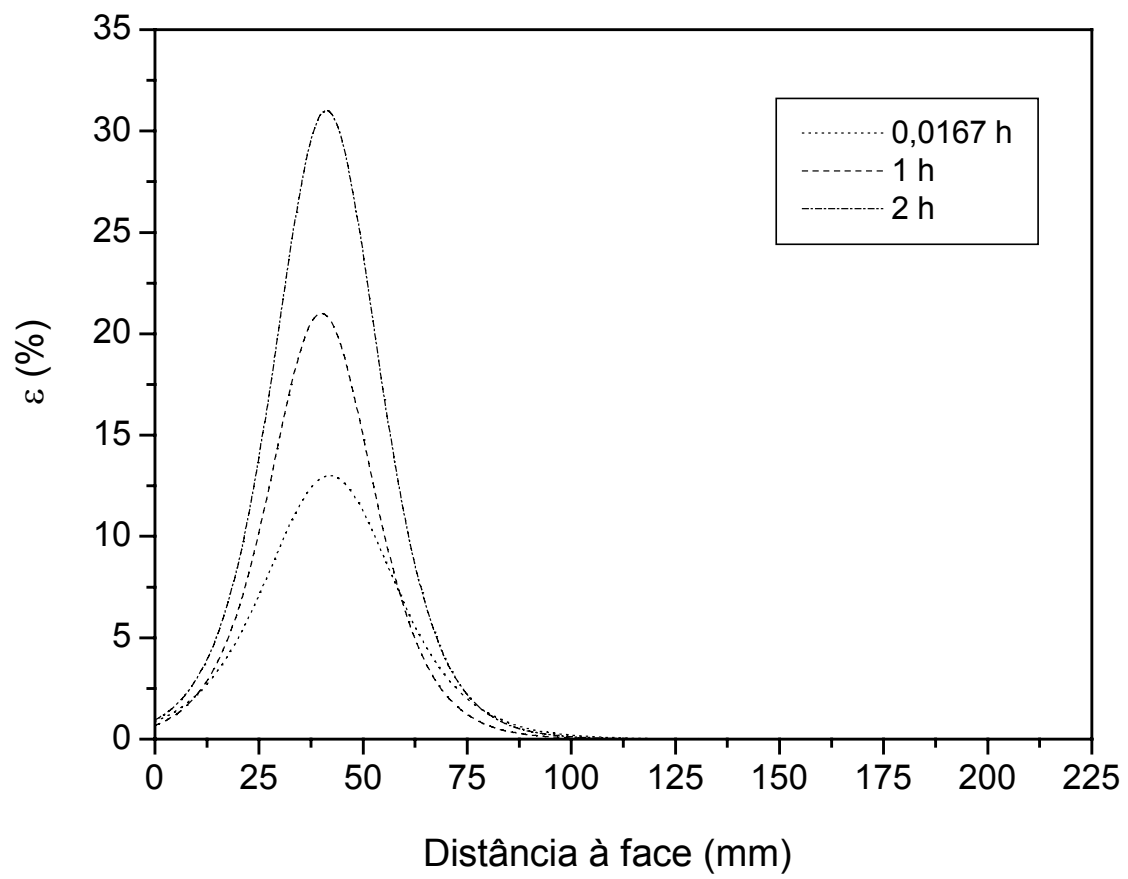

FIGURA B38 - Deformações obtidas para o ensaio F-PET-4, camada 5. 


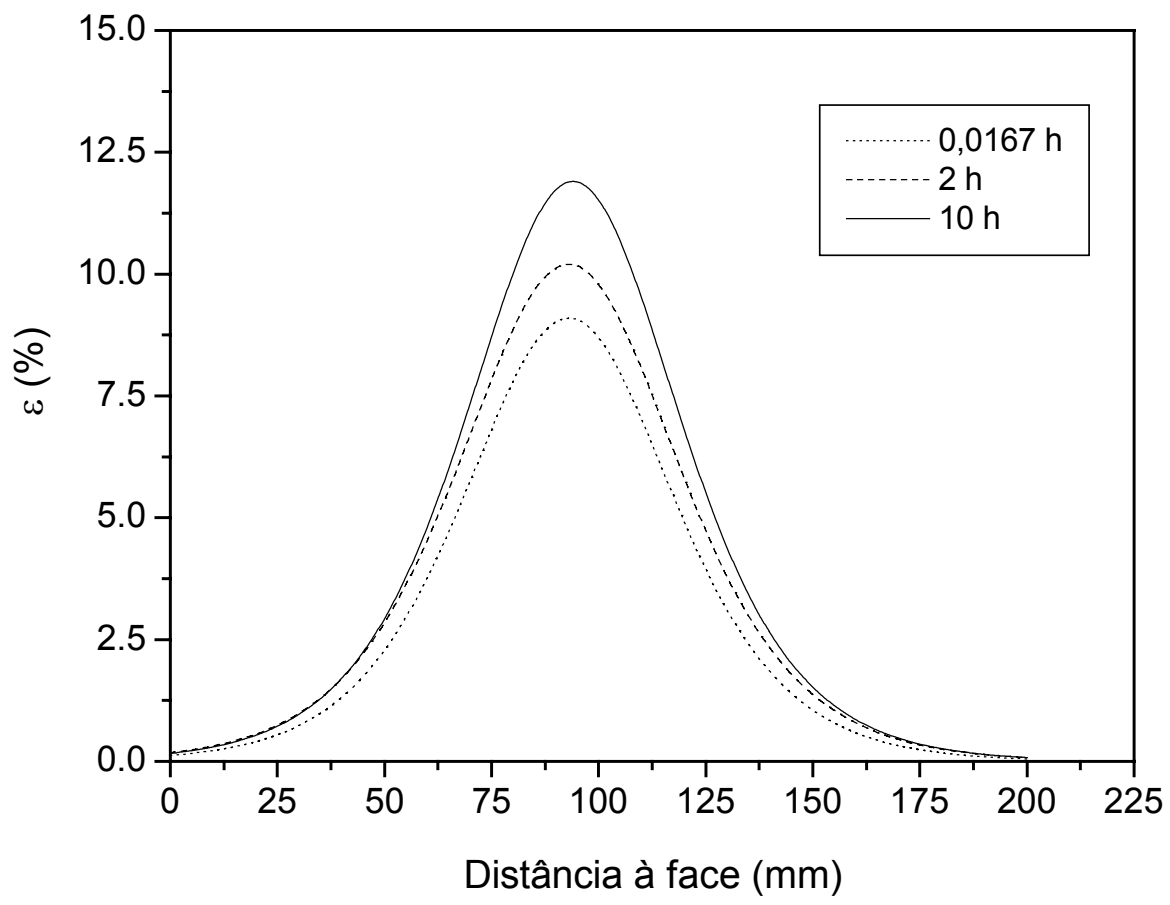

FIGURA B39 - Deformações obtidas para o ensaio F-PET-3, camada 12.

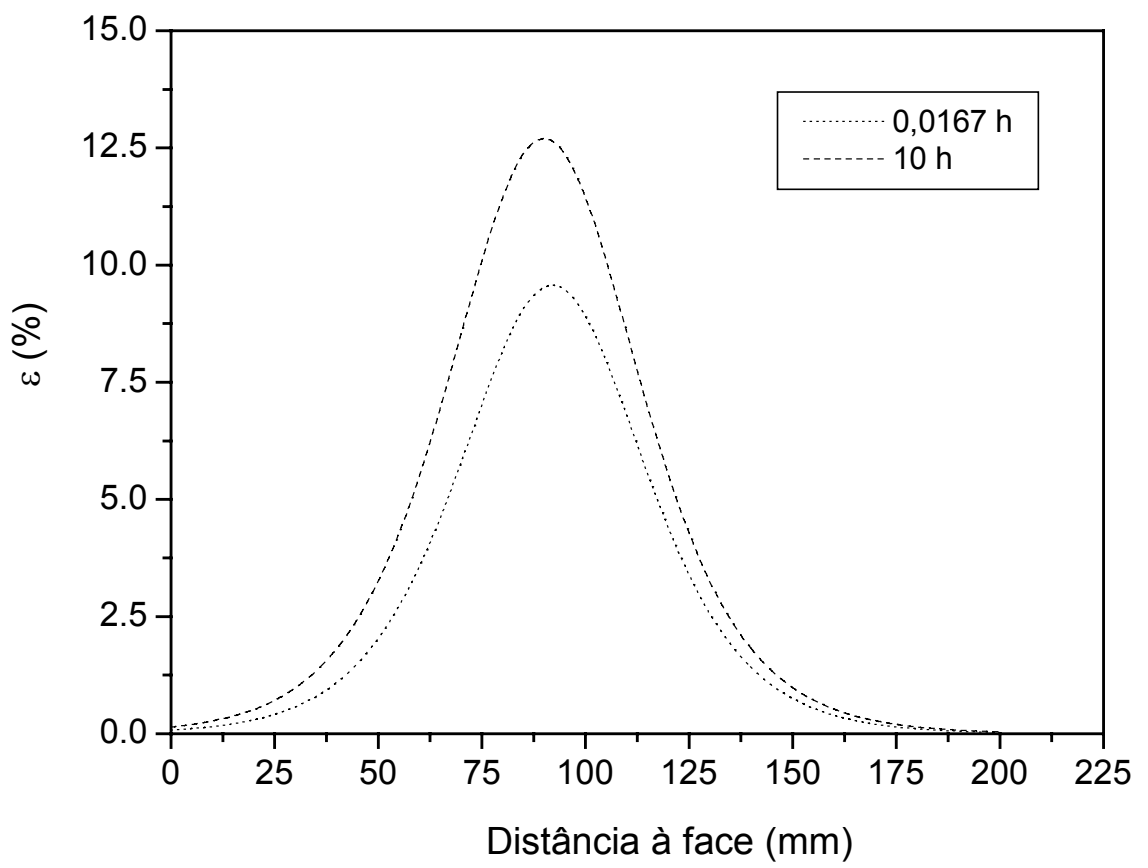

FIGURA B40 - Deformações obtidas para o ensaio F-PET-3, camada 11. 


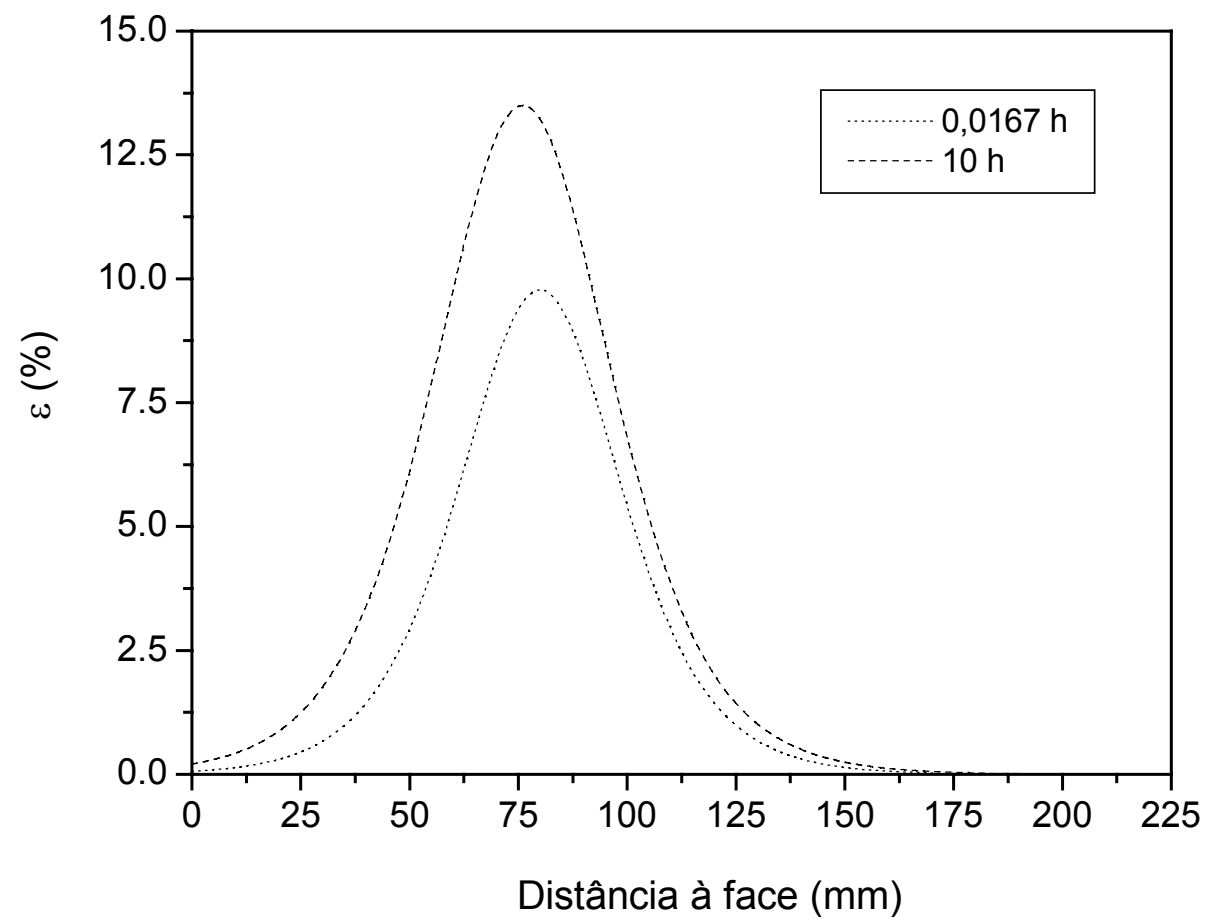

FIGURA B41 - Deformações obtidas para o ensaio F-PET-3, camada 10.

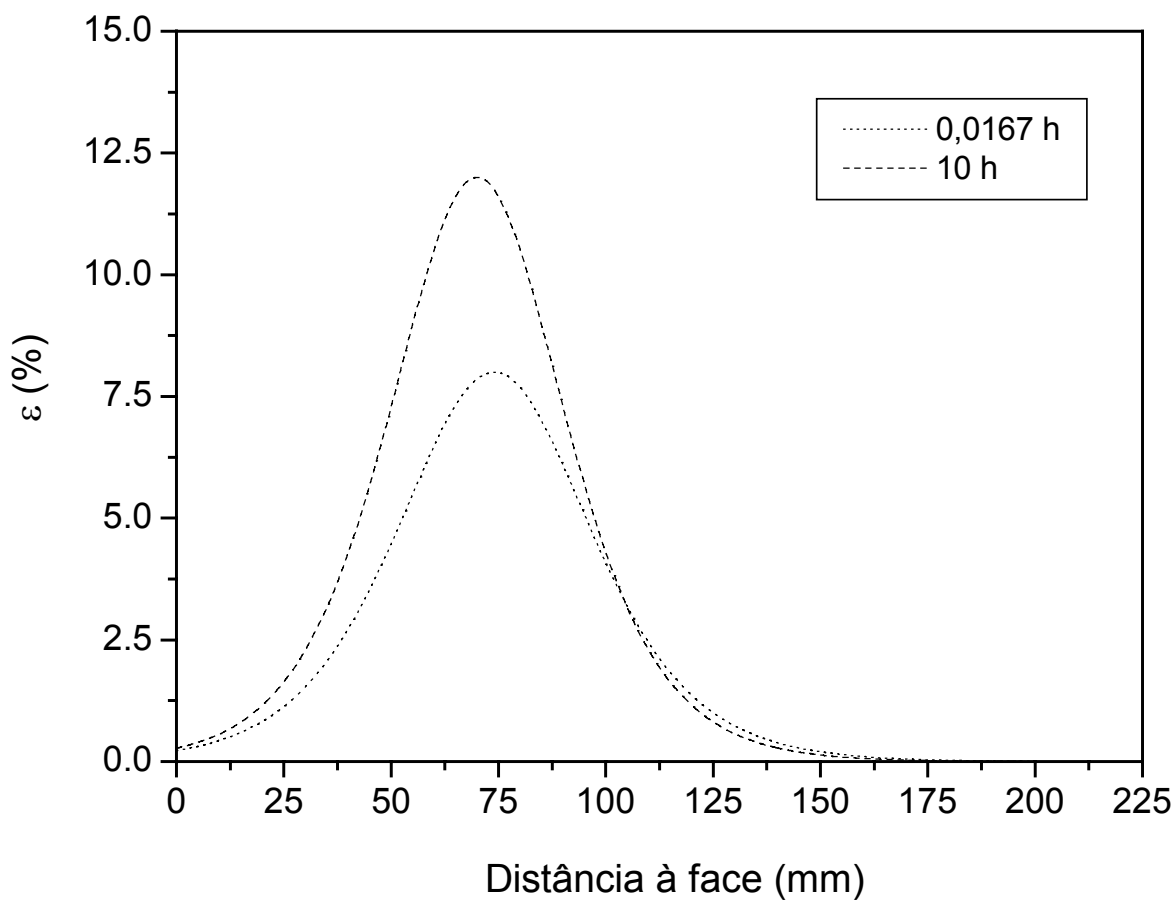

FIGURA B42 - Deformações obtidas para o ensaio F-PET-3, camada 9. 


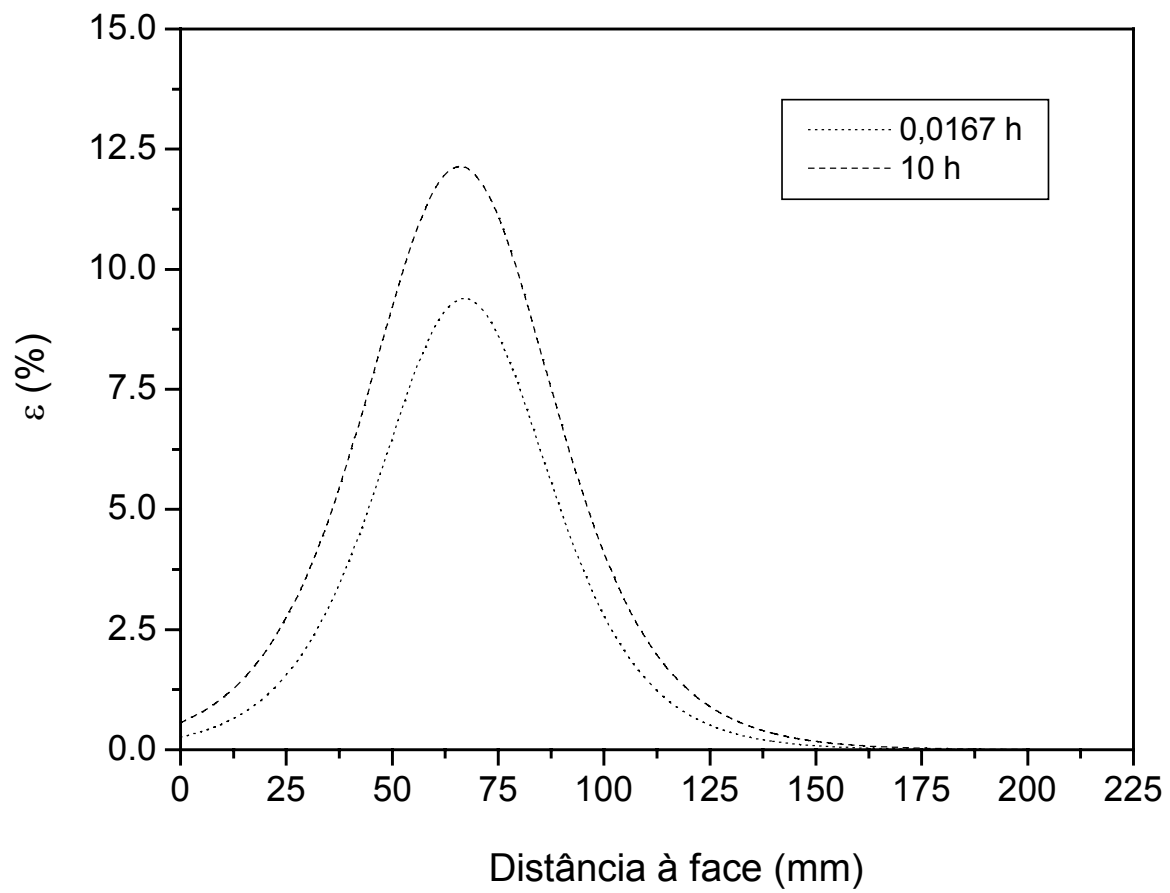

FIGURA B43 - Deformações obtidas para o ensaio F-PET-3, camada 8.

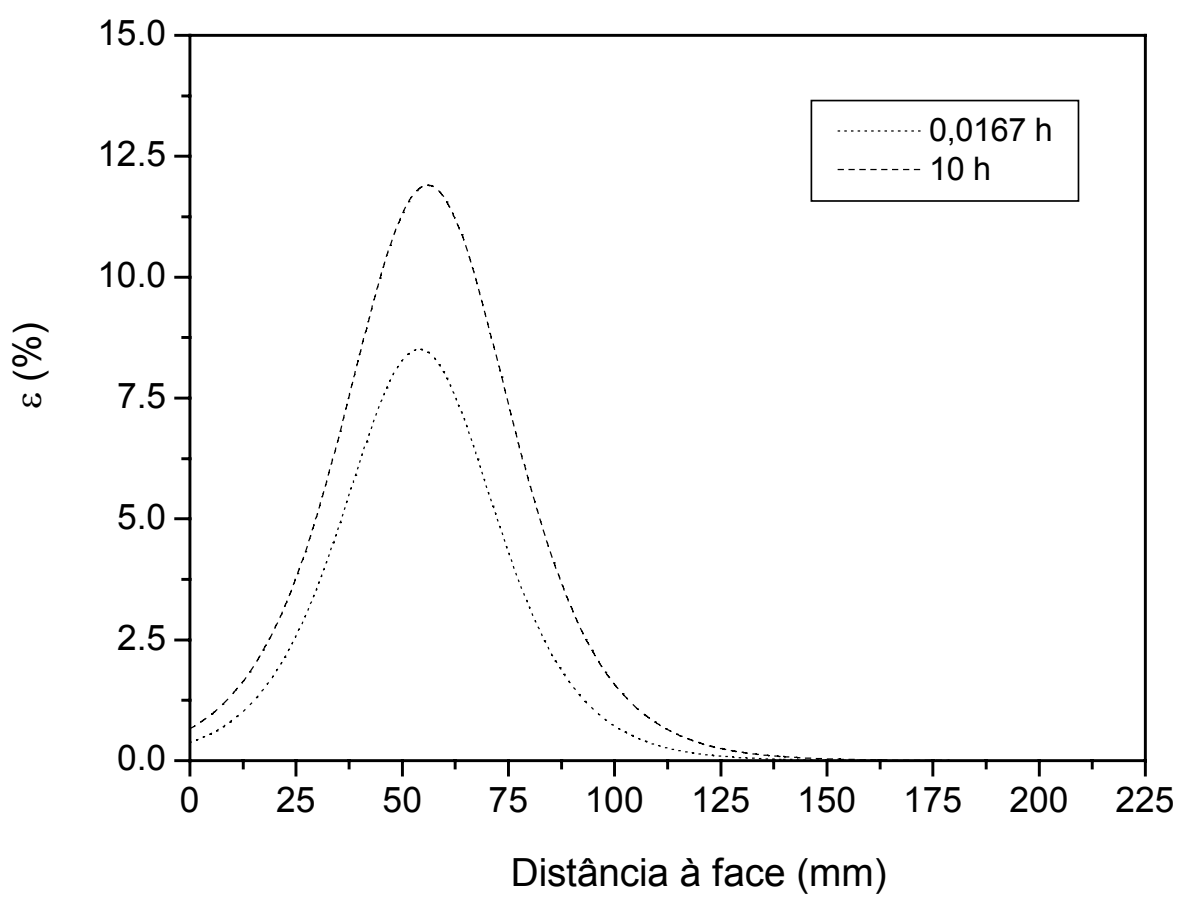

FIGURA B44 - Deformações obtidas para o ensaio F-PET-3, camada 7. 


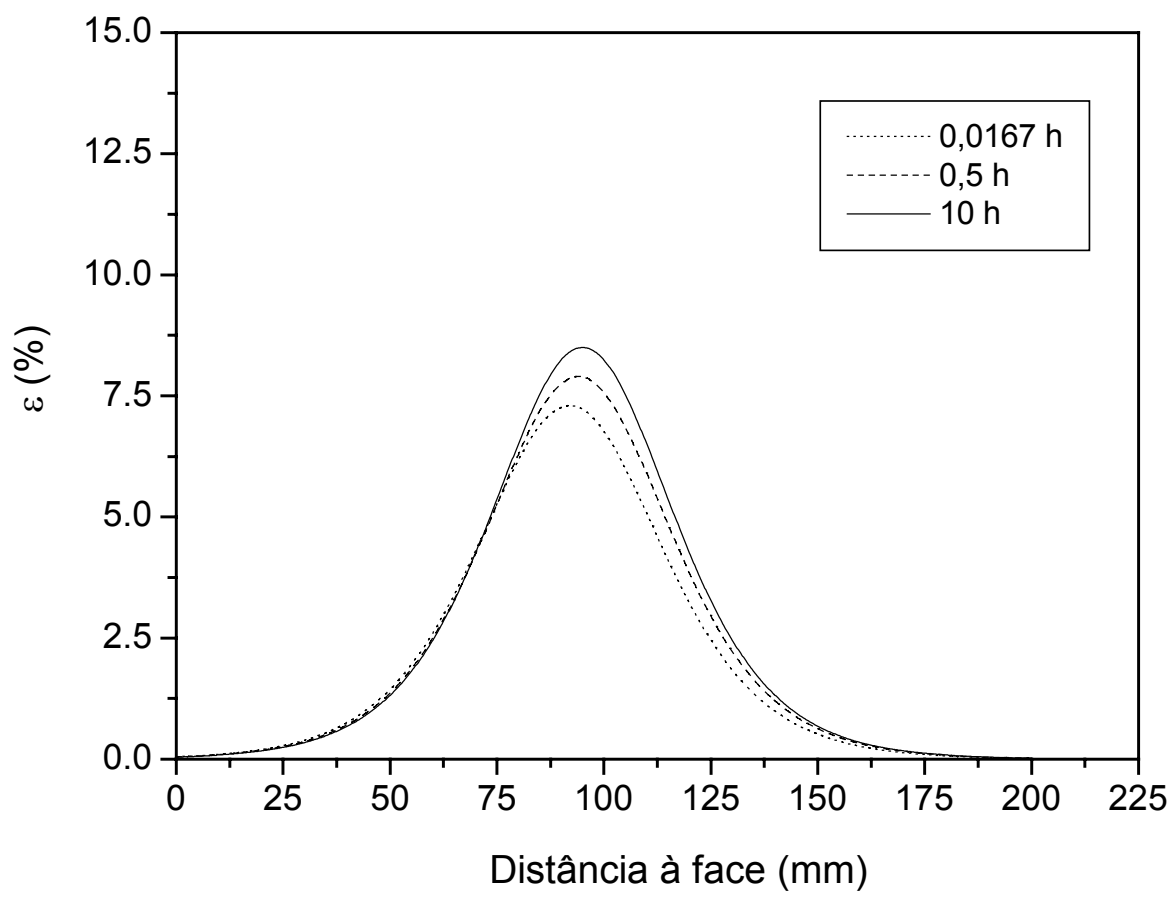

FIGURA B45 - Deformações obtidas para o ensaio F-PET-2, camada 12.

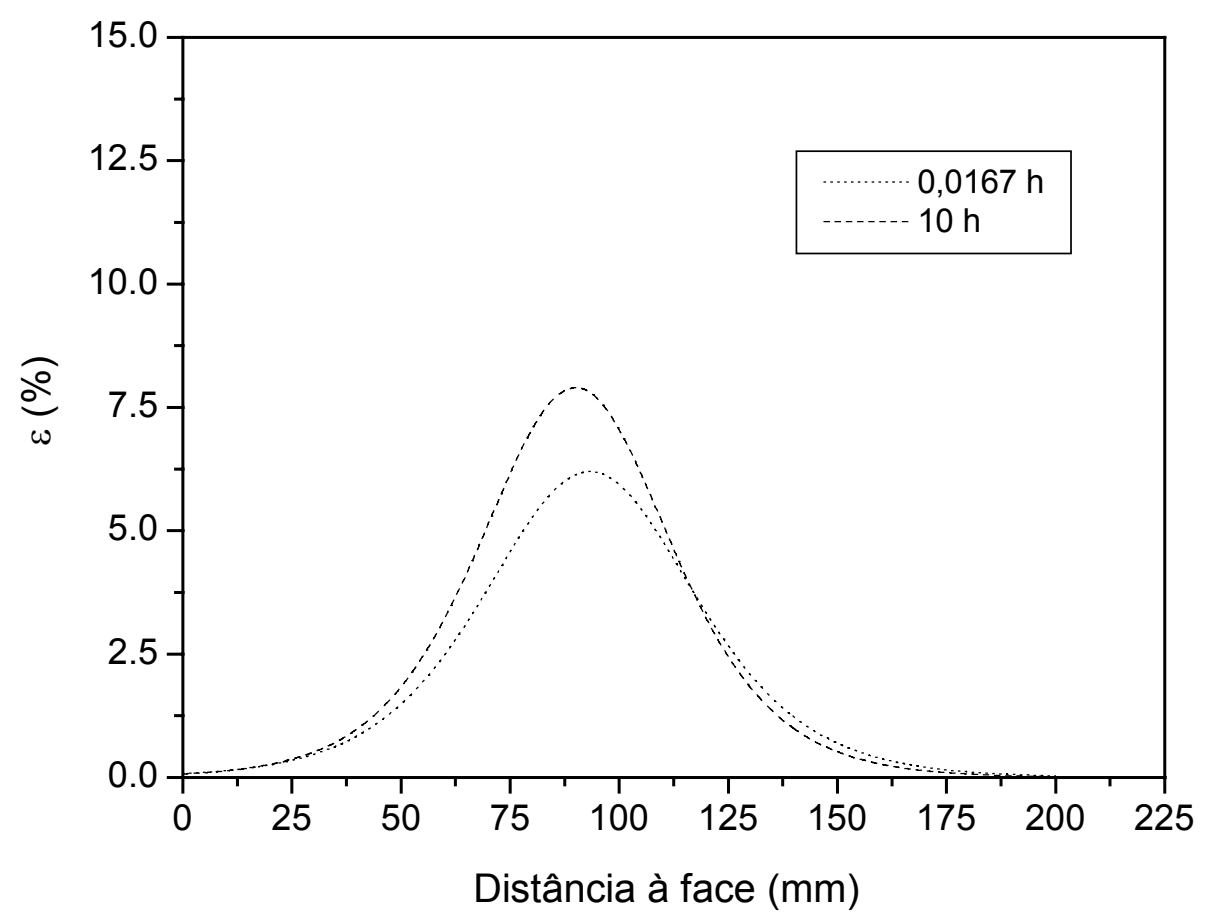

FIGURA B46 - Deformações obtidas para o ensaio F-PET-2, camada 11. 


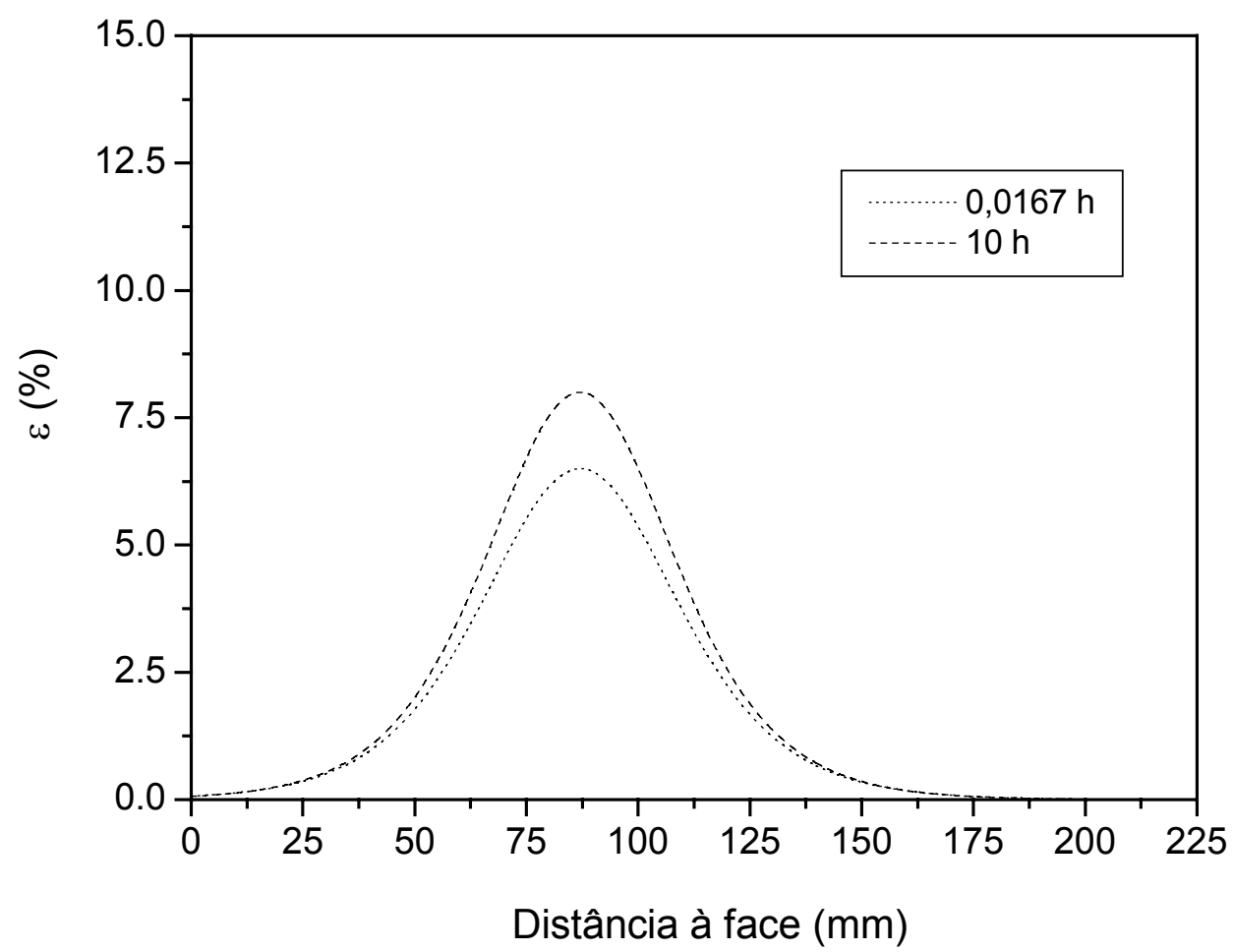

FIGURA B47 - Deformações obtidas para o ensaio F-PET-2, camada 10.

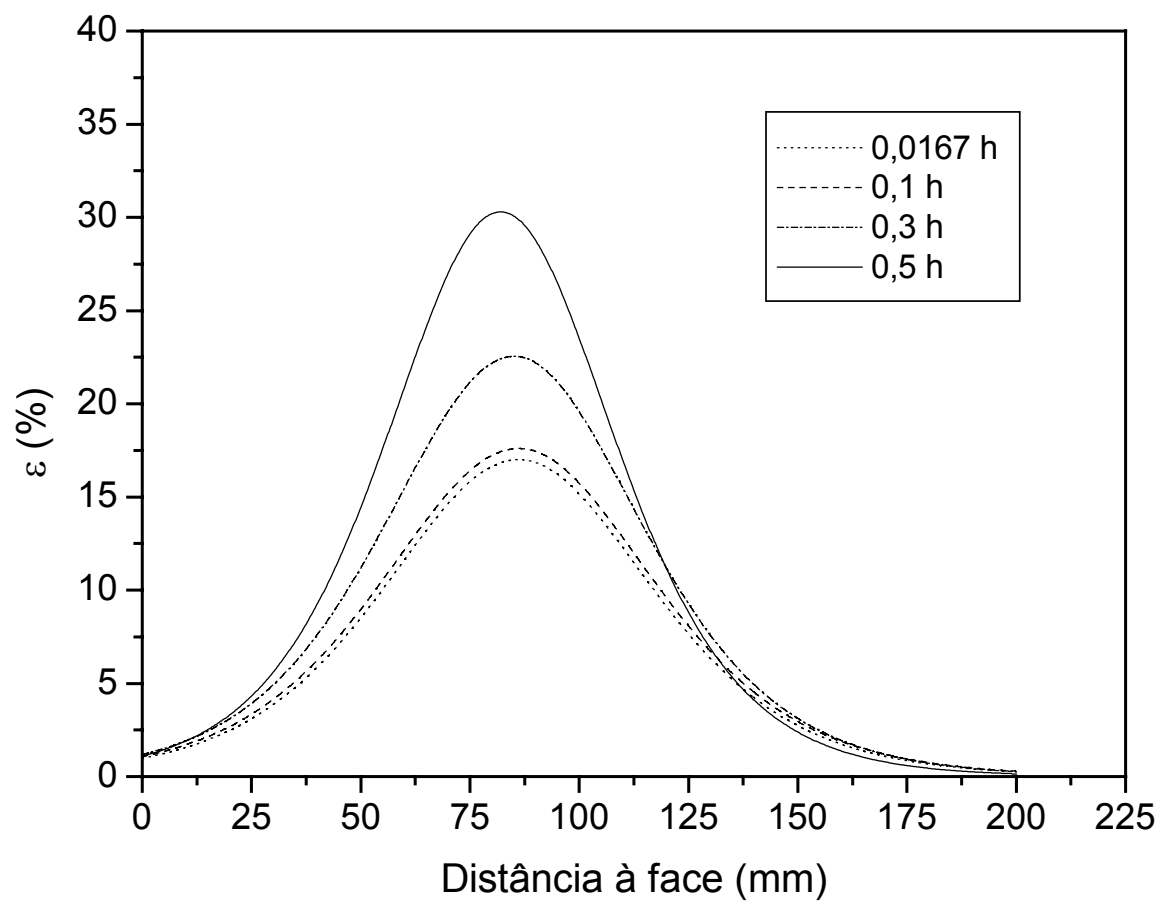

FIGURA B48 - Deformações obtidas para o ensaio F-PP-4, camada 12. 


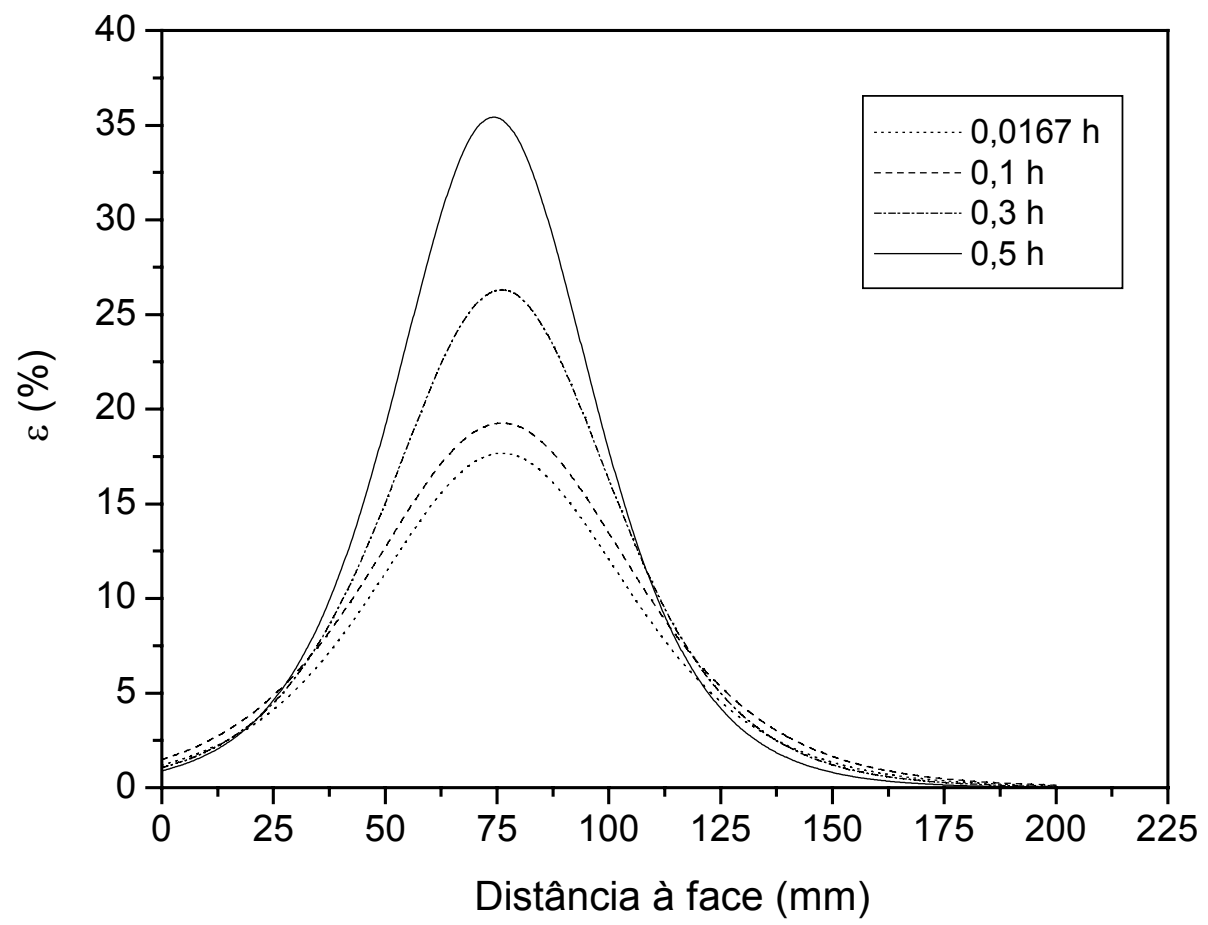

FIGURA B49 - Deformações obtidas para o ensaio F-PP-4, camada 10.

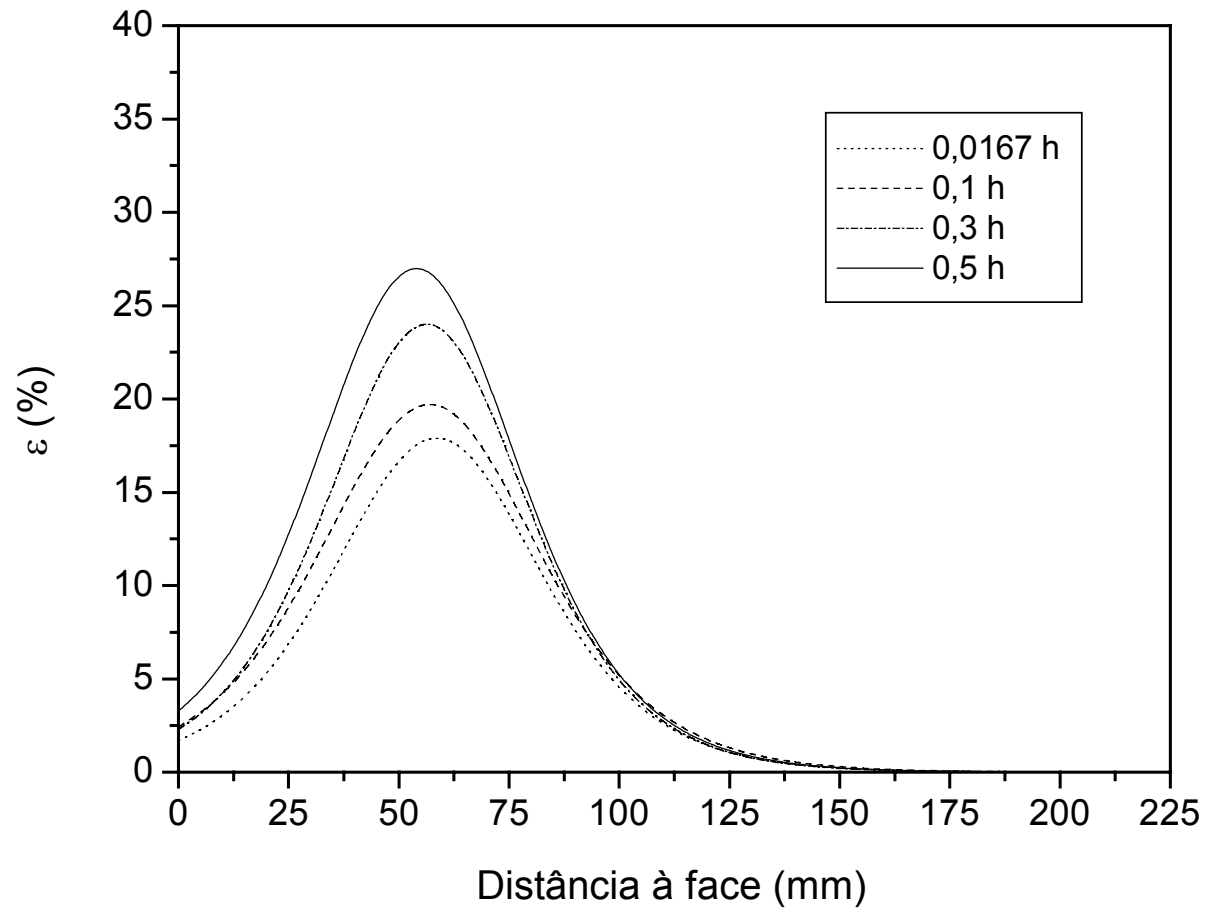

FIGURA B50 - Deformações obtidas para o ensaio F-PP-4, camada 8. 


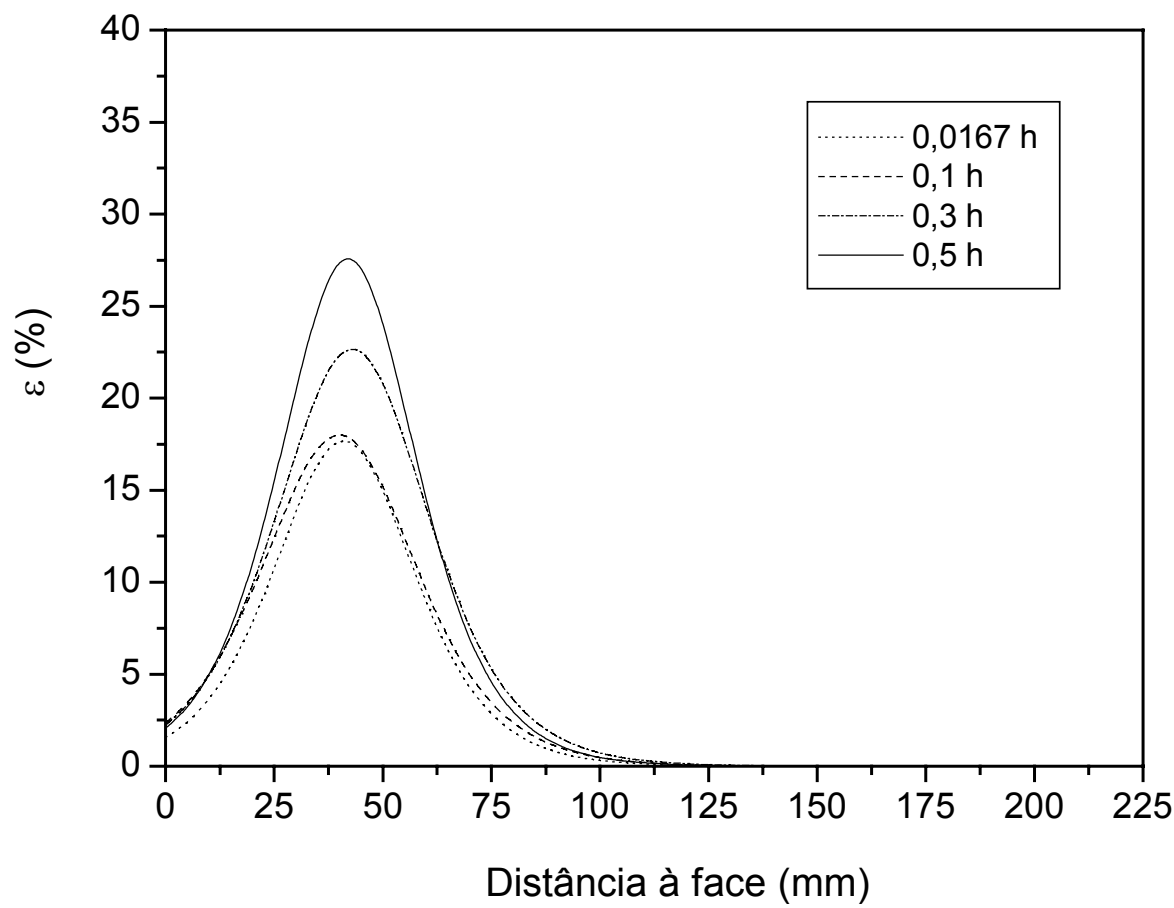

FIGURA B51 - Deformações obtidas para o ensaio F-PP-4, camada 6.

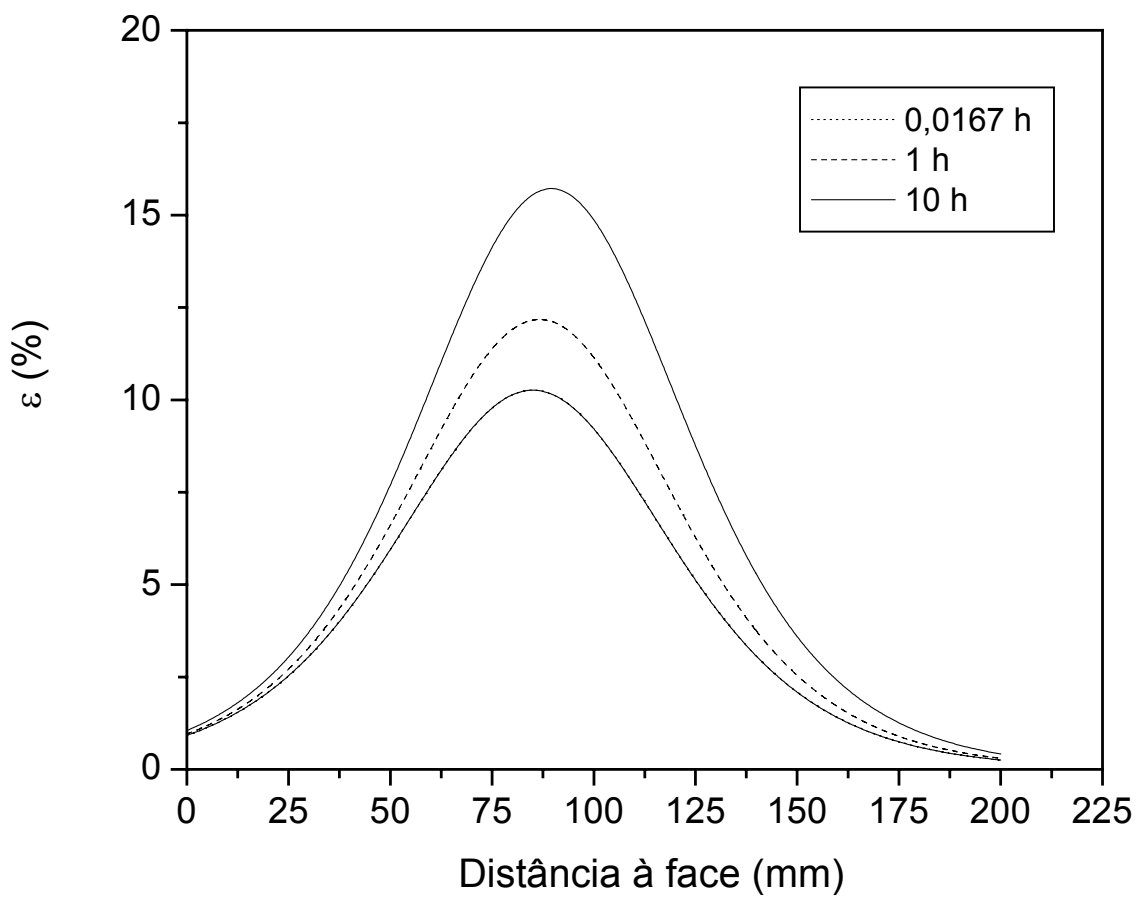

FIGURA B51 - Deformações obtidas para o ensaio F-PP-3, camada 12. 


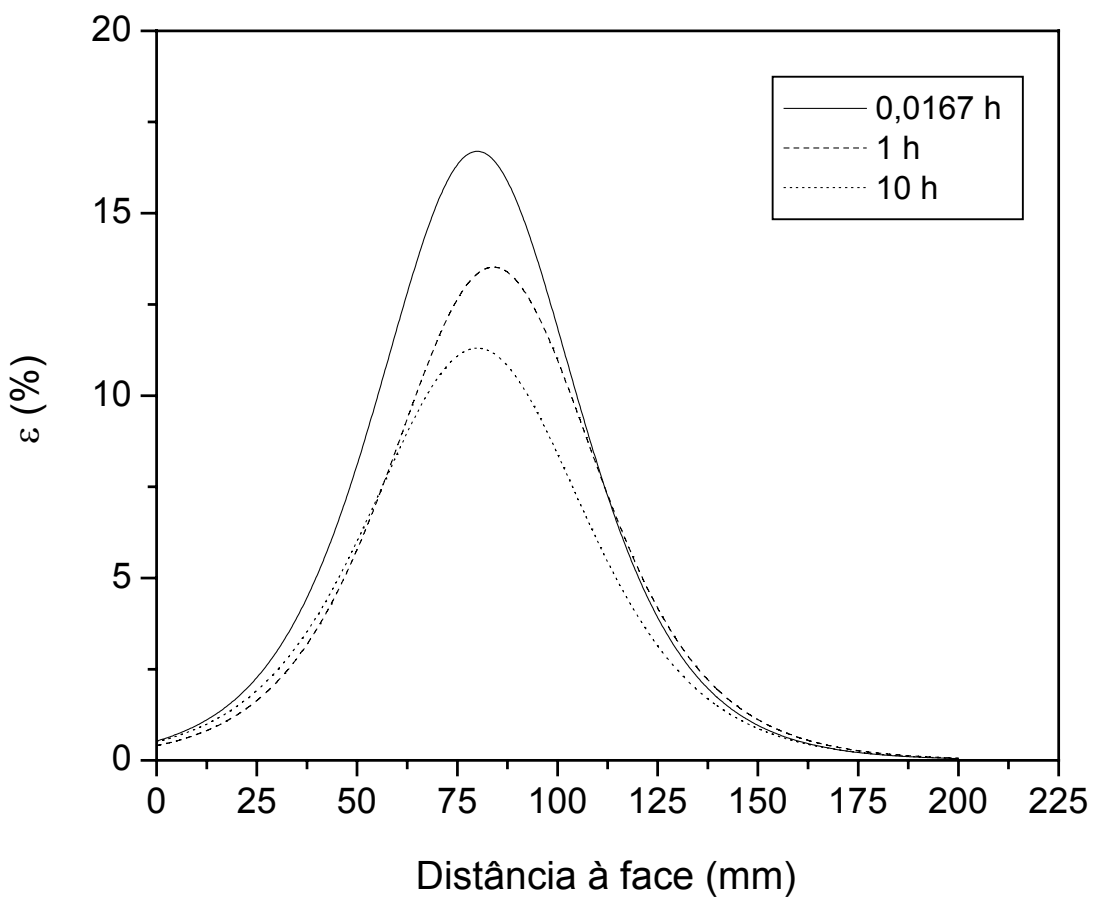

FIGURA B52 - Deformações obtidas para o ensaio F-PP-3, camada 10.

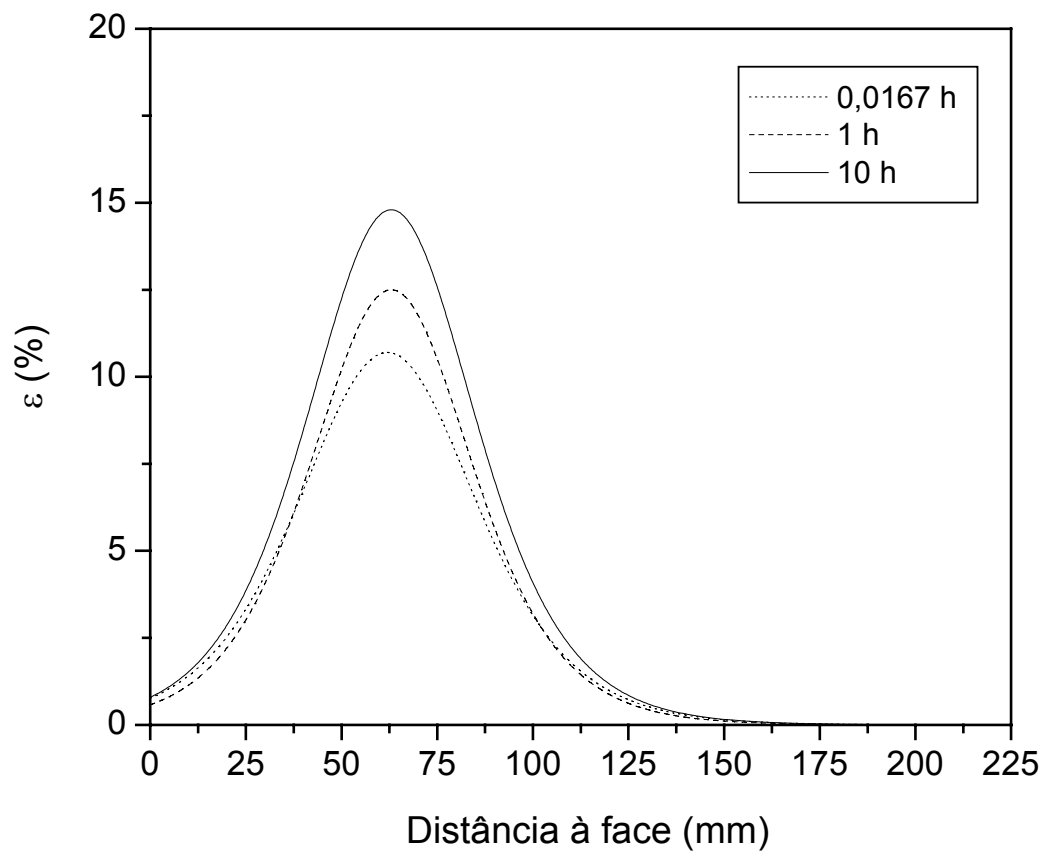

FIGURA B53 - Deformações obtidas para o ensaio F-PP-3, camada 8. 


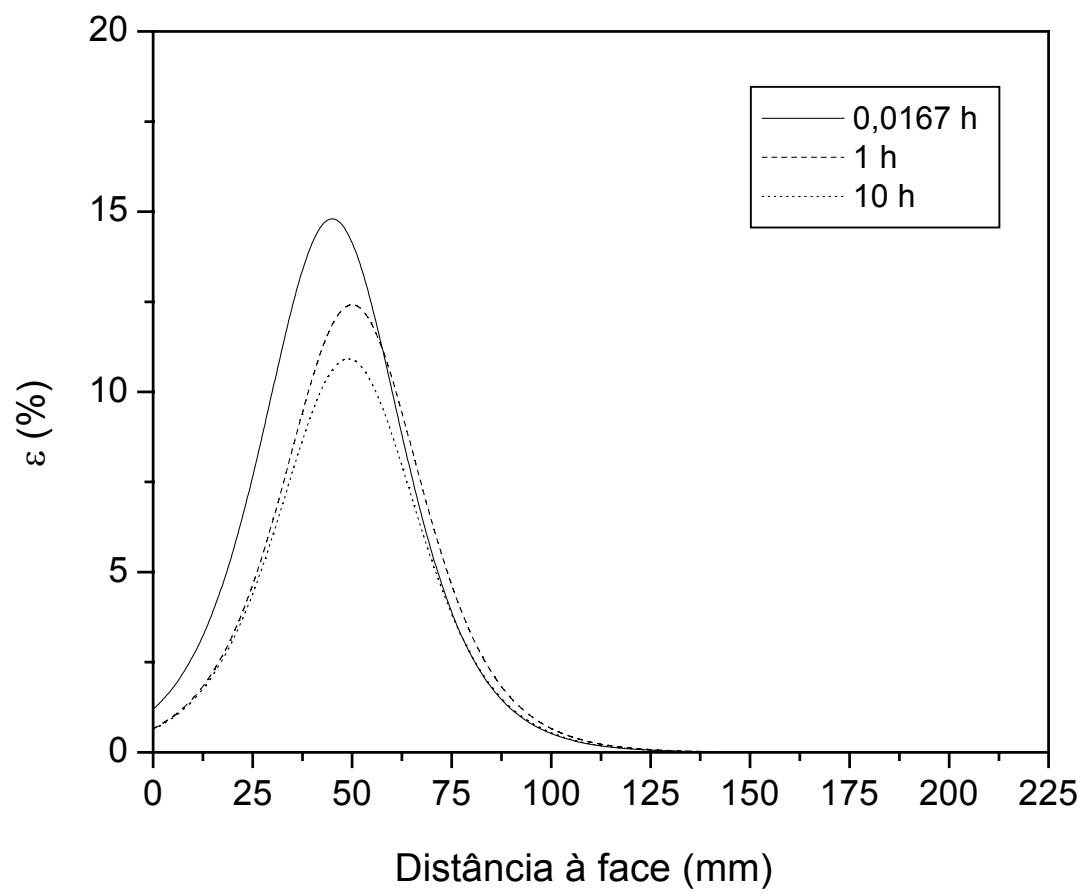

FIGURA B53 - Deformações obtidas para o ensaio F-PP-3, camada 6.

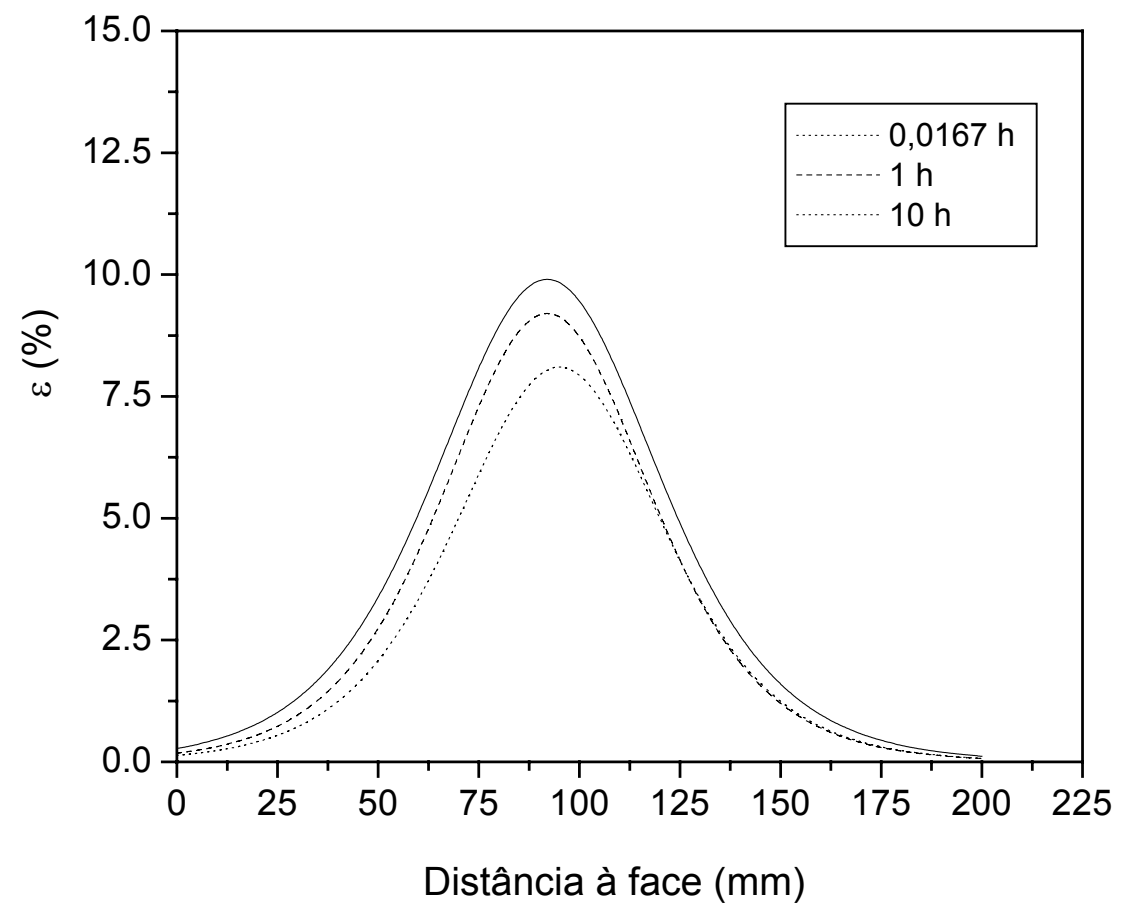

FIGURA B54 - Deformações obtidas para o ensaio F-PP-2, camada 12. 


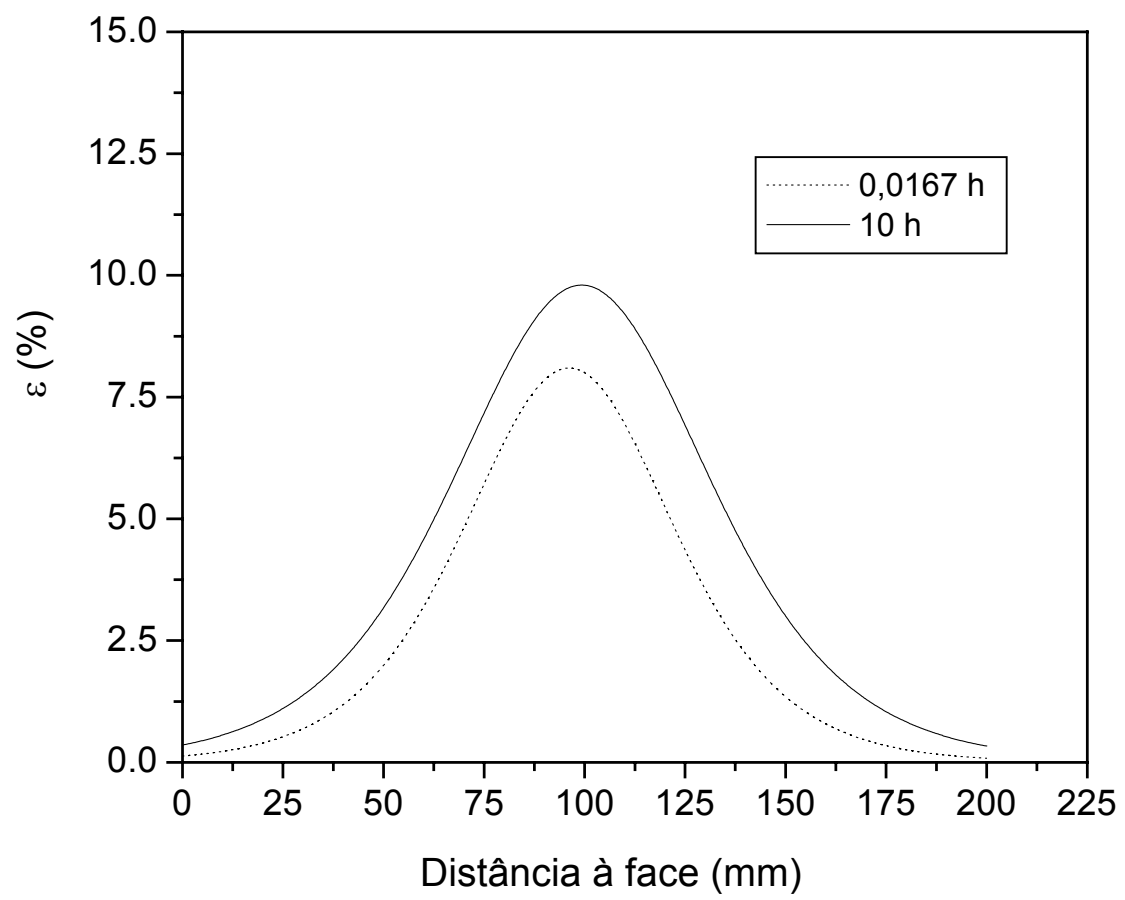

FIGURA B55 - Deformações obtidas para o ensaio F-PP-2, camada 11.

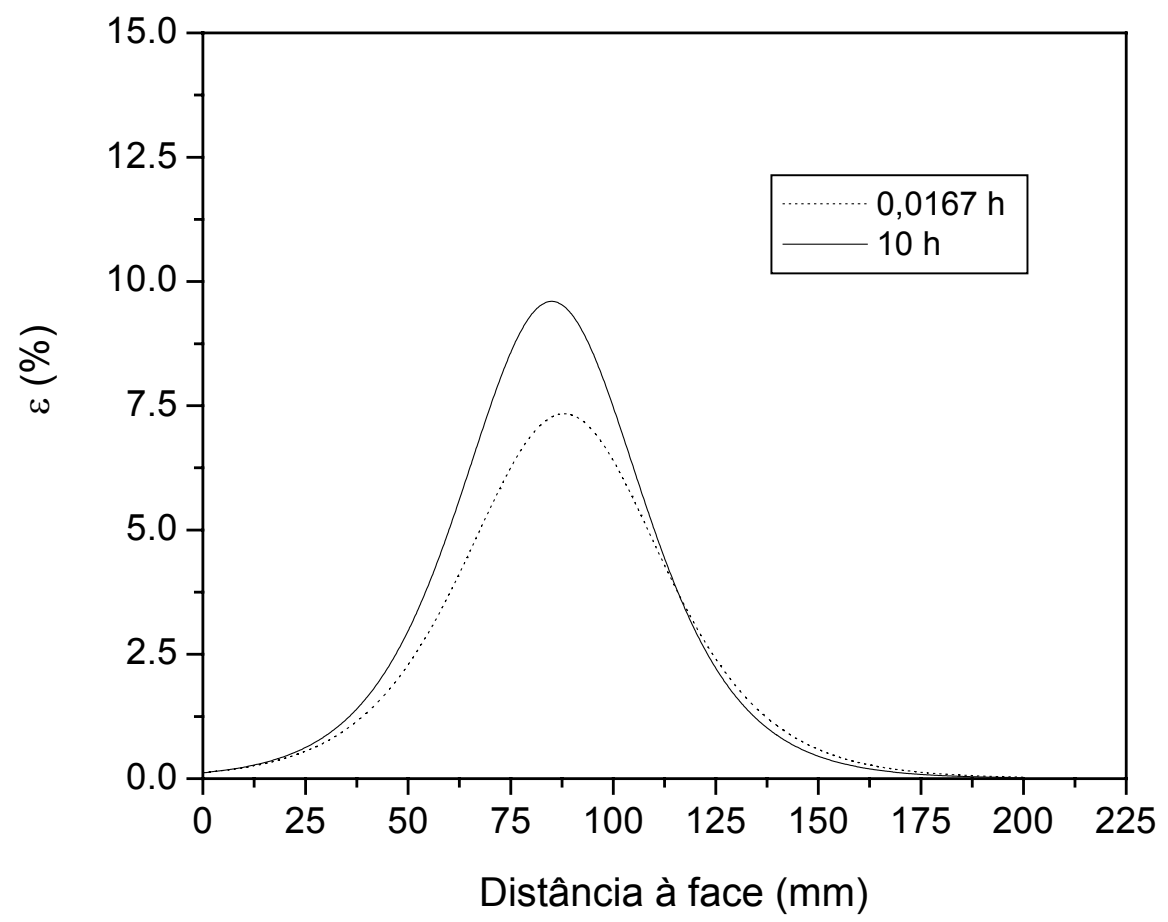

FIGURA B56 - Deformações obtidas para o ensaio F-PP-2, camada 10. 


\section{Referências Bibliográficas}

ABRAMENTO, M. (1993). Analysis and measurement of stresses in planar soil reinforcements. Massachusetts. 288p. Tese (Doutorado) - Massachusetts Institute of Technology.

ABRAMENTO, M. (1995). Durabilidade e comportamento de longo prazo de geossintéticos - Parte I: Propriedades mecânicas e hidráulicas. In: Geossintéticos 95. Anais. São Paulo, p. 217-226.

ALLEN, T. M. (1991). Determination of long-term strength of geosynthetics: A state-of-the-art review. In: Geosynthetics' 91. Proceedings. Atlanta. v. 1, p.351379 .

ALLEN, T. M.; CHRISTOPHER, B. R.; HOLTZ, R. D. (1992). Performance of a $12.6 \mathrm{~m}$ high geotextile wall in Seattle, Washington. In: International Symposium on Geosynthetic-Reinforced Soil Retaining Walls, Dever, 1991. Proceedings. WU, J. T. H. (ed.).Rotterdam, A. A. Balkema. p. 81-100.

ALLEN, T. M.; BATHURST, R. J. (2002a). Soil reinforcement loads in geosynthetics walls at working stress conditions. Geosynthetics International, v. 9, n.5-6, p.525-566.

ALLEN, T. M.; BATHURST, R. J. (2002b). Observed long-term peformance of geosynthetic wall and implications for design. Geosynthetics International, v. 9, n.5-6, p. 567-606.

AMERICAN SOCIETY FOR TESTING AND MATERIALS (1986). ASTM D4595 - Standard test method for tensile properties of geotextiles by the wide-width strip method. In: Annual book of ASTM standards. v. 04.09, p. 1-10.

AMERICAN SOCIETY FOR TESTING AND MATERIALS (1994). ASTM D5262 - Standard test method for evaluating the unconfined tension creep behavior of geosynthetics. In: Annual book of ASTM standards. New York, p. 244-249.

ANDRAWES, K. Z.; McGOWN, A; MURRAY, R. T. (1986). The load-strain-timetemperature behaviour of geotextiles and geogrids. In: International Conference on Geotextiles, 3rd. Viena, v. 3, p. 707-712.

ARRIAGA, F. (2003). Response of geosynthetic-reinforced structures under working stress and failure conditions. Boulder. 205p. Tese (Doutorado) - University of Colorado at Boulder.

ARTHUR, J. R. F.; DALILI, A. (1979). On the lubrification of rubber surfaces. Geotechnique, v. 29, n. 1, p 96-98. 
ASSOCIAÇÃO BRASILEIRA DE NORMAS TÉCNICAS (1984). NBR 7181 - Solo - análise granulométrica. Rio de Janeiro.

ASSOCIAÇÃO BRASILEIRA DE NORMAS TÉCNICAS (1990). NBR 12004/MB 3324 - Solo - Determinação do índice de vazios máximo de solos não coesivos. Rio de Janeiro.

ASSOCIAÇÃO BRASILEIRA DE NORMAS TÉCNICAS (1991). NBR 12051/MB 3388 - Solo - Determinação do índice de vazios mínimo de solos não coesivos. Rio de Janeiro.

ASSOCIAÇÃO BRASILEIRA DE NORMAS TÉCNICAS (1992). NBR 12568 Geotêxteis - Determinação da gramatura. Rio de Janeiro.

ASSOCIAÇÃO BRASILEIRA DE NORMAS TÉCNICAS (1993). NBR 12824 Geotêxteis - Determinação da resistência à tração não confinada - Ensaio de faixa larga. Rio de Janeiro.

BALLEGEER, J. P.; WU, J. T. H. (1993). Intrinsic confined and unconfined loaddeformation properties of geotextiles. In: CHENG, S. J. C. Geosynthetics soil reinforcement testing procedures. Philadelphia. p. 16-31.

BARAS, L. C. S. (2001). Estudo da fluência em geotêxteis através de ensaios não confinados convencionais e acelerados. São Carlos. 112 p. Dissertação (Mestrado) - Escola de Engenharia de São Carlos, Universidade de São Paulo.

BARKER, D. H.; CRAIG, W. H.; GOVE, K.; JACKSON, A. M. (1996). Investigation by centrifuge modeling of the effects of the vertical reinforcement on the stability of steep slopes in clay. In: International Conference on Geosynthetics: Applications, Design, and Construction. De Groot, Den Hoedt, and Termaat (eds), p. 433-440.

BATHURST, R. J (1992). Case study of a monitored propped panel wall. In: International Symposium on Geosynthetic-Reinforced Soil Retaining Walls, Dever, 1991. Proceedings. WU, J. T. H. (ed.).Rotterdam, A. A. Balkema. p. 159166.

BATHURST, R. J.; BENJAMIN, D. J.; JARRETT, P. M. (1989). An instrumented geogrid reinforced soil wall. In: International Conference on Soil Mechanics and Foundation Engineering, $12^{\text {th }}$. Proceedings. Rio de janeiro, v. 2, p. 1223-1226.

BATHURST, R. J.; SIMAC, M. R. (1995). Recent developments in reinforced segmental retaining wall technology in north america. In: Geossintéticos 95. Anais. São Paulo, p. 17-30.

BATHURST, R. J.; ALLEN, T.; WALTERS, D. (2004). Reinforcement loads in geosynthetics walls and the case for a new working stress design method. In: 
European Geosynthetics Conference - EuroGeo, 3rd. Proceedings. Munich, p. 19-32.

BENIGNI, C.; BOSCO, G.; CAZZUFFI, D.; DE COL, R. (1996). Construction and performance of an experimental large scale wall reinforced with geosynthetics. Earth Reinforcement. Ochiai, Yasufuku \& Omine (ed.). Rotterdam, A. A. Balkema. p. 315-320.

BEJAMIN, J. R. S. (1989). Performance of full scale geogrid reinforced soil retaining walls. Kingston. 256 p. Dissertação (Mestrado) - Royal Military College.

BENJANMIM, C. V. S.; BUENO, B. S.; PALMA, S. L. (2003). Análise experimental e numérica de um protótipo de estrutura de contenção em solo reforçado com geotêxtil. In: In: Simpósio Brasileiro de Geossintéticos, IV. Porto Alegre, 2003. Anais (CD ROM).

BOYLE, S. R. (1995). Unit Cell Tests on reinforced cohesionless soils. In: Geosynthetics' 95. Proceedings. Tennessee. v. 3, p.1221-1233.

BOYLE, S. R.; GALLAGHER, M.; HOLTZ, R. D. (1996). Influence of strain rate, specimen length and confinement on measured geotextile properties. Geosynthetics International, v. 3, n.2, p. 205-225.

BRACHMAN, R. W. I.; MOORE, I. D.; ROWE, R. K. (2000). The design of a laboratory facility for evaluating the structural response of small-diameter buried pipes. Canadian Geotechnical Journal, v. 37, p. 281-295.

BROMS, B. (1971). Lateral earth pressures due to compaction of cohesionless soils. In: International Conference on Soil Mechanics, $4^{\text {th }}$. Proceedings. Budapest, $p$. 373-384.

BRUNO, A. C. B. (1997). Monitoração de um muro de solo reforçado com geotêxtil. Rio de Janeiro. 134 p. Dissertação (Mestrado) - COPPE, Universidade Federal do Rio de Janeiro.

BS 8006 (1995). Code of practice for strengthened /reinforced soils and other fills. British Standards Institution, London, UK.

BUENO, B. S. (1987). The bahavior of thin walled pipes in trenches. Leeds. 337p. Tese (Doutorado) - University of Leeds.

CARRUBA, P; MORACI, N.; MONTANELLI, F. (1999). Intrumented soil reinforced retaining wall: analysis of measurements. In: Geosynthetics' 99. Proceedings. Massachusetts. v.2., p.921-934.

CARRUBA, P; MORACI, N.; MONTANELLI, F. (2000). Intrumented soil reinforced retaining wall: analysis of measurements. In: European Geosynthetics Conference - EuroGeo, 2nd. Proceedings. Bologna. v.1., p. 125-129. 
CAZZUFFI, D.; GHINELLI, A.; SACCHETTI, M.; VILLA, C. (1997). European experimental approach to the tensile creep behavior of high-strength geosynthetics. In: Geosynthetics' 97. Proceedings. California. v.1. , p.253-266.

CHRISTOPHER, B. R.; HOLTZ, R. D.; BELL, W. D. (1986). New tests for determining the in-soil stress-strain properties of geotextiles. In: International Conference on Geotextiles, $3^{\text {rd }}$. Proceedings. Vienna, v. 3, p. 683-688.

CHRISTOPHER, B. R.; HOLTZ, R. D; ALLEN, T. M. (1990). Instrumentation for a $12.6 \mathrm{~m}$ high geotextile-reinforced wall. In: International Reinforced Soil Conference - Performance of Reinforced Soil Structures. Proceedings. British Geotechnical Society, p. 73-78.

COSTA, C. M. L. (1999). Fluência de geotêxteis. São Carlos. 97 p. Dissertação (Mestrado) - Escola de Engenharia de São Carlos, Universidade de São Paulo.

DANTAS, B. T.; EHRLICH, M., (1999). Ábacos para dimensionamento de taludes reforçados sob condições de trabalho. In: South American Symp. on Geosynthetics, 1. Proceedings. Rio de Janeiro.

DEN HOEDT, G. (1986). Creep and relaxation of geotextile fabrics. Geotextiles and Geomembranes, v. 4, n. 2, p. 83-92.

DEN HOEDT, G. (1988). Durability of geotextiles. London, Chapman and Hall. p.34-38: Principles of creep and relaxation.

DJARWADI, D.; WONG, I. H. (1994). Construction and performance of spillway walls for Mukakuning dam. In: Geotextiles, Geomembranes and Related Products, $5^{\text {th }}$. Proceedings. Singapore. v.1, p. 289-292.

EHRLICH, M. (1995). Deformação em muros de solos reforçados. In: Geossintéticos 95. Anais. São Paulo, p. 31-40.

EHRLICH, M.; MITCHELL, J. K. (1994). Working stress design method for reinforced soil walls. Journal of Geotechnical Engineering, v. 120, n. 4, p. 625645.

EHRLICH, M.; VIANNA, A. J. D.; FUSARO, F. (1994). Comportamento de um muro de solo reforçado. In: Congresso Brasileiro de Mecânica dos Solos e Engenharia de Fundações, 10. Anais. São Paulo, p. 217-226.

EHRLICH, M.; AZAMBUJA, E. (2003). Muros de solo reforçado. In: In: Simpósio Brasileiro de Geossintéticos, IV. Porto Alegre, 2003. (CD ROM).

EL-FERMAOUI, A.; NOWATZKI, E. (1982). Effect of confining pressure on performance of geotextiles in soils. In: International Conference on Geotextiles, $2^{\text {nd }}$. Proceedings. Las Vegas, v. 3, p. 799-804. 
FARRAG, K. (1997). Prediction of long-term strains of geosynthetics from accelerated-creep tests. In: Geosynthetics' 97. Proceedings. California. v.1., p. 267-276.

FISHMAN, K. L.; DESAI, C. S.; SOGGE, R. L. (1993). Field behavior of instrumented geogrid soil reinforced wall. Journal of Geotechnical Engineering, v. 119, n. 8, p. 1293-1307.

GOTO, S.; PARK, C.; TATSUOKA, F.; MOLENKAMP, F. (1993). Quality of the lubrification layer used in element tests on granular materials. Soils and Foundations, v. 33, n. 2, p. 47-59.

GOTTARDI, G.; SIMONINI, P. (2000). Time and temperature effects on the behaviour of geosynthetics-reinforced walls. In: EuroGeo 2000, European Geosynthetics Conference, $2^{\text {nd }}$. Proceedings. Bologna, v. 1, p.175-180.

GOURC, J.; MATICHARD, Y. (1992). Development of geotextile reinforcement techniques in France - application to retaining structures. In: International Symposium on Geosynthetic-Reinforced Soil Retaining Walls, Dever, 1991. Proceedings. WU, J. T. H. (ed.).Rotterdam, A. A. Balkema. p. 131-152.

GREENWOOD, J. H.; MYLES, B. (1986). Creep and stress relaxation of geotextiles. In: International Conference on Geotextiles, $3^{\text {rd }}$. Proceedings. Vienna, v.3, p. 821-826.

GREENWOOD, J. H. (1990). Creep of geotextiles. In: Geotextiles, Geomembranes and Related Products, $4^{\text {th }}$, The Hague, 1990. Proceedings. Rotterdam, Balkema. v.2, 645-650.

GREENWOOD, J. H. (1998). Derivation of design parameters and partial safety factors from laboratory data. In: Creep and Assessment of Geosynthetics for Soil Reinforcement, Leatherhead, 1997. Proceedings, Leatherhead, p.3.1-3.11.

GREENWOOD, J. H.; KEMPTON, G. T.; WATTS, G. R. A.; BUSH, D. I. (2000). Twelve year creep tests on geosynthetic reinforcement. In: European Geosynthetics Conference - EuroGeo, 2nd. Proceedings. Bologna. v.1., p. 333336.

GULER, E.; GOODINGS, D. J. (1992). Centrifuge models of clay-lime reinforced soil walls. In: International Conference on Grouting, Soil Improvement, and Geosynthetics. New Orleans, Louisiana, p. 1249-1260.

HELWANY, M. B. (1993). Long-term soil-geosynthetic interation in geosyntheticreinforced soil structures. Dever. 265 p. Tese (Doutorado) - University of Colorado at Denver. 
HELWANY, S. M. B.; SHIN, S. (1998). Creep and stress relaxation of geotextilereinforced soils. Geosynthetics International, v. 5, n. 4, p. 425-434.

HELWANY, S. M. B.; REARDON, G.; WU, J. T. H. (1999). Effects of backfill on the performance of GRS retaining walls. Geotextiles and Geomembranes, v. 17, n. 1, p. 1-16.

HO, S. K.; ROWE, R. K. (1996). Effect of wall geometry on the behaviour of reinforced soil walls. Geotextiles and Geomembranes, v. 14, n. 10, p. 521-541.

HORROCKS, A. R.; D'SOUZA, J. A. (1992). Degradation of polymers in geomembranes and geotextiles. In: HAMID, S. H. et al. Handbook of polymer degradation. New York, Marcel Dekker. Cap. 15, p. 433-505.

INGOLD, T. S. (1979). The effects of compaction on retaining walls. Geotechnique, v. 29, n. 3 , p. $265-285$.

INTERNATIONAL ORGANIZATION FOR STANDARDIZATION (1998). ISO 13431 - Geotextile and geotestile related products - Determination of tensile creep and creep rupture behaviour. Switzerland.

JABER, M. B. (1989). Behavior of reinforced soil walls in centrifuge model tests. Berkeley. 239p. Tese (Doutorado) - University of California, Berkeley.

JABER, M.; MITCHELL, J. K. (1990). Behaviour of reinforced soil walls at limit state. In: International Reinforced Soil Conference - Performance of Reinforced Soil Structures. Proceedings. British Geotechnical Society, p. 53-57.

JEWELL, R. A. (1991). Application of revised design charts for steep reinforced slopes. Geotextiles and Geomembranes, v. 10, n. 3, p. 203-233.

JEWELL, R. A. (1996). Soil reinforcement with geotextiles. London, CIRIA.

JEWELL, R. A.; GREENWOOD, J. H. (1988). Long term strength and safety in steep soil slopes reinforced by polymer materials. Geotextiles and Geomembranes, v. 7, $\mathrm{n}^{\text {os }} .1$ e 2, p.81-118.

JONES, C. J. F. P. (1990). Construction influences on the performance of reinforced soil structures. In: International Reinforced Soil Conference - Performance of Reinforced Soil Structures. Proceedings. British Geotechnical Society, p. 97116.

KALIAKIN, V. N.; DECHASAKULSOM, M.; LESHCHINSKY, D. (2000). Investigation of the isochrone concept for predicting relaxation of geogrids. Geosynthetics International, v. 7, n. 2, p. 79-99.

KAWAMURA, M.; OKABAYASHI, K. (1998). Interaction between earth pressures against a reinforced retaining wall and tensile forces of reinforcements. In: 
Centrifuge 98. Proceedings. KIMURA, KUSAKABE, TAKEMURA (eds.).Rotterdam, A. A. Balkema, p. 767-772.

KETCHART, K.; WU, J.T.H. (2002). A modified soil-geosynthetic interactive performance test for evaluating deformation behavior of GRS structures. Geotechnical Testing Journal, v. 25, n.4.

KO, H. Y. (1988a). Summary of the state-of-the-art in centrifuge model testing. In: Centrifuges in Soil Mechanics. . Proceedings. James and Schofield (eds.), p. $11-18$.

KO, H.Y. (1988b). The Colorado centrifuge facility. In: Centrifuge 88. Proceedings. Paris, p. 73-75.

KOERNER, R. M.; LORD, A. E. Jr.; HSUAN, Y. H. (1992). Arrhenius modeling to predict geosynthetic degradation. Geotextiles and Geomembranes, v. 11, n. 2, p.151-183.

KOERNER, R. M. (1998). Designing with geosynthetics, Englewood Cliffs, New Jersey, Prentice Hall, $4^{\text {th }}$ Ed.

KOKKALIS, A.; PAPACHARISIS, N. (1989). A simple laboratory method to estimate the in-soil behavior of geotextiles. Geotextiles and Geomembranes, v. 8, n. 2 , p. $145-157$.

KONGKITKUL,W; HIRAKAWA, D; UCHIMURA, T; TATSUOKA, F. (2004). Loading rate effects due to viscous property on the strength and deformation property of geosynthetic reinforcement . In: In: European Geosynthetics Conference - EuroGeo, 3rd. Proceedings. Munich, p. 533-538.

KOUTSOURAIS, M. (1995). Correlating the creep-strain component of the total strain as a function of load-level for high-tenacity polyester yarns, geogrids and geotextiles. In: Geosynthetics' 95. Proceedings. Tennessee. v.3., p.989-1001.

KUHN, M. R.; MITCHELL, J. K. (1993). New perspectives on soil creep. Journal of Geotechnical Engineering, v. 119, n. 3, p. 507-523.

KUHN, E. (1998). Investigations into the degradation of the structure of lubrificating greases. Tribology Transactions, v. 41, n. 2, p. 247-250.

LADE, P.; DUNCAN, J. M. (1973). Cubical triaxial tests on cohesionless soil. Journal of Soil Mechanics and Foundation Engineering. v.99, n. 10, p.793-812.

LAMBE, T. W.; WHITMAN, R. V. (1979). Soil Mechanics, New York, John Wiley \& Sons. 
LESHCHINSKY, D.; BOEDEKER, R. H. (1989). Geosynthetic reinforced soil structures. Journal of Geotechnical Engineering, v. 115, n. 10, p. 1459-1478.

LESHCHINSKY, D.; FIELD. D. A.; (1987). In-soil load elongation, tensile strength and interface friction of non-woven geotextiles. In: Geosynthetics' 87, New Orleans, 1987. Proceedings. p. 238-249.

LESHCHINSKY, D.; PERRY, E. B. (1989). On the design of geosyntheticreinforced walls. Geotextiles and Geomembranes, v. 8, n. 4, p. 311-323.

LEVACHER, D.; BLIVET, J. C.; MSOUTI, F. (1994). Tensile and creep behavior of geotextiles. In: Geotextiles, Geomembranes and Related Products, $5^{\text {th }}$. Proceedings. Singapore. v.3, p. 1131-1134.

LING, H. I.; TATSUOKA, F.; TATEYAMA, M. (1995). Simulating performance of GRS-RW by finite-element procedure. Journal of Geotechnical Engineering, v. 121, n. 4, p. 330-340.

LING, H. I.; WU, J. T. H.; TATSUOKA, F. (1992). Short-term strength and deformation characteristics of geotextiles under typical operational conditions. Geotextiles and Geomembranes, v. 11, n. 2, p. 185-219.

MARACHI, N.; DUCAN, J. M.; CHAN, C.; SEED, H. B. (1981). Plane strain testing of sands. Laboratory shear strength of soil. ASTM STP 740. p. 294-302.

MARQUES, G. L. O. (1994). Uso de geotêxteis em muros de contenção de pequeno porte. Viçosa. 126 p. Dissertação (Mestrado) -Universidade Federal de Viçosa.

MARQUES, G. L. O.; BUENO, B. S.; LIMA, D. C. (1995). Observações de deslocamentos externos e internos de maciços reforçados com geossintéticos. In: Geossintéticos 95. Anais. São Paulo, p. 61-70.

MATICHARD, Y.; LECLERCQ, B.; SEGOUIN, M. (1990). Creep of geotextiles: soil reinforcement applications. In: Geotextiles, Geomembranes and Related Products, $4^{\text {th }}$, The Hague, 1990. Proceedings. Rotterdam, Balkema. v.2, p. 661665.

McGOWN, A.; ANDRAWES, K. Z.; KABIR, M. H. (1982). Load-extension testing of geotextiles confined in soil. In: International Conference on Geotextiles, $2^{\text {nd }}$. Proceedings. Las Vegas, v. 3, p. 793-798.

McGOWN, A.; ANDRAWES, K. Z.; MURRAY, R. T. (1986). The load-strain-timetemperature behavior of geotextiles and geogrids. In: International Conference on Geotextiles, $3^{\text {rd }}$. Proceedings. Vienna, v.3, p. 707-712.

McGOWN, A.; ANDRAWES, K. Z.; PRADHAN, S.; KHAN, A. J. (1998). Limit state design of geosynthetic reinforced soil structures. In: International 
Conference on Geosynthetics. Geotextiles, $6^{\text {th }}$. Proceedings. Atlanta, v. 1, p. 143-179.

MITCHELL, J. K.; JABER, M.; SHEN, C. K.; AND HUA, Z. K. (1988). Behavior of reinforced soil walls in centrifuge model tests. In: Centrifuge ' 88. Proceedings. Paris, p. 259-271.

MITCHELL, J. K.; CHRISTOPHER, B. R. (1990). North American practice in reinforced soil systems. In: ASCE Conference on Design and Performance of Earth Retaining Structures, 1990. Proceedings. New York, p. 322-346.

MSOUTI, M. F.; BLIVET, J. C.; LEVACHER, D. (1997). Comportement au fluage des géotextiles en reforcement mécanique. Études et recherches des laboratories des Ponts et Chaussées, GT n. 63.

MÜLLER-ROCHHOLZ, J. (1998). Practicalities of measurement of creep and stress rupture. In: Creep and Assessment of Geosynthetics for Soil Reinforcement, Leatherhead, 1997. Proceedings, Leatherhead, p.1.1-1.12.

MÜLLER-ROCHHOLZ, J.; KIRSCHNER, R. (1990). Creep of geotextiles at different temperatures. In: Geotextiles, Geomembranes and Related Products, $4^{\text {th }}$, The Hague, 1990. Proceedings. Rotterdam, Balkema. v.2, p. 657-659.

MURATA, O.; TATEYAMA, M.; TATSUOKA, F. (1990). Steep slopes reinforced with a planar geotextile having a rigid facing. In: Geotextiles, Geomembranes and Related Products, $4^{\text {th }}$, The Hague, 1990. Proceedings. Rotterdam, Balkema. v.1, p. 122.

MURATA, O.; TATEYAMA, M.; TATSUOKA, F. (1992). Load tests of geosynthetic-reinforced soil retaining walls and their stability analyses. In: International Symposium on Earth Reinforcement Practice, Fukuoka, 1992. Proceedings. OCHIAI, H.; HAYASHI, S.; OTANI, J. (ed.).Rotterdam, A. A. Balkema. p. 385-390.

MURAYAMA, S.; MICHIHIRO, K.; SAKAGAMI, T. (1984). Creep characteristics of sands. Soils and Foundations, v. 24, n. 2, p. 1-15.

MURRAY, R. T.; McGOWN, A. (1988). Durability of geotextiles. London, Chapman and Hall. p.52-73: Assessment of the time dependent behavior of geotextiles for reinforced soil applications.

NAEMURA, S.; ONODERA, S.; MARUO, S.; NAKANE, A. (1991). Case recod of test steep slopes having different facing types. The Foundation Engineering \& Equipment, v. 19, n. 11, p. 68-74.

NAKAMURA, K.; TAMURA, Y.; TATSUOKA, F.; IWASAKI, K. Y.; YAMAUCHI, H. (1988). Roles of facings in reinforcing steep clay slopes with a non-woven geotextile. In: International Geotechnical Symposium on Theory and 
Practice of Earth Reinforcement, Fukuoka, 1988. Proceedings. YAMANOUCHI, T.; MIURA, N.; OCHIAI, H. (ed.).Rotterdam, A. A. Balkema. p. 553-558.

NAKANE, A.; NAGAOKA, T.; ONODERA, S.; SHIMADA, I. (1990). Long-term observation of reinforced retaining structure with geotextile. In: Japan National Conference on Soil Mechanics and Foundation Engineering, $25^{\text {th }}$. p. 2013-2016.

OCHIAI, Y.; FUKUDA, N. (1996). Experimental study on geotextile-reinforced soil walls with different facings.Geosynthetics: Applications, Design and Construction. De Groot, Den Hoedt \& Termaat (ed.). Rotterdam, A. A. Balkema. p. 113-120.

PALMEIRA, E. M. (1999). Solo reforçado. Manual técnico da Husker Ltda.

PALMEIRA, E. M.; LANZ, D. (1994). Stresses and deformations in geotextile reinforced model walls . Geotextiles and Geomembranes, v. 13, n. 5, p. 331-348.

PEDROSO, E. O. (2000). Estruturas de contenção reforçadas com geossintéticos. São Carlos. 74 p. Dissertação (Mestrado) - Escola de Engenharia de São Carlos, Universidade de São Paulo.

PORBAHA, A.; GOODINGS, D. J. (1994). Geotextile reinforced cohesive slopes on weak foundations. In: Centrifuge '94. Proceedings, Singapore. Leung, Lee, and Tan (eds). Rotterdam, Balkema, p. 623-628.

RAD, N. S,; TUMAY, M. T. (1987). Factors affecting sand specimen preparation by raining. Geotechnical Testing Journal, v. 10, n.1, p.31-37.

RAGHEB, A.; ELGAMAL, A. W. (1991). Effect of gradual reinforcement compromise on the behavior of mechanically stabilized earth walls. In: Centrifuge 91. Proceedings. KO, H. Y. (ed.).Rotterdam, A. A. Balkema, p. 333340.

RESL, S. (1990). Soil-reinforced mechanisms of nonwoven geotextiles. In: Geotextiles, Geomembranes and Related Products, 4 ${ }^{\text {th }}$, The Hague, 1990. Proceedings. Rotterdam, Balkema. v.1, p. 93-96.

RIMOLDI, P.; MONTANELLI, F. (1993). Creep and accelerated creep testing for geogrids. In:Geosynthetics '93, Vancouver, 1993. Proceedings. v.2, p. 773-785.

ROWE, R. K.; HO, S. K. (1992). A review of the behaviour of reinforced soil walls. In: International Symposium on Earth Reinforcement, Fukuoka, 1992. Proceedings. OCHIAI, H.; HAYASHI, S.; OTANI, J. (ed.).Rotterdam, A. A. Balkema, v. 2. p. 801-830.

ROWE, R. K.; HO, S. K. (1998). Horizontal deformation in reinforced soil walls. Canadian Geotechnical Journal, v. 35, p. 312-327. 
SAWICKI, A. (1999). Creep of geosynthetic reinforced soil retaining walls. Geotextiles and Geomembranes, v. 17, n. 1, p. 51-65.

SAWICKI, A.; KAZIMIEROWICZ-FRANKOWSKA, K. (1998). Creep behavior of geosynthetics. Geotextiles and Geomembranes, v. 16, n. 6, p. 365-382.

SCHOFIELD, A. N. (1980). Cambridge geotechnical centrifuge operations. Geotechnique, v. 20, p. 227-268.

SHAHAR, Y.; FRYDMAN, S. (2002). Centrifuge modeling of narrow reinforced retaining walls. In: Physical Modelling in Geotechnics. Proceedings. Canada, p. 1005-1010.

SHRESTHA, S. C.; BELL, J. R. (1982). Creep behavior of geotextiles under sustained loads. In: International Conference on Geotextiles, $2^{\text {nd }}$. Proceedings. Las Vegas, v. 3, p. 769-774.

SIEL, B. D.; TZONG, W. H.; CHOU, N. N. S. (1987). In-soil stress-strain behavior of geotextiles. In: Geosynthetics'87, New Orleans, 1987. Proceedings. p. 260265.

SILVA, A. E. F.; VIDAL, D. (1999). Estruturas em solo reforçado e os métodos de dimensionamento por equilíbrio limite. In: Geossintéticos 99. Anais. Rio de Janeiro, p. 139-147.

SIMAC, M. R.; CHRISTOPHER, B. R.; BONCZKIEWICZ, C. (1990).Instrumented field performance of a $6 \mathrm{~m}$ geogrid soil wall. In: Geotextiles, Geomembranes and Related Products, $4^{\text {th }}$, The Hague, 1990. Proceedings. Rotterdam, Balkema. v.1, p. 53-59.

TATSUOKA, F.; TATEYAMA, M.; MURATA, O. (1989). Earth retaining wall with a short geotextile and a rigid facing. In: International Conference on Soil Mechanics and Foundation Engineering, $12^{\text {th }}$. Proceedings. Rio de janeiro, v. 2, p. 1311-1314.

TATSUOKA, F.; MOLENKAMP, F.; TORII, T; HINO, T. (1984). Behavior of lubrification layers of platens in element tests. Soils and Foundations, v. 24, n. 1, p. 113-128.

TATSUOKA, F. (1992). Roles of facing rigidity in soil reinforcing. In: International Symposium on Earth Reinforcement, Fukuoka, 1992. Proceedings. OCHIAI, H.; HAYASHI, S.; OTANI, J. (ed.).Rotterdam, A. A. Balkema, v. 2. p. 831-870.

TATSUOKA, F.; MURATA, O.; TATEYAMA, M. (1992). Permanent geosyntheticreinforced soil retaining walls used for railway embankments in Japan. In: International Symposium on Geosynthetic-Reinforced Soil Retaining Walls, 
Dever, 1991. Proceedings. WU, J. T. H. (ed.).Rotterdam, A. A. Balkema. p. 101130.

TATSUOKA, F.; TATEYAMA, M.; UCHIMURA, T.; KOSEKI, J. (1997). Geosynthetic-Reinforced soil retaining walls as important permanent structures. Geosynthetics International, v. 4, n.2, p. 81-136.

TAYLOR, R. N. (1995). Geotechnical Centrifuge Technology. R. N. Taylor (ed), London, Blackie Academic and Professional, p. 19-33.

THAMM, B. R. (1990). Theory and design related to the performance of reinforced soil structures. In: International Reinforced Soil Conference - Performance of Reinforced Soil Structures. Proceedings. British Geotechnical Society, p. 15-20.

THORNTON, J. S.; ALLEN, S. R.; THOMAS, R. W. (1997). Approaches for the prediction of long term viscoelastic properties of geosynthetics form short term tests. In: Geosynthetics '97. Proceedings. California. v.1. , p.277-291.

THORNTON, J. S.; et al.; ALLEN, S. R.; THOMAS, R. W.; SANDRI, D. (1998). The stepped isothermal method for time-temperature superposition an its application to creep data on polyester yarn. In: International Conference on Geosynthetics, $6^{\text {th }}$. Proceedings. Atlanta. V. 2, p. 691-698.

THORNTON, J. S. (2001). Characterization of short and long term creep and relaxation properties of a polypropylene geogrid. In: Geosynthetics 2001. Proceedings. Oregon. v.2, p. 835-845.

TOYOSAWA, Y.; HORII, N.; TAMATE, S.; SUEMASA, N.; KATADA, T.; ICHIKAWA, T. (2002). Lateral earth pressures with wall movements in centrifuge tests. In: Physical Modelling in Geotechnics. Proceedings. Canada, p. 881-885.

TSUKADA, Y.; OCHIAI, Y.; MIYATAKE, H.; TAJIRI, N. (1998). Field performance test of a geosynthetic-reinforced soil wall with rigid facing. In: International Conference on Geosynthetics. Geotextiles, $6^{\text {th }}$. Proceedings. Atlanta, v. 2, p. 577-580.

TUPA, N.; PALMEIRA, E. M. (1995). Comportamento de geotêxteis não-tecidos confinados em solos finos. In: Geossintéticos 95. Anais. São Paulo, p. 139-147.

VAN ZANTEN, R. V. (1986). Geotextiles and geomembranes in civil engineering. Rotterdam, Balkema.

WALTERS, D.; ALLEN, T.M.; BATHURST, R.J. (2002). Conversion of geosynthetic strain to load using reinforcement stiffness. Geosynthetics International, v. 9, n. 5-6, p. 483-523. 
WAWRYCHUK, W. F. (1987). Two geogrid reinforced soil retaining walls. Dissertação (mestrado). Royal Military College of Canada, Ontario.

WETZEL, R. A.; BUTTRY, K. E.; McCUllough, E. S. (1995). Preliminary results form instrumented segmental retaining wall. In: Geosynthetics' 95. Proceedings. Tennessee. v. 1, p.133-146.

WILSON-FAHMY, R. F.; KOERNER, R. M.; FLECK, J. A. (1993). Unconfined and confined wide width tension testing of geosynthetics. In: CHENG, S. J. C. Geosynthetics soil reinforcement testing procedures. Philadelphia. p. 49-63.

WOODRUFF, R. (2003). The performance of MSE shoring composite walls Boulder. Dissertação (Mestrado) - University of Colorado at Boulder (em andamento).

WU, C. S.; HONG, Y. S. (1994). Creep behavior of geotextile under confining stress. In: Geotextiles, Geomembranes and Related Products, $5^{\text {th }}$. Proceedings. Singapore. v.3, p. 1135-1138.

WU, J. H. T.; ARABIAN, V. (1990). Cubical and cylindrical tests for measuring insoil load-extension properties of geotextiles. In: Geotextiles, Geomembranes and Related Products, $4^{\text {th }}$, The Hague, 1990. Proceedings. Rotterdam, Balkema. v.2, p. 785 .

WU, J. T. H. (1991). Measuring inherent load-extension properties of geotextiles for design of reinforced structures. Geotechnical Testing Journal, v. 14, n. 2, p. $157-$ 165.

WU, J. T. H. (1992). Geosynthetic-reinforced soil retaining walls. In: International Symposium on Geosynthetic-Reinforced Soil Retaining Walls, Dever, 1991. Proceedings. WU, J. T. H. (ed.).Rotterdam, A. A. Balkema.

WU, J. T. H.; HELWANY, S. M. B. (1996). A performance test for assessment of long-term creep behavior of soil-geosynthetic composites. Geosynthetics International, v. 3, n.1, p. 107-124.

YEO, K. C.; ANDRAWES, K. Z.; SAAD, M. A. (1992). The use of a compressive boundary layer in reinforced soil structures. In: International Symposium on Earth Reinforcement Practice, Fukuoka, 1992. Proceedings. OCHIAI, H.; HAYASHI, S.; OTANI, J. (ed.).Rotterdam, A. A. Balkema. p. 449-454.

YUAN, Z.; SWAN, R. H.; BACHUS, R. C. (1998). Soil Confinement effect on stress-strain properties of geosynthetics. In: International Conference on Geosynthetics, 6th. Proceedings, Atlanta, v. 2, p. 523-528.

ZAMMITT, R. A. (1998). Approval procedures for geosynthetics for soil reinforcement application - UK practice. In: Creep and Assessment of 
Geosynthetics for Soil Reinforcement, Leatherhead, 1997. Proceedings, Leatherhead, p.5.1-5.20.

ZHANG, W.; LAI, Z.; XU, G. (2002). Centrifuge model test of geosynthetics reinforced retaining walls. In: Physical Modelling in Geotechnics. Proceedings. Canada, p. 999-1004.

ZORNBERG, J. G. (1994). Performance of geotextile-reinforced soil structures. Berkeley. Tese (Doutorado) - University of California, Berkeley.

ZORNBERG, J. G.; MITCHELL, J. K.; SITAR, N. (1997). Testing of reinforced slopes in a geotechnical centrifuge. Geotechnical Testing Journal, v. 20, n.4, p. 470-480.

ZORNBERG, J. G.; SITAR, N.; MITCHELL, J. K. (1998a). Performance of geosynthetic reinforced slopes at failure. Journal of Geotechnical and Geoenvironmental Engineering, v. 124, n. 8, p. 670-683.

ZORNBERG, J. G., SITAR, N., MITCHELL, J. K. (1998b). Limit equilibrium as basis for design of geosynthetic-reinforced slopes. Journal of Geotechnical and Geoenvironmental Engineering, v. 124, n. 8, p. 684-698. 